1917

\title{
A Manual on Land Registration
}

Arthur Gray Powell

Follow this and additional works at: https://digitalcommons.law.uga.edu/historic_treat

Part of the Land Use Law Commons, Legal Education Commons, Legal History Commons, and the State and Local Government Law Commons

\section{Repository Citation}

Powell, Arthur Gray, "A Manual on Land Registration" (1917). Historical Treatises. 9.

https://digitalcommons.law.uga.edu/historic_treat/9

This Book is brought to you for free and open access by the Alexander Campbell King Law Library at Digital Commons @ University of Georgia School of Law. It has been accepted for inclusion in Historical Treatises by an authorized administrator of Digital Commons @ University of Georgia School of Law. Please share how you have benefited from this access For more information, please contact tstriepe@uga.edu. 



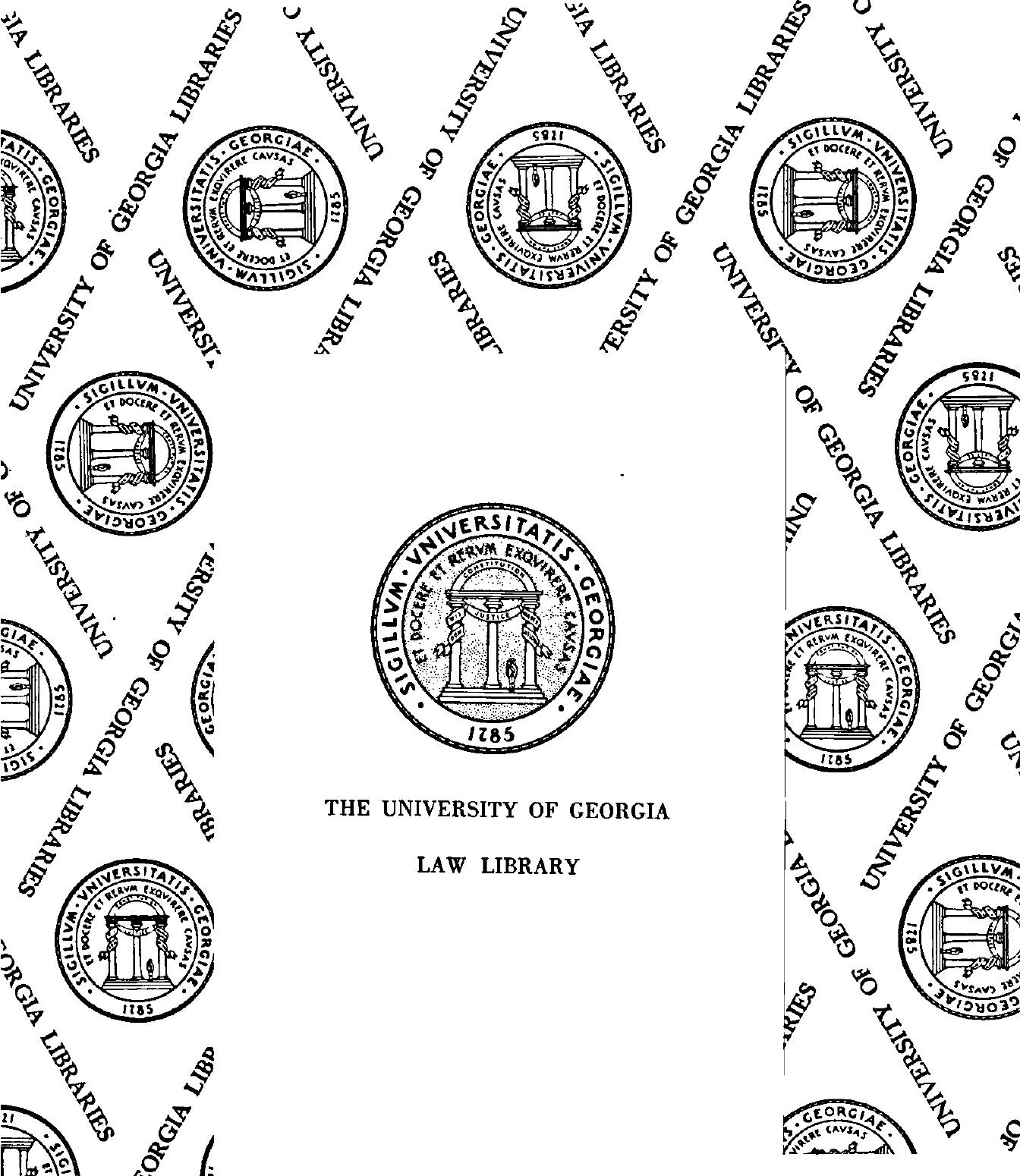

,

$\frac{5}{3}$ 


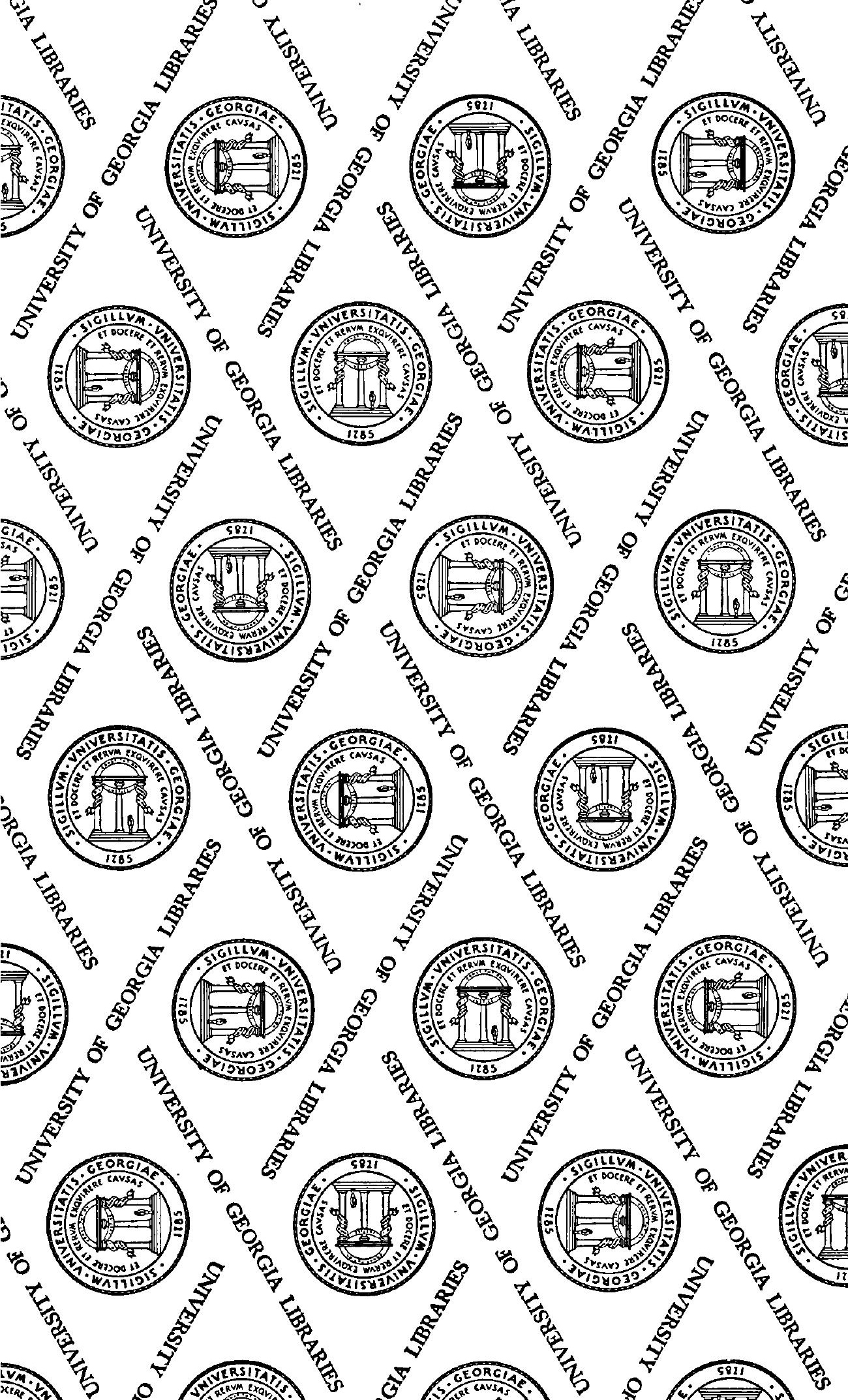




\section{A MANUAL \\ ON \\ LAND REGISTRATION}

WITH A FULL, COMPLETE ANNOTATED COPY OF THE

LAND REGISTRATION ACT

of the

STATE OF GEORGIA

By

ARTHUR GRAY POWELL, LL. D.

Atlanta, Georgia, Bar; formerly a Judge of the Court of Appeals of the State of Georgia ; Author of Powell on Actions for Land

ATLANTA

THE HARRISON COMPANY

LAW Book PublisherRs

1917

LAM IIIRRARY

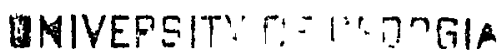

ATHFNSI, $?$, 
$K F G / 12$

P6q

Copyright 1917

BY

Arthur G. Poweld 


\section{Personal Foreword.}

I have written this book as a duty, not as a pleasure; for, while it might have been a pleasure to have written a book on this subject, if I had had the time, the fact is I didn't have the time. In the first place, the time between the passage of the Land Registration Act and the date set by the publishers whereon the printers should have the manuscript was too short a period in which to write on the subject in a way which would have given pleasure. And, then, I have long since sold myself into the slavery of a law practice; and that takes time.

I say it was my duty to write the book, because I owe so much to my brothers of the bar that when they make a demand of me I ought not to let my personal convenience prevent my compliance-and they have asked me to write this book.

It happens this way: Some years ago a commission was appointed to study and put into the form of a bill a system of land registration for this State. ${ }^{1}$ I served on the commission and gained some knowledge of the then existing systems. The death of the brilliant chairman of that commission, Hon. Washington Dessau, prevented its labors from coming to fruition. In the year 1914 the General Assembly authorized the appointment of a similar commission, ${ }^{2}$ and the Governor named me on it. This commission devoted several weeks to public hearings and to a study of the subject, and then drew the bill which was enacted into law at the last session of the General Assembly. Owing to the fact that the two other members of this commission (Hon. R. N. Holtzclaw and Hon. S. M. Turner) resided away from Atlanta, where the hearings of the commission were had, the larger part of the preparation of the bill fell upon me. Hence, I was supposed to know more about the subject than any one else upon whom the bar might have called to write the book; therefore, the demand and the duty that I should write it.

1. See Georgia Laws, 1903, p. 689; Georgia Laws, 1904, p. 758; Georgia Laws, 1905, p. 1256.

2. Georgia Laws, 1914, p. 1248.

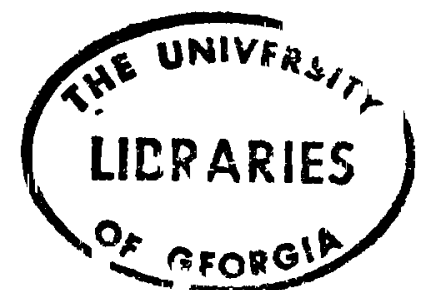


I decided that my labors would prove most useful if I attempted to write a practical, rather than a learned treatise on the subject. While the subject is one that might bear much fruit under learned treatment, still what the present moment most demands is a practical handbook which will inform the profession and the officers who are to administer the law what to do and how to do it, when a landowner comes seeking to register his land.

There has been no effort at style, except that I have striven to state matters in a plain understandable way and in language that a layman can understand. I have not hesitated to use repetition, either of words or of ideas, where I felt that the same would give either greater clearness or greater emphasis.

But few cases are cited. On the immediate subject, naturally there are no local cases to cite, since the Act has not yet gone into effect. A few cases have arisen in other states involving the constitutionality of similar statutes, and the leading of these cases have been cited. Most of the other cases which might be cited on the general subject relate to points of practice, dependent for the most part on the construction of the peculiar language of local statutes, and I have not thought it worth while to cite them. However, any one desiring to examine these cases will find them briefed in L. R. A., 1916D, pp. 14 et seq. Many of them are cited in the notes accompanying the American Uniform Land Registration Act which is reproduced in the Appendix.

I have not hesitated to express an opinion here and there as to the proper construction or as to the effect of the various sections of the Act. These opinions may be taken for what they are worth. I put them forth without recourse or warranty, except that they are genuine and delivered in good faith.

I trust that the Act will prove to the bar and to the people of this State the great blessing which its friends, I among its number, believe it will be. If this book shall help to make it so, I shall feel repaid for all the labor I have bestowed upon it.

Atlanta, September, I9I7.

A. G. P. 


\section{TABLE OF CONTENTS.}

CHAPTER I.

INTRODUCTION.

$\S$ 1. Historical Sketch-Torrens System-Other Systems.

$\S$ 2. The Dual Meaning of the Word "Title"-Registration Affects Title Only in the Adjective Sense.

$\S$ 3. Title in Its Substantive Sense Not Affected by Registration.

$\S$ 4. General Object of the Land Registration Act.

$\S$ 5. The Various Methods Used to Evidence Title-Objections to Common Modern Methods.

§ 6. Registration as Synchronizing Title in Evidentiary Sense

With Title in Abstract Sense.

$\S$ 7. Registration as Localizing Title in Point of Space.

$\S$ 8. Land Value Increased by Registration-Land as a Liquid Security.

$\S$ 9. Safety and Certainty of Landownership Assured.

$\S$ 10. Settling Doubtful Matters as They Arise-Advantages.

$\S 11$. Registered Lands Subject to the Ordinary Jurisdiction of the Courts-Equities, How Enforced and Protected.

$\S$ 12. Same Continued.

$\S$ 13. The Act a Remedial Statute-To Be Liberally Construed.

$\S 14$. The Practicability and Simplicity of the System.

$\S 15$. General Outline of the Act.

\section{CHAPTER II.}

The, Constitutionality of the Law.

$\S$ 16. Earlier Acts Declared Unconstitutional as Conferring Judicial Powers on Non-Judicial Officers.

$\S$ 17. Earlier Act Declared Unconstitutional Because No Provision For Service of Process.

§ 18. Later Acts Sustained.

$\S$ 19. Constitutional Questions Avoided in the Georgia Act.

$\S 20$. Estoppel against Raising Constitutional Questions After Land Is Once Registered.

CHAPTER III.

Definitions.

$\S 21$. Certain Words and Phrases Defined.

[v] 


\section{CHAPTER IV.}

Pleadings on Initial Registration.

§ 22. Equitable Procedure But Not Equitable Jurisprudence Applies. $\S 23$. Venue of Petitions for Registration.

$\S 24$. Filing and Docketing.

$\S 25$. Who Are Proper Petitioners for Registration.

$\S 26$. The Character of Ownership Required-Grantor and Grantee in Security Deed-Vendor and Vendee in Executory Sale.

$\S 27$. Persons or Corporations Having the Power of Appointing or Disposing of the Fee Simple.

\& 28. Corporations as Petitioners-Unincorporated Associations.

$\S 29$. Infants and Other Persons under Disability as Petitioners.

$\S$ 30. How Far Those Owning Less than Fee Simple May Invoke the Act

$\S$ 31. The Petition for Initial Registration.

$\S 32$. Suggestions as to Filling the Blanks in Prescribed Form of Petition.

§ 33. Same Continued-Appointment of Local Agent or Attorney by Non-Resident Petitioner.

§ 34. Same Continued-Description of the Land.

$\S$ 35. Same Continued-Including Several Parcels in Same Application.

$\S$ 36. Same Continued-Dividing a Single Tract into Parcels for Separate Registration.

$\S 37$. Same Continued-Allegation as to Value and Last Assessment for Taxation.

$\S 38$. Same Continued-Allegation as to Estate or Interest.

$\S$ 39. Same Continued-Allegation as to Source of Ownership.

$\S$ 40. Same Continued-Alleging Title by Prescription.

$\S$ 41. Same Continued-Information as to Title Papers.

\$ 42. Same Continued-Information as to Homestead, Dower, etc.

§43. Same Continued-Statement as to the Occupancy.

$\S$ 44. Same Continued-Listing Adverse Claimants, Known and Unknown-Taxes.

§ 45. Same Continued-Listing Adjoining Owners and Occupants.

§ 46. Same Continued-Easements.

§ 47. Same Continued-Age of Applicant-How Stated in Case of a Minor.

§ 48. Same Continued-Husband or Wife to Be Named as Defendant.

§ 49. Same Continued-Naming the Defendants.

§ 50. Same Continued-The Abstract of Title.

$\S$ 51. Verification of the Petition.

\$ 52. Defensive Pleadings-Who May File.

$\S$ 53. Cross Petitions. 
$\S$ 54. Verification of Defensive Pleadings.

$\S 55$. Demurrer-Slackness of Pleading Not Allowed.

$\S$ 56. The Time within Which Defensive Pleadings May Be Filed.

$\S$ 57. Right of Amendment.

$\S$ 58. Severance.

$\S 59$. The Effect of a Severance.

$\S$ 60. Appearance and Pleading by Those Who Deal with the Land Pending Registration Proceedings.

\section{CHAPTER V.}

\section{Process and No'tice.}

§ 61. Relation between Provisions as to Service and the Object of Suit.

$\S 62$. The Process.

$\S 63$. Copies and Second Originals.

$\S 64$. Service by Publication-Service on Non-Resident and Unknown Defendants.

$\S 65$. Additional Service-When and How Ordered.

\$ 66. Defendants by Representation-Service on Some as Representatives of Numerous Class.

$\S 67$. Service upon the State, Counties and Municipalities

$\S 68$. Acknowledgment of Service.

$\S 69$. Waiver by Appearance or Pleading.

$\S 70$. Perfecting Service on Persons under Disability.

$\S$ 71. The Constructive Seizure of the Land.

$\S$ 72. Notice to the Occupants of the Land.

$\S$ 73. The Return of Seizure, Service and Notice-Traverse, How Far Allowable.

$\S$ 74. No Denial of Service after Judgment.

$\S$ 75. Adverse Claimants Disclosed by Examiner's Reports-Checking up Returns of Service by Examiner's Reports.

$\S$ 76. Provisions for Service Not Unduly Onerous-Effectiveness of the Provisions.

\section{CHAPTER VI.}

EXAMINERS-REPORTS-ExCEPTIONS.

$\S$ 77. Examiners, General and Special-Considerations Influencing the Number to Be Appointed.

$\S 78$. Term of Office, Eligibility and Official Oath.

$\S 79$. Order of Reference.

$\S$ 80. Examiner's Preliminary Report-When to Be Filed.

$\S 81$. Contents of the Examiner's Preliminary Report. 
$\S$ 82. Same Continued-Examiner's Abstract of Title.

\$ 83. Same Continued-Schedule B.

$\S$ 84. Same Continued-Schedule C.

$\S 85$. Same Continued-History of the Possession.

$\S$ 86. Same Continued-Where the Examiner Finds the Description Insufficient.

$\S 87$. How Far the Preliminary Report is Prima Facie Evidence.

$\S$ 88. Bringing the Case to Hearing before Examiner-Notice of the Hearing.

$\S 89$. Functions and Duties of the Examiner on the Hearing.

$\S$ 90. Special Powers of the Examiner-Independent Investigation.

$\S$ 91. Same Continued-Power of Examiner as Court Commissioners to Take Depositions.

\$ 92. Introduction of Evidence before the Examiner.

$\S$ 93. Employment of Stenographer.

$\S$ 94. Burden of Proof-Methods of Proof.

$\S$ 95. Examiner's Final Report.

$\S$ 96. Exceptions to the Examiner's Report.

$\S$ 97. Hearing on Exceptions-Jury Trial on the Facts.

$\S$ 98. Same Continued-Procedure and Evidence on the Trial before Jury.

$\S$ 99. Recommitment-New Trial.

$\S$ 100. Survey-When Ordered-How Made-Trial of Protest to Surveyor's Return.

\section{CHAPTER VII.}

Final Judgment and Decree of Title.

$\S$ 101. Decision of the Cause by the Court.

$\S$ 102. No Judgment by Default.

$\S$ 103. Voluntary Dismissal of the Petition-When Allowable, When Not-Involuntary Dismissal.

§ 104. Right to Amend, Instead of Dismissing Where Plaintiff Shows Title to Less than Fee.

$\S$ 105. Dismissal Where Petitioner Proves Only an Undivided Interest.

§ 106. Judgment Authorizing Registration-Decrees of Title-Severance For Purpose of Rendering Separate Decrees.

\$ 107. Tract Divided Into Parcels-Separate Decrees-Advantages of This Privilege.

$\S 108$. Form of the Decree-Necessity for Adherence to Prescribed Form.

$\S$ 109. Preparation of the Decree of Title-Suggestion as to Filling in the Blanks in Prescribed Form-Description of the Land. 
$\S$ 110. Same Continued-Filling in Names of the Owners-Description of Their Respective Estates.

$\S$ 111. Same Continued-Declaring Limitations and Conditions.

$\S$ 112. Same Continued.

$\S$ 113. Same Continued-Declaring Liens and Encumbrances.

$\S$ 114. Same Continued-The "Residuary Clause" in the Blank Form -Easements - Building Restrictions - Cautionary Statement of the Possibility of Appeal.

$\S$ 115. No Issue as to Mesne Profits or Set-Off of ImprovementsStatement in Decree as to Improvements.

$\S$ 116. Recording the Judgment or Decree.

$\S$ 117. Conclusiveness of the Decree of Title-A Covenant Running With the Land.

$\S$ 118. Writ of error to Supreme Court-Fast Writ-Supersedeas.

$\S$ 119. Enrolling the Decree of Title-The Register of Decrees of Title.

$\S$ 120. Same Continued-Suggestions as to the Enrollment of Decrees-Decrees, How Numbered.

$\S$ 121. Same Continued-Outside Recording of Plats and Lengthy Details.

$\S$ 122. Same Continued.

$\S$ 123. Indexing Decree-Full Individual Indexing Required.

\section{CHAPTER VIII.}

\section{Certificate of Title.}

§ 124. Completing Initial Registration-The Title Register.

$\S$ 125. Preparing and Registering the Certificate of Title-How Numbered.

$\S$ 126. Same Continued-Filling the Blanks-Description of the Land.

\$ 127. Same Continued-Names and Description of Owners.

$\$$ 128. Same Continued-Designation of the Owner's Estate.

$\S$ 129. Same Continued-Declaring Limitations, Conditions, Encumbrances, Etc.

$\S$ 130. Same Continued-Dating, Signing and Sealing.

$\S$ 131. Same Continued-Right, and Method of Asking Direction From Judge in Case of Doubt.

$\$$ 132. Indexing the Certificate of Title.

\$ 133. The Owner's Certificate-Issuance-Attaching Certified Copy of Outside Records.

$\S$ 134. Samé Continued-Form-Suggestions as to Design.

$\S$ 135. Established Duplicate of Owner's Certificate. 


\section{CHAPTER IX.}

\section{Subsequent Rfgistration Generaliy.}

$\S$ 136. Preliminary.

$\S$ 137. Ownership of Registered Lands Subject to Same Rights and Burdens as in Case of Unregistered Lands.

$\S$ 138. Same Continued-How Registration and General Law and Equity Work Together-The Sphere of Each.

$\S$ 139. Analysis of the Various Kinds of Transactions Dealt With in the Act-Voluntary Transactions-Involuntary Transactions.

$\S$ 140. Voluntary Transactions Executed in Prescribed Form Accompanied by Owner's Certificate.

§ 141. Voluntary Transfers and Mortgages Not Accompanied by Owner's Certificate.

$\S$ 142. Voluntary Cancellation of Liens and Encumbrances.

$\S$ 143. Voluntary Transactions Not in Prescribed Form.

$\S$ 144. Involuntary Transfers-Registered Only on Order of the Judge.

§ 145. Involuntary Transactions Not Involving a Transfer of Title.

\section{CHAPTER X.}

Methods of Registration-Vol,untary Transactions.

$\S$ 146. Preliminary.

$\$$ 147. Voluntary Total Transfer in Standard Form.

$\S 148$. Voluntary Transfer of Undivided Interest in Standard Form.

$\S 149$. Procedure Where Co-Owner Refuses Possession of Owner's Certificate for Registering Partial Transfer.

$\S$ 150. Voluntary Transfer of Estate Less than fee-Leases-Timber and Mineral Rights.

$\S$ 151. Voluntary Transfer of a Divided Portion of a Tract, Executed in Standard Form.

§ 152. Transferring the Certificate as Security for Debt.

$\S$ 153. Creditor's Certificate

§ 154. Same Continued-Negotiability.

$\S$ 155. Same Continued-Foreclosure.

$\$$ 156. Same Continued-Registering the Transaction.

$\S$ 157. Same Continued-Transfer to Secure Debt, Not Executed in Standard Form.

$\$$ 158. Same Continued-When the Clerk Is to Retain the Instrument of Transfer and When Not.

$\S 159$. Cancellation of Creditor's Certificate.

$\S$ 160. Transferring Title to Purchaser on Foreclosure of Creditor's Certificate. 
$\S$ 161. Mortgages-Standard Form.

$\S 162$. Mortgages Not in Standard Form-When Mortgagee Retains Original-When Not-Foreclosure.

$\S$ 163. Voluntary Transfers Not Executed in Standard Form-Transfers in Trust or upon Conditions or Special Terms.

$\S 164$. Voluntary Transfers by Corporations.

\section{CHAPTER XI.}

Methods of Registration-Involuntary Transactions.

$\S$ 165. Preliminary.

$\S$ 166. Involuntary Transfers-Registered Only under Direction of Judge after Notice and Hearing-Order of Transfer.

$\S 167$. Summary Jurisdiction of the Judge as to Involuntary Transfers.

$\S$ 168. Method of Applying for Involuntary Transfers-Execution Sales-Tax Sales-Receiver's Sales-Bankruptcy.

$\S 169$. Cancellation of Owner's Certificate on Involuntary Transfer -Cancellation by Publication.

$\S$ 170. Directions to the Clerk in Connection with Judge's Order of Transfer.

$\S$ 171. Duties of the Clerk in Registering Involuntary Transfers.

$\S$ 172. Advertising Cancellation When Owner's Certificate Not Produced.

$\S$ 173. Notation of Liens, Encumbrances and Special Rights.

$\S$ 174. Notation of Judgments and Similar Liens-Necessity and Effect of Notation.

$\S$ 175. Same Continued-Method of Notation.

$\S 176$. Notation of Sundry Other Liens.

$\$$ 177. Taxes and Public Assessments-Necessity for NotationHow Noted-When Noted-Duty and Liability of Tax Officers.

$\S$ 178. Lis Pendens-Necessity for Registration-How Registered.

\$ 179. Adverse Entries-How Removed from Register.

$\S$ 180. Same Continued-Voluntary Cancellation.

$\S$ 181. Same Continued-Cancellation by Order of Judge.

$\S$ 182. Same Continued-Procedure to Compel Cancellation-Summary Jurisdiction of the Judge.

$\S$ 183. Summary Jurisdiction for Correction of Errors on Register.

$\S$ 184. Summary Jurisdiction over Forged or Fraudulent Registration.

$\S$ 185. Distinction between Summary Jurisdiction of the Judge and General Jurisdicton of the Courts.

$\S$ 186. Notation of Tax Lien, How Cancelled.

$\S$ 187. Entries and Notations to Be Brought Forward. 


\section{CHAPTER XII.}

\section{Special Cases.}

$\S$ 188. Status and Disposition of Registered Land on Owner's Death. $\S$ 189. Same Continued-Sales by Executors and AdministratorsObjections by Heirs or Other Interested Persons.

$\S$ 190. Same Continued-Dower.

\$ 191. Same Continued-Causing the Title to Be Registered in the Name of the Personal Representative.

\$ 192. Same Continued-Where the Decedent Held Only an Undivided Interest.

§ 193. Same Continued-Transfer from Executor or Administrator.

$\S$ 194. Same Continued-Transmission of Title by Descent-Judgment Establishing Heirship.

$\S$ 195. Same Continued-How Heirs Obtain Transfer-Procedure to Establish Heirship.

$\S$ 196. Same Continued-Registering Transfer to the Heirs-Voluntary Partition among Heirs.

$\S$ 197. Same Continued-Method of Registering Transfer to Heirs.

$\S$ 198. Same Continued-Proceedings by Personal Representatives and Other Trustees to Determine Who Are Heirs or Beneficiaries.

$\S$ 199. Same Continued-Rights of Administrator Appointed after Transfer to Heirs.

$\S 200$. Guardian's Sale.

$\S 201$. Transfer from Husband to Wife and Vice Versa.

$\S$ 202. Eminent Domain-Condemnation Proceedings.

$\S 203$. Registering Change of Owner's Name-Marriage-Charter Amendment.

$\S$ 204. Transfer of Land Held in Trust or under Conditions or Unusual Limitations-Powers.

$\S$ 205. Transfer as the Result of Judicial Proceedings.

$\S$ 206. Same Continued-Partition-Equitable Actions-Specific Performance.

$\S 207$. Transfer to Hinder, Delay and Defraud Creditors.

$\S 208$. Procedure to Effectuate Transfers Resulting from Judicial Proceedings.

§ 209. Title by Year's Support, How Registered-Sales by the Widow.

§ 210. Homestead or Exemption-How Registered-Sales of Homestead Property. 


\section{CHAPTER XIII.}

\section{CONCLUSIVENESS OF Registration.}

$\S 211$. The Extent of the Conclusiveness.

$\S$ 212. Same Continued.

$\S 213$. Conclusiveness of Registration Where Transfer Forged.

$\S$ 214. Same Continued.

$\S 215$. Same Continued-Safeguards of the Act.

$\$$ 216. Registration Procured by Fraud-Protection of Innocent Persons.

§ 217. Attacking Registration For Fraud or Forgery-Summary Proceedings-Regular Court Action-Limitations.

$\S$ 218. Same Continued-Burden of Proof.

$\S$ 219. Fraud in Initial Registration-Failure to List Known Adverse Claimant.

$\S 220$. The Four Matters Excepted From the Conclusiveness of Registration.

$\S$ 221. Same Continued-Liens and Rights Under Federal Statutes.

$\S$ 222. Same Continued-Rights of Trustee in Bankruptcy.

$\S$ 223. Same Continued-Taxes and Assessments For the Current Calendar Year.

§ 224. Same Continued-Leases For Less Than Three Years.

$\S 225$. Same Continued-Highways and Railways.

§ 226. Difference Between Certificate of Title and Owner's Certificate as to Conclusiveness.

\$ 227. Same Continued-When Owner's Certificate Can Be Relied On-Entry of "Valid With All Entries Noted."

$\S 228$. How Far Summary Jurisdiction of Judge Over Registration Affects Conclusiveness.

§ 229. Twelve-Months' Limitations For Correction of Registration -When Applicable-When Not.

§ 230. Same Continued-Matters Adjudicated on Original Registration.

§ 231. Cancellation of Entry-Conclusive in Twelve Months-When -When Not.

$\S$ 232. Registered Land Not Affected by Adverse Possession or Prescription.

§ 233. Effect of Reversal of the Judgment Authorizing the Regisistration.

\section{CHAPTER XIV.}

Freeing Land from Registration.

§ 234. General Statement of the Privilege-When Advantageously Used.

$\S 235$. Method of Freeing Land from Registration. 
$\S$ 236. Effect on Future Transactions.

$\S 237$. Same Continued-Benefits of Registration Endure-Last Certificate as a Source of Title.

§ 238. Unanimous Action of Cotenants Required to Free Land From Registration.

\section{CHAPTER XV.}

\section{Registration as Evidence.}

\$ 239. Certified Copy of Certificate of Title-Conclusive and Exclusive Evidence-Owner's Certificate.

\$240 Duplicate Owner's Certificate-When Admissible.

$\S$ 241. Certified Copy of Certificate of Title or Any Entry Thereon, How Obtained-Canceled Certificate-Canceled Entries.

$\S$ 242. Where Plat or Other Detail Is Contained in Outside Record.

$\S 243$. Certified Copy of Decree of Title as Evidence.

$\S$ 244. Proof of Registered Mortgages, Creditor's Certificates and Transfers.

$\S$ 245. No Aliunde Proof of Notice-Rule, That Possession Is Notice, Abolished.

§ 246. Last Certificate of Title and Owner's Certificate Where Land Has Been Freed from Registration-Same Evidentiary Rank as Grant from the State.

$\S 247$. Certified Copy from the File of Registration Papers.

\section{CHAPTER XVI.}

The Assurance Fund.

$\S 248$. Assurance Fund Not an Essential Feature of Land Registration.

§ 249. Assurance Fund, How Created and Invested-Who Liable For Assessment-Cross-Petitioners.

$\S 250$. Who May Have Recourse on the Assurance Fund-Generally.

$\S 251$. Same Continued-Detailed Discussion.

$\S 252$. Limitation of Actions against the Fund-Disabilities.

$\S$ 253. Measure of Damage.

$\S 254$. No Action against Fund for Injury Caused by Breach of Trust.

§ 255. Defendants in Actions against the Fund-Attorney-General's Duties.

\$ 256. Other Remedies to Be Exhausted-Subrogation in Favor of the Fund.

§ 257. Suit against Assurance Fund a Cumulative Remedy. 
CHAPTER XVII.

OfFenses.

$\S$ 258. Detailed Statement of Offenses.

CHAPTER XVIII.

Costs of OFFicers.

$\S 259$. Clerk's Fees and Costs.

$\S 260$. Examiner's Fees.

$\S$ 261. Sheriff's Fees.

$\S$ 262. Services Not Expressly Provided For.

$\S$ 263. Deposit For Costs.

$\S 264$. Costs, How Taxed.

\section{CHAPTER XIX.}

\section{Miscelitane,ous.}

$\S 265$. Courts Always Open.

$\S$ 266. Judges in Convention to Make Rules.

$\S 267$. Who Acts Where Clerk Is Disqualified, Dead or Cannot Act.

$\S 268$. Deputies-Powers of.

$\S 269$. Duty of Clerk to Guard against Improper Registration-Liability of Clerk.

$\S$ 270. Clerk's Duties Purely Ministerial-Suggestions to the Clerk.

$\S 271$. Books and Filing Cases to Be Provided.

$\S$ 272. Method of Filing Papers Relating to Registered Land.

$\S 273$. All Entries to Be Dated to the Minute.

$\S 274$. Power of the Attorney-General as Ex-Officio Supervisor of County Records.

$\S 275$. Extraordinary Cases.

The Land Registration Act-Annotated, page 231. Appendix-The Uniform Land Registration Act, page :333. Index, page 387 . 


\section{Special Notice.}

Throughout the foot-notes, annotations and index, in order to prevent confusion between references to sections of the text and to sections of the Land Registration Act, the following abbreviations have been adopted: "A. \& -," meaning the designated section of the Act, and "T. § -," meaning the designated section of the text. 


\section{Manual of Land Registration}

CHAPTER I.

INTRODUCTION.

$\S$ 1. Historical Sketch-Torrens System-Other Systems.

$\S$ 2. The Dual Meaning of the Word "Title"-Registration Affects Title Only in the Adjective Sense.

$\S$ 3. Title in Its Substantive Sense Not Affected by Registration.

$\S$ 4. General Object of the Land Registration Act.

$\S$ 5. The Various Methods Used to Evidence Title-Objections to Common Modern Methods.

$\S$ 6. Registration as Synchronizing Title in Evidentiary Sense With Title in Abstract Sense.

$\S$ 7. Registration as Localizing Title in Point of Space.

$\S$ 8. Land Value Increased by Registration-Land as a Liquid Security.

$\S$ 9. Safety and Certainty of Landownership Assured.

$\S$ 10. Settling Doubtful Matters as They Arise-Advantages.

$\S 11$. Registered Lands Subject to the Ordinary Jurisdiction of the Courts-Equities, How Enforced and Protected.

\$ 12. Same Continued.

$\S$ 13. The Act a Remedial Statute-To Be Liberally Construed.

$\S$ 14. The Practicability and Simplicity of the System.

$\S$ 15. General Outline of the Act.

\section{$\S$ 1. Historical Sketch-The Torrens System-Other} Systems.-In popular speech, it is common to call practically any system of registration of land titles a Torrens system; however, this is not altogether accurate, especially as to the land registration acts in force in the American states.

The enrollment or registration of land titles has been employed in certain European countries from time immemorial; and, at least since the time of Queen Elizabeth, the origination and development of systems for that purpose have engaged the attention of the English speaking people, as scattered throughout the four corners of the earth. However, it was Sir Robert Rich- 
ard Torrens, a business man, the Collector of Customs at Port Adelaide in South Australia, who prepared and put through the local parliament a statute which took effect in that province in 1858 and which proved successful and became the model upon which similar laws have been enacted in England, in Canada, and in many British dependencies.

In more than a fourth of the states of the United States and in Hawaii and the Philippine Islands there are land registration systems which resemble and which are in the main designed to attain the same end as the original Torrens system, but which differ from it in many essential respects.

Under the original Torrens system and under many of the systems modeled on it, the settling and registration of land titles and of transactions relating thereto are under the jurisdiction of official bureaus or departments, while in this country they are under the jurisdiction of the courts. The Torrens systems proper are not judicial systems of land registration; the American systems are. The reasons for these differences will be discussed in the course of this work.

$\S 2$. The Dual Meaning of the Word "Title"-Registration Affects Title Only in the Adjective Sense.-."The word 'title' is used in two senses; the one referring to the abstract right of ownership in property, the other referring to the means by which that abstract right is evidenced." 1 Modern land registration acts are not intended to affect title in its abstract sense otherwise than incidentally; they are intended to afford a simpler, more certain, more practical means of evidencing title than obtains under any other method.

$\S$ 3. Title in Its Substantive Sense Not Affected by Registration.-The Land Registration Act ${ }^{1}$ does not divest ownership of any of its ordinary incidents, benefits or burdens. ${ }^{2}$ Title may still be held subject to trusts, conditions, equities, encumbrances and all else with which the common law and statute allow the necessities, the wishes, or even the whims of land

[§ 2] 1. Powell, Actions for Land, $\S 132$.

[\$ 3] 1. The Act of the General Assembly of Georgia, approved Aug. 21, 1917. See T. $\$ 21$.

2. See T. $\S 12$ and A. $\S 73$. 
owners to complicate it. The title when registered is merely the title as it is; not as some theorist might believe it ought to be. The right to deal with one's own as one pleases, subject of course to those restraints which the law has found necessary to impose for the common good, is one of the charms of ownership. It may be foolish for a man to encumber his title with trusts, conditions or limitations running into the future as far as the law against perpetuities will permit, still it is not the object of land registration to impose any obstacle to such matters which the law has not already imposed.

§ 4. General Object of the Land Registration Act.The object of the Land Registration Act is to afford a simple, certain, practical method by which every interested person, the owner of the land and every one dealing with him, may know at any given time just who owns a particular piece of land, and subject to what conditions, limitations, encumbrances or claims; and also incidentally to furnish a means by which the title to the land may be handled with greater ease and facility in commercial transactions than exist under other systems of evidencing title.

\section{$\S$ 5. The Various Methods Used to Evidence Title-} Objections to Common Modern Methods.-People have, in the history of the race, found various methods of evidencing title. Primaevally, might was right; possession with sufficient personal physical force to maintain it was the best evidence of ownership. At early common law, land passed by livery of seizin; that is, by a symbolic manumission in analogy to the passage of title to a chattel by sale and physical delivery. Under both of the systems just mentioned the methods of evidencing ownership were comparatively simple and reasonably certain, but were suited only to the transactions of a primitive people.

Later, deeds and other documents aided or superseded livery of seizin. Under this system, the strength of a man's title, considered from an evidentiary standpoint, is determined usually by inspection and construction of a successive chain of documents, often running back through a long period of time. Still, at no time in the history of our law has possession failed to influence the question of title; and in practically every investigation in- 
stituted, in court or out of court, for the determination of where the title is at any particular time, not only must the evidence contained in the chain of documents be considered, but also the evidence respecting the corporeal possession of the land itself.

Furthermore, in modern times expediency has forced the enactment of elaborate legislative schemes of requiring transactions relating to land to be filed or recorded in public offices. Therefore, under the common modern method of evidencing title, the proof of title is usually to be found in a combination of all the things which have been mentioned, that is to say, of documentary chain, corporeal occupancy, public files and records, and oftentimes in parol matters in addition. Under this common method of evidencing title, while the true legal title to the land (using the word "title" in the sense of ownership) is, theoretically at least, at every moment fixed in some person or persons, still the title, in the sense of the means by which that right of ownership is evidenced and is to be recognized, proved and protected, is neither fixed nor permanent.

Whenever title in the sense of ownership passes from John to James and from James to William, the connection of John and James with that ownership, so far as the right of ownership which we call title is concerned, ends; but under the common method of evidencing title, William's title (using now the word "title" in the sense of means by which his ownership is evidenced) has no such independence. The deed or will or right of inheritance or other means by which the title passed from John to James is as much a part of William's title as is the deed or will or right of inheritance or other means by which the title passed from James to William; and this dependence runs back through all the transmissions which have taken place since the title first departed the original source of title (usually the State) or until a point is reached where principles of law, based on convenience, such as statutes of limitation or prescription, close the door to further legal inquiry.

\section{§ 6. Registration as Synchronizing Title in Eviden-} tiary Sense With Title in Abstract Sense.-The various land registration acts and the Torrens system are based on the proposition that title in its evidentiary sense may be made as 
fixed to the present moment as is title in its sense of ownership. When the cave-dweller held his cave by force of arms there was no need to inquire who his predecessor in ownership was; title and evidence of title abided side by side. It is the boast of jurisprudence that it has substituted the strong arm of the law for the strong arm of the individual. Under the Land Registration Act, the law through a single court record declares at every moment of time the exact ownership of every tract of land brought under its provisions; and the registered owner, with his title thus declared, can no more be questioned as to who his predecessors in title were than could the cave-dweller in the days gone by. Under this system, the evidence of title does not depend on any chain of documents, or on ability to preserve such a chain intact as against the danger of loss or destruction, or on proof of possession, or on parol facts resting in the memories of men, subject to the treacheries of human recollection and to loss forever by the destructive force of death.

\section{§ 7. Registration as Localizing Title in Point of} Space.-The Land Registration Act localizes the evidence of title in point both of time and of space. Under it the only evidence of title is a duly registered certificate contained on a single folio of a single book, declaring the exact state of the title as it may be at any particular moment. With but few and practically unimportant exceptions, all inquiry as to predecessors in title is shut off, is unnecessary and unimportant; all the need of examining a multitude of records, files, dockets, etc., is gone. The one folio, speaking always in the present tense to the exactness of a minute, ${ }^{1}$ and speaking with all the conclusive authority possessed by the most solemn judgment of a superior court, tells the whole story.

\section{\& 8. Land Value Increased by Registration-Land as} a Liquid Security.-The permanency of land gives special value to the ownership of it; but the common methods of evidencing transactions relating to it are such as to detract from that value by impairing what may be called its commercial liquidity. Jones who owns ten shares of stock worth a thou-

1. See A. $\S 29$. 
sand dollars finds that it is much easier for him to pledge his stock certificates as security for a loan than it is for Smith who owns ten acres of land worth a thousand dollars to borrow money with his land as security. Yet the land is more permanent than the corporation issuing the stock, and the value of the land is likely to be more stable than the value of the stock. The main difference is that the stock certificate is a liquid security which can easily be pledged as collateral while the title to land cannot thus be used. Under any system of evidencing title where every transaction affecting the title becomes a part of the history of the title and, therefore, to be taken into account in determining the status of the title from time to time as the years go by, it would be very inexpedient if landowners were permitted to complicate the title chain with transactions so informal as those which take place in ordinary hypothecations of stock as collateral security; hence efforts to make land titles liquid commercial securities have not been encouraged by the courts or the law makers. But under a system of evidencing title where the past is blotted out as it expires, where a single certificate represents the whole evidence of ownership just as fully as the stock certificate evidences the ownership of the stock, there is no difficulty in making the title to land a liquid security; and this is one of the features of the Land Registration Act.

$\S$ 9. Safety and Certainty of Landownership Assured.Not only is it a burden on the landowner to be required to hold his land under a title that depends for its enforcement and value on his ability continually to trace it back through the successive transactions of years, but it is even a greater hardship that under the common system of evidencing title he can rarely be sure that his title is perfect. Many a man goes to bed at night with the fear haunting him that he may awake in the morning to find, that through some unsuspected flaw in his chain of title, he does not really own the land he has paid for and believed to be his. The landowner is entitled to demand greater certainty than this from the government under which he lives. Not only is the landowner interested in this matter, but the general public, especially those likely to deal with the landowner, are also concerned. The Land Registration Act not only relieves the landowner and those 
dealing with him of the cumbersome burden of keeping up with a chain of title and its history, but it also makes the ownership declared by the registered certificate sure, certain and indisputable.

\section{\$ 10. Settling Doubtful Matters as They Arise-Ad-} vantages.-The Land Registration Act not only provides a means by which certainty is established as to titles which under the ordinary systems would be unquestioned, but it affords a means by which those doubtful things which so often complicate the history of a title may be cleared up as they arise. ${ }^{1}$ To elucidate what is meant: A complete abstract showing the full and true history of a title is presented to a competent attorney. $\mathrm{He}$ finds that the title rests in A unless a tax deed in favor of $B$ is valid, and that the validity of this tax deed depends on whether the levy was excessive-a question which cannot be answered, except as a mere matter of opinion, in advance of a decision by court or jury; or that there is a deed from a wife to her husband which; on its face, is apparently void because made for valuable consideration without the approval of the judge of the superior court as required by statute, but which may be shown to be valid by parol evidence that it is a gift; or there is a deed by an executor purporting to act under power contained in a will and the language of the power is ambiguous; or there is a deed of doubtful construction which may or may not give an estate in remainder to persons yet unborn. In such a case, the least that can be said is that the title is neither safe nor certain. In some of the cases supposed and in many others which might easily be supposed, as in case where there is doubt as to whether a remainderman will or will not take an estate in future, there is no way of settling the doubt, even by present litigation; the doubt must cloud the title until the time arrives when the actual or supposed remainder becomes vested, and often even longer than that. Under the Land Registration Act such things as these are not allowed to haunt the title and overshadow the future; they are cleared up as they arise.

In the first place, at the initial registration all conflicting claims

1. See T. $\S 167$. 
of title are taken into consideration, all doubtful propositions are before the court for decision, and the court thereupon, once for all, adjudges among these conflicting titles and by a solemn conclusive judgment declares which is the true title, and what limitations, if any, exist in relation to it, thereby excluding all other titles and claims of title. If the court adjudges that $\mathrm{A}$ holds the fee simple but that it is subject to be divested in favor of the heirs of $B$ upon his dying childless, then not only $A$, but all persons dealing with him on the faith of his certificate of title know that his title is not indefeasible-there is no longer any.doubt as to whether the contingent remainder exists in favor of B's heirs or not. On the other hand, if the court declares the unconditional fee simple to be in $\mathrm{A}$, then he knows and all persons dealing with him are assured that there is no possibility of his title being defeated by the claims of B's heirs or any one else.

The Land Registration Act provides not only for the settling of these doubts as to the title at the date of the initial registration, but also for keeping them out thereafter. Let us suppose that the registered title stands in $\mathrm{A}$. The land is sold at tax sale, and $B$ becomes the purchaser. Under the Act before B can get title under his tax sale, unless A voluntarily surrenders his certificate, $B$ must cite $A$ before the judge who will then and there determine, once for all, whether B's tax sale is valid or not. If the court determines that it is valid the title is registered in B's name; on the other hand if the court determines that it is invalid A's title is forever freed from the cloud which might otherwise hang over it. .

Again, let us suppose that the registered title is in Mrs. Emma Smith and she undertakes to convey it to her husband, John Smith. Before a certificate of ownership can be obtained by John he and his wife must present the matter to the judge with a full statement as to the true consideration of the transaction, and thus disclose whether it is a gift or a sale. ${ }^{2}$ If the judge finds that it is a gift and that it is free from fraud or other infirmity he orders the certificate to be issued to the husband; if he finds that it is a sale and that it is such a sale as he should approve he

2. See T. $\S 201$, and A. $\S 48$. 
gives his approval then and there and orders the certificate to issue to the husband; otherwise he refuses it. The result is that the legal effect of the transaction is settled then and there and not left to cloud the title in future.

Instances might be multiplied but these are sufficient to illustrate the proposition, that the Act is so designed as that every dispute as to where the legal title reposes is settled promptly and finally.

$\S$ 11. Registered Lands Subject to the Ordinary Jurisdiction of the Courts-Equities, How Enforced and Protected.-It must not be supposed, however, that ownership of registered land is so insulated as to make it immune from the processes of courts of law and of equity. Broadly speaking, every equity, every encumbrance which may exist at law or in equity against unregistered land may exist against registered land; and the means of enforcing all such rights are amply protected. ${ }^{1}$ While no equity or encumbrance will bind the land or affect the title as against any one dealing with the registered owner unless such equity or encumbrance is noted on the certificate of title on the Title Register, still such matters may be freely noted. For example, the land is registered in the name of John Jones, and his wife, Mary Jones, claims that it was bought with her money. She has the right to require the clerk to enter her claim of this equity on the Title Register; but until she does so any one dealing with John Jones as the owner of the land will be protected against her equity. Furthermore, in the event she notes her claim, the Act makes provision by which John Jones may through a summary proceeding before the judge have his certificate cleared of the notation of the wife's claim of equity, if there is no basis for her claim and if she fails promptly to prosecute her suit in equity to have her equitable title declared. ${ }^{2}$ If she files suit and succeeds, the court of equity as a part of its decree can compel her husband to execute a transfer, whereupon the certificate standing in his name will be cancelled and a new certificate issued in favor of his wife. He cannot affect this result, provided

1. See T. $\S 205$, and A. $\S 73$.

2. See T. $\S 182$, and A. $\S 60$. 
the wife's equity is duly noted, by selling or transferring the land in the meantime. He may sell and may cause a new certificate to be issued to his transferee, but the new certificate standing in the name of the transferee will show on its face that it is subject to the claim of equity in favor of Mary Jones, and, therefore, subject to whatever decree the court of equity might render; and upon the court giving judgment in favor of this equity there is provision in the Act whereby the transferee's certificate may be cancelled and the title registered in the name of Mary Jones.

$\S$ 12. Same Continued.-While there are some exceptions to the generality of the proposition that registered lands may be dealt with by the owners and by the court as if they were unregistered lands-exceptions imposed to effectuate the general scheme of the system and in the interest of certainty-still these are not numerous. The Act itself declares in Section 73: "Except as otherwise specially provided by this act, registered land and ownership therein shall be subject to the same rights, burdens and incidents as unregistered land, and may be dealt with by the owner, and shall be subject to the jurisdiction of the court in the same manner as if it had not been registered. But registration shall be the only operative act to transfer or affect the tithe to registered land, and shall date from the time the writing, instrument, or record to be registered is duly registered on the Title Register. Subject to the provisions of Section 63, no voluntary nor involuntary transaction shall affect the title to registered land until registered or noted on the Title Register, in accordance with the provisions of this Act." The scheme of the Land Registration Act, therefore, is not to change the quality of ownership in lands or to relieve them from any of the ordinary incidents of ownership or to put registered lands beyond the reach of the remedial processes of the courts. It substitutes a different method of settling controversies as to ownership, of proving ownership, and of making"public the limitations or encumbrances, actual or asserted, which may exist against such ownership.

\section{$\S$ 13. The Act a Remedial Statute-To Be Liberally} Construed.-While the Land Registration Act is to be administered and construed as creating a complete system, the spirit of 
which must be sought and, as far as may be, conserved in every interpretation of the Act, still it is not to be considered as something apart from the rest of our system of jurisprudence. In a sense, it enacts a special proceeding somewhat similar to our statutory method of validating municipal bonds, still, except where the context or the spirit of the Act forbids, none of the ordinary rules of law or procedure are thereby repealed.

As the Supreme Court of North Carolina has declared ${ }^{1}$ in respect of the statute of that state which is very similar to the one adopted in Georgia, the Act "is not in derogation of common right, but is a remedial statute, and to be liberally construed according to its intent 'so as to advance the remedy and repress the evil." "

\section{$\S$ 14. The Practicability and Simplicity of the System.} -One of the beauties of the land registration system is its practicability and relative simplicity. Any new piece of machinery, legal or mechanical, seems complicated at first view. No system of dealing with land titles can be absolutely simple; abstract title itself presents too many complexities for that. However, perhaps ninety-nine out of any hundred transactions are uncomplicated; and as to these-the ordinary transactions which daily arise in relation to buying, selling and otherwise dealing with land-the system is extremely simple and easily workable. The details of the Act which make it appear complicated are those which relate to unusual situations or to transactions which are inherently of such a nature as that they must be handled specially under any system. As soon as novelty shall have given place to familiarity, it will be seen that the new system is not only surer, safer and more adequate than the old, but that it enables the handling of all transactions with greater ease and practicability. At first there will be a tendency on the part of officials, the bar and the public to "complicate simplicity," but a little time will remedy this.

$\S$ 15. General Outline of the Act.-The preliminary statement here given as to the broader outlines of the Act is for the

1. Cape Lookout Co. v. Gold, 167 N. C. 63,83 S. E. 3. 
benefit of those who wish to know in a general way something of the workings of the Act without being concerned with all the details that may enter into the technical operations that are involved.

The first step is the settling of the title for the purpose of registration. This is accomplished by a suit filed in the superior court by the applicant "against the world", as well as against the land in rem. The defendants are "all persons who, by the petition are disclosed to have any lien, interest, equity or claims, adverse to the petitioner or otherwise, vested or contingent, upon said land or any interest therein" and all other persons "whom it may concern." All known defendants, resident in the state, are served as in ordinary actions. Unknown adverse claimants and non-residents are served by publication. The court also obtains jurisdiction of the rem by the Sheriff's going on the land and posting a notice thereon; also by service of notice upon every occupant of the land above the age of 14 years. There are other details as to the service, which will be omitted in this context, as they will be matters of full discussion elsewhere in the course of this work.

The judge refers the petition to an auditor or master, who, for the purposes of the Act, is called an examiner, and whose functions and duties conform to those of auditors under the Code. However, in addition to the duties usually performed by auditors, the examiner also makes an independent examination of the public records and reports to the court whether there is any reason to suspect other adverse claimants than those disclosed in the petition. Any person adversely interested, whether named as a defendant or not, may file defensive pleadings. The examiner sets the case down for hearing and proceeds to take the testimony and reports to the court, in like manner as an auditor in an ordinary case. This hearing usually begins about 50 days after the petition is filed. Exceptions to the examinainer's report may be filed as in ordinary equity cases, except that any interested party may obtain a jury trial as a matter of right on any contested issue of fact. Even though no objections are filed, no judgment by default can be taken, and the court must be assured from the report of the examiner and the evi- 
dence submitted that the petitioner has the true title; else registration will be refused. If no objections are filed, or, if filed, the petitioner succeeds in overcoming them, and it appears that the petitioner has a title good against the world, the court enters a decree establishing his title. If the applicant is the owner of the fee simple, he is entitled to the decree, although his title may be subject to liens, encumbrances, or lesser estates, but in that event the court sets out in the decree these liens, encumbrances and lesser estates, thereby establishing them also. .

The clerk records the decree and, thereupon, proceeds to register the certificate of title in a book specially prepared for that purpose, called the Title Register. A folio of the Title Register is set apart for each certificate. On one of the leaves the certificate proper is transcribed. This certificate conforms to the decree, certifies to the title of the owner, but also states every limitation, condition or encumbrance, established thereon. The rest of the page on which the certificate is transcribed and the whole of the opposite page are reserved for the entry of future transfers, liens, encumbrances, and other notations. A certified duplicate of the certificate and all notations thereon is delivered to the registered owner. This completes the initial registration.

Everything thereafter which affects the title to the land must be noted on the certificate on the Title Register, to be valid.

The act does not stop, however, with providing for the initial settling and registration of the title; it is contemplated that registration shall be continuous.

If the registered owner desires to sell the land, he endorses on his duplicate certificate a simple transfer, in a prescribed form, causes his signature to the transfer to be attested as if the transfer were an ordinary deed, and delivers it to his vendee. Upon this being presented to the clerk, he notes the fact of the transfer on the certificate on the Title Register, cancels that certificate and the owner's certificate, makes out a new certificate in the name of the new owner on the Title Register and gives him a new certified owner's duplicate. All uncanceled encumbrances and other notations on the original certificate are brought forward and entered on the new one. The 
certificate thus entered on each successive registration is as conclusive as the original certificate.

Provision is made for transfers of undivided or partial interests in the land, but these details need not be elaborated here.

If the holder of the certificate desires to mortgage the land, he states so on a simple form prescribed for that purpose, gives the name of the creditor and a full description of the debt to be secured. He takes this along with his owner's duplicate to the clerk, who notes the mortgage on the certificate on the Title Register and also on the owner's duplicate, prepares a certified copy of the instrument of mortgage for the creditor and retains the original in his file.

However, if the owner desires, or the creditor requires, the owner can transfer the land to the creditor as if he were an ordinary vendee, taking back a bond for title, which too, to be effectual, should be noted on the certificate.

Transactions of this character which take place with the consent of the holder of the certificate are called voluntary transactions.

If a third person claims some lien against or interest in the land adverse to the certificate holder, he can have the same noted on the certificate of the Title Register, on application to the clerk. Such notations are not conclusive as to the validity of the liens or other rights, encumbrances or interests, thus claimed by the third persons causing them to be noted, but they operate to give notice to anyone thereafter dealing with the land. Such matters, if they are not noted, are not binding against the land.

Provisions are made by which registered land may be levied on and sold, or by which the title may be transferred under judicial process without the consent of the owner. In such cases, the transfer, the cancellation of the old certificate and the issuance of the new take place under the direct order of the judge. These are called involuntary transfers.

It is thus to be seen that there may be notations on the original certificate on the Title Register which are not on the owner's duplicate or that an owner's duplicate may be outstanding uncanceled although the original on the Title Register may have 
been canceled by order of the judge as the result of some involuntary transfer. In case of conflict between the original certificate of title on the Title Register and the owner's duplicate, the former prevails. Hence, one about to deal with the land on the faith of the owner's duplicate should take the caution of seeing that it corresponds with the original and that it has not been canceled. For this purpose, it is provided in Section 118 of the Act that the holder of an owner's certificate may at any time present it to the clerk, and if the original on the Title Register has not been canceled, the clerk shall thereupon enter on the owner's duplicate all entries and notations of every kind not already entered thereon, and shall thereupon endorse on the owner's certificate the words "Valid, with all entries noted to this date," dating the same with the year, month, day and hour, and signing the same officially. By this means, the owner's duplicate can be brought down to the minute. This provision which appears in the Georgia Act is new, this being the first state to adopt it. However, it is believed that it performs a very valuable function in the practical operation of the system.

The foregoing presents a rough outline of the general scheme of the system. The Act itself makes provision for the handling of many transactions which may occur and which are not mentioned above. The intention of the Act is to make provision, either specifically or by general rules, for every exigency that may arise.

In most of the American states it is optional with landowners whether they will register their land or not, but land once registered remains registered always thereafter. In this State, not only is initial registration optional, but there is a provision whereby any subsequent owner of the certificate may take the land out of the system and restore it to the status of unregistered land. 


\section{CHAPTER II.}

The Constitutionality of the Law.

$\S$ 16. Earlier Acts Declared Unconstitutional as Conferring Judicial Powers on Non-Judicial Officers.

$\S$ 17. Earlier Act Declared Unconstitutional Because No Provision For Service of Process.

$\S 18$. Later Acts Sustained.

$\S$ 19. Constitutional Questions Avoided in the Georgia Act.

$\S 20$. Estoppel against Raising Constitutional Questions After Land Is Once Registered.

\section{§ 16. Earlier Acts Declared Unconstitutional As Con-} ferring Judicial Powers on Non-Judicial Officers.-Reference has been made in an earlier part of this book ${ }^{1}$ to the fact that the present American systems of land registration are judicial systems in contrast to the original Torrens system and the other British systems which are modeled thereon and which are administered through bureaus or departments. In England and in other parts of the British Empire there are no constitutional limitations such as there are in this country against the conferring of judicial powers on executive officers. The settling of land titles is a judicial matter and, hence, in this country is a matter exclusively within the jurisdiction of the courts. One of the earliest, if not the earliest act on the subject in this country, the Illinois Act of 1895, was declared unconstitutional because this constitutional limitation was overlooked. The act conferred upon the registrar, or recorder of deeds, an officer corresponding to the clerk of the superior court in this State, the duty of investigating and settling the title for the purposes of initial registration and the bringing of the land under the provisions of the act. The Supreme Court of Illinois held ${ }^{2}$ that there was a delegation of judicial powers in violation of the state constitution. In 1896, an act was adopted in Ohio for the registration of

1. T. $\S 1$.

2. People v. Chase, 165 Ill. 527, 46 N. E. 464, 36 L. R. A. 105. 
land titles. Though original registration was through a court proceeding, that act conferred on the recorder, who was charged with the keeping of the records, the power of hearing evidence and of determining when liens and like matters were discharged and of making conclusive entries in respect thereto. Though the act provided for an appeal from the action of the recorder to the court, the Supreme Court held the entire act unconstitutional upon grounds which will presently be referred to, but also specifically held it unconstitutional as to the feature in which the foregoing powers were conferred on the recorder. ${ }^{3}$ The court held that since the Act sought to confer the power to determine justiciable controversies upon the recorder, it thereby made a grant of judicial power to a ministerial officer, and that no such grant was permissible under the Constitution of Ohio. The court noticed the provision for an appeal from the recorder's decision, but held that this did not cure the constitutional objection, since under the precedents in that state it had been decided that there could be no appeal except from one court to another.

The framers of the Georgia Act took no chances on this question. Section 2 of the Act provides that, "the superior court of the county in which the land lies shall have exclusive original jurisdiction of all petitions and proceedings had thereupon." Nowhere in the Act is power given to the clerk to decide any justiciable controversy, even provisionally. ${ }^{4} \mathrm{He}$ cannot make any transfer or any conclusive entry or notation on the register in any involuntary transaction without direction from the judge. ${ }^{5}$ While in cases of ordinary voluntary transfers and in the making of merely clerical entries such as clerks commonly make upon filing and execution dockets, he may act without the immediate direction of the judge to do so; still it is provided, at the conclusion of Section 59 of the Act, that, in all matters required of the clerk under this Act, he shall be subject to the direction and orders of the court. Ample provision

3. State v. Guilbert, 56 Ohio St. 575, 47 N. E. 551.

4. See T. $\S 270$.

5. See A. $\S 41$, T. $\S 166$. 
is made by which an entry or notation of the clerk may be brought under the review of the court at any time within the statute of limitations of twelve months set in Section 59 of the Act. ${ }^{6}$

\section{§ 17. Early Act Declared Unconstitutional Because No} Provision for Service of Process.-The other ground on which the Ohio statute was declared unconstitutional was that it was violative of the "due process of law" clause of the Constitution. 1 That act provided for no service of process on adverse claimants and attempted to substitute notice by publication for service upon known residents of the state as well as upon unknown or non-resident parties. This point seems to be well taken; and all the subsequent American acts have taken care to guard against it.

$\S$ 18. Later Acts Sustained.-The test cases made as to the two earliest American acts paved the way for the framing of the subsequent statutes in which these constitutional objections were obviated. The subsequent American acts have been before the courts a number of times on constitutional questions and have been uniformly sustained. ${ }^{1}$

\section{$\S$ 19. Constitutional Questions Avoided in the Georgia} Act.-The framers of the Georgia Act had before them at the

6. See A. $\S 60, T . \S 179-185$.

[\$ 17] 1. State $v$. Guilbert, 56 Ohio St. 575, 47 N. E. 551.

[\$ 18] 1. The leading case on the subject is Tyler $v$. Judges, 175 Mass 71, 55 N. E. 812,51 L. R. A. 433, the decision being delivered by Chief Justice Holmes, now Mr. Justice Holmes of the United States Supreme Court. An attempt was made to take this case to the United States Supreme Court, but the writ of error was dismissed on a technical ground.

See also People $v$. Simon, 176 Ill. 165, 52 N. E. 910, 44 L. R. A. 801; State $v$. Westfall, 85 Minn. 437, 89 N. W. 175, 57 L. R. A. 297; National Bond Co. v. Hopkins, 96 Minn. 119, 104 N. W. 175; Robinson v. Kerrigan, 151 Cal. 41, 90 Pac. 129; People v. Crissman, 41 Colo. 450, 92 Pac. 949. There are a number of other cases to the same conclusion, especially in Illinois and Minnesota. See 34 Cyc. 598. The subject is completely annotated in $\mathrm{L}$. R. A. 1916 D. 14.

The case of American Land Co. $\%$. Zeiss, 219 U. S. 47, 55 L. 
time they drew it, the acts of the other states and were aware of the constitutional objections that had been raised against them from time to time. It is apparent from the Act as adopted that extra cautions was taken to enact a system as to which no such objections could plausibly be made. In many of the states the only notice given, in addition to the constructive seizure of the land by the entry of the sheriff and the posting of a notice on it, is by publication and by the mailing of notice to known claimants even though they are within the state and subject to personal service of process. This is the effect of the Massachusetts statute, the constitutionality of which has been sustained. The Georgia statute not only provides for such a seizure of the land, through the sheriff's physically entering thereon and posting notice, and by his notifying every occupant thereon above the age of fourteen ${ }^{1}$ as, in connection with notice by publication, to give a well recognized jurisdiction in rem, or quasi in rem, such as authorizes the court to render a decree fixing the status of the land conclusively as to all persons ${ }^{2}$; but it also

Ed. 82, while not involving what was called a Land Registration Act, sustained an act designed to the same end and resting on the same constitutional basis as the land registration acts.

1. See A. $\S 14$ and T. $\S \S 70,71$.

2. "There is no difficulty in making an actual seizure of personal chattels; but owing to the difficulty of making such a seizure of land, the law has invented the fiction of constructive seizure, which may be accomplished in many ways. For instance, the officer, armed with the process, may enter upon the land, exhibit his warrant of authority to the owner or the tenant in possession, at the same time declaring his intention of levying the writ in his hands, and thereby reducing the possession of the property to the custody of the court. Or, as is sometimes provided by statute, when the land sought to be seized is vacant, the officer may enter and proclaim his act by posting notices of seizure upon each separate parcel. These illustrations are by no means exhaustive, for the statutes of several of the States of the Union provide various other methods of accomplishing the constructive seizure of land." Smith v. Brown, $96 \mathrm{Ga}$. 274, 23 S. E. 849.

In United States $v$. Fox, 94 U. S. 315, 320, 24 L. Ed. 192, it is said: "The power of the State to regulate the tenure of real property within her limits, and the modes of its acquisition and transfer, and the rules of its descent, and the extent to which a testamentary disposition of it may be exercised by its owners, is undoubted. It 
provides for such service of process as is thoroughly established to be adequate (independently of the jurisdiction in rem) to confer jurisdiction on a court to quiet the title, through the provision that all known resident adverse claimants shall be served with process as in other actions and that all unknown and nonresident claimants shall be served by publication. ${ }^{3}$ While a

is an established principle of law, everywhere recognized, arising from the necessity of the case, that the disposition of immovable property, whether by deed, descent or any other mode, is exclusively subject to the government within whose jurisdiction the property is situated."

In the case of Pennoyer $v$. Neff, 95 U. S. 714, 727, 734, 25 L. Ed. $565,570,573$, in which the question of jurisdiction in cases of service by publication was considered at length, the court, by Mr. Justice Field, thus stated the law: "Such service may also be sufficient in cases where the object of the action is to reach and dispose of property in the State, or of some interest therein, by enforcing a contract or lien respecting the same, or to partition it among different owners, or, when the public is a party, to condemn and appropriate it for a public purpose. In other words, such service may answer in all actions which are substantially proceedings in rem.. . It is true that, in a strict sense, a proceeding in rem is one taken directly against property, and has for its object the disposition of the property, without reference to the title of individual claimants, but, in a larger and more general sense, the terms are applied to actions between parties, where the direct object is to reach and dispose of property owned by them, or of some interest therein. Such are cases commenced by attachment against the property of debtors, or instituted to partition real estate, foreclose a mortgage or enforce a lien. So far as they affect property in the State, they are substantially proceedings in rem in the broader sense which we have mentioned."

"It is also argued that the decree in the action to quiet title, set forth in the special finding, is in personam and not in rem, and that the court had no power to render such decree on publication. While it may be true that such decree is not in rem, strictly speaking, yet it must be conceded that it fixed and settled the title to the land then in controversy, and to that extent partakes of the nature of a judgment in rem." Essig $v$. Lower, 129 Ind. 239, quoted approvingly in Arndt $v$. Griggs, 134 U. S. 316, 33 L. Ed. 918.

3. "The question is not what a court of equity, by virtue of its general powers and in the absence of a statute, might do, but it is, what jurisdiction has a State over titles to real estate within its limits, and what jurisdiction may it give by statute to its own 
much less elaborate and perfect scheme of service might have been, and probably would have been adequate to shield the Act against constitutional objections for lack of due process of law stilll the framers of the Georgia Act have taken no chances whatever on this subject.

\section{$\S 20$. Estoppel against Constitutional Questions after} Land Is Once Registered.-The provisions in the Act 1 whereby the owner upon registering the land thereby is construed as having attached to his title a covenant running with

courts, to determine the validity and extent of the claims of nonresidents to such real estate? If a State has no power to bring a nonresident into its courts for any purposes by publication, it is impotent to perfect the titles of real estate within its limits held by its own citizens; and a cloud cast upon such title by a claim of a nonresident will remain for all time a cloud, unless such nonresident shall voluntarily come into its courts for the purpose of having it adjudicated. But no such imperfections attend the sovereignty of the State. It has control over property within its limits; and the condition of ownership of real estate therein, whether the owner be stranger or citizen, is subject to its rules concerning the holding, the transfer, liability to obligations, private or public, and the modes of establishing titles thereto. It cannot bring the person of a nonresident within its limits-its process goes not out beyond its borders-but it may determine the extent of his title to real estate within its limits; and for the purpose of such determination may provide any reasonable methods of imparting notice. The well-being of every community requires that the title to real estate therein shall be secure, and that there be convenient and certain methods of determining any unsettled questions respecting it. The duty of accomplishing this is local in its nature; it is not a matter of national concern or vested in the general government; it remains with the State; and as this duty is one of the State, the manner of discharging it must be determined by the State, and no proceeding which it provides can be declared invalid, unless in conflict with some special inhibitions of the Constitution, or against natural justice." Arndt $v$. Griggs, 134 U. S. 316, 33 L. Ed. 918.

"The legislature may provide for determining and quieting the title to real estate within the limits of the state and within the jurisdiction of the court, after actual notice to all known claimants and notice by publication to all other persons." Hamilton $v$. Brown, 161 U. S. 256, 40 L. Ed. 691. See also Tyler v. Judges, 175 Mass. 71,55 N. E. 812,51 L. R. A. 433.

1. A. $\S 64$. 
the land, that thereafter the land shall be dealt with in accordance with the provisions of the Act, is adequate to estop the owner at the time of the initial registration and his privies, that is persons subsequently buying the land or acquiring rights therein, from questioning the constitutionality of the features of the Act by which proceedings subsequent to initial registration take place, even if there should be constitutional objection to any of them. ${ }^{2}$

2. See T. $\S 117$. 
CHAPTER III.

\section{DefinITIONS.}

$\S$ 21. Certain Words and Phrases Defined.

$\S$ 21. Certain Words and Phrases Defined.-The Act, approved August 21, 1917, on the subject of land registration in Georgia entitled "An Act to provide for the assurance, registration and transfer of land titles, and interest therein, and for other purposes," in the first section of the Act, names itself thus: "This Act shall be known as 'The Land Registration Act' and may be cited or referred to by that name." In the course of this work where the word "Act" is used, unless the context indicates otherwise, it refers to the Land Registration Act.

In Section 3 of the Act certain further definitions are given which should be kept in mind in the various contexts in which the defined words or phrases are used in the Act and in the course of this book. These definitions, which are to apply unless the context plainly indicates otherwise, are as follows:

The words "registered land" shall include any estate or interest in the lands which shall have been registered under the provisions of the Act.

The words "the court" shall mean the superior court of the county wherein the land lies. ${ }^{1}$

The word "clerk" shall mean the clerk of the superior court of the county wherein the land lies, and shall include his lawful deputies, and any person lawfully acting as clerk under the provisions of the general laws of this State or of this Act. ${ }^{2}$

The words "judge" or "judge of the court," or "judge of the superior court," or "judge of the superior court of the county where the land lies," or words of similar import, shall be held and construed to mean, embrace and include any judge of the superior courts of this State presiding in the superior court of

1. See A. $\S 2 ;$ T. $\S 23$.

2. See A. $\$ \S 69$ and 83; T. $\S \S 267-8$; Civil Code, $\S \S 4881-4888$. 
the county where the land lies; and while it is intended that, as a usual matter, the judge of the superior courts of each circuit shall be the judge who shall act upon and sit in the various matters arising in that circuit with which the judges of such courts are charged under the provisions of this Act, still as to such matters any judge of the superior court shall have the jurisdiction to perform the functions of judge under this Act; and in the event that the judge of the superior courts of the circuit in which the transaction or matter arises is disqualified, absent from the circuit, ill, dead, or from any other cause cannot act in the matter, it shall be the duty of any other judge of the superior court of the State, to whom the matter is presented, to act in the matter to the same extent as if the same arose in one of the counties of his own circuit; and, furthermore, any judge of the superior court may in any matter arising under this Act, upon the request of the judge of the superior court of the circuit in which it arose, act upon it as if it arose in his own circuit.

The words "voluntary transactions" 3 shall be construed to embrace and mean all contractual and other voluntary acts or dealings (except by will) ${ }^{4}$ by any registered owner of any es-

3. As to voluntary transactions generally see Chapter $X$. See also T. $\S 139$ et seq. For the standard forms of voluntary transfers see A. $\S 107$, and for the standard form of mortgage see A. $\S 111$.

As to the voluntary cancellation of mortgages, creditor's certificates, liens, equities, encumbrances, lis pendens, etc., see A. $\$ \S 62$, 116 , and T. $\S \S 142,180$.

As to the voluntary transfer the owner executes to free the land from subsequent registration see Chapter XIV; also A. \$ 65.

Requirement that owner's certificate must accompany the registration of all voluntary transactions (except voluntary cancellation of liens, and other adverse claims): A. $\$ \S 37,117$; T. $\$ \S 140,141$, 270.

Voluntary transfers, involving trusts, powers, unusual limitations or conditions, are dealt with very much as if they were involuntary transfers. See A. § 56; T. § 204.

Voluntary transactions between husband and wife: A. $\S 48 ; T$. $\S \S 10,201$.

4. As to how the executor obtains and holds the registered title of the testator, and other matters relating to the disposition of the land after the owner's death see T. $\S \S 188-198$, and A. $\$ \S 42-47$. 
tate or interest in land with reference to such estate or interest and any right of homestead or exemption ${ }^{5}$ therein.

The words "involuntary transactions" " shall be construed to embrace and mean all other transmission 7 of registered land or any interest therein and all other rights or claims, judicial proceedings, liens, charges or encumbrances not created directly by contract with the registered owner, ${ }^{8}$ but arising by operation of law or of equitable principles, dower, ${ }^{9}$ the exercise of the right of eminent domain, ${ }^{10}$ delinquent taxes and levies, ${ }^{11}$ and all like matters affecting registered land or any interest therein.

Certain other definitions may also be given, here in advance, with profit:

"The certificate of title" is the certificate and all accompanying notations and entries which are entered on the Title Register to declare the ownership of the land and all the limitations, conditions, lesser estates, liens, encumbrances or other claims to which the title may be subject, whether entered at the time of the initial registration of the land or at the time of any subsequent change of ownership. ${ }^{12}$ It is the conclusive evidence of the ownership and of the fact that nothing affects the title except what is thereon noted.13

The "owner's certificate" is the duplicate of the certificate of title, at the time of its issue, which is issued and delivered to the registered owner. ${ }^{14}$ Owing to the fact that the certificate of title may be affected, after its issue, by matters entered on it and

5. See T. $\S 210$.

6. As to involuntary transactions, generally, see Chapter XI. As to involuntary transfers see A. $\S 41 ; \mathrm{T}, \S 144$. As to involuntary transactions other than transfers see $T$. $\S 145$.

7. All involuntary transmissions require order of judge to be registered; A. $\$ \S 41,50 ;$ T. $\S \S 144,270$.

8. As to how such rights, claims, judicial proceedings, liens, charges, encumbrances, etc., are to be registered, see $A . \$ \$ 49,51$, $54,61,112,113$ and $114 ;$ T. $\$ \S 173-8,187$.

9. See A. $\S 42 ;$ T. 190 .

10. See T. $\S 202$.

11. See A. $\S \S 57,112 ;$ T. $177,223$.

12. See Chapter VIII; Also A. $\S 28$.

13. See Chapter XIII; also A. \$ 63.

14. See A. $\S 28 ;$ T. $\S \S 133-4$. 
not entered on the owner's certificate, the owner's certificate is not conclusive evidence of the ownership or of the fact that nothing except what is contained thereon affects the title; ${ }^{15}$ but it may be given this effect by an entry, provided for in the Act, whereby its conformity to the certificate of title is verified by the clerk. ${ }^{16}$

A "total transfer" is a transfer wherein all of the title of the registered owner of the fee to all of the land contained in a certificate of title is conveyed, voluntarily or involuntarily, out of him and into another who in turn becomes the owner.

A "partial transfer" is a transfer wherein only a fractional undivided interest in the title of the registered owner or only a divided portion of the tract of land contained in a certificate of title is conveyed.

15. See T. $\S 226$.

16. See A. § 118; T. 227.

L. '. 


\section{CHAPTER IV.}

\section{Pleadings on Initial Registration.}

§22. Equitable Procedure But Not Equitable Jurisprudence Applies.

$\S 23$. Venue of Petitions for Registration.

$\S 24$. Filing and Docketing.

§ 25. Who Are Proper Petitioners for Registration.

$\S 26$. The Character of Ownership Required-Grantor and Grantee in Security Deed-Vendor and Vendee in Executory Sale.

$\S 27$. Persons or Corporations Having the Power of Appointing or Disposing of the Fee Simple.

$\S 28$. Corporations as Petitioners-Unincorporated Associations.

\$ 29. Infants and Other Persons under Disability as Petitioners.

$\S 30$. How Far Those Owning Less than Fee Simple May Invoke the Act

$\S$ 31. The Petition for Initial Registration.

$\S 32$. Suggestions as to Filling the Blanks in Prescribed Form of Petition.

§33. Same Continued-Appointment of Local Agent or Attorney by Non-Resident Petitioner.

8 34. Same Continued-Description of the Land.

$\S$ 35. Same Continued-Including Several Parcels in Same Application.

§ 36. Same Continued-Dividing a Single Tract into Parcels for Separate Registration.

§ 37. Same Continued-Allegation as to Value and Last Assessment for Taxation.

$\S 38$. Same Continued-Allegation as to Estate or Interest.

$\S 39$. Same Continued-Allegation as to Source of Ownership.

$\S$ 40. Same Continued-Alleging Title by Prescription.

$\S$ 41. Same Continued-Information as to Title Papers.

\$ 42. Same Continued-Information as to Homestead, Dower, etc.

§ 43. Same Continued-Statement as to the Occupancy.

\$ 44. Same Continued-Listing Adverse Claimants, Known and Unknown-Taxes.

§ 45. Same Continued-Listing Adjoining Owners and Occupants.

\$ 46. Same Continued-Easements.

§ 47. Same Continued-Age of Applicant-How Stated in Case of a Minor.

§ 48. Same Continued-Husband or Wife to Be Named as Defendant.

§ 49. Same Continued-Naming the Defendants. 
§5. Same Continued-The Abstract of Title.

$\S$ 51. Verification of the Petition.

$\S$ 52. Defensive Pleadings-Who May File.

$\S$ 53. Cross Petitions.

$\S$ 54. Verification of Defensive Pleadings.

$\S 55$. Demurrer-Slackness of Pleading Not Allowed.

$\S$ 56. The Time within Which Defensive Pleadings May Be Filed.

$\S$ 57. Right of Amendment.

$\S 58$. Severance.

$\S 59$. The Effect of a Severance.

$\S$ 60. Appearance and Pleading by Those Who Deal with the Land Pending Registration Proceedings.

\section{§ 22. Equitable Procedure, but Not Equitable Juris-} prudence Applies.-Except as otherwise provided in the Act itself, suits for the registration of land are subject to the general rules of equity pleading and practice. ${ }^{1}$ However, the action is not a suit in equity and is not governed by the principles of equity jurisprudence. This is an essential distinction, for if the suit were in equity, an applicant would be required to do equity in favor of every defendant; for instance, if it developed that there was outstanding a security deed which had been executed by the applicant, but which was void because made to secure a usurious debt, the applicant would be required to pay the debt, before he could demand registration of his title as against the usurious deed. However, the Act specifically declares that the action is in rem ${ }^{2}$; and, of course, it is competent for the legislature to declare that general rules of equity pleading and practice shall apply in actions at law or in any other class of actions.

$\S 23$. Venue of Petitions For Registration.-The suit is to be filed in the superior court of the county where the land lies. ${ }^{1}$ If it should be held that the suit is such a case "respecting titles to land" as is contemplated by Article 6, Section 16,

[§ 22] 1. A. § 5.

2. A. $\S 4$. However, it is more accurate to say quasi in rem or substantially in rem. See notes to T. $\S 19$.

[§ 23] 1. A. \$ 5 merely provided that the suit shall be filed in the court, but A. $\$ 3$ defines the word "court" to mean the superior court of the county where the land lies. 
paragraph 2, of the Constitution, which provides that "Cases respecting titles to land shall be tried in the county where the land lies, except when a single tract is divided by a county line, in which case the superior court in either county shall have jurisdiction," it is probable that it would also be held that a petition for the registration of a tract divided by a county line could be filed in either county. However, it would be safer in such case, in advance of an authentic ruling on this point, to file separate applications in each county.

$\S$ 24. Filing and Docketing.--The method of instituting the suit is by a petition 1 the substance of which is set forth in Section 7 of the Act and the form of which is prescribed in Section 86. Upon the petition being lodged with the clerk of the superior court, he should mark the same filed in office and should proceed to docket the same upon the issue docket as other cases are docketed. The forms prescribed in the Act indicate that in docketing and entering the cause the usual arrangement of plaintiff vs. defendant is not to be followed, but that, supposing the applicant to be John Smith, it should be docketed thus:

$\left.\begin{array}{l}\text { In re } \\ \text { John Smith }\end{array}\right\}$ Application to Register Land.

No specific provision of the Act declares the duty of docketing the proceedings, but the general law and the general rules of equity practice would seem to require it. It is proper, among other reasons, that it should be docketed so that the docket entry may operate as notice of the lis pendens. In the land registration acts of a number of the states, there is specific provision for docketing.

$\S$ 25. Who Are Proper Petitioners for Registration.Leaving out of present consideration the exceptional case provided for in Section 6 of the Act, those who are authorized to apply for registration of land are "the person or persons or corporation, claiming singly or collectively, to own or to have the

1. A. $\$ 5$. 
power of appointing or disposing of an estate in fee simple, whether subject to liens, encumbrances or lesser estates or not." 1 It is not necessary or appropriate that, where the application is made by the owner or owners of the fee simple, the owners of lesser estates, such as life estates, estates for years, dower, homestead, etc., or the holders of liens or encumbrances such as mortgages, mechanic liens, etc., should be joined as plaintiffs or applicants. They are normally defendants and should appear as such. ${ }^{2}$ However, if the plaintiff discloses their existence in the petition or if their existence is discovered by the examiner, or otherwise, it will be the duty of the court in rendering the decree to protect their rights. If the fee be held by tenants in common, all must join in the application. An undivided interest is not the subject of initial registration, though provision is made for the transfer of undivided interests subsequently. Likewise, lands owned by tenants in common, brought under registration, cannot be freed from the provisions of the Act except upon the unanimous action of all the co-tenants. $^{3}$

The fact that the applicant's title to the fee simple may be defeasible does not prevent his having it registered, the fact of its being defeasible and under what circumstances being stated in the decree and in the Certificate of Title. The fact that the Act makes such elaborate provision for setting forth, in the decree of title, the conditions, etc., that attach to the fee clearly constrains the construction that the word "fee simple" is not used in the Act in its narrowest and most technical sense, but in its broader sense of ownership capable of descending to one's heirs. See Civil Code, $\S 3657$.

$\S$ 26. The Character of Ownership Required-Grantor and Grantee in Security-Deeds-Vendor and Vendee in Executory Sale.-The Act describes the relation of the applicant to the estate in fee simple by the word "own." In the

1. A. $\S 5$.

2. A. $\S 9 ;$ T. $\S 49$.

3. A. $\S 65 ; T . \S 238$; see also T. $\S 105$ as to dismissal of the petition if the petitioner proves title to only an undivided interest in the land he seeks to register. 
form of decree prescribed in Section 97 of the Act the language is that the fee simple "belongs to," etc.; and the language of the certificate of title is equally unlimited as to the quality of the ownership; that is, as to whether the ownership shall be legal or equitable. This much is prefatory to the statement that a landowner may register his land notwithstanding the legal title has been conveyed by security deed to secure a debt. The holder of the security deed, of course, should be named as a defendant and his rights under the security deed carefully set forth in the decree and certificate of title.

Among the reasons for the construction that an owner with security deed outstanding, and, therefore, with only equitable title to an estate in fee simple, may cause the land to be registered is that the word "own" is similarly used in most of the acts in other states from which the Georgia statute has been adopted; and under these acts, in other states, the owner who has given a mortgage on the land may register it notwithstanding that in those states a mortgage passes legal title. The security deed in Georgia is sui generis, but it is substantially the legal equivalent of the common-law mortgage. ${ }^{1}$

It is also submitted that a vendee in possession under bond for title is a competent petitioner for the registration of the land, even though the purchase money is not paid in full. The vendor's rights and legal title are, of course, to be set forth and fully protected in the decree and on the certificate of title. The vendee in an executory sale is the true owner against all persons except the vendor; and the vendor merely holds the legal title as security for his unpaid purchase money. ${ }^{2}$

Undoubtedly with the consent of the vendor, the vendee in an executory sale can cause the land to be registered, for the two, "collectively" at least, are the owners. The same is true when the holder of the security deed joins with the owner of the equity redemption. If there is no default as to the indebtedness in the case of the security deed, or as to the purchase money in the case of the executory sale, the debtor or vendee

1. Powell, Actions for Land, $\S 386$.

2. Powell, Actions for Land, $\S 374$; Fulton County v. Amorous, 89 Ga. 614 (3), 16 S. E. 201; Widincamp $v$. Insurance Co., 4 Ga. App. $759,760,62$ S. E. 478. 
(considering the quality of the right of enjoying and controlling the land which they respectively possess prior to default) ought to be allowed to register the land despite objections from the creditor or vendor, as the case may be. On the other hand, after default, the court should dismiss the application if the vendor or creditor, as the case may be, objects to the registration. Prior to default, at least, the vendor in executory sale or the creditor holding security deed ought not to be allowed to register the land over the objection of the vendee or the holder of the equity of redemption, as the case may be. It may be added that these are mere questions of procedure, which must be raised prior to judgment and which are therefore concluded by the decree.

$\S$ 27. Persons or Corporations Having the Power of Appointing or Disposing of the Fee Simple.-Not only the owner of a fee simple estate is a proper applicant for the registration of land, but such an application may be made by any "person or persons or corporations claiming singly or collectively..... to have the power of appointing or disposing of an estate in fee simple." 1 Hence any one who has been granted the power of appointment, by deed or will, as to such an estate may cause the land to be registered at any time prior to the appointment taking effect. Likewise, any trustee (including an executor who is the donee of a power of sale under the will) upon whom the power of selling the fee is conferred may cause the land to be registered. In all such cases, the decree and certificate of title must be moulded so as fully to disclose the trusts or limitations to which the title is subjected. When a trustee holds the title but has no power to sell, the cestui que trust should join in the application. However, a power to sell is sufficient to authorize the application, though it is not a power to sell at a private sale.

$\S 28$. Corporations as Petitioners-Unincorporated Associations.-Corporations are competent petitioners for registration, whether claiming as owners or as having the power of

1. A. $\S 5$. 
appointment or of disposing of the fee. The Act requires no further evidence of the fact that the corporation has authorized the application by proper corporate action than that the petition must be sworn to by some officer of the corporation. ${ }^{1}$ However, it is quite appropriate that the judge before granting the decree should require proof by duly certified transcript from the minutes of the corporation, or otherwise, that the board of directors or other governing body of the corporation has in fact authorized the application. ${ }^{2}$ Unincorporated bodies or associations cannot register lands in their names, though the individuals comprising such bodies or associations may do so as the collective owners of the property.

$\S$ 29. Infants and Other Persons under Disability as Petitioners.--Infants and other persons under disability may sue by guardian, guardian ad litem, next friend or trustee, as the case may be. ${ }^{1}$ However, the principle announced in Section 5524 of the Civil Code that "A suit commenced and prosecuted by an infant is not void" is applicable to suits for the registration of lands. The $23 \mathrm{rd}$ paragraph of the form of petition contained in Section 86 of the Act requires the petitioner to state his age. If, in answer to this question, it develops that the petitioner is a minor, the Court should appoint a guardian ad litem. Furthermore, if it is disclosed in the course of the proceeding that the title or any interest in the land rests in a minor or person under disability, the facts should be made to appear in the decree and in the certificate of title (in the case of a minor stating his exact age), so that persons dealing with the land may be made aware of the disability and, in the case of a minor, will know when the disability will end.

$\S$ 30. How Far Those Owning Less Than Fee-Simple May Invoke the Act.-Any person claiming an interest or estate less than the fee may, provided he is in possession of the land, have his title to such interest or estate established by like

[28] 1. A. §7.

2. Under $\S 24$ of the Act the judge or examiner may compel the petitioner to state facts additional to those prescribed in the Act.

[29] 1. A. § 5 . 
procedure to that in the case of the owner of the fee, but in such cases the decree is not to be registered and no certificate of title is to be issued. By this provision, appearing in Section 6 of the Act, persons who are in possession of lands and have estates or interests therein, but who are not authorized to file petitions for registration because they do not own an estate in fee simple, and who wish the assurances of the Act as to their title or interest, so as to conclusively establish it according to its true extent and quality, may do so. Furthermore, if a petition were filed by one claiming as owner in fee and it should develop in the course of the proceeding that he did not own the fee simple, but only some lesser estate, it would be permissible for him to prevent a dismissal of his petition by filing an amendment, setting up his possession and lesser estate and praying for its establishment under this Section of the Act. ${ }^{1}$ While one, whose title is thus established, cannot have it registered so as to be able to convey it or pledge it under the provisions of the Act, and while his estate continues as an estate in unregistered land, still the decree rendered in his favor is conclusive evidence of his rights as therein established.

\section{$\S$ 31. The Petition For Initial Registration.-Since} Section 7 of the Act states the matters to be set forth in the petition and Section 86 prescribes the form in which they shall be set forth, these two sections are to be construed together, and in consonance with all the other provisions of the Act. Hence there is no reason why the form should not be varied to meet the exigencies of any particular case. For example, the form is designed for use in a case wherein the applicant is a person entitled to bring the land under registration and, therefore, the language is "The petitioner applies to have the land hereinafter described brought under the provisions of the Land Registration Act, and his title thereto confirmed and registered," etc.; but since, in case the application is made by one having a lesser estate than a fee simple, registration is not permitted, in such a case the form should be varied by omitting the words "and registered" in the clause just mentioned.

1. See T. $\S 104$. 
In the immediately succeeding paragraphs suggestions will be made as to what is deemed to be the appropriate method of preparing the petition and of filling in the blanks in the form of initial petition prescribed in Section 86 of the Act.

$\S$ 32. Suggestions as to Filling the Blanks in Prescribed Form of Petition.-The information required in paragraphs 1,2 , and 3 , of the form prescribed in Section 86 of the Act, viz., the full name of such applicant; residence of each applicant; post office address of each applicant, seem sufficiently simple to require no extended commentary. It may be noted, however, that paragraph 2 calls for residence and paragraph 3 for post office address. In filling paragraph 2, the applicant should state his legal residence, giving state and county, as well as city or town, if any; while in paragraph 3 he should give the full post office address to which he desires the notices, to which he may be entitled under the Act, to be sent.

$\S$ 33. Same Continued-Appointment of Local Agent or Attorney by Non-resident Petitioner.-If the sole petitioner, or any one or more of a number of petitioners, be nonresidents of the State, such non-residents, and each of them, must appoint an agent or attorney residing in this State, upon whom process and notices may be served; and it is in paragraph 4 of the petition that the designation of the local agent or attorney should be made and his address given.

$\S$ 34. Same Continued-Description of the Land.The requirement of the Act $^{1}$ as to the description of the land is that "it shall be in such terms as shall identify the same fully, and shall be such a description as shall tend to describe the same as permanently as is reasonably practicable under the circumstances; and if it be in a portion of the state in which the land is by State survey divided into land districts and lot numbers, in the petition there should be stated the number of the land district and of the lot number or numbers in which the tract is contained...... The acreage or other superficial contents of the tract shall be stated with approximate accuracy." It is also

1. A. $\S 7$. 
required that, where it is reasonably practicable to do so, the metes and bounds are also to be stated. The court may require fuller description and may require a survey. The element of description of the land is all important in any system of land registration. ${ }^{2}$ Indeed, while the rendition of the decree will cure many delinquencies of description, still if the description is so wholly deficient as not to identify the land the decree would be void; and, consequently, the registration.

It may be said that the description is the connecting link between the land and the title to the land, or between title in the sense of evidence of the right to own and title in the abstract sense of the ownership itself. Whatever may be true in an abstract or metaphysical sense, there can be no such thing in a legal and practical sense as title to an undefined and unidentified parcel of land. To sell a man an indefinite hundred acres of a two-hundred acre tract, without giving him any means of identifying which hundred acres he is to have, would be, in practical effect, to sell him nothing. In law, a deed, or a judgment, or a decree, ${ }^{3}$ or a certificate of title, in which the only description is, say " 100 acres off of lot of land No. 400 in the 6th district" of a named county, where that lot of land contains 250 acres, would not describe or bring within the operative force of the deed, judgment, decree, or certificate of title, as the case may be, any land at all.

The books are full of cases deciding what descriptions are and what descriptions are not void for lack of certainty; and it may be said that a decree or certificate of title containing a description, which, though meagre, would be definite enough to satisfy the demands of the law if it were contained in a deed or an ordinary judgment or decree, would not be void. However, the Land Registration Act contemplates that those administering it shall not be content with such descriptions as merely attain to legal certainty, and are yet loose and meagre in practical effect. For example, a deed containing the description, "the

2. The descripion, by being inserted in the published notice, aids the seizure for purposes of jurisdiction. See T. $\$ \S 19,64,71$.

3. As to necessity of adequate description for purposes of the decree of title see T. $\S 109$. 
plantation in Early County, known as the Jack Gay place" is legally sufficient and parol evidence is competent to identify what particular lands are included in what is called the "Jack Gay" place. But when the court registers the title to a tract of land, the language by which that land is identified, set apart and segregated from every other piece of land, should be such, if possible, that the words used would be as clear and definite and as informative to all interested persons a hundred years from now as they are today.

It would be extremely desirable if every landowner, before offering his tract for registration, should set at every corner permanent monuments of stone or other enduring material. The Act provides that the judge, or the examiner with the consent of the judge, may cause the land to be surveyed by some competent surveyor (after notice to all adjoining owners) and may order durable bounds to be set and a plat to be filed among the papers of the suit. ${ }^{4}$ Although this will entail some additional expense, and is not necessary where the location and extent of the land is already identified by things permanent in their nature, still in most cases the landowner will do himself and those who come after him a distinct service by demanding such a survey; for when such a survey is made, it not only causes definite and durable landmarks to be set, but it conclusively establishes the extent and boundaries of the applicant's tract. A land-line dispute is worse than a night-mare; it should be avoided, by every precautionary means, as if it were a plague.

\section{$\S$ 35. Same Continued-Including Several Parcels in} Same Application.-The Act provides in Section 8: "Any number of separate parcels of land, claimed by the petitioner, under the same general claim of title, and lying in the same county, may be included in the same proceeding." The word "parcel," though not always synonymous with the word "tract," is manifestly so used in this context, and means a defined area of contiguous land. In case more than one tract or parcel is included in the same application, each should be described with the same completeness as if it were the only one involved. The

4. See A. $\S \S 7,22 ;$ T. $\S 100$. 
limitations upon the inclusion of more than one tract in a single application are (1) that all shall lie in the same county; (2) that all must be claimed by the petitioner; (3) that all must be claimed "under the same general claim of title." Notice here that the limitation is not to lands held under "the same title" or "under the same chain of title," as some of the other Acts provide, but that the present language is broader. For example, if a person claims two plantations which, though not contiguous, he bought at the same time and under the same deed, he may be said to hold both "under the same general claim of title." If it develops that there is such dissimilarity as to the petitioner's title to the two or more tracts contained in the same application as that it is likely to confuse the issues or bring about delay or otherwise work injustice, the court or the examiner may order an amendment or severance ${ }^{1}$ under Section 24 of the Act, upon such terms as may be just and reasonable.

\section{$\S$ 36. Same Continued-Dividing a Single Tract Into} Parcels for Separate Registraton.-Furthermore, it is provided 1 that "any one tract may be established in several parts, each of which shall be clearly and accurately described and registered separately." Since the right given in Section 26 of the Act, to have the court render separate decrees (so as to authorize the issuance of separate certificates of title) for the sub-divisions or parcels into which the tract may be divided, is dedependent upon the petitioner's having "accurately described each parcel for separate registration," it is necessary that this requirement be met in connection with the description to be given under paragraph 5 of the prescribed form or in an amendment to be filed as provided in Section 24 of the Act. Therefore, if the petitioner desires to register his tract in parcels he must give not only an accurate description of the tract as a whole, but also of each parcel into which he undertakes to subdivide it.

[§ 35] 1. See T. $\S \S 57-9$. As to the duty of the court to order a severance where it appears that the petitioner has included in his petition two or more tracts not held under the same general claim of title, see T. $\S 106$.

[§ 36] 1. A. § 8. 
$\S 37$. Same Continued-Allegation as to Value and Last Assessment for Taxation.-Paragraphs 6 and 7 of the form require the giving of information as to the value of the land. ${ }^{1}$ Many of the fees and the assessment for the insurance fund are determined in accordance with the value of the land. The court is not bound by the value of the land as given by the applicant or as contained in his tax returns, still it is evidentiary on the question. It is to be noted also that, while paragraph 7 of the form does not disclose what assessment is referred to (i. e. whether county or city), Section 7 of the Act names "the last assessment for county taxation" as the one to be given.

§ 38. Same Continued-Allegation as to Estate or Interest.-The question propounded in the 8th paragraph of the petition as to what interest or estate the applicant claims in the land is, of course, important and should be answered with legal accuracy, and shouuld clearly disclose whether the applicant claims to "own or to have the power of appointing or disposing of an estate in fee simple" or whether he is merely seeking to establish his title to a lesser estate.

The question asked in paragraph 9 of the petition as to the value of the interest or estate claimed by the applicant has special pertinence when the applicant claims less than a fee simple, though it is appropriate to answer it in all cases.

§ 39. Same Continued-Allegation as to Source of Ownership.-In filling in paragraph 10 of the form, the applicant should give not only the name of the person from whom he acquired the land, but also the date, since this information as to date is required by Section 7 of the Act. The date, however, may appear from the information furnished by the abstract accompanying the petition.

$\S$ 40. Same Continued-Alleging Title by Prescription.-If the applicant claims title by prescription, the information given in filling in paragraph 11 of the form should be

[§ 37] 1. As to the examiner's fee, see A. $\S 120 ;$ T. $\S 260$. As to the assessment for the assurance fund, see $A$. $\S 74$ and $T$. $\S 249$.

[§ 38] 1. A. $\S \S 5,6$; T. $\S \S 25,27,30$. 
full, accurate and complete. The recitals, when prescription is claimed, should show that the applicant or those under whom he claims have had actual possession of the lands, as evidenced by inclosure, cultivation, or some other use and occupation thereof, so notorious as to attract the attention of every adverse claimant, and so exclusive as to prevent actual occupation by another, and that this possession has extended physically throughout the tract, or that such possession has been held as to a part of the tract under a deed or other written color of title including in its description the entire tract; also that such possession was had in the right of the applicant or those under whom he holds and not of another; that it did not originate in fraud; that it has been continuous, exclusive, uninterrupted, peaceable, and accompanied by a claim of right; that it is adverse possession; and that such possession has been so held for as much as seven years under color of title, or for as much as twenty years under claim of right in the absence of color of title. ${ }^{1}$ These details should be given specifically, being set forth with dates and particulars, and not in the form of conclusions: else the application will be subject to demurrer.

$\S$ 41. Same Continued-Information as to Title Papers.-In answering the questions set forth in paragraphs 12, 13 and 14 of the form, the applicant should take pains to answer them accurately. They are very material questions, and a false answer would subject the applicant to the penalty of Section 85 of the Act, which is even severer than the ordinary penalty for perjury.

$\S$ 42. Same Continued-Information as to Homestead, Dower, Etc.-In filling in the 15th paragraph of the form, if the land has ever been set apart as a homestead or as an exemption or as dower, the applicant should very carefully give the details of dates, names, etc., and a reference to the pages of public record where the proceedings are recorded. If it is claimed that the homestead or dower has expired or for any other reason has ceased to affect the title to the land, the reasons should be set out in full.

1. Powell, Actions for Land, Chap. XIII. 
$\S 43$. Same Continued-Statement as to the Occupancy.-In answering as to the possession, in response to the question asked in paragraph 16 of the form, if the applicant is in the sole physical occupancy of the land, he should merely assert "I am"; but, if he holds possession through a tenant or similarly, he should elaborate the answer thus, "I am in possession through my tenants Henry Smith and John Jones."

$\S$ 44. Same Continued-Listing Adverse Claimants, Known and Unknown-Taxes.-In filling in paragraphs 17, 18, 19 and 20, and the schedule which is a part of paragraph 19 of the form, ordinarily give names and not designations; $f(r$ example, do not say "the heirs of John Smith"; say "Mary Smith, Thomas Smith and Henry Smith." However, if the ap-" plicant knows or believes there are adverse claimants, but does not know their names or addresses, he should state the facts and designate the persons as clearly as he can; for instance, he may know that the land was once claimed by a man named Henry Smith, now dead, but may have no information as to who his heirs are or where they reside, in which event the applicant may designate these claimants as the "unknown heirs of Henry Smith" and, in the columns headed "residence" and "address," should also write the word "unknown." Remember that an adverse claim or interest is to be listed whether the applicant believes it to be valid or not. Failure to list a known adverse claimant is such fraud as may vitiate the registration except as to innocent persons. ${ }^{1}$

One matter that should not be overlooked by the applicant in filling in the schedule which is a part of paragraph 20 , and that is whether he owes any past due taxes. If so, they should be listed and the State, county or city, as the case may be, must be made party and served under Section 11 of the Act. Taxes on the land itself for the current calendar year in which the decree is rendered are not affected by the decree; and, if such taxes are not in default, they need not be set out in the petition. ${ }^{2}$

1. See T. $\S 219$.

2. See A. $\S 63$, T. $\S \S 211,223$. 
$\S$ 45. Same Continued-Listing Adjoinng Owners and Occupants.-Since the persons whose names and addresses are called for in paragraph 21 of the form-the owners and occupants of all adjoining lands-are defendants, care should be taken in filling in this part of the form. ${ }^{1}$ They are interested in the suit because of their interest in the boundaries stated in the petition. In the phrase "adjoining owners and occupants" used in Section 7 of the Act and in the phrase "owners and occupants of all adjoining lands," used in paragraph 21 of the form, the word "adjoining" is not absolutely synonymous with either the word "adjacent" or the word "contiguous." It is intended to refer only to such land as has an actual, and not merely a theoretical common boundary at some point with the land presented for registration. For instance, lots lying immediately across a public street, from each other, have theoretically a common boundary, namely the center of the street, but such lots are not "adjoining" in the sense in which that word is used in the present Act. ${ }^{2}$

$\S$ 46. Same Continued-Easements.-If the applicant recognizes the existence of an easement in favor of some third person, it should be stated in paragraph 22 of the form. If a third person claims an easement but the applicant disputes it, then it should be set forth in the schedule attached to paragraph 19 of the form.

\section{$\S$ 47. Same Continued-Age of Applicant-How Stated} in Case of a Minor.-In filling in paragraph 23 of the form, if an applicant is a minor, particular care should be taken to give the exact date (year, month, and day) of his birth. When a decree is rendered in favor of a minor, the exact age of the minor should be disclosed in it, ${ }^{1}$ as well as in the certificate of title, $^{2}$ so that notice may be taken of the disability and of the time when it will end.

[\$ 45] 1. As to the examiner's duty to check up the list of adjoining owners and occupants, see T. $\$ 84$.

[§ 45] 2. Fralinger $v$. Cooke, 108 Md. 682, 71 Atl. 529, 530; Spalding $v$. Smith, 162 Mass. 543,39 N. E. 189.

[\$ 47] 1. See T. $\S 110$.

[§ 47] 2. See T. $\S 127$. 
$\S$ 48. Same Continued-Husband or Wife To Be Named as Defendant.-The information as to the applicant's marital status, elicited in paragraph 24 of the form, is not so important in this State as it is in other states where husbands and wives have interests in the property of each other. However, the requirement of paragraph 25 is more important, since the wife so often has secret equities in the property occupied by the husband, and vice versa. ${ }^{1}$

$\S$ 49. Same Continued-Naming the Defendants.-In filling in paragraph 26 of the form, cognizance must be taken of the requirement of Section 9 of the Act, as follows: "The petition shall include as defendants all persons who by the petition are disclosed to have any lien, interest, equity, or claim adverse to the petitioner or otherwise, vested or contingent, upon said land or any interest therein." 'Therefore, all persons should be listed as defendants who are named in paragraphs 19 , 20,21 , and 25 , and also such of these who are named in paragraphs 16,17, and 18, and in the abstract of title, as have any claim, lien, or interest in or upon the land, other than the applicant or applicants. The naming of a person as a defendant does not necessarily mean that such person in any wise disputes the applicant's rights; for example, a tenant having a lease for more than three years should be made a defendant, since his is an interest which would be destroyed by the decree if it were not declared in it. The wife or the adjacent landowners may have no actual interest, but the lawmakers have deemed it best that they should be notified and have an opportunity to defend in all cases.

$\S$ 50. Same Continued-The Abstract of Title.-To the petition the applicant must attach a true and correct abstract of all his title papers. It should be kept in mind that the object of this abstract is to disclose, as far as may be, the true, full condition of the title. The abstract should show not only the title into the applicant, but should also show all mortgages, security deeds, and other similar encumbrances outstanding against the property. It is not necessary to include in the ab-

1. See T. $\S \S 49,83$. 
stract mechanic's liens, laborer's liens, judgments and liens of that character arising by operation of law; but these, of course, should be set forth in paragraph 20 of the petition.

$\S$ 51. Verification of the Petition.-It is provided in Section 7 of the Act that the petition "shall be signed and sworn to by each petitioner, or in the case of a corporation, by some officer thereof, or in the case of a person under disability, by the person filling the petition"; i. e. by the guardian, guardian ad litem, next friend or trustee who, by Section 5 , is allowed to file a petition in behalf of a person under disability. The form of the oath is prescribed in Section 86 of the Act. If there are two or more applicants, all must make the affidavit, but they may verify jointly or by separate affidavits. If the applicant is represented by counsel, the attorney should also sign the petition, at the place indicated in the form.

$\S$ 52. Defensive Pleadings-Who May File.-The issuance and service of process, the constructive seizure of the land, the publication of notice, manner of service, ${ }^{1}$ the reference of the case to the examiner, and the proceedings before the examiner ${ }^{2}$ will be discussed in detail elsewhere. It will be sufficient, in this context, to state that the process is returnable not less than forty nor more than fifty days from the date the petition is filed (though the judge has power to enlarge the time), and that as soon as practicable after the return day, but not until at least ten days shall have expired after service upon all persons entitled to service, the examiner proceeds to hear the matter.

"Any person whether notified or not may become a party to the proceedings for the purpose of filing objections to the granting of the relief prayed for in the petition, or any part thereof, by filing in court an answer showing that he claims some interest in the premises and the ground of his objection." 3

It is thus to be seen that the privilege of filing defenses is not confined to those who are named in the petition as defendants.

1. Chapter V, post.

2. Chapter VI, post.

3. A. § 18. 
Any party claiming an interest may be heard. The interest of the party thus objecting need not amount to a claim of title to the land; it may grow out of some lien, encumbrance, equity, easement or special right. If any one should captiously intervene and seek to defend or should set up an unfounded claim, it is within the power of the judge to tax against such a one such parts of the costs of the proceeding as may seem just. ${ }^{4}$

$\S$ 53. Cross-Petitions.-Furthermore, any person, whether notified or not, may become a party to the proceeding for the purpose of filing a cross-action praying that the title to the land or some interest therein be decreed to be in him, and registered accordingly. ${ }^{1}$ Not only is this privilege available to those who contest the applicant's title or some part thereof, but this is the appropriate remedy of those who, recognizing that the petitioner holds the estate in fee, claim some lien, encumbrance, easement, lesser estate or subsidiary interest of that nature. While the Act does not prescribe the form of the cross-petition, still the general rules of pleading would require that the matters set forth should be stated with reasonable definiteness and certainty.

Furthermore, if the cross-petitioner denies that the petitioner Folds such a title as is capable of registration, he should disclose by his cross-petition in practically the same manner as if he were original petitioner that he is entitled to have his title registered. Therefore, the cross-petition in such a case, should, in general details, correspond in form and substance with the original petition. ${ }^{2}$ Indeed, all the matters required to be set forth in the first fourteen paragraphs of the form prescribed for the original petition, with the exception of the 5th paragraph, should usually be set forth in such a cross-petition. If the cross-petition claims only a part of the tract or contests the description given in the original petition, he should set forth with all the accuracy demanded of an original petitioner the description that corresponds with what he claims. If the infor-

4. A. $\S 120 ;$ T. $\S 264$.

1. A. $\S 18$.

2. A. $\S \S 7,86 ;$ T. $32-51$. 
mation to be set forth in paragraphs 15 to 22 , inclusive, has been fully and correctly set forth in the original petition, it need not be repeated in the cross-petition. Paragraphs 23, 24 and 25 of the form should be included in the cross-petition. The crosspetitioner need not name any additional defendants unless he discloses adverse claimants not already notified in the proceeding, in which event the court should take steps to see that such new parties are served under the provisions of either Section 17 or Section 72 of the Act. An abstract of title should also be attached.

Though the cross-petitioner does not deny the original petitioner's title to the fee in toto, but merely seeks to assert an interest therein, as, for instance, when the original petitioner claims the entire estate and the cross-petitioner claims an undivided interest along with him, the cross-petition should be practically as full as where the original petitioner's title is denied.

When the cross-petitioner does not deny the original petitioner's title to the fee in whole or in part, then the cross-petition may be abbreviated, but all the information necessary to disclose fully the nature and extent of the claim asserted should be given fully and accurately.

Every cross-petitioner should verify his petition, varying the form of affidavit shown at the end of Section 86 to meet the requirements of the particular case. If he be a non-resident, he should appoint a resident agent or attorney in conformity to paragraph 4 of the form of original petition.

As has been previously stated, each provision of the Act is to be construed in connection with the other cognate provisions of the Act and with the Act as a whole, to the end of giving it effect as establishing a uniform and harmonious system; and with the Act thus construed it would seem that the requirements which apply to an original petitioner will apply to a cross-petitioner, so far as is necessary to effectuate the general scheme of the Act.

$\S$ 54. Verification of Defensive Pleadings.- Since the general rules of equity pleading and practice apply to the suit, ${ }^{1}$

1. See A. $\S 5 ;$ T. $\S 22$. 
the rule that when the petition is verified the answer should also be verified applies. ${ }^{2}$ Since by Sections 15 and 20 of the Act the relation of the examiner to the court is that an auditor or master in chancery, ${ }^{3}$ he is empowered under Section 5643 of the Civil Code to administer the oath necessary to the verification of any defensive pleading.

\section{$\S$ 55. Demurrer-Slackness of Pleading Not Allowed.} -While the Act makes no reference to the use of demurrer, still the better view would seem to be that either party may demur, either generally or specially, to the pleadings of the other. While the court should not allow one who is not served as a defendant and who does not disclose that he has some interest in the controversy to file demurrer to, and complain of deficiencies in the pleadings, still the court, including the examiner, has, under Section 24 of the Act, ample power, of its own motion, to require delinquencies in pleadings to be cured by amendment or otherwise, and may even require facts to be stated in addition to these prescribed in the Act; and this power should be freely used to compel fullness, fairness, definiteness and accuracy in all pleadings.

\section{$\S$ 56. The Time within Which Defensive Pleadings} May Be Filed.-The Act does not prescribe the time within which defensive pleadings may be filed. The better view seems to be that the court may allow them filed at any time before final decree. Such a construction seems to be consonant with the spirit of the Act, especially of Section 21, which forbids judgment by default. However, the examiner is not required when he fixes the time and place of the hearing to give notice to anyone except the petitioner and "to such persons as shall have filed any pleading in the case." 1 Furthermore, when he shall have concluded the hearing and filed his report, he is required to mail notice only to "each of the parties who have appeared in the cause." 2 Exceptions to the auditor's report must

[§ 54] 2. Civil Code $\S 5543$.

3. See T. $\S \S 77,88$.

1. A. $\S 19 ;$ T. $\S 88$.

[§56] 2. A. $\S 20 ;$ T. $\S 95$. 
be filed within 20 days from the time the report is filed; and only on exceptions to the report can jury trial be demanded. ${ }^{3}$ However, any of the parties to the proceeding may file exceptions to the auditor's report, though they did not appear before the auditor. ${ }^{4}$

The rule, therefore, would seem to be: that anyone who wishes to defend or file a cross-petition should do so on or before the return day stated in the process, but that failure to do so does not cut off altogether the right to be heard in the case; that orily the timely filing of pleading entitles one to notice of the hearing before the examiner, but that the defensive plearlings may be filed while the hoaring is in progress before the examiner, and that he should take into consideration the issues raised by the pleadings so filed; that he should not take into consideration pleadings filed after he has closed the hearing and while he is making up the report; that any party to the proceedings, whether he has filed pleadings or not, may except to the report; that even after the report has been filed and after the time for exceptions has expired any one claiming an interest in the controversy may file pleadings bringing the matter to the attention of the court, and that the court has the discretion, upon consideration of the matter presented, either to proceed to final decree upon the report of the examiner or, of his own motion, to recommit ${ }^{5}$ the record to an examiner for report on the matter presented in the new pleading. Certainly no purpose is more clearly written into the Act than the purpose that its provisions shall not be used by an applicant for registration to cut off just and material rights of another; and, therefore, ordinarily even though a matter affecting the petitioner's title is brought to the attention of the court at the very last minute, the court will not ignore it unless it be trifling and unimportant or unless the person asserting the adverse interest has been guilty of such gross neglect in presenting his claim as to justify the belief that he is not presenting it in good faith. The court

3. A. $\S 20 ;$ T. $\S 97$.

4. Mass. Bonding \& Ins. Co. $v$. Realty Trust Co., 139 Ga. 180; 77 S. E. 86.

5. A. $\S 20 ;$ T. $\S 99$. 
should, in practically all cases, allow a person who apparently has a valid claim and who has not been personally served with notice to have opportunity of such a hearing as will protect his rights. ${ }^{6}$

$\S$ 57. Right of Amendment.-Petitions, defensive pleadings and cross-petitions may be amended with leave of the court, at any time before final decree, upon terms that may be just and reasonable. ${ }^{1}$ Amendments must be verified. ${ }^{2}$

All the privileges allowed under general equity practice in this State in respect of the joinder, substitution or discontinuance of parties, whether petitioners or defendants, are specifically made allowable, by Secs. 5 and 24 of the Act, in suits under the Act. Indeed it may be that the privileges exist more broadly under the Act than under the general equity practice.

While it has been held in one state ${ }^{3}$ that it was not error to allow an amendment modifying the description so as to include additional land, still the decision seems hardly sound. Indeed it is probably distinguishable on the ground that what the court really held was that the allowance of the amendment was harmless error under the particular facts.

$\S$ 58. Severance.-Section 24 of the Act provides for a severance, to be allowed or ordered by the court, or the examiner with the approval of the court. The severance of a cause of action is the converse of the consolidation of two or more separate actions and has the effect of dividing a single suit into two or more distinct suits. ${ }^{1}$ This method of procedure, while

6. The Act forbids judgment by default by its letter as well as its spirit. A. $\S 21 ;$ T. $\S 102$.

[§ 57] 1. A. § 24.

2. A. $\$ 7$.

3. Tower $v$. Glos, 256 Ill. $121 ; 99$ N. E. 876.

[§ 58] 1. Bryan $v$. Speary, 106 N. C. 95, 11 S. E. 510. After severance, each action thus made separate should be separately docketed, and heard, and separate judgments should be rendered; each such judgment gives a separate right of appeal. Giller $v$. West, 162 Ind. 17,60 N. E. 548.

A very excellent discussion of severance of actions is found in 1 Corpus Juris., 1140 et seq.

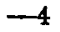


not familiar in Georgia, is frequently used in a number of States, and many instances are likely to arise in the administration of the Land Registration Act wherein it will be very expedient to make use of it. For instance, the petitioner includes in his petition two separate tracts claimed by him under the same general claim of title; ${ }^{2}$ as to one of these a defendant or group of defendants, not interested in the other tract, may appear and resist the application, while no resistance is made as to the other tract. Or a similar situation may arise where the petitioner includes in his petition only a single tract, but it appears that his title to only a part of it is contested. In such cases, the court may appropriately order a severance. ${ }^{3}$

$\S$ 59. The Effect of a Severance.-When a severance is ordered, all that has been done up to that time in the original case remains unaffected, and the record up to that point is common record in all the cases into which it may be divided. ${ }^{1}$ No new service of process or notice is required, unless new parties are brought in. ${ }^{2}$ - It is customary to make new docketings, with such notations on the dockets as will distinguish each of the cases from the others. The court, or the examiner, as the case may be, should order the pleadings, usually the defensive pleadings, so to be re-shaped as to show definitely and distinctly to what particular portions of the land each separated case relates $;^{3}$ and the order of severance should clearly set forth what is to be included in each of the suits into which the original suit is divided. Thenceforth the cases proceed separately, just as if separate applications had been originally filed. Separate judgments, separate decree, etc., are taken. In the event an appeal

[§58] 2. A. § 8; T. § 35 .

[\$ 58] 3. See also T. $\$ 106$.

1. In taking to the Supreme Court any of the cases into which the original cause of action has been severed, the record in any other of the cases, subsequent to the point of severance is not to be considered as record in the case being taken up and cannot be specified as such, but the record prior to the severance is common to all the cases and may be specified as such in any one or more of them. See T. \& 118.

[§ 59] 2. Hodges v. Railroad Company, 105 N. C. 170,10 S. E. 917. [§ 59] 3. A. $\S 24$. 
to the Supreme Court is desired in any of the severed cases, it is to be taken without reference to the other cases theretofore included in the original action. Since the record up to the time of the severance is common to all of the cases, it may be specified as record in any of them; the order of severance constituting the connecting link between the parent cases and its more or less numerous progeny. The allowance or ordering of a severance is always a matter of discretion with the court (or with the examiner, subject to review, on exceptions, by the court); and in connection with ordering or allowing it, the court may impose such terms as to costs, as to amendments, and other matters, as may be just and reasonable. ${ }^{4}$

\section{$\S$ 60. Appearance and Pleading by Those Who Deal With the Land Pending Registration Proceedings.-It is} provided in Section 25 of the Act that "The land described in any petition may be dealt with, pending registration, as if no such petition had been filed, but any person who shall acquire any interest in or claim against any such land shall at once appear as a petitioner, or answer as a party defendant, in the pleadings for registration, and such interest or claim shall be subject to the decree of the court." One purchasing the land from the applicant, pending registration, should, prior to final decree, make the fact known by petition to the court with prayer that he be substituted as petitioner. The substitution may be made under Section 24 of the Act. If the interest acquired during the pendency of the suit is not such an interest as conflicts with the applicant's ownership of the fee simple, as, for instance, if it is a mortgage, a judgment, a mechanic's lien, or something of that kind, the person acquiring the interest should intervene in the case as a defendant.

4. See T. $\S 106$. 


\section{CHAPTER V. \\ Process AND Notice.}

§ 61. Relation between Provisions as to Service and the Object of Suit.

$\S$ 62. The Process.

$\S$ 63. Copies and Second Originals.

§64. Service by Publication-Service on Non-Resident and Unknown Defendants.

$\S$ 65. Additional Service-When and How Ordered.

$\S$ 66. Defendants by Representation-Service on Some as Representatives of Numerous Class.

$\S 67$. Service upon the State, Counties and Municipalities.

$\S 68$. Acknowledgment of Service.

$\S$ 69: Waiver by Appearance or Pleading.

$\S$ 70. Perfecting Service on Persons under Disability.

$\S$ 71. The Constructive Seizure of the Land.

$\S 72$. Notice to the Occupants of the Land.

$\S$ 73. The Return of Seizure, Service and Notice-Traverse, How Far Allowable.

$\S$ 74. No Denial of Service after Judgment.

$\S$ 75. Adverse Claimants Disclosed by Examiner's Reports-Checking up Returns of Service by Examiner's Reports.

$\S$ 76. Provisions for Service Not Unduly Onerous-Effectiveness of the Provisions.

\section{$\S$ 61. Relation between Provisions as to Service and} the Object of the Suit.-The end sought to be accomplished by a suit for land registration is declared by Section 4 of the Act to be a decree operating directly on the land, vesting and establishing title thereto in accordance with the provisions of the Act (i. e. fixing the status as to title and matters affecting title) and also operating upon all persons who are parties to the proceedings, whether by name or under the general designation of "whom it may concern." Therefore, it was deemed expedient by the framers of the Act so to plan its provisions as that the jurisdiction of the court in which the proceeding is to be lodged would be acquired not only by the service of process or notice, adequate to satisfy the constitutional requirements as 
to due process of law, but also by such seizure or constructive seizure of the land itself as would confer jurisdiction in rem. ${ }^{1}$

$\S$ 62. The Process.--Section 20 of the Act, provides that the clerk shall issue a process directed to the sheriffs of this State and their lawful deputies requiring all of the defendants named in the petition (i. e. set forth in par. 26 of the form of petition for initial registration) ${ }^{1}$ and all other persons "whom it may concern" to show cause before the court on a named day, not less than 40 or more than 50 days from the date thereof, why the prayers of the petition should not be granted, and why the court should not proceed to judgment in the cause. A corresponding form of process is prescribed in Section 87 of the Act. The residence of the various defendants is or should be disclosed in the body of the petition or in the schedules, and all the names of all defendants, whether residents or non-residents, should appear in the process. The clerk fixes upon the day, not less than 40 or more than 50 days from the date of the process, to be inserted in the process, upon which the defendants should show cause. The process bearing test in the name of the judge of the superior court should, of course, be dated and signed by the clerk. ${ }^{2}$

$\S$ 63. Copies and Second Originals.-The petition having been filed and the process prepared and signed, the clerk is required to make out the necessary copies of the petition and process for service on all defendants residing in the county and enough second originals and copies for the service of all defendants resident in other counties of this State as process is served in ordinary action at law. ${ }^{1}$

$\S$ 64. Service by Publication-Service on Non-Resident and Unknown Defendants.-Non-residents and unknown defendants are served by publication. The Clerk prepares and causes to be inserted in the newspaper, in which the

[§ 61] 1. See T. $\S 19$.

[\$ 62$]$ 1. A. $\$ 86$.

2. Civil Code $\S 5552$.

[§ 63] 1. A. $\S 10$. 
advertisements of the sheriff's sales in the county are advertised for four insertions in separate weeks, a notice in the form prescribed in Sec. 88 of the Act. 1 This notice is addressed "to. whom it may concern" and also to each defendant who resides beyond the limits of the State or whose place of residence is unknown. It should contain a description of the premises accordingly as they are described in the petition $;^{2}$ should give notice of the filing of the petition and warn them to show cause on the day named in the process for that purpose. The publication of this notice not only operates as service upon non-resident and unknown parties but also tends to complete the constructive seizure of the land. However, if the address of any non-resident defendant, or any other non-resident who is disclosed in the course of the proceedings to have an interest in the controversy, appears from the petition or otherwise comes to the knowledge of the court, the clerk is required to mail to him, by registered mail, a copy of the petition and process. The mailing of this notice is merely a precautionary safeguard, and the jurisdiction of the court in no wise depends upon the addressee's receiving it.

$\S$ 65. Additional Service - When and How Ordered.It is provided in Section 10 that "the judge may grant additional time for service or return of the process, and may provide for service in cases not herein provided for wherever the exigencies of justice may so require"; and it is also provided in Section 72 that "Wherever notice is required by this Act and no provision as to how notice shall be given is made, or wherever, in the discretion of the judge, additional notice to that provided for in this Act, should be given to any particular person or persons, or to the public generally, the judge may order such notice to be given, and provide the manner in which it shall be given." The statute contemplates that, as far as reasonably practicable, notice to all residents of the State shall be given by process served as in ordinary actions; and, therefore, if in the course of the proceedings it appears that the applicant

1. A. $\$ 10$.

2. T. $\S 34$. 
has listed any resident of the State as being unknown or of an unknown residence and that there has been no service on such defendant otherwise than by publication, and the identity or residence of such defendant is thereafter disclosed, the court should order service of process on him to be made as in ordinary actions at law. The Georgia statute evinces a clear design of more thorough and specific notice than is required under the statutes of most states, but, since this is a safeguard against the Act being used as a means of the applicant's acquiring title to someone else's land rather than of settling a true title of his own, these safeguards should be rigidly observed and enforced by the courts.

\section{$\S$ 66. Defendants by Representation-Service on Some} as Representatives of Numerous Class.-When an adverse interest or claim is held collectively by a large number of persons, whose interests are identical, as, for instance, in the case of an unincorporated body or association, such numerous class may be made parties and served by representation under the principle announced in Civil Code, Section 5415, which adopts the long established rule of equity practice, that "Members of a numerous class may be represented by a few of the class in litigation which affects the interests of all." However, it is best in such cases to refer the matter in advance to the judge and have him pass an order, allowing class representation and directing as to whom the process should be served upon, under the authority given the judge in Section 10 of the Act of providing for service in special cases. An applicant, having an unincorporated church as an adjoining owner, would find this a very expedient method to be pursued.

$\S 67$. Service upon the State, Counties and Municipalities.-The method of service upon the State and upon counties and municipalities differs somewhat from the ordinary method. Section 11 of the Act provides: "If the petition discloses that it involves the determination of any public right or interest of this State, or of any county or municipality thereof, the process or notice, in order to affect the state or the county or the municipality, shall be served upon the Attorney-General, 
in the case of the State; upon the ordinary, in the case of a county (or, if the ordinary be disqualified, upon the clerk of the superior court) or upon the mayor of the municipality, in the case of a municipality (or, in case there is no mayor or the mayor is disqualified, upon a majority of the members of the council or other governing body of the municipality)." It is contemplated, of course, that when the officer named in the statute is served, he will at once take up the matter with the proper department or officer of the State, county or municipality, as the case may be, in order that the public interest may be properly protected.

$\S$ 68. Acknowledgment of Service.-While the service or notice to which any person may be entitled under the Act may be acknowledged or waived, still the Act has erected very stringent safeguards against fraud or forgery in connection with acknowledgments or waivers. ${ }^{1}$ The acknowledgment or waiver of service or notice must be in writing, and should be in the form prescribed in Section 89 of the Act, and should be entered on the petition; though it may be written on a separate paper provided it is "entitled in the cause," that is to say, the separate paper should be headed with the name and designation of the case and of the court in which it is pending. Even then, it is not to be considered by the court as sufficient, unless it is executed in the presence of the judge of the superior court or of the clerk of the court in which the case is pending, or of the examiner; and one of these officers must attest the signature. Of course, no judge, clerk or examiner, should attest a signature not actually made in his presence; and the Act not only saves an action in damages against a clerk or examiner who falsely attests, but also subjects him to severe penalties under Section 85 of the Act, if it be fraudulently done. ${ }^{2}$ By reason of the definition of the word "clerk" in Section 3 of the Act, a deputy clerk ${ }^{3}$ or any person lawfully acting as the clerk of the superior court under any of the provisions of the general laws

1. A. $\S 12$.

2. See also T. $\S 258$.

3. See A. $\S 83 ;$ T. $\S 268$. 
of this State ${ }^{4}$ or of the Act (i. e., the ordinary or the special clerk appointed under Section 69 of the Act) may also witness and attest such acknowledgments and waivers of service. The examiner, who is authorized to attest the acknowledgment or waiver, is manifestly the examiner to whom the petition has been referred, and not merely an examiner who may happen to hold an appointment from the court. Despite the strictness with which such acknowledgments and waiver must be executed, still the petitioner may usually save himself considerable expense by procuring friendly defendants to go before one of the proper officers and execute the necessary writing for that purpose.

$\S 69$. Waiver by Appearance or Pleading.-Any person by appearing or pleading (the Act uses the alternative) in the case at any stage of it, thereby waives process, service, notice, and any defect in either of them. ${ }^{1}$

$\S$ 70. Perfecting Service on Persons under Disability. - Service is completed upon minors, insane persons, and other persons under legal disability, by the appointment of guardians ad litem and the observance of the same requirements as apply in ordinary equity practice. ${ }^{1}$ The general statutes in this respect should be taken into account and carefully observed. ${ }^{2}$

$\S$ 71. The Constructive Seizure of the Land.-A constructive seizure of the land is provided for by the requirement that within 30 days from the time the petition is filed the sheriff or one of his deputies shall enter upon the land and post thereon in some conspicuous place a notice similar in form to that which is required to be published in the newspaper under Sections 10 and 88 of the Act. ${ }^{1}$ The sheriff is also in this connection required to enter upon the land and to ascertain and make official return to the court (in connection with his return of service, for which a form is prescribed in Section 90 of the Act) of the names and post office addresses of each and every

4. Civil Code $\S \S 4881-8$. See T. 267.

[§ 69 ] 1. A. $\S 14$.

$[\S 70]$ 1. A. $\S 10$.

2. Civil Code, $\S 5565$ and cognate sections.

[§ 71] 1. A. § 14. 
person above the age of 14 years actually occupying the land, including such members of the applicant's own household, if any, who are occupying any portion of it. If more than one tract is included in the petition, the sheriff must go upon each tract, post a notice and make return of the occupants over 14 years of age. Since land is incapable of manual seizure, the going of the sheriff upon the land, the posting of the notice, and the mailing of the notice to the occupants as elsewhere required constitutes such a constructive seizure as gives the court jurisdiction in rem. ${ }^{2}$

$\S 72$. Notice to the Occupants of the Land.-When the sheriff shall have made his return as to the occupancy of the land, the clerk should thereupon send, by registered mail, to each person included in the return a copy of the petition and process. ${ }^{1}$ However, if the petitioner so desire, he may have the sheriff to serve such occupants as if they were defendants. The clerk, in the event he sends the notices, makes the entry thereof; and the sheriff makes return in the event he makes the service.

\section{$\S$ 73. The Return of Seizure, Service and Notice-} Traverse, How Far Allowable.-The forms of returns or entries to be made by the clerk and sheriff are given in Sections 90 and 91 of the Act. After judgment, there can be no traverse of any of these returns or of any waiver or acknowledgments of service. ${ }^{1}$ The right to traverse any return, acknowledgment or entry of service, after it has once become a part of a court record, exists only by statute, and is subject to such limitations as the statute puts upon it. ${ }^{2}$ Hence this provision is valid.

2. See T. $\$ 19$.

[§ 72] 1. A. $\$ 14$.

[§ 73] 1. A. § 13.

2. At common law no official return of service could be contradicted or traversed. This rule obtained in this state until it was changed by statute, and it exists now only by force of, and within the limits prescribed by the statute. G. F. \& A. R. Co. v. Laseter, 122 Ga. 679; Jinks v. American Mfg. Co., $102 \mathrm{Ga}$. 694; Dozier $v$. Lamb, 59 Ga. 451.

The rule is applicable not only to sheriffs, but to all court officers. Albritton $v$. Tygart, 134 Ga. 485; Davant $v$. Carlton, 57 Ga. 489, 491; Saffold $v$. Foster, 74 Ga. 751. 
There is a negative pregnant in the language of Section 13 of the Act, that these entries and returns are subject to traverse prior to judgment. If so, the traverse should be made in the manner and under like limitations as exist in our statutes in reference to traverses in ordinary cases. However, any person aggrieved by a false entry or return, notwithstanding his inability to traverse the return, is given the right to hold the offending officer liable for such loss or damage as may have been occasioned him thereby. ${ }^{3}$

$\S 74$. No Denial of Service after Judgment.-It is provided in Section 14 of the Act that "the notices provided for and to be given under this and other sections of this Act shall stand as personal service of process (i. e., shall be given the same legal effect as if there has been personal service) and shall be conclusive and binding on all persons so notified, and on all the world." Section 13 of the Act places on the judge the duty of satisfying himself that all the service and notice required by the Act has been made, published and given, and it is therein further enacted that "the recital of service of process and of the giving and publishing of notices, contained in the decree or final judgment in the case, shall be conclusive evidence that such service, publication and notice have been legally given." 1

$\S$ 75. Adverse Claimants Disclosed by Examiner's Reports-Checking up Returns of Service by the Examiner's Report.-Furthermore, the examiner in his preliminary report, which is to be filed on or before the return day, unless the time is enlarged by the court, must make up a schedule of all persons who, from his examination of the application and the public records, appear to have any apparent or possible interest in the land. ${ }^{1}$ The examiner should indicate in his report how these persons are to be served. That is to say, if he finds that they are residents of the State and can be found, he should indicate that they are to be served with process as in ordinary actions; if they are non-residents of or unknown residence, he

3. A. $\S 13$.

[§ 74] 1. See T. $\S \S 101$ and 117.

[§ 75] 1. A. § 16. 
should indicate service by publication; and so-on in accordance with the general provisions of the Act, as to service. ${ }^{2}$ As soon as this report is filed, the clerk should check it up with the entries, returns, and acknowledgments of service already filed in the record, and, if it appears that there are persons who should be notified in addition to those already served or notified, he should take steps at once to perfect service upon such omitted persons. As to persons thus omitted and not named as defendants in the original petition, the clerk does not attach the ordinary process, but in lieu of it attaches to a copy of the petition a notice substantially in the same form as the process, but directed to the person to be notified, instead of to the sheriff, and informing him that he shall appear and show cause against the judgment being rendered in the case, if any he has, within ten days from the date of the service of the notice. This copy of the petition with the notice attached should be served on the person to whom it is directed by the sheriff of the county of his residence, if he can be found. ${ }^{3}$ No additional service is required if the omitted person be a non-resident of the State or of unknown residence or cannot be found and served; as to such person the notice already provided for by publication is sufficient. However, if the address of an omitted non-resident of the State is known the clerk should mail to him a copy of the petition and process as required in Section 10 of the Act.

$\S$ 76. Provisions for Service Not Unduly OnerousEffectiveness of the Provisions.-While the provisions for service under this Act are quite elaborate-more elaborate than is found in the similar acts of many states-still, it is submitted, they are not likely to prove unduly onerous in ordinary cases arising under the Act. It is only in the exceptional cases, principally cases where the applicant's title is really clouded by outstanding claims, that it will prove very troublesome to comply with the letter and spirit of the Act as to notifying all interested parties; and in such cases the relief to be had under the Act will

2. T. $\S \S 83-4$.

3. A. $\S 17$. 
usually be found to be worth all the pains and trouble it has imposed. Furthermore, those details of service, of publication, of posting notice on the land, of notifying adjoining owners, which are required in every case will be likely always to give such publicity to the proceeding as to make it extremely improbable that any case can be conducted so quietly as that all interested persons will not hear of it in time to protect their rights even if they are not formally notified. It will be more difficult to "steal land" under this Act, than under any other existing method of trying or quieting land titles. 


\section{CHAPTER VI.}

\section{EXAMINERS-REPORTS-EXCEPTIONS.}

§ 77. Examiners, General and Special-Considerations Influencing the Number to Be Appointed.

$\S$ 78. Term of Office, Eligibility and Official Oath.

$\S$ 79. Order of Reference.

$\S$ 80. Examiner's Preliminary Report-When to Be Filed.

$\S$ 81. Contents of the Examiner's Preliminary Report.

$\S$ 82. Same Continued-Examiner's Abstract of Title.

$\S$ 83. Same Continued-Schedule B.

$\S$ 84. Same Continued-Schedule C.

$\S 85$. Same Continued-History of the Possession.

$\S$ 86. Same Continued-Where the Examiner Finds the Description Insufficient.

$\S$ 87. How Far the Preliminary Report is Prima Facie Evidence.

$\S$ 88. Bringing the Case to Hearing before Examiner-Notice of the Hearing.

§ 89. Functions and Duties of the Examiner on the Hearing.

$\S$ 90. Special Powers of the Examiner-Independent Investigation.

$\S$ 91. Same Continued-Power of Examiner as Court Commissioners to Take Depositions.

$\S$ 92. Introduction of Evidence before the Examiner.

$\$$ 93. Employment of Stenographer.

$\S$ 94. Burden of Proof-Methods of Proof.

$\S$ 95. Examiner's Final Report.

§ 96. Exceptions to the Examiner's Report.

$\S 97$. Hearing on Exceptions-Jury Trial on the Facts.

$\S$ 98. Same Continued-Procedure and Evidence on the Trial before Jury.

$\S$ 99. Recommitment-New Trial.

$\S 100$. Survey-When Ordered-How Made-Trial of Protest to Surveyor's Return.

§ 77. Examiners, General and Special-Considerations Influencing the Number to Be Appointed.-Section 15 of the Act provides: "The judge of the superior court of each judicial circuit in this State shall appoint at least one master or auditor who shall be known as the examiner, and who shall discharge the duties provided herein for the examiner, but 
whose relation and accountability to the court shall be that of auditor or master in the general practice existing in this state ; and the judge shall appoint as many more examiners in the circuit as the public convenience in connection with the carryingout of the provisions of the Act may require, and may in any case appoint a special examiner."

It is contemplated that there shall be at least one examiner in each judicial circuit, but that there may be as many more as may appear to be necessary. Among the considerations that should control in determining the number of examiners to be appointed in any circuit are these: it would add somewhat to public convenience if there were at least one examiner in each county, and if there were an examiner in each county he would likely be more familiar with titles and with the public records in that county than an examiner coming in from another county would be; on the other hand it is very desirable that the examiner shall be a high-class lawyer, thoroughly competent to compass and discharge the duties of the office; the fees allowed to examiners under the Act are not high enough to attract highclass lawyers, unless there is a considerable volume of cases coming before them; the greater the number of examiners there are in a circuit, the smaller will be the volume of cases coming to each. Therefore, it would seem expedient that at first only a limited number of examiners should be appointed, perhaps only one, and that as the number of applications filed increases, the number of examiners should be increased accordingly.

The form to be used by the judge in appointing an examiner is found in Section 92 of the Act.

$\S$ 78. Term of Office, Eligibility and Official Oath.Examiners hold their office at the pleasure of the judge and are removable at any time with or without cause. ${ }^{1}$ No one is eligible to appointment to the office unless he is a competent attorney-

[\$ 77] 1. As to the verification of defensive pleadings before the examiner, see $T$. $\S 54$.

The judge may use the examiner in this relation in connection with proceedings pending before him on applications for involuntary transfers. A. $\S 50 ;$ T. $\S 166$.

[§ 78] 1. A. § 15 . 
at-law, of good standing in his profession, and of at least three years' experience in the practice of law. While the Act does not so require, still, considering the nature of the duties of the office, it is extremely important that no one should be appointed to this office unless he possesses the highest personal integrity; and it is also very desirable that he should be experienced in land-title work. Each examiner, whether appointed generally or for a special case, must qualify by taking the oath prescribed in Section 93 of the Act. This oath and the order of appointment are not to be filed as a part of the record in the case, as in the practice in respect of auditors, but the order of appointment and the oath are to be filed in the office of the clerk of the superior court of the county in which the examiner resides.

$\S$ 79. The Order of Reference.-As soon as a petition is filed with the clerk, he should notify the judge, giving him the name of the applicant, and such detail in regard to the land, for example, the location, the amount and value of it, as will enable the judge intelligently to decide what examiner he will refer it to. The judge will thereupon pass an order in the form prescribed in Section 94 of the Act referring the cause to one of the general examiners in his circuit, or to a special examiner. ${ }^{1}$ It is suggested that, as a matter of courtesy to the judge, either the clerk or the attorney filing the application should prepare the order of appointment in the prescribed form, leaving the space for the name of the examiner blank, and that this should be forwarded to the judge along with the clerk's letter notifying him of the filing of the petition. This order of reference should be forwarded by the judge to the examiner or by the judge to the clerk, who should promptly forward it to the examiner. It becomes a part of the file in the particular case, and it is appropriate that it should be attached to the examiner's first report.

$\S$ 80. Examiner's Preliminary Report-When to Be Filed.-Upon receiving the order of reference, the examiner should proceed promptly to make up his $e x$ parte or preliminary report, as it is called, as it is contemplated that this report shall be filed in the office of the clerk on or before the return day

1. A. $\S 16$. 
which is not less than 40 nor more than 50 days from the date of the filing of the petition, though, if necessary, an extension of this time may be granted by the court. ${ }^{1}$

\section{$\S$ 81. Contents of the Examiner's Preliminary Report.} -A form of the examiner's preliminary report is set forth in Section 95 of the Act. Three material schedules are to the included in it: (a) an abstract of the title; (b) a schedule showing the names and addresses of all person apparently or possibly interested in the land, describing the nature of their interest and indicating which of them should be served or given notice and in what manner; (c) a schedule disclosing the names and addresses of all adjoining landowners; ${ }^{1}$ also there should be embodied in the report a statement of the facts relating to the possession and any other matters which the examiner deems it appropriate to call to the attention of the court and the parties.

\section{$\S$ 82. Same Continued-Examiner's Abstract of Title.} -For the purpose of making up the abstract to be shown in Schedule $\mathrm{A}$ of his preliminary report the examiner is required to make a search of all such public records as a skilled abstractor would make if he were preparing an abstract for a loan company or for some other client demanding full and complete information. As an aid to him in this respect (as well as to enable him to perform any other duty required of him under the Act), it is provided in Section 68 of the Act that "Every clerk of the superior court, every ordinary and every other officer in this State, having charge of the public records shall allow each and every examiner appointed by any court in this State, for the purposes of this Act, free inspection of all the public records relating to his office and in any wise appertaining to any matter under the examination of such examiner." However, the examiner is not confined to public records, but should include in the abstract all such other information as he can obtain, based on evidence of a trustworthy nature. The abstract must contain full enough extracts from the records and from

$[\S 80]$ 1. A. $\S 16$.

[§ 81] 1. As to who are adjoining landowners, see T. $\S 45$. 
any other writing referred to in the abstract to disclose the effect thereof with reasonable certainty. In fine, the abstract should contain all the details which a properly prepared abstract should contain if prepared for a private person who was seeking to ascertain and deal with the true owner of the land, on a basis of all possible certainty as to the title and as to all possible liens, equities and encumbrances which might affect it. Let the examiner always keep in mind that, in doing this work, he is making an abstract for the State of Georgia, and for the purpose of protecting every person "whom it may concern," and not for the purpose of establishing or disestablishing title in the petitioner; that, if he fails to do this work well, some innocent person may suffer.

§ 83. Same Continued-Schedule B.-If, in running down the title, the examiner finds one or more rival claims of title apparently adverse to those of the applicant or not connecting up therewith, he should insert in Schedule $B$ the names and, if possible, the addresses of the persons in whom the title would repose if such a rival claim or claims should be held to be valid. Likewise, if he finds evidence of homesteads, dower rights, easements, uncancelled judgments, mortgages or other liens, whether against the applicants or affecting some prior holder of the title during the period the title reposed in him, these should also be set forth in Schedule B. It is suggested that this schedule should be made, so far as form is concerned, in general conformity to the schedules shown as a part of paragraph 19 of the form of petition for registration. However, an additional column should be included in which the examiner should indicate how service or notice should be given to the persons named in the schedule. ${ }^{1}$

The examiner in connection with making up the schedule should always ascertain whether the petitioner owes any past due taxes or other public assessments; and, if any exist, they should be listed in the schedule. ${ }^{2}$ Remember, too, that the Act

1. A. § 16 .

2. See T. $\S 44$, as to listing the State, county or municipality as a defendant in such cases. 
makes an applicant's husband, or wife, a possible adverse claimant in all cases; and that, if the applicant is married, the name of the spouse should always be included in this schedule. ${ }^{3}$

$\S$ 84. Same Continued-Schedule C.-In Schedule C. the examiner should insert the names and addresses of all adjoining owners and occupants as he finds them to be. ${ }^{1}$ This should in form generally correspond to the form suggested for Schedule $B$. The duty of the clerk to check up the list of the persons entitled to notice, according to Schedules $\mathrm{B}$ and $\mathrm{C}$ of the examiner's report, with the entries, returns and waivers of service already on file in the case, and of seeing that the omitted persons are notified is dealt with in another context. ${ }^{2}$

\section{$\S$ 85. Same Continued-History of the Possession.-} The examiner should give such a history of the possession as he can obtain from trustworthy sources, stating details and not conclusions. Owing to the provisions of Section 16 of the Act which makes the report prima facie evidence of its contents, the examiner should not make statements as to the possession, as facts, unless he knows them to be true of his own knowledge. For instance, if the examiner has information that the possession of the land began by Charles Willingham's building a house thereon ir. 1858 but does not know it of his own knowledge, he should incorporate the statement in his report with a qualifying clause, thus: "I am informed that the first possession of the land was held, etc." The same method of distinguishing between facts known to the examiner and mere information obtained by him should be observed in calling other matters to the attention of the court. 1

$\S$ 86. Same Continued-When the Fxaminer Finds the Description Insufficient.-One of the matters which the blank in the preliminary report as to bringing matters to the special attention of the court may be used for is to call attention to the

3. See T. $\S 48$.

[§ 84] 1. As to who are adjoining owners and occupants, see $T$. $\S 45$.

2. A. $\S 17 ;$ T. $\S 75$.

[§ 85] 1. See T. $\S 87$. 
inadequacy of the description or the need of a survey, a matter as to which the examiner is authorized to recommend under Section 7 of the Act. ${ }^{1}$

\section{$\S$ 87. How Far the Preliminary Report Is Prima Facie} Evidence.-It is provided at the close of Section 16 of the Act that "the said report (i. e., the examiner's preliminary report) shall be prima facie evidence of the contents thereof." This does not say or mean that all the documents referred to in the report are to be taken as prima facie genuine or valid or that all the information recited therein is to be taken as prima facie true. Take, for instance, the abstract contained in Schedule A; the incorporation of it into the report is prima facie proof that it is a true and correct abstract, that it contains a memorandum of all writings to be found on the public records and other trustworthy sources relating to the title, and any person asserting the existence or record of any other document not included therein would have the burden of proving it.

It is also prima facie evidence that such documents as are listed as being recorded in a particular record are so recorded. Where the abstract contains a summary of a judgment or other court proceeding, the burden of denying that such a court proceeding took place, or that the memorandum made of it is not full or accurate, would be upon the party challenging the correctness of the report. As to such matters, unless proof to the contrary is made, the statement in the abstract of the examiner as to the contents of records should be given the same effect as if it were a certified copy of the record.

However, the inclusion of the memorandum of a deed or other writing in the abstract is no evidence of the genuineness or validity of such deed or writing. The memorandum in the examiner's abstract may, prima facie, be used as evidence under the same limitations and with the same effect as if the party relying on it had produced in court a certified copy of the writing, provided it be such a writing or document as is entitled to record; and this is as far as the examiner's preliminary report

1. As to how the survey is to be ordered and made and how protest thereto is to be tried, see A. $\S 22 ;$ T. $\S 100$. 
is evidence as to the execution or genuineness or validity of the writings briefed in the abstract. Likewise, if the examiner states in this report any fact relating to the possession or other special matters to be brought to the attention of the court or the parties, and this fact is stated as of the examiner's own knowledge, it is to be taken as prima facie true, but when the report shows that the examiner is merely conveying to the court information derived from others, the recital in the report is merely prima facie evidence that such information came to the attention of the examiner. ${ }^{1}$

Any information likely to affect the title or the possession, brought to the attention of the examiner, ought to be included in the report, so that the information may be before the court and the parties for investigation, and so that any person likely to be interested in the result of the suit, if the information be true, may be notified; but the inclusion of such information in the report does not give it any value as evidence of the substantive facts to which such information may relate. It is to be understood, of course, that the report here under discussion is the preliminary report of the examiner, made ex parte, and not the final report to be made after he has given the parties the opportunity to be heard.

$\S$ 88. Bringing the Case to Hearing before Examiner -Notice of the Hearing.-As soon as practicable after the return day stated in the process and after such special return day as may have been inserted in such special notices as may have been served under Section 17 of the Act, the examiner should set the case down for hearing before him. ${ }^{1} \mathrm{He}$ is required to give notice of the time and place of hearing to the petitioner and to such other persons as shall have filed any pleading in the case. ${ }^{2}$ How much notice shall be given, and how it shall be given, is not prescribed. Reasonable notice should be given. $^{3}$ It may be sent by mail. ${ }^{4}$ Since by Sections 15 and 20

[§ 87] 1. See T. $\S 85$.

[§ 88] 1. A. $\S 19$.

2. See T. $\S 56$.

3. Compare Civil Code, $\S 5130$.

4. Littleton v. Patton, 112 Ga. 438, 37 S. E. 755. 
of the Act he is to proceed "in like manner as other auditors or masters in chancery" he should not hear evidence or argument out of the county in which the case is proceeding, except by the written consent of all parties. ${ }^{5}$

$\S 89$. Functions and Duties of the Examiner on the Hearing.- - In the progress of the hearing, the examiner's functions are those of an auditor, the statutory substitute in this State for a masfer in chancery. The examiner therefore has the powers, as set forth in Section 5129 of the Civil Code, "to hear demurrers, allow amendments, and pass upon all questions of law and fact"; and in cases of contempt committed before him by parties, witnesses or other persons, of having the offenders brought before the judge for punishment. By Section 20 of the Act, as well as by the section of the Code just mentioned, he has the power of compelling the attendance of witnesses, the production of books and papers, of adjourning and recessing, and of hearing all evidence submitted. Section 24 of the Art gives him the power not only of allowing "amendments to petitions or other pleadings, or the severanze ${ }^{1}$ thereof, including joinder, substitution or discontinuance of parties, and the omission or severance or any portion or parcel of the land," but also of ordering these things to be done in appropriate cases, upon such terms as may be just and reasonable. Likewise, he may require facts to be stated in the petition in addition to those prescribed by the Act. $\mathrm{He}$ is also, by Section 7 of the Act, empowered to recommend to the court that the plaintiff be required to give a more adequate or permanent description of the land, with survey and narking of boundaries, if necessary. ${ }^{2}$

Upon his request, the clerk shall issue commission for the taking of testimony of such witnesses as under the provisions of the general law on that subject may have their testimony taken by interrogatories in ordinary actions. Indeed it would seem that the parties would have the right to serve the notice and sue out commissions to take interrogatories, under the several statutes on that subject, without the request of the exam-

5. Civil Code, $\S 5130$.

1. See T. $\S \S 58-9,106$.

2. See T. $\S 34$. 
iner; and it is probable that the clause of Section 20 of the Act on this subject relates more particularly to cases when the examiner is making an independent examination, as to which see Section 90 infra.

\section{$\S$ 90. Special Powers of the Examiner-Independent} Investigation.-Besides the general powers of an auditor, the examiner has certain special powers conferred on him by the Act. ${ }^{1}$ In addition to hearing all lawful evidence that may be submitted before him by the petitioner in uncontested cases or by any of the parties in contested cases, he is empowered to make such independent examination of the title as he may deem necessary. The intention of the Act is that no one should be allowed to register land unless he really owns it, and the examiner is expected to subserve this policy of the law by his indedependent investigation. He may cause documents not introduced before him by any of the parties to be brought before him by subpoena duces tecum, or order to produce; and, in case he has evidence that such a document is beyond the jurisdiction of the court, may, if it be a registered document, use copy from the records, or may obtain other secondary evidence of its contents. He may cause witnesses not offered by either party to come before him and testify, or may cause the clerk to issue commission to take the testimony of witnesses, not subject to subpoena, by interrogatories. ${ }^{2}$ He may make personal investigation into physical facts, such as the possession of the land or other subjects of physical inspection and knowledge. The matters obtained by the independent examination of the auditor are to be separated in the proceedings from the evidence adduced by the parties and are to be included in a separate division of the examiner's final report. ${ }^{3}$

$\S$ 91. Same Continued-Power of Examiner as Court Commissioner to Take Depositions.-Another special function of the examiner is that of exercising the powers of taking testimony, such as is conferred on superior court commissioners

1. A. $\S 20$.

2. T. $\S 89$.

3. A. $\S 96$. 
by Se:tions 5910 to 5917 of the Civil Code; that is to say, the power of taking depositions for subsequent use, if the same be found to be competent or relevant to the issue, on the hearing of the case before the auditor or court. While he may not (as stated in Section 88 supra) hear evidence without the consent of the parties outside of the county in which the suit is pending, still that relates to the judicial hearing of the evidence, and has no application to the taking of depositions under the powers here being discussed. It is doubted, however, that an examiner could lawfully take depositions out of his judicial circuit, except upon consent of the parties. The power here referred to may be exercised by him either before or after the formal hearing of the case has been begun before him.

$\S$ 92. Introduction of Evidence before the Examiner.The hearing before the examiner proceeds in general respects as if it were a hearing before the court. The general rules as to the introduction of testimony and as to the competency and relevancy of evidence apply. The examiner, nevetheless, receives all evidence offered, even though he deems it inadmissible, ruling upon it in the course of his report, nevertheless reporting it to the court for final action, if exception be taken to his ruling. ${ }^{1}$ Indeed the examiner should make a careful note of every ruling made by him in the course of the hearing.

$\S$ 93. Employment of Stenographer.-Section 71 of the Act provides: "In any case, by consent of the parties or on order of the judge, the examiner may procure the services of a stenographer to report the testimony taken before him, and the compensation of such stenograhper, unless agreed on by the parties, shall be fixed by the judge and taxed as costs." Unless the parties and the stenographer agree on his compensation, he is entitled to be paid "his usual fee" 1 that is to say, the usual fees allowed by law to stenographers in the superior courts for reporting and transcribing the testimony in civil cases.

[§ 92] 1. Civil Code $\S 5132$.

$[\S 93]$ 1. A. $\S 120$. 
$\S$ 94. Burden of Proof-Methods of Proof.-The petitioner is the plaintiff, and it follows that the burden of proof rests on him, and this burden is not carried in this proceeding until he has made at least a prima facie showing that he has title good against the world to the estate or interest that he claims. ${ }^{1}$ He may do this by showing a perfect chain of title from the original source of title (usually the State) to himself $;^{2}$ or by showing a prescriptive title arising either from twenty years of actual adverse possession without color of title or of seven years of adverse possession under color of title.

The plaintiff cannot, in this action, as he might in some actions, succeed on proof of mere prior possession not sufficient to create prescription or by tracing title to some common grantor under whom he and some particular defendant may both claim, though he might thereby negative or suceessfully defend against the adverse claims of such a defendant and those setting up rights under him. However, it is submitted that where a petitioner shows that he claims directly as, or by intermediate conveyances from the heir of one dying in possession of the land, he makes a prima facie case of ownership unless there is something on the face of the record to show that the ancestor so dying in possession did not own or did not claim the fee simple. ${ }^{3}$ When the petiticner claims title by prescription and shows adverse possession for the requisite statutory period, he is not primarily charged with the burden of negativing the existence of disabilities on the part of the holder of any adverse title. The burden of proving disabilities is on the person asserting them $;{ }^{4}$ unless, of course, the same appears on the face of the record.

Prima facie, the burden of proving all liens, encumbrances, equities and adverse interests of every kind, not admitted by the petitioner (and the inclusion of them in the petition is not to admit them) is upon the person asserting them. However, and

1. A. $\S 21 ;$ T. $\S 102$.

2. As to what other original sources of title there are in Georgia, see Powell, Actions for Land, $\S \S 131,174$.

3. As to this rule and the rationale of it, see Powell, Actions for Land, §§ 303-4.

4. Powell, Actions for Land, $\S 342$. 
especially is uncontested cases, the examiner should exercise the power of independent investigation given by the Act to see, as far as he reasonably can, that the plaintiff, even though lue makes out a prima facie case of title, is in fact the true owner; and should also make such inquiry into the matter of liens, encumbrances, and things of that kind, especially matters appearing on the public records, as to satisfy himself that they are not valid or are no longer outstanding.

§ 95. Examiner's Final Report.-It is provided in Section 20 of the Act that "Within fifteen days after such hearing shall have been concluded the examiner, unless for good cause the time shall be extender' lyy the judge, shall file with the clcrk a report of his conclusions of law and fact, setting forth the state of the title, any liens or encumbrances thereon, by whom held, the amounts due thereon, together with the abstract of title to said land, and any other information affecting its validity, and a brief, or a stenographic report of the evidence taken by him." This is to be construed in connection with Sections 5131 to 5133 of the Civil Code, relating to auditors' reports, and making substantially the same requirements. In Section 96 of the Act, a form of examiner's final report is suggested, thereby indicating how the requirements of that portion of Section 20, quoted above, and of the general rules on the subject are to be complied with.

An examination of this form is instructive. It is to be recalled that the preliminary report of the examiner is prima facie evidence of its contents and, also, that is contains an abstract of the title. Therefore, the form prescribed for the final report is so designed that the examiner may have opportunity of showing how far and wherein his preliminary findings should, in his opinion, be modified by what has taken place on the hearing. Also, since the preliminary report contains an abstract of the title, the requirement of Section 20, that the final report shall contain an abstract of the title, is met by making the preliminary report, with the modifications which the examiner shall set forth, a part of the final report.

The examiner should set forth a resume of the proceedings 
which were had before him, including a statement of his rulings on all evidence, on demurrers, on motions and all similar matters, and also a brief or stenographic report of the evidence. Under Section 5131 of the Civil Code, "At the request of either farty, any original document introduced in evidence may be F:cperly identified and attached to the report in lieu of a brief thereof."

The examiner should also include a statement of the matters ascertained by his independent examination. The form contemplates that this shall be set forth in separate exhibit, so that the separateness between it and the evidence may be emphasized.

Section 5133 of the Civil Code provides that the auditor (and, hence the examiner) in his report "shall clearly and separately state his findings and report his conclusions upon the law and facts." The form provides for this classification, and, in addition, provides for his complying with the provisions of Section 20 of the Act by giving his summarized conclusions as to the state of the title, with the particulars as to liens, encumbrances, etc.

While the Act does not so state in terms, still, in accordance with the rule applicable to other auditors, the examiner may file an alternative report, in which, after stating his conclusions of law and of fact, he may set forth that if it be adjudicated that he has erred in certain particulars, that such and so other results would follow. ${ }^{1}$ Concurrently with the filing of his report, the examiner should mail to each of the parties who have appeared in the cause notice of the filing of it. Not merely these parties who have participated in the proceedings before him, but all "who have appeared in the cause" by filing pleadings of any kind, are entitled to the notice. ${ }^{2}$

It is to be hoped that it is hardly necessary to call to the attention of such examiners as shall be appointed under the Act the provisions of Section 85, that "Any examiner of title who shall knowingly and fraudulently make any false report to the

1. Hudson v. Hudson, 98 Ga. 147 (5), 26 S. E. 482; Borders v. Vance, $134 \mathrm{Ga} .85$ (2), 67 S. E. 543.

2. See T. $\S 56$. 
court as to any matter relating to any title which it is sought to register under the provisions of this Act, or as to any other matter referred to him under the provisions of this Act, or who sh:all fraudulently conspire or confederate with any other person or persons to use the provisions of this Act to the defrauding of any other person or persons, firm or corporation, or who shall be guilty of any wilful malpractice in his office, shall be guilty of a felony and be punishable by imprisonment in the penitentiary for not less than one nor more than ten years." 3

$\S$ 96. Exceptions to the Examiner's Report.-As soon as the examiner's report is filed, it becomes a public record and open to the inspection of any interested person, under the rule of court contained in Section 6322 of the Civil Code. "Any of the parties to the proceeding may, within twenty days after such report is filed, file exceptions to the conclusions of law or of fact or to the general findings of the examiner." Or, within the same time, any party at interest may move to re-commit the report for indefiniteness, lack of fullness, failure to properly separate and classify his findings of law and of fact or other like clauses. 1

The right of filing exceptions or of moving to re-commit is not confined to those who have appeared before the examiner, but any party to the cause has this privilege subject to the limitation that one who did not appear before the examiner and, therefore, who did not invoke any ruling on such procedural incidents of the trial as the admission or rejection of evidence, the allowance or disallowance of amendments, and other matters of that kind, cannot make use of exceptions to raise the points for the first time. ${ }^{2}$

"In all matters not otherwise provided for, the procedure upon the examiner's report and the exceptions thereto shall be in accordance with procedure prevailing in this State as to audi-

3. See T. $\S 258$.

1. Civil Code $\S 5139$. As to power of court to recommit on his own motion, see concluding sentence of $\S 20$ of the Act, also $T$. $\S \S$ 56 and 99.

2. Mass. Bonding \& Ins. Co. v. Realty Trust Co., 139 Ga. 180, 77 S. E. 86 . 
tor's reports in equity and exceptions thereto." 3 This practice is set forth in Sections 5135, et seq., of the Civil Code. Certain exceptions to this practice are made in Section 20 of the Act, and these will be presently noticed.

$\S$ 97. Hearing on Exceptions-Jury Trial on the Facts. -As soon as the twenty days within which the parties may except has expired, the clerk is required to notify the judge that the record is ready for his determination. ${ }^{1}$ If no exceptions or motions to re-comit have been filed, the matter is ready for the final consideration of the judge, under Section 26 of the Act, to the end of determining what judgment or decree is proper to be rendered. However, if the exceptions or motions to recommit have been filed, these should be taken up and determined by the judge as speedily as possible, after notice to the parties. The court is always in session for this purpose. 2 "Exceptions of law are for the exclusive consideration of the judge." 3

The right to jury trial on exceptions of fact is broader under the Act than it is in the general equity practice in this State; for it is provided in Section 20, as follows: "If the petitioner, or any contestant of petitioner's right, shall demand a trial by jury upon any issue of fact arising upon exceptions to the exaimner's report, the court shall cause the same to be referred to a jury either at the term of court, which may then be in session, or at the next term of the court, or at any succeeding term of the court, to which the case may be continued for good and lawful reasons; but it shall be the duty of the judge to expedite the hearing of the case and not to continue it unless for good cause shown, or upon the consent of all parties at interest. The issue or issues of fact shall be tried before the jury, in the event jury trial is requested, upon the evidence reported by the examiner, except in cases where, under the provisions of law in this State, evidence other than that reported by the auditor
3. A. § 20.
1. A. $\S 20$.
2. A. $\S 67 ;$ T. $\S 265$.
3. Civil Code $\S 5140$. 
may be submitted to the jury on exceptions to an auditor's report, and except further, that in the case the examiner has reported to the court findings of fact based on his personal examination either party may introduce additional testimony as to such facts, provided that he will make it appear under oath, that he has not been fully heard and given full opportunity to present testimony on the same matter before the examiner. The verdict of the jury upon the questions of fact shall operate to the same extent as it would in the case of exceptions to an auditor's report in an ordinary case in equity." Of course, unless one of the parties demands jury trial, the judge has the power to pass on exceptions of fact as well as of law.

$\S$ 98. Same Continued-Procedure and Evidence on the Trial before the Jury.--On the trial before the jury, the report shall be taken as prima facie correct, and the burden of proof is upon the party making the exceptions, who shall have the right to open and conclude the argument. ${ }^{1}$ If both parties have filed exceptions of fact, the party against whom judgment would be rendered if the report were approved shall be entitled to open and conclude the argument. ${ }^{2}$ In submitting to the jury the evidence reported by the examiner, if he has admitted testimony over objections and these objections are sustained by the judge, the objectionable testimony is excluded from the jury; on the other hand, if he has rejected evidence, and exceptions are sustained to his rejection of it, then, this evidence is also submitted to the jury. ${ }^{3}$ However, only so much of the report as relates to the issue raised is necessary to be read to the jury. ${ }^{4}$ The examiner cannot be made a witness for the purpose of adding to or subtracting from his report; but if the phraseology of the report is doubtful in its meaning, he may be heard to explain it. ${ }^{5}$ Under Section 5145 of the Civil Code, it is provided: "No new testimony shall be considered, except in those

1. Civil Code $\$ 5141$.

2. Civil Code $\S 5143$.

3. Civil Code $\$ 5144$.

4. Civil Code $\S 5146$.

5. Jackson v. Johnson, 67 Ga. 167 (6). 
cases where, according to the principles of law, a new trial would be granted for newly discovered evidence. Application to introduce such original and newly discovered evidence shall be made to the judge before the argument on the exceptions, if the same be then known, with a statement under oath of the party and his attorney, setting out the expected testimony and facts authorizing it to be admitted as newly discovered evidence. The opposite party shall be served with notice of such application; and if the same is admitted, the opposite party shall be entitled to a continuance, and on the trial to introduce original testimony in rebuttal of such newly discovered evidence."

Not only may such additional testimony as comes within the purview of the statutory provision just quoted be admitted, but it is further provided in the Act, ${ }^{6}$ that if the examiner has reported to the Court findings of fact based on his personal examination either party may introduce additional testimony as to such facts, provided he will make it appear under oath that he has not been fully heard and given full opportunity to present testimony on the same matter before the examiner.

§ 99. Recommitment-New Trial.-“The right to grant a new trial upon any issue submitted to a jury and right of exception to the supreme court are preserved. The judge may re-refer or re-commit the record to the examiner in like manner as auditor's reports may be recommitted in any equity cause; or he may, on his own motion, recommit it to the same or any other examiner for further information and report." 1 The judge, therefore, is not limited or restricted by the exceptions which parties have made or by their failure to except. $\mathrm{He}$ is. however, bound to give due effect to the verdict of the jury on the issues of fact submitted to them, unless a new trial is granted. It is to be kept in mind that, under Section 82 of the Act, the procedure to obtain any review of the action of the

6. A. $\$ 20$.

1. See A. $\S 20$ and T. $\S 96$. As to recommitment to hear new defense presented subsequently to the filing of the examiner's report, see T. $\$ 56$. 
judge, should be by what is known as fast writ of error, such as obtains in injunctions and criminal cases. ${ }^{2}$

$\S$ 100. Survey-When Ordered-How Made-Trial of Protest to Surveyor's Return.-It is provided in Section 22 of the Act, as follows: "While the cause is pending before the examiner of titles, or at any time before final decree, the judge, or the examiner with the approval of the judge, may require the land to be surveyed by some competent surveyor, and may order durable bounds to be set and a plat thereof to be filed among the papers of the suit. But before such survey is made all adjoining landowners shall be given at least five days' notice. The petitioner, or any adjoining owner, dissatisfied with the survey, may file a protest with the court, within ten days from the time the plat is filed, and thereupon an issue shall be made up and tried as in case of protest to the return of land processioners." 1

The practice as to protest to the return of land processioners is set forth in Civil Code, Section 3823, but it should be kept in mind that the section of the Code just referred to applies only to the making up and trial of the issue and not as to how or when the protest is to be filed, since the Act itself prescribes as to these matters. When a survey is authorized, the issue relating to the boundaries is taken out of the jurisdiction of the examiner and goes directly to the court and jury for trial.

The Act does prescribe the manner in which the five days' notice is to be given to the adjoining landowners, but the judge in ordering the survey is authorized to provide for this under the provisions of Section 71 of the Act.

2. T. $\S 118$.

1. See T. $\S \S 34$ and 86 . 


\section{CHAPTER VII.}

Final Judgment and Decree of Title.

$\S$ 101. Decision of the Cause by the Court.

$\S$ 102. No Judgment by Default.

$\S 103$. Voluntary Dismissal of the Petition-When Allowable, When Not-Involuntary Dismissal.

$\S 104$. Right to Amend, Instead of Dismissing, Where Plaintiff Shows Title to Less than Fee.

$\S$ 105. Dismissal Where Petitioner Proves Only an Undivided Interest.

$\S$ 106. Judgment Authorizing Registration-Decrees of Title-Severance For Purpose of Rendering Separate Decrees.

$\S$ 107. Tract Divided Into Parcels-Separate Decrees-Advantages of This Privilege.

$\S 108$. Form of the Decree-Necessity for Adherence to Prescribed Form.

$\S 109$. Preparation of the Decree of Title-Suggestion as to Filling in the Blanks in Prescribed Form-Description of the Land.

$\S 110$. Same Continued-Filling in Names of the Owners-Description of Their Respective Estates.

$\S$ 111. Same Continued-Declaring Limitations and Conditions.

\$ 112. Same Continued.

$\S$ 113. Same Continued-Declaring Liens and Encumbrances.

\& 114. Same Continued-The "Residuary Clause" in the Blank Form -Easements - Building Restrictions - Cautionary Statement of the Possibility of Appeal.

$\S 115$. No Issue as to Mesne Profits or Set-Off of ImprovementsStatement in Decree as to Improvements.

\$ 116. Recording the Judgment or Decree.

$\S 117$. Conclusiveness of the Decree of Title-A Covenant Running With the Land.

§ 118. Writ of error to Supreme Court-Fast Writ-Supersedeas.

$\S$ 119. Enrolling the Decree of Title-The Register of Decrees of Title.

$\S 120$. Same Continued-Suggestions as to the Enrollment of Decrees-Decrees, How Numbered.

§ 121. Same Continued-Outside Recording of Plats and Lengthy Details.

$\S$ 122. Same Continued.

\$ 123. Indexing Decree-Full Individual Indexing Required.

- 6 
$\S$ 101. Decision of the Cause by the Court.-After the record shall have been perfected and settled, that is to say, if no exceptions have been filed to the examiner's final report, or, if filed, the questions raised thereby have been settled finally, and if the report has not been re-committed or, if re-committed, all matters arising therefrom have been finally determined, and if there is no protest to a survey under Section 22 of the Act, undisposed of, in fine, if the matter is ripe for final action the court shall thereupon proceed to decide the cause. ${ }^{1}$ Before doing so, however, the judge must make a personal investigation of the file in the case and satisfy himself that all the requirements of the Act as to publication of notice and the service of process have been fully complied with. The judge's finding in this respect is final and conclusive. ${ }^{2}$

$\S$ 102. No Judgment by Default.-In considering the record, the court must keep in mind the provisions of Section 21 of the Act that "No judgment or decree shall be rendered by default, so as to authorize any decree to be rendered, without the necessary facts being shown." This is especially pertinent in uncontested cases, but is equally pertinent and somewhat more likely to be overlooked in cases where there has been a contest over some incidental interest such as the existence of a lien, encumbrance or lesser estate, and no contest over the title itself.

$\S$ 103. Voluntary Dismissal of the Petition-When Allowable, and When Not-Involuntary Dismissal.-If, upon the review of the record, the court is of the opinion that

1. $\S 26$ of the Act.

2. $\$ 13$ of the Act. This duty should be carefully performed by the judge in the interests of justice and public safety, since under this section of the Act, his decree reciting that service has been perfected is final and cannot be inquired into. As to the constitutionality of such a provision it is to be remembered, that the doctrine, that records import their own verity and cannot be contradicted, is a common-law doctrine, and that any contrary rule exists only by statute. As to the proposition that official return of service is not subject to traverse in the absence of statute, see the notes to T. $\S 73$. 
the petitioner's title is not and cannot be made proper for registration, the court, under the provisions of Section 23 of the Act, should give him the privilege of dismissing, unless, of course, some one has filed a cross-petition and has proved the right to have his title registered as the true title. This exception to the right of dismissal is not mentioned in the Act, but it is so well settled a limitation upon the right of dismissal, according to our general scheme of jurisprudence that, it is submitted that it must exist. Ordinarily the mere filing of a crosspetition is sufficient to prevent the original plaintiff from dismissing, but, when the cross-petitioner also fails to make a case, there is no reason why either or both the petitioners should not be dismissed.

It should be kept in mind that the sole object of the action is the settling of the title from an evidentiary stand-point, and that it is not an attempt to enforce a title against some opposite party alleged to have trespassed upon it by adverse possession or otherwise. ${ }^{1}$ Many a title which is not perfect against the world, so as to be capable of registration, is still sufficient to maintain the possession of the holder, or even to enable the holder to dispossess the person who is in possession. Since the holder of a title which is only relatively good cannot be accorded the privilege of registering it under the Act, the court ought not to penalize an unsuccessful attempt to register it by a formal judgment which may tend still further to cloud it, unless the court has before it the true owner demanding that his title be registered.

If the petitioner refuses to dismiss voluntarily and the court is of the opinion that the petitioner has merely failed to present an adequacy of proof, and it does not affirmatively appear that his title is not the true title, the court may order a dismissal in the nature of an involuntary non-suit. Indeed this would seem to be the proper judgment where the plaintiff desires to prosecute a writ of error to test the question. ${ }^{2}$ It is submitted that this is the correct construction to be given to

1. See T. $\S 115$.

2. Proctor \& Gamble Co. v. Blakely Oil \& Fertilizer Co., 128 Ga. 606,57 S. E. 879 . 
the language of Sections 23 and 26 of the Act relative to the contingency, dealt with in both sections, of the court's finding that the petitioner is not entitled to register his title.

$\S$ 104. Right to Amend, Instead of Dismissing Where Plaintiff Shows Title to a Less Than Fee.-However, cases may arise in which the court finds that the plaintiff's title is not the proper subject of registration because it does not cover the fee simple, but that the plaintiff is the true owner of a lesser estate or interest. In such a case, the petition should not be dismissed over the plaintiff's objection, but the court, upon the petitioner's tendering an appropriate amendment, should enter a decree establishing the title but refusing it registration, as outlined by Section 6 of the Act. ${ }^{1}$ Furthermore, if in such a case the owner of the fee-simple has established his title under a cross-petition, the court may enter judgment and decree registering the fee simple in the cross-petitioner and also setting forth the original petitioner's lesser estate.

\section{$\$$ 105. Dismissal Where Petitioner Proves Only an} Undivided Interest.- Since one or more of a number of tenants in common cannot register the title without the unanimous consent of all, ${ }^{1}$ it follows that, if it should develop that, though the petitioner or petitioners own a fractional undivided interest in the fee simple, they do not own the entire estate, the court should dismiss the petition, unless the other co-tenants are before the court by cross-petition, or otherwise, and join in asking that the entire fee be registered.

$\S$ 106. Judgment Authorizing Registration-Decree of Title-Severance For the Purpose of Rendering Separate Decrees.-If, upon consideration of the record, the title be found in the petitioner or in a cross-petitioner, the judge shall enter a decree to that effect, ascertaining all limitations, liens, encumbrances, etc., and declaring the land entitled to registration, accordingly as he shall find. ${ }^{1}$ If he finds that title

[§ 104] 1. See T. $\S 30$.

$[\S 105]$ 1. See A. $\S 5 ;$ T. $\S 25$.

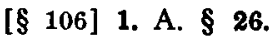


to a portion of the land included in the petition is entitled to registration and that the title to the rest of it is not, he should order a severance under Section 24 of the Act and should then enter decree in the plaintiff's favor as to the portion which he is entitled to register, and should separately deal with the action relating to the rest of the land by dismissal or otherwise, accordingly as may be appropriate. ${ }^{2}$ Likewise, a severance should be ordered where the original petitioner establishes right of registration as to a part of the land included in the petition and a cross-petitioner establishes right of registration to the remaining portion; and separate decrees should then be rendered accordingly.

If separate parcels are involved, the court shall render a separate decree as to each parcel. ${ }^{3}$ If, however, it appears that the petitioner does not hold all the separate parcels under the same general claim of title, as provided in Section 8 of the Act, the court should order a severance as to the tracts held under the dissimilar titles and, as one of the terms of the severance, should require the plaintiff to pay full costs in all the cases into which the original case shall have been severed. Under Section 24 of the Act, all amendments and severances may be ordered or allowed by the court upon terms that may be just and reasonable; and it seems but just and reasonable that, if the petitioner has attempted to impose on the officers of court the labors incident to several distinct causes of action in a single case, so as to escape the payment of the legitimate costs which he would be required to pay if he had filed separate causes, as contemplated by the Act, he ought not to complain if the court instead of dismissing his entire action for disobedience to the Act allows him to sever his causes of action on condition that he pay the legitimate costs which the several cases would have borne if they had originally been brought separately. ${ }^{4}$

§ 107. Tract Divided into Parcels--Separate Decrees -Advantages of This Privilege.-When the petitioner has

2. T. $\S \S 57-8$.

3. A. $\S 26$.

4. T. $\S \S 259,260$. 
divided a tract into separate parcels and has given a particular and accurate description of each, the court should, upon finding the title to the whole tract eligible to registration, enter a separate decree as to each parcel. ${ }^{1}$

When a landowner has divided his tract into lots for the purpose of sale, he will generally find it expedient to have a separate decree rendered as to each lot, as he thereby gets a separate certificate as to each lot, and will not be under the necessity of having his certificate to the rest of the tract cancelled and re-issued every time he sells off a lot, as would be the case if he took a single decree and therefore a single certificate for the entire tract. ${ }^{2}$ Furthermore, considering the ease with which certificates of title may be used for commercial purposes, such as pledging them as security for debt, etc., the owner of a large tract is likely to find it much more convenient to have his ownership represented by several separate certificates, each representing a divided part of the tract and each capable of being separately used without relation to the others, than to have only one certificate representing the whole tract. The additional cost of having separate decrees issued for the various parcels of a single tract is slight-only one dollar extra for each decree after the first one. ${ }^{3}$

\section{$\S 108$. Form of the Decree-Necessity for Adherence} to Prescribed Form.-The form of the decree is set forth in Section 97 of the Act. Since this form is also to be printed in the book known as the Register of Decrees of Title ${ }^{\mathbf{1}}$ in which all decrees must be recorded, it should not be varied from. The case ought to be brought to such a degree of definiteness before the decree is rendered as that this form can be used, without change, in order to express all that is necessary to be set forth in the decree.

Incidental matters such as the taxing of the costs should be included in a separate judgment.

[§ 107] 1. A. $\S 26$.

2. A. $\S 31 ;$ T. $\S 151$.

3. A. $\S 120$; T. $\S 259$.

[\$ 108] 1. A. $\$ 98 ;$ T. $\S 119$. 
$\S$ 109. Preparation of the Decree of Title-Suggestions as to Filling in the Blanks in Prescrbed Form-Description of the Land.-In the first blank in the form of decree is to be inserted the description of the land. This description is not merely to be copied blindly from the petition, though of course in many cases the description in the petition and in the decree will be the same. As has been explained in another context, ${ }^{1}$ the description in the title papers by which land is held is an essential part of the title itself; and one of the objects of the registration is to settle all uncertainty or ambiguity in the description and to fix upon terms that will, as far as practicable, permanently identify the land. To this end, the Act has conferred various broad powers on the court by which he can obtain the necessary details by which to give such a description in the decree. ${ }^{2}$

In case there has been a severance, or in case separate tracts are involved, or in case any single tract is divided into parcels for the separate registration of each, the court should, of course, insert into each of the separate decrees so to be rendered, not a dscription of the original tract or tracts, but only of the particular parcel which is to be registered under that decree.

It being recognized that cases are likely to occur in which the description in the decree is to be aided by a plat or in which it may be too long to transcribe in the blank left on the Register of Decrees of Title, the framers of the Act were unwilling to put before the court the necessity or the temptation of shortening or limiting the description so as to enable it to be copied in full on the register, hence provision is made in Section 102 of the Act whereby the clerk in transcribing the decree may record the plat and, of course, such descriptive details as may go with it, on one of the public record books in his office, and omit this part of the description from the register, except by reference to the book and page where the plat and the additional description accompanying the same is recorded. ${ }^{3}$

1. T. $\S 34$.

2. A. $\$ \S 7,22$ and 24 .

3. T. $\$ 121$. 
$\S$ 110. Same Continued-Filling in Names of the Owners-Description of Their Respective Estates.-In filling in the next blank in the prescribed form of decree the court should, of course, insert only the names and descriptive designations of those who own the fee simple, except that, if the ownership of the fee is divided into legal and into equitable estates, as where security deed is outstanding, and one person therefore owns the legal fee and the other the equity of redemption, or where bond for title has been given with the result that one person is the legal owner and another the equitable, the court may, in this blank, insert the names of both the legal and the equitable owners, accurately describing the relation between the two. ${ }^{2}$ This may be done by the court's either stating all essential details and the full tenor and effect of the security deed or bond for title in the decree itself, or, if the security deed or bond for title be recorded in some public record of the county, by the court's describing the instrument by general descriptive terms and making reference to the public record, book and page, for further details.

In addition to the name of the owner, it is expedient that the court should also give his residence or address. If the name be that of a minor or person under disability, that fact should be stated; and, in the case of a minor, the court should state the date of his birth or the date on which he will become of age, so that persons dealing with the title may be informed accordingly. ${ }^{2}$

If the fee simple is registered in the name of several persons as collective owners of the title, the court should state what undivided interest each is to hold, though the decree would probably be construed as giving each an equal interest if no specific statement on the subject were made.

$\S$ 111. Same Continued-Declaring Limitations and Conditions.-In filling in the next blank, in the form of the decree if there are no limitations or conditions, the word "none" should be inserted; if there are limitations or conditions, they

1. See T. $\S 26$.

2. See T. $\S 47$. 
should be stated accurately. If there be outstanding any lesser estate of any kind (except a lease for a term not exceeding three years under which the land is actually occupied ${ }^{1}$ ) such as life estate, dower, right to cut timber or to take minerals, or an estate for years; or, if the fee, though vested, is subject to any condition or is defeasible, the terms of the same should be accurately and fully set forth, and the names or, if it be impossible to give names, a legal description of those who hold such lesser estates or to whom the title may pass under the condition or in case the defeasance takes place, should be given. ${ }^{2}$

When bond for title has been given or other executory sale has been made, so that the vendor holds the legal title and the vendee is the equitable owner, the court has the choice of treating this transaction as a collective ownership of the fee and of including both as owners in the manner stated in the immediately preceding section or of naming the vendee as the owner and of considering the payment of the purchase money as a condition upon his title. It matters very little which way this choice is exercised, just so the transaction and the nature of the rights of the respective parties are made fully and accurately to appear.

$\S$ 112. Same Continued.-In the next blank, in the form of decree, following the words "and the title of the said," if no lesser estates, or contingent remainders or reversions, have been disclosed in the blank following the words, "subject to the following limitations and conditions," the court should merely insert the name of the owner of the fee; but, if such lesser or contingent estates have been disclosed, the court should include in this blank not only the name of the owner of the fee simple but also of the holders of the lesser or contingent estates, followed by the words "accordingly as their respective rights have been herein declared."

§ 113. Same Continued-Declaring Liens and Encumbrances.-In the next blank, in the form, all liens and encum-

1. A. $\S 63$, and T. $\S \S 220,224$.

2. A. $\S 26$. 
brances which have been found to be valid and to affect either the fee simple or any lesser estate (with the exception of taxes and levies assessed thereon for the current calendar year) 1 should be set forth. If the lien or encumbrances affects only the lesser estate, that fact should be stated. For the purposes of the decree, easements are not classed as encumbrances but are dealt with separately; but unexpired homesteads, charges upon the land, special equities, and matters of that nature are so considered. Of course, the word lien includes every form of lien known to our law.

$\S$ 114. Same Continued-The Residuary Clause in the Blank Form-Easements-Building Restrictions-Cautionary Statement of the Possibility of Appeal.-The next blank, in the form, following the words "subject also to," is left as a residuary clause, so to speak, in which any matter not already fully dealt with may be set forth. It is, however, the appropriate space in which to set forth easements (except highways in public use and railroads in actual operation, which are exempted from the operation of the Act). ${ }^{1}$ Private ways and alleys are easements of the class that should be noted.

One thing which should always be inserted in this part of the decree is a statement substantially as follows: "subject to the result of such appellate proceedings or exceptions as may be presented on or before (a day 20 days from the date of the decree ) ${ }^{2}$ to set aside this decree." Many states in their registration acts specifically require some such statement to be included; and the spirit of the Georgia Act requires it. This exception should be included in the decree, and should appear on the certificate of title until the statutory period has expired if no appellate proceedings have been prosecuted, and, if appeal has been taken, until the same is fully disposed of ; otherwise an appeal to the Supreme Court might be taken which might result in the decree being set aside and yet the certificate of title would be outstanding with no notice of its possible defeasibility on this

[§ 113] 1. A. § 63; T. $\S \S 220,223$.

[§ 114] 1. A. § 63; 8. §§ 220,225 .

2. A. $\S 82 ;$ T. $\S 118$. 
account. $^{3}$ The suggestion in the proposed protective clause that the day certain be stated instead of some such expression as "twenty days from this date" is made because the date of the decree does not appear on the certificate of title, and this clause is to be copied on each issue and reissue of the certificate of title until the time of appeal shall have expired without any appeal being prosecuted or until such appellate proceedings as shall have been filed are finally ended.

Building restriction and matters of that kind should also be set forth in this part of the decree.

\section{$\S 115$. No Issue as to Mesne Profits or Set-Off of Im-} provements-Statement in Decree as to Improvements. -Even though an application is contested by a defendant who is an occupant and adverse claimant of the land, the petitioner, though he succeeds in obtaining a decree of registration as against such adverse claimant, is not entitled to a writ of ejectment or other final process to oust him from the possession. The decree of registration merely settles and fixes the evidence of title. If the adverse occupant does not thereupon yield the possession, it is incumbent on the owner to bring a separate suit for it, using his certificate of title as conclusive evidence; ${ }^{1}$ or, if suit in ejectment or other similar action is pending at the time he may use his decree of title as a judgment estopping the adverse claimant from denying the title therein established. ${ }^{2}$ It follows that in the suit for registration the court should take no cognizance of any issue as to mesne profits or as to the right of set-off of improvements. ${ }^{3}$ All these should be postponed until some suit is brought to recover the possession of the land.

However, to preserve this equity of setting off improvements against the recovery of the land the same should be noted in the decree of title and, correspondingly, on the certificate of title.

[§ 114] 3. How far rights of third persons will be protected against appellate proceedings not noted in the certificate of title. See $\mathbf{T}$. $\S 233$.

1. T. $\S 239$.

2. T. $\S 243$.

[§ 115] 3. Civil Code $\S \S 5575$ and 5587 et seq.; Powell, Actions for Land, Chapter XVII. 
This does not mean that the court should undertake to settle the particulars and details of such a matter in advance, but should, in the blank in the decree of title, following the words, "and subject also to," insert the words, "the right of A. B. to set off, accordingly as he may prove, such improvements against recovery of the land as he may have made thereupon while in bona fide possession under claim of right."

§ 116. Recording the Judgment or Decree.-Whatever judgment or decree is rendered, whether it be a judgment dismissing the action, or a judgment establishing the title to an estate less than in fee simple, or a decree entitling the title to registration, is to be entered on the minutes of the superior court and becomes a part of the records thereof. ${ }^{1}$ If it is a judgment dismissing the action or a judgment under Section 6 of the Act, merely establishing title to an estate less than the fee simple, without privilege of registration, no further recordation of the judgment is required.

If the decree be in favor of the registration of the title, in addition to its being recorded on the minutes of the court, it is to be enrolled, registered and indexed, in a book to be kept in the office of the clerk of the superior court and known as the "Register of Decrees of Title." 2 This completes the steps necessary for the settling of the title and preliminary to initial registration, which is fully accomplished by the registration in the other book called the "Title Register" of the certificate of title, as to which more will be said hereinafter.

$\S 117$. Conclusiveness of the Decree of Title-A Covenant Running With the Land.-The conclusiveness and effect of the decree of title is stated thus in Section 27 of the Act: "Every decree rendered, as herein provided, shall bind the land and bar all persons claiming title thereto, or interest therein, quiet the title thereto, and shall be forever binding and conclusive upon and against all persons, including the State of Georgia, whether mentioned by name in the order of publication or in-

1. A. $\$ \$ 26$ and 98 .

2. A. $\S 98$; T. $\S 119$. 
cluded under the general description whom it may concern. ${ }^{1}$ It shall not be an exception to such conclusiveness that the person is an infant, lunatic, or is under any disability." This is in consonance with provisions of Section 4 that the proceedings for the registration of land shall be proceedings in rem against the land and that the decree of the court shall operate directly on the land and vest and establish title thereto in accordance with the provisions of the Act, as well as upon all persons who are parties to the proceedings, whether by name or under the general description of "whom it may concern." 2

Furthermore, it is provided in Section 64 of the Act that the act of the owner of the land in obtainnig a decree of registration and the entry of the certificate of title shall be construed as an agreement running with the land, that subject to the exception in the Act stated the same shall remain registered land subject to the provisions of the Act and all amendments thereof. The effect of the covenant running with the land, voluntarily attached thereto by the owner, is to estop him and all those afterwards dealing with the land through him or under him from questioning the validity of the original registration or of any subsequent transaction that may be had in accordance with the provisions of the Act, and from successfully asserting that anything that shall be thereafter omitted or done shall not be given the effect prescribed by the Act. In other words, the owner thereby makes the provisions of the Act a part of his title to the land and binds himself and his privies to it as a covenant running with the land. This eliminates certain objections that have been suggested (though so far not sustained by the courts) as to the constitutionality of certain of the details in connection with subsequent registration-that they constitute the taking of property without due process of law. ${ }^{3}$ Section 63 of the Act which states

1. As to the conclusiveness of the judgment on the question of service see T. $\S 74$ and $A . \S 13$.

2. As to use of the decree as conclusive evidence, see T. $\S 243$. As to the difference in conclusiveness between liens, encumbrances and other adverse claims established by the dcree of title and those noted in the certificate of title subsequently to initial registration, see $\mathrm{T}$. $\S 230$.

3. See also T. $\S 20$. 
the effect of registration, whether initial or subsequent, will be dealt with more fully in another context, ${ }^{4}$ though it is also germane to the consideration of the legal effect of the decree itself.

$\S$ 118. Writ of Error to Supreme Court-Fast Writ - Supersedeas.-The final judgment rendered upon a petition for registration, whether it be a judgment of dismissal (unless it be a voluntary dismissal) or a judgment establishing a lesser estate than the fee, or a decree of title is subject to review by the Supreme Court upon writ of error. The procedure to obtain such a review is by what is known as fast writ of error, such as obtains in injunctions and criminal cases. ${ }^{1}$ The bill of exceptions must be tendered within twenty days from the rendition of the decision, and should be served, filed and transmitted in compliance with Section 6153 and the cognate sections of the Civil Code. ${ }^{2}$

If the necessary steps are taken to obtain a supersedeas before the clerk executes the decree by entering it on the Register of Decrees of Title and by registering the certificate of title on the Title Register he should suspend the execution of the judgment (by not registering the decree or certificate of title) until the appeal to the Supreme Court has been finally disposed of. ${ }^{3}$ If the registration is completed, the party excepting to the decree should cause a notation of the pendency of his writ of error to be made on the certificate of title, in the manner prescribed in Sections 51, 61 and 114 of the Act. ${ }^{4}$ The effect of failure to do this will be discussed in another context. ${ }^{5}$

$\S$ 119. Enrolling the Decree of Title-The Register of Decrees of Title.-Every decree of title, in addition to being recorded on the minutes of the court, must be enrolled, regis-

[§ 117] 4. Chapter XIII, post.

1. A. $\S 82$.

2. As to necessity for separate writs of error and as to separate records in case of a severance, T. $\S 59$.

3. As to the duty of the judge to mention the right of appeal in the decree of title, see T. $\S 114$.

[§ 118] 4. See T. $\S \S 174,178$.

5. See T. $\S 233$. 
tered, and indexed on the "Register of Decrees of Title." 1 This book is described in detail in Section 98 of the Act. ${ }^{2}$ It should be of such size as that each page may contain a full copy of the decree of title; therefore, in order to meet the requirements of all cases, it should be a large book. On each page is printed the form prescribed in Section 97 in which decrees of title are to be rendered. At the top of the page, and preceding the decree is the printed heading "Registered Title No.

At the bottom of the page, following the decree, are printed the words "Entered and registered, this the — day of 191—, at — o'clock, — M., and certificate of title No. — issued thereon. Clerk."

A part of this register is an alphabetically arranged index, which, however, may be under the same binding with the register proper or may be under separate cover. ${ }^{3}$

$\S$ 120. Same Continued-Suggestions as to the Enrollment of Decrees-Decrees, How Numbered.-In enrolling the decree on the Register of Decrees of Title, the following matters should be observed. First, the registered title number should be inserted in the blank left for that purpose at the top of the page. The first decree entered in the book is numbered "Registered Title No. 1;" the second, "Registered Title No. 2 ;" and so on in continuous, consecutive order, until the book is filled up; and, when the old book is filled and a new one opened, the first decree entered in the new book will take the next number that follows the last number in the old book, and so on. Every tract or parcel separately registered is given its registered title number, which is the number of the decree as entered in the "Register of Decrees of Title," and this registered title number follows the tract or parcel, unchanged, throughout its history.

Whenever the court renders separate decrees, whether as to separate tracts, or as to a single tract divided into parcels, the

1. A. $\S \S 28,97$ and 98 .

2. As to the duty of the county authorities to provide this book, see A. $\S 28$ and T. $\S 271$. As to the duties of the Attorney-General, as supervisor of county records, over it see T. $\S 274$.

3. A. $\$ 98$. 
clerk should number and enroll each decree separately, and in accordance with its own particular terms. ${ }^{1}$

\section{$\S$ 121. Same Continued-Outside Recordation of Plats} and Lengthy Details.-The form of the decree as it is printed, in the book, corresponds exactly with the form of the decree as rendered by the judge; therefore, all that must be done is to copy this accurately. However, if the clerk finds that, by reason of a plat being made a part of the description or to aid the description, the description as contained in the decree cannot be conveniently transcribed in the blank space left for that purpose on the register, he should record the plat and the descriptive matter relating to it on one of the public records in his office (usually a deed book, unless a regular plat book is kept in the office as one of the public records), and then, after transcribing in the blank on the register the other descriptive matter set out in the decree, should add: "A plat more fully describing the premises and made a part hereof is duly recorded in this office in $\longrightarrow$ Book Page —." 1

$\S$ 122. Same Continued.-When the clerk shall have completed the copying of the decree on the register, he should then fill in the blanks at the bottom of the page, giving the year, month, day, hour and minute upon which he makes the entry, ${ }^{1}$ signing the same. He should also examine the Title Register and see what number the certificate of title to be entered on the decree will bear, and insert that in the blank space intended for that purpose; or he may insert this number after he has completed the filling-in of the certificate of title on the Title Register.

$\S$ 123. Indexing the Decree-Full Individual Indexing Required.-The work of registering the decree of title is not completed until it has been indexed. This should not be postponed; it is to be done concurrently with the registering of the decree. The name of every person in whom the court decrees

[§ 120] 1. A. $\S 98$.

[§ 121] 1. See A. § 102.

[§ 122] 1. A. § 29; T. § 273. 
any part of the title to be, whether the fee simple or some lesser estate, should be inserted in its proper alphabetical place in the index, followed by the registered title number of the decree.

The clerk must remember that if the decree is in favor of a number of persons it is not sufficient to index it under the name of one of them followed by "et. al." or some similar abbreviation. Each name must be inserted in the index and it must be inserted in its own appropriate alphabetical order. ${ }^{1}$ It may seem to some persons that it would hardly be necessary to stress so strongly the requirement of full individual indexing. Any abstractor who has had any very wide experience in the examination of the indexes, execution dockets, etc., as they are kept in many counties in this State, can easily give testimony to the need of stressing this requirement, the neglect of which may not only occasion injury to members of the public but also subject to liability the clerk and the sureties on his official bond.

\section{A. § 98.}




\section{CHAPTER VIII.}

\section{Certificate of Tithe.}

§ 124. Completing Initial Registration-The Title Register.

$\S$ 125. Preparing and Registering the Certificate of Title-How Numbered.

§ 126. Same Continued-Filling the Blanks-Description of the Land.

$\S$ 127. Same Continued-Names and Description of Owners.

$\S$ 128. Same Continued-Designation of the Owner's Estate.

$\S$ 129. Same Continued-Declaring Limitations, Conditions, Encumbrances, Etc.

$\S$ 130. Same Continued-Dating, Signing and Sealing.

$\S$ 131. Same Continued-Right, and Method of Asking Direction From Judge in Case of Doubt.

$\S$ 132. Indexing the Certifrcate of Title.

$\S$ 133. The Owner's Certificate-Issuance-Attaching Certified Copy of Outside Records.

$\S$ 134. Same Continued-Form-Suggestions as to Design.

$\S$ 135. Established Duplicate of Owner's Certificate.

$\S$ 124. Completing Initial Registration-The Title Register.-The final step in initial registration is the entering of a certificate of title corresponding to the decree, ${ }^{1}$ in the large book called the "Title Register." Section 99 of the Act gives a description of this book and prescribes its form. ${ }^{2}$ It is to be well-bound, with pages not less than 18 inches wide and deep enough to carry the matter indicated in the form. On the back, it carries appropriate descriptive labels. It is so arranged that the two pages of the folio, which face each other, may both be used in full for the purposes of registering the certificate and such notations and entries as are to be placed thereon. A part of this register, also, is an alphabetically arranged index, which, as the Act, suggests, may most conven-

1. T. $\S 108$, et seq.

2. As to the duties of the county authorities to provide this Book see A. § 28; T. \$271. As to the duties of the Attorney-General, as supervisor of county records, in respect of it see $T$. $\S 274$. 
iently be kept in a separate book. At the top of each page is the heading:

Tithe Register - County.

Registered Tithe No.

Certificate of Title No.

Immediately following this, on the first of the two pages, is the blank printed for the certificate of title proper. This does not take up the entire page, so the rest of this page and all of the opposite page is devoted to blanks designed for the registering of such entries and notations as are to be made from time to time. For fuller descriptive reference is had to the form itself, which is shown in full in Section 99 of the Act.

$\S$ 125. Preparing and Registering the Certificate of Title-How Numbered.-The clerk, having enrolled the decree on the Register of Decrees of Title, should then proceed to enroll, register and index the certificate of title in the Title Register. He first inserts the registered title number in the blank left for that purpose. This is the same number as that of the decree upon which the certificate is being issued. He then inserts the certificate of title number in the blank left for that purpose. The first certificate of title entered in the book should be numbered 1 , the second 2 , and so on, consecutively throughout the book and so on throughout all subsequent title registers that may prove necessary in the course of time. ${ }^{1}$ On the first few certificates of title issued in a given county, the registered title number and the certificate of title number are likely to be the same; but, as soon as ever in the course of time a certificate is cancelled and a new one is issued for the same land, this identity between the two numbers will cease, and thereafter the registered title number and the certificate of title number will always be different.

Every certificate of title, which may at any time be issued as to any single registered tract or parcel of land, whether it be the one first issued on a decree of title or whether it be one subsequently issued as the result of cancellation and re-issue, always bears the same registered title number, the number that is

1. A. $§ 99$. 
borne on the Register of Decrees of Title by the decree under which the particular piece of land in question was brought under registration. The object is that the owner of a certificate of title may always be able to go at once to the original decree under which the title to his land is registered, without having to trace back through a series of transfers.

\section{§ 126. Same Continued-Filling the Blanks-Descrip-} tion of the Land.-The next step is to fill in properly the blanks in the certificate of title. In the first blank in the certificate is to be inserted the description of the land, which should be in the same language as it appears in the registered decree of title. If, in registering the decree, it has been found necessary to record a plat in some other book, under the provisions of Section 102 of the Act, and in the manner and with the form of reference described in Section 121 ante, then, in filling in the certificate, make the same reference, using the same language. ${ }^{1}$

\section{$\S$ 127. Same Continued-Names and Description of} Owners.-The next blank following the words "vested in," is to be filled in with the respective names, address and other designation (such, for instance, as "a minor who will be 21 years of age on Aug. 25, 1920"), 1 of each person, accordingly as it is set forth in the blank, in the decree of title, following the words, "The fee simple belongs to"; and, if in filling in that blank in the decree, the court has used other language descriptive of the nature of the holding (for instance, that one of the owners holds the legal title and the other the equitable title, or that the several owners own each some specified undivided interest, or anything of that kind), ${ }^{2}$ using the same language in full that the court has used. The next blank, following the words, "The estate owned by said," should be filled in with the names of those whose names have been set forth in the immediately preceding blank, but omitting the addresses, special designations and other particulars already given.

[§ 126] 1. See also A. $\$ 103$.

[§ 127] 1. See T. $\$ \S 47,110$.

2. See T. $\S 110$. 
$\S$ 128. Same Continued-Designation of the Owner's Estate.-If only one person is registered as the owner, that is to say if only one person's name appears in the blank following the words "vested in," then in filling in the blank following the words "in said land is as follows," it is proper to write only the words "a fee simple;" but, if more than one person's name appears in the preceding blank, the proper phrase to use is "a fee simple, in the manner set forth above."

§ 129. Same Continued-Declaring Limitations, Conditions, Encumbrances, etc.-The blank following the words "limitations, conditions, encumbrances, etc., viz:" should be filled in by copying all the language which the court has used in the decree in filling in the blank therein following the words "limitations and conditions"; ${ }^{1}$ also all the language used in the decree in the blank therein following the words "subject to." 2 If room is still left in this same blank in the certificate to do so, then the clerk may also copy into it the language used by the court in the decree following the words "liens and encumbrances, viz." 3 But, if room is lacking to copy the liens and encumbrances in the body of the certificate, the clerk should enter them in the blanks on the other page of the certificate under the heading there found of "Liens, encumbrances, and other Matters Affecting This Certificate." If this is done, then, under the head of "Remarks" should be written the words "Entered under the authority of the decree of title." Or, if the reason that all the liens and encumbrances mentioned in the decree cannot be copied in full in the body of the certificate of title is that the details of some transaction as there set forth is too lengthy, the clerk, instead of copying the description of such matter in full may brief it, stating it in general terms followed by the words "for further details, see registered title No. — on the Register of Decrees of Title." 4

$\S$ 130. Same Continued-Dating, Signing and Sealing.-The clerk should then date the certificate and the entry

1. See T. $\S 111$.

2. See T. $\S 114$.

3. See T. $\S 113$.

4. Adapted from A. $\S 103$.

\section{LAW LIBRARY \\ GNIVERSITY OF GEDRGI}


of registration with the year, month, day, hour, and minute, ${ }^{1}$ and sign it officially, putting his official seal at the place shown in the blank.

\section{$\S$ 131. Same Continued-Right and Method of Asking} Direction from Judge in Case of Doubt.-If the clerk in any case is in doubt as to how he shall fill in the certificate of title, he has the privilege, under Section 59 of the Act, of seeking the direction of the judge. An appropriate method for him to pursue in such a case is for him to make out a short informal application to the judge, stating that he is in doubt as to how the certificate of title should be prepared in decree of title number (stating the number) and asking that the court give direction by filing in a form of the certificate for the clerk's guidance. To this the clerk should attach a copy of the decree and also a blank certificate of title. (The clerk will usually have a number of blank certificates of title on hand for use in making out certified copies and owner's duplicates.) The judge should then fill in the blank certificate and return it to the clerk, who will copy it on the Title Register. The clerk should then place the copy thus furnished by the judge in the file with the other papers relating to the decree of title. ${ }^{1}$

$\S$ 132. Indexing the Certificate of Title.-Having enrolled the certificate of title, the clerk should proceed to complete the registration of it by indexing it in accordance with the provisions of the Act. ${ }^{1}$ In the index he inserts in its proper alphabetical place the name of every person who takes any estate under the certificate, followed by both the registered title number and the certificate number. All that is said in Section 123, ante, as to the separate and individual indexing of the names of all of a number of persons taking under the same decree, applies fully to the indexing of the certificate of title.

$\S$ 133. The Owner's Certificate-Issuance-Attaching Certified Copy of Outside Records.-Registration of the

[§ 130] 1. A. $\S 29 ;$ T. $\S 273$.

[\$ 131] 1. See T. $\$ 272$.

[§ 132] 1. A. $\S \S 28$ and 99. 
certificate of title being completed, the clerk then proceeds to issue the owner's certificate of title, which is to be an exact copy of the certificate of title as it appears on the Title Register, with the clerk's official seal attached, and which is to be delivered to the owner or to his duly authorized agent or attorney. ${ }^{1}$ If, in the certificate of title, the description of the premises or of the details of any other matter included in the certificate, is aided by reference to some document recorded in some other public record, the clerk shall upon the request of the owner of the certificate make out a full and complete copy of the instrument thus recorded in the other book, certify to it, and attach it to the owner's certificate as a part thereof. ${ }^{2}$ In such cases, the clerk in addition to his regular fee for issuing the certificate gets ten cents per hundred words for making and certifying the copy of the additional record.

\section{$\S$ 134. Same Continued-Form-Suggestions as to} Design.-The form of the owner's certificate is prescribed in Section 105 of the Act. The only difference between the language of it and of the certificate of title is that it is headed with the words: "Owner's Certificate of Title." In Section 105 suggestions are made as to the appropriate printing, ruling and folding of blanks to be used in the preparation of owner's certificates, with the view of making it a convenient and attractive document.

Public, as well as the clerk's own convenience, will be subserved by the clerk's keeping on hand at all times an adequate supply of these blanks, prepared by some competent printer, who will use intelligence in following the form and the directions given in Section 105 of the Act in so arranging the spacing and other mechanical details as to make it available for the exigencies of practically any case that may arise. As it is a valuable document, care and taste should be exercised in the selection of paper and type; and engraving will add to its attractiveness.

In addition to carrying all the matter contained in the certificate on the register, the owner's certificate also should have

1. A. $\$ 28$.

2. A. $\S 104$. 
printed on its back the blank form prescribed by the Act to be used in case of transfer. ${ }^{1}$

$\S$ 135. Established Duplicate of Owner's Certificate. -If an owner's certificate is lost or destroyed a duplicate may be established and issued. ${ }^{1}$ Section 58 of the Act provides: "Whenever an owner's certificate of title is lost or destroyed, the owner, or his personal representative, may petition the court for the issuance of a duplicate. Notice of such petition shall be published once a week for four successive weeks in the newspaper in which the sheriff's sales of the county are published, and upon satisfactory proof having been exhibited before it that said certificate has been lost or destroyed, the court may direct the issuance of a duplicate certificate, which shall be appropriately designed and take the place of the original owner's certificate. Provided, that the court may in any case order additional notice to be given, either by publication or otherwise, before directing the issuance of a duplicate certificate, and provided further that in case the application is made by personal representative of a deceased person claiming that the certificate was lost or destroyed while in the possession of the decedent the notice of the petition shall be published once a week for eight successive weeks, instead of four, as required in other cases."

The reason why a longer advertisement is required in case the original owner's certificate is alleged to have been lost or destroyed while it was in the possession of a deceased person, grows out of the possibility that the decedent may have pledged or otherwise have transferred it, without his personal representative or heirs being aware of the fact. ${ }^{2}$

[§ 134] 1. A. $\$ \S 105$ and 107.

[\$135] 1. As to how and when a duplicate of the owners certificate is admissible in evidence, see T. $\S 240$.

2. See T. $\S \S 191,197$. 


\section{CHAPTER IX.}

\section{Subsequent Registration Generaliy.}

§ 136. Preliminary.

\$ 137. Ownership of Registered Lands Subject to Same Rights and Burdens as in Case of Unregistered Lands.

$\S$ 138. Same Continued-How Registration and General Law and Equity Work Together-The Sphere of Each.

\$ 139. Analysis of the Various Kinds of Transactions Dealt With in the Act-Voluntary Transactions-Involuntary Transactions.

$\$$ 140. Voluntary Transactions Executed in Prescribed Form Accompanied by Owner's Certificate.

$\$ 141$. Voluntary Transfers and Mortgages Not Accompanied by Owner's Certificate.

$\S$ 142. Voluntary Cancellation of Liens and Encumbrances.

$\S$ 143. Voluntary Transactions Not in Prescribed Form.

\$ 144. Involuntary Transfers-Registered Only on Order of the Judge.

§ 145. Involuntary Transactions Not Involving a Transfer of Title.

$\S$ 136. Preliminary.-When the status of the title shall have been settled against the world, and initial registration completed, the land is brought under the provisions of the Act and is, thereafter, to be dealt with as registered land, ${ }^{1}$ unless and until the registered owner shall take the steps indicated in Section 65 of the Act to free it from subsequent registration. The Act has made provision not only for initial registration, but for the subsequent registration of the title and of every transaction affecting the title to the land. However, the title having been once settled as against the world, and the lawfully and conclusively adjudicated owner having attached to the title a covenant running with the land that the title shall be transferred or affected thereafter only in accordance with the provisions of the Act, subsequent registration becomes, except in rare cases, a very simple transaction.

1. A. $\S 64 ;$ T. $\S \S 20$ and 117. 


\section{$\S$ 137. Ownership of Registered Lands Subject to} Same Rights and Burdens as in Case of Unregistered Lands.-As has been stated in another context, ${ }^{1}$ it is not an object of the Act to affect the rights or the burdens which under our general laws attach to the ownership of land; its object is to make certain and to localize the evidence by which such ownership may be proved, and by which the extent of such limitations or burdens as may attach to it, may be easily and definitely ascertained. While the Act prescribes certain forms which may be conveniently used in connection with dealings and transactions affecting registered land, and while the use of these forms will usually enable the parties to accomplish the desired transaction with greater ease and less expense than otherwise, still the use of these forms is not compulsory and effect may be given to the transaction though it be otherwise consummated. Hence it is provided in Section 73 of the Act that "Except as otherwise specially provided by this Act, registered land and ownership therein shall be subject to the same rights, burdens and incidents as unregistered land, and may be dealt with by the owner, and shall be subject to the jurisdiction of the courts in the same manner as if it had not been registered. But registration shall be the only operative act to transfer or affect the title to registered land, and shall date from the time of the writing, instrument, or record to be registered is duly registered on the Title Register. Subject to the provisions of Section 63, no voluntary nor involuntary transaction shall affect the title to registered land until registered or noted on the Title Register, in accordance with the provisions of this Act."

$\S$ 138. Same Continued-How Registration and General Law and Equity Work Together-The Sphere of Each.-While the form in which the transaction relating to registered lands may be consummated is, prima facie and from a substantive standpoint, immaterial, still no transaction whether consummated according to the forms prescribed by the Act or otherwise can affect the title until such transaction is registered or noted on the Title Register. Such transactions

1. T. $\S 11$. 
prior to their being registered or in the absence of their registration may give rise to personal rights, duties and equities between the parties, but they do not affect the title to the land.

For instance, a husband buys registered land with his wife's money and takes the certificate of title in his own name, the law will imply a trust in this case to the same extent as if the land were unregistered; but the implied trust or secret equity does not affect the title to the land until a notation of it is made upon the certificate of title on the register; and, if the husband, prior to such notation, being made, sells the land so that another becomes the registered owner, the latter takes it entirely free from the implied trust or secret equity; and this is true whether he had aliunde notice of the wife's rights or not. However, in such a case, the wife would have a right of action against her husband, and also against the purchaser, if the latter had knowledge of the equity, but not against the land itself.

Or, to take another illustration, if the owner of registered land executes a mortgage on it, the mortgage does not bind the land or become a lien upon it until an entry of the mortgage is made on the certificate of title on the Title Register, even though the mortgage be recorded in the ordinary mortgage records of the county; so that if the owner should sell to another and the latter obtained his transfer and new certificate before the mortgage was noted on the register, the purchaser would hold his title to the land clear of the lien of the mortgage; and the question as to whether he did or did not have notice of the mortgage cannot be inquired into, so as to affect his title to the land.

$\S$ 139. Analysis of the Various Kinds of Transactions Dealt with in the Act-Voluntary Transactions-Involuntary Transactions.-For the purposes of a discussion as to how transactions relating to registered land may be entered on the register, they may be classed into five heads:

(1) Voluntary transactions, executed in the prescribed form, accompanied by the owner's certificate. ${ }^{1}$

1. T. \& 140 and Chapter $X$, post. 
(2) Voluntary transactions, not executed in the prescribed form. ${ }^{2}$

(3) Voluntary transactions not accompanied by the owner's certificate. $^{3}$

(4) Involuntary transactions. ${ }^{4}$

(5) Special cases. ${ }^{5}$

A voluntary transaction, according to definition of that phrase as given in Section 3 of the Act, is any contractural or other voluntary act or dealing (except by will) by any registered owner of any estate or interest in land, with reference to such estate or interest, and any right of homestead or exemption thereon. All other matters affecting the title to the land are called involuntary transactions. ${ }^{6}$

Under the plan of the Act, the judge of the superior court is what may be called the general supervisor of the Title Register. He has the ultimate power of controlling all registrations (subject to review by the Supreme Court); and many registrations provided for in the Act cannot be made without his authority having first been expressly exercised. In some cases, cases in which no discretion or decision of justiciable controversy is involved, the clerk may act without express direction from the judge, but at all times subject to his directions and orders. ${ }^{7}$

What kinds of transactions may be registered by the clerk without express authority of the judge and what may not will be disclosed in the discussion which is to follow in the immediately succeeding chapters.

$\$$ 140. Voluntary Transactions Executed in the Prescribed Form Accompanied by Owner's Certificate.-Generally speaking, if a voluntary transaction is executed on the standard form prescribed in the Act and if the owner's certifi-

2. T. $\S \S 157-8,161-3$.

3. T. $\S 141$.

4. Chapter XI, post, and T. $\S \S 144-5$.

5. Chapter XII, post.

6. T. $\S 21$.

7. T. $\S 270$. 
cate is presented along with it, the clerk is authorized to register the transaction without the direction of the judge being first obtained ; 1 and this is done by simply filling in on the title register, in the appropriate blanks arranged there for that purpose, the matter contained in the corresponding blanks in the form prescribed for the execution of the transaction, the entering of the cancellation and the re-issue of the certificate of title or the notation of the transaction on the register and on the owner's certificate accordingly as the nature of the transaction may be. ${ }^{2}$

Exceptions to the general proposition that a voluntary transfer accompanied by the owner's certificate may be entered by the clerk without the previous authorization of the judge, are treated, under the classification previously made, as special cases.

The special cases to which reference has been made are, where a registered owner has died, when a court of equity orders a transfer, when a person's name has been changed by marriage, or other cause, when transactions have taken place between husband and wife, where the title is held in trust or under special powers, limitations or conditions, etc.,-all of which will be discussed hereinafter in their proper order. ${ }^{3}$ In all of these cases, the clerk cannot make the registration until he is first authorized by the judge to do so.

\section{$\S$ 141. Voluntary Transfers and Mortgages Not Ac-} companied by Owner's Certificate.-If the voluntary transaction consist of a transfer, either absolute or as security for debt, or a mortgage, or any other voluntary transaction (except voluntary cancellations of liens and other similar matters, as provided in Sec. 62 of the Act), 1 the clerk must not register it, if the owner's certificate is not produced along with it. ${ }^{2}$ This

[§ 140] 1. A. § 37, T. § 270.

[§140] 2. For suggestion as to what the clerk shall do in the event he is unable to register the transaction from the information given in the instrument presented for registration see $T$. $\S 270$.

3. See Chapter XII, post.

[§ 141] 1. T. $\S \S 142,159$, and 180 .

[\$ 141] 2. A. § 37 . 
is a great safeguard against fraud or forgery ${ }^{3}$ and must in no case be relaxed by the clerk. If, by any chance, any one becomes the holder of a voluntary transfer or mortage, and fails to get the owner's certificate to accompany it to the registry and cannot succeed in getting it, a court of equity has express power under Section 49 of the Act to afford relief in case of a transfer, and implied power, under that part of Section 73 which subjects registered land to the jurisdiction of the courts, to grant appropriate relief in case of the mortgage. ${ }^{4}$

\section{$\S$ 142. Voluntary Cancellation of Liens and Encum.} brances.-The cancellation of a lien or any other similar interest in the registered land is a voluntary transaction, ${ }^{1}$ when considered from the standpoint of the holder of the lien or other encumbrances, but such cancellations may be made without the production of the owner's certificate (though if it be produced the entry may also be cancelled on it at the same time) under the provisions of Section 62 of the Act, as follows: "Voluntary cancellations may be made of any mortgage, certificate of indebtedness or any lien, equity, encumbrance, lis pendens, or other similar matter relating to registered land or any interest therein, and may be entered by the clerk upon the Title Register and the owner's certificate. The entry, notation or registry of such cancellation may be made upon the written authority of the person for whose benefit the original registration, notation or entry was made, or his personal representative, or lawful assignee, in a form substantially in compliance with that herein prescribed, attested by any officer authorized to attest deeds; or upon order of the judge. In case of a creditor's certificate the same shall also be surrendered and canceled. ${ }^{2}$ Notations of delinquent taxes or assessments may be canceled upon the production of a certificate of the proper tax officer showing that such taxes or assessments have been paid." 3 The form prescribed to authorize such cancellations is set forth in Section 116 of the

[§ 141] 3. See T. $\S 215$.

4. See T. §205.

1. See the definition given in A. $\S 3$, T. $\S 21$.

2. See also A. $\S 33$; T. $\S 159$.

[§ 142] 3. See also T. $\S 180$. 
Act. This form omits the attesting clause, but Section 62 of the Act requires that the authority or request to cancel shall be attested by some officer authorized to attest a deed.4

\section{$\S$ 143. Voluntary Transactions Not in Prescribed} Form.-Voluntary transactions though not executed in the prescribed form may be registered by the clerk, ${ }^{1}$ provided the owner's certificate is produced along with the instrument evidencing the transaction. ${ }^{2}$ Special provisions are made as to how such transactions shall be dealt with; but a discussion of these is reserved for another context. ${ }^{3}$

$\S$ 144. Involuntary Transfers-Registered Only on Order of the Judge.-It is provided in Section 41 of the Act that, "Except as herein otherwise provided, in cases of involuntary transactions, no transfer of title shall be registered except upon an order granted by the judge of the court in the form substantially as that hereinafter prescribed." The form mentioned is set forth in Section 110 of the Act, and the method of applying for the order and the proceedings thereon are set forth in Sections 50 and 52 of the Act. The exceptions referred to will be discussed hereinafter under the topic of "Special Cases". ${ }^{1}$ Notice that Section 41, quoted above, relates only to transfers and not to all voluntary transactions.

\section{$\S$ 145. Involuntary Transactions Not Involving a Trans-} fer of Title.-Involuntary transactions, not involving a transfer of the title, do not ordinarily require any sanction of the judge before they can be noted on the certificate of title on the Title Register. The registration of such transactions, which usually consist of claims which third persons are asserting against the owner, such as liens arising by operation of law, encumbrances, the assertion of equities, notice of lis pendens, etc., carries with it no presumption that such liens or claims are in

4. As to cancellation of tax liens, see T. $\S 186$.

[§ 143] 1. See A. $\S 117$.

2. See A. $\S \S 37$ and 117 .

3. See T. $\S \S 162-3$.

[§ 144] 1. Chapter XII, post.

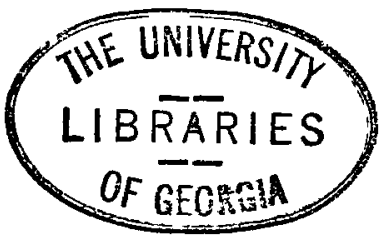


fact valid, but operates only as notice. ${ }^{1}$ Unless they are noted on the certificate of title on the register, they do not affect the title, ${ }^{2}$ hence the importance of noting them. Therefore, it is provided in Section 51 of the Act that "Any writing or instrument for the purpose of encumbering or otherwise dealing with equitable interests in registered land, or tending to show a claim of lien or encumbrance thereon or right therein may be noted on the certificate of title in the Title Register with such effect as it may be entitled to have." The method of causing such notations to be made and the form to be used in that connection are prescribed in Sections 57, 61, 112, 113, and 114 of the Act. ${ }^{3}$

1. See T. $\S 235$.

2. A. $\$ \S 63,73$.

3. See T. $\S \S 173$ et seq. 


\section{CHAPTER X.}

Methods of Registration-Voluntary Transactions.

$\S$ 146. Preliminary.

$\$$ 147. Voluntary Total Transfer in Standard Form.

$\S$ 148. Voluntary Transfer of Undivided Interest in Standard Form.

$\S$ 149. Procedure Where Co-Owner Refuses Possession of Owner's Certificate for Registering Partial Transfer.

\$ 150. Voluntary Transfer of Estate Less than fee-Leases-Timber and Mineral Rights.

$\S 151$. Voluntary Transfer of a Divided Portion of a Tract, Executed in Standard Form.

$\S 152$. Transferring the Certificate as Security for Debt.

$\S$ 153. Creditor's Certificate

$\S$ 154. Same Continued-Negotiability.

$\S$ 155. Same Continued-Foreclosure.

$\S$ 156. Same Continued-Registering the Transaction.

$\S$ 157. Same Continued-Transfer to Secure Debt, Not Executed in Standard Form.

\$ 158. Same Continued-When the Clerk Is to Retain the Instrument of Transfer and When Not.

$\S$ 159. Cancellation of Creditor's Certificate.

$\S 160$. Transferring Title to Purchaser on Foreclosure of Creditor's Certificate.

$\S$ 161. Mortgages-Standard Form.

$\S$ 162. Mortgages Not in Standard Form-When Mortgagee Retains Original-When Not-Foreclosure.

\$ 163. Voluntary Transfers Not Executed in Standard Form-Transfers in Trust or upon Conditions or Special Terms.

$\S$ 164. Voluntary Transfers by Corporations.

$\S$ 146. Preliminary.-So far, the discussion of the various kinds of transactions which may affect a title has proceeded with the view of determining which of the transactions may be registered by the clerk without prior authorization of the court, and which may not. It will now turn to the question of how these various transfers and other transactions are to be effected, with practical suggestions as to the details which attend the procedure under the varying circumstances which may be presented. 
$\S$ 147. Voluntary Total Transfer in Standard Form.The simplest case of transfer is where the owner transfers the whole of the registered estate, without any trust or unusual conditions attached thereto, and uses the form prescribed in Section 107 of the Act. This form is usually printed on the back of the owner's certificate, ${ }^{1}$ but it may be written on a separate paper, if it is so desired, and attached to the owner's certificate. The filing of the blank is a simple matter, no information being required except the consideration, the name of the owner, the name of the vendee, the number of certificate of title, and the registered title number. It must be signed in the presence of and attested by two witnesses, one of whom must be an officer authorized by the laws of this State to attest deeds; indeed, it has all the force and effect of a deed, and might be recorded as such under the general laws of this State relating to unregistered lands. ${ }^{2}$

When an owner's certificate, with such a transfer written on it or attached to it, is presented to the clerk, he opens the Title Register at the certificate of title of which the owner's certificate is a duplicate, and enters in the ruled blanks under the heading "Transfers" the name of the vendee, the date appearing in the transfer, the consideration; enters under the subhead "Total or Partial" the word "total"; enters under the subhead "Voluntary or Involuntary" the word "voluntary"; looks ahead in the Title Register and ascertains what the number of the new certificate about to be issued will be and inserts that in the appropriate blank; fills in the date of the entry of the transfer and signs it. He then skips to the bottom of the second page of the certificate of title and fills in the cancellation entry there shown, dates it and signs it. He makes the same entries, that of the transfer and that of the cancellation, on the owner's certificate, dating and signing them. He then makes out the new certificate on the Title Register, substituting therein the name of the vendee where the former owner's name had appeared, but in other respects copying into the new certificate

1. A. $\$ 105$.

2. A. $\$ 30$. 
everything that had appeared in the old certificate, including all notations and entries ${ }^{3}$ (except, of course, the entry of transfer and cancellation which has just been put on the old certificate in order to issue the new one) except that entries, notations, and other matters which have been cancelled or have expired by their own limitations (as, for instance, where one is described as a minor in the cancelled certificate, but has become of age since it was issued), may be omitted from the new certificate. As to entries thus brought forward, the clerk should enter the words "Brought forward" under the heading "Remarks"." In the parenthesis, following the words "Entered and registered" at the bottom of the certificate proper, he should insert the number of the old certificate just cancelled. It should be kept in mind that the new certificate bears the same registered title number as the old certificate, but takes its own certificate of title number. The clerk then makes out a new owner's certificate, an exact duplicate of the new certificate and of all its notations and entries, delivers it to the new owner, collects one dollar from him for making the transfer $;^{5}$ and the registration and consequent transfer is accomplished.

\section{$\S$ 148. Voluntary Transfer of Undivided Interest in} Standard Form.-If the land stands in the name of several owners and all join in executing a total transfer, the transaction is handled just as if there was only a single owner; but, if the land stands in the name of several owners as co-tenants and one wishes to transfer his undivided interest, or if it stands in the name of a single owner and he wishes to transfer an undivided interest, leaving himself owning the remaining interest, the Act in Section 107, prescribes a sightly different form from that used in the case of total transfer. ${ }^{1}$ It is to be executed, attested, and attached to ${ }^{2}$ the owner's certificate, just as in the

3. A. $\$ \S 39$ and 100 ; T. $\S 187$.

4. A. $\S 100$.

5. A. $\S 120 ;$ T. $\S 259$.

1. A. $\S 31$.

2. In case of the transfer of an undivided interest the instrument of transfer should be attached to and not written upon the owner's certificate. The reason of this is that the clerk is required to keep 
case of a total transfer. However, in this case, where only an undivided interest is transferred, the clerk does not cancel the old certificate.

Upon the presentation of the transfer, with the owner's certificate attached, the clerk enters the transfer in the blank for that purpose on the certificate of title and under the sub-head “Total or Partial," states just what interest is transferred and, in case the certificate stands in the name of several owners, and only one or less than all of them is transferring, he should also state whose interest or interests is being transferred. Under the head of "Remarks," the clerk should make a memorandum of what interests are left outstanding in the owners of the certificate. Thus, suppose the certificate stands in the name of Smith, Jones and Brown, as tenants in common, each owning a onethird interest. Suppose that Jones and Brown transfer to Thomas their two-thirds undivided interest. The clerk, after noting the transfer of Jones and Smith's two-thirds interest, should, under the head of "Remarks," write "This leaves the certificate outstanding as to the one-third undivided interest of Brown." Or, suppose Smith were the sole owner and he sold Thomas a one-half undivided interest, the entry under the head of "Remarks" would be "This leaves the certificate outstanding as to a one-half undivided interest in Smith."

After registering the entry of the undivided interest on the certificate of title on the Title Register, the clerk should make exactly the same entry on the owner's certificate. He should then, without cancelling the old certificate or the owner's duplicate, issue a new certificate in the name of the transferee of the undivided interest. This new certificate should state on its face that it is only for an undivided interest; that is to say, in making out the certificate, when the clerk comes to the words "thereby vested in," he should fill in the blank with the name of the transferee, and the same is true as to the blank following the

and file away the instrument of transfer, and in the case of a transfer of an undivided interest the owner's certificate is not to be canceled but is to be returned to the owner. Therefore, the instrument of transfer should be so prepared that it may be detached and filed away, when the owner's certificate is returned. 
words "The estate owned by said"; but, when he comes to the blank following the words "in said land is as follows", he should say "an undivided one-half (or one-third, or two-thirds, of whatever it is) interest in the fee simple."

All limitations, entries and notations of every kind appearing uncancelled on the old certificate must be noted, also, on the new one, excepting such entries or limitations as relate only to the undivided interest not transferred and do not cover or relate to the undivided interest which is transferred. ${ }^{3}$ An owner's certificate for the undivided interest is made out in exact duplicate with the new certificate on the register, and delivered to the transferee of the undivided interest.

\section{$\S$ 149. Procedure Where Co-Owners Refuse Posses- sion of Owner's Certificate for Registering Partial Trans- fer.-In the event a certificate stands in the name of several as common owners, but the owner's certificate is held in the physi- cal possession of one of them, and he should refuse to deliver it up in order that a transfer of the undivided interest of one or more of his co-tenants may be made, the transaction should be handled as an involuntary transaction under the provisions of Sections 50 and 52 of the Act.}

\section{$\S$ 150. Voluntary Transfer of Estate Less Than Fee} Leases-Timber and Mineral Rights.-No form is prescribed and no specific details are given in the Act as to how a lesser estate may be sold off and conveyed by one who owns the entire estate. However, it is prescribed in Section 117 of the Act that, "Where it is desired to register a voluntary transaction other than those for which forms have been otherwise indicated or prescribed the instrument showing the voluntary transaction shall be presented along with the owner's certificate, and the same shall be noted not only on the certificate of title in the Title Register, but also on the owner's certificate. If the instrument be already recorded on some public record, reference shall be made in the Title Register and on the owner's certificate to the book and page where it is recorded; if it be not

3. A. $\S \S 39$ and $100 ;$ T. $\S 187$. 
already recorded, the clerk shall record it, making like reference to the Title Register and on the owner's certificate to the book and page where recorded."

The act of the owner in selling off a lesser estate is, of course, a voluntary transaction. ${ }^{1}$ Such a lesser estate is an encumbrance, for the recongized definition of an encumbrance (or incumbrance, as the word is often written) is any right to or interest in land which may subsist in a third person to the diminution of the value of the estate of the tenant (i. e., of the owner of the fee simple), but consistent with the passing of the fee. ${ }^{2}$ Therefore, while the grant of the lesser estate (such as a life estate, a lease for years, the right to cut timber or remove minerals) may be registered, there is no provisions whereby a certificate of title may issue in favor of such an owner. Being a voluntary transaction, the clerk should refuse to register it unless accompanied by the owner's certificate, ${ }^{3}$ though he may note the third person's claim of such a right under the provisions of Section 51 of the Act.

In case the transaction is registered on production of the owner's certificate, it should be entered on the certificate of title under the head of "Transfers"; if entered merely as a claim and without the production of the owner's certificate, it must be accompanied by the formal request for notation in accordance with provisions of Section 114 of the Act, and should, in that event, be noted on the certificate of title on the register in the blank space under the head "Special entries and notations." In either event, the provisions of Section 117 of the Act, require that the instrument conveying the lesser estate should be recorded in some public record in the office of the clerk, and reference should be made in the entry or in the notation to the book and page of the public records where the instrument is recorded.

In many respects, it would have been more expedient if the

1. See definition, A. $\S 3 ;$ T. $§ 21$.

2. Words and Phrases, pp. 3619 et seq.; Prescott $v$. Trueman, 4 Mass, 627, 629, 3 Am. Dec. 249; Van Ness v. Royal Phosphate Co., 60 Fla. 284, 53 So. 381, 30 L. R. A. (N. S.) 833, Ann. Cas. 1912 C. 647.

3. A $\S 37 ;$ T. $\S 140$. 
framers of the Act had made provision for the issuance of independent certificates of title in favor of the transferees of such lesser estate as are of possible extensive duration, (such as life estates or estates of more than five years); however, this is a matter which can easily be provided for either by legislative amendment of the Act or by the adoption of a superior court rule under the authority of Section 70 of the Act. ${ }^{4}$

\section{$\S$ 151. Voluntary Transfer of a Divided Portion of} Tract, Executed in Standard Form.-If the owner transfers a divided portion of the tract contained in his certificate, ${ }^{1}$ he may execute the instrument of transfer in accordance with the form prescribed for that purpose in Section 107 of the Act, - a form corresponding in general details to the form used in case of total transfer. This should be written on or attached to the owner's certificate and attested as a deed. Unless the divided portion of the land which is transferred is described in such terms and with such accuracy as to identify it completely as a part of the tract contained in the outstanding certificate and, also, as to show definitely and exactly what part of the tract is to be transferred and what part is to remain in the seller, the clerk should refuse to register the transfer and should submit the matter to the judge for his direction, ${ }^{2}$ unless the parties voluntarily correct the delinquencies.

If the instrument of transfer is in proper shape, the clerk registers the transfer on the certificate of title on the register and on the owner's certificate. He then fills out and signs the entry cancelling the certificate on the register and on the owner's certificate, proceeding in general conformity to the method of registering a total transfer, except that in this case two new certificates are to be issued, and, therefore, two new certificate numbers are to be inserted in the space indicated for that purpose in the certificate being cancelled. The outstanding certificate and owner's duplicate being cancelled, the clerk registers two new certificates of title on the register (delivering two new

4. See T, $\S 266$.

1. A. $\$ 31$.

2. A. $\$ 59$. 
owner's certificates correspondingly), one in favor of the transferee for the part of the tract that goes to him, and one in favor of the transferer for the part he retains.

All notations, and entries of every character, remaining unexpired or uncancelled on the certificate cancelled by the transfer are to be copied on both the new certificates, on the register, and on the owner's certificate, except that in case of an entry or notation affecting only a divided portion of the land, in which case such an entry or notation is to be copied only on the certificate which includes the land to which it relates. ${ }^{3}$ The provisions for cross-reference between the two new certificates ${ }^{4}$ may most easily be complied with by the clerk entering the cross-reference under the heading "Special Entries and Notations," thus "See Certificate of Title No._ as to a divided portion of the tract contained in the original decree." $\mathbf{s}$

\section{$\S$ 152. Transferring the Certificate as Security For} Debt.-The Act contemplates that the owner of a certificate of title may wish to use it as security for debt, and contains several provisions on this subject. One way in which he may use it is to execute a transfer on the certificate itself, just as if it were a stock certificate, attest it as if it were a deed, and deliver it to the creditor as collateral security. ${ }^{1}$ The danger to the owner, in such a case, is that if the creditor were to take the certificate and carry it to the clerk and cause the transfer to be registered, the old certificate cancelled, and a new one issued in his name, the debtor would lose the title to his land, though he might have an action against the creditor for any loss or damage occasioned to him, or if the creditor had not retransferred the certificate might get relief and a restoration of his title through resort to a suit in equity. Section 36 of the Act affords protection against such a contingency by providing that the debtor may cause his title to be transferred to the cred-

\footnotetext{
3. A. $\$ \S 39$ and $100 ;$ T. $\S 187$.

4. Concluding sentence of A. \$31.

5. As to clerk's fees to be charged in cases of this kind see T. $\S$

1. A. $\S 36$.
} 259. 
itor and may take back a bond for title, which too must be attested as if it were a deed, and, to be effectual, must be noted on the certificate of title issued in the crditor's favor.

When the debt is paid, the creditor should transfer back to the debtor and have new certificate issued, and, if he refuses to do so, the judge can order an involuntary transfer and new certificate under the provisions of Sections 50 and 52 of the Act. $^{2}$

$\S$ 153. Creditors's Certificate.-The Act, however, provides a very simple and expedient method by which the title may be transferred as security for debt, without requiring the debtor to surrender his certificate, and yet as fully protecting the creditor as if the owner's certificate stood in his name and giving him a very easy method of foreclosure in the event the debt is not paid at maturity. This result is obtained through the issuance of a "creditor's certificate" which is intended to operate as to registered lands very much in the same manner as security deeds with power of sale without foreclosure operate as to unregistered lands. It is provided in Section 32 of the Act that "Whenever the owner of any registered land shall desire to convey the same as security for debt, with power of sale without foreclosure, it may be done by a short form of transfer, substantially in the form hereinafter set forth. The same shall be signed and properly acknowledged or attested, as if it were a deed to land, and shall be presented, together with the owner's certificate to the clerk, ${ }^{1}$ whose duty it shall be to note upon the owner's certificate and on the certificate of title in the Title Register the name of the creditor, the amount of the debt, and the date of maturity of same, and showing that a creditor's certificate has been issued therefor, and when only a part of the registered estate shall be so conveyed, the clerk shall note upon the said book and owner's certificate the part so conveyed." The form of transfer to be executed by the creditor is prescribed in Section 107 of the Act, and the form of creditor's certificate is prescribed in Section 108.

1. The transfer should not be written on the owner's certificate, but upon a separate paper. See note 2 to T. $\S 148$.

2. T. $\S \S 166$ et seq. 
The transfer to secure debt and creditor's certificate may relate only to a portion (divided or undivided) of the land, and for that contingency it is provided in Section 109 of the Act that "Where only a portion of the registered land or only an undivided interest is transferred to secure a debt, the instrument of transfer and the creditor's certificate may be in the same form as those prescribed in the two preceding sections (i.e. Secs. 107 and 108) with the exception that the portion or the undivided interest shall be distinctly stated.

$\S$ 154. Same Continued-Negotiability.-The creditor's certificate thus issued is not only a very effective means of securing the debt named in it, but itself becomes an instrument capable of the easiest negotiability, readily adaptable to commercial usages. It is provided in Section 33 of the Act that, "The creditor's certificate shall be assignable or negotiable to the same extent as the note or other evidence of indebtedness secured thereby may be, but assignments or transfers of the creditor's certificate need not be noted on the Title Register. A transfer or assignment of the indebtedness shall operate to transfer the creditor's certificate securing the same, in like manner and to the same extent as is set forth in Section 4276, of the Civil Code, ${ }^{1}$ relating to the case of transfer of indebtedness secured by mortgage, unless otherwise agreed between the parties." This gives to the creditor's certificate the maximum of liquidity as a commercial instrument where it secures promissory notes and other negotiable instruments; for, in connection with the negotiable instrument secured thereby, it may be passed from holder to holder by simple endorsement in blank or otherwise.

1. $\$ 4276$ of the Code provides: "The transfer of notes secured by a mortgage or otherwise conveys to the transferee the benefit of the security. If more than one note is secured and the mortgagee transfers some and retains others, the holder of the transferred notes has a preference over the mortgagee if the security is insufficient to pay all the notes."

See also, construing this section as giving equality among transferees taking assignments at different times, Georgia Realty Co. $v$. Bank of Covington, 19 Ga. App. 219, 91 S. E. 267. 
$\S$ 155. Same Continued-Foreclosure.-Foreclosure under creditor's certificate is likewise prompt and simple. It is provided in Section 35 of the Act that, "If the debt secured by the creditor's certificate so issued, or any part thereof shall be due and unpaid, the holder of said creditors certificate may, after advertising the property for sale in the manner prescribed by law for advertising sheriff's sales of land, expose the same at auction before the court-house door of the county and sell the same to the highest and best bidder for cash. The sale need not be conducted by the creditor or holder of the creditor's certificate personally, but may be conducted through an agent or attorney. The holder of said certificate, his agent or attorney, shall thereupon make oath to the facts, and apply to the judge for an order of transfer to the purchaser." 1 The disposition of the proceeds is regulated by the same section, as follows: "The proceeds of the sale shall be applied, first, to the payment of the costs of advertising the sale and obtaining the judge's order of transfer, then to the payment of the debt, and the remainder, if any, shall be paid to the debtor, or his order."

\section{$\S$ 156. Same Continued-Rgistering the Transaction.-} If the transfer to secure debt is executed in the form prescribed for that purpose in Section 107, and contains nothing more than the filling in of the blanks therein, so that the entry of registration on the Title Register construed in connection with the form shows the full transactions, ${ }^{1}$ the clerk, upon presentation of the instrument of transfer, accompanied by the owner's certificate, enters on the Title Register and on the owner's certificate under the head of "Liens, Encumbrances and Other Matters affecting this Certificate" and under the sub-head "Creditor's Certificate," there shown, a memorandum of the creditor's certificate, giving the name of the creditor, the date of the certificate, the total amount of the debt, and describing the indebtedness in detail, that is showing the dates, maturities, rate of interest, attorney's fees, if any, included in each note or evidence of indebtedness secured by the certificate. In the event

[§ 155] 1. Further on the same subject see T. $\S 160$.

$\left[\begin{array}{ll}\S & 156\end{array}\right]$ 1. A. $\S 38$. 
only a part of the tract is conveyed (whether a divided or an undivided portion), that fact should be stated under the head of "Remarks," and, if the description of the divided portion be too long for convenient copying in the blank space on the register, the instrument of transfer may be copied in one of the public records with reference to such records for details. ${ }^{2}$ The clerk, after having registered the creditor's certificate on the certificate of title and the owner's certificate, returns to the owner his certificate and makes out and delivers to the creditor the certificate of indebtedness on the form shown in Section 108 of the Act. ${ }^{3}$

The creditor's certificate should bear the same registered title number and the same certificate of title number as that borne by the certificate of title on which it is issued. The lands should be described in it in the exact terms in which they are described in the certificate of title in the register, unless only a part (divided or undivided) of the tract is included in the creditor's certificate, in which event that part or fractional interest should be set forth and accurately described. In the blank following the words "vested in" in the prescribed form is to be inserted the name of the creditor. At the space left for that purpose is to be given a full and accurate description of the debt, just as it is described on the Title Register. Following the words "The estate in said lands so held is as follows" the clerk should copy all that is contained in the certificate of title, following substantially the same words contained on the certificate of title. All uncancelled entries of encumbrances, rights, or adverse claims of any kind, affecting the land contained in the creditor's certificate and appearing on the certificate of title at the time the creditor's certificate is issued must be noted and entered on the creditor's certificate. It should be signed by the clerk, with his official seal attached.

$\S$ 157. Same Continued-Transfers to Secure Debt Not Fxecuted in Standard Form.-While Section 107 of the Act prescribes the standard form of transfers to secure

2. A. $\$ \S 38$ and 104 .

3. A. § 32. 
debt, for the purpose of issuance of creditor's certificates, still it is provided in the beginning of that section that other forms may be used, but special requirements apply to the registration of the transaction whenever the standard form is deviated from. Reasons will often appear, in actual practice, for inserting other provisions into the contract than those which are included in the standard form of instrument of transfers to secure debt, or than those which can conveniently be set forth therein.

For instance, the standard form contains no consent on the part of the debtor that the creditor may be a purchaser at the foreclosure sale, and in the absence of such express consent a well recognized equity rule would prevent him as the person exercising the power of sale from being a bidder at the sale. It is doubtless true that the debtor's consent to the creditor's purchasing at the sale could be validly given separately, either by an instrument executed contemporaneously with the transfer or subsequently, but the cautious creditor may prefer to have this right stated and registered as a part of the rights contained in his certificate. Ordinary security deeds commonly contain covenants as to insurance, taxes, the acceleration of the maturity of the indebtedness by the default of interest or an instalment of principal, and a variety of similar matters, which cannot be conveniently included in the standard form or entered in the available space on the Title Register. In all such cases, the parties may add to the form prescribed in Section 107 , though all that is contained in substance there should be contained in the informal substitute for the standard form.

Upon such an instrument being presented to the clerk, if it be properly attested, and is accompanied by the owner's certificate, ${ }^{1}$ he first proceeds to record the instrument in full on one of the deed books of the county and then registers the certificate of indebtedness in the space for that purpose on the certificate of title and on the owner's certificate, following, in the main, the same method as is to be observed in the case of a certificate of indebtedness in the standard form, but giving only

1. A. $\S 37 ;$ T. $\S 140$. 
general details instead of full, specific details of the transaction, and noting a reference in the column designed for that purpose, as follows: "With special terms; see Deed Book-page-." 2

Since the creditor will have the original instrument of transfer returned to him after it shall have been recorded, ${ }^{3}$ he will not need to have a certified copy of it made to attach to his certificate of indebtedness, but if any matter relating to the owner's title has been briefed on the register with reference to some other public record for full particulars, the creditor will likely wish to have a certified copy of that. To this end it is provided in Section 104 that "Whenever any of the description or details of a certificate of title on the Title Register shall be set out in full in some other record of the clerk's office, with reference thereto on the Title Register, as hereinbefore provided, like reference shall be made on the owner's certificate and on creditor's certificates when thereafter issued, but if the holder of such owner's certificate or creditor's certificate shall so require, the clerk shall make a full and complete copy of such record to which reference is made and certify it as such and attach it to the owner's certificate or the creditor's certificate, as the case may be. For making and certifying such copy of the recorded document or writing and attaching it to the owner's certificate or creditor's certificate, as the case may be, the clerk shall be paid ten cents per hundred words in addition to the other regular fees in this Act provided."

In issuing the creditor's certificate upon a registration where the standard form has been added to or deviated from, the clerk should, after describing the indebtedness in the blank in the creditor's certificate, left for that purpose, add the words "and upon the special terms and conditions set forth in an instrument relating thereto, recorded in Deed Book page _." The clerk may be reminded that in this, as in all other cases, "All registered encumbrances, rights or adverse claims affecting the estate represented in existence at the time the creditor's certificate is issued shall be noted thereon." 4

2. A. $\S 38$.

3. A. $\S 38 ;$ T. $\S 158$.

4. A. $\$ 32$. 
$\S$ 158. Same Continued-When the Clerk Is to Retain the Instrument of Transfer and When Not.-If the standard form of transfer to secure debt is used, the clerk will, after making the registration and issuing the creditor's certificate, retain the instrument of transfer and file it away in the file devoted to the papers bearing the same registered title number as it does. ${ }^{1}$ If the standard form is departed from, the clerk will not retain the original instrument, but will, after having recorded and registered it, give it to the creditor to be attached to his certificate of indebtedness. ${ }^{2}$

$\S$ 159. Cancellation of Creditor's Certificate.-It is contemplated that when the certificate of indebtedness shall have subserved its legitimate ends, it shall be canceled off the registry. It is provided in the course of Section 33 of the Act, that "The creditor's certificate may be surrendered and canceled at any time by the owner thereof. It shall be the creditor's duty to surrender the same and give order for cancellation of the same when the debt is paid. If he refuses to do so he may be compelled by the court to do so, and in any proper case the judge may order a cancellation on the Title Register. Upon presentation of an order of cancellation, with the surrendered creditor's certificate, or upon presentation of the judge's order directing cancellation, the clerk shall enter a notation of the same in the Register of Titles and on the owner's certificate of title."

The method of effectuating a voluntary cancellation is set forth in Section 115 of the Act, as follows: "Authority may be given to register the cancellation of a creditor's certificate by the owner thereof writing thereon 'Canceled, the clerk will please cancel the same on the Title Register,' dated and signed in the presence of any officer authorized to attest deeds. If the person owning the creditor's certificate is not the person in whose name it was issued and if the original creditor shall not have endorsed it in blank, the owner signing the cancellation shall also make affidavit that he is the owner of the creditor's certificate and entitled to cancel it. The creditor's certificate

1. A. $\S 119 ;$ T. $\S 272$.

2. A. $\S 38$. 
shall be surrendered to the clerk at the time of the registration of the cancellation."

In case the holder of the certificate of indebtedness refuses to cancel it and it is necessary to appeal to the judge for an involuntary cancellation, the procedure should be in general conformity with the provisions of Sections 50 and 52 of the Act. ${ }^{1}$

\section{$\S 160$. Transferring Title to Purchaser on Foreclosure} of Creditor's Certificate.-Whenever the land held under the creditor's certificate shall have been sold in accordance with the provisions of the Act, ${ }^{1}$ it is incumbent upon the holder of the creditor's certificate, his agent or attorney, to make oath to the facts and to apply to the judge for an order transferring the owner's certificate and, consequently, the title to the land to the purchaser at the sale. It is further provided in Section 35 of the Act, that "The application shall be accompanied by a certified copy of the certificate of the title from the Title Register as of the date of the same. The judge shall cause at least five days notice to be given to the debtor and to any person who, according to the Title Register, shall have acquired any interest in the property subsequently to the issuance of the creditor's certificate; and if no objections are made, or after hearing if objections be made, the judge shall grant an order of transfer with such directions for cancellation of other certificates and entries, and otherwise as shall be in accordance with the justice of the case, and with the spirit of the Act."

The requirement that the application shall be accompanied by a certified copy of the certificate of title from the Title Register as of the date of the sale, is that the court may give not only the original debtor but any person who may have acquired any rights under or through him, an opportunity to be heard on the question of whether he shall order an involuntary transfer of the title. The owner may have transferred his certificate of title to some one else after he authorized the creditor's certificate, or some third person may have acquired a mortgage, a judgment or other lien, against the land in the meantime; indeed the land

[§ 159] 1. See also T. $\S \S 179,181$.

$[\S 160]$ 1. A. $\S 35$. 
may have passed through the hands of a number of successive owners between the date of the certificate of indebtedness and the date of the sale. Any of these, as well as the debtor, would have the right to contest the validity of the sale under the creditor's certificate. The holders of such liens, encumbrances or other rights as were noted on the certificate of title prior to the registration of the creditor's certificate would, of course, be unaffected by the issuance of it. Their rights could ordinarily be protected by causing a notation or entry of them to be noted on the purchaser's certificate of title in the event the court should find the sale legal and direct the outstanding certificate of title to be canceled and a new one issued in the purchaser's favor. The creditor's certificate would ordinarily be superior to anything noted on the Title Register after its issuance or to any subsequent transfer or transfers of the certificate of title, and, if the sale be legally conducted, their rights or title would be divested. The original debtor being the Adam of their race, his fall redounds to them.

If the court finds that the purchaser is entitled to an order of transfer, he grants it with such directions as may be appropriate to the facts of the particular case-the same to conform, as closely as the exigencies of the case will allow, to the form prescribed in Section 110 of the Act. ${ }^{2}$ The cancellation of outstanding certificates of title and the issuance of the new certificate to the purchaser are performed by the clerk in conformity to the order of the judge and the general provisions of the Act relating to involuntary transfers. ${ }^{3}$

However, if the debtor is still the owner of the land at the time of the sale under the creditor's certificate, and if no intervening rights of third persons have arisen between the date of the creditor's certificate and the date of the sale, and the debtor makes no contest as to the validity of the sale, he can save himself the cost of the proceeding before the judge by voluntarily transferring his certificate of title to the purchaser and having it and the creditor's certificate canceled and a new certificate issued on the voluntary transfer to the purchaser.

2. T. $\S \S 166-8$.

3. T. $\S 171$. 
$\S$ 161. Mortgages-Standard Form.-The method of creating a mortgage on the whole or any part of a registered tract of land is simple. Mortgages, under the laws of this State, do not pass the title, but merely create a lien, ${ }^{1}$ differing substantially in this respect from creditor's certificates, which, under the Act, pass the title. Section 111 of the Act prescribes the standard form to be used in mortgaging registered land, but other forms are permissible.

The mortgaging of land is a voluntary transaction, ${ }^{2}$ hence under the provisions of Section 37 of the Act, the owner's certificate must accompany the mortgage to the registry at the time the entry of the mortgage is to be registered on the certificate of title; and this is true whether the mortgage is the standard form or is informal or irregular. If the mortgage is in the standard form and is accompanied by the owner's certificate, upon its presentation to the clerk, he registers it by entering a brief of its material parts on the certificate of title and on the owner's certificate under the head, "Liens, Encumbrances and Other Matters Affecting This Certificate." A comparison of the prescribed standard form with the blanks under this head on the certificate of title will show that all that is necessary to do is to copy into the appropriate columns on the certificate of title the language used by the parties in filling in the mortgage form. Where only a part of the tract or an undivided interest is mortgaged, the form shown in Section 111 of the Act may be varied accordingly, but this does not render the mortgage irregular or prevent its being registered as being in the standard form.

\section{$\S$ 162. Mortgages Not in Standard Form-When} Mortgagee Retains Original-When Not-Foreclosure.If the mortgage is executed otherwise than on the short form prescribed in the Act, or if its provisions be such that they cannot be conveniently contained in the allotted space on the certificate of title, when it is presented to the clerk along with the owner's certificate of title, the clerk first records the mortgage in one of the mortgage records of the county, then enters a no-

1. Civil Code $\S 3256$.

2. A. $\S 3 ;$ T. $\S 21$. 
tation of it on the Title Register and on the owner's certificate in practically the same manner as a regular mortgage is entered, except that the full terms are not stated but are briefed, followed by the reference entry in the appropriate column "On special terms; see mortgage book ." 1

When the mortgage, formal or informal, is registered on the certificate of title and on the owner's certificate, the clerk returns the owner's certificate to the owner. If the standard form of mortgage has been used, the clerk will not return the mortgage to the mortgagee, but will file it away in the file in which the other papers bearing the same registered title number are filed, but will, on request of the mortgagee, make out and deliver to him a certified copy of it, which "shall stand for all purposes in lieu of the original, and shall be original evidence. to the same extent that an original mortgage ordinarily is, in any court." 2 If the mortgage is irregular or not on the standard form, the clerk, after having recorded and registered it, as stated above, will return it to the mortgagee.

Mortgages on registered land are to be foreclosed through the ordinary process of law or equity in the same munner as mortgages on unregistered land. The method by which the purchaser at foreclosure sale procures the title to be registered in his name will be discussed in another context. ${ }^{3}$

$\S$ 163. Voluntary Transfers Not Executed in Standard Form-Transfers in Trust or Upon Conditions or Special Terms.- In the discussion of the registration of mortgages and transfers to secure debt, it has been seen that variation from the prescribed form brings about variation in the method by which registration is accomplished. ${ }^{1}$ The same is true in respect of all voluntary transfers. The method by which

[§ 162] 1. A. $\S 38$.

2. A. § 38. Since a mortgage in the short form does not describe the land, it may be found useful or convenient at times to have recourse to the provisions of $\S 101$ of the Act, whereby a certified copy of the certificate of title showing the description of the land may be obtained.

3. T. $\S \S 166-172$.

[§ 163] 1. See T. $\S \S 157-8,162$. 
voluntary transfers executed on the standard form may be effectuated and registered has already been outlined and discussed. It is now to be seen that the same general rules under which informal or irregular transfers to secure debt and mortgages are to be registered, apply with only such variation as the inherent differences in the nature of the respective transactions necessitate, to all voluntary transfers where the instruments of transfer are not executed in accordance with the forms prescribed in Section 107 of the Act. For it is provided in Sction 38 of the Act, "Wherever a transfer, or transfer as security for debt, or mortgage, as to an estate in registered land, is executed in the form prescribed in this Act and the same duly registered and noted in the register of titles, and the same contains nothing more than the filling in of the blanks in said forms prescribed so that the entry of registration on the Title Register construed in connection with the prescribed form shows the full transaction, it shall not be necessary to record the transfer, security transfer, or mortgage, otherwise than by the registration on the Title Register; and such registration shall, for all purposes, take the place of recordation as to such instruments so executed; and a certified copy of such registration shall be admissible in evidence on like terms and with like effect as a certified copy of a deed, mortgage or other similar instrument is admissible under existing laws. In such cases the original instrument of transfer (together with the canceled owner's certificate), or original instrument of transfer as security for debt, or original mortgage, as the case may be, shall be numbered with the registration number of the title to which it relates, and carefully filed away, in such manner as to be of easy access, and preserved as a part of the records of the office of the clerk of the superior court. . . . . If the instrument of transfer be not in the short form herein prescribed, or if it contains any provisions not provided for in said form, or if it is executed for the purpose of transferring any estate or interest in the registered iand in trust, or upon any condition, or upon any peculiar, unusual limitation, the details at variance with or additional to those provided for under the prescribed form need not be entered in full on the Title Register and the owner's certificate, 
but the clerk shall record such instrument in full on the deed book of the county in like manner as deeds to unregistered lands are recorded, and shall after the general entry of the transfer on the Title Register and on the owner's certificate add thereto a notation that the same is in trust, upon condition, or on special terms as the case may be followed by the words: "See deed book (or mortgage book, as the cause may be) page -."

It is perhaps appropriate to reiterate that no voluntary transfer, whether executed on the standard form or not, should be registered unless it is accompanied by the owner's certificate, ${ }^{2}$ or unless the judge gives an express order for its registration.

$\S$ 164. Voluntary Transfers by Corporations.-Voluntary transfers executed on behalf of corporations should be executed as other voluntary transfers except that the proper corporate authority of the persons purporting to act and sign on behalf of the corporation should be made to appear. Prima facie, a transfer executed by any executive officer of a corporation, with the seal of the corporation attached, is presumed to be the authorized act of the corporation; but, since this presumption is only prima facie, the clerk has the right to require that there should also be attached a properly certified copy of the by-law, resolution of the board of directors or other corporate action authorizing the persons purporting to act on behalf of the corporation to do so. In case of doubt, ${ }^{1}$ the clerk may play safe by obtaining the direction of the judge, under Section 59 of the Act, before he makes the registration.

2. A. $\S 37$.

1. A. $\S 59 ;$ T. 269. 


\section{CHAPTER XI.}

Methods of Registration-Involuntary Transactions.

$\S$ 165. Preliminary.

\$ 166. Involuntary Transfers-Registered Only under Direction of Judge after Notice and Hearing-Order of Transfer.

$\S 167$. Summary Jurisdiction of the Judge as to Involuntary Transfers.

$\S$ 168. Method of Applying for Involuntary Transfers-Execution Sales-Tax Sales-Receiver's Sales-Bankruptcy.

$\S$ 169. Cancellation of Owner's Certificate on Involuntary Transfer -Cancellation by Publication.

$\S$ 170. Directions to the Clerk in Connection with Judge's Order of Transfer.

$\S 171$. Duties of the Clerk in Registering Involuntary Transfers.

$\S$ 172. Advertising Cancellation When Owner's Certificate Not Produced.

\$ 173. Notation of Liens, Encumbrances and Special Rights.

$\S 174$. Notation of Judgments and Similar Liens-Necessity and Effect of Notation.

$\S$ 175. Same Continued-Method of Notation.

$\S$ 176. Notation of Sundry Other Liens.

$\S$ 177. Taxes and Public Assessments-Necessity for NotationHow Noted-When Noted-Duty and Liability of Tax Officers.

$\S$ 178. Lis Pendens-Necessity for Registration-How Registered.

$\S$ 179. Adverse Entries-How Removed from Register.

$\S$ 180. Same Continued-Voluntary Cancellation.

$\S$ 181. Same Continued-Cancellation by Order of Judge.

$\S$ 182. Same Continued-Procedure to Compel Cancellation-Summary Jurisdiction of the Judge.

$\$ 183$. Summary Jurisdiction for Correction of Errors on Register.

$\S$ 184. Summary Jurisdiction over Forged or Fraudulent Registration.

$\S$ 185. Distinction between Summary Jurisdiction of the Judge and General Jurisdicton of the Courts.

$\S$ 186. Notation of Tax Lien, How Cancelled.

$\S 187$. Entries and Notations to Be Brought Forward.

$\S 165$. Preliminary.-When it comes to the consideration of involuntary transactions, a distinction must be kept in mind 
between involuntary transfers and other involuntary transactions; and between those transactions of this nature which when registered become conclusive and those which are registered merely for the purpose of effecting notice of some adverse lien, encumbrance or other special right asserted by some third person against the land or against the owner as to the land.

\section{§ 166. Involuntary Transfers-Registered Only Under} Direction of Judge after Notice and Hearing-Order of Transfer.-It frequently becomes necessary in the just administration of the affairs of men to take one man's property and transfer it to another without the former's consent, as, for instance, where it is sold under execution or other judicial sale, when it is condemned under right of eminent domain, etc. All transfers of registered lands which take place without the consent of the registered owner are called involuntary transfers. ${ }^{1}$ Omitting the special cases which have been reserved for separate discussion hereinafter, ${ }^{2}$ it may be stated that the method of effectuating such transfers is set forth in Sections 50 and 52 of the Act.

It is provided in Section 50 of the Act, that "Wherever in any other case [that is in cases other than the special cases which will be more fully discussed hereinafter] it is desired to have an involuntary transfer entered of record, application therefor shall be made to the judge of the court. The judge may hear the facts or, if he deems best, he may refer the application to an examiner of titles to make up and report the facts. ${ }^{3}$ $\mathrm{He}$ shall see to it that all parties at interest are given reasonable notice before any order of transfer is made. Wherever, in his judgment, the interests of justice so require he shall, before granting such order, cause notice of the application to be published in the newspaper in which the sheriff's sales are advertised for not less than four insertions in separate weeks. Before granting such order directing the transfer he shall fully satisfy himself that all parties who have or may have an inter-

1. A. § 3.

2. Chapter XII, post.

3. See T. $\S 77$. 
est in the matter of the transfer have been notified, and in the case of minors or other persons under disability, that guardians ad litem have been appointed to represent their interests, and that there is no valid reason why the order directing involuntary transfer should not be made, and thereupon he shall enter a decree or judgment upon the minutes of the court reciting the facts and that an order of transfer has been issued, and shall issue the order of transfer in substantially the form and manner hèrein prescribed." The form of the judge's order of transfer is prescribed in Section 110 of the Act.

Wide discretion as to what character of notice shall be given to the parties at interest is conferred by Section 72 of the Act, which provides that "Wherever notice is required by this Act and no provision as to how notice shall be given is made, or wherever, in the discretion of the judge, additional notice to that provided for in this Act, should be given to any particular person or persons, or to the public generally, the judge may order such notice to be given, and provide the manner in which it shall be given."

$\S 167$. Summary Jurisdiction of the Judge as to Involuntary Transfers. - The hearing before the judge is a judicial proceeding. For the purposes of the Act, the superior courts are always open, "and every official act of the judge on any matter shall be considered as having been rendered in open court." 1 "All proceedings in the court in relation to registered land shall be proceedings in rem against the land" 2 though perhaps it would have been more accurate to say "quasi in rem or substantially in rem to determine the status of the land." If the judge orders a transfer, his judgment, (subject only to right of review by the Supreme Court on fast bill of exception) ${ }^{3}$ is final and concludes the world so far as the title to the particular registered land is concerned-it passes from the the old owner to the new. 4
1. A. $\S 67$; T. $\S 265$.
2. A. $\S 4$.
3. A. $\S 82 ;$ T. $\S 118$.
4. A. $\S 63$; T. $\S 211$, et seq. 
This provision by which controversies as to the effect of involuntary transactions affecting land titles may be settled in advance and, while the controversy is fresh, is one of the most beneficial in the entire Act. ${ }^{5}$ For instance, as to unregistered land, a sheriff's sale takes place and years later the purchaser may find himself defending a suit respecting the title to his land growing out of some unsuspected alleged defect in the execution, the levy or the manner of conducting the sale, or something else, that really did not affect the transaction seriously enough to attract anybody's attention at the time.

The proceeding before the judge is summary, however, and if the transaction before him is one that presents a bona fide justiciable controversy, especially a controversy involving disputed questions of fact, there is nothing which prevents him from rendering a judgment refusing to order the transfer, but without prejudice to the rights of either party and remitting the parties to the courts for a settlement of their controversy there; for a transfer of registered land may be made as the result of a proceeding in a court, either of law or of equity. ${ }^{6}$

The Act makes no provision as to what effect the refusal of the judge to order a transfer shall have; it merely provides, among other things, that upon the judge's fully satisfying himself "that there is no valid reason why the order directing the involuntary transfer should not be made," he shall order it to be made. ${ }^{7}$ It seems, therefore, that the Act contemplates that the judge shall not, upon the summary hearing, conclude further inquiry, except in clear cases, and that he has the power to refuse to pass an affirmative judgment in doubtful cases, but without prejudice to the rights of either of the parties as to further action in the courts.

Take an example: Jones purchases Smith's registered land at sheriff's sale. He pays the purchase price and gets a sheriff's deed (though a sheriff's deed is inadequate to convey registered land) or he gets a certificate from the sheriff or an official return on the fi. fa. showing the fact of the sale and the payment

5. Compare T. $\S 10$.

6. A. $\S 49 ;$ T. $\S 205$.

7. A. $\$ 50$. 
of the purchase money. If the sale be valid, this creates in Jones a perfect equity against Smith. He applies to the judge for an order of transfer. Smith objects on the ground that the levy was excessive; and the court finds the question truly doubtful. He refuses to order the transfer and remits the parties to the courts. Jones is able to go into a court of equity on the allegation of his perfect equity. He brings the suit; the court decides with him; the court of equity, under Section 49 of the Act and its general equitable powers, can decree a transfer and the matter is finally settled in his favor. On the other hand, suppose the court finds with Smith on his defense that the levy was excessive; the result is just as final; Jones is not entitled to a transfer; but, under a well known equitable doctrine, is subrogated to all the rights of the plaintiff in the fi. fa. under which the sale, now declared void, took place.

\section{$\S$ 168. Method of Applying for Involuntary Transfer} -Execution Sales-Tax Sales-Receiver's Sales-Bankruptcy.-The Act makes no provision as to the form or contents of the application which is to be made to the judge by one praying an involuntary transfer, and this is probably due to the fact that there are so many varying situations in which this power of the judge is likely to be invoked that no reasonably satisfactory form likely to prove suitable in any great number of cases could be suggested. Hence it may be said that the application should adjust itself to the facts of the particular case but should be full enough in its recitals to give the court full information as to the transaction. The requirements specifically made in one case of involuntary transfer (the case of a sale under creditor's certificate dealt with in Section 35 of the Act) that a certified copy of the certificate of the title showing all entries and notations thereon should be attached to the application seems to be an essential that the judge should demand in all cases.

If the applicant for the transfer is basing his right to it on account of an execution sale, he should show the date on which the judgment was noted on the certificate of title and should disclose the full state of the certificate of title at that time and all entries and notations subsequently made, up to the time of 
the sale. He should also show the fi. fa., levy and sale, and either the official return of the officer, showing the payment of the purchase money or the sheriff's deed. The same, in the main, applies to tax sales. The exact things to be shown in case of a purchase at receiver's sale would differ somewhat from the above, but the general nature of the things to be shown would be the same.

Where the owner of the land has been adjudged bankrupt and his title has. passed to the trustee in bankruptcy, the trustee is probably entitled to have the certificate of title transferred to him; and an application of the trustee in bankruptcy would probably be sufficient if accompanied by a certified copy of the order approving his bond. ${ }^{1}$ Whether the title conferred on a trustee in bankruptcy, by operation of law, under the Bankruptcy Act, is such a "claim or right arising under the laws or Constitution of the United States which the statutes of this State cannot require to appear of record under registry laws" so as to be exempt from the operation of Section 63, of the Act, is not a question germane to the present context. ${ }^{2}$

In case of tax-sales the judge should protect the owner's equity of redemption, in case he orders the transfer, by directing that a notation of it be made on the certificate issued to the purchaser, unless the statutory period in which the right of redemption may be exercised has already expired at the time the transfer is ordered.

$\S$ 169. Cancellation of Owner's Certificate on Involuntary Transfer-Cancellation by Publication.-It is contemplated by the Act that, so far as it is in the power of the court to enforce the requirement, no certificate of title shall be canceled without the corresponding owner's certificate being canceled at the same time. In voluntary transfers, this is accomplished by the requirement that the owner's certificate shall accompany the instrument of transfer. With the same end in view, it is provided in Section 52 of the Act, that "Wherever it is sought to have an involuntary transfer registered under the

1. See Bankruptcy Act, $\S 21$ (E).

2. See T. § 222 . 
provisions of this Act, and the owner's certificate is not produced so as to be attached to the order directing a transfer, the court shall have the power to issue subpœna duces tecum or any other process designed to compel the production of the owner's certificate, including attachment for contempt."

Still the presence or surrender of the owner's certificate is not a sine qua non to the cancellation of the certificate of title; for it is further provided in the Section of the Act just mentioned, that "if after the process issues the owner's certificate shall not have been produced, or it appears to the court that there is no practical means of compelling its production, the court may nevertheless grant the order of transfer, but shall cause the clerk to enter a cancellation of the certificate of title on the Title Register and to give notice once a week for four weeks in the newspaper in which the sheriff's sales of the county are advertised that such certificate has been canceled, the cost of making such advertisement to be deposited with the clerk before the judge grants the order of transfer without the production of the certificate." Of course, the subpœnas and processes of the courts of this State do not run beyond the limits of the State; hence, if it appears that the owner's certificate is in the possession of one beyond the State, no further evidence of its accessibility is required.

$\S$ 170. Directions to the Clerk in Connection with Judge's Order of Transfer.-In connection with the order of transfer, it is intended that the judge shall give explicit directions to the clerk not only as to canceling the old certificate of title, but also as to what differences, if any, shall exist between the old certificate and the new. For instance, if the involuntary transfer is ordered as the result of a sale of the property under execution, the rule, that the sale frees the title from the lien of all other judgment, entitles the purchaser to a certificate of title free from the encumbrance of such judgments and other liens against the holder as shall have been extinguished as the result of the sale. Hence, in granting the order of transfer the judge should direct the clerk which of the limitations, conditions, encumbrances, etc., appearing on the old certificate are to be retained on the new one and which are not. 
In the form prescribed in Section 110 of the Act, the space left after the words "as follows," appearing therein, is intended to be used for the giving of such directions, as well as the giving of the name of the new owner. Indeed, one of the most certain and appropriate methods to be used in such cases is for the judge to attach to his order of transfer a copy of the new certificate of title filled out just as he intends for it to be issued and registered by the clerk. In that event, all that is necessary for him to do is to fill the space in the blank after the words "as follows:" with the words "in the form and manner shown in the writing attached as the Exhibit hereto."

The exigencies of particular cases, as where, for instance, a transfer of only a part of the land, or an undivided interest, is awarded, may require variation from the standard form of order. In such cases, the judge should give the clerk full directions.

\section{$\$$ 171. Duties of the Clerk in Registering Involuntary} Transfers.-The clerk should always keep in mind that he should never register an involuntary transfer without the authority of the judge being produced. ${ }^{1}$ Upon the judge's granting an order for an involuntary transfer, the clerk should proceed to register it in accordance with the order of the judge.

The first step is to register the transfer on the old certificate of title. This is done in the same manner as if it were a voluntary transfer except that, on the certificate of title, under the sub-head "Voluntary or Involuntary," the clerk should write the word "Involuntary," followed by a reference to the minute book and page where the judgment on which the order of transfer is based is recorded. If the judge has issued the order of transfer in special form at variance with the general form, the order of transfer should also be entered on the minutes of the court and in the column left in the certificate of title for such references, the clerk should make the notation "Special, see Minute Book —, page —.". If the owner's certificate does not accompany the order of transfer, the clerk should enter under the

1. A. $\S 41$.

2. A. $\S 110$. 
head of "Remarks": "Owner's certificate not produced, but canceled by publication." The entry of cancellation at the bottom of the certificate of title (and of the owner's certificate, if produced) should be filled in, dated and signed. The old certificate of title being canceled, the clerk should proceed to make out a new certificate in accordance with the directions given in the order of transfer and deliver a corresponding owner's certificate to the new owner.

$\S$ 172. Advertising Cancellation When Owner's Certificate Not Produced.-In the event the owner's certificate corresponding to the certificate of title which the judge has ordered to be canceled is not also delivered to the clerk, and canceled, the clerk should give notice once a week for four weeks in the newspaper in which the sheriff's sales of the county are advertised, that the certificate has been canceled. ${ }^{1}$ The Act does not provide a form of notice, but a notice in the following form would be sufficient:

Georgia, County.

Notice is given that by an order of the judge of the superior court of said county, dated — day of —_, 19_, Certificate of Title No. —, Registered Title No. _, standing in the name of - as owner of the registered lands therein set forth, was ordered canceled, and the same has been canceled.

$$
\text { This - day of } \longrightarrow \text { Clerk Superior Court. }
$$

$\S$ 173. Notation of Liens, Encumbrances and Special Rights.-Keeping in mind that, subject to the provisions of Section 63 of the Act, which exempts from registration certain matters arising under federal statutes and certain taxes and easements, "no voluntary or involuntary transaction shall affect the title to registered land until registered or noted on the Title Register," 1 it becomes needful to inquire how such transactions, other than transfers and other matters already specially dealt,

[§ 172$]$ 1. A. $\$ 52$.

[§ 173] 1. A. $\$ \S 54$ and 73 . 
may be registered or noted. First then is an omnibus section in the Act ${ }^{2}$ which makes the general provision that "Any writing or instrument for the purpose of encumbering or otherwise dealing with equitable interests in registered land, or tending to show a claim of lien or encumbrance thereon or right therein may be noted on the certificate of title in the Title Register with such effect as it may be entitled to have."

The regular form to be used where any person desires a notation to be made of any lien, encumbrance, special right, lis pendens, or other matter affecting the title or any interest therein, except voluntary transactions and the matters as to which the Act has prescribed a special method, such as judgments, delinquent taxes, etc., is prescribed in Section 114 of the Act, as construed in connection with Section 61 of the Act. If the lien, encumbrance, or other special right relates only to a part of the land included in the certificate the form should be varied accordingly. The person seeking to have the special right noted must verify his application (as the form itself indicates) before some officer authorized to administer oaths. If the claimant of the lien, encumbrances, or other special right bases his claim upon any matter of record or court proceeding, he is not required to produce a certified copy of such record or proceeding, but must give in the appropriate place, in the prescribed form, the book and page of the record, if it be a matter of record, or shall clearly identify the proceeding if it be an unrecorded proceeding in court.

$\S$ 174. Notation of Judgments and Similar Liens-Necessity and Effect of Notation.-It is provided in Section 54 of the Act that, "No judgment,- levy or other lien (except for taxes, as to which special provision is herein made) shall be effective against registered land so as to affect any person taking a transfer thereof or obtaining any right or interest therein unless and until a notation of such judgment or levy or lien be made upon the Title Register." It is to be noticed that this does not affect the validity of the judgment or other lien as between the parties, but only as between the holder of the judg-

2. A. $\S 51$. 
ment or lien and some third person taking a transfer of the land or obtaining some right or interest in the land.

Whenever the judgment or other lien is entered, on the certificate of title on the Title Register, the entry operates, so far as the registered land contained in the certificate is concerned, to give as full and effectual notice to all persons as if it were recorded, filed or entered in any clerk's office. ${ }^{1}$ Hence, in cases of judgments, so far as registered land is concerned, the entering of the execution on the general execution docket is unnecessary. Actual notice of the judgment or lien on the part of the third person acquiring the transfer or interest is immaterial; entry on the register is the all-sufficient and the all-exclusive mode of effectuating notice.

However, the entering of the judgment in the register gives to it no validity which it would not otherwise possess; does not affect or prevent dormancy or any statute of limitation as to its enforcement. The entry of it on the Title Register gives effective notice to all persons dealing with the land in any wise thereafter, so far as the land is concerned-and that is all.

$\S$ 175. Same Continued-Method of Notation.-The method by which a judgment lien is to be noted on the Title Register is set forth in Section 61 of the Act. The holder of the judgment, his agent, or attorney, fills in the simple form prescribed in Section 113 of the Act, giving a statement of the court rendering the judgment, the parties to it, and the amount, and requesting that a notation of it be made on the certificate of title. If the judgment be one that has been rendered by the superior court of the county where the land lies, nothing further is required to authorize the clerk to register the entry, as in that case he acts on an inspection of the record in his own office. If the judgment be rendered in any other court, either the execution or a certified copy of the judgment must be exhibited to the clerk along with the written request for the notation.

The clerk should enter the notation of the judgment on the second page of the certificate of title on the register. In the column headed "Nature of the Instrument," the clerk should

1. A. $\S 40 ;$ T. $\S 245$. 
state the nature of it in full, thus, for example, "judgment rendered by the Superior Court of Early County, in favor of John Jones v. William Smith and George Brown under date of May 16,1918 ". If the judgment has any special features, these should be noted under the head of "Remarks".

$\S$ 176. Notation of Sundry Other Liens.-With the exception of judgment liens, tax liens, and liens voluntarily placed by the owner on the land in writing, the entry of all liens, for instance, mechanic's liens, laborer's liens, attorney's liens, etc., should be noted in conformity to Sections 61 and 114 of the Act. In case of liens, such as mechanic's liens,. which are recorded, reference to the record should be given. What has been said in regard to the effect of registration of a judgment lien applies to all the other liens herein referred to. ${ }^{1}$

$\S$ 177. Taxes and Public Assesssments-Necessity for Notation-How Noted-When Noted-Duty and Liability of Tax Officers.-Taxes and other public assessments levied on registered land for the current calendar year are exempted from the operations of the Act. ${ }^{1}$ Persons dealing with registered lands are charged with the duty of making outside investigation as to the existence of such taxes or assessments and deal with the land subject to them and to any lien they may create. But, except as to taxes and assessments for the current calendar year, any person dealing with the land takes his rights free from any unpaid taxes or assessments that may exist if notation thereof has not been made on the register. Section 57 of the Act provides: "It shall be the duty of every officer in this State charged with the collection of taxes or assessments which shall be a charge upon any registered land or any interest therein, if such taxes or assessments are not paid when due, on or after the expiry of the 31st day of December of the year in which such tax or assessment shall become due, to cause to be entered upon the certificate of title on the Title Register a notation of the fact that such tax or assessment on such registered land or in-

[§ 176$]$ 1. A. $\S 40 ;$ T. $\S 174$.

[§ 177] 1. A. $\S 63 ;$ T. $\S 223$. 
terest therein has not been paid, and the amount thereof. Until and unless such notation is made such delinquent tax or assessment shall not affect any transfer or other dealing with such registered land, but the tax officer failing to perform such duty, and his surety, shall be liable for the payment of said taxes and assessments, with all lawful penalties and interest thereon if any loss is occasioned to the political body, be it State, county, municipality or other division, by which such loss is sustained."

The notation is not to be made until the current calendar year in which the tax or assessment is levied has expired, but immediately thereafter it becomes the duty of the proper tax-offcer to make it: It may be made at any time thereafter so as to bind the owner, as of the date of midnight of December $31 \mathrm{st}$ of the year in question, and all others who have not acquired some interest in the land between that date and the time the entry of the tax or assessment is made; but all who have acquired interests in the land in the meantime hold such interests in superiority to the tax or assessment. Of course, no other property of the person by whom the tax is due is exempted from the lien of the tax or assessment by reason of the officer's failure to register it as against the registered land.

Section 112 of the Act prescribes the form of certificate which the officer charged with the collection of the taxes shall file with the clerk in order to cause the notation to be made. In making the notation on the certificate of title on the register, the clerk should be careful to show the amount of the tax, its nature, to what taxing body owing (i. e., whether State, county or municipality), and for what year or years.

It may be noticed that in the definition of "involuntary transactions" in Section 3 of the Act reference is made to "delinquent taxes and levies"; hence, until a tax or levy becomes delinquent it is not such a transaction as may be noted on the Title Register.

$\S$ 178. Lis Pendens-Necessity for Registering-How Registered.-It is provided in Section 54 of the Act, among other things, that "The pendency of any suit affecting the title to registered land, or any interest therein, shall not be held to be notice to any person other than the actual parties to such 
suit, unless a notation of the pendency of such suit be made upon the Title Register." This abolishes, so far as registered land is concerned, the doctrine that the pendency of an action in a court of competent jurisdiction may constitute notice to the world of the rights therein asserted and subsequently therein established, and limits the common-law maxim, pendente lite nihil innovetur, to cases wherein a notation of the pendency of the action is entered upon the certificate of title to the land to be effected. ${ }^{1}$ The actual parties to the action will be bound by the judgment, anyway; and, if no rights of others have intervened, the result of the action may be given effect against the land, even though no notice of the lis pendens has been registered. It is specifically provided in Section 114 of the Act that the form there prescribed may be used to give notice of a lis pendens. $^{2}$

In all cases when any suit is brought affecting the title notice of the lis pendens should be registered on or before the beginning of the suit, else the judge may, when application for an order of transfer is made, be under the necessity of refusing it, or substantially limiting it, on account of rights acquired by third persons pending the litigation. This precaution is recommended to those about to begin divorce or alimony proceedings, or suit to set aside judgments appointing administrators or admitting wills to probate.

§ 179. Adverse Entries-How Removed from Register.-It is not contemplated that such entries or notations as do not establish some permanent right in the land in favor of the persons causing them to be entered, and especially such as serve merely to give notice of rights or claims asserted, shall remain noted on the certificate of title indefinitely, and after all need for their remaining noted is ended; or that an owner shall not have redress against having his title embarrassed or clouded by the entry of frivolous or unfounded claims upon the

1. Discussion as to whether this applies to a writ of error sued out from a decree of initial registration, and the view presented that it does; T. $\S 233$.

2. See also A. $\$ 61$. 
certificate of title. Indeed, it may be stated in passing that a registered landowner would probably have an action in damages against anyone who should cause an adverse notation to be registered on the certificate maliciously and without probable cause. The act provides two ways in which notations and entries may be removed from a certificate of title; first, by voluntary cancellation; ${ }^{1}$ second, by order of the judge. ${ }^{2}$ Possibly equity would also have jurisdiction, through an action in the nature of quia timet to remove a cloud from title.

\section{$\S$ 180. Same Continued-Voluntary Cancellation.-} Voluntary cancellation is provided for in Section 62 of the Act. ${ }^{1}$ Upon presentation of the request to cancel, duly attested, the clerk will cancel the specified entry on the certificate of title and on the owner's certificate. Space is left in the certificate, under properly headed columns, following each such entry for the registration of the cancellations. All that is necessary for the clerk to do is to insert the full date, opposite the entry involved and under the head "Date Cancelled" and to sign it.

\section{$\S$ 181. Same Continued-Cancellation by Order of} Judge.-In case the person in whose favor the notation of entry operates refuses to execute a voluntary request for cancellation, the owner or any other person at interest may have it canceled, in any proper case, by following the procedure outlined in Section 60 of the Act, which provides that, "If any person at interest shall object to any entry, registration or notation made by the clerk upon the Title Register, he may, unless such entry, registration or notation shall have become conclusive by lapse of time under the provisions of this Act, ${ }^{1}$ file with the clerk of the court a caveat setting forth the entry, notation or registration to which he objects; setting forth what interest he has in the subject-matter, and setting forth the ground of his objection and praying for such relief as he desires and deems appropriate in

[§ 179] 1. T. $\S \S 180,186$. See also T. $\S 142$.

2. T. $\S \S 181-2$.

[§ 180] 1. See T. $\S 142$.

[\$ 181] 1. Reference is had to the twelve-month's limitation set in A. $\S 59$. See T. $\S 229$. 
the premises. Thereupon the clerk shall note upon the Register of Titles the fact that caveat has been filed, and by whom, and to what entry, notation or act of registration it applies. Thereupon the matter shall be presented to the judge, who shall order all persons at interest, to show cause on a day named why the relief prayed for in the caveat should not be granted, and upon proof being made that due notice has been given to all parties at interest the judge shall proceed to hear the matter and shall render a judgment of the court, giving direction to the matter, and may thereupon require such entry, registration or notation to be cancelled or modified, and may require the outstanding certificate of title and owner's certificate to be modified accordingly. To that end the court may require the outstanding owner's certificate of title to be brought into court by subpœna duces tecum, or other process, including attachment for contempt, and if the court finds that production of the certificate cannot be compelled, then he shall provide for publication of notice of the court's action thereon for a period of time not less than once a week for four weeks in the paper in which the sheriff's sales of the county are advertised, the expense of making the publication to be provided for in such manner as the court shall order."

$\S$ 182. Same Continued-Procedure to Compel Cancellation-Summary Jurisdiction of the Judge.-No time is set within which the owner or other party at interest must move to have the entry canceled, except in the case of entries and notations of transfers or the cancellation or discharge of liens or encumbrances, as to which the parties must move within 12 months. ${ }^{1}$

The first step of the objecting party is to file with the clerk a caveat setting forth the entry or entries objected to, setting forth what interest the moving party has in the matter and the grounds of his objection and praying for the relief he deems to be appropriate. The clerk will make an entry on the certificate of title on the register, under the caption "Special Entries and Notations," of the filing of the caveat. Thereupon the moving

1. See A. § 59 . 
party should present the caveat to the judge and procure a rule nisi, calling on the person or persons in whose favor the attacked entry or entries exist, and all other parties at interest, if any, to show cause, on a day to be named by the judge in the rule, why the relief prayed for should not be granted. The judge should also, under the authority of Section 72 of the Act, make provision as to how the respondents in the rule are to be served.

At the time set, and upon it appearing that the service has been properly perfected, the court will proceed to hear the matter and to pass his order, giving such directions to the matter as the nature of the case may require. He may require such entry, registration, or notation to be canceled either peremptorily or upon such conditions as he may set or may dismiss the caveat, without prejudice, and refer the parties to the appropriate court for a judicial settlement of their controversy, in general conformity to what has been suggested as to a somewhat similar situation in Section 167 ante.

To illustrate, if the court finds that the entry has, plainly, fully served its purpose or that for any other reason it should no longer stand upon the certificate of title, he should peremptorily order it canceled. If he finds that its temporary retention may be of some possible importance, but that it would be improper that it should indefinitely and unconditionally be allowed to remain, he may order it removed after a certain period or on certain conditions. For example, a notation is entered claiming equitable title to the land because paid for with the money of the person causing the notation to be made. In such a case, the court could properly order the notation removed at the expiration of some future period, say six months, unless in the meantime the person claiming the equity should begin an action to have the equity legally ascertained and declared.

$\S$ 183. Summary Jurisdiction for Correction of Errors on Register.-However, the provisions of Section 60 are not only available for the cancellation, but also for the correction of entries, registration and notations. If the clerk has improperly entered a matter or without proper authority being produced or if someone has succeeded in procuring a registration through fraud or forgery, and the transaction is not one of 
those as to which the twelve-month limitation of Section 59 applies, or if, though it be within the purview of that limitation, the twelve months have not expired, the judge has the power of summary adjustment and correction of all such entries, registrations and notations, by caveat and rule nisi under Section 60 of the Act. ${ }^{1}$ Since the clerk is responsible in case he has made an improper registration, he is such a party at interest as that he may file a caveat under this section.

\section{$\S$ 184. Summary Jurisdiction over Forged or Fraudu-} lent Registration.-While the registration of a certificate of title procured through fraud or forgery, may, subject to the limitations set forth in Section 63 of the Act, be attacked through court proceedings at any time within 7 years from the date of the transaction; still the judge may give summary directions in regard to the matter if caveat be filed as provided in Section 60 within twelve months from the date it is registered. The court has wide discretion as to what direction he should give in such a case. If the fraud or forgery be denied and the proof submitted on the summary hearing leaves the matter in doubt, he should refuse to order the registration cancelled, but without prejudice to the right of the objecting party to note his claim in the certificate of title on the register and to file his suit in the proper court to have the controversy adjudicated. If on the other hand, though the fraud or forgery is denied the proof of it is strong and substantial, the court would have the discretion to order the attacked registration cancelled and, if necessary, a new certificate issued to the person alleged to be defrauded, but giving to the alleged defratuder or forger the right to note his claim upon the certificate of title and to press his alleged rights in the courts.

$\S$ 185. Distinction between Summary Jurisdiction of the Judge and General Jurisdiction of the Courts.-This summary jurisdiction is given to the judge in order that he may

1. However, this power is not so to be exercised as to interfere with the conclusiveness of the registration, so far as affects the rights of persons dealing with the land on the faith of the registration as made. T. $\S 228$. 
effectively discharge the general supervisory powers over the registry, conferred on him by the Act, ${ }^{1}$ but it is not contemplated that this should be made a substitute for that jurisdiction which it is intended that the courts shall still continue to exercise in bona fide justiciable controversies substantially affecting the rights of the parties. The judge, therefore, in discharging this duty of seeing that the registry is correctly kept should always refrain, as far as possible, from cutting off the bona fide claims of anyone. He should, of course, always keep in mind that the rights of innocent third persons who have had dealings in respect to the land on the faith of the certificate of title and the entries registered thereon are to be fully subserved and no cancellation or modification should in any case be ordered in such a manner as to affect them in any wise adversely. ${ }^{2}$

The provision in the concluding portion of Section 60 , as to the power of the court to call in the outstanding owner's certificate, has but little applicability to ordinary cases of cancellation or correction of entries, but applies mainly to cases wherein it is necessary for the court to effectuate his judgment by canceling the certificate of title and issuing a new one in its place.

$\S$ 186. Notation of Tax Lien, How Canceled.-Where a tax or an assessment has been noted on a certificate of title all that is necessary to procure a cancellation of the entry is the production of a certificate of the proper tax officers showing that such tax has been paid. ${ }^{1}$

\section{$\S$ 187. Entries and Notations to Be Brought Forward.} - It may be appropriate to reiterate in this context the provisions. of Section 39, that "All registered encumbrances, rights, or adverse claims affecting the estate represented thereby shall continue to be noted upon every outstanding certificate of title and owner's certificate, until the same shall have been released or discharged, unless the same shall relate to only a particular portion of the property, when the same shall be noted only upon such certificate and duplicate certificates as relate to that por-

[§ 185] 1. A. § 59; T. § 270.

2. See T. 228 and note to Section 183 , supra.

[§ 186] 1. A. $\S 62$. 
§ 187] REGISTRATION OF INVOLUNTARY TRANSACTIONS. 153

tion of the property." This means that until an entry is canceled by voluntary cancellation of the party or by order or direction of the judge, it is to be brought forward from certificate to certificate, upon each issue and re-issue indefinitely. 


\section{CHAPTER XII.}

\section{Special Cases.}

$\S$ 188. Status and Disposition of Registered Land on Owner's Death. $\S$ 189. Same Continued-Sales by Executors and AdministratorsObjections by Heirs or Other Interested Persons.

$\S$ 190. Same Continued-Dower.

$\S$ 191. Same Continued-Causing the Title to Be Registered in the Name of the Personal Representative.

$\S$ 192. Same Continued-Where the Decedent Held Only an Undivided Interest.

$\S$ 193. Same Continued-Transfer from Executor or Administrator.

$\S$ 194. Same Continued-Transmission of Title by Descent-Judgment Establishing Heirship.

$\S$ 195. Same Continued-How Heirs Obtain Transfer-Procedure to Establish Heirship.

$\S$ 196. Same Continued-Registering Transfer to the Heirs-Voluntary Partition among Heirs.

$\S$ 197. Same Continued-Method of Registering Transfer to Heirs.

$\S$ 198. Same Continued-Proceedings by Personal Representatives and Other Trustees to Determine Who Are Heirs or Beneficiaries.

$\S$ 199. Same Continued-Rights of Administrator Appointed after Transfer to Heirs.

$\S 200$. Guardian's Sale.

$\S$ 201. Transfer from Husband to Wife and Vice Versa.

$\S$ 202. Eminent Domain-Condemnation Proceedings.

$\S 203$. Registering Change of Owner's Name-Marriage-Charter Amendment.

$\S$ 204. Transfer of Land Held in Trust or under Conditions or Unusual Limitations-Powers.

$\S 205$. Transfer as the Result of Judicial Proceedings.

$\S$ 206. Same Continued-Partition-Equitable Actions-Specific Performance.

$\S 207$. Transfer to Hinder, Delay and Defraud Creditors.

$\S 208$. Procedure to Effectuate Transfers Resulting from Judicial Proceedings.

$\S 209$. Title by Year's Support, How Registered-Sales by the Widow.

$\S 210$. Homestead or Exemption-How Registered-Sales of Homestead Property. 
$\S$ 188. Status and Disposition of Registered Land on Owner's Death.-It has been deemed expedient to take up for separate treatment certain special cases of transfer, as to most of which the Act prescribes the details. The first of these special cases to be considered is as to the status and disposition of registered land upon the death of the owner. Sections 42 and 43 of the Act, which are taken bodily from the "Uniform Land Registration Act" are as follows: "Lands and any estate or interest therein registered under this Act, shall, upon the death of the owner, testate or intestate, go to his personal representative in like manner as personal estate, and shall be subject to the same rules of administration as personalty, except as otherwise provided in this Act, and except that nothing herein contained shall alter or affect the course of ultimate descent under the statute of descents and distributions and the rights of dower, when duly registered, nor shall alter or affect the order in which real and personal assets, respectively, are now applicable in and towards the payment of funeral and testamentary expenses, debts, or legacies, or the liability of real estate to be charged with the payment of debts and legacies."

"Subject to the powers, rights and duties of administration, the personal representative of such deceased owner shall hold such real estate as trustee for the persons by law beneficially entitled thereto, but, unless otherwise entitled by law to commissions, shall be entitled to no commissions thereon, except in cases of necessary sales in due course of administration. And the heirs at law or beneficiaries aforesaid shall have the same power of requiring a transfer of such estate as if it were personal estate."

These sections of the Act do not make as great a change in the law of this State as occurs or would occur in most states upon their being adopted there. Section 3895 of the Civil Code already provides in effect that, if the decedent die testate, his executor holds title to both the realty and the personalty till assent is given to the devise or legacy, as the case may be. The Act does, however, modify Section 3929 of the Civil Code which proides that, "Upon the death of the owner of any estate in realty, which estate survives him, the title vests immedi- 
ately in his heirs at law. The title to all other property owned by him vests in the administrator of his estate for the benefit of the heirs and creditors." This Code section, of course, refers to the case of an owner dying intestate. The rule as to registered land is that, upon the death of the owner, the title passes to the personal representative-the administrator or the executor, as the case may be.

$\S$ 189. Same Continued-Sales by Executors and Administrators-Objection by Heirs or Other Interested Persons.--Registered land is subject to the same general rules of administration as personalty. This changes the method of sale somewhat in the event it is necessary to sell the land for the purpose of distribution or payment of debts. Though under Section 4032 of the Civil Code, personalty as well as realty must be advertised and sold at public outcry, the effect of this provision is to dispense with the preliminary order of the ordinary authorizing the sale of the land.

However, the rights of the heirs are not materially affected by this change in the rule; for the present Act clearly implies that the administrator is not to sell the land unless it is necessary for the purposes of distribution or the payment of debts. This is shown by the provision in Section 42 of the Act to the effect that the order in which real and personal assets are applicable in and toward the payment of debts is not to be altered or affected; also by the statement in Section 43 of the Act that the personal representative shall hold the real estate as trustee for the persons by law beneficially entitled thereto, subject to the duties of administration; also by the first sentence in Section 47 which provides how the land shall be transferred to the heirs in the event "it is not necessary to sell such registered land for the purposes of administration."

While the necessity of selling the registered land for purposes of administration is not determined in advance of the sale, by a judgment of the ordinary, as it is in the case of unregistered land; still, since, as will be hereinafter shown, ${ }^{1}$ the personal representative cannot transfer the certificate of title

1. T. $\S 193$. 
to the purchaser until an order of transfer is issued by the judge after notice to all persons interested, and since upon the hearing before the judge it would be a good objection against the granting of the order of transfer to show that the personal representative had sold the land without any necessity in the course of the administration existing therefor, the right of the heir to protest against an unnecessary sale of the land is protected, though in a different way from what it would be if the land were unregistered. It may be noted also that, in case of unobjectionable sales, all the costs and delay of advertising for and obtaining the preliminary order of the ordinary is obviated.

The rule that the personal representative cannot sell pending adverse possession is in effect abolished by the Act, since none of the legal incidents of adverse possession affect registered land. ${ }^{2}$

$\S$ 190. Same Continued-Dower.-Another change as to the decedent's land, effected by Section 42, relates to the matter of dower. As to unregistered land, the doctrine of "Seizure, death, dower" is applicable, and though the personal representative sells the land at regular sale, the purchaser takes it subject to the right of dower, unless that right be barred in one of the methods prescribed in the Code. Under the Land Registration Act the right of dower exists, as before, but if the widow intends to assert it she must act affirmatively to the extent, at least, of causing her claim of dower to be noted on the certificate of title on the register ${ }^{1}$ prior to a sale and transfer of the land by the personal representative. Under Section 42 of the Act the right of dower is saved only "when duly registered." This is true whether the dower has been assigned or not. The result of this section of the Act is also to modify the provisions of Section 4094 of the Civil Code, that "No administrator or executor shall be authorized to sell the reversionary interest in the land set apart as dower during the lifetime of the widow, except it be necessary to pay debts."

2. A. $\S 66 ;$ T. $\S 232$.

1. The notation should be made in the form prescribed in A. $\S 114$. See also T. $\S 173$ et seq. 


\section{§ 191. Same Continued-Causing the Title to Be Reg- istered in the Name of the Personal Representative.-} The method by which the certificate of title is to be transferred to the personal representative is set forth in Section 44 of the Act, as follows: "Upon the grant of letters of administration or executorship by the court of ordinary and upon presentation of a certified copy of the same to the clerk of the superior court and the presentation of the owner's certificate, the clerk shall make a special entry on the certificate of title on the Title Register showing the presentation of the letters of administration or executorship, the name of the representative, the court and county of his appointment, and the date of the letters and of the transfer of the title to the representative. The clerk shall thereupon cancel the certificate of title and the owner's certificate outstanding in the name of the decedent and issue to the administrator or the executor, as the case may be, a new owner's certificate."

The appropriate method of the clerk's making the special entry on the certificate of title referred to is as follows: Under the head "Transfers," and in the column having the sub-head "Transferred to," enter the name of the administrator or executor with his representative capacity described in full, thus, for example, "John Jones, as administrator of William Smith, deceased." In the column headed "Date of instrument" insert the date of the letters of administration or executorship. Skip over to the column in which the number of the new certificate is to be stated and fill that in. Then, in the column headed "Remarks," write "By authority of the presentation of letters of administration (or executorship, as the case may be) issued to said — by the Court of Ordinary of — County." Date and sign the entry as usual. Fill in and sign the entry of cancellation at the bottom of the second page of the certificate. Make the same entries on the owner's certificate. Make out a new certificate of title in the name of the executor or administrator, as the case may be, adding his full representative designation to his name, keeping in mind that all notations and entries existing on the old certificate prior to its transfer must be brought forward and noted in the new. Issue corresponding 
owner's certificate and deliver to the executor or administrator. Do not make the transfer unless the owner's certificate of the decedent, or a duplicate thereof established under the provisions of Section 58 of the Act, is produced or unless the judge otherwise directs by an order of transfer.

\section{$\S$ 192. Same Continued-Where the Decedent Held} Only an Undivided Interest.-The procedure is slightly different where the decedent was the owner of only a fractional undivided interest, along with others, in the same certificate of title. As to this it is provided, also in Section 44 of the Act, that "In the event the decedent was the owner of only a fractional undivided interest in the title and the outstanding certificate stood in the name of the decedent and others, or where, from any other cause, the decedent was not the sole owner of the certificate, the outstanding certificate shall, nevertheless, be canceled, and a new certificate registered and new owner's certificate issued with the name of the personal representative substituted for the name of the decedent."

Construing this in connection with Section 31 of the Act, the procedure in such a case would seem to be that the transfer should be entered in the same manner as is described in the immediately preceding section, except that in the column "Total or partial" the undivided interest involved in the transfer should be stated. The certificate of title and the owner's certificate should be canceled and two new certificates issued one in favor of the executor or administrator for the undivided interest of the decedent, and one in favor of his co-owners for their undivided interest in general conformity to the method described in Section 148 ante.

\section{$\S$ 193. Same Continued-Transfer from Executor or} Administrator.-Since the executor or administrator holds the title in trust, no transfer on his part can be registered except by order and direction of the judge, under a proceeding in general conformity to that provided for in Sections 49 and 50 of the Act, and discussed in Sections 166-171, ante, and Section 204 , infra. For it is provided in Section 56 of the Act, that "Whenever a writing or record is filed for the purpose of trans- 
ferring registered land in trust, or upon any condition or unusual limitation expressed therein, or where power is given to sell, encumber or deal with the land in any manner, no subsequent transfer or voluntary transaction purporting to be exercised under the powers given in such writing or instrument or record shall be registered on the Title Register or on the owner's certificate, except upon application to the court and order of direction from the judge to the clerk as to how the same shall be entered."

This effectuates one of the very wholesome purposes of the Act, namely that all questions as to the legality of the sale made by the executor or administrator, as the same may be, shall be settled at once and for all time, and that they shall not remain open to haunt the title like spectres, throughout the future. It has the further wholesome effect of bringing all such sales under the eye and confirmation of the judge; thus acting as a deterrent to fraud and irregularity.

\section{$\S$ 194. Same Continued-Transmission of Title by} Descent-Judgment Establishing Heirship.-One of the most serious inconveniences in the common method of evidencing title to land is that there is no provision in our law by which descent and heirship may be established and recorded, except in so far as the same may be established and determined by the judgment in some litigation as between the parties to that litigation. An abstract of title may show that the title was in someone, say Elias Harper, forty years ago, and that he died, and that thereafter certain persons claiming to be the children and heirs at law of Elias Harper conveyed the land, and that the title has come on through a chain of intermediate conveyances into some present claimant; still if that claimant's title is brought into litigation his chain is broken unless he can make aliunde proof that the persons purporting to be the heirs of Elias Harper were really his heirs and his only heirs. The fact that they so described themselves in the old deed is no evidence of the fact. This evil in the old law the present Act proposes to correct, so far as registered lands is concerned, by a provision for a binding adjudication in advance as to who are the heirs of any decedent from whom registered land descends. 
$\S$ 195. Same Continued-How Heirs Obtain TransferProcedure to Establish Heirship.-While the title to registered land passes to the personal representative, if there be one, still the transmission of the title by descent is provided for in cases where a person dies intestate and there is no administration upon his estate within twelve months from the date of his death, or in the event the administration terminates without the land being disposed of. In such cases, the person or persons claiming to be the heirs at law of the decedent, or any one or more of them, may petition the superior court of the county where the land lies to have their heirship adjudicated and their title by descent to the registered land disclosed and established.

The procedure is outlined in Section 45 of the Act, as follows: "In such application there shall be set forth the names of all persons who are alleged to be the heirs at law, and if all are not joined, process or notice shall be served, as in cases in equity, upon all not so joined. The petition shall be verified by the affidavit of one of the petitioners, shall set forth in detail the name and address, as last known, of the decedent, a statement as to whether he was married or single, or a widower; if married more than once, the names of all of his wives; the names of all children and descendants of children, if any, showing in detail how and wherein the persons who are alleged to be the heirs at law are in fact the heirs at law of such decedent under the rules of inheritance in this State. It shall also give the date of the death of the decedent and set forth that he died leaving no will and that, in the judgment of the applicant, there is no need for administration upon the estate. Upon such application being filed the judge shall thereupon grant an order setting the application down to be heard at the court-house in the county where the land lies on some day not less than thirty days from the date of the application, and calling on all persons to show cause before the court on that day why the persons named as heirs at law in the application should not be so declared to be by the judgment and decree of the court. A copy of the application and the order of the court thereon shall be published in the newspaper in which the sheriff's sales of the county are advertised in like manner as sheriff's sales are 
advertised. Upon the day named, unless the matter be continued by order or orders of the judge to some future time, the court shall proceed to hear and determine the question, together with all objections, if any, which may be filed, and to adjudge and decree that the alleged decedent is dead and that there is no administration on his estate, and that he left no will, and who are his heirs at law; unless it appears that the alleged decedent is not dead, or that there is administration upon his estate, or that an application for administration is pending, or that the decedent left a will; in either of which events the petition shall be dismissed."

The fact that the court is required to state in the judgment, among the other things mentioned, "who are his [the decedent's] heirs at law" indicates that other parties may file intervention, in the nature of a cross-action, praying that they be adjudged to be the heirs at law.

"Where the wife claims to be entitled to take possession of the estate without administration, under the provisions of subsection 1 of Section 3931 of the Code, the procedure shall be substantially in the same manner."

It is further provided in Section 45 of the Act that if the decedent left a widow, the application must disclose whether she has elected to take dower or to claim as an heir of the estate, and that she must be a party (either plaintiff or defendant) to the proceeding, and that the court must specifically provide what interest or estate she shall take under the decree of heirship. In case the decedent be a female, the procedure is similar, except in so far as the difference between the rights of the husband and wife upon the death of the spouse shall make changes necessary.

$\S$ 196. Same Continued-Registering Transfer to the Heirs-Voluntary Partition among Heirs.-It is also provided in Section 45 of the Act that, "Upon granting an order of heirship the court shall thereupon order a transfer of the registered title from the decedent to the heirs at law to be registered, and upon production of the owner's certificate of the decedent, and the judge's order for a transfer, the clerk shall register the transfer and cancel the certificate registered in the name of the 
decedent and the owner's certificate, and issue a new owner's certificate in the name of the persons declared to be the heirs at law. In such an application, if the alleged heirs at law be of full age and under no disabilities, and the same shall so appear to the court, and it shall further appear that they have voluntarily partitioned the land in kind among themselves, the court may, in connection with the order of transfer, direct that the certificate standing in the name of the decedent be canceled and that new certificates shall be registered and issue to each of the heirs for the particular parcel of land coming to each under the voluntary partition set forth in the application.

Except where, in the decree, the land is partitioned into separate tracts, the court shall, in the decree of heirship and in the order of transfer, specifically set forth (except in the case of sole heir) what undivided interest each heir shall take."

The form of the order of transfer issued by the judge on the judgment of heirship should be an adaptation of the form prescribed in Section 110 of the Act. In the event any of the heirs are minors or persons under disability, that fact should be noted on the order of transfer, and a statement given as to when the minors will become of age.

\section{$\S$ 197. Same Continued-Method of Registering Trans-} fer to Heirs.- The transfer and cancellation of the certificate of title standing in the name of the decedent should be accomplished by the clerk in substantially the same manner as has been hitherto described for cancellation and transfer under judge's order of transfer in ordinary involuntary transactions, ${ }^{1}$ except that the clerk should, in connection with the names of the transferees or under the head of "Remarks," make it appear that the transferees are taking as heirs at law of the deceased owner in whose name the certificate of title stood; and in the column headed "If special or irregular, etc.," he should give the reference to the book and page of the minutes of the superior court on which the judgment of the court declaring the heirship is recorded.

If the court has declared what undivided interest each heir is to take, the corresponding declaration should appear in the

1. See T. $\S 171$. 
body of the new certificate. If voluntary partition has been made, and the judge's order declares accordingly, the clerk, on cancelling the decedent's certificate of title, should issue to each of the heirs a separate certificate of title for the portion he is to receive on the partition. If any of the heirs are shown to be minors or other persons under disability, that fact should be stated in the body of the certificate.

This is a case in which the clerk should refuse to register the transfer, even though the judge's order of transfer is produced, until and unless the owner's certificate standing in the name of the decedent is produced. If the original be lost or destroyed, a duplicate may be procured through the procedure outlined in Section 58 of the Act $;^{2}$ or, if that is unavailable, resort may be had to equity to establish the lost instrument.

$\S$ 198. Same Continued-Proceedings by Personal Representatives and Other Trustees to Determine Who Are Heirs or Beneficiaries.-The Act does not leave to the administrator, where one is appointed, the determination of the question as to who are the heirs at law of the decedent to whom he shall transfer the land if it is not necessary to sell it for the purposes of administration. Section 47 of the Act provides: "Wherever an administrator shall have caused registered land to be transferred into his name and he stands ready to be discharged and it is not necessary to sell such registered land for the purposes of administration and it should properly go to the heirs at law of the decedent, he may institute a proceeding substantially similar to that prescribed in Section $45^{1}$ of this act for the ascertainment of the heirs at law and for an order directing the transfer of such estate from him to such heirs at law when so ascertained. In case any other trustee shall hold title where the beneficiaries of the trust are not definitely and particularly disclosed, and it becomes appropriate that they should be definitely ascertained, such trustee may, in like manner, petition the court, upon showing that the trust has become executed, for a decree settling and ascertaining who the benefi-

2. See T. $\S 135$.

1. See T. $\$ 195$. 
ciaries are, and directing a transfer to such beneficiaries." An executor is such a trustee as falls within the purview of the last sentence of the section of the Act just quoted.

\section{$\S$ 199. Same Continued-Rights of Administrator Ap-} pointed after Transfer to Heirs.-Whenever a transfer of registered land is made to the heirs at law, the subsequent appointment of an administrator does not disturb or divest their title, and he cannot have the title transferred to him for the purposes of administration, but, as Section 46 of the Act provides, "if it appears that the heirs have thereby appropriated to their use and ownership property which should have been appropriated to the purposes of administration, the personal representative of the decedent shall have a right of action against the heirs for the value of the property so appropriated, the judgment in such action to be moulded according to the exigencies of the particular case in accordance with the principles of equity." It is to be recalled in this connection that Section 45 of the Act does not permit an application for transfer to the heirs to be made until twelve months have elapsed from the death of the intestate.

$\S 200$. Guardian's Sale.-The Act makes no specific provision for the sale of the lands of an infant or other person under disability by his guardian. However, this would merely be a case for the application of the regulations relating to involuntary transfers. ${ }^{1}$ A guardian does not take title to his ward's estate, and, hence, is not entitled to have the ward's certificate transferred into his name; however, he has the power to sell his ward's property and to pass the title thereto under certain conditions and upon compliance with certain statutory prerequisites.

When the guardian's sale has been consummated according to the general law on that subject the transfer is to be made to the purchaser by an order of transfer issued by the judge as if it were an involuntary transaction. While it may be in point of fact voluntary, it is, nevertheless, an involuntary transfer within

1. See T. $\S \S 166-9$. 
the purview of the Act and the definition of that phrase as given in Section 3 of the Act.

\section{$\S$ 201. Transfer from Husband to Wife and Vice} Versa.-There is a special case of voluntary transfer which can not be entered by the clerk without the specific direction of the judge, even though the owner's certificate of title be produced along with the instrument of transfer; and that is a transfer from wife to husband or vice versa.

Under Section 3009 of the Civil Code and the construction put upon it by the Supreme Court, no conveyance between husband and wife is valid, if based on a valuable consideration, unless the same is approved by the judge of the superior court, but deeds of gift between them are valid. The consideration recited in the conveyance is not controlling but aliunde evidence may be heard to determine whether the transaction falls within the purview of the code section or not. This opens a very wide door to fraud and perjury. Furthermore, transactions between husband and wife are to be scanned with care; and a wife's deed of gift to her husband is impeachable for slight duress, fraud, or imposition on his part.

To guard against these evils and uncertainties and in recognition of the conclusive effect of registration of a transfer, the Act, in Sec. 48, provides: "In cases of transfers of registered land, or any interest therein, from wife to husband, or vice versa, the transfer shall not be entered nor made until the same shall have been approved by the judge of the superior court and the fact of such approval shall be entered upon the Register of Titles."

All that is necessary for the judge to do is merely to enter his approval upon the instrument of transfer. No formal procedure before him is required. Still, he should satisfy himself of the full nature of the transaction before he gives his approval and, if the transfer is in violation of, or contrary to the spirit of the general law on the subject of dealings between husband and wife, should withhold his approval. However, even though the judge approves and the transfer is entered, the transaction may, under the provisions of Section 55 of the Act and subject to the limitations there stated, as well as under the gen- 
eral jurisdiction of a court of equity, be attacked because made to hinder, delay, or defraud creditors, or for other fraud.

\section{$\S 202$. Eminent Domain-Condemnation Proceedings.} -The exercise of the right of eminent domain and the condemnation of property thereunder is one of the involuntary transactions mentioned in Section 3 of the Act, though it usually does not involve an involuntary transfer, strictly speaking, since ordinarily only an easement and not the fee simple is taken. If only an easement is sought against the registered land, the condemnation proceedings should be followed just as in other cases, and the person or corporation condemning, upon getting the judgment of condemnation, may have the result noted and the easement protected by causing it to be entered on the certificate of title, in pursuance of Section 51 of the Act, by following the method prescribed in Section 114 of the Act. ${ }^{1}$ No authority from the judge is necessary to the notation of such a right on the certificate of title on the register.

$\S$ 203. Registering Change of Owner's Name-Marriage-Charter Amendment.-It is provided in Section 53 of the Act that, "Any person having any interest in registered land whose name shall have been changed by marriage or other cause may, by petition to the judge of the court, and upon proof of the facts, obtain an order directed to the clerk to note the change of name upon the Title Register, and upon the owner's certificate upon the same being produced." This privilege is available not only in the special case mentioned, namely, that of a change of name by marriage, but also in other similar cases, as where a corporation is the registered owner and it procures a charter amendment changing its corporate name.

$\S$ 204. Transfers of Land Held in Trust or under Conditions or Unusual Limitations-Powers.-It is provided in Section 56 of the Act that, "Whenever a writing or record is filed for the purpose of transferring registered land in trust, or upon any condition or unusual limitation expressed therein, or where power is given to sell, encumber or deal with the land

1. See T. $\$ 173$. 
in any manner, no subsequent transfer or voluntary transaction purporting to be exercised under the powers given in such writing or instrument or record shall be registered on the Title Register or on the owner's certificate, except upon application to the court and order of direction from the judge to the clerk as to how the same shall be entered."

This section has already been discussed in its application to administrators and executors 1 but it has a much wider scope of applicability. Wherever a certificate of title is registered in the name of a person in trust, or on condition, or upon any unusual limitation, or where it stands in the name of a person as the donee of a power to sell or encumber, the Act is unwilling to leave to the unguided discretion of the clerk the determination of whether such a registered owner has the power to convey the land, or whether he is proceeding in the proper manner to convey it, but in all such cases the clerk must refuse to register the transfer until application has been made to the court and he issues an order of transfer under Section 110 of the Act, not only directing the transfer to be made, but also directing how it shall be made. Before the judge orders the transfer he should cause notice and opportunity to be heard to be given to all interested parties.

\section{$\S 205$. Transfers as the Result of Judicial Proceed-} ings.-As stated in Section 73 of the Act, and as has been explained elsewhere in this book, ${ }^{1}$ the registration of land does not take it out of the jurisdiction of the courts, but it still remains generally subject to the same rights, incidents and burdens, as unregistered land and subject to the jurisdiction of the courts in the same manner as if it had not been. registered. Registration deals mainly with title from an evidentiary standpoint and is paramount in that field, but it affects title in the substantive sense, but incidentally - that is left to the courts to deal with as in other cases. Hence, provision is made in the Act, and especially in Section 49, as to how the judgments or decrees relating to registered land may be given effect through the registration

[§ 204] 1. T. $\S 193$.

[§ 205] 1. T. § 11. 
system. That section provides: "Whenever, as the result of a proceeding in any court of law or in equity, it is adjudged that a transfer of registered land should be made, such transfer may be made by the clerk upon the production of a certified copy of such decree showing in what book and page of the minutes of the court that rendered it the decree is recorded, and an order of the judge of the superior court of the county in which the land lies directing such transfer to be made; and the certificate of title on the Register of Titles, and the owner's certificate, shall be canceled and new certificates shall be registered and issued accordingly. Production of the certified copy of the decrees shall not be required when it is rendered in the same court as that in which the title is registered, but the clerk shall act upon the judge's order of transfer and the inspection of his own minute book."

The person in whose favor the judgment or decree exists must, therefore, first apply to the judge, under Section 50 of the Act, and must get an order of transfer in form as prescribed in Section 110 of the Act before the clerk can register the transfer. The judge, before granting the order, must take cognizance of the rights of other persons, if any, as they appear noted on the record, keeping in mind the proposition that the decree cannot affect the rights of those who have dealt with the land on the faith of the registered owner being the true owner, unless notice of the lis pendens has been entered on the certificate of title, in pursuance of Section 54 of the Act and in the manner prescribed in Section 114 of the Act. ${ }^{2}$

\section{$\S$ 206. Same Continued-Partition-Equitable Actions} - Specific Performance.-The provisions of Section 49 are general in their terms as to the classes of cases intended to be covered thereby-they apply to any case at law or in equity, as a result of which it is adjudged that a transfer of registered lands should be made. Some of the cases, which readily present themselves to mind, are proceedings at law or in equity for partition; suits brought to attack a registration for fraud or forgery, consonantly with the provisions of Section 63 of the

2. See T. $\S 178$. 
Act; ${ }^{1}$ equitable actions to declare an implied or resulting trust as to the title; actions for specific performance; suits by devisees to compel assent by executors.

$\S 207$. Transfer to Hinder, Delay or Defraud Creditors.-One special case which falls within the general category of Section 49 of the Act but which is specially dealt with is when a transfer or dealing in equitable land is attacked as being made to hinder, delay or defraud creditors. Section 55 of the Act provides, as to this, as follows: "Nothing herein shall prevent any transfer or other dealing with registered land from being attacked in a court of law or equity as having been made for the purpose of hindering, delaying or defrauding creditors, provided, that the court having jurisdiction of the case, upon the trial thereof, shall find that the person taking the transfer, or the apparent beneficiary of such dealing, took the benefit of the same with knowledge of the fact that the intention of the transaction was to hinder, delay or defraud creditors, and provided further that none of the rights of innocent parties shall be affected thereby. If a court having jurisdiction of the case, upon such proceeding, shall find that any transfer or other dealing with registered land shall have been made for the purpose of hindering, delaying or defrauding creditors and that the rights of no innocent parties will be prejudiced by the court's judgment or decree, it shall be within the power of said court to pass such judgment or decree as will avoid such transfer or the effect of such other transaction as may have been made to hinder, deday or defraud creditors, and, upon the decree or judgment of such court, the judge of the superior court of the county where the land lies, upon application as hereinbefore provided, shall have the authority and power to direct such cancellations and transfers to be entered upon the Title Register and upon the owner's certificate as shall be necessary to carry the same into effect."

The language used in this section of the Act as to the knowledge of the beneficiary of the fraud differs slightly from the language used in Sections 4109 and 3224 of the Civil Code on the same

1. See T. $\S \S 217-9$. 
general subject, but it is believed that the courts will construe the language here to have the same meaning and effect as has been given to the similar language already appearing in the Code.

It should be kept in mind that as between the parties thereto a transaction entered into for the purpose of hindering, delaying or defrauding creditors is valid; hence the court in such cases will not usually order or decree a transfer back from the vendee to the vendor, but will merely subject the vendee's title to the encumbrance of the decree, which may be accomplished by entry or notation on the certificate of title and without cancellation of the certificate. However, if the court finds it necessary that the title should be put into a receiver, or that for any other reason a transfer should be entered in accordance with the equities of the case, power to effectuate the same is conferred.

$\S$ 208. Procedure to Effectuate Transfers Resulting from Judicial Proceedings.-In all these cases of transfer as the result of judicial proceedings the mode of registering the transfer prescribed in Section 49 of the Act should be followed, that is to say a certified copy of the judgment or decree (unless rendered in the superior court of the county where the land lies) should be presented to the judge, who will grant an order of transfer in conformity to Section 110 of the Act. This order of transfer and the certified copy of the judgment or decree, being presented to the clerk, he will proceed to register the same as in other cases of involuntary transfer, making a reference to the book and page of the minutes of his own court, or of such other courts as the judgment or decree may have been rendered in.

$\S 209$. Title by Year's Support How Registered-Sale by the Widow.-In case, pending the administration of an estate, year's support is set aside to a widow or minor children, or both, and it includes all or some designated portion of a registered tract, the proceedings to perfect the transfer of the registered land thus set apart to the beneficiaries should be under either Section 49 or 50 of the Act. ${ }^{1}$ The important thing is that

1. T. $\S \S 205-6,166$ et seq. 
the judge should in his order of transfer state whether the estate is for the benefit of the widow alone, or for the benefit of herself and minor children, and the clerk should make out the certificate of title in her favor accordingly and should note the fact that the same is held by her as an award for year's support.

The widow holds the legal title to the property set apart as a year's support, and has the power to sell it, but, since she holds it as a quasi trustee, in the event there are minor beneficiaries, she cannot make a transfer of registered land held by her in this capacity, without obtaining an order of the judge, as provided in Section 56 of the Act. ${ }^{2}$

\section{$\S 210$. Homestead or Exemption-How Registered-} Sales of Homestead Property.-Homestead or exemption is an encumbrance and does not involve a transfer of the fee simple. It is a voluntary transaction. ${ }^{1}$ When, therefore, a homestead or exemption in registered land is set apart to the owner, it must, in order to bind the land, be registered on the certificate of title; but the owner has the right to have it noted without any order of the judge and upon his own written request, accompanied by his owner's certificate, ${ }^{2}$ and the original or certified copy of the homestead or exemption papers. ${ }^{3}$ The request may be simply in this form:

Georgia, County.

To the Clerk of the Superior Court of said County:

Please enter upon Certificate of Title No. —, Registered Title No. name, and herewith produced, that all of the land therein described (or some specifically described part, as the case may be), has been set apart to me, as the head of a family, as a homestead, by judgment of the Court of Ordinary of county, on the - day of - $19-$, as appears from the original (or certified copy) herewith shown. This - day of

Owner.

[§209] 2. See T. $\S 204$.

1. A. $\S 3$; T. $\$ 21$.

[§ 2,10] 2. A. $\S 37$.

3. A. $\S 117$. 
$\S 210]$

SPECIAL CASES.

173

The clerk should thereupon enter upon the certificate of title and owner's certificate a notation, under the head of "Liens, Encumbrances and Other Matters Affecting This Certificate", following the description of the transaction given on the owner's request for the entry, being careful to make reference to the book and page of the record in the ordinary's office where the homestead proceedings are recorded.

The registration of the homestead attaches to the owner's tithe a quasi trust. Therefore, no subsequent transfer from the owner should be registered except upon order of the judge. ${ }^{4}$ Before ordering a transfer, the judge should satisfy himself either that the homestead has expired, or that the statutory proceedings prerequisite to a sale of homesteaded property have been complied with.

4. See A. $\S 56 ;$ T. $\S 204$. 


\section{CHAPTER XIII.}

\section{Concluniveness of Registration.}

$\S$ 211. The Extent of the Conclusiveness.

$\S$ 212. Same Continued.

$\S$ 213. Conclusiveness of Registration Where Transfer Forged.

$\S$ 214. Same Continued.

$\S$ 215. Same Continued-Safeguards of the Act.

$\S$ 216. Registration Procured by Fraud-Protection of Innocent Persons.

§ 217. Attacking Registration For Fraud or Forgery-Summary Proceedings-Regular Court Action-Limitations.

$\S$ 218. Same Continued-Burden of Proof.

\$ 219. Fraud in Initial Registration-Failure to List Known Adverse Claimant.

\$220. The Four Matters Excepted From the Conclusiveness of Registration.

$\S$ 221. Same Continued-Liens and Rights Under Federal Statutes.

$\S$ 222. Same Continued-Rights of Trustee in Bankruptcy.

$\S$ 223. Same Continued-Taxes and Assessments For the Current Calendar Year.

§ 224. Same Continued-Lease For Less Than Three Years.

$\S$ 225. Same Continued-Highways and Railways.

$\S 226$. Difference Between Certificate of Title and Owner's Certificate as to Conclusiveness.

§ 227. Same Continued-When Owner's Certificate Can Be Relied On-Entry of "Valid With All Entries Noted."

$\S$ 228. How Far Summary Jurisdiction of Judge Over Registration Affects Conclusiveness.

$\S$ 229. Twelve-Months' Limitations For Correction of Registration -When Applicable-When Not.

$\S$ 230. Same Continued-Matters Adjudicated on Original Registration.

§ 231. Cancellation of Entry-Conclusive in Twelve Months-When -When Not.

§ 232. Registered Land Not Affected by Adverse Possession or Prescription.

§ 233. Effect of Reversal of the Judgment Authorizing the Regisistration.

§ 211. The Extent of the Conclusiveness.-The conclusiveness of the decree of title on which initial registration is based 
has been discussed in another context. ${ }^{1}$ But the intention of the Act is that similar conclusiveness shall attach to all subsequent registrations of the land and of estates and interests therein. Section 63 of the Act relates not only to initial registration, but to all succeeding registrations. It is as follows: "Every registered owner of any estate or interest in land brought under this Act shall, except in cases of fraud or forgery to which he is a party, or to which he is a privy without valuable consideration paid in good faith, hold the land free from any and all adverse claims, rights, or encumbrances not noted on the certificate of title in the Title Register, except:

"First. Liens, claims or rights arising or existing under the laws or Constitution of the United States which the statutes of this State cannot require to appear of record under registry laws.

"Second. Taxes and levies assessed thereon for the current calendar year.

"Third. Any lease for a term not exceeding three years, under which the land is actually occupied.

"Fourth. Highways in public use and railroads in actual operation.

"No proceedings to attack or to set aside any transaction for such fraud or such forgery as is referred to in this section shall be brought or be entertained by any court unless the same shall have been brought within seven years from the date of the transaction or of the registration to which the same relates. Nothing herein shall conflict with the provisions of this Act allowing attack for good cause to be made upon a registration made by the clerk at any time within twelve months from the date of such registration."

$\S$ 212. Same Continued.-It is to be noticed that section 63 of the Act does not give conclusiveness to everything which may happen to be noted or entered on the Title Register. Though adverse claims, liens and encumbrances may be registered and noted on the certificate of title, no conclusiveness is

1. T. § 117 . 
given to them thereby, their validity is left to the determination of the courts. ${ }^{1}$ The conclusiveness relates only in favor of the registered owner of some estate or interest in registered land and against the validity of any adverse claim, right or encumbrance, not noted on the certificate of title in the register, and not excepted in Section 63 of the Act. This legislative declaration means that in any court of law or of equity the certificate of title is conclusive evidence that the person named therein as the owner is the owner and that there are no adverse rights, claims or encumbrances affecting his title unless they are noted on the certificate of title in the register. ${ }^{2}$

It does not mean that a court of proper jurisdiction may not, while recognizing the completeness of the owner's legal title to the land, find that such equities exist against him and in favor of another as that he should be compelled to convey and transfer the certificate and consequent title to such other person. ${ }^{3} \mathrm{~A}$ little elucidation of this statement may not be inappropriate. If Jones takes Smith's money and invests it in unregistered land, but, in breach of his duty to Smith, takes the title in his own name, the law recognizes that Jones holds the legal title, but it imputes to Jones an intention of holding the title in trust for Smith, and a court of equity has the power, by a decree operating on Jones personally, to compel him to do what he ought to do, namely, to convey it to Smith. Likewise, if Jones takes Smith's money and invests it in registered land, but, in breach of duty to Smith, takes the certificate of title in his own name, the Land Registration Act says that Jones is the owner of the land; but, in this case, as in the other, a court of equity has the power, by a decree operating on Jones personally, to compel him to transfer the certificate of title to Smith.

However, if Smith fails to note his equity on the Title Register, and some third person deals with Jones as the owner and takes a transfer of the certificate of title, Smith can no longer compel Jones to do equity by transferring his title to him; he must seek another remedy to redress his wrong, that is
1. A. $\S 51$.
2. T. $\$ 239$.
3. A. $\S 73 ;$ T. $\S \S 205-206$. 
to say, an action in damages, or for money had and received, or some action of that nature, which will not disturb the title of the new holder of the certificate. The Act, therefore, means that anyone may deal with the owner stated in the certificate of title as the true owner of the land, and with the assurance of the law that any right or interest in the land which he obtains as the result of such dealing and causes to be duly registered in his name shall not be affected or disturbed by anything which does not appear on the certificate of title at the time he acquires and registers his right or interest; except, or course, the four things excepted in Section 63 of the Act.

\section{$\S 213$. Conclusiveness of Registration Where Trans-} fer Forged.-One of the serious problems involved in every system of dealing with lands is the problem of forgery. The question "Who should suffer if some one should procure an owner's certificate and forge a transfer thereon and sell it to another-the owner whose name has been forged or the person who has paid his money in good faith to the forger and has obtained the new certificate thereon?" is a hard question to answer; though it should be answered in the law itself; and it has been answered. The Georgia Act, as do many similar acts, answers that the owner whose certificate has been surrendered and transferred by the forger must suffer-that the new certificate is valid, unless the person taking it was a party to the forgery or unless he did not acquire his transfer and new certificate in good faith and on valuable consideration.

Our law operates somewhat but not altogether differently as to unregistered land. If some one forges a landowner's name to a deed to unregistered land and sells it to an innocent person, the latter gets no immediate title, but if he enters into possession under his forged deed, it operates as color of title, and at the end of seven years of peaceable possession, so held, this color of title ripens into a title superior to that of the true owner; and this is true even though the possessor of the land becomes aware of the forgery pending his possession and even though he paid no valuable consideration for his forged deed. All that is necessary to perfect the title of the forger's vendee 
is that he should have acquired it in good faith, entered into possession believing it to be genuine, and held it for the statutory period.

Why does the law in such a case say that the person who had no title at all and only a forged deed as a color of title should become the true owner of the land by merely continuing to occupy and enjoy the land which in fact does not belong to him, but which belongs to the victim of the forgery? The answer is that public policy, expediency, and the need of a statute of repose as to the possession of land, demand such a rule. Likewise, public policy, expediency, and the need of repose and certainty as to land titles demand that the bona fide purchaser of a certificate of title to registered land, who, though he buys on a forged transfer, succeeds in having the land registered in his name, should nevertheless hold an unimpeachable title. There is more natural justice in recognizing his title as being valid than there is in recognizing as valid the title of one who has succeeding in ripening a forged color of title by prescription.

In the first place, a forger cannot effectuate his forgery in the case of registered land by executing a transfer which can be registered, unless the owner has allowed him, in some way, to get possession of the owner's certificate. The Act has erected in favor of the owner, as a safeguard, against a forged transfer being perpetrated against him, the requirement that no voluntary transfer shall be registered unless the owner's certificate is produced along with the instrument of transfer. ${ }^{1}$ Therefore, if the owner has voluntarily or carelessly allowed the forger to come into possession of his owner's certificate he is to be judged according to the maxim, that when one of two innocent persons must suffer by the wrongful act of a third person the loss falls on him who put it into the power of that third person to perpetrate the wrong. Furthermore, even if the forger stole the owner's certificate, the owner is up against no greater hardship than is experienced by one whose money or negotiable paper payable to bearer is stolen and transferred by the thief to an innocent purchaser.

1. A. $\S 37 ;$ T. $\S \S 146,215$. 
$\S$ 214. Same Continued.-The rule under most of the Torrens acts in British countries, as construed by the courts, is that the immediate taker of the forged transfer is not protected, but that persons dealing with him as the registered owner, including subsequent transferees, will be protected. There is much to be said in favor of the logic of this rule, but the framers of the Georgia act choose to follow the language of the "Uniform Land Registration Act" 1 on the subject, and that language imposes its own legal consequences.

There can be no serious question as to the constitutionality of the rule prescribed in the Georgia Act, since one of the covenants following the land, and therefore binding on every registered holder, is that the land shall, after registration, (and until and unless it shall have been freed from registration in the method prescribed in Section 65 of the Act), be subject to all the provisions of the Act; ${ }^{2}$ hence the result declared by the Act follows not only as the result of statutory enactment, but also of the landowner's implied consent.

The Georgia rule not only protects the bona fide registered owner from any forgery that may stand back of his certificate, but protects all other persons dealing with him as the owner. The object of the Act is to give every assurance of safety to those who accept the contents of a certificate of title at its face value.

\section{$\S$ 215. Same Continued-Safeguards of the Act.-} However, it is comforting to keep in mind in this connection, that notwithstanding the large number of registration systems which are in force in English and American jurisdictions, many of which have been in force for a long time, less than a half dozen cases involving this question have arisen so far as reported cases show. The severe penalty prescribed by the Act, ${ }^{1}$ the practical safeguards erected by the Act, such as the requirement that the owner's certificate must be produced with the transfer, ${ }^{2}$ and that the instrument of transfer must be attested

[§ 214] 1. See Appendix.

[§ 214] 2. A. $\S 64 ;$ see also T. $\S \S 20,117$.

[§ 215] 1. A. § 85; T. § 258 .

[§ 215] 2. A. $\S 37 ;$ T. $\S \S 136,140$. 
by a public officer and another witness, ${ }^{3}$ all tend to make a forgery relating to registered land extremely dangerous and difficult to perpetrate. As to unregistered land the forgery may, and most frequently does relate to some old deed, so that the forgery is not so readily suspected and not so easy of proof as it would be in case of a forged transfer to registered land; for if the instrument of transfer should antedate its being offered for registration by any considerable period of time, the clerk would be put on guard and should refuse to register the transfer until satisfied as to its genuineness, as he has the right to do under Sections 59 and 106 of the Act.

\section{\$ 216. Registration Procured by Fraud-Protection} of Innocent Persons.-The rule announced by the Act as to the limits within which an attack may be made upon the registration for fraud ${ }^{1}$ is not new ; it is the ordinary rule commonly applicable under our general system of laws, namely, that one who procures title to property by fraud may be compelled to restore it to the person defrauded, but that innocent third persons dealing for value with the fraud-doer as the owner of the property will obtain rights superior to those of the person defrauded.

$\S 217$. Attacking Registration for Fraud or ForgerySummary Proceedings-Regular Court Action-Limitations.-Proceedings to attack a registration for fraud or forgery under the Act are of two kinds: first, by caveat and summary application to the judge under Section 60 of the Act; ${ }^{1}$ second, by resort to the courts. The right to pursue the summary remedy is reserved in such cases by the concluding sentence in Section 63 of the Act, but it exists for only twelve months; for after that period the clerk's entry of registration becomes conclusive and cannot be corrected or modified by the judge under his supervisory powers over the registry. ${ }^{2}$

Within the twelve-month period, the judge has summary ju-

3. A. $\S \S 30,106$ and 107 of the Act; T. $\S 269$.

[§ 216] 1. A. §63; T. $\S 211$.

[§ 217] 1. See T. $\S \S 182-5$.

2. A. $\S 59 ;$ T. $\S \S 228$ et seq. 
risdiction, as explained in Section 184, ante, to cause the certificate of title which has been obtained by fraud or forgery to be canceled and the status of the old certificate restored, except as against the intervening rights of innocent third persons. After the twelve-month period has expired, the registration cannot thus be canceled or modified, but the injured person is remitted to a different remedy. He may bring any appropriate action (though it seems that only a court of equity would have the power to give adequate relief) to compel the wrongdoer to execute such a transfer as would restore his title to him, provided, of course, the certificate of title still stands in the name of the wrongdoer, and no intervening rights of innocent third persons have attached thereto. Even if intervening rights of third persons have attached, if they were not acquired for value or if they are of such a nature that they can be adequately protected by being noted on such new certificate as the court may find it necessary to cause to be issued, the court of equity dealing with the matter may still order a restoration of rights by a decree compelling the wrongdoer or his transferee, if the latter has not acquired for value and in good faith, to execute a transfer in favor of the person wronged, upon such conditions as may be equitable.

Upon such a decree, even if the wrongdoer or his transferee should fail or refuse to execute the transfer, and the court of equity found itself unable to compel him to do so by attachment for contempt or otherwise, effect could be given to the decree by the obtaining of an order of transfer from the judge under the provisions of Sections 49 and 50 of the Act. ${ }^{3}$

As to such suits the Act, in the course of Section 63, provides that, "No proceedings to attack or set aside any transaction for such fraud or such forgery as is referred to in this section shall be brought or be entertained by any court unless the same shall have been brought within seven years from the date of the transaction or of the registration to which the same relates." The limitation here set is a maximum, and does not interfere with the general doctrine that a court of equity may re-

3. T. $\S 205$. 
fuse relief in cases of fraud, even though the full period of the statutory limitation has not expired, where there has been laches or other circumstances making it inequitable to grant the relief.

$\S$ 218. Same Continued-Burden of Proof.-The statement in the body of Section 59 of the Act, that all registrations made by the clerk shall be prima facie conclusive, puts upon the person asserting the fraud or forgery, whether in a summary proceeding or in an action in equity, the burden of proving the fraud or forgery and the other essentials requisite to the modification or setting aside of the registration or to the other relief prayed in respect of the same.

$\S 219$. Fraud in Initial Registration-Failure to List Known Adverse Claimants.- There is one species of fraud which may affect the initial registration, and that is the fraud of the petitioner for registration in omitting from the list of defendants some person whom he knows to be an adverse claimant. ${ }^{1}$ Such a case arose under the Minnesota Land Registration Act, and the Supreme Court of that State held that notwithstanding that Act made no exception as to fraud, still that the general powers of the court of equity to set aside judgments and all other transactions procured by fraud, provided no rights of innocent third persons were effected thereby, were not abolished. ${ }^{2}$ The court there points out that, while the decree of registration has all the conclusiveness accorded to any regular judgment, and while the legal title passes as a result of the registration, notwithstanding the defrauded adverse claimant was not personally served, still that a court of equity has power to give equitable relief against the fraudulent transaction, provided the defrauded party has not been guilty of laches and provided no rights of innocent third persons will be affected. It is believed that this states the rule as it exists in Georgia.

$\S 220$. The Four Matters Excepted from the Conclusiveness of Registration.-The Act, in Section 63, excepts

1. T. $\$ 44$.

2. Baart $v$. Martin, 99 Minn. 197, 108 N. W. 945, 116 Am. St. Rep. 394. 
from the operation of the Act and from the necessity of registration in order to affect the land only four classes of transactions: These are: "First. Liens, claims or right existing under the laws or Constitution of the United States which the statutes of this State cannot require to appear of record under registry laws. Second. Taxes and levies assessed thereon for the current calendar year. Third. Any lease for a term not exceeding three years, under which the land is actually occupied. Fourth. Highways in public use and railroads in actual operation."

$\S 221$. Same Continued-Liens and Rights under Federal Statutes.-As to the first exception, the one in favor of liens, claims or rights arising or existing under the laws or Constitution of the United States, it is to be noticed that all such are not excepted, but only such as "the statutes of this State cannot require to appear of record under registry laws." 1 This is to be construed in connection with the Act of Congress of Aug. 1, 1888, Ch. 729, 25 Stat. L. 357, and the amendments thereof ${ }^{2}$ which now leave the Act, so far as pertinent to this context, to read: "That judgments and decrees rendered in a circuit or district court of the United States within any State, shall be liens on property through such State in the same manner and to the same extent and under the same conditions only as if such judgments and decrees had been rendered by a court of general jurisdiction of such State: Provided, That whenever the laws of any State require a judgment or decree of a State court to be registered, recorded, docketed, indexed, or any other thing to be done, in a particular manner, or in a certain office or county, or parish in the State of Louisiana before a lien shall attach, this act shall be applicable therein whenever and only whenever the laws of such State shall authorize the judgments and decrees of the United States courts to be registered, recorded, docketed, indexed, or otherwise conformed to the rules and re-

1. Compare Cooke v. Avery, 147 U. S. 375; 37 L. Ed. 209.

2. 4 Fed. Stat. Ann. (2d Ed.) 608.

Last amendment was the Act of Congress of Aug. 23, 1916, effective Jan. 1, 1917. See Pamph. Supp. No. 8, Fed. Stat. Ann. 
quirements relating to the judgments and decrees of the courts of the State."

$\S$ 222. Same Continued-Rights of Trustee in Bankruptcy.-The title of a trustee in bankruptcy as to the bankrupt's estate is, of course, a right arising under the laws of the United States. Section 70 of the Bankruptcy Act confers on the trustee, upon his appointment and qualification, and on his successor or successors, title to the property of the bankrupt as of the date he was adjudicated; and Section 21 (e) of that Act provides that "A certified copy of the order approving the bond of the trustee shall constitute conclusive evidence of the vesting in him of the title to the property of the bankrupt, and, if recorded, shall impart the same notice that a deed from the bankrupt to the trustee, if recorded, would have imparted had not bankruptcy praceedings intervened."

The filing of the petition in bankruptcy is a caveat in rem operating as notice to the world. ${ }^{1}$ However, except in so far as the bankruptcy act confers upon the trustee in bankruptcy certain special rights in regard to preferences and property transferred in fraud of creditors, the trustee takes the property encumbered with the same general burdens as attached to it in the hands of the bankrupt. ${ }^{2}$ Any registered land that a bankrupt may own is encumbered by a covenant running with the land that it shall be subject to all the provisions of the Land Registration Act. $^{3}$ It may, therefore, be held that the trustee takes his title to registered land subject to this covenant and that he cannot exercise the title conferred on him by the Bankruptcy Act except in conformity to the provisions of the Land Registration Act. Until there is an authoritative adjudication on this subject, and up to date there seems to be none, no opinion of any real value can be expressed upon this question. However, it may be suggested that, to be on the safe side, trustees in bankruptcy and those purchasing at trustee's sales would best

1. Mueller v. Nugent, 184 U. S. 1, 46 L. Ed. 405.

2. Hewitt $v$. Berlin Mach. Works, 194 U. S. 296, 48 L. Ed. 986; Security Warehousing Co. v. Hand, 206 U. S. 415, 51 L. Ed. 1117, and cases therein cited.

3. A. $\S 64 ;$ T. $\S \S 117,136$. 
note or register their rights or title under the Act; and on the other hand, one dealing with a registered owner should take the precaution of ascertaining whether a petition in bankruptcy has been filed against him, irrespective of whether any notation is made of it on the Title Register. The trustee in bankruptcy is entitled to proceed under Section 49 of the Act to cause the title to be registered in his name; and a purchaser from him, even if the trustee had not registered his title, would be authorized to apply for an involuntary transfer in conformity with Section 50 of the Act.

\section{§ 223. Same Continued-Taxes and Assessments for} the Current Calendar Year.-The exception in Section 63 of the Act in favor of taxes and assessments relates only to the taxes and assessments for the current calendar year. The method of preserving the lien for such taxes, etc., after the expiration of the year in which they are assessed is set forth in Section 57 of the Act. ${ }^{1}$ Notice also that only such taxes and levies as are assessed against the land itself are excepted from the necessity of registration.

\section{$\S$ 224. Same Continued-Lease For Less Than Three} Years.-The third exception in Section 63 of the Act is in favor of "any lease for a term not exceeding three years, under which the land is actually occupied." The word "lease" is manifestly used in the broad sense of any contract oral or written creating the relation of landlord and tenant. A condition of the exception is that the tenant should have the land in actual occupation, through himself or an agent or sub-tenant. All other leases should be noted to be enforceable. This exception is designed to prevent the annoyance that would be occasioned if every annual or other short letting of the land to a tenant had to be noted.

\section{$\S$ 225. Same Continued-Highways and Railways.-} There has been much written by the courts on the question as to whether a public highway or a railroad on the land is an encumbrance or a benefit-the question usually arising in suits

1. T. $\S 177$. 
for breach of covenants against encumbrances. Without undertaking to decide this much mooted question, the Act, in the fourth and last exception in Section 63, renders it immaterial by excepting these particular encumbrances, if they be encumbrances, from the necessity of being registered. They are things which, in their nature, can readily be seen and known by anyone dealing with the land; and the danger of anyone being injured by their not being noted is too slight to off-set the inconvenience of requiring them to be registered.

$\S$ 226. Difference between Certificate of Title and Owner's Certificate as to Conclusiveness.-Having noticed the nature and extent of the conclusiveness that attaches to registration, and the exceptions that relate thereto, it is now appropriate to call attention to the specific thing, that determines these matters. It is the certificate of title on the Title Register. ${ }^{1}$ Liens, encumbrances and special rights may be noted on the certificate of title which are not noted on the owner's certificate; they are binding nevertheless in so far as they may have inherent validity; any person dealing with the land must take notice of them. Furthermore, an owner's certificate may be outstanding without any evidence of cancellation on it, notwithstanding the corresponding certificate of title on the Title Register may have been canceled; for involuntary transfers and consequent cancellations may take place without the judge's being able to call in the outstanding certificate for cancellation otherwise than by publication. ${ }^{2}$

Does this mean that everyone dealing with the land must go to the registry and inspect the certificate of title to be safe in dealing with the land and that in no case is it safe to rely on the contents of the owner's certificate? It will presently be shown that such is not the case, and that the Act has provided a practical remedy against such inconvenience.

$\S$ 227. Same Continued-When Owner's Certificate Can Be Relied on-Entry of "Valid, with All Entries Noted."-It is provided in Section 118 of the Act that, "The

1. A. $\S \S 40,63,73$.

2. See T. $\S 169$. 
holder of an owner's certificate of title may at any time present it to the clerk, and if the certificate of title on the Register has not been canceled, the clerk shall thereupon enter on the owner's certificate all entries and notations of every kind which shall appear on the certificate of title, if all such entries shall not have already been entered on the owner's certificate, and shall thereupon endorse upon the owner's certificate the words 'Valid, with all entries noted to this date, this - day of 191—, at — o'clock, — M.,' signing the same officially."

It follows that the owner's certificate can be thus made in effect a certified copy of the certificate of title, as of any desired moment. ${ }^{1}$ This enables any one to deal with practical safety on faith of the owner's certificate, and without personal inspection of the registry. However, one about to buy the land or to advance money upon a mortgage or creditor's certificate on the registered land may make himself absolutely secure by requiring the owner, in the case he is buying, to complete the transfer and bring him the new owner's certificate before he pays the purchase money; or, in case he is making a loan to require the owner to have the mortgage or creditor's certificate registered and to produce the owner's certificate with the mortgage or creditor's certificate registered on it, with the clerk's entry of "Valid, with all entries to this date noted," signed as of some moment after that on which the entry of the mortgage or creditor's certificate is dated, before he pays over the money he is expected to lend. In such cases the owner can protect himself also by requiring the money to be deposited in escrow.

$\S$ 228. How Far Summary Jurisdiction of Judge over Registration Affects Conclusiveness.-In connection with a consideration of the conclusiveness attaching to the registration of any estate or interest in land brought under the Act, referred to in Section 63 of the Act, there is another provision to which reference should be made. This is the provision in Section 59 of the Act that all registration of title and all entries and notations made by the clerk upon the Title Register of transfers or of the cancellation or discharge of liens or encumbrances

1. Compare T. 239. 
shall become absolutely conclusive upon all persons unless a caveat be filed, as provided in Section 60 of the Act, seeking to set aside, modify or otherwise affect such entry, notation or registration, within twelve months from the date of the making of the same upon the Title Register. This is followed in the same context with the explanatory statement that, this is to be considered and construed as a statute of limiations against the questioning of the correctness of the clerk's action, and is to be without exception on account of disabilities.

This language is liable to be misunderstood unless it is construed in connection with its context. The intention of Sections 59 and 60 of the Act is to declare the relations of the clerk and of the judge to certain registrations-that the clerk's relation is ministerial, that the judge's is judicial and supervisory ${ }^{1}$ -and to provide a means by which this supervisory power may be invoked. The clerk, as the ministerial officer of the court having the registry in charge, has the primary duty of determining whether the instrument offered for registration is in proper shape for registration and with the duty of correctly making the registration, including all formal incidents thereto. If he has doubt at the time the instrument is presented for registration, as to whether he should register it or how, he may ask and obtain the instructions of the court at that time; or he may go ahead and make the registration according to his best judgment and the lights before him. The statute creates the presumption that he has made the registration correctly; but allows twelve months within which the judge may exercise his supervisory powers and cause the registration, notation or entry, to be corrected, vacated or modified (provided there are no intervening rights of third persons who have dealt on the faith of the registration to prevent it); but, unless caveat is flled within the time allowed, the judge cannot, in the exercise of his summary jurisdiction over the register, modify or vacate the notation, entry or registration.

There is nothing in Section 59 of the Act which is intended, in anywise, to modify the conclusiveness given to the certificate of title by Section 63 of the Act or to postpone that conclusive-

1. T. $\S \S 270,275$. 
ness for 12 months. The twelve-months' limitation contained in Section 59 is merely a limitation upon the judge's exercising over the registry, as to such registrations as are within the provision of the limitation, the summary supervisory powers set forth in Section 60 of the Act. After the twelve months shall have expired, while neither the clerk as the ministerial officer in charge of the registry, nor the judge, as the supervisory judicial officer in charge, can vacate or modify a registration of the character that falls within the limitation clause of the Act; still in all proper cases a court of equity acting upon the party in whose favor the entry exists may decree that he shall make such a transfer or do such other act as will right the wrong in the event a wrong has been committed through the registration. ${ }^{2}$

The deduction, therefore, to be made is that, even during the period of twelve months within which registrations may be modified or corrected, the registration as made, is conclusive in favor of any one acquiring rights on the faith of it, and that only such corrections or changes may be made as will not interfere with such intervening rights.

\section{$\S$ 229. The Twelve-Months' Limitation for Correc-} tions of Registration-When Applicable, When Not.Not all entries and notations are within the twelve-months' limitation of Section 59; only registrations of title and entries and notations made by the clerk of transfers or of the cancellation of liens or encumbrances are included.

The subjects of how far registration of title and transfers may be set aside and to what extent they may be subjected to jurisdiction in equity have been fully discussed in another context. ${ }^{1}$ The other matter to which the limitation of Section 59 applies is registration of the cancellation of liens and encumbrances-a matter which will be presently discussed. ${ }^{2}$

The point to which attention is now called is that the regis-

[§ 228] 2. See T. $\S \S 137,205-6$. As to attacks for fraud or forgery see $T$. $\S 217$.

1. See T. $\S \S 137-9,205-6,217,228$.

[§ 229] 2. T. $\S 231$. 
trations to which the twelve-months' limitation applies are registrations in favor of the person appearing as the owner. This reflects the difference between the effect of registering matters in favor of the owner and of registering matters adverse to his interests. The Act makes the certificate of title the sole and conclusive evidence of title; and it is just as full and conclusive proof of title as to the estate therein declared in the owner's favor as a regular perfect chain of title from the State down to him would be if the land were unregistered. It is also conclusive evidence that there are no liens, encumbrances or other adverse claims which are capable , $_{r}$ affecting his title, at any particular time, unless they are noted on the certificate of title at that time; but the fact that such liens, encumbrances or adverse claims are registered on the certificate of title is no evidence that such liens, encumbrances or adverse claims are valid or enforceable. Therefore in registering liens, encumbrances and adverse claims, the clerk is performing merely such a ministerial duty as he would perform if he were entering a judgment on the general execution docket-a very different function from the function he performs in registering a certificate that conclusively imports its own verity and proves, by its own virtue, the title it declares.

$\S 230$. Same Continued-Matters Adjudicated on Original Registration.-This distinction may be noted as between liens, encumbrances, etc., declared in the decree of title at the time of initial registration and those placed on the certificate of title subsequently: The petition for registration brings into justiciable controversy all liens, encumbrances and other adverse claims which may be asserted at that time and in the decree they are either granted or refused registration, accordingly as they are or are not found to be valid. Hence such liens and other adverse claims as are given the right of registration by the decree of title are given a conclusive presumption of validity under the doctrine of estoppel by judgment; 1 but it is the judgment and not the act of registration that establishes their validity.

1. See T. $\S \S 117,243$. 
$\S 231$. Cancellation of Entry-Conclusive in Twelve Months-When-When Not.-The twelve-months' limitation of Section 59 of the Act does not apply to caveats filed under Section 60 to have entries and notations adverse to the owner's title removed from the Title Register. However, the registration of the cancellation of a lien or encumbrance is an entry in favor of the owner, and is within the twelve-months' limitation of Section 59 of the Act as to the summary vacation or correction by the judge. But the language of Section 63 of the Act is also such as to include within its purview an exception in favor of a cancellation obtained through fraud or forgery. It says that, "every registered owner...... shall, except in case of fraud or forgery...... hold the land free from any and all adverse claims, rights or encumbrances not noted on the certificate of title." It would seem to follow, therefore, that the vacation of an entry cancelling a lien, if the registration of the entry has been procured by fraud or forgery, stands on the same footing and with like remedies for relief as in the case of a transfer similarly obtained, a subject already treated in Section 217, supra.

If the cancellation has been made not as the result of fraud or forgery and not under such circumstances as that equity can administer relief and the twelve months have expired without its being vacated, the land stands finally relieved of the lien or encumbrance, and the person injured by the cancellation will have to look for relief to the action saved him, under Section 59 of the Act, against the clerk or, under Section 84 of the Act, against any person or any officer whose fraud or negligence may have caused his injury. ${ }^{1}$

§ 232. Registered Land Not Affected by Adverse Possession or Prescription.-The certificate of title is not only the conclusive but also the exclusive method of proving title to the registered land-the registered title is the only title. Even title by prescription, a title usually superior even to the State's own grant, is abolished as against registered land. The language of Section 66 of the Act is plain and direct: "No title to

1. See also T. $\S 257$. 
nor right nor interest in registered land in derogation of that of the registered owner shall be acquired by prescription or adverse possession."

Possession is no longer an incident of title as to registered land. Any one may safely deal with the registered owner as the owner without being compelled, as in case of unregistered land, to take any cognizance of the possession. ${ }^{1}$ Furthermore, one about to buy, or to lend money on registered land may be sure that the title is not liable to be defeated by the constructive possession of some one who has no possession of the land itself, but who is in possession of some land, perhaps a mile away, and has a deed recorded in some unsuspected record covering the registered land as a part of the tract. Section 66 of the Act would also seem to repeal Sections 5587 et seq. of the Civil Code so far as relates to setting off of improvements made by an adverse occupant after the registration, as against the recovery of the land. ${ }^{2}$

\section{$\S$ 233. Effect of Reversal of the Judgment Authorizing} the Registration.-A question which naturally arises is: "What would be the effect if some interested person should sue out a writ of error to the decree authorizing the registration and the Supreme Court should reverse the judgment of the lower court?" The Act does not answer the question explicitly, and yet it seems safe to draw certain deductions.

The suggestion has been made that in entering the decree of title the judge should make a memorandum of the right of appeal and that this should be retained on the certificate of title till the time for appeal has expired or, if writ of error is sued out, till final judgment. ${ }^{1}$ The suggestion has also been made that any interested person may note his right of appeal on the certificate of title, in the nature of a notice of lis pendens. ${ }^{2}$ In neither of these cases is there much difficulty in answering the

[§ 232] 1. The rule, that possession is notice, abolished, T. $\S 245$.

[\$232] 2. See also, as to how far mesne profits and improvements are to be taken into consideration at the time of initial registration, T. § 115 .

[§ 233] 1. T. § 114.

[§ 233] 2. T. $\S 118$. 
question. The owner securing the initial registration and all persons thereafter dealing with the land hold the same affected with notice of the appeal, and, therefore, subject to the results. In such a case upon the decree of registration being reversed the judge should order it and all proceedings had thereafter in the course of the registration made thereunder cancelled.

It has already been stated in another context that if a writ of error has been filed and supersedeas obtained before the clerk executes the decree, that is before he issues a certificate of title thereon, he should desist from doing so until the case on appeal is finally disposed of. ${ }^{3}$

But if the judge fails to make a memorandum of the right of appeal in the decree, and it is not noted on the certificate of title, and the decree is afterwards reversed, it then becomes proper to consider the question from the standpoint of whether or not rights of third persons have been acquired pending the appeal. In such a case, if no rights of third persons have been acquired the court upon a reversal of the judgment authorizing the registration should order complete cancellation. ${ }^{4}$

However, if a third person has acquired a registered transfer or any other registered right, on the faith of the certificate of title and of the lack of any adverse notice thereon, then Section 63 of the Act, ${ }^{5}$ which makes registration conclusive, prevents any interference with his registered rights, and in such a case, it is submitted, neither the decree nor the certificate of title should be cancelled.

It must be remembered that it is competent for the General Assembly to prescribe the conditions on which appeal may be had; and the necessary result of construing together Sections 82,63 and 73 of the Act is, that the registering of notice of the right of appeal is essential to its preservation, at least so far as the rights of third persons are concerned-that Sections 63 and 73 of the Act are limitations upon the right given in Section 82 of the Act.

3. T. § 118.

4. Notation of a lis pendens is not necessary as between the actual parties to the action. A. $\S 54$.

5. See also A. $\S 54$ to the same effect. See T. $\S \S 178,245$. 
Indeed, it would seem to follow that if the rights of third persons should be registered, in the absence of any notation of the right of appeal, and this matter should be brought to the attention of the Supreme Court, during the pendency of the writ of error, it would be the duty of that court to dismiss the writ of error, as in other cases where the judgment has been so fully executed pending the appellate proceedings as to render the questions in that court moot.

Of course, if the appeal relates only to some lien or encumbrance, the rights of the parties might be protected in some less drastic way, but the foregoing will indicate the rationale according to which the decision of the particular case is to be made. The key to the question presented in the opening sentence of this section is that the writ of error is such a suit as falls within the purview of Section 54 of the Act which requires lis pendens to be registered to be effective. 


\section{CHAPTER XIV.}

\section{Freeing Land from Registration.}

$\S$ 234. General Statement of the Privilege-When Advantageously Used.

$\S$ 235. Method of Freeing Land from Registration.

$\S 236$. Effect on Future Transactions.

$\S$ 237. Same Continued-Benefits of Registration Endure-Last Certificate as a Source of Title.

$\S 238$. Unanimous Action of Cotenants Required to Free Land From Registration.

§ 234. General Statement of the Privilege-When Advantageously Used.-The provision in Section 65 of the Act, whereby the registered owner, whether on initial or subsequent registration, may free the land from registration and return it to the category of unregistered land, is not taken or adapted from any other registration act, but is new matter in the Georgia statute. The methor of freeing the land from registration, as set forth in the section of the Act just mentioned, is as follows: "If any person who is the registered owner of the fee simple title to the land shall at any time so desire, he may cause a transfer of the title to be registered to himself, "his heirs and assigns, free from further registration.' Thereupon the land and the title thereto shall be free from the necessity of subsequent registration, and shall as to subsequent transactions be exempt from the provisions of this Act, so far as the interest of the person thus freeing it from registration and subsequent holders under him are concerned; but as to such interest the certificate of title and owner's certificate registered and issued on the last transfer shall stand as a conclusive source of subsequent title to the same extent as if it were a grant from the State. However, if the interest thus freed is, according to the title register, subject to liens, exceptions, encumbrances, trusts or limitations of any kind, such liens, exceptions, encumbrances, trusts or limitations shall not be affected, but shall be noted on the owner's certificate as issued on the last transfer and shall 
be effective against the same as long as they shall subsist. If the fee simple be registered undividedly in the name of more than one person, as tenants in common or other like relationship of joint or common interest, it shall not be freed from registration except upon the unanimous action of the owners of the entire fee."

As the result of the foregoing provision a landowner may avail himself of what is sometimes called the "title-laundry" feature of the Act, that is to say of the provisions of the Act by which his title may be settled against the world, without keeping his land thereafter under the registration system. Owing to the prejudice which some people have against the ownership of registered land (whether wisely or unwisely is not a part of the present discussion) if the owner of land by registering it, or if any one by buying registered land should thereby find himself, if he should desire to sell it or to deal with it in any other commercial way, limited to selling it to, or to dealing concerning it with only those who wish to own or were willing to deal with registered land, he might at times find registration a handicap; but if any such handicap exists it can promptly be relieved, so far as registrations in Georgia are concerned.

\section{$\S 235$. Method of Freeing Land from Registration.-} The process of freeing the land from registration is simple. The owner of the land executes upon his owner's certificate a transfer in the same manner as if he intended to sell it except that he names as the transferee himself, "his heirs and assigns, free from further registration." He takes the owner's certificate to the clerk who notes the transfer and cancels the outstanding certificate, just as if it were a case of ordinary sale and voluntary transfer. ${ }^{1}$ The clerk then issues a new certificate in favor of the owner, "his heirs and assigns, free from further registration," notes on it all the liens, encumbrances, etc., noted on the old certificate of title, issues a new corresponding owner's certificate; and the transaction is completed.

$\S$ 236. Fffect on Future Transactions.-Upon the certificate of title being issued in favor of an owner, "his heirs and

1. See T. $\S \S 140,147$. 
assigns, free from further registration," the land is thenceforth, as to all subsequent transactions, voluntary or involuntary, exempt from the operations of the Act. Thereafter conveyances, mortgages, etc., affecting the land are to be executed and recorded as similar transactions are as to other unregistered land. Future liens, encumbrances, etc., are not to be noted on the Title Register, but are subject to the ordinary provisions of the law on the subject of filing, docketing, etc.

$\S 237$. Same Continued-Benefits of Registration Endure-Last Certificate as a Source of Title.-However, the owner, by freeing the land from registration, does not lose the benefits which the past registration has conferred. The certificate of title or the owner's certificate issued on the transfer by which the land is freed from future registration stands as conclusive evidence of the title therein declared, to the same extent as if it were a grant from the State. ${ }^{1}$ A chain of title may spring from it, as from the State's grant. When the owner sells and deeds the land his vendee can, in any court, prove complete title by introducing in evidence the certificate of title or the owner's certificate and the deed from the owner; and subsequent holders, throughout a line of holders, howsoever long, will find it a legally sufficient source from which to deraign their title.

However, if the title of the owner at the time it is freed from registration is encumbered by liens, encumbrances or other adverse claims, these are not affected by the owner's act in freeing the land from registration; all transactions, voluntary or involuntary, duly registered on the certificate of title up to that time, continue to operate as notice, to the full extent as "if they were recorded, filed or entered in any clerk's office," and to the full extent that they would if the land were still registered. ${ }^{2}$

\section{$\S$ 238. Unanimous Action of Cotenants Required to} Free Land from Registration.-Just as it takes the unanimous consent of all the tenants in common to subject land to registration when the fee simple is held in undivided interests, ${ }^{1}$

[§ 237] 1. T. $\S 246$.

2. See A. $\$ \S 39,40$.

[§ 238] 1. See T. §25. 
likewise it takes the unanimous consent of all the owners of the fee to free it from registration if the certificate of title stands undividedly in the name of more than one person, as joint or common owners of the fee simple. No certificate of title can be issued to any one "his heirs and assigns, free from further registration," on a partial transfer. 
CHAPTER XV.

\section{Registration as Evidence.}

§ 239. Certified Copy of Certificate of Title-Conclusive and Exclusive Evidence-Owner's Certificate.

§ 240. Duplicate Owner's Certificate-When Admissible.

$\S 241$. Certified Copy of Certificate of Title or Any Entry Thereon, How Obtained-Canceled 'Certificate-Canceled' Entries.

$\S 242$. Where Plat or Other Detail Is Contained in Outside Record.

\$ 243. Certified Copy of Decree of Title as Evidence.

$\S$ 244. Proof of Registered Mortgages, Creditor's Certificates and Transfers.

$\S 245$. No Aliunde Proof of Notice-Rule, That Possession Is Notice, Abolished.

§ 246. Last Certificate of Title and Owner's Certificate Where Land Has Been Freed from Registration-Same Evidentiary Rank as Grant from the State.

$\S$ 247. Certified Copy from the File of Registration Papers.

$\S$ 239. Certified Copy of Certificate of Title-Conclusive and Exclusive Evidence-Owner's Certificate.Whenever in the course of any judicial inquiry the question of the title to registered land is involved, the highest and best evidence-indeed the conclusive and exclusive evidence is a certified copy of the certificate of title. ${ }^{1}$ However, an owner's certificate is, in practical and legal effect, a certified copy of the certificate of title as of the date of its issue, and if it bear an entry of "Valid with all entries noted" under Section 118 of the Act, it has that effect of the date of such entry. ${ }^{2}$ However, in the absence of such an entry as of the date to which the inquiry as to the title relates, the owner's certificate would not -be admissible in evidence, since the court could not legally be informed that it was in truth and in fact a full and complete copy of the certificate of title as of that date.

Generally in actions by the owner the date of filing of the suit is the time to which the inquiry as to title relates; and in

1. A. $\S 73 ;$ T. $\S 226$.

2. A. $\S 118 ;$ T. $\S 227$. 
such cases the owner's certificate with an entry of "Valid with all entries noted," put upon it by the clerk as of that date, would be appropriate evidence. However, it frequently happens that it is material to inquire into the state of a title as of some other date than that on which the suit was filed, and usually in such cases it will be necessary to use certified copy from the Title Register.

$\S$ 240. Duplicate Owner's Certificate-When Admissible.-Provision is made in Section 58 of the Act by which a duplicate owner's certificate may be issued if the original is lost or destroyed. 1 It is also provided that the duplicate so issued shall "take the place of the original owner's certificate." Hence, such a duplicate would be admissible in evidence to the same extent as the original owner's certificate would have been.

$\S 241$. Certified Copy of Certificate of Title or Any Entry Thereon, How Obtained-Canceled CertificatesCanceled Entries.-Ample provision is made for the procurement of a certified copy of any certificate of title, as of any date, whether cancelled or uncancelled, or of any entry thereon, by Section 101 of the Act as follows: "The clerk shall upon the request of any person, and the payment of lawful fees, issue a certified copy of any certificate of title or of any entry thereon, in like manner as he may issue certified copies of any other public record in his office, but whenever he so does he should plainly mark in large legible letters across the face of the certificate the word, "Copy." If certified copy of a cancelled certificate or entry shall be made, in addition to transcribing a copy of the entry of cancellation, the clerk shall also plainly mark the words, "Cancelled certificate," or, "Cancelled entry," as the case may be, across the face of the copy."

$\S$ 242. Where Plat or Other Detail Is Contained in Outside Record.-Where, by reason of the necessity of copying a plat, lengthy description or some other document of special terms on some public record other than the certificate of title, the entry on the certificate of title does not fully state the

1. See T. $\S 135$. 
transaction but makes reference to some other book or record for particulars, such outside book or record, so far as the particular matter recorded thereon is concerned, becomes a part of the title register and of the certificate of title to which it relates. ${ }^{1}$ Therefore, unless the matter copied on the outside record relates to some phase of the title not involved in the controversy, a certified copy of the outside record should also accompany the owner's certificate or certified copy of the certificate of title when it is offered in evidence.

$\S 243$. Certified Copy of Decree of Title as Evidence. -If the validity or extent of any lien, encumbrance, or special right which was involved in the proceedings for initial registration becomes subsequently in controversy between the initial registrant, or his privies, and the person in whose favor such lien, encumbrance or special right was asserted at the time of the initial registration, or his privies, a certified copy of the decree or title is conclusive evidence on that subject. ${ }^{1}$

$\S$ 244. Proof of Registered Mortgages, Creditor's Certificate and Transfers.-In case it is necessary to prove a transfer or a transfer as security for debt or a mortgage which has been registered, if the same shall have been executed in the standard short form prescribed in the Act, a certified copy of the entry of registration, as Section 38 of the Act provides, "shall be admissible in evidence on like terms and with like effect as a certified copy of a deed, mortgage or other similar instrument is admissible under existing laws." Since the original of these instruments becomes, after registration, a part of the files of the clerk's office and are not in private custody, the effect of this provision is to make the certified copy of the entry primary evidence. Of course the creditor's certificate itself is also primary evidence until it shall have been surrendered and cancelled and thus become a matter of file in the clerk's office.

However, in case of a mortgage, the clerk is authorized to deliver to the mortgagee a certified copy of it, "and such certified copy shall stand for all purposes in lieu of the original and

[§ 242] 1. A. $\S \S 38,102-4$.

[§ 243] 1. A. $\S 27 ;$ T. $\S \S 117,230$. 
shall be original evidence to the same extent that an original mortgage is, in any court." 1

Where instruments of transfer, or of transfer to secure debt, or of mortgage, are not executed in the standard short form, the clerk records the instrument and returns the original to the proper holder. In such cases the instrument itself is the primary evidence, and certified copy from the record only secondary.

It should be kept in mind, however, that except in the case of mortgages, recourse to the provisions of this section of the Act so far as relates to methods of proof, will be of rare occasion. The certificate of title which is registered on the transfer, and not the transfer itself, is the proper evidence of the title of the transferee. Hence, it is not likely that many cases will arise in which the factum of the transfer will be involved, so as to make the instrument of transfer or a copy of it or of the entry of it on the register material.

$\S 245$. No Aliunde Proof of Notice-Rule, That Possession Is Notice, Abolished.-The notation or entry registered on the certificate of title of any lien, encumbrance or other matter adverse to the owner's title being the only kind of notice capable of affecting those dealing with the title, ${ }^{1}$ no aliunde proof of notice, actual or constructive, is admissible. Proof that the notation or entry has been registered may be made either through a certified copy of the entry or by showing the owner's certificate with it noted thereon.

It may be appropriate to call attention to the fact that Section 66 of the Act, as well as the general scheme of the registration system, has repealed, so far as registered lands are concerned, Section 4528 of the Civil Code which provides that, "Possession of land is notice of whatever right or title the occupant has." 2

$\S$ 246. Last Certificate of Title and Owner's Certifcate Where Land Has Been Freed from RegistrationSame Evidentiary Rank as Grant from State.--If land has

[§ 244] 1. A. $\S 38$.

[§ 245] 1. A. § 73; T. § 174.

2. See. T. $\S 232$. 
once been registered and afterwards freed from registration, neither party in any subsequent action involving the title to the land can go back of the last certificate of title in order to prove or to disprove title. Either the certificate of title (that is to say, so far as use in court is concerned, a certified copy of the certificate of title) or the owner's duplicate issued on the last transfer and in the name of the owner "his heirs and assigns, free from further registration," under Section 65 of the Act, stands "as a conclusive source of subsequent title to the same extent as if it were a grant from the State" 1-that is to say, it takes the place of the "old original beeswax," to borrow from the local vernacular an expression quite familiar to landowners in most parts of Georgia.

Since no further entries or notations can be made on the certificate of title after the land has been freed from registration, it and the owner's certificate will thereafter remain identical; hence, in this case, the owner's certificate has the same probative force as a certified copy of the certificate of title.

\section{$\S 247$. Certified Copy from the File of Registration} Papers.-All of the papers relating to every registered tract become a part of the files in the office of the clerk of the superior court, ${ }^{1}$ and certified copies thereof may be used, whenever relevant, in like manner as certified copies may be used from any other court file.

[§ 246] 1. T. $\S 237$.

[§ 247] 1. A. § 119; T. § 272. 


\section{CHAPTER XVI.}

\section{The Assurance Fund.}

§ 248. Assurance Fund Not an Essential Feature of Land Registration.

§ 249. Assurance Fund, How Created and Invested-Who Liable For Assessment-Cross-Petitioners.

$\S 250$. Who May Have Recourse on the Assurance Fund-Generally.

$\S$ 251. Same Continued-Detailed Discussion.

$\S 252$. Limitation of Actions against the Fund-Disabilities.

$\S 253$. Measure of Damage.

$\S$ 254. No Action against Fund for Injury Caused by Breach of Trust.

§ 255. Defendants in Actions against the Fund-Attorney-General's Duties.

§ 256. Other Remedies to Be Exhausted-Subrogation in Favor of the Fund.

$\S$ 257. Suit against Assurance Fund a Cumulative Remedy.

$\S$ 248. Assurance Fund Not an Essential Feature of Land Registration.-The Act, Sections 74 to 81 inclusive, provides for an assurance fund for the benefit of certain innocent persons who may suffer loss through the natural operations of the Act. It may be well enough to state in the outset that the limitations of the Act are such as that it is almost practically impossible for a claimant to reach this fund. ${ }^{1}$

Furthermore it should be kept in mind that the providing of an assurance fund for the compensation of those who have been injured by the natural operations of the Act is not an essential feature of a land registration system. There would be no constitutional objection to the Act even if such a fund were not

1. It is stated that in only one American case has an action against the fund been successful. This is the case of Shevlin-Matheiu L. Co. v. Fogarty, 130 Minn, 456, 153 N. W. 871, wherein the registered land had never been granted by the United States, hence not subject to registration. The case is also a very instructive case on the subject of the reliance which may be put upon the effectiveness of registration and the completeness of the assurance that it gives. 
provided for. It is manifestly inserted out of a solicitude that no irreparable wrong shall flow to any one from certain features of the Act which are supposed to be drastic.

To elucidate the proposition that the assurance feature of the Act is not essential to its constitutionality, attention is called to the fact that a person sometimes loses valuable rights through the operation of the rule, prevailing in ordinary cases, that judgment by default may be taken where no answer is filed, even though service of the process is made on the defendant only by leaving copy at his most notorious place of abode and though he fails to receive notice of the suit until after judgment had been rendered and his day in court is gone. The legislature might, to ameliorate the hardship that arises from the natural operation of the general law in such cases, provide an assurance fund; but it has not done so, and the law which gives conclusive effect to the judgment in those cases is none the less valid because of the omission to provide such a fund.

$\S$ 249. Assurance Fund, How Created and InvestedWho Liable for the Assessment-Cross Petitioners.-The assurance fund provided for under the Act is to be created by requiring each registrant, at the time of the original registration, to pay to the clerk one-tenth of one per cent. of the value of the land registered, as determined by the court; the clerk being required, in turn, to forward the sum to the State Treasurer, to be kept in a special fund known as the "Land Registration Assurance Fund." 1 The assessment to be made to create this fund is payable only in the event of the land being admitted to registration; hence, it is not payable if the petition is dismissed. If a cross-petitioner succeeds in obtaining a decree in his favor he is the one to pay the amount. If there is a severance, it is to be assessed severally; each owner paying in ratio to the value of the land he succeeds in registering.

The assurance fund is to be invested in certain designated classes of securities. Any excess in it, after paying such judgments, if any, as may be rendered against it, is to accumulate until the amount of five hundred thousand dollars is reached.

1. A. $\$ \$ 74$ and 75 . 
Any excess beyond that sum become a part of the general fund in the State treasury. ${ }^{2}$

If at any time the assurance fund is insufficient to satisfy all judgments rendered against it, the judgments bear interest and are to be paid in order of rendition out of any amounts thereafter coming into the fund. ${ }^{3}$

\section{$\S 250$. Who May Have Recourse on the Assurance} Fund-Generally.-The Act provides in Section 77 that "Any person entitled to notice and who had no actual notice of any registration under this Act by which he may be deprived of any estate or interest in land, and who is without remedy thereunder, may within two years next after the time at which the right to bring such action shall have first accrued to him, or to some person through whom he claims, bring an action of assumpsit against the Treasurer of the State in the superior court in the county where such land is located for the recovery, out of the assurance fund, of any damage to which he may be entitled by reason of said deprivation . . . If any person entitled to bring such action be under the disability of infancy, insanity, imprisonment or absence from the State in the service of the State or of the United States at the time the right to bring such action first accrued, the same may be brought by him or his privies within two years after the removal of such disability, but, provided, nevertheless, that all persons non-resident of the State, all persons who are described in the proceedings as being unknown, or of unknown address, or as to whom it appears from the record that they could not be found so as to be served, shall be considered as having had actual notice where notice has been published in accordance with the provisions of this Act."

This should be construed in connection with the provisions of Section 27 of the Act which provides: "Every decree rendered, as herein provided, shall bind the land and bar all persons claiming title thereto or interest therein, quiet the title thereto, and shall be forever binding and conclusive upon and against all persons, including the State of Georgia, whether

2. A. \& 76 .

3. A. $\S 81$. 
mentioned by name in the order of publication, or included under the general description, 'whom it may concern.' It shall not be an exception to such conclusiveness that the person is an infant, lunatic, or is under any disability, but such person may, in the manner provided, have recourse upon the indemnity fund hereinafter provided for, for any loss he may suffer by reason of being so concluded."

$\S$ 251. Same Continued-Detailed Discussion.-While it is not altogether clear what classes of injured persons are to have recourse on the insurance fund, still certain deductions are to be made from the language employed.

The first thing that must appear to bring a person within the category of those who are protected by this fund is that he is a "person entitled to notice". of the registration of which he complains. Who are entitled to notice in the case of any particular registration depends on the nature of the transaction and upon whether the Act has provided for notice, and to whom, in connection with transactions of that nature.

Next it must appear that the alleged injured person "had no actual notice." Mere lack of service is not sufficient. No matter how the actual notice was acquired, if it was acquired, that is sufficient to prevent recourse on the assurance fund. Furthermore, the words, "had no actual notice," must be construed in connection with the provision of Section 14 of the Act that, "the notices provided for and to be given under this and all other sections of this Act shall stand as personal service of process ;" 1 and, of course, a person who has had personal service of process has, in legal contemplation, had actual notice. To elucidate this a little further, it is called to the attention that in several places in the Act service by methods other than personal service (for example, service by leaving at one's most notorious place of abode or service on the agent of a corporation or on the attorney appointed by a non-resident under Section 7 of the Act) are provided for, or may be provided for by the judge under Section 72 of the Act. All such service operates, under Section 14 of the Act, to give what is to be considered as

1. See T. $\S 74$. 
actual notice. The Act expressly provides that non-residents, unknown claimants and claimants whose addresses are unknown so that they cannot be found and served may be served by publication; and Section 77 of the Act expressly states that all such are to be considered as having had actual notice.

The words "any registration under the Act," appearing in Section 77 of the Act, are broad enough to include subsequent as well as original registration. However, since the Act calls for notice in subsequent registration only as to cases in which the judge orders a registration under Section 50 or 60 or some cognate section of the Act, most cases of voluntary transactions are excluded.

The injury must consist of some person having been "deprived of some estate or interest in land." Hence, one who has lost the lien of a judgment or has suffered similar injury as to something which does not give an estate or interest in the land itself, is given no remedy against the assurance fund. The holder of a creditor's certificate has, however, such estate or interest in the land itself and, therefore, may be a claimant against the assurance fund.

It is not clear whether the concluding sentence in Section 27 intends to give a remedy to infants, lunatics and other persons under disability, without respect to the conditions prescribed in Section 77 , or not.

The language of Section 77 does not seem to be broad enough to include the case of one who has lost his title by reason of a forged voluntary transfer having been registered in favor of an innocent purchaser. ${ }^{2}$ This omission should address itself to the attention of the General Assembly in order that an amendment to the Act may be made to cover it; for it would seem fair to give such an injured person recourse upon the fund.

The phrase, "and who is without remedy hereunder," appearing in Section 77 of the Act, standing alone, would seem to exclude those who had a remedy against the sheriff or the clerk for making a false return, but study of the further provisions relating to actions against the assurance fund will disclose that

2. See T. $\S \S 213-5$. 
it is not so to be construed; because Sections 78 and 79 of the Act clearly contemplate that there may be actions in which these officers may also be joined as defendants. The proper construction of the language under consideration would therefore seem to be the same as if the words "and who is without remedy hereunder or who has pursued the remedies saved to him without obtaining relief" had been used.

Personal representatives and privies of a person entitled to recourse on the fund succeed to the right of action, subject to the statute of limitation set out in Section 77 of the Act.

$\S$ 252. Limitation of Actions against the Fund-Disabilities.-A statute of limitations of two years from the "time at which the right to bring such action shall have first accrued" is set by Section 77 of the Act. If one sues as a personal representative or privy the action must be brought within the time within which the "person through whom he claims" might have brought it. In case of persons under the disability of infancy, insanity, imprisonment or absence from the State in the service of the State or of the United States "at the time the right to bring such action first accrued" the period of the duration of such disability is added to the two years of the normal limitation. The running of the statute is not suspended by disabilities occurring after it has once commenced to run.

$\S$ 253. Measure of Damage.-The measure of damage in any action against the assurance fund is prescribed in Section 77 of the Act as "the value of the property at the time the right to bring such action first accrued." Hence if the bringing of the action is delayed no interest accrues on the cause of action in the meantime. Under Section 81 of the Act, a judgment certified against the assurance fund and unpaid for lack of funds bears interest at the normal rate, which in this state is seven per cent., until it is reached in order for payment.

\section{$\S$ 254. No Action against Fund For Injury Caused by} Breach of Trust.-No remedy is given against the fund in favor of one whose injury is caused through a breach of trust on the part of any registered owner. On this subject the language 
of Section 80 of the Act is explicit in declaring that "the assurance fund shall not, under any circumstances, be liable for any loss, damage or deprivation occasioned by a breach of trust. whether express, implied or constructive, on part of the registered owner of any state or interest in the land." This therefore excludes any action against the fund based on the ground that an executor, administrator, widow under year's support, or other trustee, express or implied, in whom a registered right may stand, has dealt with the land in violation of the trust. It also prevents recourse on the fund for the destruction of secret equities.

$\S 255$. Defendants in Actions against the Fund-Attorney-General's Duties.-It is provided in Section 78 of the Act: "If such action be brought to recover for loss or damage arising only through the legal operation of this Act, then the Treasurer of the State shall be the sole defendant. But if such action be brought to recover for loss or damage arising on account of any registration made or procured through fraud, neglect or wrongful act of any person not exercising judicial function, then both the Treasurer of the State and such person or persons shall be made parties defendant." This clearly not only allows, but requires the plaintiff to join in the action against the State Treasurer, as the official representative of the assurance fund, all other persons, if any, private or official, ('except the judge or the examiner in the exercise of their respective judicial functions) through whose fraud, neglect or wrongful act the injury arose. Of course, if by reason of absence from the State or other legal cause, any of these parties cannot be served, the plaintiff, upon the fact being made to appear to the court, may proceed without them under the general practice rules on that subject.

It is provided in Section 77 of the Act that the Attorney-General shall represent the interests of the assurance fund in the case in the court below and on appeal.

§ 256. Other Remedies to Be Exhausted-Subrogation in Favor of the Fund.-The Act contemplates that the assurance fund shall not be touched if the plaintiff can make his 
money out of any other person or officer, and that if the judgment is paid out of the assurance fund the State Treasurer, as the official representative of that fund, shall be subrogated to the rights of the plaintiff as against such other persons. Hence it is provided in Section 79 of the Act that "If judgment be rendered for the plaintiff in any such action, execution shall issue against the defendant, if any, other than the Treasurer of the State. And if such execution be returned unsatisfied in whole or in part, or if there be no such defendant, then the clerk of the court in which the judgment was rendered shall certify to the Treasurer the amount due on account thereof, and the same shall then be paid by said Treasurer out of the assurance fund under the special appropriation hereby made of said fund for that purpose. Any person other than the Treasurer of the State against whom any such judgment may have been rendered shall remain liable therefor, or for so much thereof as may be paid out of the assurance fund, and said treasurer may bring suit at any time to enforce the lien of said judgment against such person or his estate for the recovery of the amount, with interest, paid out of the assurance fund as aforesaid."

It would seem to follow as the result of the language of this section that if the defendant other than the State Treasurer be an officer who is under official bond, the plaintiff may proceed against the bond, but if he fails to do so and the State Treasurer pays off the judgment he may do so.

\section{$\S$ 257. Suit against Assurance Fund a Cumulative} Remedy.-If any person has suffered loss as a result of the fraud or negligence of any person or as the result of any official wrongful act of omission or commission on the part of any bonded officer, in relation to transactions concerning registered land, whether he is in a position to go upon the assurance fund or not, he still has his remedy against such person or officer and the sureties on the official bond of the officer, at any time in the ordinary period of the statute of limitations; for it is provided in Section 84 of the Act that "neither the limitations provided by this Act within which proceedings hereunder may be brought, nor the provisions setting times whereupon matters and things 
may become conclusive, shall prevent any injured party from having an action at law against any person or officer through whose fraud or negligence he may have suffered any loss or damage arising out of any acts of omission or of commission of such person or officer in connection with the matters and things arising from the provisions of this Act, but all such actions shall be governed by the statutes of limitations which would otherwise relate to the transaction."

The statute of limitations against private persons in such cases is ordinarily four years, but against officials and the sureties on their official bonds is twenty years, provided the bond be under seal, as it usually is. ${ }^{1}$

1. Harris v. Black, 143 Ga. 497 (5), 85 S. E. 742; Slaton v. Morrison, $144 \mathrm{Ga} .471,87$ S. E. 390. 


\section{CHAPTER XVII.}

\section{OfFEnses.}

§ 258. Detailed Statement of Offenses.

$\S$ 258. Detailed Statement of Offenses.-The following offenses are created by Section 85 of the Act, and each is made a felony, punishable by imprisonment in the penitentiary for not less than one or more than ten years, but may be reduced to misdemeanors, in the matter of punishment, under the provisions of Section 1062 of the Penal Code, to-wit:-

ON THE PART OF ANY PERSON :-

Fraudulently to obtain a decree of registration of title to any land or interest therein;

Fraudulently to attempt to obtain such decree;

Knowingly to offer in evidence any forged or fraudulent document in the course of any proceeding in regard to registered land or any interest therein. This applies not only to initial proceedings but also to proceedings in connection with subsequent registration.

To make or utter any forged instrument of transfer;

To make or utter any forged instrument of mortgage;

To make or utter any other paper, writing or document used in connection with any of the proceedings required for the registration of land, or for the notation of entries upon the Title Register;

To steal any owner's certificate, creditor's certificate or other certificate of title provided for under the Act;

Fraudulently to secrete any of the certificates just mentioned;

Fraudulently to alter, change or mutilate any writing, instrument, document or record or registration or register provided for under the Act;

To make any false oath or affidavit in respect of any matter or thing provided for in the Act; 
To make any counterfeit of any certificate provided for in the Act;

Knowingly to use any counterfeit of any such certificate.

ON THE PART OF ANY CLERK, DEPUTY CLERK, SPECIAL CLERK, OR ANY PERSON PERFORMING THE DUTIES OF THE CLERK :- 1

Fraudulently to enter a decree of registration without authority of the court;

Fraudulently to register any title. This applies to subsequent as well as to original registration.

Fraudulently to make any notation or entry on the Title Register;

Fraudulently to issue any certificate of title or creditor's certificate or any other instrument provided for by the Act;

Knowingly, intentionally and fraudulently to do any act of omission or of commission, under color of his office, in relation to the matters provided for in the Act. ${ }^{2}$

In addition to the other penalty prescribed by the Act any clerk, deputy clerk, special clerk or any person performing the duties of the clerk shall, upon conviction of any of the offenses named be removed from office and forever disqualified from holding any public office.

ON THE PART OF ANY EXAMINER OF TITLE:-

Knowingly and fraudulently to make any false report to the court as to any matter relating to any title which it is sought to register under the provisions of the Act, or as to any matter affecting the same, or as to any other matter referred to him under any of the provisions of the Act;

Fraudulently to conspire or confederate with any other person or persons to use the provisions of the Act to the defrauding of any person or persons, firm or corporation;

To be guilty of any willful malpractice in his office.

1. As to who are included in this category see $A . \S \S 3,69,83$ and T. $\S \S 267-8$.

2. As to fraudulently attesting acknowledgment of service see $T$. 68 . 
ON THE PART OF ANY SHERIFF, DEPUTY-SHERIFF, OR OTHER PERSON PERFORMING THE DUTIES OF THE OFFICE OF SHERIFF :-

Knowingly and fraudulently to make any false entry or return in connection with any matter, arising under the provisions of the Act;

Fraudulently to conspire with any person or persons to defraud any other person or persons through the provisions of the Act.

In addition to the other penalty provided for by the Act, any such offending sheriff, deputy-sheriff or other person performing the duties of the office of sheriff shall on conviction of any of the offenses mentioned be removed from office and thereafter forever disqualified from holding any public office in this State. 


\section{CHAPTER XVIII.}

\section{Costs of OfFicers.}

$\S$ 259. Clerk's Fees and Costs.

$\S$ 260. Examiner's Fees.

$\S$ 261. Sheriff's Fees.

$\S 262$. Services Not Expressly Provided For.

$\S$ 263. Deposit For Costs.

$\S$ 264. Costs, How Taxed.

§ 259. Clerk's Fees and Costs.-Under Section 120 of the Act, the fees and costs of the clerk are fixed as follows:-

For all services in initial registration from the time of filing the petition up to and including the registration and issue of the first certificate and owner's certificate registered on a decree of title, four dollars and postage, unless separate decrees are rendered, when he shall get one dollar extra for each additional decree and the registering and issuing of the first certificate thereon. In contested cases three dollars additional may be taxed as costs. It is contemplated that this shall cover everything, except those things for which additional compensation is prescribed in the Act itself. These are the $\$ 1.00$ allowed under Section 102 of the Act for making certified copy of plat and attaching it to the owner's certificate; the 10 cents per hundred words allowed by Section 104 of the Act for making, certifying and attaching to an owner's certificate or creditor's certificate a copy of the record, when by reason of length of description or some detail it is necessary to make a reference from the certificate of title to some other record. The original copying of the plat or the description or detail on the record if it be a part of initial registration, is included in the $\$ 4.00$. The costs and fees mentioned in this paragraph do not cover any services rendered in connection with the appellate proceedings in the event the case or any part of it is taken to the Supreme Court. In the case of a severance being ordered by the court the clerk is 
entitled to the above costs in each case into which the original action is severed. ${ }^{1}$

For registering a transfer and registering thereon certificate of title and issuing new owner's certificate and making all necessary cancellations in connection therewith, full service, one dollar. While the Act is not entirely clear on the subject it would seem to be a fair construction of this language to say that in cases of transfer when more than one new certificate of title and owner's certificate is to be issued, as in cases under Section 31 of the Act when there is a partial transfer of a divided portion of the land, the clerk gets one dollar for each of the new certificates of title issued.

For issuing a duplicate certificate in lieu of lost certificate, fifty cents. This does not include any costs of the proceeding to establish the lost certificate.

For issuing a certified copy of certificate of title and entries thereon, one dollar.

For noting a judgment or other lien (not including mortgages) on the Title Register, fifteen cents.

For certifying an owner's certificate, under Section 118, as "valid with all entries noted to date," twenty-five cents.

For the notation or registration of any mortgage or other voluntary transaction executed in the standard short form prescribed in the Act and not otherwise provided for, including every act necessary therefor, and in case of creditor's certificate, including the issuance of the creditor's certificate, seventy-five cents.

For each entry of cancellation, twenty-five cents.

For other notations and entries, fifty cents.

In case further record of an instrument is required on account of its form, as in case of instruments of transfer, transfer to secure debt, mortgages, etc., not executed in the standard short form and recorded in some other book in accordance with the provisions of Section 38 of the Act, ten cents per hundred words for the recording, in addition to the other fees prescribed above.

1. T. § 106 . 
In cases of involuntary transactions, caveats, etc., referred to the court for action, the clerk is allowed in addition to the above fees ten cents per hundred words for recording the proceedings on the minutes of the court, and fifty cents for each judgment rendered therein. It is assumed that it is not intended that the clerk shall get this additional compensation when the clerk himself asks the direction of the court, under Section 59 of the Act, because of his doubt as to how a matter should be entered, unless some contest arises over the matter so that the judge is called on to render a formal judgment.

In any matter carried to the Supreme Court or to the Court of Appeals, either in relation to the initial or any subsequent registration, the clerk collects, in addition to the costs and fees specified above, for his services rendered in connection with the appellate proceedings the same costs and fees as he does in other cases carried to the Supreme Court.

The clerk should not forget to collect also at the time of the initial registration the one-tenth of one per cent. of the value of the land which he is required immediately to transmit to the State Treasurer for the assurance fund. The clerk is required to keep these assurance fund fees in a separate account and not to mix them with other funds. ${ }^{2}$

§ 260. Examiner's Fees.-The fees payable to the examiner of title are fixed by Section 120 of the Act as follows:

For examining a title and making report to the court one dollar per thousand (or fraction thereof) on the value of the land, as determined by the court (but not to exceed a maximum of one hundred dollars) and postage, and ten dollars. For example if the land is worth $\$ 5000$, he gets $\$ 15$ and postage.

In contested cases, for hearing the case and making report to the court, the judge may in his discretion allow additional compensation, but in an amount not exceeding the same fee as that allowed an auditor for reporting his findings in equity cases under Civil Code, Section 5148. He shall not be paid extra for reporting the evidence, but when a stenographer is used by

2. A. $\S \S 74-5 ;$ T. $\S 249$. 
consent of the parties or order of the judge the stenographer shall be paid his usual fee. ${ }^{1}$

In case of a severance being ordered by the court the examiner would be entitled to the extra ten dollars in each of the actions into which the original action is severed. ${ }^{2}$

$\S 261$. Sheriff's Fees.-The fees allowed to the sheriff under Section 120 of the Act are as follows:

For ascertaining and reporting to the court the names and addresses of the persons actually occupying the premises described in the petition, as required in Section 14 of the Act, one dollar.

For posting copy of the petition upon the premises, as required in Section 14 of the Act, fifty cents.

If the petition includes more than one tract the above fees are payable for each tract, since the services required are to be separately performed for each tract, though all be included in a single petition.

For each service of process and notice required, one dollar.

$\S$ 262. Services Not Expressly Provided For.-For any other services required of the clerk, sheriff or surveyor, not specially provided for in the Act, the court is required to fix the fee, under the direction given in Section 120 of the Act, that the fee shall be fixed in conformity with what is usual and lawful for similar services rendered by such officers in ordinary cases.

$\S$ 263. Deposit For Costs.-It is required by Section 120 of the Act that with each application for initial registrations the applicant shall deposit with the clerk the sum of twenty dollars to guarantee costs; and the court may from time to time require the deposit to be increased. Of course, any overplus after the costs are paid is to be returned to the owner. The clerk is not required to enter any notation, entry or registration (initial or subsequent) until all the costs or fees due in connection therewith by the person desiring the notation are paid in full. Under Section 52 of the Act, when a judge orders an

1. See A. $\S 71 ;$ T. $\S 93$.

2. See T. \& 106 . 
owner's certificate to be cancelled by publication the costs of making the advertisement must be deposited with the clerk before the judge grants the order of transfer. ${ }^{1}$

$\S$ 264. Costs-How Taxed.-Authority is conferred on the judge by Section 120 of the Act to award the costs, in all contested cases and in all matters referred to the judge for direction under any of the provisions of the Act, accordingly as in his discretion the justice of the case may dictate, and to that end he may assess all the costs against one of the parties or may divide it among the parties in such ratio as seems just. ${ }^{1}$

[§ 263] 1. See T. $\S 169$.

[§264] 1. See T. $\S 52$ as to taxing costs against one intervening captiously in a proceeding to register land. 


\section{CHAPTER XIX.}

\section{Misceilaneous.}

\$265. Courts Always Open.

$\$$ 266. Judges in Convention to Make Rules.

$\S$ 267. Who Acts Where Clerk Is Disqualified, Dead or Cannot Act.

$\S$ 268. Deputies-Powers of.

$\S 269$. Duty of Clerk to Guard against Improper Registration-Liability of Clerk.

$\S 270$. Clerk's Duties Purely Ministerial-Suggestions to the Clerk.

$\$ 271$. Books and Filing Cases to Be Provided.

$\S$ 272. Method of Filing Papers Relating to Registered Land.

$\S 273$. All Entries to Be Dated to the Minute.

$\S 274$. Power of the Attorney-General as Ex-Officio Supervisor of County Records.

$\S$ 275. Extraordinary Cases.

$\S 265$. Courts Always Open.-While if jury trial should become necessary ${ }^{1}$ in connection with some proceeding for land registration, it might be necessary to hold some such proceeding in abeyance till the court opened in regular sessions and the juries were empaneled; still the superior courts are deemed to be perpetually in session for purposes of land registration. Section 67 of the Act provides on this subject: "For the purposes of this Act, ${ }^{2}$ the superior courts of the various counties of this State shall be considered as being open and in session at all times, except on Sundays; and every official act of the judge on any matter shall be considered as having been rendered in open court; and no recess or adjournment of the court taken generally or for any other particular purpose shall be considered as having recessed or adjourned the court so far as the purposes of this Act are concerned; and any limitations existing, either under general law or special acts as to the length of time in which the various superior courts of this State may sit in the various counties shall not be construed as affecting the provisions of this Act."

1. T. $\S \S 97-8$.

2. Applies to transactions subsequent to initial registration. 
As to what judges may hold the court, and perform the duties imposed on the judge by the Act, see the definition of the word "judge" in Section 3 of the Act and in Section 21, ante.

$\S 266$. Judges in Convention to Make Rules.-It is provided in Section 70 of the Act that "the judges of the superior courts in convention may from time to time make general rules and forms for procedure relating to the subjects in this Act dealt with, and may modify the forms herein prescribed, but such rules and forms shall be uniform throughout the State, and shall be subject to the provisions of this Act and the general laws of this State."

This power, thus conferred on the judges in convention, will enable them to perfect the precedural phases of the Act in the event practice under it develops the need of other or further provisions in this respect. ${ }^{1}$ This power may be valuably exercised in the outlining of procedure in connection with those matters which are to be presented to the judge for the exercise of his summary jurisdiction as general supervisor of the registry.

\section{$\S$ 267. Who Acts Where Clerk Is Disqualified, Dead,} or Cannot Act.-Complete provision is made for some one to act in the event the clerk is disqualified, dead or otherwise unable to perform any of the duties required by the Act. Section 69 of the Act is as follows: "In case any clerk is disqualified by reason of relationship or interest, or from any other cause, or in case of the death or other disability of the clerk of the superior court to act in any manner arising under this Act, the duties required of such clerk may be performed either by the ordinary of the county or by a special clerk appointed by the judge for that purpose, the entry of appointment of such special clerk and of the purpose for which he is appointed being duly entered and recorded upon the minutes of the court."

This corresponds to the definition of the word "clerk" as given in Section 3 of the Act; except that Section 3 of the Act relieves all doubt as to whether persons filling the office of

1. A suggestion is made as to a proper use for the exercise of this power in T. $\S 150$. 
clerk in the emergencies provided for in Sections 4881-4888 of the Civil Code are to be considered as clerks for the purposes of the Act.

$\S$ 268. Deputies-Powers of.-Under Section 83 of the Act deputy clerks and deputy-sheriffs are empowered to perform any duty required, under the Act, of their respective principals. ${ }^{1}$

$\S$ 269. Duty of Clerk to Guard against Improper Registration-Liability of Clerk.-It is provided in Section 106 of the Act that "The clerk shall first satisfy himself before registering any voluntary transfer that the same is witnessed and attested or acknowledged in accordance with law; and he and the sureties on his bond are liable for any loss or damage occasioned to any person through the registration of a transfer not so executed."

This is a safeguard against forgery which must not be relaxed by the clerks. 1

It is also provided in Section 59 of the Act that the clerk "is charged with the primary duty of determining whether anyinstrument, writing or record or other matter is in proper shape for registration, and with the duty of correctly and legally making the registration, ${ }^{2}$ including all formal incidents thereto, and shall be liable to any injured person for any failure of duty in this respect."

\section{$\S$ 270. Clerk's Duties Purely Ministerial-Suggestions} to Clerk.-The Clerk should also keep in mind that the Act nowhere confers on him the power to pass on any contested matter; his duties are purely and exclusively ministerial. The Act contemplates that the judge shall decide all controversies that may arise; and that, as to any such controverted matter, the clerk shall merely register the result declared by the judge.

The framers of the Act were very careful not to confer ju-

[§ 268] 1. They are likewise criminally responsible. See T. $\S 258$.

[§ 269] 1. See T. $\S 215$.

2. As to precaution to be taken in case of voluntary transactions by corporations, see T. $\S 164$. 
dicial powers on the clerk. Therefore, if a matter is presented, which requires the clerk to decide upon its legal effect, otherwise than to determine that it is properly attested or that it is in the form prescribed by the Act, he may know at once that he ought not to register it without a judge's order. 1 . If the owner of the certificate executes a voluntary transfer or mortgage or any other voluntary transaction (excepting transactions between husband and wife ${ }^{2}$ and transfers by persons holding title in trust or with unusual limitations or with powers ${ }^{3}$ ) and the owner's certificate is presented to the clerk along with the transaction, the clerk performs only a ministerial act in registering that which the owner voluntarily asks as to his own property; hence, such registrations may be made without the judge's order.

Likewise when some third person desires a mere entry made which does not interfere with the ownership, but which he wishes made in order to give notice of some lien, encumbrance or other right he claims, for instance the notation of a judgment, mechanic's lien, notice of pendency of a suit or similar matter, the clerk merely enters the matter for what it may afterwards prove to be worth, and, hence. he may register such a matter without the judge's order, because he does not have to decide any controversy as to the validity of the thing claimed.

The clerk should never cancel a certificate or register a transfer unless he has the authority of one or the other of two persons, namely: (1) the owner, as expressed by his duly attested signature accompanied by the owner's certificate; or, (2) the judge, as expressed by his formal order.

Furthermore, the standard forms prescribed in the Act and the blanks on the Title Register are designed to work in connection with each other; and, if the clerk cannot readily and without difficulty complete the registration on the Title Register from the information contained in the form, this should be to him a red flag, warning him to stop and to examine the transaction carefully to see if he has the authority to register it without the order of the judge. If, after such careful examination, he

1. Compare T. $\S 228$.

2. See A. $\S 48 ;$ T. $\S 201$.

3. See A. $\S 56 ;$ T. $\S 204$. 
still has doubts or difficulties he should seek the advice of the judge under the provisions of Section 59 of the Act.

When the clerk defers a registration, because he is in doubt as to how it should be entered and desires the instructions of the judge, as he is authorized to do under Section 59 of the Act, he should be careful to protect the person seeking the registration against some subsequent transaction being registered ahead of the one being held up for the judge's direction. Ordinarily this can best be done by a temporary memorandum being made on the certificate of title, under the head of "Special Notations and Entries," stating the nature of the transaction held up, and the fact that it has been presented to the judge for direction; canceling the memorandum when the direction of the judge is obtained.

$\S 271$. Books and Filing Cases to Be Provided.-The county commissioners or other officer or tribunal having county matters in charge in each county of the state are required to provide the clerk with the necessary books and files. The books, which must be furnished by Jan. 1, 1918, and which are to be replaced in kind from time to time as they are filled, are the Register of Decrees of Title $^{1}$ and the Title Register. ${ }^{2}$ As to filing cabinets it is provided in Section 119 of the Act as follows: "The county commissioners or other officer in each county having in charge county business shall furnish the clerk with the necessary durable filing cases and he shall carefully number and file away all papers relating to registered lands and dealing therewith. All the papers relating to each registered title shall be filed together and separately from the papers relating to any other registered title. They shall be filed away in such regular consecutive numerical arrangement as to make them easily accessible at all times. ${ }^{3}$ Vertical filing is recommended."

$\S$ 272. Method of Filing Papers Relating to Registered Land.-After completing the initial registration and the issu-

1. A. $\S 28 ;$ T. $\S 119$.

2. A. $\$ 28 ;$ T. $\S 124$.

3. As to the right to use certified copy from the files, see $T$. $\$ 247$. 
ance of the owner's certificate, the clerk should carefully collect all the papers in the case (all the pleadings, evidence of service, publication, etc., the auditor's reports, all the orders, judgments, etc.) and number them with the registered title number (not the certificate number) of the decree to which they relate, and file them away in the durable file which Section 119 of the Act requires the county authorities of each county to furnish. The papers relating to each registered title are to be filed together and separately (that is to say, in separate folder or package) from the papers relating to any other registered title; and they are to be filed away in such regular consecutive numerical arrangement as to make them easily accessible at all times; vertical filing being recommended. ${ }^{1}$

When two or more separate decrees have been rendered on the same application, the petition and papers which commonly relate to all the decrees should be filed in the filing cover or space devoted to the first decree rendered on the application, but these papers and the file or cover should also have endorsed on them a reference to the numbers of all the decrees to which they relate; and in the file cover bearing the number of each additional decree, there should be placed a reference sheet showing the filing number of the decree, under which the papers can be found in the file.

If a severance has been ordered in the course of a proceeding, the papers subsequent to the severance should be filed under the decree number to which the severed portion relates, with crossreferences to the original papers.

To illustrate, suppose that John Jones files an application to register lots 11,12 and 13 in the 1 st district, asking separate decrees to each lot, and, during the proceedings, some one files a defense or cross-petition as to lot 13 only, and a severance is ordered as to that lot. The separate decrees are entered; the decree covering lot 11 being, say No. 101; the decree covering lot 12 being No. 102; and the decree covering lot 13 being No. 103. The clerk will file the petition and the rest of the record, except that relating to lot 13 , after the severance, under the

1. A. $\$ 119$. 
number 101, with cross-reference to decrees No. 102 and No. 103; will place in the file numbered 103 all the papers relating to lot 13 after the severance, with cross-reference to decree No. 101 ; and will file the decree as to lot 12 under the number 102 with cross reference to decree No. 101.

§ 273. All Entries to Be Dated to the Minute.-The ordinary rule that the law knows no fractions of a day does not obtain as to land registration. Section 29 of the Act provides: "Every entry made in the Register of Decrees of Title, or in the Title Register or upon the owner's certificate under any of the provisions of this Act, shall be signed by the clerk and dated with the year, month, day, hour and minute, accurately stated."

\section{$\S$ 274. Powers of the Attorney-General as Ex-Officio} Supervisor of County Records.-The Act, approved Aug. 8, 1916, ${ }^{1}$ making the Attorney-General ex-officio supervisor of county officers and county records does not interfere in anywise with the supervisory powers of the judge under the Land Registration Act; the functions of the judge and of the Attorney General are separate and yet coordinate. The judge's supervision relates to the substance of the registration records; the Attorney General's to the form. It is very important not only that the books used in land registration be properly prepared, but also that they be neatly and correctly kept, even from the formal standpoint; hence, the Act of 1916 is a valuable adjunct to the Land Registration Act.

$\S 275$. Extraordinary Cases.-In the nature of things, there will arise in the course of time extraordinary situations, for which the Act has made no explicit provision. Human foresight cannot make specific provision against every possible contingency or exigency; some things must be left to be dealt with as they arise. However, the Act proposes a complete system and what is not specially provided for is to be dealt with in accordance with the spirit of the Act as gathered from its general provisions and purposes.

To illustrate, if the extraordinary matter relates to the suit

1. Ga. Laws, 1916, p. 142 . 
by which the title is to be settled for the purposes of initial registration, it should be kept in mind that, as to this feature of the Act, the propositions which stand in boldest outline and evince most strongly the purposes of the Act in this respect are, that notice of the proceedings shall be as full and complete as it is possible for the practical operations of ordinary jurisprudence to make it; that all known residents of the State, of known address, are to be served as in ordinary actions, ${ }^{1}$ and that nonresidents and unknown persons, and persons of unknown address are to be served by publication, ${ }^{2}$ and by mailing of notice when practicable; that the ordinary rules of equity pleading apply, ${ }^{3}$ and that there is to be no judgment by default 4 admitting a title to registration.

As to subsequent registration, the cardinal provisions are, that every matter affecting the title or asserted as an adverse claim against it must be noted on the certificate of title in the Title Register, ${ }^{5}$ that the clerk's power over the register is purely ministerial, 6 but that the judge's power is broad and supervisory; and that it is plenary. ${ }^{7}$

An extraordinary situation might arise by the blank space left on the Title Register for the registration of certain transactions proving inadequate to contain all the entries necessary to be made in some particular case. The clerk would have no jurisdiction to remedy such a situation; the judge would. Hence it would be the duty of the clerk to bring the matter to the attention of the judge, and the duty of the judge to give the necessary instructions.

Such an exigency might be dealt with in a variety of ways. Probably the most feasible way ordinarily would be for the judge to instruct the clerk to adopt some subsequent sheet in his register as a part of the certificate of title involved, and to enter

1. A. $\S 10 ;$ T. $\S 63$.

2. A. $\S \S 10,14$, T. $\S 64$.

3. A. $\S 5 ;$ T. $\S 22$.

4. A. $\S 21 ; T . \S 102$.

5. A. $\S \S 40,51,63,73$; T. $\S \S 138,165,173,174,176,178,205,220$ et seq., 245 .

6. A. $\S 59 ;$ T. $\S \S 228,270$.

7. A. $\S \S 56,60 ;$ T. $\S \S 182-3,185,228-9$. 
the overflow of entries there, making such cross-references, back and forth from page to page of the register, as to give plain and unmistakable information on both the original certificate and on the supplementary page that each is incomplete in itself but is a part of the whole represented by the certificate and the supplement.

Such an exigency may sometimes be met by outside recordation, ${ }^{8}$ with reference entry; but in many cases especially where the over-crowding comes from the excessive number of liens, encumbrances and other similar matters to be noted, this will not be deemed to be the advisable method of handling the transaction.

To repeat: The clerk has no power to vary the ordinary course to meet an unusual exigency; but the judge has the full power to provide for every situation that may arise.

8. A. $\S \S 38,103$; T. $\S \S 126,129,242$. 

The Land Registration Act 


\section{Special Notice.}

Throughout the foot-notes, annotations and index, in order to prevent confusion between references to sections of the text and to sections of the Land Registration Act, the following abbreviations have been adopted: "A. §-," meaning the designated section of the Act, and "T. §-," meaning the designated section of the text. 


\section{The Land Registration Act}

\section{Prefatory Statement.}

The Land Registration Act of the State of Georgia was prepared by a commission of three, appointed under a joint resolution of the General Assembly in 1914. Most of the labors of this commission took place in the summer of 1915 and culminated in the preparation of a bill which was introduced in the General Assembly of that year, but which did not pass, owing to its being crowded off the calendar by other matters. It was reintroduced at the 1917 session and passed just as it had been drawn by the commission with only one minor amendment in Section 77.

The copy of the Act which has been included in this book has been carefully compared with the enrolled Act in the office of the Secretary of State, and corresponds with it. It is thought that the report of the commission which drew the bill may prove of sufficient historic interest to justify its inclusion in this work. It is as follows:

\section{Report of the Commission Appointed under Joint Reso- lution of the General Assembly to Recommend a System of Land Registration.}

The Commission was appointed under a joint resolution of the General Assembly, approved August 14th, 1914. (See Acts 1914, p. 1248.)

The first meeting of the Commission was held in May [1915]. A number of subsequent meetings were held. The Commission invited an expression of views from those interested pro and con and a number of prominent citizens appeared and made talks on the various phases of the subject. A number of others furnished useful papers. Mr. Barfield, one of the present representatives from Bibb County, and Hon. T. S. Felder, former Attorney-General, both of whom had devoted considerable study 
to the subject, gave valuable assistance to the Commission. As guides, we had before us the land registration Acts of a number of the States, as well as what is known as the "American Uniform Land Registration Act," which was presented at the 1914 Annual Conference of Commissioners on Uniform State Laws.

The subject of land titles is one that commands almost universal attention and interest. Land is the most valuable commodity of any State. Title to land should be the surest and safest of all investments; but practical experience has demonstrated that, under our present laws on the subject, this is not the case.

The ownership of land should be a sure and easy basis of credit; but, owing to our present method of dealing with land titles, the borrowing of money on land is a slow and expensive process.

Every doubt as to title makes land less valuable. The necessity of investigating and reinvestigating the title from time to time, as it is sold or given as security, detracts from its choiceness as an investment. Too frequent have been the cases where men have invested savings of years in lands and lost them through some unsuspected defect of title.

The prime object of the Commission's investigation, therefore, has been to devise a method of making titles safer.

Many States have deemed the element of safety so important that they have enacted, and put into effect, systems that are very cumbersome and expensive in their operations. The Commission has put much thought upon the planning of a system which will be neither cumbersome nor unduly expensive, and still will make titles safe and keep them safe. It hopes that it has done so, and a proposed bill is presented as a part of this report. Its general outlines have been borrowed from the laws in force in the various States and from the provisions of the American Uniform Land Registration Act; but many modifications have been made in order to adapt it to our local laws and conditions.

The general outlines of a land registration system readily present themselves to the minds of most lawyers and of those business men who have had experience in land transactions. First, there should be a proceeding by which the claimant to the 
land gives notice to the world that he claims the land and calls upon all persons to show cause why his title should not be confirmed; followed by the judgment of a competent court, confirming his title as against every other claimant. Then there must be some system by which the title thus confirmed may be transferred and otherwise dealt with in the course of years, so that each subsequent holder, and every other person acquiring an interest therein, may hold with like security. This involves a continuous and permanent system of registration.

Easy as it is to organize in one's mind the general plan of such a system, the outlining of details through which the system must work is fraught at every point with difficulties, both practical and constitutional.

For example, the proceedings by which the title is to be originally confirmed must be such as to guard carefully against the opportunity of the system's being used by dishonest persons as a means of stealing the lands of others. This is a practical question. No decree or judgment can be rendered, so as to bind the world unless such legal notice is given as will afford any and all persons an opportunity to be heard. This is a constitutional question. It is the consensus of all legislative opinion on the subject, as expressed in the Acts of the various States, that some provision by way of an insurance fund should be made to compensate those who, by the operation of the system, have lost lands or some interest therein, without fault or negligence on their part; and when such a fund is provided for, it is to the interest of the State to see that the law on the subject affords little or no opportunity for such a case arising. This is a financial question. It is believed that the proposed bill herewith submitted has so safeguarded the original proceedings to confirm and register a title as to leave but little opportunity for "land larceny," as to meet all constitutional requirements, and as to reduce the probability of recourse on the insurance fund to a minimum.

The system proposed in the bill herewith presented forces no man to register his land; it is purely voluntary. Any landowner may avail himself of the benefits of the sustem; no landowner is required to do so. 
Most States provide that when once land is placed under registration it shall permanently remain so, and that all subsequent sales, etc., must, likewise, be registered. The Commission thought it wise to provide, in the present bill, for a means by which a registered title might be freed at the instance of any subsequent owner, from requirements of registration. The chief reason for this provision is that every restraint upon alienation tends to diminish, what might be called, the sale-value of land. It will likely be a long time before all people will prefer registered to unregistered land. This may be folly, but it is that form of folly which determines choice; and every man is free to choose whether he will buy registered or unregistered land. If there were no provision for freeing registered land from registration, the registered landowner, wishing to sell his land, would find himself confined as to prospective buyers to those who wish to own registered lands. Under the present proposed bill the registered landowner may offer it to both classes of buyers; for, if he meets with a prospective buyer who does not wish to own registered land, he merely goes through a short, inexpensive process, and the land is free from subsequent registration requirements; but even then the advantages of the previous registration are not lost, for even though a title be freed from subsequent registration, the prior registration is conclusive evidence that the last registered owner was the true owner, so that every subsequent purchaser is relieved from tracing the abstract further back.

Furthermore, landowners, not being familiar with land registration, would hesitate to register their land if, when once put under registration it could never be freed therefrom, while they would be much more willing to try the experiment, knowing that if it did not work satisfactorily the land could be placed again under the old system.

The methods by which transactions in registered land subsequent to the initial registration are dealt with vary in the different States, but the same general principles underly them all. All the systems provide for a public record on which every title brought under the Act is registered in the name of some owner. The owner is given a certificate showing that he is the 
owner, and showing what encumbrances, if any, are on the land. If the owner wishes to sell the land, he merely transfers the certificate and the person to whom he transfers it goes to the court-house and causes the land to be registered in his name, and the old certificate is surrendered and a new certificate is issued to the purchaser. Certificates for registered lands are as negotiable as bank stock or other legal securities. They may be transferred in whole or in part as security for debt. The holder of a certificate for a tract of land who wishes to borrow money on it can take it to the bank and transfer it in blank and attach it to his note as collateral security, as if it were a share of stock or a negotiable bond. Or he may keep the certificate and give his creditor a mortgage on it; the mortgage being noted in the certificate and on the title register.

The advantage of being able to handle lands in this fluid manner is almost beyond the comprehension of most of us, who have been accustomed to the old awkward way of handling similar transactions.

It is the experience of most States adopting land registration systems that the people are slow at first in taking advantage of the system. This is largely due to that skepticism of the untried and the unfamiliar which pervades all human nature. But a study of the Acts of the various States has convinced the commission that there is an additional reason; the Acts are not simple enough to be understood except by those of technical legal training. Many of these Acts are models of conciseness; but they are not explicit enough; those who drew them sacrificed clearness for the sake of brevity. An Act dealing with so technical, intricate and important a subject as land titles should be drawn, of course, in most carefully chosen language. Every word must be studied with its ultimate legal effect in view. Still, when one of the objects of the Act is to outline a new and unfamiliar procedure on an important subject, it should enter enough into descriptive details to enable those who are to work under it readily to know just what to do in each case and how to do it.

The transactions which are likely to arise in the life of a land title are multiform. In the history of a land title we find it af- 
fected by deaths, marriages, trusts, disabilities, by odd and unusual provisions inserted by the whim of some eccentric owner, by debts, liens, encumbrances, tax sales and what not. A system which does not provide for all these things and provide for them in an understandable way is not likely to work smoothly in its earlier days.

Reference to these things has been made to explain why the proposed bill herewith submitted is so long. An examination of the proposed bill will show that, after dealing in a somewhat technical way with the various matters of substantive law and procedure, the bill goes on to describe, in detail, just how each transaction is to be handled. A large part of the bill is taken up in prescribing forms. In the first place, these forms being prescribed will tend to make the operations of the Act uniform throughout the State; but there is the further advantage that they will show to the officers charged with the administration of the Act and to the members of the legal profession and to the public just how everything is to be done.

While at first blush the system here proposed may seem intricate, still it is the belief of the Commission that a full and careful reading of the entire bill will show that it is very simple.

It is intended to provide:

(1) A cheap, but thorough and comprehensive, procedure by which any one who really owns a tract of land may have his title confirmed and established by a decree which will stand in any court just as if it were the State's plat and grant issued to him, and at the same time will make it exeremely difficult for one who is not the true owner to register, and thereby steal some one else's land.

(2) A system of so registering the title that everything connected with it or affecting it in any way, such as mortgages, liens, homesteads, encumbrances and like matters will appear on a single page.

(3) Ownership of land by a certificate, which is conclusive as to the ownership, but which shows on its face all encumbrances put on the land by the owner, and which, by being taken to the 
clerk's office at any time and stamped with a single entry, will show that there are no judgments or encumbrancs against the land, other than those shown on the face of the certificate.

(4) A method by which land can be transferred almost as simply as ordinary commericial paper and by which it can be used as collateral with as great facility as if it were a stock or bond of equal value.

(5) A system which, while it does not altogether free the title from those troublesome and ofttimes expensive proceedings which are brought about by the death of an owner or other involuntary transmissions, simplifies these matters and provides a sure way of ascertaining at all times who is the true owner, notwithstanding the entanglements that may have occurred.

(6) A system that is simple, though comprehensive.

(7) A system that is purely voluntary.

Robert N. Holtzclaw, Perty, Ga.

S. M. Turner, Quitman, Ga.

Arthur G. Powell, Atlanta, Ga.

Commissioners. 
An Act to Provide for the Assurance, Registration and Transfer of Land Titles, and Interests Therein, and for Other Purposes.

Be it enacted by the General Assembly of Georgia, and it is enacted by authority of the same:

$\S$ 1. Official Designation of the Act.-This Act shall be known as "The Land Registration Act," and may be cited or referred to by that name.

$\S 2$. Venue and Jurisdiction of Proceedings.-For the purpose of enabling all persons owning real estate within this State to have the title thereto settled and registered, as prescribed by the provisions of this Act, the superior court of the county in which the land lies shall have exclusive original jurisdiction of all petitions and proceedings had thereupon.

Cited in T. $\S 16$ on the point that the Act provides a judicial system of land registration, in contradistinction to the original Torrens system and the systems based thereon.

Compare the definition of the word "court" in A. § 3 and in T. § 21 .

§ 3. Definitions.-As used in this Act, the following words shall have the following meanings, unless the context plainly indicates otherwise : ${ }^{1}$

The words "registered land" shall include any estate or interest in lands which shall have been registered under the provisions of this Act.

The words "the court" shall mean the superior court of the county wherein the land lies. ${ }^{2}$

The word "clerk" shall mean the clerk of the superior court of the county wherein the land lies, and shall include his lawful deputies, ${ }^{3}$ and any person lawfully acting as clerk under the provisions of the general laws of this State, or of this Act.4

The words "judge" or "judge of the court" or "judge of the superior court" or "judge of the superior court of the county where the land lies," or words of similar purport, shall be held and construed to mean, embrace and include any judge of the superior courts of this State presiding in the superior court of 
the county where the land lies; and, while it is intended that, as a usual matter, the judge of the superior courts of each circuit shall be the judge who shall act upon and sit in the various matters arising in that circuit with which the judges of such courts are charged under the provisions of this Act, still as to such matters any judge of the superior court shall have jurisdiction to perform the functions of judge under this Act; and in the event that the judge of the superior courts of the circuit in which the transaction or matter arises is disqualified, absent from the circuit, ill, dead, or from any other cause cannot act in the matter, it shall be the duty of any other judge of the superior court of the State, to whom the matter is presented, to act in the matter to the same extent as if the same arose in one of the counties of his own circuit; and, furthermore, any judge of the superior court may in any matter arising under this Act, upon the request of the judge of the superior court of the circuit in which it arose, act upon it as if it arose in its own circuit.

The words "voluntary transaction" shall be construed to embrace and mean all contractual and other voluntary acts or dealings (except by will) by any registered owner of any estate or interest in land with reference to such estate or interest ${ }^{-}$ and any right of homestead or exemption ${ }^{6}$ therein; and the words "involuntary transaction" 7 shall be construed to embrance and mean all other transmission of registered land or any interest therein ${ }^{8}$ and all other rights or claims, ${ }^{9}$ judicial proceedings, ${ }^{10}$ liens, charges or encumbrances not created directly by contract with the registered owner, but arising by operation of law or of equitable principles, ${ }^{11}$ dower, ${ }^{12}$ the exercise of the right of eminent domain, ${ }^{13}$ delinquent taxes and levies, ${ }^{14}$ and all like matters affecting registered land or any interest therein. ${ }^{15}$

1. Discussed in T. $\S 21$.

2. Cited in T. $\S 23$ on the question of venue as fixed in A. $\S 5$.

3. Special clerk where clerk is disqualified, A. $\S 69$, T. $\S 267$.

4. Power of deputy- or special clerk to attest acknowledgment of service, T. $\S 68$.

5. Voluntary total transfers, A. $\S 30 ;$ T. $\S 147$. See also T. $\S 139$ et seq.

Voluntary partial transfers, A. § $31 ;$ T. $\S \S 148-151$. 
Voluntary transfers to secure debt, A. $\S 32,36 ;$ T. $\$ \S 152-8$.

Forms for voluntary transfers, A. $\S 107$.

Owner's certificate must accompany all registrations of voluntary transactions, A. $\S \S 37,117$; T. $\S \S 140,270$.

Voluntary transactions between husband and wife, A. $\S 48 ;$ T. $\S$ 201.

Voluntary cancellations, A. $\S \S 62,115 ;$ T. $\S \S 142,159,180$.

Voluntary transfer to free land from registration, A. $\S 65 ;$ T. $\S \S$ 234-8.

Clerk's duty to verify attestation of voluntary transfers, A. $\S 106$; T. $\S \S 215,269$.

Mortgages, A. § 38; T. §§ 161-2; form A. § 111.

Voluntary transfer by those holding title in trust, or on conditions or unusual limitations or with power to sell or encumber, A. §56; T. § 204 .

Volunary transactions not otherwise provided for, how registered, A. $\S 117$; T. $\S 150$.

Voluntary transactions by corporations, T. $\$ 164$.

Guardian's sale, not a voluntary transaction, T. $\S 200$.

Sale by widow under year's support, T. $\S 209$.

6. Homestead, how registered and sold, T. § 210.

7. Subject of involuntary transactions treated generally, T. $\S \S 165-$ 187.

8. No involuntary transfer to be registered without order of judge, A. $\S 41$; T. $\S 144$.

Method of procuring judge's order, A. \&50; T. § 168.

Cancellation of owner's certificate on involuntary transfer being ordered, A. § 52; T. $\S \S 169,172$.

Refusal of co-owner in possession of certificate to surrender it on transfer of divided interest, T. $\S 149$.

Transmission on death of owner, A. $\$ \S 42-47$; T. $\$ \S 188-199$.

Guardian's sale, as an involuntary transfer, T. $\S 200$.

Duty of clerk in registering involuntary transfers, T. § 171.

9. Adverse rights and claims, how noted, and effect of noting them. A. $\S \S 51,73$; T. $\S \S 145,173,176,229,230$, Form A. $\S 114$.

10. Involuntary transfer as result of judicial proceedings, A. $\S 49$; T. $\S \S 205-6,208$.

Title by year's support, T. $\$ 209$.

11. Judgments, how noted on register, A. § 54; T. $\S \S 173-4$; Form for A. \& 113.

Other adverse transactions, permission to note, necessity and effect of noting. A. $\S \S 51,61$; T. $\S \S 173-6$. General discussion of, $T$. $\S \S 145-6$. Form for noting, A. $\S 114$.

Registration exclusive method of giving notice of liens and adverse claims, A. $\S \S 40,73 ;$ T. $\S 245$.

12. Right of dower, how affected by registration, $T$. $\S 190$. 
13. Condemnation proceedings how made effective against registered lands, T. $\S 202$.

14. Taxes and assessments, necessity for noting on register, and method of notation, A. $\S 57$; T. $\S \S 177,186$, Form, A. $\S 112$.

15. Adverse entries how removed from register, A. $\S 60 ;$ T. $\S \S 179$, $182,186$.

Notation of all registered liens, encumbrances and other adverse claims to be brought forward on each successive issue of the certificate of title, till cancelled, A. $\S \S 39,100 ;$ T. $\S 187$.

General Note-For other definitions, see T. $\S 21$.

$\S$ 4. The Nature of the Proceedings-In Rem-Binding on the World.-The proceedings under any petition for the registration of land, and all proceedings in the court in relation to registered land ${ }^{1}$ shall be proceedings in rem against the land, ${ }^{2}$ and the decree of the court shall operate directly on the land, and vest and establish title thereto in accordance with the provisions of this Act, as well as upon all persons who are parties to said proceedings, whether by name or under the general designation of "whom it may concern."

1. It is to be noticed that this clause makes proceedings subsequent to registration proceedings of the character mentioned in this section. See T. $\S 167$. This is effectuated through A. § 64 making the obtaining of a decree of registration a covenant running with the land. See T. $\$ \S 20,117,136$.

2. It would be more accurate to say "substantially in rem." See T. $\S \S 19,22$.

As to the seizure in rem, A. $\S 14 ; \mathrm{T} . \S \S 71-3$.

General Note-Section discussed, T. $\$ 22$.

Relation between the provisions of the Act as to service of process, the publication of notice and the seizure of the land and the object of the suit as stated in this section, discussed, T. $\S 61$.

Effect of this section on the conclusiveness of the decree, A. $\$ 27$, T. $\$ 11 \%$.

All persons including "Whom it may concern" to be named as defendants, A. $\S 9$, T. $\S 49$. Process and service accordingly, A. $\S$ i0; T. $\$ \S 62,64$.

$\S$ 5. Petition for Initial Registration-Who May FileEquity Pleading and Practice Applies.-Suit for registration of title shall be begun by a petition ${ }^{1}$ to the court ${ }^{2}$ by the person or persons or corporations ${ }^{3}$ claiming, singly or collectively, ${ }^{4}$ to own, ${ }^{5}$ or to have the power of appointing or dispos- 
ing of $\dot{\boldsymbol{\theta}}$ an estate in fee simple $\boldsymbol{T}$ in any land, whether subject to liens, encumbrances or lesser estates or not. ${ }^{8}$ Infants and other persons, under disability, may sue and defend by guardian, guardian ad litem, next friend, or trustee, as the case may be. ${ }^{9}$ Except as otherwise provided, the suit shall be subject to the general rules of equity pleading and practice. ${ }^{10}$

1. As to the form and substance of the petition, see A. $\S 7$ and annotations thereunder.

Method of filing and docketing the petition, T. § 24.

2. This means the superior court of the county where the land lies, thus fixing the venue of the suit, A. $\S 3$; T. $\S \S 21,23$.

3. Corporations and unincorporated associations as petitioners, $T$. \& 28.

4. Rule that all tenants in common must join in the petition, and effect of non-joinder, T. $\S \S 25,105$.

5. Who are owners,-legal owners, equitable owners-discussion, T. § 26. Allegation of ownership, A. § 86, par. 8; T. § 38.

6. Discussed, T. $\S 27$.

7. Conditional and defeasible fees are included, T. $\S 25$.

8. Discussed, T. § 25.

9. Discussed, T. $\S 29$.

10. Equitable jurisprudence is not adopted by this provision, $T$. $\S 22$.

Amendments allowable as in equity practice, T. $\S 57$. Compare $\mathrm{A}$. \&24.

Provision referred to in connection with discussion of the powers of the court to adjust the provisions of the Act to the exigencies of any extraordinary situation arising in the course of proceedings for initial registration, T. $\S 275$.

$\S$ 6. Establishing Estate Less Than Fee.-Any person in the possession of lands within the State, claiming an interest or estate less than the fee therein, may have his title thereto established under the provisions of this Act, without the registration and transfer features herein provided.

For discussion of this section see T. $\S 30$.

Right to amend and ask for judgment establishing lesser estate where petitioner fails to prove ownership of the fee, T. $\S 104$.

No decree of tiitle to be awarded such a petitioner; only a judgment on the minutes, T. $\S 116$.

Suggestion as to form of petition in such cases, T. $\S 31$. 


\section{§ 7. Petitions - Contents - Verification - General} Details-Survey.-The petition, ${ }^{1}$ and any amendment thereto, ${ }^{2}$ shall be signed and sworn to ${ }^{3}$ by each petitioner, or in the case of a corporation, by some officer thereof, or in the case of a person under disability, by the person filing the petition. It shall contain a full description of the land ${ }^{4}$ and its valuation and its last assessment for county taxation; ; shall show when, how, and from whom it was acquired, ${ }^{6}$ a description of the title by which he claims the land, ${ }^{7}$ and an abstract of title, ${ }^{8}$ and shall state whether or not it is occupied ${ }^{9}$ and shall give an account of all known liens, interests, and claims, adverse or otherwise, vested or contingent. ${ }^{10}$ Full names and addresses, if known, of all persons that may be interested in any wise, ${ }^{11}$ including adjoining owners and occupants, ${ }^{12}$ shall be given. A non-resident petitioner shall appoint a resident agent or attorney upon whom process and notices may be served. ${ }^{13}$ The description of the premises to be given in the petition shall be in such terms as shall identify the same fully, and shall be such a description as shall tend to describe the same as permanently as is reasonably practicable under the circumstances. If it be in a portion of the State in which the land is by State survey divided into land districts and lot numbers, in the petition there shall be stated the number of the land district and of the lot number or numbers in which the tract is contained. The judge, on his own motion, or upon recommendation of the examiner, may, before passing a decree upon any petition for registration, require a fuller and more adequate description, or one tending more permanently to identify the tract in question, to be included into the petition by amendment, ${ }^{14}$ and if, in the discrefion of the court, it shall be necessary, may, for that purpose, require a survey of the premises to be made and the boundaries marked by permanent memorials.15 The acreage or other superficial contents of the tract shall be stated with approximate accuracy, and where reasonably practicable the court may require the metes and bounds to be stated.

1. For the form prescribed, see $A$. $\S 86$; for suggestions as to preparation of the same, T. $\S \S 32-51$.

2. Amendments how far allowable, A. § 24; $T$ §§ 57-9. 
3. Form of verification, A. $\S 86$. See also T. $\S \S 51,57$.

4. Accurate and permanent description required, A. $\S 86$ par. 5; T. $\S 34$.

Necessity for same as affecting decree of title, T. $\$ 109$.

5. A. $\S 86$, par. 6 and 7 ; T. $\S 37$.

6. A. $\S 86$, par. $10 ;$ T. $\S 39$.

7. A. $\S 86$, par. 11 and 12 ; T. $\S \S 40-1$.

8. A. $\S 86$, par. $13 ;$ T. $\S 50$.

9. A. $\S 86$. par. $16-18$; T. $\S \S 43-4$.

10. A. $\S 86$. par. $19,20,22$; T. $\S 44$.

Failure to list known adverse claimants as fraud for which registration may be set aside, T. $\S 219$.

11. Easements, A. $\S 86$, par. 22, T. $\S 46$.

12. A. $\S 86$, par. 21 ; T. $\S 45$.

13. A. $\S 86$, par. 4 ; T. $\S 33$.

14. A. $\S 24$; T. $\S \S 86,89$.

15. A. $\S 22 ;$ T. $\S 100$.

General Note-As to who may file petitions, see A. $\S 5$ and the annotations thereunder.

As to the right to include more than one tract or to divide a tract into parcels for registration, see $A . \S 8$ and annotations thereunder.

Sections 7 and 86 of the Act are cognate, and are to be construed together, T. $\S 31$.

As to what rights, liens and easements are to be omitted from the petition, see A. $\S 63$, T. $\S 220$, et seq.

$\S$ 8. Registering Separate Tracts in Same PetitionSingle Tract Divided into Parcels.-Any number of separate parcels of land, claimed by the petitioner under the same general claim of title, ${ }^{1}$ and lying in the same county, may be included in the same proceeding, and any one tract may be established in several parts, ${ }^{2}$ each of which shall be clearly and accurately described and registered separately. ${ }^{3}$

1. Discussed, T. $\S 35$.

As to duty of the court to order a severance when it appears that the tracts are not held under some general claim of title, see T. $\S 106$; also T. $\S 58$.

2. Discussed, T. $\S 36$. Advantages of dividing into separate parcels, T. $\S 107$.

3. Discussed, T. $\S \S ~ 106-7$.

$\S$ 9. Defendants.-The petition shall include as defendants all persons who, by the petition, are disclosed to have any 
lien, interest, equity or claim adverse to the petitioner or otherwise, vested or contingent, upon said land or any interest therein ${ }^{1}$ and shall also include as defendants all other persons "whom it may concern." 2

1. Discussed, T. $\S 49$.

Husband or wife, to be named as defendant, T. $\S 48$.

Fraud in failure to name known adverse claimant as defendant, T. $\S 219$.

2. A. $\S 86$, par. 26. Compare A. $\S \S 4$ and 27.

$\S$ 10. Process-Service-Notice by Publication-Mailing Notice-Guardian ad Litem.-Upon such petition being filed in the office of the clerk of the superior court, in the county where the land lies, the clerk shall issue a process ${ }^{1} \mathrm{di}-$ rected to the sheriffs of this State and their lawful deputies, requiring all of the defendants named in the petition, ${ }^{2}$ and all other persons "whom it may concern" to show cause before the court on a named day not less than forty or more than fifty days from the date thereof, why the prayers of the petition should not be granted, and why the court should not proceed to judgment in such cause; and shall make the necessary copies of the petition and process for service. Within thirty days from the time of the issuance of process, a copy of the petition and process shall be served, in like manner as ordinary process is served in ordinary actions at law, upon each party named as defendant in the original petition, if a resident of this State. ${ }^{3}$ Second original and copies may issue and be served in like manner as second originals are issued and copies served in ordinary actions. 4 The clerk of the superior court shall also cause to be inserted in the newspaper in which the advertisements of sheriff's sales in the county are advertised for four insertions in separate weeks, a notice 5 addressed "to whom it may concern," and also to each person named in the petition as a defendant who resides beyond the limits of the State, or whose place of residence is unknown, and giving notice of the filing of the petition by the petitioner, and a description of the land which petitioner seeks to register, and warning them to show cause to the contrary, if any they can before the 
court on the date named in the process. The judge of the court may grant additional time for service or return of the process, and may provide for scrvice in cases not herein provided for wherever the exigencies of justice may so require. ${ }^{6}$ Wherever the petition discloses, or it otherwise becomes disclosed to the court in the progress of the proceedings ${ }^{7}$ that any non-resident is interested, such non-resident, if his post office address be known, shall be notified also by the clerk of the court mailing to him a copy of the petition and process by registered mail to the post office address as the same may be disclosed to the court through the petition or other proceedings in the case. ${ }^{8}$ Guardians ad litem shall be appointed for infants and other persons under disability, in like manner as they are appointed in equity cases in the general practice in this State. ${ }^{9}$

1. Form of process, A. $\S 87$. How prepared, T. $\S 62$.

2. A. $\S 86$, par. 26 ; T. $\S \S 48-9$.

3. T. $\S 63$.

4. T. $\$ 63$.

5. Form of notice, A. $\S 88$. Discussed, T. $\S 64$.

6. Judge's power as to prescribing mode of giving additional notice, A. $\S 72 ;$ T. $\S 65$.

7. Disclosure of additional defendants through examiner's report, A. $\S 17 ;$ T. $\S 75$.

8. The sending of this notice is not jurisdictional, T. $\S 64$.

9. Discussed, T. § 70 .

General Note-As to service on a few as representatives of a class, T. $\S 66$.

Relation of the methods of service to the constitutionality of the Act, T. § 19 .

$\S 11$. Service on State, County or Municipality.-If the petition discloses that it involves the determination of any public right or interest of this State, or of any county or municipality thereof, the process or notice, in order to affect the State or the county or the municipality, shall be served upon the Attorney-General, in the case of the State; upon the ordinary, in the case of a county (or, if the ordinary be disqualified, upon the clerk of the superior court); or upon the mayor of the municipality, in the case of a municipality (or, in case there is no mayor or the mayor is disqualified, upon a majority of the members of the council or other governing body of the municipality). 
For discussion of this section, see T. $\S 67$.

As to the necessity of naming state, county or municipality as defendant where there are liens for delinquent taxes, T. $\S 44$.

$\S$ 12. Waiver of Service or Notice.-Any person entitled to notice or service of process under this Act may waive such notice or service by a written acknowledgment of service, or waiver of service, ${ }^{1}$ entered upon the petition or entitled in the cause and signed by him in the presence of the judge of the superior court or of the clerk of the superior court of the county, ${ }^{2}$ or the examiner, his signature being attested by such officer.

1. Form of acknowledgment of service, A. $\$ 89$.

2. As to power of deputy clerk or special clerk to attest, A. $\S \S 3,69,83 ;$ T. $\S \S 68,267-8$.

General Note-General discussion of this section, T. $\S 68$.

No traverse of the acknowledgment, A. § 13; T. § 74 .

\section{$\S$ 13. No Traverse of Entry of Service-Action against} Offending Officer.-The court, before passing the decree authorizing the registration of land, shall first satisfy himself that publication of notice and service of process, as herein required, have been made. ${ }^{1}$ After judgment ${ }^{2}$ the entry of service by the sheriff or his deputy shall be conclusive evidence and shall not be subject to traverse, nor shall any acknowledgment of service be subject to traverse. The recital of service of process and of the giving and publishing of notices, contained in the decree ${ }^{3}$ or final judgment in the cause, shall be conclusive evidence that such service, publication and notice have been legally given; provided, however, that nothing herein shall prevent any person aggrieved from having his right of action against any sheriff who makes a false return of service, or against any clerk or examiner who falsely attests a waiver or acknowledgment of service, or any clerk who fails to publish the notice or to mail the notices as required by this Act.

1. Discussion, T. $\S \S 74,101$.

2. How far return of service is subject to traverse before judgment, T. $\S 73$.

3. See recital in form of decree in A. $\S 97$. 
$\S$ 14. Posting Notice on the Land-Listing Occupants - Notice to Occupants-Waiver by Appearance or Pleading.-A notice similar to the notice directed to be published, as provided in the tenth section of this Act, ${ }^{1}$ shall also be delivered by the clerk to the sheriff of the county, or one of his lawful deputies, and the sheriff or his lawful deputy, shall, within thirty days from the date the petition is filed, post the same upon the land in some conspicuous place; and if there be more than one tract of land enough notices shall be furnished by the clerk to the sheriff or his deputies, and he shall post the same upon each tract of land included in the petition. ${ }^{2}$ The sheriff shall also, within said thirty days, go upon the land and ascertain and make official return ${ }^{3}$ to the court, stating the names of each and every person above the age of fourteen years actually occupying the premises, together with the post office addresses of such persons. ${ }^{4}$ Upon such return being made, the clerk shall thereupon mail, by registered mail, to each person so upon the land a copy of the petition and process, or, if the petitioner so desires, he may require such persons, so upon the land, to be served by the sheriff or his deputy. The clerk shall make entry ${ }^{5}$ of having mailed the notices unless the sheriff shall have made the service, in which event the sheriff shall make the return. The notices provided for and to be given under this and other sections of this Act shall stand as personal service of process, and shall be conclusive and binding on all persons so notified, and on all the world. ${ }^{6}$ Appearances or pleading in the case shall constitute a waiver of process and service, and of notice and of any defect therein. ${ }^{7}$

1. Form of notice, A. $\S 88$.

2. This constitutes constructive seizure of the land and confers jurisdiction in rem, T. $\$ \S 19,71$.

3. Form of return, A. $\S 90$.

4. This provision aids the constructive seizure, T. $\S 71$.

5. Form of clerk's certificate of service, A. § 91.

6. As to the effect of this provision as limiting right of action against the assurance fund, T. $\$ 251$.

7. Discussion, T. $\$ 69$. 
§ 15. Examiners - Appointment - Duties - Eligibility-Oath.-The judge of the superior court of each judicial circuit in this State shall appoint ${ }^{1}$ at least one master, or auditor, who shall be known as the examiner, and who shall discharge the duties provided herein for the examiner, but whose relation and accountability to the court shall be that of auditor or master in the general practice existing in this State; and the judge shall appoint as many more examiners in the circuit as the public convenience in connection with the carrying out of the provision of this Act may require, ${ }^{2}$ and may, in any case, appoint a special examiner. Such examiners shall hold office at the pleasure of the judge and shall be removable at any time with or without cause. Each examiner so appointed must be a competent attorney at law, of good standing in his profession, and of at least three years' experience in the practice of law. Each examiner shall take and file in the office of the clerk of the superior court of the county of his residence, along with the order of his appointment, an oath ${ }^{3}$ or affidavit substantially in the form herein prescribed.

1. Form of appointment, A. $\S 92$.

2. For suggestion as to the number of examiners to be appointed in a judicial circuit, see T. $\S 77$.

3. Form of examiner's oath, A. § 93.

General Note-As to power of judge to refer a controversy arising subsequently to initial registration to the examiner, see $A$. $\S 50$, T. $\S 166$.

General discussion of appointment and qualification of examiners, T. $\S \S 77-8$.

\section{$\S$ 16. Reference to Examiner-Preliminary Report.-} Upon the filing of a petition, as provided in this Act, the clerk shall at once notify the judge, who shall refer the cause to one of the general examiners, or to a special examiner. ${ }^{1}$ It shall thereupon become the duty of such examiner to make up a preliminary report ${ }^{2}$ containing an abstract of the title to the land from public records and all other evidences of a trustworthy nature that can reasonably be obtained by him, which said abstract shall contain full enough extracts from the records and 
other matters referred to therein, to enable the court to decide the questions involved; 3 also a statement of the facts relating to the possession of the lands ; ${ }^{4}$ also containing the names and addresses, so far as he is able to ascertain, of all persons interested in the land, as well as all adjoining owners, showing their several apparent or possible interests and indicating upon whom and in what manner process should be served or notices given, in accordance with the provisions of this Act. ${ }^{5}$ The preliminary report of the examiner shall be filed in the office of the clerk of the superior court, on or before the return day of the court, as stated in the process, ${ }^{6}$ unless the time for filing the same shall be extended by the court; and the said report shall be prima facie evidence of the contents thereof.?

1. Form of reference, A. $\S 94$.

Discussion of this provision, T. $\$ 79$.

2. Form of preliminary report and schedules, A. $\S 95$.

3. Discussed, $T$. $\S 82$.

4. Discussed, T. $\S 85$.

5. Discussed, T. $\S \S 83-4$.

6. Not less than $\mathbf{4 0}$ nor more than $\mathbf{5 0}$ days, from the date on which the petition is filed, A. $\S 10, T$. $\S 80$.

7. Discussed, T. $\& 87$.

General Note-As to the duty of all custodians of public records to allow the examiner free access to all public records, see $A . \S 68$, T. $\S 82$.

$\S 17$. Notice to Additional Defendants Disclosed by Examiner's Report.-If it is disclosed, from the report of the examiner, that other persons than those who shall have been notified under the provisions of this Act are entitled to notice, a copy of the petition shall be served upon such person in like manner as other persons named as defendants in the petition are required to be served by this Act, and, in addition to the copy of the petition, there shall be attached a notice from the clerk directed to such person, informing him that he shall appear and show cause against the judgment being rendered in the case, if any he has, within ten days from the date of the service of the notice. ${ }^{1}$ However, nothing herein shall be construed to require the giving of additional notice by publication, 
otherwise than in this Act provided for, ${ }^{2}$ to non-residents or persons who, by reason of absence from the State, or by reason of their whereabouts being unknown, can not be found and served with process.

1. T. $\S 75$.

2. A. $\S 10$.

$\S$ 18. Objections, Answers and Cross-Petitions.-Any person, whether notified or not, may become a party to the proceeding for the purpose of filing objections to the granting of the relief prayed for in the petition, or any part thereof, by filing in court an answer, showing that he claims some interest in the premises, and the grounds of his objection; ${ }^{1}$ or he may file a cross action ${ }^{2}$ praying that the title to the land, or some interest therein, be decreed to be in him, and registered accordingly.

1. Discussed, T. $\S 52$.

Right to file demurrer, T. $\S 55$.

2. Discussion as to form and substance of cross-petition, T. $\S 53$. Decree in favor of cross-petitioner, A. $\S 26, T$. $\S \S 104,106$.

Cross-petitioner, if successful pays assessment for assurance fund, A. $\S 74$, T. $\S 249$.

General Note-Verification of defensive pleadings and cross-petitions, T. $\$ 54$.

Time within which defensive pleadings may be filed, T. § 56.

Awarding costs against cross-petitioner or defendant, A. $\S 120, T$. $\$ \S 52,264$.

Severance where defense or cross-action goes to only a portion of the land included in the original petition, T. $\S \S 58,106$.

\section{$\S$ 19. Setting the Case for Hearing before Examiner} - Notice.-As soon as practicable, after the return day stated in the process, the examiner shall proceed to hear evidence and make up his final report to the court, unless it shall have developed from the preliminary report filed by him that persons other than those named as defendant in the original petition ${ }^{1}$ were entitled to service or notice, in which event he shall not begin the hearing until after ten days from the date of the serv- 
ice of notice upon such persons. He shall give notice ${ }^{2}$ of the time and place of hearing to the petitioner and to such persons as shall have filed any pleading in the case.

1. That is to say, such defendants as are additionally disclosed by the examiner's preliminary report or by a cross-petition. See A. $\S \S 16,17 ;$ T. $\$ \S 53,75$.

2. Discussed, T. $\S 88$.

\section{§ 20. Hearing before Examiner-Powers of Examiner} - Final Report-Exceptions-Jury Trial on Issue of Fact - Evidence-Recommitment- New Trial-Writ of Error. -At the time and place set for the hearing the examiner shall, in like manner as other auditors or masters in chancery, proceed, ${ }^{1}$ with similar powers as to the compelling of the attendance of witnesses, the production of books and papers, and of adjournment and recessing, to hear all lawful evidence submitted. $^{2}$ In addition thereto he is empowered to make such independent examination ${ }^{3}$ of the title as he may deem necessary. Upon his request, the clerk shall issue commission for the taking of testimony of such witnesses as, under the provisions of law on that subject, may have their testimony taken by interrogatories in ordinary actions. ${ }^{4}$ He shall also have the powers of a commisioner ${ }^{5}$ appointed by the superior court under Sections 5910 to 5917, inclusive, of the Civil Code of 1910. Within fifteen days after such hearing shall have been concluded the examiner, unless for good cause the time shall be extended by the judge, shall file with the clerk a report of his conclusions of law and of fact, setting forth the state of the title, any liens or encumbrances thereon, by whom held, the amounts due thereon, together with the abstract of title to said land, and any other information affecting its validity, and a brief, or a stenographic report of the evidence taken by him. ${ }^{6} \mathrm{He}$ shall mail to each of the parties who have appeared in the cause notice of the filing of his report. ${ }^{7}$ Any of the parties to the proceeding may, within twenty days after such report is filed, file exceptions to the conclusions of law or of fact or to the general findings of the examiner. ${ }^{8}$ The clerk shall thereupon notify the judge that the record is ready for his determination. If 
the petitioner, or any contestant of petitioner's right, shall demand a trial by jury ${ }^{9}$ upon any issue of fact arising upon exceptions to the examiner's report, the court shall cause the same to be referred to a jury either at the term of court, which may then be in session, or at the next term of the court, or at any succeeding term of the court, to which the case may be continued for good and lawful reasons; but it shall be the duty of the judge to expedite the hearing of the case and not to continue it unless for good cause shown, or upon the consent of all parties at interest. The issue or issues of fact shall be tried before the jury, in the event jury trial is requested, upon the evidence reported by the examiner, except in cases where, under the provisions of law in this State, evidence other than that reported by the auditor may be submitted to the jury on exceptions to an auditor's report, and except further, that in the case the examiner has reported to the court findings of fact based on his personal examination either party may introduce additional testimony as to such facts, provided that he will make it appear, under oath, that he has not bcen fully heard and given full opportunity to present testimony on the same matter before the examiner. ${ }^{10}$ The verdict of the jury upon the questions of fact shall operate to the same extent as it would in the case of exceptions to an auditor's report in an ordinary case in equity. In all matters, not otherwise provided for, the procedure upon the examiner's report and the exceptions thereto shall be in accordance with procedure prevailing in this State as to auditor's reports in equity and exceptions thereto. The right to grant a new trial ${ }^{11}$ upon any issue submitted to a jury and right of exception to the supreme court are preserved. ${ }^{12}$ The judge may re-refer or recommit the record to the examiner in like manner as auditor's reports may be recommitted in any equity cause; or he may, on his own motion, recommit it to the same or any other examiner for further information and report. ${ }^{13}$

1. Discussed, T. $\S 89$.

May recommend survey pending hearing, A. $\S \S 7,22 ;$ T. $\$ \S 34,86$, $89,100$.

2. Reports all evidence offered whether he thinks it admissible or not, T. $\S 92$. 
Stenographer, how and when employed, how paid, A. $\S 71$, T. § 93. Burden of proof generally, and how carried, T. $\S 94$.

3. Discussed, T. $\S 90$.

Result of independent examination is to be included in a separate division of the report, A. $\S 96$; T. $\S 90$.

4. Discussed, T. $\$ 89$.

5. Discussed, T. $\S 91$.

6. Discussed, T. $\$ 95$.

Form of examiner's final report, A. $\S 96$.

Report is open to public inspection on and after its filing, T. $\S 96$.

7. Who entitled to notice, T. $\S \S 56,95$.

8. Discussion of who may file exceptions or motion to recommit, T. $\S 96$.

Court always open for hearing of exceptions or completing the record, A. $\$ 67$; T. $\$ \S 97,265$.

Exceptions of law are for exclusive consideration of the judge, $T$. $\S 97$.

9. Discussed, $T$. $\$ \S 97-8$.

10. Discussed, 'T. $\S 98$.

11. Discussed, T. $\$ 99$.

12. The appellate procedure is by fast writ of error, A. $\S 82, T$. $\S \S 99,118$.

13. Discussed, T. $\S 99$.

General Note-The provisions of A. \$ 5, making applicable the general rules of equity pleading and practice, and the provisions of A. $\S \S 15$ and 20 making the functions of the examiner generally those of an auditor render the Code sections and the decisions on the subject of auditor's reports and exceptions thereto relevant to this context; and these are noticed and applied in the course of T. $\S \S 88-99$.

$\S 21$. No Judgment by Default.-No judgment or decree shall be rendered by default, so as to authorize any decree to be rendered without the necessary facts being shown.

As affecting the duty of the examiner to make full independent examination, see T. $\S 90$.

As affecting duty of judge when record is presented to him, T. $\S 56$.

Discussed generally, T. $\S 102$.

$\S$ 22. Survey-How Ordered-Protest and Trial of Protest.-While the cause is pending before the examiner of titles, or at any time before the final decree, the judge, or the examiner with the approval of the judge, may require the land to be surveyed by some competent surveyor, and may order durable bounds to be set and a plat thereof to be filed among the 
papers of the suit. But before such survey is made all adjoining landowners shall be given at least five days' notice. The petitioner, or any adjoining owner, dissatisfied with the survey, may file a protest with the court, within ten days from the time the plat is filed, and thereupon an issue shall be made up and tried as in case of protest to the return of land processioners.

The details of this section are discussed in T. $\S 100$. Special reference to them is made in connection with the duties of the examiner in T. $\S 86$; also noticed as affecting the necessity of an adequate description in the original petition in T. $\S 34$. See also A. $\S 7,20$.

$\S 23$. Dismissal of Petition.-If in any case the petitioner so desires, or if the court is of opinion that the petitioner's title is not and cannot be made proper for registration, the petition may, with leave of the court, be dismissed without prejudice on terms to be determined by the court.

This section is discussed in detail and construed in connection with A. $\S 26$ in T. $\S 103$.

As to right to amend and avoid dismissal where petitioner proves estate less than fee, T. $\S 104$.

Necessity for dismissal where petitioner proves only an undivided interest, T. $\$ 105$.

\section{$\S$ 24. Amendments - Severance - Making Parties. -} Amendments 1 to petitions or other pleadings, or the severance ${ }^{2}$ thereof, including joinder, substitution ${ }^{3}$ or discontinuance of parties, and the omission or severance of any portion or parcel of the land, may be ordered or allowed by the court at any time before final decree upon terms that may be just and reasonable, ${ }^{4}$ and the court may require facts to be stated in the petition in addition to those prescribed by this Act. ${ }^{5}$ The examiner shall have these powers, subject to review by exception to his report. ${ }^{6}$

1. Right of amendment generally, T. § 57 .

Amendments allowable in general equity practice are allowable in registration proceedings, A. § 5, T. §57.

No amendment allowable to include additional land, $T$. $\S 57$.

All amendments must be sworn to, A. $\S 7, T$, $\$ \S 54,57$.

2. Meaning and use of severance, T. $\S 58$. 
Effect of severance, T. $\S 59$.

Duty of court to order severance under certain circumstances, $T$. § 106.

3. Substitution of party buying land pending registration, A. $\S 25$, T. $\S 60$.

4. Discussed, T. $\S 106$; see also T. $\S 264$.

5. Power of court to compel fuller details even in absence of demurrer, T. $\S 55$.

6. Discussed, T. $\S 89$.

$\S$ 25. Dealing with the Land Pending Registration Proceedings.-The land described in any petition may be dealt with, pending registration, as if no such petition had been filed, but any person who shall acquire any interest in or claim against any such land shall at once appear as a petitioner, or answer as a party defendant, in the pleadings for registration, and such interest or claim shall be subject to the decree of the court.

Discussed, T. $\S 60$.

As to substitution of person purchasing pending registration as party plaintiff, A. \& 24 .

$\S$ 26. Decision of the Cause - Judgment - Decrees, How Rendered.-After the record shall have been perfected and settled 1 the judge of the superior court shall thereupon proceed to decide the cause ; and if, upon consideration of such record, the title be found in the petitioner, ${ }^{2}$ the judge shall enter a decree to that effect, ${ }^{3}$ ascertaining all limitations, ${ }^{4}$ liens, encumbrances, etc., 5 and declaring the land entitled to registration accordingly as he shall find, and such decree shall be entered upon the minutes ${ }^{6}$ of the superior court and become a part of the records thereof. If, upon consideration of the record, he finds that the petitioner is not entitled to a decree declaring the land entitled to registration, he shall enter judgment and decree accordingly. ${ }^{7}$ If any person shall have filed a cross action ${ }^{8}$ praying for the registration of the title [to] be found in him, the judge may enter a decree to that effect, in like manner ascertaining and declaring all limitations, liens, etc., and declaring the land entitled to registration accordingly. If separate parcels are involved ${ }^{9}$ the court shall render separate decree as to each parcel; and the same shall be done where the petitioner 
has divided a tract into separately described parcels and has accurately described each parcel for separate registration.10

1. How settled in event of exceptions to examiner's report, T. $\S \S 96-7$.

Necessity for and conclusiveness of judge's finding as to compliance with Act and proper service, A. § 13; T. §§ 74, 101.

Necessity for settling record and making all necessary severances, amendments, etc., prior to rendering decree, T. $\S 108$.

Provisions by which court can cause the record to include an accurate and permanent description of the land, A. $\S \S 7,22,24 ;$ T. $\S 109$.

2. No judgment by default; the record must affirmatively show title in the petitioner or cross-petitioner, as the case may be. A. $\S$ 21; T. $\S 102$.

3. Form of decree, A. $\S 97$.

Suggestions as to preparation of decree, T. $\S \S 109-114$.

Necessity for adherence to prescribed form, T. $\S 108$.

4. Suggestions as to how estates, limitations, conditions, etc., are to be set forth in decree, T. $\S \S 110-112$.

6. Suggestions as to how liens, encumbrances, etc., are to be set forth in decree, T. $\S 113$.

Need for reference to right of appeal T. $\S 114$.

6. See also to same effect, A. $\S 97 ;$ T. $\S 116$.

In addition to being recorded, the decree is also enrolled on the Register of Decrees of Title, A. $\S \S 28,97$; T. $\S 119$.

7. The proper judgment in such a case is usually a dismissal. A. $\S 23 ;$ T. $\$ 103$.

Judgment establishing a lesser estate if proved and if petitioner amends accordingly, T. $\S 104$.

Dismissal, if petitioner proves only an undivided interest, T. $\S 105$. Where petitioner proves title to only a part of the land included in the petition, T. $\S 106$.

8. See A. $\S 18 ;$ T. $\S 53$.

Costs and assessment for assurance fund, how far taxed against cross-petitioner, A. $\$ \S 74,120 ;$ T. $\$ \S 249,264$.

9. See A. $\S 8 ;$ T. $\S \S 35,106$.

10. See A. $\S 8 ;$ T. $\S 36$.

Advantages of dividing tract into separately described parcels, T. $\S 107$.

General Note-Obtaining a decree as effecting a covenant running with the land, subjecting it to all the provisions of the Act, A. $\S 64$; T. $\S 117$.

Conclusiveness of decree, A. $\S 27$; T. $\S \S 117,230,239$.

Conclusiveness as to validity and extent of liens, encumbrances, etc, set forth in the decree, T. $\$ 230$.

Certified copy of decree as evidence, T. $\$ 243$. 
Writ of error to decree, A. $\S 82 ;$ T. $\S 118$.

Effect of failure to note pendency of writ of error on Title Register, T. $\S 233$.

Judgment taxing costs to be separately rendered, T. $\S 108$.

How far any issue as to mesne profits and improvements, is to be noticed in the decree, T. $\S 115$.

What rights, liens and easements are not to be noticed in the decree, A. $\S 63$; T. $\S \S 211,220$, et seq.

$\S 27$. Effect of the Decree-Conclusiveness.-Every decree rendered, as herein provided, shall bind the land and bar all persons claiming title thereto or interest therein, quiet the title thereto, and shall be forever binding and conclusive upon and against all persons, including the State of Georgia, whether mentioned by name in the order of publication, or included under the general description, "whom it may concern." It shall not be an exception to such conclusiveness that the person is an infant, lunatic, or is under any disability, but such person may, in the manner provided, have recourse upon the indemnity fund hereinafter provided for, for any loss he may suffer by reason of being so concluded.

Compare A. § 4.

Section discussed. T. $\S \S 117,230,243$.

Matters not concluded, A. $\S 63$; T. $\S \S 211,220$.

Rights of infants and persons under disability to go upon assurance fund, T. $\S \S 250,252$.

$\S 28$. The Register of Decrees of Title-The Title Register-Certificate of Title-Owner's Certificate.-The county commissioners, or other officer having charge of the county business, of each county shall provide ${ }^{1}$ for the clerk of the superior court in said county a book, in which he shall enroll and register and index all decrees of title, to be known as the "Register of Decrees of Title," 2 also a book to be prepared, printed and ruled in substantially the manner hereinafter provided, to be called the "Title Register," ${ }^{3}$ in which said clerk shall enroll, register and index, as herein provided, the certificate of title herein provided for, ${ }^{4}$ and all subsequent transfers of title, ${ }^{5}$ and note all voluntary or involuntary transactions in anywise affecting the title to said land ${ }^{6}$ authorized to be en- 
tered thereon; and they shall, from time to time, furnish such additional books as may be necessary. Upon the registration of such decree and certificate of title, the clerk shall issue an owner's certificate of title, ${ }^{7}$ under the seal of his office, which shall be delivered to the owner, or his duly authorized agent or attorney.

1. Cited, T. § 271 .

2. Form and description of Register of Decrees of Title, A. § 98; T. $\$ 119$.

Suggestions as to enrolling decrees of title, T. $\S \S 119-123$.

Numbering the decrees, A. $\S 98 ;$ T. $\S 120$.

Indexing decrees of title, A. $\S 98 ;$ T. $\S 123$.

Outside recordation of plats and lengthy details, A. § 102; T. § 121.

Separate enrollment of the several decrees rendered where more than one tract included in petition or where a single tract is divided into parcels, A. \& $98 ;$ T. $\S 120$.

Minute dating of entry of decree, A. § $29 ;$ T. § 122.

Decree to be recorded on minutes as well as enrolled in the Register, A. $\S \S 26,97$; T. $\S 116$.

3 Form and description of Title Register, A. $\S 99 ;$ T. $\S 124$. Index, how kept, T. $\S 132$.

Certified copy of entries, A. $\S 101 ;$ T. $\S 241$.

4. Certificate of title, defined, T. $\$ 21$.

Form and description of certificate of title, A. $\S 99 ;$ T. $\S 125$.

Issuance and numbering of certificate of title, A. § 99; T. \& 125 .

Suggestions as to preparation of the certificate of title, T. $\S \S 125-$ 132.

Right of clerk to ask instructions of judge if he is in doubt as to any detail in connection with registering the certificate of title, A. $\S 59 ;$ T. $§ \S 131,275$.

Extraordinary Cases discussed, T. $\S 275$.

Outside recordation of plats or other matters of lengthy detail, A. $\S \S 103,104 ;$ T. $\S \S 126,129,275$.

Signing, sealing and dating the certificate of title, A. § 29; T. § 130 .

Certified copy of certificate of title as evidence, A. $\S 101$; T. $\$ \S 239$, 241.

5. See T. $\S \S 136$, et seq.

6. See A. $\S 3$ and notes 5-15 thereunder.

7. "Owner's certificate" defined, T. § 21.

Form and description of owner's certificate, A. § 105; T. § 134. $\S 133$.

Certified copy of outside record attached to owner's certificate, $T$.

Suggestions as to issuance of owner's certificate, T. $\S 133$. 
Owner's certificate must be presented with every voluntary transfer, A. $\S \S 37,117 ;$ T. $\S \S 140,141$.

Owner's certificate canceled on voluntary total transfer, A. $\S 30$, T. $\S 147$.

Owner's certificate not canceled on transfer of undivided interest, A. $\S 31 ;$ T. $\S 148$.

Owner's certificate canceled when a divided portion the land is transferred, A. $\S 31 ;$ T. $\S 151$.

Owner's certificate, how canceled in case of involuntary transfers, A. $\S 52 ;$ T. $\S 169$.

Established duplicate of owner's certificate, how and when issued, A. $\$ 58$; T. $\S 135$.

Difference between evidentiary conclusiveness of certificate of title and owner's certificate, T. $\S \S 226,239$.

Owner's certificate, how made to correspond with certificate of title and thus become equally conclusive, A. $\S 118$; T. $\S \S 227,240$.

§ 29. Minute Dating of All Entries.-Every entry made in the Register of the Decrees of Title, or in the Title Register, or upon the owner's certificate, under any of the provisions of this Act, shall be signed by the clerk and dated with the year, month, day, hour and minute, accurately stated.

Section discussed, T. $\S 273$.

§ 30. Registration of Total Voluntary Transfers.Whenever the whole of any registered estate is transferred or conveyed, the same may be done by a transfer or conveyance upon, or attached to, the owner's certificate of title, substantially in the form herein provided for. ${ }^{1}$ The same shall be signed and acknowledged or attested as if it were a deed to land, ${ }^{2}$ and shall have the full force and effect of a deed. Provided, that if the said sale or transfer be in trust, upon condition, with power to sell, or other unusual form of conveyance, the same shall be set out in said transfer, and shall be entered upon the Registration of Titles Book as hereinafter provided. ${ }^{3}$ Upon presentation of the said transfer, together with the owner's certificate of title, ${ }^{4}$ to the clerk, it shall be duly noted and registered in the Title Register, in accordance with the provisions of this Act, ${ }^{5}$ and, the certificate of title on the Title Register, and the owner's certificate of title so presented, shall be canceled and a new certificate of title in the name of the trans- 
feree shall be registered on the Title Register, ${ }^{6}$ and a new owner's certificate of title shall be issued to the transferee, which new certificates shall refer to the former certificates just canceled.

1. Standard form prescribed, A. § 107 .

2. Clerk's duty and liability as to requiring attestation in accordance with the Act, A. § 106; T. § 269.

3. See T. § 163.

As to how next transfer is to be made when a transfer is registered in trust, etc., see A. § 56; T. § 204.

4. Owner's certificate must accompany every voluntary transfer, A. $\S \S 37,117 ;$ T. $\S \S 140,141$.

Requirement a safeguard against fraud and forgery, which must not be relaxed, T. $\S \S 215,269 ; 270$.

5. Method of registering total transfer in standard form, T. $\S \S 140$, 147.

Method of registering total transfer not in standard form, T. $\S \S 143$, 163.

6. All uncanceled notations or entries on old certificate must be brought forward on the new, A. $\S \S 39,100 ;$ T. $\S 187$.

$\S$ 31. Registration of Partial Voluntary TransfersDivided Portions-Undivided Interests.-Whenever a part of any registered land is transferred or conveyed, the same shall be by form substantially, as in case of a total transfer, ${ }^{1}$ but setting forth, particularly and specifically, the portion of the land transferred, if it be an undivided interest, or if it be a particular portion of the tract, describing the same accurately and definitely. In case an undivided interest is transferred, upon presentation of such transfer, together with the owner's certificate of title, ${ }^{2}$ the clerk shall not cancel the owner's certificate so presented nor the certificate of title on the Title Register but shall enter a notation of such partial transfer on the certificate of title, on the Title Register and on the owner's certificate; and said clerk shall also register upon the Title Register a certificate of title in the name of the grantee of the undivided portion of said estate so transferred and issue to him an owner's certificate correspondingly, setting out the part or amount of land transferred, as the case may be. ${ }^{3}$ If the transfer be of a divided part of the land the clerk shall first enter 
the fact of the transfer upon the certificate of title, on the Title Register, and shall cancel the certificate of title, on the Title Register and the owner's certificate of title. ${ }^{4}$ Thereupon he shall register new certificates of title on the Title Register, separately, the one in the name of the transferee, for the portion of the tract conveyed to him, and the other to the transferor for the portion retained; and the clerk shall also issue new separate owners' certificates accordingly. ${ }^{5}$ The said clerk shall note upon the Title Register and the owners' certificates the reference and cross references to the certificates herein referred to.

1. Standard forms prescribed, A. § 107.

2. Necessity for presentation of owner's certificate, A. \$\$ 37, 117; T. $\S \S 140,141,215$. But the transfer in this case should not be written on the owners' certificate, T. $\S 148$, note 2.

3. Method of registering transfer of undivided interest in standard form, T. § 148.

4. This implies that owner's certificate must be presented with the transfer, A. $\S \S 37,117$.

5. Method of registering transfer of a divided portion of the registered tract, T. $\S 151$.

General Note-All uncanceled entries and notations on old certificate must be brought forward on the new, A. $\S \S 39,100 ;$ T. $\S 187$.

Method of registering voluntary partial transfers not in standard form or transferring in trust or condition or with unusual limitations, T. § 163 .

Clerk is under duty of seeing that partial as well as total transfers are duly attested, A. § 106; T. $\S \S 269,270$.

$\S$ 32. Transfer to Secure Debt, with Power of Private Sale-Creditor's Certificate.-Whenever the owner of any registered land shall desire to convey the same as security for debt, with power of sale without foreclosure, it may be done by a short form of transfer, substantially in the form hereinafter set forth. ${ }^{1}$ The same shall be signed and properly acknowledged or attested, as if it were a deed to land, ${ }^{2}$ and shall be presented, together with the owner's certificate ${ }^{3}$ to the clerk, whose duty it shall be to note upon the owner's certificate and on the certificate of title in the Title Register the name of the creditor, the amount of debt, and the date of maturity of same, and showing that a creditor's certificate has been issued 
therefor, and when only a part of the registered estate shall be so conveyed, the clerk shall note upon the said book and owner's certificate the part so conveyed. ${ }^{4}$ The clerk shall retain, number and file away, ${ }^{5}$ the instrument of transfer and shall issue and deliver to the creditor what shall be known as a creditor's certificate, ${ }^{6}$ over his hand and seal, setting out the portion so conveyed. All registered encumbrances, rights or adverse claims affecting the estate represented thereby in existence at the time the creditor's certificate is issued shall be noted thereon. ${ }^{7}$

1. Standard form prescribed, A. § $10 \%$.

2. Clerk's duty and liability as to the attestation, A. $\S 106$; T. $\S 269$.

3. This is a voluntary transaction, A. $\S 3$; T. $\S 21$; hence the provisions of $A$. $\S 37$ apply. See also T. $\S \S 140-1$.

4. Method of registering transfer and issuing creditor's certificate, T. $\$ \S 153$ et seq.

When only a part of the land is pledged, A. § 109.

5. How filed away, T. $\S 272$.

Exception, when transfer is not in standard form, A. § 38; T. § 158 .

6. Form of creditor's certificate, A. § 108. Partial, A. § 109.

7. See also A. § 108.

General Note-As to other transfers to secure debt, A. § 36; T. $\S 152$.

Transfer for issuance of creditor's certificate not in standard form, A. $\S 38 ;$ T. $\S \S 143,157,158$. Compare T. $\S \S 162-3$.

Attaching copies of any outside record referred to in certificate of title, A. § 104; T. § 157 .

$\S$ 33. Negotiability of Creditor's Certificate-Cancellation.-The creditor's certificate shall be assignable or negotiable to the same extent as the note or other evidence of indebtedness secured thereby may be, but assignments or transfers of the creditor's certificate need not be noted on the Title Register. A transfer or assignment of the indebtedness shall operate to transfer the creditor's certificate securing the same, in like manner and to the same extent as is set forth in Section 4276 , of the Civil Code, relating to the case of transfer of indebtedness secured by mortgage, unless otherwise agreed between the parties. ${ }^{1}$ The creditor's certificate may be surrendered and canceled at any time by the owner thereof. ${ }^{2}$ It shall be the creditor's duty to surrender the same and give order for 
cancellation of the same when the debt is paid. If he refuses to do so he may be compelled by the court to do so, and in any proper case the judge may order a cancellation on the Title Register. $^{3}$ Upon presentation of an order of cancellation, with the surrendered creditor's certificate, or upon presentation of the judge's order directing cancellation, the clerk shall enter a notation of the same in the Register of Titles and on the owner's certificate of title.

1. Negotiability of creditor's certificate discussed. T. $\S 154$.

2. Form of voluntary cancellation of creditor's certificate, A. § 115 . Methods of cancellation discussed, T. $\S 159$. Compare T. $\S 142$.

3. Cancellation of creditor's certificate by order of judge, T. $\$ 159$. See also T. $\S 181$ et seq.

\section{$\S 34$. [The official enrolled act contains no Section 34.]}

$\S$ 35. Sale under Creditor's Certificate-Making Transfer to Purchaser-Disposition of Proceeds.-If the debt secured by the creditor's certificate so issued, or any part thereof shall be due and unpaid, the holder of said creditor's certificate may, after advertising the property for sale in the manner prescribed by law for advertising sheriff's sales of land, expose the same at auction before the court-house door of the county and sell the same to the highest and best bidder for cash. The sale need not be conducted by the creditor or holder of the creditor's certificate personally, but may be conducted through any agent or attorney. The holder of said certificate, his agent or attorney, shall thereupon make oath to the facts, and apply to the judge for an order of transfer to the purchaser. The application shall be accompanied by a certified copy of the certificate of title from the Title Register as of the date of the sale. The judge shall cause at least five days' notice to be given to the debtor and to any person who, according to the Title Register, shall have acquired any interest in the property subsequently to the issuance of the creditor's certificate; and if no objections are made, or after hearing, if objections be made, the judge shall grant an order of transfer with such directions for cancellation of other certificates and en- 
tries, and otherwise as shall be in accordance with the justice of the case, and with the spirit of this Act.

The proceeds of the sale shall be applied, first, to the payment of the costs of advertising the sale and obtaining the judge's order of transfer, then to the payment of the debt, and the remainder, if any, shall be paid to the debtor, or his order.

The provisions of this section are discussed in T. $\$ \S 155,160$. Compare T. $\S 166$ et seq.

\section{\$ 36. Other Transfers as Security-Bond to Recon-}

vey.-Nothing herein shall prevent the owner from transferring his registered title as security for debt, or from causing the title to be registered in the name of the creditor by transferring to the creditor as if he were an ordinary vendee of the registered title; and if bond for title or bond to reconvey be given, the same may be noted on the certificate of title on the Title Register and on the owner's certificate, provided the same be attested or acknowledged as if it were a deed.

The provisions of this section are discussed in T. $\$ 152$. The transaction is a voluntary transaction and is to be handled as such. A. § $3 ;$ T. § 21.

$\S$ 37. Presentation of Owner's Certificate with Every Voluntary Transaction.-In all voluntary transactions the owner's certificate of title must be presented, along with the writing or instrument filed for registration; and thereupon, and not otherwise, the clerk shall be authorized to register the transaction.

See note 5 to $A . \S 3$. See also A. $\S 330,31$.

While voluntary cancellations of adverse entries are included within the definition of "voluntary transactions" as given in A. § 3, still it is manifest, from other provisions of the Act, that this section does not have reference to such voluntary cancellations, which are the acts of third persons and not of the owner. See T. $\S \S 159,180,186$.

Voluntary transfers between husband and wife are an exception to the rule that such transactions when accompanied by the owner's certificate may be registered without the prior sanction of the judge. A. $\S 48 ;$ T. $\S 201$. So also are transfers by any one holding the land in trust or upon any condition or unusual limitations or with power to 
sell or encumber. A. $\S 56$;. T. $\S 204$. This exception applies also to executors and administrators (T. $\S 193$ ) and to widows under year's support (T. § 209).

$\S$ 38. Transfers and Mortgages in Standard Form, How Registered-Not on Regular Form-Special Provisions.-Wherever a transfer, or transfer as security for debt, or mortgage, as to an estate in registered land, is executed in the form prescribed in this Act ${ }^{1}$ and the same duly registered and noted in the register of titles, and the same contains nothing more than the filling in of the blanks in said forms prescribed so that the entry of registration on the Title Register construed in connection with the prescribed form shows the full transaction, it shall not be necessary to record the transfer, security transfer, or mortgage, otherwise than by the registration in the Title Register; and such registration shall, for all purposes, take the place of recordation as to such instruments so executed $;^{2}$ and a certified copy of such registration shall be admissible in evidence on like terms and with like effect as a certified copy of a deed, mortgage or other similar instrument is admissible under existing laws. ${ }^{3}$ In such cases the original instrument of transfer (together with the canceled owner's certificate), or original instrument of transfer as serurity for debt, or original mortgage, as the case may be, shall be numbered with the registration number of the title to which it relates, and carefully filed away, in such manner as to be of easy access, and preserved as a part of the records of the office of the clerk of the superior court. ${ }^{4}$ In case of a mortgage so executed the clerk shall, on request, make a certified copy and deliver to the mortgagee, and such certified copy shall stand for all purposes in lieu of the original and shall be original evidence to the same extent that an original mortgage ordinarily is, in any court. 5 If the instrument of transfer be not in the short form herein prescribed, or if it contains any provisions not provided for in said form, or if it is executed for the purpose of transferring any estate or interest in the registered land in trust, or upon any condition, or upon any peculiar, unusual limitation, the details at variance with or additional to those provided for under the prescribed form need not be entered in full on the 
Title Register and the owner's certificate, but the clerk shall record such instrument in full on the deed book of the county in like manner as deeds to unregistered land are recorded, and shall after the general entry of the transfer on the Title Register and on the owner's certificate add thereto a notation that the same is "in trust," "upon condition" or "on special terms" as the case may be, followed by the words "See deed book (or mortgage book, as the case may be)........page........"6 Like procedure shall be followed in case of a transfer to secure debt $^{7}$ or a mortgage ${ }^{8}$ not following the form herein prescribed, but in such cases the clerk shall not retain the original instrument, but shall return the same to the creditor after it shall have been registered and recorded.

1. The standard forms of transfer and of transfer to secure debt are prescribed in A. $\S 107$; the standard form of mortgage in A. $\S 111$.

2. Registration as the exclusive and conclusive method of giving notice, A. \$§ 40,$73 ;$ T. $\S 245$.

3. Discussed, T. $\S 244$.

4. Method of filing, T. § 272.

5. See T. $\S \S 161,244$.

6. See T. $\$ \S 162-3$.

Clerk's fees for making outside record, A. § 120; T. § 259.

When such copy of outside record should accompany the instrument when offered in evidence, T. § 242.

As to how subsequent transfers are to be made after a transfer is registered in trust or on unusual limtations, etc., see A. $\$ 56$ and notes.

7. See T. $\S \S 157-8$.

8. See T. $\S 162$.

\section{$\S$ 39. Entries to Be Brought Forward on Subsequent} Registrations.-All registered encumbrances, rights, or adverse claims affecting the estate represented thereby shall continue to be noted upon every outstanding certificate of title and owner's certificate, ${ }^{1}$ until the same shall have been released or discharged, ${ }^{2}$ unless the same shall relate to only a particular portion of the property, when the same shall be noted only upon such certificate and duplicate certificates as relate to that portion of the property.

1. Compare A. $\S 100$. See also notes to A. $\S \S 30,31$. Discussed T. $\S 187$.

2. As to how such entries and notations are to be released or discharged, A. $\S \S 60,62 ;$ T. $\S \S 142,159,180-3,186$. 


\section{§ 40. Registration as Notice and as Substitute for Re-} cordation.-Every voluntary or involuntary transaction, ${ }^{1}$ which if recorded, filed or entered in any clerk's office, would affect unregistered land, shall, if duly registered on the Title Register, and not otherwise, ${ }^{2}$ be notice ${ }^{3}$ to all persons from the time of such registration, and operate, in accordance with law and the provisions of this Act, ${ }^{4}$ upon such registered land. ${ }^{5}$

1. For definition see A. $\S 3$, T. $\S 21$.

2. To the same effect, see A. $\S 73 ;$ T. $\S \S 174,176$.

It is not necessary that it should be entered on the owner's certificate to have this effect, T. $\S 226$.

3. It is the exclusive and conclusive method of giving notice, A. § 73, T. § 245. Compare A. § 38, note 2.

4. Compare A. $\S 73$.

5. When the land is freed from registration, entries and notations made on the register prior to the transfer by which the exemption from registration takes place, still have the effect stated in this section, A. § 65; T. §§ 236-7.

$\S$ 41. Involuntary Transfers-Order of Judge Required.-Except as herein otherwise provided, ${ }^{1}$ in cases of involuntary transactions, ${ }^{2}$ no transfer of the title ${ }^{3}$ shall be registered except upon an order granted by the judge of the court 4 in the form substantially as that hereinafter prescribed. ${ }^{5}$

1. Transfer to executor or administrator on death of owner is the exception. By the definition given in A. $\S 3$, T. $\S 21$, this is an involuntary transfer; and yet under the provisions of $A$. $\S 44$, the transfer is made on presentation of the letters of executorship or of administration, and the order of the judge is not required.

2. Defined, A. § 3, T. \& 21.

3. Notice that not all involuntary transactions are included; only transfers of title. See T. $\S 165$.

4. Discussed, T. $\S \S 144,171$.

Involuntary transfers, how applied for and how ordered, A. § 50; T. $\$ \S 166$ et seq.

Duties of clerk in registering involuntary transfers, T. § 171.

Owner's certificate how canceled, A. § 52, T. § 169.

5. Form of judge's order of transfer, A. $\S 110$.

$\S$ 42. Death of Owner-Title of Personal Representative.-Lands and any estate or interest therein registered un- 
der this Act, shall, upon the death of the owner, testate or intestate, go to his personal representative in like manner as personal estate, and shall be subject to the same rules of administration as personalty, except as otherwise provided in this Act, and except that nothing herein contained shall alter or affect the course of ultimate descent under the statute of descents and distributions and the rights of dower, when duly registered, nor shall alter or affect the order in which real and personal assets, respectively, are now applicable in and towards the payment of funeral and testamentary expenses, debts, or legacies, or the liability of real estate to be charged with the payment of debts and legacies.

Discussed, T. $\S 188$ et seq.

$\S$ 43. Fiduciary Ownership of Personal Representative.-Subject to the powers, rights and duties of administration, the personal representative of such deceased owner shall hold such real estate as trustee for the persons by law beneficially entitled thereto, but, unless otherwise entitled by law to commissions, shall be entitled to no commissions thereon, except in cases of necessary sales in due course of administration. And the heirs at law or beneficiaries aforesaid shall have the same power of requiring a transfer of such estate as if it were personal estate.

Discussed, T. § 188, et seq.

§ 44. Transfer to Personal Representative.-Upon the grant of letters of administration or executorship by the court of ordinary and upon presentation of a certified copy of the same to the clerk of the superior court and the presentation of the owner's certificate the clerk shall make a special entry on the certificate of title on the Title Register showing the presentation of the letters of administration or executorship, the name of the representative, the court and county of his appointment, and the date of the letters and of the transfer of the title to the representative. The clerk shall thereupon cancel the certificate of title and the owner's certificate outstanding in the name of 
the decedent and issue to the administrator or the executor, as the case may be, a new owner's certificate. In the event the decedent was the owner of only a fractional undivided interest in the title and the outstanding certificate stood in the name of the decedent and others, or where, from any other cause, the decedent was not the sole owner of the certificate, the outstanding certificate shall, nevertheless be canceled, and a new certificate registered and new owner's certificate issued with the name of the personal representative substituted for the name of the decedent.

Discussed, T. $\S 191-2$.

This is an involuntary transfer, under the definition given in A. $\S 3$ and T. $\S 21$; and is the exception to the general rule stated in $A$. $\S 41$ that no involuntary transfer shall be registered except upon order of the judge.

$\S$ 45. Descent to Heirs if No Administration-Proceedings to Establish Heirship-Transfer to HeirsRights of Widow.-In case the owner of registered land die intestate, and there is no administration upon the estate within twelve months from the date of his death, or in the event administration terminates without the land being disposed of, the heirs at law of such intestate, or any one or more of the persons who claim to be heirs at law of such intestate, may petition the superior court of the county to have their title by descent declared as to such registered land. In such application there shall be set forth the names of all persons who are alleged to be the heirs at law, and if all are not joined, process or notice shall be served, as in cases in equity, upon all not so joined. The petition shall be verified by the affidavit of one of the petitioners, shall set forth in detail the name and address, as last known, of the decedent, a statement as to whether he was married or single, or a widower; if married more than once, the names of all of his wives; the names of all children and descendants of children, if any, showing in detail whether the parents of such children are living or dead, and showing in detail how and wherein the persons who are alleged to be the heirs at law are in fact the heirs at law of such decedent under the rules of in- 
heritance in this State. It shall also give the date of the death of the decedent and set forth that he died leaving no will and that, in the judgment of the applicant, there is no need for administration upon the estate. Upon such application being filed the judge shall thereupon grant an order setting the application down to be heard at the court-house in the county where the land lies on some day not less than thirty days from the date of the application, and calling on all persons to show cause before the court on that day why the persons named as heirs at law in the application should not be so declared to be by the judgment and decree of the court. A copy of the application and the order of the court thereon shall be published in the newspaper in which the sheriff's sales of the county are advertised in like manner as sheriff's sales are advertised. Upon the day named, unless the matter be continued by order or orders of the judge to some future time, the court shall proceed to hear and determine the question, together with all objections, if any, which may be filed, and to adjudge and decree that the alleged decedent is dead and that there is no administration on his estate, and that he left no will, and who are his heirs at law; unless it appears that the alleged decedent is not dead, or that there is administration upon his estate, or that an application for administration is pending, or that the decedent left a will, in either of which events the petition shall be dismissed. Upon granting an order of heirship the court shall thereupon order a transfer of the registered title from the decedent to the heirs at law to be registered, and upon production of the owner's certificate of the decedent, and the judge's order for a transfer, the clerk shall register the transfer and cancel the certificate registered in the name of the decedent and the owner's certificate and issue a new owner's certificate in the name of the persons declared to be the heirs at law. In such an application, if the alleged heirs at law be of full age and under no disabilities, and the same shall so appear to the court, and it shall further appear that they have voluntarily partitioned the land in kind among themselves, the court may, in connection with the order of transfer, direct that the certificate standing in the name of the decedent be cancelled and that new certificates shall be reg- 
istered and issue to each of the heirs for the particular parcel of land coming to each under the voluntary partition set forth in the application. If the decedent shall have left a widow the application shall disclose whether the widow has elected to take dower or to become an heir of the estate, and she shall be a party to the proceedings, and the court shall specifically provide what interest or estate she shall take under the decree of heirship and, except where, in the decree, the land is partitioned into separate tracts, the court shall, in the decree of heirship and in the order of transfer, specifically set forth (except in the case of sole heir) what undivided interest each heir shall take. In case the decedent be a female the procedure shall be similar, except in so far as the differnce between the rights of the husband [and] wife upon the death of his spouse shall make changes necessary. Where the wife claims to be entitled to take possession of the estate without administration, under the provisions of sub-Section 1 of Section 3931 of the Code, the procedure shall be substantially in the same manner.

Discussed, T. §§ 195-7.

\section{$\S$ 46. Rights of Administrator after Transfer to Heirs.} -Wherever a transfer of registered land shall have been made to heirs at law, or to the widow claiming to be the sole heir, as stated in the preceding section, if at any time thereafter a personal representative is appointed upon the estate of the decedent he shall not be entitled to have such registered land transferred to him for purposes of administration, but if it appears that the heirs have thereby appropriated to their use and ownership property which should have been appropriated to the purposes of administration the personal representative of the decedent shall have a right of action against the heirs for the value of the property so appropriated, the judgment in such action to be moulded according to [the] exigencies of the particular case in accordance with the principles of equity.

Discussed, T. § 199.

$\S$ 47. Ascertainment of Heirs or Beneficiaries by Administrator or Other Trustee.-Wherever an administrator 
shall have been appointed and shall have caused registered land to be transferred into his name and he stands ready to be discharged and it is not necessary to sell such registered land for the purposes of administration and it should properly go to the heirs at law of the decedent, he may institute a proceeding substantially similar to that prescribed in Section 45 of this Act for the ascertainment of the heirs at law and for an order directing the transfer of such estate from him to such heirs at law when so ascertained. In case any other trustee shall hold title where the beneficiaries of the trust are not definitely and particularly disclosed, and it becomes appropriate that they should be definitely ascertained, such trustee may, in like manner, petition the court, upon showing that the trust has become executed, for a decree settling and ascertaining who the beneficiaries are, and directing a transfer to such beneficiaries.

Cited, T. § 189.

Discussed, T. \& 198.

$\S$ 48. Transactions between Husband and Wife.-In cases of transfers of registered land, or any interest therein, from wife to husband, or vice versa, the transfer shall not be entered nor made until the same shall have been approved by the judge of the superior court and the fact of such approval shall be entered upon the Register of Titles.

Cited, T. $\S 10$.

Discussed, T. § 201.

This is an exception to the general rule stated in A. $\S 37$ that a voluntary transfer accompanied by the owner's certificate may be registered without the prior sanction of the judge.

$\S$ 49. Transfer as the Result of Judgment or Decree, at Law or in Equity.-Wherever, as the result of a proceeding in any court of law or in equity, ${ }^{1}$ it is adjudged that a transfer of registered land should be made, such transfer may be made by the clerk upon the production of a certified copy of such decree showing in what book and page of [the] minutes of the court that rendered it the decree is recorded, and on order ${ }^{2}$ of the judge of the superior court of the county in which the land lies directing such transfer to be made; and the certificate 
of title on the Register of Titles, and the owner's certificate, shall be canceled and new certificates shall be registered and issued accordingly. ${ }^{3}$ Production of the certified copy of the decree shall not be required when it is rendered in the same court as that in which the title is registered, but the clerk shall act upon the judge's order of transfer and the inspection of his own minute book.

1. Registered lands are subject to same burdens and incidents and to the ordinary jurisdiction of the courts in like manner as unregistered lands are, A. $\S 73 ;$ T. $\S \S 137-8$.

Remedy where owner executes voluntary transfer or mortgage but refuses to deliver owner's certificate to accompany the registration of the transaction, T. $\$ \S 141,149$.

Transfers as result of judicial proceedings generally, T. \& 205.

Section applies to partition procedings, specific performance and other equitable actions, T. $\S 206$.

Set ting aside transfer in fraud of creditors, A. § 55; T. § 207.

Transfer on judgment setting apart year's support, T. $\S 209$.

Judgment setting aside transfer for fraud or forgery, T. $\S 217$.

2. Form of the order, A. $\S 110$.

Order summarily granted, T. $\S 167$.

3. Owner's certificate, how canceled, A. 52; T. § 169.

General Note-Proceeding to effectuate the transfer on judicial proceedings discussed, $\mathrm{T} \S 208$.

Necessity of noting the lis pendens to protect the judicial proceeding, A. §§ 51, 54, 73; T. §§ $178,205$.

$\S$ 50. Involuntary Transfer - Application - Notice Hearing-Order of Judge.-Wherever in any other case it is desired to have an involuntary transfer entered of record, application therefor shall be made to the judge of the court. ${ }^{1}$ The judge may hear the facts or, if he deems best, he may refer the application to an examiner of titles ${ }^{2}$ to make up and report the facts. He shall see to it that all parties at interest are given reasonable notice before any order of transfer is made. ${ }^{3}$ Whereever, in his judgment, the interests of justice so require he shall, before granting such order, cause notice of the application to be published in the newspaper in which the sheriff's sales of the county are advertised for not less than four insertions in separate weeks. Before granting such order directing the transfer he shall fully satisfy himself that all parties who have or may 
have an interest in the matter of the transfer have been notified; and in the case of minors or other persons under disability, that guardians ad litem have been appointed to represent their interests, and that there is no valid reason why the order directing involuntary transfer should not be made, ${ }^{4}$ and thereupon he shall enter a decree or judgment ${ }^{5}$ upon the minutes of the court reciting the facts and that an order of transfer has been issued, and shall issue the order of transfer in substantially the form ${ }^{6}$ and manner herein prescribed.

1. Cognate provisions, A. $\S 41$; T. $\S \S 144,166$.

2. See A. § 15 .

3. The provisions of $A$. $\S 72$ which give the judge power to prescribe the mode of service, are pertinent to this context.

4. As to what is a valid reason for refusing summary order of transfer, see T. § 167.

5. Subject to review on writ of error to Supreme Court, A. $\S 82 ; T$. $\S 118$.

6. Form of order of transfer, A. $\S 110$.

General Note-As to the summary nature of this hearing, see $T$. $\S \S 167,185$.

General discussion of the provisions of this section, T. $\S \S 165-171$.

Use of the procedure herein outlined where land has been transferred as security and creditor refuses to re-transfer on payment of debt, T. § 152.

Procedure available to obtain re-transfer when transfer obtained by fraud or forgery, T. $\S 217$.

Procedure available to effectuate judicial sales, tax sales, sales in bankruptcy, etc., T. $\$ 168$.

Cancellation of outstanding owner's certificate, how accomplished, A. $\S 52 ;$ T. $\S 169$.

Directions to the clerk to be given in the order of transfer, T. $\S 170$.

$\S$ 51. Notation of Liens, Encumbrances and Other Adverse Claims.-Any writing or instrument for the purpose of encumbering or otherwise dealing with equitable interests in registered land, or tending to show a claim of lien or encumbrance thereon or right therein may be noted on the certificate of title in the Title Register with such effect as it may be entitled to have.

Method of causing notation to be made, A. $\S 61$; T. $\S 173$.

Notations of this kind require no order of the judge to authorize their registration, T. $\S \S 165,173$, et seq. See A. $\S 41$ and notes. 
- Form of request for such notations, A. $\$ 114$.

Pendency of writ of error to be noted under this section, T. $\S 118$.

Effect of failure to note pendency of writ of error, T. $\S 233$.

Necessity of notation of lis pendens to protect judicial proceedings affecting the title, A. §§ 54, 73; T. §§ 178, 205.

Appropriate method of registering transfer of interests and estates less than fee, A. $\S 117$; T. $\S 150$.

Notice resulting from such notations, T. $\S 245$.

Notation of judgments and tax liens, see $A . \S \S 54,57$ and annotations.

Method of causing such entries to be canceled, A. $\S \S 60,62 ;$ T. $\S \S$ $142,179-182,186$.

Form for voluntary cancellation, A. $\S 116$.

\section{$\S$ 52. Compelling Production of Owner's Certificate} on Ordering Involuntary Transfer-Cancellation by Publication.-Wherever it is sought to have an involuntary transfer registered under the provisions of this Act, ${ }^{1}$ and the owner's certificate is not produced so as to be attached to the order directing a transfer, the court shall have the power to issue subpona duces tecum or any other process designed to compel the production of the owner's certificate, including attachment for contempt, and if after the process issues the owner's certificate shall not have been produced, or it appears to the court that there is no practical means of compelling its production, the court may nevertheless grant the order of transfer, ${ }^{2}$ but shall cause the clerk to enter a cancellation of the certificate of title on the Title Register ${ }^{3}$ and to give notice once a week for four weeks in the newspaper in which the sheriff's sales of the county are advertised that such certificate has been canceled, the $\operatorname{cost}^{5}$ of making such advertisement to be deposited with the clerk before the judge grants the order of transfer without the production of the certificate.

1. Reference is had to A. $\$ \S 49,50$.

This procedure is also available where co-owner in possession of owner's certificate refuses to allow use of it for registration of an undivided interest, T. $\S 149$.

2. General discussion of this provision, $T$. $\S 169$.

3. An inspection of the form of the Title Register shown in A. $\S 99$ discloses that a memorandum must be made thereon of the page of the minutes on which the order of transfer and cancellation is recorded. See also, in same connection, T. $\S 171$. 
After such a cancellation is made the holder of the unproduced canceled certificate can never thereafter obtain on it the entry provided for in A. $\S 118$ of "Valid with all entries noted to the date." See T. $\S 227$.

4. The method and form of the advertisement is shown in T. $\S 172$.

5. Deposit for costs, T. $\S 263$.

$\S$ 53. Noting Change of Name.-Any person having any interest in registered land whose name shall have been changed by marriage or other cause may, by petition to the judge of the court, and upon proof of the facts, obtain an order directed to the clerk to note the change of name upon the Title Register, and upon the owner's certificate upon the same being produced.

Applies when the name of a corporation is changed by charter amendment, T. $\S 203$.

$\S$ 54. Judgments and Liens to Be Noted-Lis Pendens-Effect of Failure to Note.-No judgment, levy or other lien ${ }^{1}$ (except lien for taxes, as to which special provision is herein made) ${ }^{2}$ shall be effective against registered land so as to affect any person taking a transfer thereof or obtaining any right or interest therein unless and until a notation of such judgment or levy or lien be made upon the Title Register. The pendency of any suit ${ }^{3}$ affecting the title to registered land, or any interest therein, shall not be held to be notice to any person other than the actual parties to such suit unless a notation of the pendency of such suit be made upon the Title Register.

1. Method of noting judgment on register, A. $\S 61 ;$ T. $\S \S$ 174-5. Form for causing notation to be made, A. $\S 113$ :

Compare A. $\S \S 39,40,51,73$ and annotations thereunder.

Cancellation of entry, A. $\S \S 60,62 ; T$. $\S \S 142,179$, et seq.

Form of request for cancellation, A. \& 116.

2. See A. § 57.

3. Method of noting lis pendens, A. § 61; T. § 178.

Necessity for noting lis pendens, A. $\S \S 40,51,73$; T. $\S \S 178,205$.

Necessity for noting pendency of writ of error in order to effectuate judgment of Supreme Court, T. § 233.

Cancellation of entry, A. $\S \S 60,62 ;$ T. $\S \S 142,179$ et seq.

Form of request to cancel, A. § 116 . 
$\S$ 55. Transfers to Hinder, Delay or Defraud Creditors.-Nothing herein shall prevent any transfer or other dealing with registered land from being attacked in a court of law or equity as having been made for the purpose of hindering, delaying or defrauding creditors, provided, that the court having jurisdiction of the case, upon the trial thereof, shall find that the person taking the transfer, or the apparent beneficiary of such dealing, took the benefit of the same with knowledge of the fact that the intention of the transaction was to hinder, delay or defraud creditors, and provided further that none of the rights of innocent parties shall be affected thereby. If a court having jurisdiction of the case, upon such proceeding, shall find that any transfer or other dealing with registered land shall have been made for the purpose of hindering, delaying or defrauding creditors and that the rights of no innocent parties will be prejudiced by the court's judgment or decree, it shall be within the power of said court to pass such judgment or decree as will avoid such transfer or the effect of such other transaction as may have been made to hinder, delay or defraud creditors, and upon the decree or judgment of such court the judge of the superior court of the county where the land lies, upon application as hereinbefore provided, shall have the authority and power to direct such cancellations and transfers to be entered upon the Title Register and upon the owner's certificate as shall be necessary to carry the same into effect.

If the decree rendered in the suit to set aside the transfer requires a cancellation of the transfer the same is to be accomplished through the proceedings outlined in $A . \$ \$ 49,50,52$.

As to necessity for noting the lis pendens, A. § 54 and notes, T. $\S 178$.

Section cited, T. $\S 201$.

Section discussed, T. $\S 207$.

$\S$ 56. Transfers of Land Held in Trust, or with Power of Sale or on Unusual Limitations or Conditions.-Whenever a writing or record is filed for the purpose of transferring registered land in trust, or upon any condition or unusual limitation expressed therein, or where power is given to sell, encumber or deal with the land in any manner, no subsequent 
transfer or voluntary transaction purporting to be exercised under the powers given in such writing or instrument or record shall be registered on the Title Register or on the owner's certificate, except upon application to the court and order of direction from the judge to the clerk as to how the same shall be entered.

This is an exception to the general rule stated in A. $\$ 37$ that voluntary transfers accompanied by owner's certificate may be registered by the clerk without prior sanction of the judge.

General discussion of the section, T. § 204.

Applies to sales by executors and administrators, T. § 193.

Applies to sale of property set apart as year's support, T. $\S 209$.

Applies to sale of homestead property, T. $\S 210$.

It is to be noticed that this section applies to the transfer from, and not the transfer to the trustee or persons holding on condition or with unusual limitations or with power of dealing. The method of registering the transfer to such persons is dealt with in A. §38.

\section{\$ 57. Notation of Taxes and Assessments-Effect of} Failure to Note.-It shall be the duty of every officer in this State charged with the collection of taxes or assessments which shall be a charge upon any registered land or any interest therein, if such taxes or assessments are not paid when due, on or after the expiry of the 31 st day of December of the year in which such tax or assessment shall become due, to cause to be entered upon the certificate of title on the Title Register a notation of the fact that such tax or assessment on such registered land or interest therein has not been paid, and the amount thereof. Until and unless such notation is made such delinquent tax or assessment shall not affect any transfer or other dealing with such registered land, but the tax officer failing to perform such duty, and his surety, shall be liable for the payment of said taxes and assessments, with all lawful penalties and interest thereon if any loss is occasioned to the political body, be it State, county, municipality or other division by which such loss is sustained.

Taxes and assessments for current year excepted, A. § 63, T. § 223. Notation how made, T. $\S 177$.

Form requesting notation, A. $\S 112$.

Cancellation of entry, A. $\S \S 60,62 ;$ T. $\S 186$. 
§ 58. Duplicate in Lieu of Lost Owner's CertificateHow Issued.-Whenever an owner's certificate of title is lost or destroyed, the owner, or his personal representative, may petition the court for the issuance of a duplicate. Notice of such petition shall be published once a week for four successive weeks in the newspaper in which the sheriff's sales of the county are published, and upon satisfactory proof having been exhibited before it that said certificate has been lost or destroyed, the court may direct the issuance of a duplicate certificate, which shall be appropriately designed and take the place of the original owner's certificate. ${ }^{1}$ Provided, that the court may in any case order additional notice to be given, either by publication or otherwise, ${ }^{2}$ before directing the issuance of a duplicate certificate, and provided further that in case the application is made by personal representative of a deceased person claiming that the certificate was lost or destroyed while in the possession of the decedent ${ }^{3}$ the notice of the petition shall be published once a week for eight successive weeks, instead of four, as required in other cases.

1. General discussion of provisions of this section, T. $\S 135$.

2. Compare A. $\S 72$.

3. Discussion of these provisions as applied to executor or administrator, T. $\S 191$; as applied to heirs at law, T. $\$ 197$.

\section{$\S$ 59. Duties of Clerk as to Registration-Supervisory Powers of Judge-Caveat to Entry or Transfer-Twelve} Months' Limitation.-The clerk of the superior court is charged with the primary duty of determining whether any instrument, writing or record or other matter is in proper shape for registration, 1 and with the duty of correctly and legally making the registration, including all formal incidents thereto, and shall be liable to any injured person for any failure of duty in this respect. ${ }^{2}$ All registrations of title and all entries and notations made by him upon the Title Register of transfers or of the cancellation or discharge of liens or encumbrances, shall be prima facie conclusive $;^{3}$ and unless a caveat be filed, as provided for in this Act, ${ }^{4}$ seeking to set aside, modify or otherwise affect such entry, notation or registration within twelve months ${ }^{5}$ from the date of the making of the same upon the Title Regis- 
ter the same shall become absolutely conclusive upon all persons; $;$ this to be considered and construed as a statute of limitations against the questioning of the correctness of the clerk's action, and is to be without exception on account of disabilities but shall not operate as a limitation in favor of the clerk as to any action against him for wrongdoing or neglect of duty. ${ }^{7}$ In the event application is made to a clerk to have any transfer or other transaction registered or noted, and he shall be in doubt as to whether the same should be registered, entered or noted, or shall be in doubt in regard to any detail thereof, either the clerk or any party at interest may petition the judge of the court for direction, ${ }^{8}$ and such judge, after it shall have appeared that the parties at interest have had reasonable notice, ${ }^{9}$ may proceed to hear the matter and to give directions and instructions to the clerk, whose duty it shall be to follow the directions and instructions of the court. In all matters required of the clerk under this Act, he shall be subject to the direction and orders of the court. ${ }^{10}$

1. Duty and liability of clerk as to verifying correctness of attestation, A. $\S 106$; T. $\S \S 269,270$.

2. Clerk must not relax safeguards of the Act against fraud and forgery, T. § 215.

General discussion of the duty and liability of the clerk, T. $\S \S 269$, 270.

3. As affecting the burden of proof in attacks on registration, $T$. $\S 218$.

Meaning and effect of this provision, T. § 228.

Does not apply to all entries, T. $\S 229$.

4. See A. $\S 60$ and notes thereunder.

5. When this limitation is applicable and when not, $T$. $\S 229$.

Matters adjudicated on original registration not within the purview of this provision, A. $\S 27 ;$ T. $\S 230$.

How far this affects conclusiveness of registration, T. $\S 228$.

6. Cancellation of entries, how affected by this provision, T. $\S 231$; see also T. $\S 181$.

7. Compare A. § 84; also T. §§ 256-7, 269.

8. Method of asking instructions of the judge, T. $\S 131$.

Suggestions on this subject, T. $\S \S 270,275$.

When clerk has doubt as to authority of person purporting to act for corporation to do so, T. $\S 164$.

9. Judge's authority as to prescribing method of notice, A. $\S 72$. 
10. Judge is general supervisor of registry; clerk is purely Ministerial officer, T. $\S \S 228,270,275$.

Relation of this provision to constitutionality of the Act, T. $\S 16$.

Powers of Attorney-General as ex-officio supervisor of county records, T. $\$ 274$.

Judge's power to give direction in every extraordinary situation, see T. $\S 275$.

\section{$\S 60$. Proceedings to Correct, Modify or Cancel Reg-} istration-Summary Powers of Judge.-If any person at interest shall object to any entry, registration or notation 1 made by the clerk upon the Title Register, he may, unless such entry, registration or notation shall have become conclusive by lapse of time under the provisions of this Act, ${ }^{2}$ file with the clerk of the court a cavcat, setting forth the entry, notation or registration to which he objects; setting forth what interest he has in the subject matter, and setting forth the ground of his objection and praying for such relief as he desires and deems appropriate in the premises. ${ }^{3}$ Thereupon the clerk shall note upon the Register of Titles the fact that caveat has been filed, and by whom, and to what entry, notation or act of registration it applies. Thereupon the matter shall be presented to the judge, who shall order all persons at interest, to show cause on a day named why the relief prayed for in the caveat should not be granted, and upon proof being made that due notice ${ }^{4}$ has been given to all parties at interest the judge shall proceed to hear ${ }^{5}$ the matter and shall render a judgment of the court, giving direction to the matter, ${ }^{6}$ and may thereupon require such entry, registration or notation to be canceled or modified, and may require the outstanding certificate of title and owner's certificate to be modified accordingly. To that end the court may require the outstanding owner's certificate of title to be brought into court by subpoena duces tecum, or other process, including attachment for contempt, and if the court finds that production of the certificate cannot be compelled, then he shall provide for publication of notices ${ }^{7}$ of the court's action thereon for a period of time not less than once a week for four weeks in the paper in which the sheriff's sales of the county are advertised, the expense $^{8}$ of making the publication to be provided for in such manner as the court shall order. 
1. This language is broader than the language of the cognate provision of A. \$ 59. That language refers only to registrations and entries of transfers and cancellations; this language includes "any entry registration or notation." See T. $\$ 229$.

The clerk is such a person at interest as that he may take the benefits of this section, T. $\S 183$.

2. Reference is to the twelve-months' limitation set in A. § 59 . See T. $\S 229$.

Does not apply to regular court action attacking registration for fraud or forgery or affect the limitation set in A. $\$ 63$; T. $\S 217$.

3. This is the appropriate method of obtaining correction of registrations and entries erroneously made. T. $\S 183$.

May be used within the twelve-months to attack a transfer for fraud or forgery, T. $\S \S 184,217$.

Suggestion as to form of caveat and procedure thereunder, T. $\S \S$ 181-5.

4. Judge's power as to prescribing mode of notice, A. § 72 .

5. The summary nature of the hearing, T. $\S \S 182,185,228$.

6. Discretion of the judge as to what direction he shall give, $T$. $\S 185$.

Conclusiveness of registration not to be affected by any direction so given, T. $\S 228$.

Matters adjudicated on original registration not to be disturbed, T. $\S 230$.

7. Compare A. $\$ \mathbf{5 2}$ and notes.

8. Discretion as to taxing the costs, A. $\S 120 ;$ T. $\S 264$.

General Note-Entries thus canceled or discharged are not to be brought forward on subsequent issues of the certificate of title, A. §39.

\section{$\S$ 61. Liens, Encumbrances and Other Adverse Claims} -Method of Noting.-The method of causing notations of judgments, liens, encumbrances or special rights of any kind, 1 other than voluntary transactions ${ }^{2}$ claimed by any person against registered land, shall be as follows: The person desiring the notation to be made shall, by himself, his agent or attorney, file, upon a form substantially in compliance with that herein provided for, ${ }^{3}$ a request for the notation to be made, giving the particulars, and in case the lien or special rights relate to any other matter of record or court proceeding, he shall state the book and page where recorded, and if it relates to any special right, shall succinctly give the details of such right so claimed. In case the notation is for the purpose of protecting 
the lien of a judgment ${ }^{4}$ the person making the application for the notation shall produce and exhibit to the clerk the execution or a certified copy of the judgment, except in cases where the judgment is rendered in the superior court of the same county where the registration is made, in which event production of the execution or certified copy of the judgment shall not be required, but the clerk may act upon inspection of the original judgment on the minutes of his own court.

1. Among other things to which this section applies are the notations allowable under A. $\S 51$.

Taxes and assessments are specially dealt with in A. § 57 .

This section also applies to notation of lis pendens, which is specially dealt with in A. $\S 54$.

General discussion of the provisions of this section, T. $\S \S 145$, 173-6.

2. In addition to the provision relating to voluntary transfers, transfers to secure debt and mortgages, see $\mathrm{A}$. $\S \mathbf{1 1 7}$ as to the registration of other voluntary transactions such as homestead and exemption rights. This section applies only to notations adverse to the owner.

For definition of "voluntary transactions," see A. § 3, T. § 21 .

3. The general form for requesting the notation of an adverse entry is prescribed in $A . \S 114$.

4. The notation of judgments is specially dealt with in A. \& 54; the form of noting a judgment is given in A. \& 113 .

\section{$\S$ 62. Voluntary Cancellation of Mortgages, Liens and} Other Adverse Notations.-Voluntary cancellations 1 may be made of any mortgage, certificate of indebtedness or any lien, equity, encumbrance, lis pendens or other similar matter relating to registered land or any interest therein, and may be entered by the clerk upon the Title Register and the owner's certificate. The entry, notation or registry of such cancellation may be made upon the written authority of the person for whose benefit the original registration, notation or entry was made, or his personal representative, or lawful assignee, in a form substantially in compliance with that herein prescribed, ${ }^{2}$ attested by any officer authorized to attest deeds; or upon order of the judge. ${ }^{3}$ In case of a creditor's certificate ${ }^{4}$ the same shall also be surrendered and canceled. Notations of delin- 
quent taxes or assessments may be canceled upon the production of a certificate of the proper tax officer showing that such taxes or assessments have been paid. ${ }^{5}$

1. As to how involuntary cancellation may be compelled, A. $\S 60$ and notes.

2. The form is prescribed in A. § 116. The form there set forth omits the attesting clause required by this section.

3. If a judgment or other lien is satisfied but the owner refuses to execute the necessary formal request for its cancellation on Title Register, the judge may nevertheless order it canceled.

4. See A. $\S 33$, T. $\S 159$.

5. See T. $\S 186$.

General Note-General discussion of the provisions of this section, T. $\S \S 142,180$.

After an entry is canceled under this section, it is no longer to be brought forward on subsequent issues of the certificate of title, as required by $\mathrm{A}$. $\S 39$.

How far an incorrect entry of a cancellation can be corrected, $T$. $\S 231$.

$\S 63$. Conclusiveness of Registration-ExceptionsAttacks for Fraud or Forgery.-Every registered owner of any estate or interest in land brought under this Act shall, except in cases of fraud or forgery ${ }^{1}$ to which he is a party, or to which he is a privy without valuable consideration paid in good faith, ${ }^{2}$ hold the land free from any and all adverse claims, rights, or encumbrances not noted on the certificate of title in the Title Register, ${ }^{3}$ except:

First. Liens, claims or rights arising or existing under the laws or Constitution of the United States which the statutes of this State cannot require to appear of record under registry laws. 4

Second. Taxes and levies assessed thereon for the current calendar year. ${ }^{5}$

Third. Any lease for a term not exceeding three years, under which the land is actually occupied. ${ }^{6}$

Fourth. Highways in public use and railroads in actual operation. ${ }^{7}$

No proceedings to attack or to set aside any transaction for 
such fraud or such forgery as is referred to in this section shall be brought or be entertained by any court unless the same shall have been brought within seven years from the date of the transaction or of the registration to which the same relates. ${ }^{8}$ Nothing herein shall conflict with the provisions of this Act allowing attack for good cause to be made upon a registration made by the clerk at any time within twelve months from the date of such registration. ${ }^{9}$

1. Attacks for fraud or forgery generally, T. $\S \S 217-8$.

Fraud in initial registration, T. $\S 219$.

2. New registered owner purchasing in good faith and for value holds against old owner when transfer results from fraud or forgery, T. §§ 213-6.

3. The certificate of title and not owner's certificate is what controls, T. § 226 .

This includes entries and notations brought forward, under $A$. $\S 39$.

Every voluntary or involuntary transaction noted on the register operates to its own lawful extent, $A . \S \S 40,51$, and notes thereunder. Judgments though not noted are binding between the original parties, A. \& 54; but not as to third persons dealing with the land whether with or without aliunde notice, T. $\$ 245$.

The same is true as to lis pendens, A. $\S 54$; T. $\S \S 178,245$.

The same is also true as to liens for delinquent taxes, A. \& 57; with or without aliunde notice, T. $\$ 245$.

4. Generally, T. § 220 .

Liens under federal statutes or as the result of proceedings in United States courts, T. § 221.

Rights acquired through bankruptcy proceedings, T. $\$ 222$.

5. Discussed, generally, T. § 220; particularly, T. $\S 223$.

6. Discussed, generally, T. $\S 220$; praticularly, T. \& 224.

7. Discussed, generally, T. § 220 ; particularly, T. § 225.

8. See $T$. $\S \S 217-8$.

9. Reconcilement between the provisions of this section and the provisions of A. $\S 60$ giving the judge summary supervisory powers over register, $T$. $\S \S 185,228$.

General Note-This section does not, in any wise, militate against the provisions of $A$. $\S 73$, that registered lands are subject to the ordinary jurisdiction of the courts. For the reconciliation between the two sections, see T. $\S \S 11,205-6$.

The conclusiveness of registration is in no wise affected by adverse possession, A. $\S 66$; T. $\S 232$.

Effect of reversal of judgment authorizing registration, T. $\S 233$. 


\section{$\S$ 64. Obtaining a Decree of Registration as a Cove-} nant Running with the Land.-The obtaining of a decree of registration and the entry of a certificate of title shall be construed as an agreement running with the land, and except as hereinafter provided, the same shall remain registered land subject to the provisions of this Act and all amendments thereof.

General discussion of this section, T. § 117.

The exception mentioned relates to an owner's freeing his land from registration, A. $\S 65 ;$ T. $\$ \S 234-8$.

Effect of this section on the constitutionality of certain provisions of the Act, T. $\S 20$.

§ 65. Freeing the Land from Registration.-If the person who is the registered owner of the fee simple title to the land shall at any time so desire, he may cause a transfer of the title to be registered to himself, "his heirs and assigns, free from further registration." Thereupon the land and the title thereto shall be free from the necessity of subsequent registration, and shall as to subsequent transactions be exempt from the provisions of this Act, so far as the interest of the person thus freeing it from registration and subsequent holders under him are concerned; but as to such interest the certificate of title and owner's certificate registered and issued on the last transfer shall stand as a conclusive source of subsequent title to the same extent as if it were a grant from the State. However, if the interest thus freed is, according to the Title Register, subject to liens, exceptions, encumbrances, trusts or limitations of any kind, such liens, exceptions, encumbrances, trusts or limitations shall not be affected, but shall be noted on the owner's certificate as issued on the last transfer and shall be effective against the same as long as they shall subsist. If the fee simple be registered undividedly in the name of more than one person, as tenants in common or other like relationship of joint or common interest, it shall not be freed from registration except upon the unanimous action of the owners of the entire fee.

Discussed, T. $\S \S 234-8$.

Certificate issued on last registration as evidence on behalf of subsequent owners, T. \& 246. 
§ 66. Registered Title Not Affected by Prescription or Adverse Possession.-No title to nor right nor interest in registered land in derogation of that of the registered owner shall be acquired by prescription or adverse possession.

Discussed generally, T. § 232.

Rule, that possession is notice, abolished as to registered land, T. $\S 245$.

Statute against administrator or executor selling pending adverse possession, how affected by this section, T. $\S 189$.

\section{$\S$ 67. Courts Always Open for Purposes of Registra-} tion.-For the purposes of this Act, the superior courts of the various counties of this State shall be considered as being open and in session at all times, except on Sundays; and every official act of the judge on any matter shall be considered as having been rendered in open court; and no recess or adjournment of the court taken generally or for any other particular purpose shall be considered as having recessed or adjourned the court so far as the purposes of this Act are concerned; and any limitations existing, either under general law or special acts as to the length of time in which the various superior courts of this State may sit in the various counties shall not be construed as affecting the provisions of this Act.

Discussed, T. § 265.

Applies also to summary proceedings before judge, T. $\S 167$.

$\S$ 68. Free Access to Public Records by Examiner.Every clerk of the superior court, every ordinary and every other officer in this State having charge of public records shall allow each and every examiner appointed by any court in this State, for the purposes of this Act, free inspection of all the public records relating to his office and in any wise appertaining to any matter under the investigation of such examiner.

$\S$ 69. Disqualification of Clerk-Special Clerk.-In case any clerk is disqualified by reason of relationship or interest, or from any other cause, or in case of the death or other disability of the clerk of the superior court to act in any matter arising under this Act, the duties [required] of such clerk may be per- 
formed either by the ordinary of the county or by a special clerk appointed by the judge for that purpose, the entry of appointment of such special clerk and of the purpose for which he is appointed being duly entered and recorded upon the minutes of the court.

All officers so acting fall within the purview of the word "clerk" as used throughout the Act, A. § $3 ;$ T. $\S 21$.

All the penalties imposed on the clerk apply also to the special clerks, T. \& 258.

General subject discussed, T. § 267.

Deputies, A. $\S 83 ;$ T. $\S 268$.

$\S 70$. Rules of Court to be Prescribed by Judges in Convention.-The judges of the superior courts in convention may from time to time make general rules and forms for procedure relating to the subjects in this Act dealt with, and may modify the forms herein prescribed, but such rules and forms shall be uniform throughout the State, and shall be subject to the provisions of this Act and the general laws of this State.

Discussed, T. $\S 266$.

Suggestion as to making provision for issuance of special certificate in favor of holder of a lesser estate than the fee, T. $\S 150$.

$\S$ 71. Employment of Stenographer.-In any case, by consent of the parties or upon order of the judge, the examiner may procure the services of a stenographer to report the testimony taken before him, and the compensation of such stenographer, unless agreed on by the parties, shall be fixed by the judge and taxed as costs.

See T. \& 93.

Compensation, A. § 120; T. § 260.

$\S$ 72. Power of the Judge to Provide for Notice.Wherever notice is required by this Act and no provision as to how notice shall be given is made, or wherever, in the discretion of the judge, additional notice to that provided for in this Act, should be given to any particular person or persons, or to the public generally, the judge may order such notice to be given, and provide the manner in which it shall be given. 
Discussed generally, T. $\S \S 65,166$.

For instances in which the judge may be called on to exercise this power see A. $\S \S 10,50,58,59,60 ;$ T. $\S \S 53,166,182$.

$\S$ 73. Ordinary Rights, Incidents and Burdens Attach to Registered Land-Necessity of Registering Such Matters-Jurisdiction of the Courts.-Except as otherwise specially provided by this Act, registered land and ownership therein shall be subject to the same rights, burdens and incidents as unregistered land, ${ }^{1}$ and may be dealt with by the owner, and shall be subject to the jurisdiction of the courts in the same manner as if it had not been registered. ${ }^{2}$ But registration shall be the only operative act to transfer or affect the title to registered land, ${ }^{3}$ and shall date from the time the writing, instrument or record to be registered is duly registered on the Title Register. Subject to the provisions of Section 63, no voluntary nor involuntary transaction shall affect the title to registered land until registered or noted on the Title Register, in accordance with the provisions of the Act. ${ }^{4}$

1. Title in its substantive sense of ownership is not affected by registration; only the means of evidencing it and the burdens on it are affected, T. $\S 3$.

2. As to how the ordinary jurisdiction of the courts is made effective against registered lands, T. $\S \S 11,12,205-6$.

The harmony between the Act and the general rules of substantive law and equity, T. $\S 138$.

Reconciliation between this section and $A . \S 63 ; T$. $\S \S 205-6$.

Procedure to enforce rights against registered lands, A. $\S \S 49,50$, 55 , and notes thereto.

Necessity of noting lis pendens to make judicial action effective, A. $\S 54$ and notes thereto.

3. The certificate of title is conclusive and exclusive as to what rights attach to and what burdens may affect registered land. $T$. $\S 239$.

But any adverse claim may be noted so as to be made effective, A. \& 51 and notes thereto.

No aliunde proof of notice, T. $\S 245$.

4. Cognate provision, A. $\S 40$.

Reversal of judgment authorizing registration does not affect the conclusiveness of the registration unless notice of the pendency of the writ of error is noted on the register, T. § 233. 
$\S$ 74. Assessment for Assurance Fund.-Upon the original registration of any land under this Act there shall be paid to the clerk one-tenth of one per centum of the value of such land, to be determined by the court, as an assurance fund, which shall be subject to the trusts and conditions hereinafter declared for the uses and purposes of this Act.

Assurance fund not an essential feature of land registration, T. $\S$ 248.

Who liable for the assessment, T. $\$ 249$.

$\S$ 75. Deposit in State Treasury.-All moneys received by the clerk under the preceding section shall be kept in a separate account and be paid promptly into the State Treasury upon the special trust and condition that the same shall be set aside by the Treasurer in trust as a separate fund for the uses and purposes of this Act, to be known as the "Land Registration Assurance Fund," which said fund is hereby appropriated to the uses and purposes set forth in this Act.

See T. $\S 249$.

$\S$ 76. Investment and Use of Assurance Fund.-Said moneys, in so far as the same may not be required to satisfy any judgment certified against the assurance fund under Section 79 of this Act, shall be invested by the Treasurer of the State in State bonds, or validated county or municipal bonds in trust for the uses and purposes set forth in this Act until said fund amounts to the sum of five hundred thousand dollars; but the income, or so much thereof as may be required therefor, may be applied towards the payment of the expenses of the administration of this Act and the satisfaction of any such judgment. Whenever and so long as the face value of the bonds purchased as aforesaid equals said sum of five hundred thousand dollars, other moneys thereafter coming into said fund, together with any income not required for the purposes aforesaid, shall be transferred from the land registration assurance fund to the general Treasury.

$\S$ 77. Actions against Assurance Fund-LimitationsMeasure of Damage.-Any person entitled to notice and who 
had no actual notice 1 of any registration under this Act by which he may be deprived of any estate or interest in land, ${ }^{2}$ and who is without remedy hereunder, ${ }^{3}$ may, within two years ${ }^{4}$ next after the time at which the right to bring such actions shall have first accrued to him, or to some person through whom he claims, ${ }^{5}$ bring an action of assumpsit against the Treasurer of the State ${ }^{6}$ in the Superior Court in the county where such land is located for the recovery, cut of the assurance fund, of any damages to which he may be entitled by reason of any such deprivation. The Treasurer shall be served by second original copy of proceedings so filed, which service shall be sufficient. The assurance fund shall be defended in such action and in any appeal by the Attorney-General for the State. ${ }^{7}$ The measure of damages in such action shall be the value of the property at the time the right to bring such action first accrued, and any judgment rendered therefor shall be paid as herein [before] provided. ${ }^{8}$ If any person entitled to bring such action be under the disability of infancy, insanity, imprisonment or absence from the State in the service of the State or of the United States at the time the right to bring such action first accrued, ${ }^{9}$ the same may be brought by him or his privies within two years after the removal of such disability, but, provided, nevertheless, that all persons non-resident of the State, all persons who are described in the proceedings as being unknown, or of unknown address, or as to whom it appears from the record that they could not be found so as to be served, shall be considered as having had actual notice where notice has been published in accordance with the provisions of this Act. ${ }^{10}$

1. Under A. $\S 14$, any method of notice prescribed by the Act stands as if it were actual notice, T. $\$ \S 74,251$.

2. Mere lien-holders not protected hereby, T. $\S 251$.

3. Does not exclude persons having remedy against officers for breach of duty, T. $\S \S 251,257$.

4. Discussed, T. $\S 252$.

5. This provision extends the right of action to privies, T. $\S 251$.

6. Compare A. $\S 78 ;$ T. $\S 255$.

7. See T. $\S 255$.

8. Discussed, T. $\S 253$. The enrolled act uses the word "hereinafter."

Demand bears interest after judgment if not paid for lack of sufficient funds, A. $\S 81 ;$ T. $\S 253$. 
9. Compare A. § 27.

No suspension of statute of limitations for disability occurring after time begins to run, T. $\S 252$.

10. See A. § $14 ;$ T. $\S 251$.

$\S$ 78. Parties to Actions against Assurance Fund.-If such action be brought to recover for loss or damage arising only through the legal operation of this Act, then the Treasurer of the State shall be the sole defendant. But if such action be brought to recover for loss or damage arising on account of any registration made or procured through fraud, neglect or wrongful act of any person not exercising judicial function, then both the Treasurer of the State and such person or persons shall be made parties defendant.

Discussed, T. § 255.

$\S$ 79. Judgments against Fund-Subrogation.-If judgment be rendered for the plaintiff in any such action, execution shall issue against the defendant, if any, other than the Treasurer of the State. And if such execution be returned unsatisfied in whole or in part, or if there be no such defendants, then the clerk of the court in which the judgment was rendered shall certify to the Treasurer the amount due on account thereof, and the same shall be then paid by said Treasurer out of the assurance fund under the special appropriation hereby made of said fund for that purpose. Any person other than the Treasurer of the State against whom any such judgment may have been rendered shall remain liable therefor, or for so much thereof as may be paid out of the assurance fund, and said Treasurer may bring suit at any time to enforce the lien of such judgment against such person or his estate for the recovery of the amount, with interest, paid out of the assurance fund as aforesaid.

Discussed, T. § 256-7.

$\S$ 80. No Action against Fund from Breach of Duty by Trustee.-The assurance fund shall not, under any circumstances, be liable for any loss, damage, or deprivation occasioned by a breach of trust, whether express, implied, or con- 
structive, on the part of the registered owner of any estate or interest in land.

Discussed, T. § 254 .

§ 81. Where Assurance Fund Insufficient to Pay All Judgments.-If at any time the assurance fund be insufficient to satisfy any judgment certified against it as aforesaid, the unpaid amount shall bear interest and be paid in its order out of any moneys thereafter coming into said fund.

Discussed, T. $\S \S 249,253$.

$\S$ 82. Review of Registration Proceedings by Supreme Court-Fast Writ.-All judgments and decrees of the superior court ${ }^{1}$ or the judge thereof rendered under the provisions of this Act ${ }^{2}$ shall be subject to review by the supreme court upon writ of error, ${ }^{3}$ and the procedure to obtain such review shall be by what is known as fast writ of error, ${ }^{4}$ and such as obtains in injunction and criminal cases.

1. Judgment of dismissal or decree of title rendered as result of proceedings for initial registration, A. $\S 26 ; T$. $\S \S 99,118$. See also A. $\S 20$.

Suggestion as to the need of reference to the right of appeal, in the decree of title, $T$. $\S 114$.

2. This gives the right of writ of error to any judgment rendered in summary proceedings under $A$. $\S \S 49,50,60$ and cognate provisions of the Act or in proceedings to establish heirship under A. $\S 45$ and similar proceedings provided for in the course of the Act.

3. General discussion of the subject, T. $\S 118$.

Separate writs of error and separate records in case of severance, T. $\S \S 58-9,118$.

Effect of failure to note the pendency of the writ of error on the Title Register, A. §§ 54, 63, 73; T. § 233.

4. See T. $\S 118$.

$\S$ 83. Deputy Clerks and Sheriffs-Powers and Responsibilities.-The duties required of the clerk and sheriff hereunder may be performed through their lawful deputies, the clerk or sheriff, as the case may be, however, being responsible for the act of such deputy.

See A. $\S 3 ;$ T. $\S \S 21,68,258,268$. 


\section{$\S$ 84. Rights of Action Saved against Officers and} Others for Acts Occasioning Injury.-Neither the limitations provided by this Act within which proceedings hereunder may be brought, nor the provisions setting times whereupon matters and things shall become conclusive, shall prevent any injured party from having an action at law against any person or officer through whose fraud or negligence he may have suffered any loss or damage arising out of any acts of omission or of commission of such person or officer in connection with the matters and things arising from the provisions of this Act, but all such actions shall be governed by the statutes of limitations which would otherwise relate to the transaction.

See generally on the subject $T$. $\S \S 231,257$.

The conclusiveness given to the judgment reciting proper service does not protect the officers charged with the duty of correctly making it, A. § 13 ; T. $\S \S 73-4$.

Cognate provision, A. $\S 59$.

$\S$ 85. Crimes and Offenses.-Any person who shall fraudulently obtain or attempt to obtain a decree of registration of title to any land or interest therein, or who shall knowingly offer in evidence any forged or fraudulent document in the course of any proceedings in regard to registered lands or any interest therein, or who shall make or utter any forged instrument of transfer or instrument of mortgage, or any other paper, writing or document used in connection with any of the proceedings required for the registration of lands, or the notations of entries upon the Register of Titles, or who shall steal or fraudulently secrete any owner's certificate, creditor's certificate, or other certificate of title provided for under this Act, or who shall fraudulently alter, change or mutilate any writing, instrument, document or record or registration or register provided for under this Act, or who shall make any false oath or affidavit in respect to any matter or thing provided for in this Act, or who shall make or knowingly use any counterfeit of any certificate provided for by this Act shall be guilty of a felony and be punished by imprisonment in the penitentiary for not less than one nor more than ten years. Any clerk, deputy clerk, special clerk or other person performing the duties of clerk, who shall fraudu- 
lently enter a decree of registration without authority of the court, or who shall fraudulently register any title, or who shall fraudulently make any notation or entry upon the Title Register, or shall fraudulently. issue any certificate of title, or creditor's certificate or other instrument provided for by this Act, or who shall knowingly, intentionally and fraudulently do any act of omission or commission under color of his office in relation to the matters provided for by this Act shall be guilty of a felony and be punished by imprisonment in the penitentiary for not less than one nor more than ten years and shall, upon his conviction, be removed from office and thereafter forever disqualified from holding any public office. Any examiner of title who shall knowingly and fraudulently make any false report to the court as to any matter relating to any title which it is sought to register under the provisions of this Act, or as to any matter affecting the same, or as to any other matter referred to him under the provisions of this Act, or who shall fraudulently conspire or confederate with any other person or persons to use the provisions of this Act to the defrauding of any person or persons, firm or corporation, or who shall be guilty of any willful malpractice in his office shall be guilty of a felony and be punishable by imprisonment in the penitentiary for not less than one nor more than ten years. Any sheriff or deputy sheriff or other person performing the duties of the office of sheriff who shall knowingly and fraudulently make any false entry or return in connection with any matter arising under the provisions of this Act, or who shall fraudulently conspire with any person or persons to defraud any other person or persons through the provisions of this Act, shall be guilty of a felony and be punished by imprisonment in the penitentiary for not less than one nor more than ten years, and on conviction shall be removed from office and thereafter forever disqualified from holding any public office in this State.

The felonies provided for in this Act may, in the matter of punishment, be reduced to misdemeanors in the manner prescribed in Section 1062 of the penal code of this State.

Discussed in detail, T. $\S 258$. 
$\S$ 86. Form of Petition for Initial Registration.-The following is prescribed as the form of petition to be used when application is made for the original register of lands: ${ }^{1}$

INITIAL PETITION FOR REGISTRATION OF LAND.

Georgia,........................

To the Superior Court of said County:

The petition of.

shows:

The petitioner applies to have the land hereinafter described brought under the provisions of the Land Registration Act, and his title thereto confirmed and registered as provided therein, and under oath shows the following facts:

(1) Full name of each applicant

(2) Residence of each applicant

(3) Post office address of each applicant.

(4) The name and address of applicant's agent or attorney upon whom process or notices may be served (not required unless applicant is a non-resident)...

(5) Full description of the lands (giving also land district and lot numbers where the land lies in that portion of the State where the lands have been surveyed by districts and numbers; and if more than one parcel is included, describe each parcel separately and distinctly)

containing. acres.

(6) What is the value thereof? $\$ \ldots \ldots \ldots \ldots \ldots \ldots$

(7) At what value was it last assessed for taxes? $\$ \ldots \ldots$ 
(8) What interest or estate does the applicant claim therein?

(9) What is the value of the interest or estate claimed by the applicant?.

(10) From whom did the applicant acquire the land?.....

(11) Does the applicant claim title by prescription?.......

(If so, set forth fully the color of title, if any, under which the prescription is claimed and state the details of the possession by which it is claimed prescription has ripened. If the color of title consists of one or more instruments of record on the public records of the county such instruments need not be copied or exhibited to the application otherwise than by giving the name of the grantor, and the grantee, the date and nature of the instrument and a reference to the book and page where recorded.)

(12) Does the applicant claim title by a complete chain of title from the State or other original source of title?.

(13) Is there a true and correct abstract of applicant's title

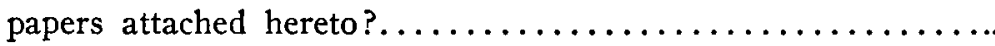

(14) Do you know, or have information, of any other deed, writing, document, judgment, decree, mortgage or instrument of any kind not set forth in the abstract which relates to this land or any part thereof or which might affect the title thereto or some interest therein? If so, state the same............

(15) Has the land, or any part thereof, ever been set apart as a homestead or exemption or as dower? If so, state particulars.

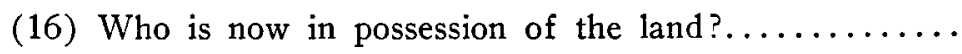


(17) Do you know any one else who claims to be in possession of the land or any part thereof? If so, give name and address.

(18) Give name and address of each person occupying the land or any part thereof, and state by what right or claim of right such occupancy is held.........................

(19) Give the name, residence and address of each and every person, other than the applicants who claim any interest, adverse or otherwise, vested or otherwise, in the land [or] any part thereof, stating the nature of the claim, and if any such persons are under disability of any kind, state the nature of the disability:

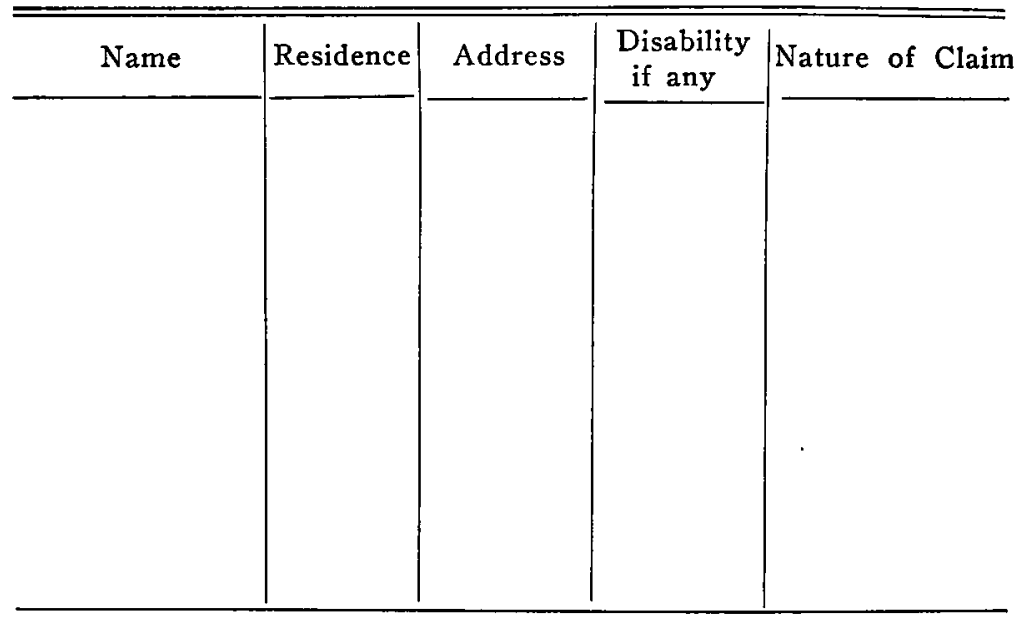

(20) Give the name, residence and address of the holder of every known lien, whether considered by the applicant to be valid or not: 


\begin{tabular}{l|l|l|l}
\hline \hline Name & Residence & Address & Nature of Lien \\
\hline & & & \\
& & & \\
& & & \\
\end{tabular}

(21) Give the names and addresses of the owners and occupants of all adjoining lands..$\ldots \ldots \ldots \ldots \ldots \ldots \ldots \ldots$

(22) Is the land subject to any easement, except public highways and railroads in actual operation? If so, state fully

(23) Give age of applicant.

(24) Is the applicant male or female?.........married or

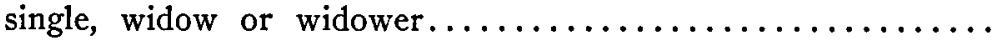

(25) If married, give wife's (or husband's) name and include her or him in the list of defendants.

(26) The applicant names as defendants the following persons whose names have been given above, viz.............

and also all other persons "whom it may concern."

Wherefore the applicant prays process and judgment accordingly. 
(To be sworn to by each applicant. Verification in case of a corporation may be made by any officer thereof; in case of minor or other person under disability, by the person filing the petition in his behalf.)

I do swear that I have read the foregoing petition, and I have examined the schedules thereto attached, and that the same are true to the best of my knowledge and belief, and that nothing has been withheld in the answers which would in any wise affect the title to the land or any interest therein or which would disclose any person claiming an adverse interest, valid or not. I do further swear that I bona fide believe that the applicant is the true owner of the estate he seeks to have registered.

Sworn to and subscribed before me, this...... day of ..........191.....

(If more than one applicant, they may verify jointly or by separate affidavits.)

\section{Exhibit A.}

\section{(Abstract of Title.)}

1. This is to be construed in connection with $A$. $\S 7$, which states the substance of the petition.

Adaptation of this form to cross-petitions, T. $\S 53$.

Adaptation of this form where petitioner seeks to establish title to less than fee under A. $\S 6$, T. $\S 31$.

General Note-In T. $\$ \S 31-51$, suggestions are made in great detail as to the preparation of the petition and the filling of the various blanks. These suggestions are intended to be considered as a whole, hence no attempt is made to annotate them distributively.

$\S$ 87. Form of Process.-The following is prescribed as the form of process to be attached to the petition:

Georgia,.....................

In the Superior Court of said County:

To the Sheriffs of said State and their Lawful Deputies:

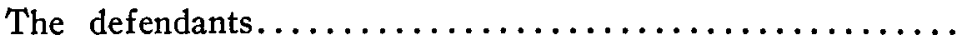


and all other persons whom it may concern are required to show cause before said court on the...... day of......... $191 \ldots$... (not less than forty or more than fifty days from date of process), why the prayers of the foregoing petition should not be granted, and why the court should not proceed to judgment in such cause. Witness the Honorable.............. Judge of said court, this the..... day of..............

Clerk.

See A. $\S 10 ;$ T. $\S 62$.

$\S$ 88. Form of Notice by Publication and Posting on the Land.-The advertisement to be inserted in the newspaper in which the sheriff's sales of the county are advertised for four insertions in separate weeks should be substantially in the following form:

Georgia,......................

In the Superior Court of said County:

To whom it may concern, and to (here insert the names of all defendants, if any, who reside beyond the limits of the State, or whose place of residence is unknown).

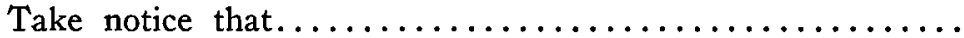
has filed in said court a petition seeking to register the following lands under the provisions of the Land Registration Act, to-wit: (Here describe lands.) You are warned to show cause to the contrary, if any you have, before said court on the..... day of..........191.....

This..... day of ..........191....

\section{Clerk.}

See A. $\S 10 ;$ T. $\S 64$.

This also constitutes the form of notice to be posted on the land by the sheriff when he makes his constructive seizure, A. $\S 14 ; T$. $\S 71$.

$\S$ 89. Form of Acknowledgment of Service.-Acknowledgment of service may be made in the following form, provided it be entered on the petition or entitled in the cause and signed in the presence of the judge, the clerk or the examiner, and attested by such officer: 
Due and legal service of the within and foregoing petition for registration is acknowledged. Further service, process and notice waived, this the..... day of........191...

In the presence of

See A. § $12 ;$ T. § 68.

$\S$ 90. Form of Sheriff's Return.-The sheriff's return should be made substantially in the following form, and entered on or attached to the petition:

Georgia,

County:

I have served copies of the within petition for registration and process upon the following persons at the time and in the

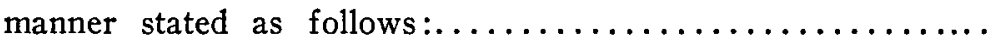

I have also posted in a conspicuous place on the land described herein and on each separate tract thereof a copy of the notice as required by law. I have furthermore gone upon the land and the following is the name and postoffice address of each and every person above the age of 14 years actually occupying

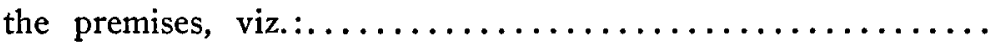

This the.

day of...

Sheriff.

See A. § $14 ;$ T. $\S \S 71-3$.

No traverse after judgment, A. $\S 13$; T. $\S 74$.

$\S$ 91. Form of Clerk's Return.-The clerk should also enter on the petition a certificate substantially in the following form : 
I certify that on the..... day of........191...., I mailed to each of the following persons a copy of the within petition and process to his postoffice address as disclosed by the

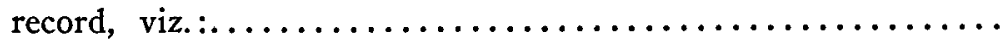

and that advertisement has been published in accordance with law, a copy of said advertisement being hereto attached.

This...... day of.........191....

Clerk.

See A. § $14 ;$ T. $\S \S 72-4$.

§ 92. Form of Order Appointing Examiner.-Substantially, the following form should be used in appointing examiners :

Mr.............. a competent attorney at law, of good standing in his profession, and of at least three years' experience, is hereby appointed a master or auditor in and for the ...............Judicial Circuit to discharge the duties of Examiner as provided in the Land Registration Act. This appointment is............... (either general or for a particular case, as the case may be).

This...... day of .........191....

\section{Judge, Superior Court.}

See A. $\S 15 ;$ T. $\S 77$.

§ 93. Form of Examiner's Official Oath.-The examiner is required to take the following oath to be filed along with the order of his appointment in the office of the clerk of the superior court of his residence:

I,.................., do swear that I will faithfully, well and truly perform the duties of Examiner under the Land Registration Act, according to law to the best of my skill and ability. 
Sworn to and subscribed before me, this

...... day of ..................

See A. $\S 15 ;$ T. $\S 78$.

§ 94. Form of Reference to Examiner.-Upon the clerk's notifying the judge that a petition has been filed, he should promptly refer it to an examiner in substantially the following form:

In the Superior Court of............ County, Georgia:

In $\operatorname{Re}$

Application to

\} Register Land.

Ordered that this matter be and is hereby referred to...... .................., as examiner for proceedings in conformity with the Land Registration Act. This........... $191 . . . . .$.

See A. § 16; T. § 79 .

Judge.

$\S$ 95. Form of Examiner's Preliminary Report.-The following is suggested as the general form of the preliminary report of an examiner:

In the Superior Court of............. County, Georgia :

In $\operatorname{Re}$

$$
\left\{\begin{array}{l}
\text { Application to } \\
\text { Register Land. }
\end{array}\right.
$$

The undersigned, as examiner, makes the following preliminary report:

I have examined all records as required by the Land Registration Act.

I attach an abstract of the title (Schedule A) as shown on the public records and so far as obtainable from other trustworthy sources.

The names and addresses of all persons, so far as I have been able to ascertain who have any interest in the land, are set out in Schedule B hereto showing their several apparent or possible interests and indicating upon whom and in what manner serv- 
ice should be made. A like disclosure of all adjoining land owners is set out in Schedule $\mathrm{C}$ hereto.

I find the following to be a history of the possession:

Special attention is called to the following matters:

This

Examiner.

\section{Schedule A. (Examiner's Full Abstract.) \\ SCHEDULE B.}

(Name and address of all persons having apparent or possible interests in the land, other than applicants, and indicating upon whom and in what manner further service, if any, should be made.)

\section{Schedule C.}

(Name and addresses of all adjoining owners.)

See A. $\S 16 ;$ T. $\S 80-87$.

Suggestions as to Schedule A. of this form, T. $\$ 82$.

Suggestions as to Schedule B., T. $\S 83$.

Suggestions as to Schedule C., T. $\S 84$.

Suggestions as to how the history of the possession should be given, T. $\S 85$.

Suggestion as to inclusion of other special matters, T. $\S 86$.

$\S$ 96. Form of Examiner's Final Report.-The following is suggested as the general form of the examiner's final report: In the Superior Court of.................. Gounty, Georgia : In $\operatorname{Re}$ 
The undersigned, as examiner, makes this his final report:

The preliminary report filed by the undersigned is made a part hereof and is correct except as herein otherwise stated.

The following proceedings have occurred before the examiner, and accompanying herewith is a brief (or a stenographic) report of the evidence taken on the hearing...............

In Exhibit....., hereto, is a report of the matters ascertained by the independent examination of the examiner.

My conclusions of fact are set forth in Exhibit......, hereto annexed.

My conclusions of law are set forth in Exhibit......, hereto, attached.

I find the state of the title to be as follows:

I find that there are liens and encumbrances on the land as follows :

This

191

Examiner.

See A. $\S 20 ;$ T. $\S 95$.

$\S$ 97. Form of Decree of Title.-Decrees of title should be rendered in accordance with the following form:

State of Georgia,.................. County:

In the Superior Court of said County:

In $\operatorname{Re}$

\{ Application to

The above entitled cause coming on to be heard, and it ap- 
pearing to the court that process has been served and notice given and publication made, all in full compliance with the Land Registration Act, and that all the requirements of said Act have been complied with, it is decreed, ordered and adjudged that the title to the lands involved, to-wit: (here describe lands) is held and owned as follows:

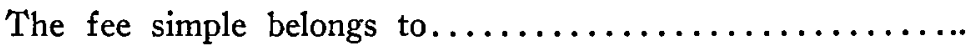

subject to the following limitations and conditions:

It is further ordered and decreed that said lands be and are hereby brought under the operation and provisions of the Land

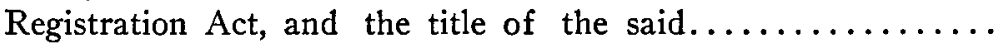

in and to the estate herein set forth above is confirmed and ordered registered; subject, however, to the following liens and encum-

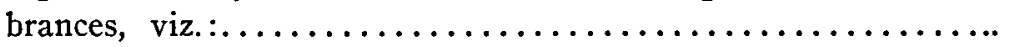

and subject also to

Let this decree be entered on the minutes of this court and on the Register of Decrees of Title of said county.

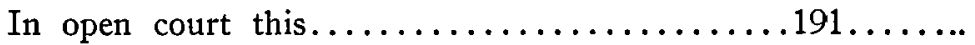

Judge.

See A. $\S 26$.

In $T$. $\S \S 109-114$, sundry suggestions are made as to how the blanks in this form should be filled.

Necessity for adhering strictly to prescribed form, T. $\S 108$.

This form is also printed in the Register of Decrees of Title, A. § $98 ;$ T. $\S 119$.

$\S$ 98. Description of Register of Decrees of TitleSuggestions as to Use of It.-It is contemplated by this Act that the book known as the Register of Decrees of Titles 1 shall be made up in the following manner. It should be of such size as that each page may contain a full copy of the decree of 
title. Only one (1) decree should be entered on any page. Each page should have printed thereon the form of the decree of title as herein prescribed, with ample spacing left in the blanks. At the bottom of the page should be the words, "Entered and registered this......... day of......191....., at .......... 'olock,......M., and certificate of Title No...... issued thereon.

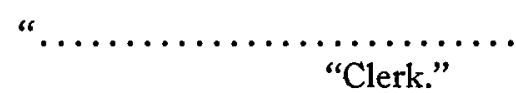

At the top of the page and preceding the copy of the decree should be the words, "Registered Title No........." 2 The first decree entered is numbered, "Registered Title No. 1"; the second, "Registered Title No. 2," and so on in continuous, consecutive order. The registered title number of a registered tract never changes, though any number of subsequent certificates may be issued thereon; therefore the registered title number and the certificate number will usually be different. ${ }^{3}$

Even though several separate tracts may be joined in the same application the judge should render separate decrees as to each tract; and these decrees should be separately entered and given separate registered title numbers. ${ }^{4}$

Every certificate of title and every owner's certificate and creditor's certificate must carry on it (in addition to its own certificate number) the registered title number of the decree under which the tract to which it pertains was registered. ${ }^{5}$

A part of the Register of Decrees of Titles shall be an alphabetical index ${ }^{6}$ thereto which the clerk shall carefully keep. Whenever a decree is entered on the Register of Decrees of Title the clerk shall immediately index the same in the name of the person in whose favor the title is registered, under proper alphabetical head; the name being followed by the registered title number. If the decree is in favor of more than one person it shall be separately indexed under the name of each and all of them; the name of each of said persons being shown under the proper alphabetical head.

1. Duty of county commissioners to furnish, A. § 28; T. § 271 .

2. See T. $\S 119$.

3. Discussed, T. $\S 120$. 
4. See T. $\S 120$.

5. See A. $\S 99 ;$ T. $\S 120$.

6. Discussed, T. $\S 123$.

General Note-Outside recordation of plats, A. $\S 102$; T. $\S 121$.

In T. $\S \S 119-123$, suggestions are made as to the method of correctly enrolling the decree of title on the register.

See also Notes to A. $\S 28$.

$\S$ 99. Form and Description of Title Register-Suggestions as to Use of it.-It is contemplated by this Act that the Title Register shall be a well-bound book with pages not less than 18 inches wide. It shall be labeled on the back with the words "Title Register" followed by the name of the county. Additional labels may be put on to show what certificates are included (as for example, "Certificates 1501-2000, inclusive,") or other similar information, for convenience's sake. It shall be printed and ruled in substantially the form here shown: 


\section{Title Register}




\section{STATE OF GEORGIA, COUNTY OF}

CERTIFICATE OF TITLE

This is to CERTIFY, That the title to the estate hereinafter mentioned in and to the following described tract of land in said, county, viz.:

is registered under the provisions of the land registration Act and thereby vested in.

The estate owned by said. in said lands is as follows:

subject to the following limitations, conditions, encumbrances, etc., viz.:

and to any other that may be noted hereon. Witness my hand and seal of office, this. day of ..19......., at........ o'clock............. M.

(OFFICIAL, SEAL)

Clerk Superior Court. ENTERED AND REGISTERED (on transfer from Certificate of Title No............)*, this... day of. . .19 , at............. o'clock...................................................

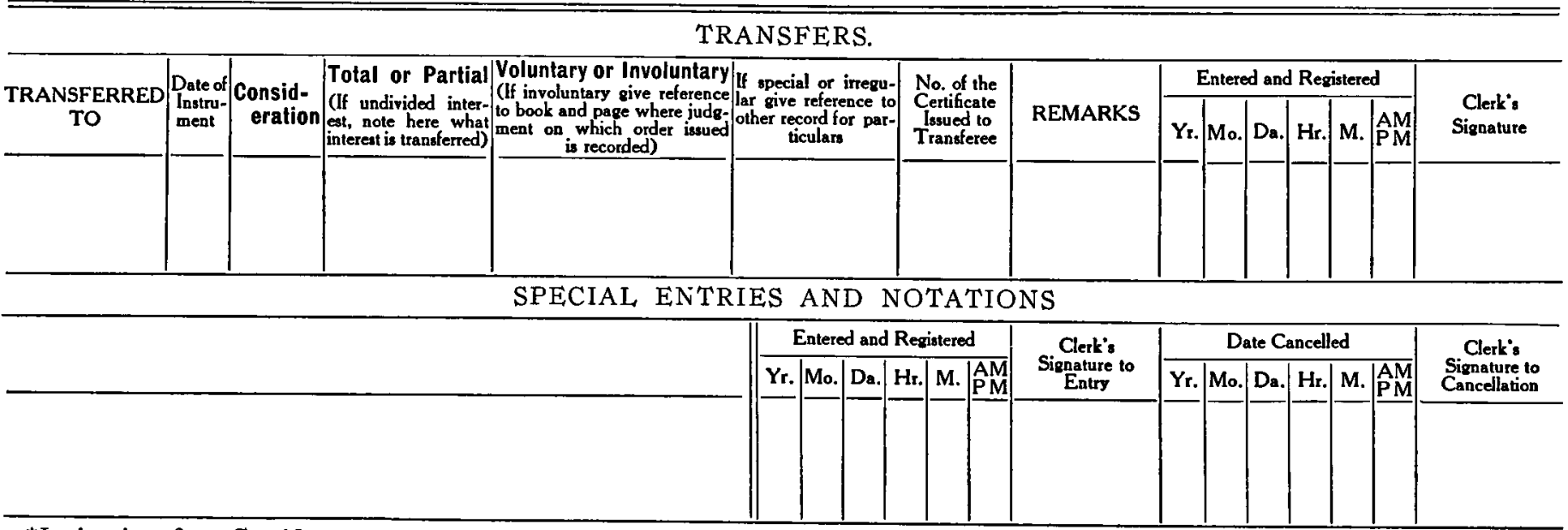

*In issuing first Certificate on a decree, strike the words in parenthesis. 
REGISTERED TITLE No.

CERTIFICATE OF TITLE No.

LIENS, ENCUMBRANCES, AND OTHER MATTERS AFFECTING THIS CERTIFICATE

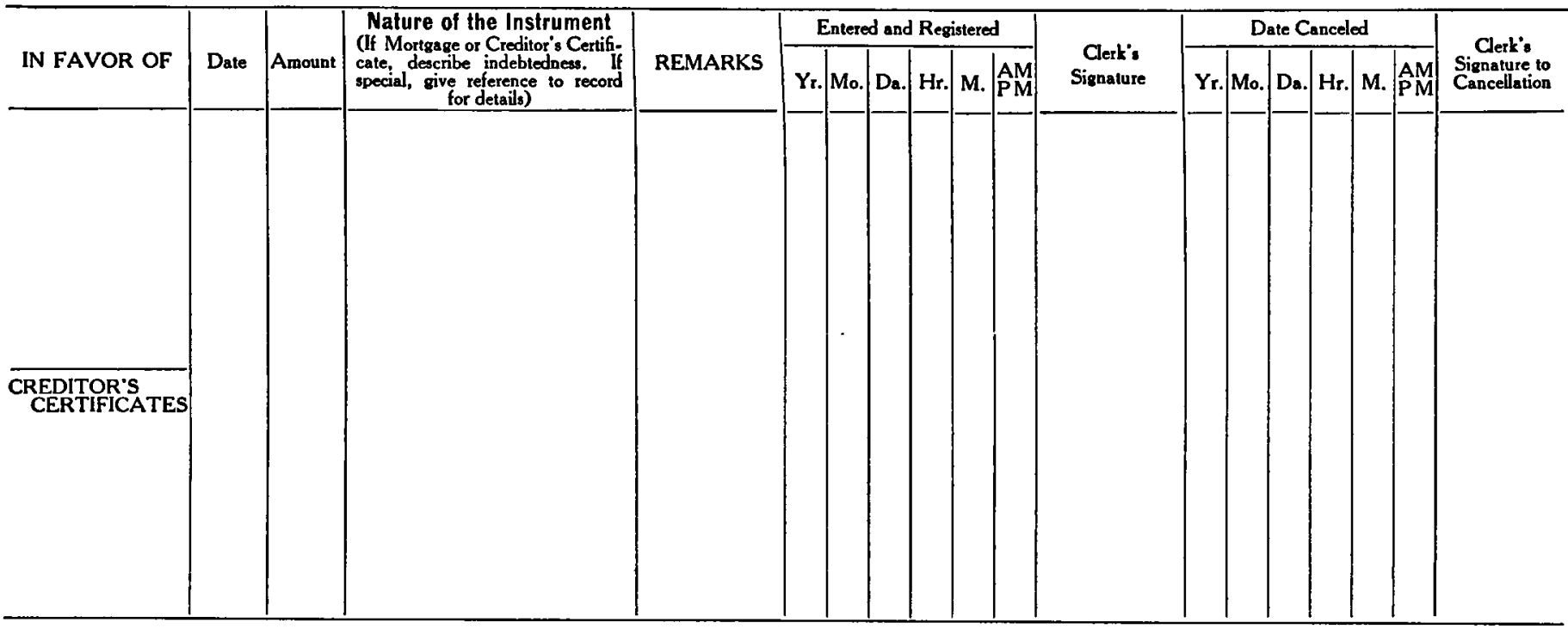

This Certificate of Title Cancelled, and Certificate of Title No.............issued in lieu thereof, this........day of.............19........., at ..o'clock.........M.

Owner's Duplicate Cancelled*

Clerk.

*In case cancellation is by order of Judge, state that fact and give reference to book and page of the minutes. 
The two pages thus facing each other on the register constitute the original certificate of title, when the blanks are duly filled in and signed by the clerk. The first certificate of title in the book should be numbered "Certificate No. 1," the next one "Certificate No. 2," and so on, in continuous, consecutive order. If a new book be opened the numbering therein should begin with the number next succeeding the last number in the book just completed.

In registering a certificate of title, in addition to the certificate number, the registered title number should also be inserted. The registered title number is always the same as that which appears on the decree of title, by virtue of which the land to which the certificate relates was originally registered. Therefore, every certificate of title registered in the Title Register, bears a different certificate number from every other certificate of title registered therein, but all certificates of title which refer to the same registered tract, no matter how many such certificates may be issued in the course of time, bear the same registered title number.

The clerk shall keep an alphabetical index of the Title Register. This may most conveniently be kept in a separate book. Whenever a certificate of title is entered in the Title Register the clerk shall insert in the index under proper alphabetical head the name of the person in whose favor the certificate is registered, and the reference to the certificate number and the registered title number. Whenever a certificate is entered in the name of more than one person, the name of each shall be likewise alphabetically indexed.

Duty of county commissioners to furnish, A. $\S 28 ;$ T. $\S 271$.

As to certificate of title, see notes to A. $\$ 28$.

Suggestions as to correct method of filling in the certificate of title from the decree of title, T. $\S \S 124-130$.

Indexing, T. § 132.

Outside recordation of lengthy details, A. $\S 103 ;$ T. $\S 133$.

Certified copies of entries on this register, A. $\S 101$; T. $\$ \S 239,241$.

Extraordinary situations, as where space proves inadequate to record all entries, and other unusual exigencies, see T. $\S 275$.

$\S 100$. Bringing Forward Entries and Notations.When registering a certificate of title upon a transfer the clerk 
shall bring forward and appropriately enter on the new certificate of title all entries and notations appearing on the certificate from which the transfer is made, except such as shall have been canceled. In transcribing entries brought forward the clerk will note under the column headed "Remarks" against such entries the words "brought forward."

See A. $\S 39$; and notes thereunder.

$\S$ 101. Certified Copies from Title Register.-The clerk shall upon the request of any person, and the payment of lawful fees, issue a certified copy of any certificate of title or of any entry thereon, in like manner as he may issue certified copies of any other public record in his office, but whenever he so does he shall plainly mark in large legible letters across the face of the certificate the word "Copy." If certified copy of a canceled certificate or entry shall be made, in addition to transcribing a copy of the entry of cancellation, the clerk shall also plainly mark the words "Canceled certificate," or "Canceled entry," as the case .may be, across the face of the copy.

See T. $\S \S 162,241$.

$\S$ 102. Method of Recording Plat.-Whenever a plat of the premises, too large or too intricate for easy transcription on the Register of Decrees of Title or on the certificate of title, is a part of the description of the lands or is used to aid description, it shall not be necessary for the clerk to copy the same on the Register of Decrees of Title or on the certificate of title, but he shall record the same in one of the public record books in his office, and in lieu of copying the plat shall note the existence of the same, together with a reference to the book and page where recorded. If the holder of the owner's certificate desires a copy of the plat attached as a part of his owner's certificate, the clerk shall make a copy and certify it upon payment of a fee of $\$ 1.00$ for that particular service.

See A. $\S 98$ and notes; also T. $\S \S 109,121$.

When necessary for certified copy of outside record to accompany certificate of title when introduced in evidence, T. $\$ 242$. 


\section{$\S$ 103. Method of Recording Lengthy Description of} Other Details.-Whenever in the registering of any certificate of title or any notation or entry on the Title Register it is found that the description of the premises or the portion thereof involved or any other detail in connection with the transaction is too lengthy to be transcribed in full in the proper space on the Register it shall be permissible to record the instrument, document or writing in which such lengthy detail or description is contained on some public record book of the county, and, instead of setting forth the description or other detail, as the case may be, in extenso, on the Title Register, to state it in general terms with the reference for further particulars to the public record where recorded thus: "For further details see Deed Book......page....." and such registration shall be adequate to all intents and purposes, and the record thus made on the public record shall be considered as a part of the certificate of title contained on the Title Register.

Compare A. § 38. See also T. §§ 126, 129, 242, 275.

$\S$ 104. Certified Copy of Outside Records Attached to Owner's Certificate.-Whenever any of the description or details of a certificate of title on the Title Register shall be set out in full in some other record of the clerk's office with reference thereto on the Title Register, as hereinbefore provided, like reference shall be made on the owner's certificate and on creditor's certificates when thereafter issued, but if the holder of such owner's certificate or creditor's certificate shall so require, the clerk shall make a full and complete copy of such record to which reference is made and certify it as such and attach it to the owner's certificate or the creditor's certificate, as the case may be. For making and certifying such copy of the recorded document or writing and attaching it to the owner's certificate or creditor's certificate, as the case may be, the clerk shall be paid ten cents per hundred words in addition to the other regular fees in this Act provided.

Discussed T. $\$ \S 133,157,242$.

$\S 105$. Form and Description of Owner's Certificate. -The form of the owner's certificate of title shall correspond 
in general form with the certificate of title except that it shall be headed with the words, "Owner's Certificate of Title." It is suggested that it be prepared on paper of suitable size, to be folded into four pages; the first page to contain the certificate proper (i. e., omitting the notations and special entries); the inner pages (i. e., pages 2 and 3 ) to be ruled and written or printed (preferably the latter) in conformity with the form herein shown for the printing and ruling of the Title Register for the entry of transfers, liens, encumbrances, creditor's certificates and other like matters, these two pages being treated for this purpose as a single sheet, so that ample space will thereby be given for the crosswise extension of the entries. On the back of the fourth page, it is to be endorsed thus:

“OWNER'S CERTIFICATE OF TITLE.

Registered Title No..................

Certificate No.......................

Issued to $\ldots \ldots \ldots \ldots \ldots \ldots \ldots \ldots \ldots \ldots$

Georgia.$\ldots \ldots \ldots \ldots \ldots \ldots \ldots \ldots \ldots \ldots \ldots \ldots \ldots \ldots \ldots$ County.

Entered and Registered (in lieu of certificate No............. which has been canceled). This.......... day of ...........191...., at......... o'clock...........

Clerk, Superior Court."

In case of the first issuance of the owner's certificate on the granting of a decree of registration the words shown in parenthesis in the endorsement above should be omitted.

It is suggested that convenience will be subserved by folding the certificate in the manner of folding documents written on legal cap or fool's cap paper, and by writing or printing the endorsement in the style and manner in which similar endorsements are usually put on legal documents. When printed blanks are prepared for use in this connection, it is also suggested that blank form of transfer be printed on part of the fourth page, other than that part used for the endorsement. Space, however, should be left on the fourth page for such en- 
tries as the clerk may be required to make from time to time, under the provisions of this Act, certifying that the certificate is valid with all entries to date noted.

See notes to A. $\$ 28$.

Suggestions as to forms and design, T. $\S 134$.

Established duplicate of lost or destroyed owner's certificate, A. § 58; T. § 135 .

$\S 106$. Duty of Clerk as to Requiring Proper Attestation-Liability for Delinquency.-The clerk shall first satisfy himself before registering any voluntary transfer that the same is witnessed and attested or acknowledged in accordance with law; $;^{1}$ and he and the sureties on his bond are liable for any loss or damage occasioned to any person through the registration of a transfer not so executed. ${ }^{2}$

1. Must be attested as if it were a deed to land, A. $\S \S 30,31,32,107$.

2. Compare A. $\S \S 59$. See also T. $\S \S 215,269$.

$\S$ 107. Standard Forms of Transfer.-The following are prescribed as the regular forms of transfer. ${ }^{1}$ Other forms may be used in accordance with the provisions of this Act : ${ }^{2}$

Transfer of Whole of Registered Estate. ${ }^{3}$

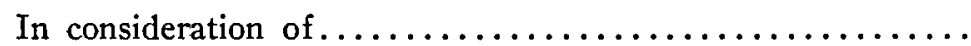

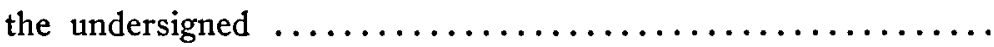
hereby transfers, sells and conveys to............... .his entire right, title, estate and interest in the tract of land described in the certificate of title No.............hereto attached registered as Registered Title No........ in the office of the clerk of the Superior Court of ........... County, Georgia. This....... day of .191.....

Signed and delivered in presence of : 
Transfer of Undivided Interest in Registered EsTate. 4

In consideration of. the undersigned

hereby transfers, sells and conveys to

an undivided. interest in the tract of land described in the certificate of title No.........hereto attached, registered as Registered Title No......... in the office of the clerk of the Superior Court of............ County, Georgia.

This. day of 191

Signed, sealed and delivered in presence of :

\section{Transfer of Divided Portion of a Registered Estate. ${ }^{5}$}

In consideration of

the undersigned hereby transfers, sells and conveys to

his entire right, title, interest and estate in and to the following lands, viz.:

being a divided portion of the tract of land described in the certificate of title No...........hereto attached registered as Registered Title No.......... in the office of the clerk of the Superior Court of................... County, Georgia.

This. day of 191

Signed, sealed and delivered in presence of:

Transfer to Secure Debt with Power of Sale. ${ }^{6}$

To secure a debt payable to. in the sum of

evidenced as follows: 
the undersigned hereby transfers, sells and conveys to said....

all the title of the undersigned in and to the tract of land described in the certificate of title No........... herewith shown, registered as Registered Title No.......... in the office of the clerk of the Superior Court of............. County, Georgia, with power to sell the same after lawful advertisement, without foreclosure, in accordance with the provisions of the Land Registration Act, if any part of said debt is not paid at maturity.

This. day of. .191............

Signed, sealed and delivered in presence of :

1. Advantages and methods of using the standard forms, A. § 38; T. $\S \S 140,147,148,151,153$.

2. Method of using other forms, A. $\S 38$; T. $\S \S 143,157,162,163$.

3. See A. $\S 30 ;$ T. $\S 147$.

4. See A. $\S 31 ; T$. $\S 148$.

5. See A. $\S 31 ;$ T. $\S 151$.

6. See A. $\S 32 ;$ T. $\S 153$.

$\S$ 108. Creditor's Certificate.-The following is the form of creditor's certificate referred to in this Act:

Creditor's Certificate.

State of Georgia,..........................

Registered Title No.

Certificate No.

I hereby certify that the title to the estate hereinafter mentioned in the following described land lying in said county, viz.:

is registered under the provisions of the Land Registration Act and thereby vested in...

as security for a debt created by the holder of the owner's cer- 
tificate of title to said estate, viz.: (here insert name of the holder of the owner's certificate); said debt being particularly

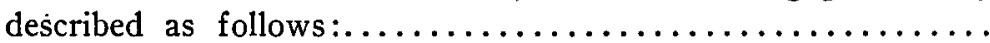

with power conferred to sell the same after lawful advertisement without foreclosure in accordance with the provisions of the Land Registration Act, if any part of said debt is not paid at maturity. The estate in said land so held is as follows:....

subject to the following limitations, conditions, encumbrances,

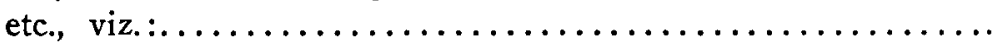

and such others as may be noted hereon.

Witness my hand and seal of office this...........day of ...............191..., at.........o'clock,.......... (Official Seal.)

Clerk, Superior Court.............. County.

All uncanceled entries appearing on the certificate of title at the time the creditor's certificate is issued shall be noted and entered on the creditor's certificate.

The creditor's certificate shall bear an endorsement on its back in the following form:

CREDITOR'S CERTIFICATE.

Registered Title No............

Certificate No.

On Lands Registered in the name of

Issued to

Georgia,

County.

Entered and Registered this........

day of .............191.......

at............'clock,........

Clerk, Superior Court.

See A. $\S \S 32-35$; T. $\S \S 151-160$.

Cancellation of creditor's certificate, A. $\S \S 33,115 ;$ T. $\S 159$. 


\section{$\$ 109$. Creditor's Certificate for Only Part of a Tract.} -Where only a portion of the registered land or only an undivided interest is transferred to secure a debt, the instrument of transfer and the creditor's certificate may be in the same form as those prescribed in the two preceding sections with the exception that the portion or the undivided interest shall be disstinctly stated.

\section{$\S 110$. Form of Judge's Order of Transfer-Sugges-} tions.-Where the judge orders a transfer to be made under any of the provisions of this Act the judge's order of transfer shall be in the following form, unless the exigencies of the case require a different form:

\section{Judge's Order of Transfer.}

In the Superior Court of..................... Georgia :

For good cause shown to the court the clerk is directed to cancel the certificate of title No........, Registered Title No. $\ldots \ldots \ldots$, standing in the name of.................., on the Title Register, and to register a certificate of title in lieu thereof as follows:

in accordance with the decree of court rendered in the suit of

in Court; and transfer of title is accordingly ordered. You will enter this transfer upon the Title Register, noting upon the same a reference to the book and page upon which the above recited order or decree may be found. This order or [of] transfer to be effective upon the presentation of the outstanding owner's certificate, which you will

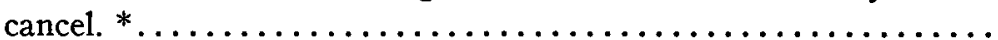

This.

day of

Judge.

(*If the court has not been able to require the production of the outstanding owner's certificate, the judge shall erase this 
sentence from the order and substitute in the blank space below it the following: "You will cause notice to be published in accordance with the law, that the certificate is canceled.")

If the exigencies of the case require a variation from the form above prescribed the clerk shall also record the judge's order on the minutes of the court and under the appropriate heading in the entry of transfer on the Title Register, write the words, "Special, See Minute Book,.........page.........."

If the judge's order of transfer is made without obtaining production of the outstanding owner's certificate the clerk in entering the transfer shall, under the heading, "Remarks," write "Owner's certificate not produced, but canceled by publication."

An order substantially in this form is required before the clerk can register any involuntary transfer, A. $\$ \S 41,50$; T. $\S \S 144,166$.

Transfers to heirs, A. $\S 45 ;$ T. $\S 196$.

Transfers as result of judicial proceedings, A. $\S \S 49,55$; T. $\S \S 205$, 208.

Transfer where land held in trust or on condition or unusual limitation or with powers attached, A. $\S 56 ;$ T. $\$ \S 204,209,210$.

Directions to the clerk as to how to register the transaction to be included in the order of transfer, T. $\S 170$.

Cancellation of outstanding owner's certificate, A. § 52; T. § 169.

$\S$ 111. Standard Form of Mortgage.-The regular form of mortgaging land shall be as follows:

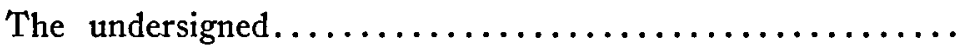
to secure the following indebtedness, viz.:............

mortgages to.

the estate, title and interest of the undersigned in and to all of the tracts of land described in the certificate of Title No......., herewith shown, registered as Registered Title No....... in the office of the clerk of the Superior Court of ............. county, Georgia.

Signed, sealed and delivered in presence of : 
If only a part or undivided interest is mortgaged, strike the word "all" and insert particularly a description of the portion or interest mortgaged.

Mortgages so executed may be registered as regular instruments, as hereinbefore provided. ${ }^{1}$

Mortgages in other forms and with other provisions may be registered, but shall also be recorded in accordance with the provisions of this Act regulating the registration of such irregular instruments. ${ }^{2}$

1. Where the standard form is used, A. $\S 38 ;$ T. $\S 161$.

2. Where other form is used, A. $\S 38$; T. $\S \S 143,162$.

$\S$ 112. Form for Notation of Delinquent Taxes.-Delinquent taxes and assessments shall be noted on the Title Register upon the officer charged with the collection of taxes filing with the clerk a certificate substantially in the following form:

\section{Notation of Delinguent Taxes.}

I certify that................... (State, county or city, as the case may be) has a lien for unpaid taxes (or assessments, as the case may be) for the year $191 . .$. , against the land described in Certificate No..........., Registered Title No............, registered in the office of the clerk of the Superior Court of.............county, in the amount of $\$ \ldots . \ldots \ldots \ldots$ The clerk will please note the same on the Title Register.

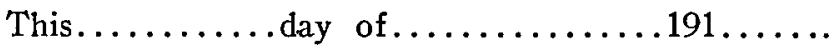

Tax Collector.

See A. $\S 57$; T. $\S \S 145,177$.

Cancellation, A. $\S 62 ;$ T. $\S 186$.

$\S$ 113. Form for Notation of Judgment.-The regular form to be used by any person, his agent or attorney, desiring a judgment to be noted on the Title Register, is as follows :

Notation of Judgment.

To the Clerk, Superior Court.................. Georgia:

Please note on certificate of title No........., Registered 
Title No.........., a judgment, issued from...... court of $\ldots \ldots \ldots \ldots \ldots$ in favor of $\ldots . . . \ldots \ldots$ vs............... for the amount of $\$ \ldots \ldots \ldots \ldots \ldots \ldots$

This........... day of. 191

See A. $\S \S 54,61 ;$ T. $\S \S 145,174,175$.

Cancellation, A. $\S \S 62,116 ;$ T. $\S \S 142,179$ et seq.

$\S$ 114. Form for Notation of Other Adverse ClaimsLis Pendens.-The regular form to be used where any person desires a notation to be made of any lien, encumbrances or special right (other than voluntary transactions, and other than those herein otherwise provided for), is as follows:

Reguest for Notation of Special Right.

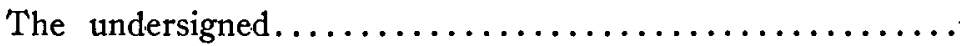
claims against the land described in certificate No........., Registered Title No........., registered in the office of the clerk of the Superior Court of.............. County, the following lien (encumbrance, equity or special right, as the case may be)

in proof of which reference is had to the following record or

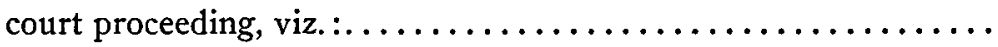

Please note the same upon the Register of Titles accordingly.

Sworn to and subscribed before me, this

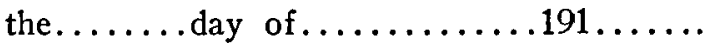

The above form may be used to give notice of a lis pendens.

If the description of the alleged encumbrance, equity or special right to be too lengthy to note with convenience on the blanks in the Title Register, the request for the notation of the same shall be recorded on the deed book of the county and the clerk shall register only a general description of it, but shall note under the appropriate column heading in the Title Register the reference, "Special, see Deed Book........, page......." 
Right to make notation, A. $\S \S 51,61 ;$ T. $\S 145$.

General use of the form, T. $\$ \S 173,176$.

Use in registration of rights acquired through condemnaton proceedings, T. $\S 202$.

Use in noting lis pendens, A. $\S 54 ; T$. $\S 178$.

Use in noting pendency of writ of error, $T$. $\S 118$.

Use in noting claim of dower, T. $\S 190$.

$\S$ 115. Method of Canceling Creditor's Certificate.Authority may be given to register the cancellation of a creditor's certificate by the owner thereof writing thereon "Canceled, the clerk will please cancel the same on the Title Register," dated and signed in the presence of any officer authorized to attest deeds. If the person owning the creditor's certificate is not the person in whose name it was issued and if the original creditor shall not have endorsed it in blank, the owner signing the cancellation shall also make affidavit that he is the owner of the creditor's certificate and entitled to cancel it. The creditor's certificate shall be surrendered to the clerk at the time of the registration of the cancellation.

See also A. § 33; T. § 159.

§ 116. Form of Request to Cancel Entry.-Authority to the clerk to cancel entries or other liens, mortgages, encumbrances, special claims and like matters may be conferred by the person in whose favor the same exists or his personal representative executing a request as follows:

\section{Request to Cancel Entry.}

To the clerk of the Superior Court of............... County:

You are directed to cancel the entry registered in my favor on certificate of title No............, Registered Title No. ......., claiming the following lien (encumbrance or special right, as the case may be) $\ldots \ldots \ldots \ldots \ldots \ldots \ldots \ldots \ldots \ldots$

This.......... day of ..................

See A. $\S 62 ;$ T. $\S \S 142,180$.

The form does not add an attesting clause but $A$. $\S 62$ requires that it be attested by some officer authorized to attest a deed. 
$\S$ 117. Method of Registering Other Voluntary Transactions.-Where it is desired to register a voluntary transaction other than those for which forms have been otherwise indicated or prescribed the instrument showing the voluntary transaction shall be presented along with the owner's certificate and the same shall be noted not only on the certificate of title in the Title Register, but also on the owner's certificate. If the instrument be already recorded on some public record, reference shall be made in the Title Register and on the owner's certificate to the book and page where it is recorded; if it be not already recorded the clerk shall record it, making like reference in the Title Register and on the owner's certificate to the book and page where recorded.

See generally A. 3 ; T. $\S \S 21,140$.

Registration of interests and estates less than fee, leases, timber rights, mineral rights, etc., T. $\S 150$.

Registration of homestead, T. $\S 210$.

$\S$ 118. Entry of "Valid With All Entries Noted" on Owner's Certificate.-The holder of an owner's certificate of title may at any time present it to the clerk, and if the certificate of title on the Register has not been canceled, the clerk shall thereupon enter on the owner's certificate all entries and notations of every kind which shall appear on the certificate of title if all such entries shall not have already been entered on the owner's certificate, and shall thereupon endorse upon the owner's certificate the words "Valid, with all entries noted to this date, this........ day of ..............191....., at........ o'clock,........." signing the same officially.

Discussed, T. $\S 227$.

Use in evidence, T. $\S 239$.

$\S$ 119. Duty of County Officials to Provide FilesMethods of Filing.-The county commissioners or other officer in each county having in charge county business shall furnish the clerk with the necessary durable filing cases and he shall carefully number and file away all papers relating to registered lands and dealing therewith. All the papers relating to each 
registered title shall be filed together and separately from the papers relating to any other registered title. They shall be filed away in such regular consecutive numerical arrangement as to make them easily accessible at all times. Vertical filing is recommended.

Discussed, T. § 271.

Method of filing papers relating to registered land, T. § 272.

Exception as to transfers and mortgages not in standard form, A. $\S 38 ;$ T. $\S \S 158,162,163$.

Certified copies from the files, T. $\S 247$.

$\S 120$. Fees and Costs of Officers-Deposit for CostsTaxing the Costs.-The fees payable under this Act shall be as follows:

To the Clerk of the Superior Court:

For all services in initial registration from the time of filing the petition up to and including the registration and issue of the first certificate and owner's certificate registered on a decree of title, four dollars and postage, unless separate decrees are registered, when he shall get one dollar extra for each additional decree and the registering and issuing of the first certificates thereon. In contested cases three dollars additional may be taxed as costs.

Registering a transfer and registering thereupon certificate of title and issuing new owner's certificate and making necessary cancellations in connection therewith, full service, one dollar.

For issuing a duplicate certificate in lieu of lost certificate, fifty cents.

For issuing a certified copy of certificate of title and entries thereon, one dollar.

For noting a judgment or other lien on Title Register, fifteen cents.

For certifying an owner's certificate as "valid with all entries noted to date," twenty-five cents.

For the notation or registration of any mortgage or other voluntary transaction not herein otherwise provided, including every act necessary therefor, and, in the case of creditor's cer- 
tificate, including the issuance of the creditor's certificate, seventy-five cents.

Other notations and entries (not otherwise provided for), fifty cents.

In case further record of an instrument is required on account of its form the clerk shall be paid for the record of such instrument at the rate of ten cents per hundred words, in addition to the other fee herein prescribed.

For each entry of cancellation, twenty-five cents.

In cases of involuntary transactions, and in case of caveats and other matters referred to the court for action, the clerk shall be allowed, in addition to the fees herein otherwise prescribed, the sum of ten cents per hundred words for recording such proceedings upon the minutes of the court, and fifty cents for each judgment rendered therein.

If any matter be carried to the Supreme Court the clerk's fees in connection with proceedings to take the case to the Supreme Court shall be the same as in other cases carried from the superior court to the Supreme Court.

To the Examiner of Titles:

For examining a title and making report to the court one dollar per thousand (or fraction thereof) on the value of the land, as determined by the court (but not to exceed a maximum of one hundred dollars) and postage and ten dollars.

In contested cases for hearing the case and making report to the court the judge may in his discretion allow additional compensation, but in an amount not exceeding the same fee as that allowed an auditor for reporting his findings in equity cases under Civil Code, Section 5148. He shall not be paid extra for reporting the evidence, but when a stenographer is used by consent of the parties or order of the judge the stenographer shall be paid his usual fee.

\section{To Sheriffs :}

For ascertaining and reporting to the court the names and addresses of the persons actually occupying the premises described in the petition, one dollar. 
For each service of process and notice required, one dollar. For posting copy of the petition upon the premises, fifty cents. For any other services of the clerk, sheriff or surveyor, not specially provided for herein, a fee to be fixed by the court in conformity with what is usual and lawful for similar services rendered by such officer in ordinary cases.

With each application for initial registration the applicant shall deposit with the clerk the sum of twenty dollars as a deposit to guarantee costs and may from time to time be required by the court to make additional deposits. The clerk shall not be required to enter any notation, entry or registration upon the Register of Title or the owner's certificate unless fees prescribed therefor are paid to him. In all contested cases, and in all matters referred to the judge for his direction by any of the provisions of this Act he shall award the cost of such proceeding accordingly as in his discretion the justice of the case may dictate, and to that end may assess all the cost against one of the parties, or may divide it among the parties in such ratio as seems just.

The subject of costs is fully discussed in T. $\S \S 259-264$.

$\S$ 121. Effective Date.-This Act shall take effect on the First of January next after its passage.

The Act is, therefore, effective on and after Jan. 1, 1918.

$\S$ 122. Repealing Clause.-All laws and parts of laws in conflict are repealed.

Approved, August 21st, 1917. 
APPENDIX

\section{UNIFORM LAND REGISTRATION ACT}




\section{Author's Note.}

The version of the Uniform Land Registration Act here shown is not the exact version which the Georgia commission had before it when it drew the Land Registration Act of this State. At that time only the 1914 report of the "Committee on Registration of Title to Land," made to the National Conference of Commissioners on Uniform State Laws was available. However, there is but slight difference between the tentative model act then submitted and the final draft as here shown.

The note matter, accompanying the text of the Uniform Land Registration Act, is the work of the commission just referred to, and the members of that commission are entitled to the credit for the preparation and publication of the valuable memoranda therein contained.

The inclusion herein of the copy of that Act and the annotations accompanying the same is with the permission of the commission. 


\section{Uniform Land Registration Act}

PREFACE.

The Uniform Land Registration Act is an adaptation of the Torrens System to the Constitution and laws of the United States.

The Torrens System takes its name from Sir Robert Richard Torrens, author of the registration act adopted in South Australia on January 27, 1858, the principles of which soon spread throughout Australia, Tasmania, New Zealand, and other English possessions. The registration of possessory titles has been compulsory in London since 1897. The Torrens System was original with Sir Robert, but in the brief of Attorney-General Knowlton in the suit of Tyler vs. Judges, 175 Mass. 71, it is stated:

"Registers of ownership have existed from time immemorial in Bohemia. In Vienna, registers of 1368 are still preserved; in Prague, of 1377; in Munich, of 1440. In the Rhine provinces the present system of registering titles was introduced comparatively recently.

"Registration of title was made universal in Australia in 1811 ; it was adopted in Saxony in 1843; in Hungary in 184956, and in Prussia in 1872."

In the United States we now have the following acts based upon the Torrens System:

1. In Illinois in 1897 (Laws 1897, pp. 165, 207-212; Laws 1903, pp. 121-123).

2. In California in 1897 (Statutes 1897, ch. 110, pp. 138-167; General Laws, pp. 1219-1257; Statutes 1915, pp. 1932-1951).

3. In Massachusetts in 1898 (Acts 1898, pp. 682-722; Revised Laws 1911, ch. 128).

4. In Minnesota in 1901 (General Laws, pp. 348-378).

5. In Oregon in 1901 (General Laws 1901, pp. 438-467). 
6. In Colorado in 1903 (Laws 1903, pp. 311-352; Rev. Stats. 1908, pp. 334-355).

7. In Washington in 1907 (Session Laws 1907, pp. 693-738).

8. In New York in 1908 (Laws 1908, pp. 1247-1283; Consolidated Laws 1909, pp. 3459-3496; Laws 1910, ch. 627).

9. In North Carolina in 1913 (Acts 1913, pp. 147-159).

10. In Mississippi in 1913 (Laws 1913, pp. 159-173).

11. In Ohio in 1913 (Laws 1913, pp. 914-960).

12. In Nebraska in 1915 (Laws 1915, pp. 494-526).

13. In Virginia in 1916 (Acts 1916, ch. 62, p. 70).

14. In South Carolina (Acts 1916).

To these may be added the following possessions of the United States:

1. Hawaii.

2. Philippine Islands.

It is also interesting to note that an act has twice been passed by the Legislature of Utah, once in 1907 and again in 1915; but upon both occasions it has been vetoed by the Governor; in the first instance, because an entire line in a vital part of the act was omitted in its engrossment, and from other considerations in the last instance.

Similar legislation has been pending in Georgia, Louisiana and other states; and the enactment of the Federal Farm Loan Act, recently passed by Congress, will stimulate action along this line in many states.

The subject was pending before the National Conference of Commissioners on Uniform State Laws from 1903 to 1915.

In 1903 the Conference met at the Hot Springs of Virginia immediately following the fifteenth annual meeting of the Virginia State Bar Association, at which a land registration bill prepared for Virginia was under discussion. One of the fruits of that discussion in the State Bar Association was a resolution adopted by the Conference of Commissioners for the appointment of a committee to report upon the feasibility of drafting a uniform act on the subject. And from 1903 down to the present time the Torrens Land Registration System has been under discussion in the National Conference of Commissioners. At first the matter was referred to a special committee, but since 
1905 it has been in the hands of one of the standing committees of the Conference, formerly entitled the Committee on the Torrens System and Registration of Land Titles, and now known as the Committee on Registration of Title to Land under the new constitution of the Conference. It chanced that in 1912 the draughtsman of the Virginia act was made Chairman of this committee of the Conference. In the meantime the original Virginia bill had been pending in every Legislature of Virginia since 1903, and had been subjected to the criticism not only of lawyers in Virginia, but of lawyers and publicists throughout the United States; and in passing through these fires it was being purged and refined. It was used as the basis of the first tentative draft for the Uniform Land Registration Act presented to the National Conference of Commissioners on Uniform State Laws at their twenty-third annual conference held at Montreal in August, 1913. A second tentative draft was presented to the Conference at its twenty-fourth annual meeting held in the city of Washington in October, 1914. And in August, 1915, the third tentative draft was presented to the Conference in its twenty-fifth annual meeting held at Salt Lake City, having been brought up to the standard of form recommended by the Committee on Drafting of Legislation of the American Bar Association, through the skilful and devoted labors of Dean John H. Wigmore, of the Northwestern Law School of Chicago, who had long been a member of the Conference Land Registration Committee. Other members of the committee rendered valuable service, and finally their labors were rewarded by the adoption of said third tentative draft, with certain amendments, after a prolonged and thorough discussion.

The resolution of the Conference adopting the act authorized the committee to make such verbal changes as they might deem appropriate not affecting any matter of substance, and to recommend it to the Legislatures of the various states for adoption as the Uniform Land Registration Act; which the committee now does in the following form.

Eugene C. Massie, Chairman, Committee on Registration of Title to Land. 


\section{UNIFORM LAND REGISTRATION ACT.}

\section{AN ACT 1}

To Provide for the Setrlement, Registration, Transfer, and Assurance of Titles to Land, and to Establish or Designate Courts of Land Registration, with Jurisdiction for SaId Purposes, and to Make Uniform the Laws of the States Enactrng the Same.

Be it enacted as follows:

\section{PART I.}

\section{Préliminary Provistons.}

Section 1. [Name of Act.] This act may be cited as the Uniform Land Registration Act.

SEc. 2. [Definitions.] Words and phrases used in this act are to be construed as follows :

(1) The words "voluntary transaction" means all devises and all contractual or other acts or dealings, by any registered

1. Illinois and Colorado: "An act concerning land titles." Massachuselts and Washington: "An act relating to the registration and confirmation of titles to land." California: "An act for the certification of land titles and the simplification of the transfer of real estate." Minnesota: "An act concerning the registration of lands and the title thereto in the State of Minnesota." Mississippi and North Carolina: "An act to provide for the assurance and registration of land titles." New York: "An act in relation to registering titles to real property and facilitating and expediting its transfer." Oregon: "An act concerning land titles, creating the offices of registrars of titles, prescribing the duties of said offices, providing for the registration of title to real estate, prescribing the manner in which registration of title may be obtained and the rights accruing thereunder." California and Colorado are the only States in which the act has been attacked as unconstitutional on account of its title. In Robinson $v$. Kerrigan, $151 \mathrm{Cal}$. 41 the court said: "The same criticism might be made of many acts on a general subject which have always been considered as valid. . . . If it were necessary to mention every subdivision of the general subject of an act in the title to the extent here claimed, our statutes would present a somewhat ludi- 
owner of any estate or interest in land with reference to such estate or interest, and to any statutory right or exemption claimed therein.

(2) The words "involuntary transaction" means the transmission of registered land or any interest therein by descent, the rights of curtesy and dower, all equitable rights and claims, judicial proceedings or statutory liens or charges, the exercise

crous appearance. The statement of the subject in the title would generally occupy almost as much space as the act itself. Furthermore, if subjects, as intended by the Constitution, must be so minutely subdivided, it would be impracticable to enact any comprehensive law on any general subject, by reason of the necessity of dividing it into so many separate acts. The provision must receive, and it has received a more liberal construction." The title was therefore held sufficient. See also People $v$. Crissman, 41 Colo. 450, holding Colorado title sufficient.

Registration of title has been employed in certain parts of Europe from time immemorial. The original act among English speaking peoples was prepared by Sir Robert Richard Torrens, not a lawyer but Collector of Customs at Port Adelaide, in South Australia. This act took effect in South Australia in 1858. Similar acts were adopted in Queensland in 1861, in Victoria, New South Wales and Tasmania in 1862, and in New Zealand in 1870. It then crossed the seas to British Columbia. They are generally known as "Torrens Acts." The system has spread throughout the Dominion of Canada and obtains in the Provinces of Manitoba, Saskatchewan and Alberta and in the Northwest territories and also in Nova Scotia and in parts of Ontario. In the United States it has been adopted by Cal. (Stats. 1897, pp. 138-167); Colo. (Laws 1903, pp. 311-352; Rev. Stats. 1908, pp. 334-355); Ill. (Laws 1897, pp. 141-165, 207-212, amended by Acts of $1907,1909,1910$ and 1913); Mass. (Laws 1898, pp. 682-722, amended by Acts 1899, 1900, 1903, 1904, 1905 and 1910); Minn. (General Laws 1901, pp. 348-378, amended 1903 and 1905); Miss. (Laws 1914); Neb. (Laws 1915, pp. 492-526); $N . Y$. (Laws 1908, Vol. 2, pp. 1247-1283, amended 1909 and 1910); N.C. (Acts 1913, pp. 147-159); Ohio (Constitution, Art. 2, Sec. 40, amendment of 1913; Laws 1913, pp. 914-960, amended 1914); Oregon (Gen. Laws 1901, pp. 438-467); S. C. (Acts 1916); Va. (Acts 1916, c. 62, p. 70); Wash. (Session Laws 1907, pp. 693-738); Hawaii (Laws 1903, Act 56, pp. 273-328); Philippine Is. (Compilation Laws 1908, pp. 777-820). There have been a series of acts leading up to registration in England since 1862, culminating in the land transfer act of 1897 . This act renders registration of titles compulsory in certain places by order of certain local authorities, and the whole of 
of the right of eminent domain, the lien of delinquent taxes and levies, affecting registered land, or any interest therein.

(3) The phrase "writing, instrument, or record," means all transactions, whether voluntary or involuntary, as herein defined.

(4) The word "registrar" means the clerk of the court having jurisdiction of the cause within the county or city in which the land lies.

(5) The word "decree" means judgment, decision, order, or decree.

(6) The word "appeal" means writ of error, supersedeas, or appeal.

(7) Except where the context requires a different construction, the word "court" means the court having jurisdiction for the settlement, registration, transfer and assurance of titles to lands in the county or city where the land lies. ${ }^{2}$

Sec. 3. [Purposes.] For the certain, cheaper, and more speedy settlement, registration, transfer and assurance of titles to land, there is hereby established a system of land title registration, having the following purposes in detail:

(1) To establish or designate courts of land registration;

(2) To provide for the appointment and duties of registrars of title;

London county, and city has been placed under the compulsory order. The London land registry office is located in a building specially erected for its purposes at a cost of $\$ 1,325,000$. As to the constitutionality of such legislation in the United States see Robinson v. Kerrigan, 151 Cal. 40; People v. Crissman, 41 Colo. 450; People v. Simon, 176 Ill. 165; McMahon v. Rowley, 238 Ill. 31; Brooke v. Glos, 243 Ill. 392; Waugh v. Glos, 246 Ill. 604; Tower $v$. Glos, 256 Ill. 121; Tyler $v$. Judges, 175 Mass. 68; do. 179 U. S. 405; State $v$. Westfall, 85 Minn. 437; Nat'l Bond Co. v. Hopkins, 96 Minn. 119; Peters v. Duluth, 119 Minn. 96; American Land Co. v. Zeiss, 219 U. S. 47; Hammond $v$. Glos, 250 Ill. 32.

Constitutional objections not even noticed by the court, Teninga v. Glos, 260 Ill. 121.

2. The definitions given in this section materially aid in reducing the length of the act. None of the State acts contain any definitions, but this feature obtains in the Australian and Canadian acts and is believed to be of value. 
(3) To regulate proceedings to obtain registration of title;

(4) To authorize the adjudication of title;

(5) To prescribe the nature of certificates of title;

(6) To provide for the registration of subsequent dealings with registered titles;

(7) To regulate sundry proceedings after registration of title;

(8) To determine the legal effects of registration of title;

(9) To establish an assurance fund;

(10) And to regulate the fees for registration of titles.

PART II.

Courts of Land Registration.

SEC. 4. [Courts of Land Registration.] The ${ }^{3}$.........courts throughout those portions of the state specified in section 89 of this act, and in those portions of the state which shall so elect as provided in said section, are hereby constituted or designated courts of land registration for the purpose of the settlement, registration, transfer, and assurance of titles to lands (or any interest therein as hereinafter provided) within their respective jurisdictions.

Minn. $\$ 3379$.

Miss. $\$ 1$.

N. C. $\$ 1$.

N. Y. $\$ 371$.
Ohio \$1.

Ore. \$14.

Wash. §8.

3. 'Superior Court: Cal., Ill., N. C., Wash. District Court: Colo. and Minn. Chancery Court: Miss. Supreme Court: N. Y. Common Pleas Court: Ohio. Circuit Court: Ore. Land Court: Mass. One of the crowning excellencies of the Mass. act is the establishment of a special court for registering titles. This has done much to make the Mass. act popular and effective. Wherever it is possible, administration of the act should be committed to a special court. It is only on account of the cost of conducting such a court that it is not suggested in this act. The Ohio act, sec. 1, provides: "In counties having three or more common pleas judges said judges may select one or more of their number who shall act as judge or judges in land registration cases and matters." This affords the best substitute for a special court. 
SEc. 5. [Jurisdiction.] Such courts shall have exclusive, original, and general jurisdiction, ${ }^{4}$ subject to the right of appeal hereinafter allowed.

(1) Of all petitions ${ }^{5}$ and proceedings for the registration of titles to lands,

(2) And of all transactions affecting registered titles to lands lying within their respective jurisdictions.

SEc. 6. [Powers.] Their powers shall include all the powers possessed by the (circuit and corporation) courts of the state, in law and equity, for the purpose of enforcing any of the provisions of this act.

SEc. 7. [Sessions.] They shall be open as courts of land registration, except on Sundays and legal holidays; and their process as such may be issued at any time, returnable as they may direct.

SEc. 8. [Mode of Trial.] The whole matter of law and fact ${ }^{6}$ in any case shall be heard and determined by the court;

4. Pendency of registration proceedings precludes the right of any defendant to bring another suit of any sort for the determination of his rights in the property involved. Any subsequent action by a party to determine adverse claims must be abated. Seeger $v$. Young, 127 Minn. 416.

5. People $v$. Crissman, 41 Colo. 450. Replying to the obiection that no judgment or decree can be rendered or entered, in favor of a defendant, regardless of the showing he may make, the court said: "The act does accord to all persons equal rights and privileges. Anyone desiring to avail himself of its terms can do so by filling his application, and can obtain the registration of his title by complying with the requirements of the statute. Although the Legislature has seen fit to allow affirmative relief only to the applicant who initiates the proceedings, this does not render the proceedings objectionable for the reason assigned. The right to a particular remedy is not a vested right. Every State has complete control over the remedies which it offers to suitors in its courts."

6. Jury trial is provided for by the acts of Mass., Miss., N. C. and New York. No jury trial is provided for by the acts of Cal.. Colo., Ill., Minn., Ohio, Ore., and Washington. In Peters v. Duluth, 119 Minn. 96, held: that Torrens laws have the general purpose to clear up and settle land titles, and are nothing more or less than an enlargement of remedy to quiet title. Hence there is no constitutional 
provided, however, that, on the motion of any person interested, the court shall direct and frame an issue or issues to be tried by jury. ${ }^{7}$
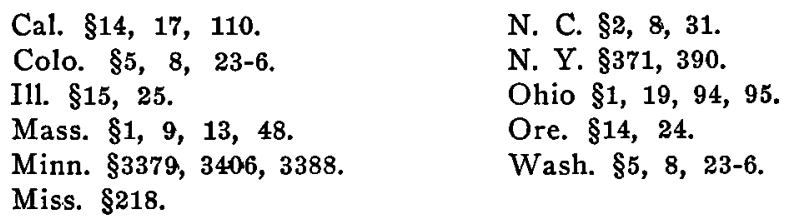

SEC. 9. [Proceedings to be in rem.] The proceedings under any petition for the registration of land, and all proceedings or transactions in relation to registered land, shall be proceedings in $\mathrm{rem}^{7 \mathrm{a}}$ against the land, and the decrees of the court and reg-

right to a jury trial in Minn. under Art. I, sec. 4, which says: "The right of trial by jury shall remain inviolate, and shall extend to all cases of law without regard to the amount in controversy." The court said: "There was no such right upon the ancient bill to remove cloud and quiet title, and it has been held in this State that the constitutional guaranty does not apply thereto. Yanish v. Pioneer Co., 64 Minn. 175."

Foss $v$. Atkins, 201 Mass. 158: Facts found by Land Court become final upon dismissal of appeal to Superior Court. Marvel v. Cobb, 204 Mass. 117: Finding of facts by Land Court cannot be revised by Supreme Court. Id. Gorton $v$. Tolman, 210 Mass. 402. Findings of fact by Land Court when no trial by jury is claimed are conclusive. Van Ness v. Boiney, 214 Mass. 340; Curtis v. Brown, 219 Mass. 157; Habib v. Evans, 222 Mass. 480.

7. Issues must be framed in Land Court for appeal. McQuesten $v$. Atty. Gen., 187 Mass. 185. Issues for jury trial may be amended by Superior Court, Luce v. Parsons, 192 Mass. 8; Foss $v$. Atkins, 193 Mass. 486. The judge of Land Court may refuse to certify immaterial issue for appeal. Dunbar $v$. Kronmuller, 198 Mass. 591. The court has no right to refuse jury trial when title to land is in issue. Weeks $v$. Brooks, 205 Mass. 458. 'Torrens' laws have the general purpose to clear up and settle land titles, and are nothing more or less than an enlargement of the remedy to quiet title. Hence there is no constitutional right to a jury trial in Minnesota. Peters $v$. Duluth, 119 Minn. 96. On appeal petitioner for registration has the right to open and conclude before the jury. Bigelow $v$. Wiggin, 209 Mass. 542.

7a. The provisions fixing the character of the proceedings in rem are vital and are found in all the acts in practically the same terms. 
istered transactions shall operate directly on the land, and shall vest and establish title thereto in accordance with the provisions of this Act.

SEC. 10. [Rules of Court.] The........ Court (court of last resort) shall from time to time make general rules and forms $^{7 b}$ for procedure, subject to the provisions of this act and the general laws, and such rules and forms shall be uniform throughout the state.

SEc. 11. [Petitions for Rehearing, Appeals, and Bills of Review.] A petition for rehearing or an appeal ${ }^{7 c}$ may be taken, (or a bill of review or bill of exceptions, or writ of certiorari) may be filed, within (ninety days, ${ }^{8}$ ) and not afterwards, from

7b. As to the preparation of rules and forms, Cal. places this duty on the Attorney-General, State Controller and Secretary of State; Mass. on the Land Court; Minn. permits each court to adopt general forms. In New York each Registrar must provide a book of covenants, restrictions and forms. Sec. 408. In Ohio the Attorney-General is to prepare a uniform system of books and forms.

7c. Appeal for $\$ 2.46$ of taxes paid by holder of tax title-and reversal. Stallings $v$. Glos, 271 Ill. 201. Defendants interested only in lot described in amended application, cannot raise question whether all the lots described in original petition were contiguous, or substantially of the same chain of title. Schiessle $v$. Glos, 271 Ill. 374. A legatee of money has no interest in testator's land and no right to appeal as an "aggrieved party." Waban v. Hall, 218 Mass. 533. Appeal dismissed because no ruling of law appears to have been made. Mitchell $v$. Cobb, 220 Mass. 60.

8. This section is in effect a ninety-day statute of limitations. Tyler v. Judges, 175 Mass. 68; Cal. limitation 5 years; Colo. and Wash. 90 days; Ill. and Ore. 2 years; Minn. and N. Y. 6 months; Mass. and Ohio 30 days. Limitations of 60 days not unconstitutional. State $v$. Westfall, 85 Minn. 437. Illinois limitation good. People $v$. Simon, 176 Ill. 165. In North Carolina an appeal may be taken "as in other special proceedings"; and in Mississippi "as in other cases." But in these States the bars seem to be wholly let down by another provision permitting an adverse claim existing at initial registry to be filed at any time thereafter, and requiring action thereon to be brought within six months after the entry of such claim, unless the clerk for cause shall extend the time. In practice, registration of title is only resorted to for business reasons and purposes. Business demands clear and quick certain results. A long statute of limitation must destroy the usefulness of any registration act. The two years' limitation has been one of the greatest handicaps in Illi- 
any decree of the court under the same circumstances, in the same manner and on the same condition as if such decree had been rendered by a........ court.

Said period may not be extended by any disability.

Cal. $\$ 45$.

Colo. \$27, 28, 29.

IIl. $\$ 26,27,28$.

Minn. §3394, 3396-7.

N. Y. $\$ 380,392$.

Ohio $\$ 25,80$.
Ore. §25, 26, 27.

Wash. \$27-29.

Mass. §13, 15.

Miss. $\S 8,25$.

N. C. $\S 8,25$.

SEc. 12. [Books and Cases for Records.] It shall be the duty of the....... of each county (or the....... of each city) in which the office of a registrar of titles may be located to provide appropriate cases and other furniture for the safe and convenient keeping of all the books, documents and papers in the custody of such registrar, and also an official seal, and all necessary books and such printed blanks and stationery for use in registration in such county or corporation as may be ordered by the court.
Cal. $\$ 109$.
N. Y. $\$ 376$.

Ohio $\$ 91$.

SEc. 13. [Court May be Held by Designated Judge.] If the judge of the court, for any reason shall become disqualified or temporarily incapacitated, the court may be held by any other judge of a court of record designated according to law.

Ohio §1.

\section{PART. III.}

REgistrars AND EXAMiners OF Tithes.

SEC. 14. [Clerks to be Registrars of Title.] The clerks ${ }^{9}$ of said courts shall be registrars of title under this act.

nois. The five-year limitation in California has been one of the reasons preventing any general resort to that act.

9. The act creates no new office. "It was clearly within the provisions of the Legislature to impose upon the clerk in his capacity of recorder of deeds the duties enjoined upon him by this statute. Making him registrar of titles, does not constitute him a new county officer." People v. Crissman, 41 Colo. 450. 
(1) They shall do all things required of them by this act, under the direction ${ }^{10}$ of their respective courts, and pursuant to rules and regulations established for such courts, and shall be governed by the same general laws as clerks of (circuit and municipal) courts in so far as the same may be applicable.

(2). Their official designation under this act shall be registrar of title for their respective counties or cities.

(3) They shall qualify and give bond in accordance with law for the faithful performance of their duties as such.

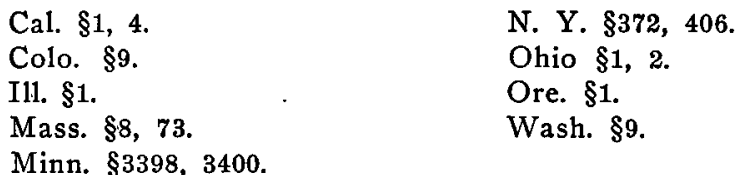

SEC. 15. [Duties and Powers of Registrars of Title.] Registrars of title and their deputies shall be authorized and required, under the direction of their respective courts

(1) To issue process and to enter the decree of the court touching lands in their respective counties or cities;

(2) To enter and issue certificates of title as provided herein;

(3) To affix the seal of the court to such certificate and their duplicates;

10. Under this provision registration is the act of the court. Tyler $v$. Judges, 175 Mass. 68. See also People $v$. Simon, 176 Ill. 165 and State $v$. Westfall, 85 Minn. 437. Fierce battles have raged over the duties of registrars. The first Illinois act of 1895 was successfully assailed and declared unconstitutional because it conferred judicial powers on the registrars. People $v$. Chase, 165 Ill. 526; and the same fate befell the first Ohio act of 1897. State $v$. Guilbert, 56 Ohio St. 575. Subsequent acts have, however, been upheld over such objections. To avoid any difficulty or doubt in this regard Art. II of the Constitution of Ohio has been amended by the addition of Section 40 for the establishment of a land registration system and especially providing that "Judicial powers with right of appeal may by law be conferred upon county recorders or other officers in matters arising under the operation of such system." The provisions of the above section are believed to be suffient to avoid any constitutional question. 
(4) To make entries and memoranda and perform all acts of registration affecting the title to such lands;

(5) To keep a separate account of all moneys with which they may be chargeable under this act, and to make a special return thereof in accordance with the general laws and the special provisions of this act.

(6) And generally to perform such other acts as the court may prescribe.

Cal. \$1, 4.

Colo. $\$ 9,10,11$.

III. $\S 2,3,6,29$.

Mass. §8.

Minn. \$3399, 3401.
N. Y. \$373-4.

Ohio $\S 2$.

Ore. \$2.

Wash. §9, 10, 11.

SEc. 16. [Examiners of Titles.] The courts of land registration shall appoint, ${ }^{11}$ subject to removal at any time, one or more attorneys at law in their respective counties or cities to be examiners ${ }^{12}$ of titles, or the court may, in any case on motion, appoint special examiners.

(2) Their duty shall be to search the records and investigate all facts stated in the petition or otherwise brought to their notice in any case referred to them.

(3) They shall have the powers of (commissioners in chancery) and may hear the parties and receive evidence. ${ }^{13}$

11. Cal: Referee appointed by court in each case; $\$ 10,000$ bond. Colo. and Wash.: one attorney in each county appointed by court; bond. IIl. and Ore.: two or more attorneys appointed by registrar in each county; bond fixed by court. Mass.: one or more attorneys in each county appointed by judge; removal by Supreme Judicial Court. Minn.: one or more attorneys appointed by judges; no provision for removal. Miss. and $N . C .:$ three attorneys in each county appointed by clerk for two years; removal at will of clerk or court. $N$. $Y$.: Attorneys or corporation authorized to guarantee or insure titles qualified under rules of Court of Appeals; bond fixed by court. Ohio: one or more attorneys appointed by court; bond $\$ 1,000$ to $\$ 10,000$.

12. Examiners of title not county officers but court officers. State $v$. Westfall, 85 Minn. 437. Examiner acts as a master in chancery. Gage v. Consumers' Co., 194 Ill. 30.

13. Objections to testimony must be made before examiner of titles. O'Laughlin $v$. Covell, 222 Ill. 162. Examiner must not make ex parte examinations of abstracts and other evidence of title. Glos $v$. Grant 
(4) They shall make report to the court, in the form required by it, with a certificate of their examination of the title and their findings of fact.

Cal. §16, 18, 19.

Colo. $\$ 13,24$.

I11. §5.

Mass. $§ 11$.

Minn. \$3381.

Miss. §3.
N. C. $\$ 3$.

N. Y. $\$ 377,380$.

Ohio $\$ 3$.

Ore. \$5.

Wash. §13, 24.

\section{PART IV.}

\section{Procendings to Obtain Registration.}

SEc. 17. [Petition for Registration.] Suit for registration of title shall be begun by a petition ${ }^{14}$ to the court, by a person or persons claiming, singly or collectively,

Bldg. Assn., 229 Ill. 387. Objections to admissibility of evidence before examiner must be made at the time it is offered, or will otherwise be excluded. Exceptions to examiner's report must not be general but specific, and must point out the evidence objected to and give reasons for the objections. Bjork $v$. Glos, 256 Ill. 447.

14. Complaint in action for registration need not set out the statute. It is sufficient to plead facts showing the right to registration. Duffy $v$. Shirden; 139 N. Y. App. Div. 755. Applicant for registration must prove fee simple title either by the production of a regular chain of conveyances from the general government, or by proof of the creation of a title by adverse, open, continuous and hostile possession under claim of title for the period of twenty years, or by the acquisition of a good tax title. Glos $v$. Kingman, 207 Ill. 26; Glos $v$. Holberg, 220 I11. 167. It is not incumbent on applicant to affirmatively establish the invalidity of tax deeds held by parties defendant. McMahon $v$. Rowley, 238 Ill. 31. The filing of application for registration stops the running of statute limitations and prevents holder of tax title from mending his hold. Woods $v$. Glos. 257 Ill. 125. Any "owner" of land, whether his title be of record or not, may maintain proceedings for registration. A case in which title under an unrecorded deed was registered. National Bond Co. $v$. Alderson, 99 Minn. 137. A party not in possession may bring suit for registration of title against party in possession. "The purpose of the statute is to provide a speedy and summary remedy to clear up title to land. Reed $v$. Siddall, 94 Minn. 216. The remedy provided is not a substitute for an action of ejectment. . . . Moreover, the relief in 
(1) To own,

(2) Or to have the power of appointing or disposing of, an estate in fee simple in any land ${ }^{14 a}$ whether subject to liens or not.

Sec. 18. [Petition by Representative.] Infants and other persons under disability may sue and defend by guardian, committee, or trustee, as the case may be, and corporations by an officer duly authorized.

(2) But the person in whose behalf the petition is made shall always be named as petitioner.

(3) A non-resident petitioner shall appoint a resident agent upon whom process and notices may be served.

SEc. 19. [Equity Practice.] Except ${ }^{15}$ as otherwise pro.

ejectment is not co-extensive with that which may be had upon an application to register. . . it needs no argument to show that a title could never, in ejectment, be settled as against the whole world, as can be done in an application to register." The several pieces of land must form one compact body or must have the identical chain of title; must not be in different blocks separated by a street, nor in the same block separated by other lots owned by others. Culver $v$. Waters, 248 I1l. 163.

Objection to registration, by holder of tax title, overruled, provision being made to reimburse him for taxes paid by him. Loehde $v$. Glos, 265 Ill. 401. Objections to registration by holder of tax titles overruled. Teninga $v$. Glos, 266 Ill. 94. Application for initial registration must show title against all the world. Teninga, Receiver, $v$. Glos, 266 Ill. 94. The act authorizing registration is not a substitute for a bill in equity to remove a cloud from title, and only authorizes initial registration of a title good against everyone. Glos v. Kingman, 207 Ill. 26; Teninga, Receiver, $v$. Glos, 266 Ill. 94; Teninga $v$. Glos, 266 Ill. 121. Title by adverse possession under color, registered without regard to whether claimant can trace back to government by an unbroken chain. Goetz $v$. Glos, 266 I1l. 238. Several tracts with substantially the same chain of title may be registered in one proceeding. Gibson $v$. Glos, 271 Ill. 368.

14a. In some jurisdictions renewable lease-hold estates for long terms are in common use and often constitute a title practically equivalent to the fee. Under such conditions the following words may here be added, to-wit: "or any lease hold exceeding - years."

15. Procedure under the act is same as in chancery practice unless as otherwise provided. O'Laughlin $v$. Covell, 222 Ill. 162. "All rules 
vided, the suit shall be subject to the general rules of pleading and practice in equitable actions.

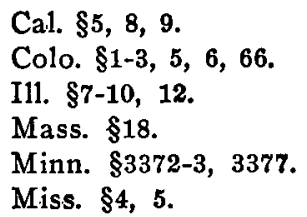

SEc. 20. [Signature and Oath to Petition.] The petition and any amendment thereto shall be signed and sworn to by each petitioner, or in the case of a corporation or person under disability by the person authorized to file the petition.

SEc. 21. [Contents of Petition.] The petition shall set forth

(1) A full description of the land, and any improvements thereon, with the description and valuation in its last assessment for taxation;

(2) When, how, and from whom it was acquired;

(3) Whether or not it is occupied; ${ }^{16}$

(4) An enumeration of all known ${ }^{17}$ liens, interests, and claims, adverse or otherwise, vested or contingent.

and principles of law applicable to equitable actions and proceedings, and rules of practice with respect to trial, introduction of evidence, findings and order of judgment, should so far as not clearly inappropriate or otherwise provided for by the act, be followed and applied." Owsley $v$. Johnson, 95 Minn. 168. It is well settled that proceedings to register title to land are of an equitable nature. Brown v. Hagadorn, 119 Minn. 491; Amundson v. Glos, 271 I11. 209.

16. If applicant alleges lot is unoccupied, he must prove it, otherwise title cannot be registered. Jackson $v$. Glos, 243 Ill. 280. Title cannot be registered without proof of occupancy or vacancy. Brooke v. Glos, 243 Ill. 392; Mihalik v. Glos, 247 Ill. 597; Strebel $v$. Glos, 271 I11. 65; Miller v. Glos, 271 Ill. 285. Is "occupancy" equivalent to "possession"? Miller v. Glos, supra; Harts v. Glos, 271 Ill. 376; Foulkes $v$. Glos, 272 Ill. 364; Harty $v$. Glos, 272 Ill. 395.

17. If applicant asks for tax deed to 1 vigintillionth of the lot to be set aside as a cloud on the title, he must reimburse tax-holders. Jackson $v$. Glos, 243 Ill. 280.

Applicant for registration not chargeable with constructive notice of any encumbrance not in his chain of title. Tomczak v. Bergman, 269 Ill. 330. 
(5) And the full names and addresses, ${ }^{18}$ if known, of all persons that may be interested by marriage or otherwise, including adjoining ${ }^{19}$ owners and occupants.

(6) The petition shall be accompanied by a plan made in accordance with the rules of court.

Cal. \$6.

Colo. \$4.

I11. $\$ 11,14,16$.

Mass. §20.

Minn. §3374, 3375, 3378 .

Miss. §5.
N. C. $\$ 5$.

N. Y. $\$ 379,384$.

Ohio $\$ 8,10,11$.

Ore. §9, 12, 13.

Wash. §4.

SEc. 22. [Petition to be Filed and Docketed.] The petition shall be filed with the registrar of titles, and shall be forthwith docketed, numbered and indexed by him in a book to be known as the land registration docket of his county or city.

SEc. 23. [Notice of Lis Pendens.] The registrar shall also forthwith cause to be recorded and indexed in the proper record book of such county or city a notice, such as is required by law for notice of lis pendens, which shall be filed with the petition, and which shall have the full force and effect of a notice of lis pendens.

SEc. 24. [Memorandum of Other Papers.] A memorandum of all other pleadings and papers filed with said registrar shall in each case be entered upon his registration docket under the proper number as aforesaid, and the papers in the cause and all writings, instruments and records filed with him shall be safely kept by him in his office, duly numbered, dated, and indexed.

Cal. §11.

Colo. $\$ 15,16,43$.

I11. $\$ 16,17$.

Mass. $\$ 12,48$.

Minn. $\$ 3380$.
N. Y. $\$ 370,382$.

Ohio $\$ 7,36,38,92$.

Ore. $\$ 15,16$.

Wash. $\S 15,16,42$.

18. Street address of applicants should be given, but may be supplied later. Creger $v$. Spitzer, 244 I11. 208.

19. An abutting owner claiming interest in land to be registered cannot attack constitutionality of act, nor can he plead that complaint fails to state a cause of action; and if not shown by examiner's report to have any interest in tract to be registered and not designated by 
SEC. 25. [Reference to Examiner of Titles.] Upon the filing ${ }^{20}$ of a petition for the registration of any land, the court shall refer the same to one of the examiners of title provided for by the act, to examine and report thereon.

SEC. 26. [Report of Examiner.] Such report ${ }^{21}$ shall include: (1) An abstract of title to the land, made from the records

order of court as a party to be served, he is not a necessary party; if made a party by complaint, it is subject to demurrer. Duffy $v$. Shirden, 139 N. Y. App. Div. 755.

20. In Miss. and N. C. no reference is made to the examiner until after the publication of notice and service of process. In other States reference is made as soon as the application or petition is filed. In Illinois, however, the examiner does not report until after expiration of the time specified in the order of publication for the appearance of defendants, and until opportunity is given them to contest the rights of the applicant. An abstract of title is required to be filed in Mississippi and North Carolina. In other States the examiner is required to report his opinion, and sometimes to report the facts on which it is based. Such a report as is contemplated by this section will probably disclose the name and addresses of all persons having any interest in or claim against the land. If any should be omitted or overruled, they will be discovered under subsequent proceedings. In Niew York an examiner's certificate must accompany the complaint, and it is for the court to decide whether that is sufficient. It seems better to have an impartial examiner appointed by the court. As he has the powers of a master in chancery, he can compel the testimony of witnesses. He is required to make a report with full extracts from the records, so that the court can judge for itself of the condition of the title.

21. It will be presumed that the examiner considered only competent evidence in making his findings, if the report contains sufficient competent testimony to support such findings. McMahon $v$. Rowley, 238 I11. 31. Substance of proofs need only be reported by examiner, unless otherwise required by some party. If evidence be not returned, party complaining should ask trial judge for rule on examiner. Creger $v$. Spitzer, 244 Ill. 208. Procedure where examiner fails to report evidence on request. Harmless errors not regarded. Mundt $v$. Glos, 246 I11. 636. If no exception be taken to report of examiner, it is conclusive. Kenney v. Glos. 258 Ill. 555. Exceptions to master's report; practice on appeal. Welsh $v$. Briggs, 204 Mass. 540.

Report of examiner, based on copy of abstract of title, sustained. Loehde $v$. Glos, 265 Ill. 401; Wilson $v$. Glos, 266 Ill. 504; Walther $v$. Glos, 270 Ill. 390; Bonner v. Glos, 270 Ill. 567; Harty v. Glos, 272 Ill. 
and all other evidence ${ }^{22}$ that can be reasonably obtained by the examiner;

(2) Full extracts from the records to enable the court to decide the questions involved;

(3) The names and addresses so far as ascertained of all persons interested in the land, as well as adjoining owners and occupants showing their several interests, and indicating upon whom ${ }^{23}$ and in what manner process should be served or notice given in accordance with the provisions of this act.

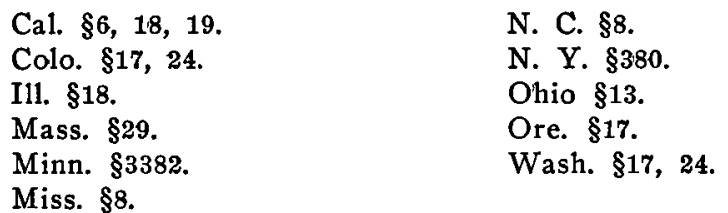

SEc. 27. [Order of Publication in Rem.] Upon the filing of the report of the examiner of titles, the court shall cause notice ${ }^{24}$ thereof to all persons shown therein to be entitled to the

395. Court may act on evidence taken by an examiner though he dies before returning it. Amansden v. Glos, 271 Ill. 209.

The position of examiner under this law is one of high responsibility. Unless the examiner performs his duties fully and thoroughly, the court is liable to be misled to the substantial prejudice of some property owner. Shevlin $v$. Fogarty, 133 Minn. 456.

22. Objections to evidence must be made by exceptions to examiner's report Gage $v$. Consumer's Co., 194 Ill. 30. Rules for objections to examiner's report. Glos $v$. Hobane, 212 Ill. 222; Glos $v$. Holberg, 220 Ill. 167.

23. If State holds tax liens, it should be made a party. Nat'l. Bond Co. $v$. Hopkins, 96 Minn. 119. Persons whose claims are barred are not necessary parties. O'Laughlin $v$. Covell, 222 Ill. 162. Court cannot disregard examiner's report nor decline to make defendant any party whom the examiner finds to have such an interest as to require that he shall be so named. Registration is void against any such party and his privies not made parties. Dewey $v$. Kimball, 89 Minn. 454.

24. When application omits names of parties holding easements, but examiner's report gives names and recommends that they be made parties, if not made parties the registration is void and subject to collateral attack on account of constructive fraud. Riley $v$. Pearson, 120 Minn. 210. Title by registration under the Torrens Act of Colorado, by order of publication, is good against a resident of New York. Hunt v. Hay, 214 N. Y. 578. 
same, and "to all whom it may concern," to be published, and to be posted in the county or city where the land lies, in the same manner and with the same effect as an order of publication in other proceedings in rem, subject, however, to the limitation imposed by section eleven of this act.

Cal. \$13.

Colo. \$17, 19, 20.

III. \$20.

Mass. $\$ 30$.

Minn. §3383-4.

Miss. §6, 7 .
N. C. $\S 6$.

N. Y. \$385-6.

Ohio \$14.

Ore. $\$ 19$.

Wash. $\$ 17,19,20$.

SEc. 28. [Notice by Mail.] A copy of the order of publication shall in all cases be mailed by registered letter demanding a return, to every person interested, named in the petition or in the report of the examiner of titles whose address is given or known.

SEc. 29. [Notice by Posting on Land.] The Court shall also cause an attested copy of said order to be posted in a conspicuous place by the sheriff on each parcel of land included in the petition.

It shall require such sheriff to go upon the lands and ascertain and report to court the names and addresses of any person, or persons, actually occupying the premises under any claim of title.

SEc. 30. [Notice to State.] If the petition involves the determination of any public rights or interests, the court shall cause a copy of the order of publication to be delivered by the registrar to the proper attorney for the state, county or city.

SEC. 31. [Other Notice.] The court may cause other or further notice to be given in such manner and to such person as it may deem proper.

And such personal service of process as is required in equitable actions shall also be made upon residents of the state, not under disability who are made known ${ }^{25}$ to the court before final

25. When a name of a claimant is known to applicant, he must be summoned and an order of publication does not bind him. "As he 
decree and can be reached by its process, unless such service be waived ${ }^{25 a}$ by appearance or otherwise.

SEc. 32. [Effect of Notice.] Notice ${ }^{26}$ given under the preceding sections shall be in lieu of personal service of process,

is not an 'unknown party' the concealment of his claim is a fraud on the court, and the decree therein is as to him of no force and effect." Baart $v$. Martin, 99 Minn. 197. Failure to republish notice after amendment of description of lots in application is not fatal, where all parties having or claiming to have any interest in the lots were personally served by summons or entered their appearance in writing. Tower $v$. Glos, 256 Ill. 121. If written consent be given to application for registration, no summons against such party is necessary, nor that he be given an opportunity to be heard. He cannot appeal. Such written consent need not be acknowledged before a notary, and it is immaterial whether the statute expressly provides for such consent. Mooney $v$. Valentynovicz, 262 Ill. 355.

Defendant served with process cannot complain because others were not properly served by publication or otherwise. McDonnell $v$. Glos, 266 Ill. 504; Finn v. Glos, 268 Ill. 350; Gibson v. Glos, 271 Ill. 368.

25a. Consent of persons other than husband and wife, under Ill. Act, $\S 13$, need not be acknowledged. Teninga, Receiver, $v$. Glos, 266 Ill. 94.

26. This statute changes the rule of law as to notice, but the Legislature has the right to do this, without violating the Constitution. "Even if the proper construction of the provision were that it attempted to authorize judgment against a resident notified only by publication, yet the law can be given practical effect, in which event only the particular provision would fail, and not the whole law." People v. Simon, 176 111. 165. By Section 31 service of process is required to be made on all known residents interested. In delivering the opinion of the court in the suit of Tyler $v$. Judges, 175 Mass. 68, Chief Justice Holmes said: "I am free to confess, however, that with the rest of my brethren, I think the act ought to be amended in the direction of still further precautions to secure actual notice before a decree is entered, and that, if it is not amended, the judges of the court ought to do all that is in their power to satisfy themselves that there has been no failure in this regard before they admit a title to registration." Acting on this suggestion the Massachusetts act was amended in 1898 and in 1900 to this effect: "The court shall, so far as it considers it possible, require proof of actual notice to all adjoining owners, and to all persons who appear to have any interest in or claim to the land included in the application. Notice to such 
except as provided in section thirty-one, and shall be conclusive and binding on all the world.

Cal. \$13.

Colo. §20a.

I11. $\$ 19,21$.

Mass. §31.

Minn. $\$ 3384$.

Miss. $\$ 6$.
N. C. $\$ 6$.

N. Y. $\$ 385-7$.

Ohio $\$ 15$.

Ore. $\$ 18,20$.

Wash. §20a.

SEC. 33. [Certificate of Service.] Certificate from the registrar and sheriff, or their deputies, showing the due execution of said order of publication and the mailing and posting of copies thereof, as required by sections twenty-seven to thirty, inclusive, shall be filed among the papers in the cause and be conclusive ${ }^{27}$ proof of such service.
Colo. \$20a.
N. Y. \$387-8.
Mass. §31, 32 .
Ohio \$16.
Miss. \$7.
Wash. §20a.
N. C. \$7.

SEc. 34. [Time of Hearing.] After the expiration of at least (fifteen) days from the publication and posting of said order of publication as aforesaid the cause shall be set down for hearing.

Sec. 35. [Guardian ad Litem.] And thereupon the court shall appoint some discreet and competent (attorney at law) of the county or city in which the land lies, as guardian ad litem for all persons under disability, not in being, unascertained, unknown or out of the state, who may have or appear to have an interest in or claim against the land.

person by mail shall be by registered letter." In this section we have gone even further to meet all objections and to insure as far as possible the discovery and notification of all possible claimants.

27. "The Torrens System of registration of land titles is different from the prevalent method of recording; the manner of bringing lands under such system must be provided by statute; the proceeding is of a different nature from an ordinary action at law or suit in chancery; and we cannot say that the Legislature acted unreasonably in providing for a rule of evidence applicable to the proceeding without extending it to all other forms of action in which the title of real estate is involved." Waugh $v$. Glos. 246 Ill. 604. 
SEc. 36. [Answer to Petition.] Any person having any interest in or claim against the land, whether named in the petition and order of publication or not, may appear and file an answer at any ${ }^{28}$ time before final decree, unless such person shall have been served personally with notice.

SEc. 37. [Signature and Oath to Answer.] The answer shall be personally signed and sworn to, by the claimant, or in case of a corporation or a person under disability, by the person authorized to file the answer, unless the court, for good cause shown otherwise direct.

\section{PAR'T V. \\ Adjudication of Trthe.}

SEC. 38. [Action on Report of Examiner of Titles.] After the expiration of the time as provided by section thirty-four, the court may proceed to take such action as may be proper, ${ }^{29}$ upon the report of the examiner of titles and all other evidence before it with reference to the rights ${ }^{29 a}$ of all persons appearing to have any interest in or claim against the land, and may refer the cause again or require further proof.

Cal. §14, 18.

Colo. $\$ 18,23,25$.

I11. $\$ 23,24$.

Mass. $\$ 36$.

Minn. §3382.
Miss. §8.

N. C. $\$ 8$.

Ohio $\$ 18,19$.

Ore. \$23, 24.

Wash. §18, 23, 25.

28. The Colorado and other acts having special provisions on this subject provide that an answer may be filed within the time named in the summons, "or within such further time as may be allowed by the court." It is fairer and better to allow an answer at any time before final decree."

29. Under this provision the cause will be taken for confessed as to all persons who have not appeared and answered and the court will proceed to dispose of the claims of those who have not appeared. People $v$. Crissman, 41 Colo. 450, expressly decides that the court is not bound by the examiner's report.

29a. Rights of intervening parties will be protected. Specific performance of contract enforced. Midway Co. $v$. City of St. Paul, 128 Minn. 135. 
SEc. 39. [Order of Survey, etc.] While the cause is pending before the examiner of titles, or at any time before final decree, and whenever after initial registration a tract of land is subdivided, the court

(1) May require ${ }^{30}$ the land to be surveyed, after due notice to owners of adjoining land, by a competent surveyor appointed by the court;

(2) Shall order durable bounds to be set and a plat thereof to be filed among the papers of the suit;

(3) Shall enter all necessary decrees for the establishment, declaration and protection of the right and title of all persons appearing to have any interest in or claim against the land.

Cal. §14.

I11. §25.

Mass. §35.

Miss. §5, 13, 15.
N. C. $\$ 5,13,15$.

N. Y. $\$ 381$.

Ohio $\$ 19$.

Ore. \$24.

Sec. 40. [Petition May Be Dismissed.] If in any case the petitioner so desires, or if the court is of opinion that the petitioner's title is not and cannot be made proper for registration, the petition may be dismissed ${ }^{31}$ without prejudice, on terms to be determined by the court.

Cal. \$12.

Colo. $\$ 26$.

Minn. \$3382.
Ohio, §20.

Wash. §26.

30. When property is subdivided for registration of any subdivision there must be proof thereof by plat or other evidence sufficient for conveyance. Glos v. Ehrhardt, 224 I11. 532. Decree reversed because no plat was proved before registration, and it was impossible to locate the subdivision from the evidence. Glos v. Bragdon, 229 Ill. 223; Glos v. Grant Bldg. Assn., 229 Ill. 387. A survey is of prime importance and necessity especially in states in which lands have not been laid off by government survey.

31. Petitioner must comply with terms fixed by court in withdrawing petition. McQuesten $v$. Commonwealth, 198 Mass. 172. After decree for petitioner, when on appeal and trial by jury a verdict is given for respondent, petition must be dismissed. Robinson v. Richards, 209 Mass. 295. A provision authorizing a dismissal of application does not violate constitution. Peters v. Duluth, 119 Minn. 96. Court must dismiss application, on motion, without prejudice, 
Sec. 41. [Amendments to Petition and Other Proceedings.] Amendments ${ }^{32}$ to petitions or other pleadings, or the severance ${ }^{33}$ thereof, including joinder, substitution of any person or

upon such terms as may be fixed by it. "The Torrens Act makes provisions for a special proceeding . . . In a special proceeding, it being within the power of the Legislature to limit the jurisdiction of the court, the bounds of the court's jurisdiction are to be found in the limitations of the act under which its jurisdiction is invoked. The Legislature might have provided for a determination of conflicting interests if it had been so inclined. But it did not do so. . . There is more or less difference in the Torrens acts as adopted in the several States. Where, as in Illinois, no provision is made for a voluntary dismissal, but the court is put to a final determination of the issue, it has been held that the court may grant relief as to such portion of the land as the evidence shows the title in fee to be in the applicant, and deny it as to the remainder. Glos v. Holberg, 220 Ill. 167. But our law was drawn upon a different theory." Krutz v. Dodge, 66 Wash. 178.

Undoubtedly, under this section, the court may, in the proper case, dismiss or allow dismissal without prejudice, as in any other action, and must, furthermore, dismiss where applicant fails to establish title, whether because a defendant has established title in himself or otherwise; but what court would, after trial on the merits of defendant's claim of title, fail to make findings according to the facts proved? Indeed, failure to make such findings to a defendant's prejudice would be reversible error. (Owsley $v$. Johnson, 95 Minn. 168.) - . In short, where defendant establishes title, the court must so find, and thereupon dismiss, not without prejudice as between applicant and such defendant, but absolutely. Hence the defendant in a registration proceeding may have all the relief usually available in an action to determine adverse claims wherein he is defendant. Seeger $v$. Young, 127 Minn. 416.

32. Amendment of petition by substituting name of respondent for petitioner is illegal and void. "If the respondents had wished to become petitioners they should have brought their own petition." Foss v. Atkins, 204 Mass. 337. Court properly permitted answer to be amended. Kuby $v$. Ryder, 114 Minn. 217.

33. Title to a portion of the property may be registered when properly established. Glos $v$. Holberg, 220 Ill. 167. G holding tax title to a portion of land offered for registration, claims ownership. Examiner of titles reported against validity of G's claim, but applicant dismissed application as to said portion of land. Held: G. cannot complain because his claim was allowed; also cannot complain of the application, nor because not allowed to make unnecessary 
persons, or discontinuance of parties and the omission or severance of any portion or parcel of the land, may be ordered or allowed by the court at any time before final decree upon terms that may be just and reasonable; and the court may require facts to be stated in an amended petition in addition to those prescribed by this act.

Cal. \$10.

Colo. $\$ 4$.

Mass. §20, 21, 23, 27.

Minn. $\$ 3378$.
II1. \$14.

Ore. $\$ 13$.

Wash. § 4.

SEC. 42. [Land May be Dealt With, Pending Registration, Subject to Decree of Court.] The land described in any petition may be dealt with pending ${ }^{34}$ registration as if no such petition had been filed.

(1) But any instrument admitted to record under the general laws in relation to such land pending action on said petition shall be docketed and indexed as required by section twenty-two of this Act;

(2) Any person who shall acquire any interest in or claim against such land shall at once appear as a petitioner, or answer as a party defendant, in the proceedings for registration, and such interest or claims shall be subject to the decree of the court.

Colo. \$32.

Mass. §22, 28.

Minn. \$3395.
N. Y. $\$ 398$.

Ohio §12.

Wash. §32.

SEC. 43. [Certificate of Taxes Paid.] No final decree of registration shall be entered until proof is made by certificate

amendments to his answer. Glos v. Murphy, 225 Ill. 58. See also Tower $v$. Glos, 256 Ill. 121. The provisions of this section have been broadened in the interest of business under the act. It covers the amendments to the Massachusetts act and adopts suggestions made by Hon. Charles Thornton Davis, Chief Judge of the Massachusetts Land Court, as to the omission or severance of any portion or parcel of the land.

34. Alienees of claimant pending registration proceedings are not entitled to answer as a matter of right, but answer must be filed in a reasonable time; a delay of six months is unreasonable, and the court did not abuse its discretion in denying the right to answer after such delay. Brown v. Haggadorn, 119 Minn. 491. 
from the proper officer that all taxes and levies assessed on said land and then due or delinquent have been paid in full.

SEC. 44. [Decree of Registration is Final, Quiets Title, and Binds All the World, Subject to Appeal, etc.] If the court, after final hearing, is of opinion that the petitioner has title ${ }^{35}$ proper for registration, a decree of confirmation and registration shall be entered; and every decree of registration entered in accordance with the provisions of this Act,

(1) Shall bind ${ }^{36}$ the land and quiet the title thereto, except as herein otherwise provided;

(2) Shall be forever binding and conclusive upon all persons, resident or non-resident, including the state, whether mentioned by name in the order of publication or included under the general description, "to all whom it may concern;"

(3) And shall not be attacked or opened or set aside by reason of the absence, infancy, or other disability of any person affected thereby, nor any proceeding at law or in equity

35. Applicant must prove fee simple title in himself by tracing back the government grant or by statutory limitations. Glos v. Holberg, 220 I1l. 167. Applicant must show title good against the world; prima facie title not sufficient. Glos $v$. Wheeler, 229 Ill. 272. Defendant to application cannot complain of title to lots in which he claims no interest. Mundt $v$. Glos, 231 Ill. 158. A good tax title may be registered. Tobias $v$. Kaspzyk, 247 Ill. 80 . In a petition for registration of tax title, former owner was made defendant. Time for redemption had not expired when application was filed, but owner failed to take advantage of this and the title was registered in name of claimant after redemption period. Held: a good registry, and that no one but former owner might have complained; State could not. Gates $v$. Keigher, 99 Minn. 138. Tax title registered subject to lien of city assessments. Gould $v$. City of St. Paul, 110 Minn. 324. Tax title registered. Hendricks $v$. Hess, 112 Minn. 252. Title by adverse possession under statute of limitations may be registered; partition decree gives color of title. Peters $v$. Dicus, 254 Ill. 379. When one consents to registration, decree is final as to him and cannot be set aside at a subsequent term. Mooney $v$. Valentynovicz, 255 Ill. 118. Petitioner's right to fee in land under $R$. R. right of way and station may be registered. Battelle $v$. N. Y. \&c. Ry., 211 Mass. 442. Petitioner must recover upon strength of his own title, and not upon the weakness of his adversary's title. Owsley $v$. Jackson, 95 Minn. 168.

36. A decree of registration cannot be collaterally attacked for error or fraud. State v. Ries, 123 Minn. 397. 
for rehearing or reversing judgments or decrees, except as herein especially provided.

Cal. $\S 9,14,1517$.

Colo. \$23, 27.

I11. \$25 26 .

Mass. §34, 37.

Minn. $\$ 3390$.

Miss. $\S 8,9$.
N. C. $\S 8,9$.

N. Y. $\S 391$.

Ohio \$22.

Ore. \$24, 25.

Wash. \$23, 27.

SEc. 45. [Form of Decree and Manner of Registration.] Every decree of initial registration and subsequent memorial shall be made in convenient form for transcription upon the certificate of title, showing the following items:

(1) Owmers:

Name and residence of the owner, and whether married or unmarried, and the name of the consort, if any;

If the owner is under disability the nature thereof, and if an infant, his age;

If a corporation, the place of incorporation and its chief office;

If a personal representative or trustee, the name of decedent or beneficiary.

(2) Land:

Description of the land as finally determined by the court;

The estate of the owner therein;

Also all the rights and easements appurtenant to said land;

And also a description of all particular estates, easements, ${ }^{37}$ liens, or other encumbrances, or rights ${ }^{37 \text { a }}$ to

37. "There is no provision in the Land Registration Act for an application by the owner of an easement for the registration of his title . . It seems to us, therefore, that the statute was not intended to afford a remedy by which owners of easements in the same land could have the nature and extent of their rights settled, and should not be so construed." Minot $v$. Cotting, 179 Mass. 325. Land Court may determine boundaries of highway. First National Bank $v$. Woburn, 192 Mass. 220.

37a. Title registered subject to possible claims of creditors of a decedent dead for less than seven years. Finn $v$. Glos, 268 Ill. 350. 
which the land or the owner's estate is subject showing their relative priorities.

(3) Other Matters: Any other matter determined in pursuance of the provisions of this Act.

SEc. 46. [Time of Taking Effect.] Such decree or memorial shall take effect upon the land described therein as of the day, hour and minute it is filed for registration in the office of the proper registrar.

SEc. 47. [Registrar's Memorandum.] The registar shall forthwith record the said decree in the proper book of the court, and shall forthwith enter and properly number, minutely date, and index a memorandum thereof on his land registration docket and in the entry book hereinafter directed to be kept by him, and shall cause to be recorded and indexed a like memorandum in the proper deed book of the county or city.

\section{PART VI.}

\section{Centificates of Tithe.}

SEc. 48. [Entry in Registry of Titles.] Said decree or memorial, or so much thereof as may be ordered by the court, shall be copied, numbered signed and sealed with the seal of the court by said registrar and registered in the book hereinafter directed to be kept by him to be known as the register of titles, for his county or city; and when so registered shall constitute the original certificate of title.

Subsequent certificates covering the same land shall be in a like form, but shall be designed "transfer certificate No..... (the number of the next previous certificate covering the same land), original certificate registered $\ldots \ldots \ldots$ (date, volume and page of registration)."

New and appropriate numbers shall be adopted for any subsequent certificates not covering the whole of said land.

Cal. $\$ 15,16,23,31,57$.

Colo. \$31, 36, 39, 41.

III. \$29-33, 38, 56.

Mass. §39, 41, 53, 54.

Minn. §3391.
N. Y. $\$ 394$.

Ohio \$22, 23, 37, 75, 76.

Ore. $\$ 28,32$.

Wash. \$31, 35, 38, 40. 
Sec. 49. [Entry Book Kept by Registrars.] (1) Each registrar shall keep an entry book in which he shall enter, in the order of their reception, a memorandum of any writing, instrument, or record filed with him for registration, and shall note in such book the year, month, day, hour, and minute of such filing.

(2) Every such writing, instrument, or record shall be numbered, indexed and indorsed with reference to the entry thereof and securely kept in the office of the registrar.

(3) Every such entry shall be minutely dated, numbered and indexed, and shall refer to the certificate of title hereinafter mentioned, upon which, as well as upon its duplicate or duplicates, a memorandum of such entry shall be made.
Cal. §22, 51.
N. Y. $\$ 409$.
Colo. $\$ 47$.
Ohio §35.
III. §49-51.
Ore. \$48-50.
Mass. $§ 55$.
Wash. \$46.
Minn. \$3402, 3406.

SEc. 50. [Register of Titles Kept by Registrar.] Each registrar shall also keep a register of titles book, in which, under the direction of the court, he shall

(1) Register, number and index the original certificates of title and all subsequent certificates of title, and all voluntary or involuntary transactions authorized to be registered under this Act; and

(2) Note thereon, and also upon the duplicate certificate thereof, when originally issued or subsequently presented, the day, hour, and minute of registration in each case in conformity with the date shown by the entry book.

\author{
Cal. \$29. \\ Colo. $\$ 35$. \\ I11. $\$ 35,98$. \\ Mass. $\S 55$. \\ Minn. §3402, 3406. \\ Miss. $\$ 10$.
}

N. C. $\$ 10$.

N. Y. $\$ 395$.

Ohio \$23, 82.

Ore. $\$ 34,97$.

Wash. \$34.

SEC. 51. [Certificate of Title.] (1) Every certificate of title entered in the register of titles as aforesaid, together with the memorials thereon, if any, shall be known as "the certificate of title." 
(2) Said certificate shall be conclusive evidence of all matters contained therein, except as otherwise provided in this Act.

(3) No erasure, alteration, or amendment of said certificate, or of any memorial thereon, shall be made except by order of court.

Cal. \$23, 30.

Colo. $\$ 35,37,48,57$.

Ill. §35-7, 39.

Mass. $\$ 40,46,107$.

Minn. \$3404, 3408, 3439.
N. Y. $\$ 395-7,399$.

Ohio $\$ 23,27,72,93,98$.

Ore. \$34-6, 38.

Wash. §34, 36, 47, 50.

SEc. 52. [Owner's Duplicate Certificate.] An exact copy of the certificate of title shall be made, except that it shall be conspicuously stamped or marked "owner's duplicate," and shall be delivered to the owner, or his attorney, duly appointed, upon his receipt therefor in writing upon said certificate of title attested by the registrar or his deputy.

SEC. 53. [Certificates of Title to be Numbered, and Memorials Thereon to be Signed and Sealed.] (1) All the certificates of title of land in each county or city shall be numbered consecutively.

(2) A separate folium, with appropriate spaces for subsequent memorials, shall be devoted to each title in the register of titles for each county or city.

(3) Every certificate and memorial thereon shall appropriately conform to the requirements of sections forty-five and forty-eight of this Act as to particulars of form.

(4) Every memorial made upon any certificate of title or duplicate certificate under any provision of this Act shall be signed by the registrar and sealed with the seal of the court and minutely dated and numbered in conformity with the date and number shown by the entry book.

Cal. \$23, 50.

Colo. $\$ 36,81$.

III. $\S 35,56$.

Mass. $\$ 40$.

Minn. \$3403.
Miss. \$11.

N. C. \$11.

N. Y. \$394.

Ohio \$23, 37.

Ore. \$34, 55. 
PART VII.

Registration of Transfers and Other Transactions.

SEC. 54. [Transfers of the Whole of any Registered Estate.] Whenever the whole of any registered estate is transferred, the transactions shall be duly noted and registered in accordance with the provisions of this Act.

Thereupon the certificate of title and any duplicate certificate relating to such estate shall be cancelled by the registrar of each county or city in which the land, or any part thereof, lies, if desired by the registered owner, and a new certificate or certificates of title shall be entered in the register of titles for such county or city, and a duplicate or duplicates thereof issued, as the case may require.

Cal. \$25, 26, 48.

Colo. \$38, 52, 60, 61 .

IIl. §34, 47, 57, 64 .

Mass. $\$ 56$.

Minn. \$3409, 3417, 3420 .

Miss. $\$ 12$.
N. C. $\$ 12$.

N. Y. $\$ 413$.

Ohio $\$ 37$.

Ore. $\$ 33,46,56,63$.

Wash. §37, 51, 59, 60 .

SEc. 55. [Partial Transfers, Encumbrances, Leases.] If only a portion of such estate is transferred, or in case of an encumbrance or lease for more than one year, the transaction shall be duly noted and registered as aforesaid; and a new certificate of title shall be entered in the register of titles and new owner's duplicate certificate shall be issued for the portion transferred and the portion untransferred, or a beneficiary's duplicate or lessee's duplicate may be issued as the case may require.

Cal. \$25, 26, 49.

Colo. $\$ 40,49,52,63$.

III. $\$ 48,64$.

Mass. $\$ 47,57,59$.

Minn. $\$ 3417,3420,3422$.

Miss. $\S 13,14$.
N. C. $\$ 13,14$.

N. Y. $\$ 407$.

Ohio $\$ 3,8,39$.

Ore. \$47, 63.

Wash. \$39, 48, 51, 62.

SEc. 56. [Memorials to be Noted.] All registered encumbrances, rights, or adverse claims affecting the estate represented thereby, shall continue to be noted upon every outstand- 
ing certificate of title and duplicate certificate until the same shall have been released or discharged or terminated.
Cal. §43.
N. C. $\$ 14$.
Colo. $\$ 56,57$.
N. Y, $\$ 403$.
III. $\$ 45$.
Ohio §33.
Mass. $\$ 5.8$.
Ore. \$44.
Minn. \$3420.
Wash. §55, 56.
Miss. \$14.

SEc. 57. [Registration of Voluntary Transactions.] In voluntary transactions, the duplicate certificate of title must be presented along with the writing or instrument filed for registration; and thereupon, and not otherwise, the registrar shall be authorized to register the transaction, under the direction of the court, upon proof of payment of all delinquent taxes and levies, if any.

Cal. \$58-65.

Colo. $\$ 50,52-3,57-8,63$.

I11. \$54-5, 59-67, 80-81.

Mass. $\$ 60$.

Minn. \$3419, 3420, 3423.

Miss. $\$ 14,15$.
N. C. $\$ 14,15$.

N. Y. $\$ 406,415$.

Ohio \$44-49.

Ore. \$53-54, 58-66

Wash. §49, 51-2.

SEC. 58. [Registration of Involuntary Transactions.] In involuntary transactions, a certificate from the proper state, county, city, or court officer, or a certified copy of the order, decree, or judgment of any court of competent jurisdiction, or other appropriate evidence of compliance with the statute in relation to such transaction, when filed in the office of the proper registrar, shall be authority for him to register the transaction under the direction of the court.

Provided that any writing or instrument for the purpose of transferring, encumbering, or otherwise dealing with equitable interests in registered land, may be registered with such effect as it may be entitled to have.

Cal. \$72-3.

Colo. $\$ 60-61,72,76,91$.

I11. $\$ 80-81,84-91$.

Mass. $\$ 66,70,75,77,79-86$.

Minn. $\$ 3419,3426-7,3430$, 3434-5, 3441.

Miss. $\$ 14,16$.
N. C. $\S 14,16$.

N. Y. $\$ 417$.

Ohio $\S 43,50-6,59-64,66-7$, 78.

Ore. \$79-80, 83-90.

Wash. §59, 60. 
SEc. 59. [Production of Duplicate Certificate Required.] Whenever a duplicate certificate is not presented to the registrar along with any writing, instrument, or record filed for registration under this Act, he shall forthwith send notice by registered mail to the owner of such duplicate requesting him forthwith to produce the same, in order that a memorial of the transaction may be made thereon; and such production may be required by suitable process of the court, if necessary.

Colo. \$50, 78.

I11. $\S 60,64,88$.

Mass. §51, 71, 106.

Minn. $\$ 3413,3419,3430$.

Miss. $\$ 14,17$.
N. C. $\$ 14,17$.

Ohio $\$ 28,37,41,74,78,100$.

Ore. $\$ 59,63,87$.

Wash $\$ 49,77$.

SEC. 60. [Registration of Trusts, Conditions, Limitations and Other Equitable Interests and Estates.] Whenever a writing, instrument, or record is filed for the purpose of transferring registered land in trust, or upon any equitable condition or limitation expressed therein, or for the purpose of creating or declaring a trust or other equitable interest in such land without transfer, the particulars of the trust, condition, limitation, or other equitable interest shall not be entered on the certificates, but it shall be sufficient to enter in the entry book and upon the certificates a memorial thereof by the terms "in trust," or "upon condition," or other apt words, and to refer by number to the writing, instrument, or record authorizing or creating the same.

And if express power is given to sell, encumber, or deal with the land in any manner, such power shall be noted upon the certificates by the terms "with power to sell," or "with power to encumber," or by other apt words.

And unless express power be given as aforesaid, no subsequent transfer or memorial shall be registered on such certificate except by special order of court.

Cal. \$67, 70.

Colo. $\$ 64$.

I11. §68-9.

Mass. §64-8.

Minn. \$3429.
Miss. $\$ 10,19$.

N. C. $\$ 10,19$.

Ohio \$32, 65.

Ore. $\$ 67-8$. 
SEC. 61. [Registration of Estates of Decedents.] Lands and any estate or interest therein registered under this act shall, upon the death ${ }^{\mathbf{3 8}}$ of the owner, testate or intestate, go to his personal representative in like manner as personal estate, and shall be subject to the same rules of administration as personalty, except as otherwise provided in this Act.

(2) But nothing herein contained shall alter or affect

(a) The course of ultimate descent under the statute of descents and distributions and the rights of dower and curtesy, when duly registered;

(b) Nor the order in which real and personal assets respectively are now applicable in and towards the payment of funeral and testamentary expenses, debts, or legacies;

(c) Nor the liability of real estate to be charged with the payment of debts and legacies.

Cal. \$74-5.

Colo. \$74.

III. \$70-2.

Mass. $\$ 91$.

Minn. §3436.
N. Y. $\$ 423-5$.

Ohio $\$ 42-3$

Ore. $\$ 69-71$.

Wash. §73.

SEC. 62. [Powers of Personal Representatives.] (1) Subject to the powers, rights and duties of administration, the personal representatives of such deceased owner shall hold such real estate as trustees for the persons by law beneficially entitled thereto,

(2) But, unless otherwise entitled by law to commissions, shall be entitled to no commissions thereon except in cases of necessary sales in due course of administration.

(3) And the heirs at law or beneficiaries aforesaid shall have the same power of requiring a transfer of such estate as if it were personal estate.

III. \$70-72.

Ore. \$69-78.

38. "We are not impressed with the soundness of the objections to those sections of the statute which relate to the descent of lands on the death of a registered owner." People $v$. Simon, 176 Ill. 165. 
SEC. 63. [Registration of Delinquent Taxes and Levies.] (1) It shall be the duty of the treasurer or other collector of taxes or levies of each county, town, or city, not later than the .... day of ........ in each year, to file an exact memorandum of the delinquency, if any, of any registered land for the non-payment of the taxes or levies thereon, including the penalty therefor, in the office of the proper registrar for registration.

(2) If any such officer fail to perform said duty, he and his sureties shall be liable for the payment of said taxes and levies with the penalty and interest thereon.

Miss. \$21.

N. C. $\$ 21$

II1. §82.

SEC. 64. [Registration of Sales for Delinquent Taxes or Levies.] (1) Whenever any sale of registered land is made for delinquent taxes or levies, it shall be the duty of the treasurer or other officer making such sale, forthwith to file a memorandum thereof for registration in the office of the proper registrar.

(2) Thereupon the registered owner shall be required to produce his duplicate certificate for cancellation, and a new duplicate certificate shall be issued in favor of the purchaser, and the land shall be transferred on the land books to the name of such purchaser, unless such delinquent charges and all penalties and interest thereon be paid in full within ninety days after the date of such sale.

(3) But a memorial shall be entered upon the certificate of title, and also upon any such new duplicate certificate, reserving the privilege of redemption in accordance with law.

Cal. \$77-83.

III. \$82-3.

Miss. §22.
N. C. \$22.

Ohio \$57-8.

Ore. \$81-2.

SEc. 65. [Same: Registration of Redemption.] In case of any redemption under the preceding section, a memorial of the fact shall be duly registered; and if a duplicate certificate has been issued to any purchaser, the same shall be cancelled and a new duplicate shall be issued to the person who has redeemed. 
Sec. 66. [Same: Registration of Final Sale, if No Redemption.] (1) If there be no redemption under said section in accordance with law, it shall be the duty of the treasurer, or other collector of taxes of the county or corporation in which the land lies, to sell the same, at public auction, for cash, having first given reasonable notice of the time and place of sale.

(2) The proceeds of sale shall be applied-

First, to the payment of all taxes then due the state, and all levies then due the county, town, or city, with interest, penalty and costs;

Second, to the payment of all sums paid by any person who purchased at the former tax sale, with interest and the additional sum of five dollars;

Third, to the payment of a commission to the officer making the sale of five per centum on the first three hundred dollars and two per centum on the residue of the proceeds;

Fourth, to the satisfaction of any liens other than said taxes and levies registered against said land in the order of their priorities;

Fifth, and the surplus, if any, to the person in whose name the land was previously sold for taxes, subject to redemption, as provided by section sixty-four of this Act, his heirs, personal representatives, or assigns.

(3) A memorial of the sale under this section shall be duly registered, and a new certificate shall be entered and a duplicate issued in favor of the purchaser, in whom title shall be thereby vested as registered owner, in accordance with the provisions of this Act.

SEc. 67. [Same: Future Interests Not Affected.] Nothing in the preceding section shall be so construed as to affect, or divest, the title of a tenant in reversion or remainder to any real estate which has been returned delinquent and sold on account of the default of the tenant for life in paying the taxes or levies assessed thereon.

Cal. $\$ 77-83$.

III. §82-3.

Miss. §23.
N. C. $\S 23$.

Ohio \$57.

Ore. \$81-2. 


\section{PAR'T VIII.}

\section{Sundry Proceedings After Registration.}

SEC. 68. [Petitions Concerning Registered Land and Caveats and Decrees Thereon.] Any registered owner of any estate or interest in land, or any person having any claim against registered land arising from any other cause than fraud or forgery since the land was registered, may, within ninety days after the claim or cause of complaint shall have arisen, petition the court for relief in any matter within its jurisdiction; and it shall be the duty of the proper registrar, upon the request of any such person, to register a memorial that such petition has been or will be filed, which memorial shall serve as a caveat and be notice to all persons.

(2) And whenever any registrar is in doubt as to the proper registration to be made in any case, or when any person is aggrieved by any act or refusal to act by the registrar, the question may be likewise submitted by petition.

SEc. 69. [Same: Hearing and Decree.] After notice to the parties interested, the court shall hear the cause, and, with due regard to the provisions of this Act, shall enter such decree as justice and equity may require, which shall be registered, and take effect in like manner as the original decree for registration.

SEc. 70 [Same: Service of Notice.] Notice in lieu of process under this Act or otherwise in relation to registered land, may be served upon any person by registered mail, and the post office registry return receipt shall be evidence of such service, and shall be binding, whether such person resides within or without the state; but the court may in any case order different or further service by publication once a week for four successive weeks in some convenient newspaper or otherwise, which shall be likewise binding.

Cal. §39, 97-100.

Colo. $\$ 49,62,78,82,89$.

Ill. \$92-6.

Mass. §52, 105, 107.

Minn. §3407, 3426, 3435, 3438-9.
Miss. §25.

N. C. $\$ 25$.

N. Y. $\$ 383,422$.

Ohio \$40, 168, 70, 79.

Ore. \$91-5.

Wash. $\S 48,61,77,81,88$. 
SEc. 71. [Proceedings Upon Loss or Destruction of Duplicate Certificate.] (1) Whenever a duplicate certificate of title is lost or destroyed, the owner, or his personal representative, may petition the court for the issuance of a new duplicate.

(2) Notice of such petition shall be published once a week for four successive weeks, under the direction of the court, in some convenient newspaper.

(3) Upon satisfactory proof that said duplicate certificate has been lost or destroyed, the court may direct the issuance of a new duplicate certificate, which shall be appropriately designated and take the place of the original duplicate.

Cal. \$27.

Colo. \$51.

III. $\$ 58$.

Mass. 104 .

Minn. \$3412.
Miss. §24.

N. C. $\S 24$.

N. Y. $\$ 414$.

Ore. $\$ 57$.

Wash. §50.

PART IX.

Legal EFfects of Registration of Title.

SEC. 72. [Effect of Registration as Notice to Subsequent Purchasers.] Every voluntary or involuntary transaction which, if recorded, filed, or entered in any clerk's office, would affect unregistered land, shall, if duly registered in the office of the proper registrar, and not otherwise, be notice to all persons from the time of such registration, and operate in accordance with law and with the provisions of this Act upon any registered land in the county or city of such registrar to which it relates.

SEc. 73. [Effect of Registration Upon Adverse Claims.] Every registered owner of any estate or interest in land brought under this act shall hold the land free ${ }^{39}$ from any and all ad-

39. Registration is good against purchaser at tax sale who fails to take out tax deed, and bars any claim for reimbursement of taxes and special assessments paid by claimant while holding certificate of tax sale, upon which the time for the execution of a deed subsequently expired without any deed being taken. Snow $v$. Glos, 258 I11. 275. 
verse claims, rights, or encumbrances not noted on the certificate of title, except-

First. Liens, claims, or rights arising or existing under the laws or Constitution of the United States 40 which the statutes of this state cannot require to appear of record under registry laws.

Second. Taxes and levies assessed thereon but not delinquent.

Third. Any lease for a term not exceeding one year under which the land is actually occupied.

$\begin{array}{ll}\text { Cal. §34, 37-8, 41, 45-6. } & \text { N. C. \$25. } \\ \text { Colo. \$30. } & \text { N. Y. §392, 400. } \\ \text { Ill. §40, 42-4 } & \text { Ohio §22, 25, 98. } \\ \text { Mass. \$37-8, 54, 63. } & \text { Ore. \$39. } \\ \text { Minn. §3393. } & \text { Wash. \$30. } \\ \text { Miss. §25. } & \end{array}$

SEC. 74. [Same: Fraud or Forgery.] The protection of the foregoing section shall not apply to the benefit of a registered owner in cases of fraud or forgery $*$ to which he is a party, or in which he is a privy without valuable consideration paid in good faith.

40. Title registered before land had been patented and granted by U. S. void. Shevlin v. Fogarty, 130 Minn. 456.

*The effect of this and the preceding section is to give an absolute and unassailable title to every innocent registered purchaser for value, even though the registration of his title was obtained through fraud or forgery. In other words the theory of this act is that every Certificate of Title imports absolute verity, and that the title passes by registration in like manner as by original government grant of ungranted lands. One of the chief benefits of this registration system is that it makes land a commercial asset. Those jurisdictions which are unwilling to protect the title of innocent registered purchasers for value against forgery, should adopt the following substitute section:

SEC. 74. [Fraud or Forgery.] The protection of the foregoing section shall not apply to the benefit of a registered owner:

(1) In cases of forgery, whether or not he be a party or privy thereto.

(2) In cases of fraud, if he be a party thereto, or in which he is a privy without valuable consideration paid in good faith. 
SEc. 75. [Effect of Registration Procured Through Fraud or Forgery.] Any registration procured through fraud or forgery may be set aside by the court according to the rules of equity; but the rights and title of an innocent intervening registered encumbrancer or purchaser for value and without notice shall not be affected thereby. ** And in all such cases the injured party may pursue all his legal and equitable remedies ${ }^{40 a}$ against the party or-parties to such fraud or forgery.

Colo. $\$ 46$.

III. $\$ 42-3,65$.

Mass. $§ 59,70$.

Minn. §3416, 3430, 3440-1.

Miss. §18.
N. C. $\S 18$.

N. Y. $\$ 392,402,410$.

Ohio \$41, 50, 88, 89.

Ore. \$41-2.

Wash. $\$ 45$.

**If substitute Section 74 be adopted, here add: "except as provided in section seventy-four."

40a. Application to vacate a decree of registration for fraud is governed by general equitable considerations. "The fact that a statute does not expressly provide that fraud shall invalidate acts authorized to be done under it does not deprive the courts of the general power to protect the rights of the parties. . . The 60day limitation contained in the statute when these transactions occurred (now mads six months by R. L. 1905, Sec. 3396) has no application to the case at bar. If the defrauded party is not guilty of laches, he may attack the decree on the ground that it was obtained by fraud, so long as the land stands registered in the name of the party who was guilty of the fraud." Baart $v$. Martin, 99 Minn. 197. In this case the court said: "An examination of the Torrens laws of the different states and colonies discloses the fact that those of Minnesota and the Fiji Islands only contain no express exception of cases of fraud. All the original Torrens statutes carefully guard against the possibility of an owner being fraudulently deprived of his property." When applicant omits names of parties holding easements and examiner mentions them and recommends, that they be made parties, registration without making them parties is void and subject to collateral attack for constructive fraud. "Any other conclusion would go far to remove the safeguards which make the law constitutional. It would make a strong argument for holding that the act was invalid, because the proceedings do not constitute due process of law." Riley $v$. Pearson, 120 Minn. 210. Decree of registration is not good against claimant whose name, though known, is given incorrectly in application, and who has no actual notice. Arnold $v$. Smith, 121 Minn. 116. The question whether an innocent 
SEC. 76. [Land to Remain Forever Registered.] The obtaining of a decree of registration and the entry of a certificate of title shall be construed as an agreement running with the land, and the same shall forever remain registered land, subject to the provisions of this Act and all amendments thereof.
Cal. $\$ 44$.
N. C. $\S 26$.
Colo. \$33.
N. Y. $\$ 404$.
I11. $\$ 46$.
Ohio $\$ 26,86$.
Mass. $\$ 44$.
Ore. $\$ 45$.
Miss. §26.
Wash. \$33.

SEC. 77. [No Rights by Adverse Possession of Prescription.] No title to, nor right, nor interest in, registered land in derogation of that of the registered owner shall be acquired by prescription or adverse possession.

Cal. §35.

Colo. $\$ 34$.

IIl. $\$ 41$.

Mass. $\$ 45$.

Minn. \$3371.
Miss. §27.

N. C. $\S 27$.

N. Y. $\$ 401$.

Ohio $\$ 85$.

Ore. \$40.

SEC. 78. [Effect of Subsequent Dealings With Registered Land.] Except as otherwise specially provided by this act, registered land and ownership therein shall be subject to the same

purchaser of a registered Torrens title is protected against the fraud of his grantor in failing to disclose in the registration proceedings an unrecorded mortgage, cannot be raised by demurrer to answer pleading innocent purchase and a general denial of all the allegations. of the complaint. Henry $v$. White, 121 Minn. 527. Where owner fraudulently fails to mention unrecorded mortgage in application, and does not make mortgagee a party to proceedings for registration, held that innocent purchaser of registered title takes it free of lien. "It is difficult to see what would remain of the indefeasible character of a Torrens title, if the decree is open to collateral attack as against one who purchases in good faith for a valuable consideration, and with nothing to put him on inquiry as to fraud on the part of the applicant. Henry $v$. White, 123 Minn. 182; State $v$. Rees, 123 Minn. 397. "Good faith in the acquirement of title, within the meaning of the statute, does not require ignorance of adverse claims or defects in the title. Notice actual or constructive is of no consequence." So held in a suit for registering title by adverse possession. Peters $v$. Dicus, 254 Ill. 379. 
rights, burdens and incidents as unregistered land, and may be dealt with by the owner, and shall be subject to the jurisdiction of the courts in the same ${ }^{41}$ manner as if it had not been registered.

(2) But registration ${ }^{42}$ shall be the only operative act to transfer or affect the title to registered land, and shall date from the time the writing, instrument, or record to be registered is duly filed and entered in the office of the proper registrar.

(3) Subject to the provisions of section seventy-three hereof, no voluntary nor involuntary transaction shall affect the title to registered land until registered in accordance with the requirements of this Act.

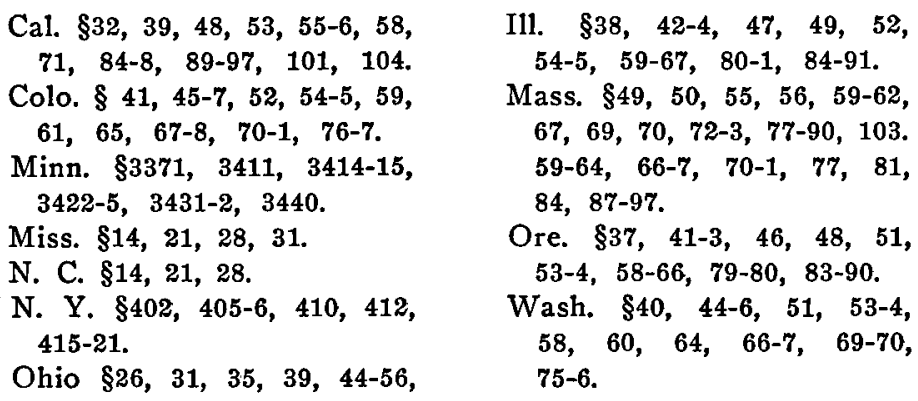

41. Mechanic's liens cannot be foreclosed in registration proceedings. This section "shows beyond doubt an intention on the part of the legislature to require all such liens to be foreclosed in the usual manner and under the provisions of the general statutes providing for their foreclosure and enforcement." Reed $v$. Siddall, 94 Minn. 216.

42. "Our construction of this section is in keeping with the obvious purpose of the Torrens act to create an absolute presumption that the certificate of registration in the registrar's office at all times speaks the last word as to the title, thus doing away with secret liens and hidden equities. . . . This is the distinctive feature, the vital principle of the Torrens System. For the courts to refuse to recognize and enforce it would be to emasculate the law, and by construction make it not the Torrens System of land titles, but a mere change in the form of the record, a mere modification of the recording act." Brace $v$. Superior Land Co., 65 Wash. 681. A mechanic's lien, recorded prior to registration but with insufficient description of land, of which applicant had no actual notice, and which was not reported 
SE'C. 79. [Conflicting Claims Between Registered Owners.] In case of conflicting claims between registered owners, the right, title or estate derived from or held under the older certificate of title shall prevail.

Miss. \$29.

N. C. §29.

\section{PART X.}

\section{Assurance Fund.}

SEc. 80. [Fee for Original Registration.] Upon (the filing of the petition for) the original registration of any land under this act there shall be paid to the registrar one-tenth of one per centum of the assessed value of such land as an assurance fund, which shall be subject to the trusts and conditions hereinafter declared for the uses and purposes of this act.

$\begin{array}{ll}\text { Colo. } \$ 83 . & \text { N. C. } \$ 33 . \\ \text { III. } 99 . & \text { N. Y. } \$ 426 . \\ \text { Mass. } \$ 93 . & \text { Ohio } \$ 102 . \\ \text { Minn. } \$ 3442 . & \text { Ore. } \$ 98 . \\ \text { Miss. §32. } & \text { Wash. } \$ 82 .\end{array}$

SEc. 81. [Payments Into State Treasury Upon Trust.] All moneys received by the registrars under the preceding section shall be kept in a separate account, and shall be paid into the state treasury upon the special trust and condition that the same shall be set aside by the ......... in trust as a separate fund for the uses and purposes of this act, to be known as the "land registration assurance fund," which said fund is hereby appropriated to the uses and purposes set forth in this act.
Cal. $\$ 108$.
N. C. $\S 33$.
Colo. $\$ 84$.
N. Y. $\$ 426$.
Ill. $\$ 100$.
Ohio $\$ 103$.
Mass. §94.
Ore. §99.
Minn. \$3443.
Wash. §83.
Miss. §32.

by examiner, is barred by registration, and does not affect title. "The registration proceedings were regular, and there was no fraud in obtaining the decree. It follows that the plaintiffs were bound by the decree, although it did not recognize or establish their lien." Doyle v. Wagner, 108 Minn. 443. 
SEC. 82. [Funds to Be Invested.] Said moneys, in so far as the same may not be required to satisfy any judgment certified against the assurance fund under section eighty-five of this act, shall be invested by the treasurer of the state in state bonds in trust for the uses and purposes set forth in this act until said fund amounts to the sum of (five hundred thousand) dollars; but the income, or so much thereof as may be required therefor, may be applied towards the payment of the expenses of the administration of this act and the satisfaction of any such judgment.

Whenever and so long as the face value of the bonds purchased as aforesaid equals said sum of (five hundred thousand) dollars, other moneys thereafter coming into said fund, together with any income not required for the purposes aforesaid, shall be transferred from the land registration assurance fund to the general treasury.

Colo. \$84.

Ill. $\$ 100$.

Mass. $\$ 100$.

Minn. \$3443.

Miss. §32.
N. C. $\$ 33$.

N. Y. \$426.

Ohio $\$ 103,111$.

Ore. \$99.

Wash. $\$ 83$.

SEc. 83. [Suits Against the Assurance Fund.] Any person ${ }^{42 a}$ who had no actual notice of any registration under this act by which he may be deprived of any estate or interest in land, and who is without remedy hereunder, may within two years next after the time at which the right to bring such action shall have first accrued to him or to some person through whom he claims, bring an action against the treasurer of the state in the..$\ldots \ldots$ court of..$\ldots \ldots$ for the recovery out of the assurance fund of any damages to which he may be entitled by reason of such deprivation.

(2) The assurance fund shall be defended in such action and in any appeal by the attorney-general for the state.

(3) The measure of damages in such action shall be the value of the property at the time the right to bring such action

42a. Claim against assurance fund sustained. Shevlin v. Fogarty, 130 Minn. 456. 
first accrued, and any judgment rendered therefor shall be paid as hereinafter provided.

(4) If any person entitled to bring such action be under the disability of infancy, insanity, imprisonment, or absence from the state in the service of the state or of the United States at the time the right to bring such action first accrued, the same may be brought by him or his privies within two years after the removal of such disability.
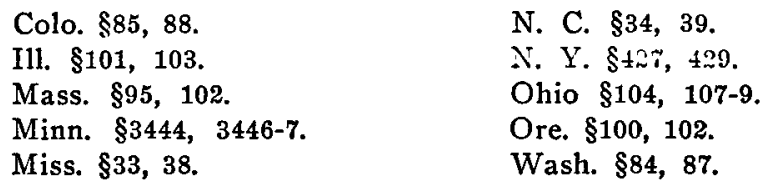

SEc. 84. [Defendants to Suits Against Assurance Fund.] If such action be brought to recover for loss or damage arising only through the legal operation of this act, then the treasurer of the state shall be the sole defendant.

(2) But if such action be brought to recover for loss or damage arising on account of any registration made or procured through the fraud or wrongful act of any person not exercising a judicial function, then both the treasurer of the state and such person shall be made parties defendant.
Colo. $\$ 86$.
N. C. $\$ 35$.
IIl. $\$ 102$.
N. Y. $\$ 428$.
Mass. $\$ 96$.
Ohio $\$ 105$.
Minn. $\$ 3445$.
Ore. $\$ 101$.
Miss. \$34.
Wash. §85.

SEc. 85. [Judgments Against the Assurance Fund.] If judgment be rendered for the plaintiff in any such action, execution shall issue against the defendants, if any, other than the treasurer of the state.

(2) And if such execution be returned unsatisfied in whole or in part, or if there be no such defendants, then the clerk of the court in which the judgment was rendered shall certify to the ....... the amount due on account thereof, and the same shall then be paid by said treasurer out of the assurance fund on warrant from said ........ under the special appropriation hereby made of said fund for that purpose. 
(3) Any person other than the treasurer of the state against whom any such judgment may have been rendered shall remain liable therefor, or for sc much thereof as may be paid out of the assurance fund and said treasurer may bring suit at any time to enforce the lien of such judgment against such person or his estate for the recovery of any amount, with interest, paid out of the assurance fund as aforesaid.
Colo. §86.
IIl. \$102.
Minn. §3445.
Mass. §97.
Ohio $\$ 106$.
Wash. §85.

SEc. 86. [When Assurance Fund Not Liable.] The assurance fund shall not, under any circumstances, be liable for any loss, damage, or deprivation occasioned by a breach of trust, whether express, implied or constructive on the part of the registered owner of any estate or interest in land.
Colo. \$87.
N. C. $\S 38$.
Mass. $\$ 101$.
N. Y. $\$ 429$.
Minn. \$3446.
Ohio $\$ 108$.
Miss. §37.
Wash. §86.

SEC. 87. [How Judgments Shall be Satisfied Out of Assurance Fund.] If at any time the assurance fund be insufficient to satisfy any judgment certified against it as aforesaid, the unpaid amount shall bear interest and be paid in its order out of any moneys thereafter coming into said fund.

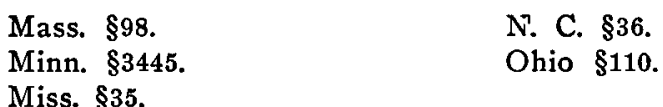

\section{PART XI.}

Fees for Registration.

SEC. 88. [Fees of Registrar and Other Officers of the Court.] The fees payable under this act shall be as follows:

(a) [To Registrars.] For docketing, indexing, and filing any original petition and exhibits therewith and publishing and mailing the notices thereof, the postage required, and three dollars. 
For docketing, indexing, and filing any other paper, fifty cents.

For the entry of the original certificate of title and issuing one duplicate certificate and recording and indexing memorandum, three dollars.

For each additional duplicate, fifty cents.

For the registration of any writing, instrument, or record, or any memorial, including every act necessary therefor, one dollar.

(b) [To Examiners of Titles.] For examining title and making report to the court, one-tenth of one per centum of the value of the land, and postage, and ten dollars. ${ }^{42}$

(c) [To Sheriffs.] For ascertaining and reporting to court the names and addresses of the persons actually occupying the premises described in any petition, one dollar.

(d) For any service of the registrars, or of any sheriff or or surveyor not specially provided for herein, such fee as may be allowed by law for like services in other cases.

Cal. \$114.

Colo. \$95-6.

I11. \$107-8.

Mass. $\$ 109$.

Minn. §3449-50.
Miss. $\$ 30$.

N. C. $\$ 30$.

N. Y. $\$ 432$.

Ore. \$106-7.

Wash. \$94-5.

\section{PART XII.}

\section{Application of Act.}

* Sec. 89. [Referendum.] This act shall not apply to land in any city or county, except the ........, until ${ }^{\mathbf{4 3}}$ it shall

*This section to be used only in states whose constitutions permit such provisions.

42a. Notwithstanding Ill, \$108, court decreed special allowance for fees to examiner. Tomczak $v$. Bergman, 269 Ill. 330 . See also Waugh $v$. Glos, 246 Ill. 604.

43. The referendum is not unconstitutional. Legislative power is not "delegated," but takes effect under certain conditions. People $v$. Simon, 176 Ill. 165. Legislature may amend act without a second referendum. Brooke $v$. Glos, 243 Ill. 392. And to the same effect is 
be so determined by the votes of a majority of those voting for or against the adoption thereof at any general or special election to be held in such city or county, after notices thereof shall have been duly posted for at least thirty days at each voting precinct in such city or county by order of the judge of the.......... court of such city or ccunty upon the petition of one hundred freeholders residing in such city or fifty freeholders residing in such county, the question to be submitted by ballots upon which the words "For Land Registration" and "Against LAND REGISTRATION" shall be printed, and one or the other of said expressions being stricken out as the voter may favor or oppose the act.

II1. $\$ 110$.

SEC. 90. This act shall be so interpreted and construed as to effectuate its general purpose 44 to make uniform the law of those states which enact it.

Waugh $v$. Glos, 246 IIl. 604, and Mihalik $v$. Glos. 247 Ill. 597, and Culver $v$. Waters, 248 Ill. 163. Illinois act is not unconstitutional as local law because only yet adopted by Cook County. Tower $v$. Glos, 256 Ill. 121.

44. The purpose of the statute is to provide a speedy and summary method to clear up title to land. Reed $v$. Siddall, 89 Minn. 417; Seeger $v$. Young, 127 Minn. 416. We think the purpose of the statute was to create an indefeasible title in the person adjudged to be the owner, and who thus becomes the original registered proprietor. Baart v. Martin, 99 Minn. 197. Torrens laws have the general purpose to clear up and settle land titles, and are nothing more than an enlargement of the remedy to quiet title. The remedy provided is not a substitute for an action of ejectment. Peters $v$. Duluth, 119 Minn. 96. The purpose of the statute was to create an indefeasible title in the person adjudged to be the owner. The basic principle of the system is the registration of the title to land instead of registering only the evidences of such title. A title is created by the decree and certificate of registration. Henry $v$. White, 123 Minn. 182, Citing; State $v$. Westfall, 85 Minn. 437; Baart $v$. Martin, 99 Minn. 197; Riley $v$. Pearson, 120 Minn. 210. The design of the system is to vest the title holder with a certificate behind which outsiders need not look, as toward them, it is forever binding and conclusive. Lachman $v$. Brookfield, 135 N. Y. S. 261. The title registration law is not for the purpose of registering bad titles or by the judgment of the court giving to the plaintiff a title which he does not have. Its ob- 
ject is to establish by a judgment of the court a fact once for all that the plaintiff has title so that thereafter the records need not be examined. Crabbe v. Hardy, 135 N. Y. S. 119. The intention of the title registration act is to provide a new system of land registration whereby persons can ascertain by an inspection of the register, in whom the title to a particular piece of property is vested. Partenfelter $v$. People, 211 N. Y. 355. The principle of the "Torrens System" is conveyance by registration and certificate instead of by deed, and assimilates the transfer of land to the transfer of stocks in corporations. . . . In this country the first states to adopt it were Illinois, California, Massachusetts, Oregon, Minnesota, and Colorado. In some of these constitutional defects were at first found by those courts whose judges were not favorable to the innovation. But the act was corrected in those states to remove the objections found, or succeeding judges held the act to be constitutional. . . . The defendants contend that the act is "in derogation of common right" and should be strictly construed. It is not in derogation of common right, but is a remedial statute and to be liberally construed, according to its intent, "so as to advance the remedy and repress the evil." It seems, however, to be a very plain statute, and was evidently drawn with great care and doubtless after consideration of the numerous statutes of this kind in force in the other states and carefully adopting what was thus culled out of our system of law and procedure and to our local conditions. Cape Lookout Co. v. Gold, $167 \mathrm{~N}$. C. 63 . This act is a beneficial one for the purpose of settling titles to real estate and to facilitate the transfer of the same without the expense of making a new investigation and abstract of the title at each successive conveyance. It has operated most beneficially and satisfactorily in the several countries and states that have adopted it. It has not been looked on with favor by some who believe that the act will deprive them of fees for the investigation and making an abstract of titles, but it was passed at the demand of the farmers and owners of real estate to save that very expense. Its adoption was a matter of public policy committed solely to the legislative department of the Government, and with which the courts have nothing to do. But we find nothing in the act which can be construed as intending to cut off claimants of adverse titles from a full examination and decision of their claims. On the contrary, the act was intended to give, once for all, the fullest examination into all controversies over the title to the land set out in the petition, because thereafter the order of the court in such cause will be conclusive. Manufacturing Co. v. Spruill, 169 N. C. 618.

\section{LAW LIBRARY \\ DNIVERSITY OF GEORGIA \\ ATHENS, GEQRGIA}




\section{ADDENDUM.}

The verbal changes made by the committee in the text of the foregoing act are as follows:

SEC. 2 (5), after "judgment" add decision.

SEC. 4, line 6, after "lands" add (or any interest therein, as hereinafter provided).

SEC. 11, bracket the words (90 days).

SEC. 17 (2), after "land" add (or any leasehold exceeding ....... years).

SEC. 20, line 4, strike out "filing" and substitute authorized to file.

Sec. 29, after the last word add under any claim of title.

SEC. 34, bracket (15).

SEC. 35, bracket (attorney at law).

SEC. 37, strike out "filing" and substitute authorized to file.

SEC. 41, after "substitution" add of any person or persons.

SEC. 56, after last word add or terminating.

SEC. 73, make this Section 75; and after "thereby," line 6, add except as provided in Section 74.

SEc. 74, make this Section 73.

SEc. 75, make this Section 74, and, for changes, see Section 74 , supra, the words "protection of the" being added, together with a footnote.

SEC. 78 (3), "74" changed to 73 .

SEC. 80, bracket (the filing of the petition for).

SEC. 89, words "be construed liberally for the purpose of effecting its general intent, but shall" stricken out, and a footnote added. 



\section{INDEX.}

References are to sections. A. $\&$ - means section of Act; T. $\&$ - means section of text.

\section{ABSTRACT OF TITLE:-}

Examiner's final report on, A. \$20; T. \$95.

In examiner's preliminary report, A. \$16; T. §82.

Petition for initial registration must contain, A. \$86; T. $\$ 50$. suggestions as to preparation of same, T. $\$ 50$.

To cross-petition, T. \$53.

\section{ACKNOWLEDGMENT OF SERVICE:-}

Attestation of, A. $\S \S 12,89 ;$ T. $\S 68$.

liability of officers falsely attesting, A. $\$ 13$; T. $\S 68$.

Form of, A. $\$ 89$.

Method of, A. §12; T. §68.

No traverse of, after judgment, A. §13; T. §§73-4.

\section{ACTIONS:-}

See Equity; Judicial Proceedings; Lis Pendens; Petition for Initial Registration; Registration; Summary Proceedings.

\section{ADJOINING OWNERS AND OCCUPANTS:-}

Definition of the phrase, T. $\$ 45$.

Examiner's preliminary report as to, A. \$16; T. \$84.

Names and addresses of, to be given in petition for initial registration, A. $\$ \$ 7,86(21)$; T. $\$ 45$.

Notice to in case of survey, A. $\S 22 ;$ T. $\$ 100$.

Protest to survey, A. $\$ 22 ;$ T. $\$ 100$.

To be designated as defendants in initial petition, A. $\S \S 7,86(21)$; T. $\S \S 45,49$.

\section{ADJOURNMENT:-}

See Courts.

\section{ADMINISTRATORS AND EXECUTORS:-}

Administration of registered lands, A. \$\$42-7; T. \$\$188-198.

Appointed subsequently to transfer of title to heirs-right of, A. $\$ 46 ;$ T. $\$ 199$.

As petitioners for initial registration, $T$. §27.

Assurance fund not liable for breach of trust by, A. §80; T. §254. Certificate of title in favor of, how issued, A. $\$ 44$; T. $\$ \S 191-2$. 
References are to sections. A. $\$-$ means section of Act; T. $\S-$ means section of text.

\section{ADMINISTRATORS AND EXECUTORS:-(Continued).}

Character of title held by, A. $\S 43 ;$ T. $\$ 188$.

Proceedings by, to determine heirs or devisees, A. $\$ 47$, T. $\$ 198$.

Proceedings by, to obtain duplicate of lost owner's certificate, A. $\$ 58$, T. $\$ 135$.

Sales by:

no order of the ordinary required, $T$. $\$ 189$.

not prevented by adverse possession, T. $\$ 189$.

objections to, how and when made, T. $\$ \S 189,193$.

transfer upon, how effectuated, T. $\$ 193$.

\section{ADVERSE CLAIMS:-}

See Involuntary Transactions, III; LiEns and Encumbrances.

Adjuricated by decree of title, A. \$26; T. $\S 111,113-4,230$.

All nust be fully disclosed in initial petition, A. $\S \S 7,86 ;$ T. $\$ \S 44$, 219.

Burden of proof as to, on examiner's hearing, T. $\$ 94$.

Cancellation of entry of:

involuntary, by order of judge, A. $\$ \S 60,62 ; \mathrm{T} . \S \S 181-2$.

twelve-months' limitation not apply to, T. \$229.

voluntary, A. $\S 62 ;$ T. $\S \S 142,180$.

form of requesting, A. $\$ 116$.

attestation of, A. $\S 62 ;$ T. $\S 142$.

Clerk's fee for noting, A. \$120; T. §259.

Effect on, where land freed from registration, A. §65; T. §§236-7.

Entry of brought forward on reissue of certificate, A. $\$ \S 39,100$;

T. \$187.

Exarniner's final report as to, A. §20; T. \$95.

Examiner's preliminary report as to, A. §16; T. \$83.

Failure to list, as fraud in initial registration, T. $\$ \$ 44,219$.

Holders of, to be named as defendants, A. $\S \S 9,86(26) ; T$. $\$ 49$.

Methods of setting out on initial issue of certificate of title, T. \$129.

Notation of on Title Register:

effect of failure to note, A. $\S \S 63,73 ; T . \S \S 145,245$.

effect of noting, A. $\$ 51$; T. $\$ \S 145,174$.

form of request for notation, A. \$114.

method of, A. $\$ 61$; T. $\$ \$ 173,175-7$.

right of any interested person to make, A. $\$ 51, T$. $\S \S 145$, 173-8.

verification of request for, A. §114; T. \$173.

Phrase "involuntary transaction" includes, A. §3; T. §21.

Summary proceedings for removal from Title Register, A. §60;

T. $\$ \$ 181-2,185$.

Under federal laws, A. §63; T. §\$211, 221-2. 
References are to sections. A. $\$$ means section of Act; T. $\$-$ means section of text. *

\section{ADVERTISEMENT:-}

See Notice; Service of Process.

Costs of, how paid, A. §52; T. \$263.

Form of clerk's certificate as to, A. $\$ 91$.

Form of, on initial registration, A. $\$ 88$.

Of application for issuance of duplicate in lieu of lost owner's certificate, A. \$58; T. \$135.

Of cancellation of owner's certificate not produced on involuntary transfer, A. \$52; T. \$172.

Of court's action on caveat to registration, A. $\S 60 ;$ T. $\$ 181$.

Of notice of application for involuntary transfer, A. \$50; T. \$166.

Of proceedings to establish heirship, A. $\S 45 ; \mathrm{T}$. $\$ 195$.

Of sale under creditor's certificate, A. $\$ 35 ;$ T. $\$ 155$.

\section{AFFIDAVIT:-}

See Verification.

\section{AMENDMENTS:-}

See SEVERAnCE.

Additional land not to be included by, T. §57.

Asking judgment establishing lesser estate, where plaintiff fails to prove title to the fee simple, T. $\$ 104$.

Allowed or ordered, when, A. §24; T. §57.

Examiner's powers as to, A. §24; T. §89. reports action on to court, T. $\$ 95$.

Ordered by court to compel the giving of better description, A. $\$ 7 ;$ T. $\$ 34$.

Parties, joined, substituted or stricken by, A, §24; T. §57. purchaser of land, pending initial registration, $T$. $\$ 60$.

Power of court to require additional facts to be stated by, A. $\$ 24$.

Terms, power of judge to impose, A. §24.

Verification of, A. \$7; T. $\$ 57$.

\section{ANSWER:-}

See Df,Fensive Pleadings.

\section{APPEARANCE OR PLEADING:-}

By those dealing with the land pending registration proceedings, A. $\$ 25 ;$ T. $\$ 60$.

Waiver of process and notice by, A. §14; T. $\$ 69$. 
References are to sections. A. $\S-$ means section of Act; T. $\$-$ means section of text.

\section{APPELLATE PROCEEDINGS:-}

See WrIT OF E,RROR.

\section{ASSESSMENT:-}

See Assurance Fund; Taxes and Assessments.

\section{ASSURANCE FUND:-}

Actions against, A. \$§77-8; T. §§250-257.

Attorney-General to defend, A. \$77; T. \$255.

a cumulative remedy, A. $\S 84 ;$ T. $\$ 257$.

defendants in, A. $\$ 78$; T. $\$ 255$.

limitation of actions, A. \$77; T. \$252.

disabilities, A. \$77; T. \$252.

measure of damage, A. \$77; T. \$253.

none for injury by breach of trust, A. \$80; T. \$254.

none for loss by forgery, $T$. \$251.

other remedies to be exhausted, A. \$79; T. \$256.

venue of, A. $\$ 77$; T. $\$ 250$.

Assessment for, A. \$74; T. §249.

clerk's duty to collect, A. $\S 74 ;$ T. $\$ \S 249,259$.

Created, how, A. \$§74-5; T. §249.

Cross-petitioner-liability of, for assessment, T. \$249.

Deposit in State treasury, A. \$75; T. \$249.

Disposition of, A. $\$ 76$; T. $\$ 249$.

Investment of, A. $\$ 76 ;$ T. $\$ 249$.

Judgments against, how paid, A. $\S \S 76,79$; T. $\S \S 249,256$.

execution on, how satisfied, A. \$79; T. \$256.

interest on, A. §81; T. §253.

Not an essential feature of the Act, $T$. $\$ 248$.

State Treasurer as custodian of, A. \$75; T. \$249.

Subrogation in favor of, A. §79; T. \$256.

\section{ATTESTATION:-}

Of acknowledgment of service, A. $\$ \S 12,89 ;$ T. $\S 68$.

As a safeguard against forgery, T. \$215.

Of bond for title to debtor transferring to secure debt, A. §36; T. \$152.

Of request to cancel entry of lien, encumbrance or other adverse claim, A. §62; T. $\$ 142$.

Of transfers, A. $\S 30 ;$ T. $\$ \$ 147-8,151$. transfer to secure debt, A. $\$ 32 ;$ T. $\$ 153$. 
References are to sections. A. $\$-$ means section of Act; T. $8-$ means section of text.

\section{ATTORNEY-GENERAL:-}

Defends suits against assurance fund, A. §77; T. $\$ 255$.

Service on when State is party, A. §11; T. \$67.

Supervisory powers over registration books and files, T. \$274.

\section{BANKRUPTCY:-}

Rights arising through, how far subject to the Act, T. \$222.

Trustee in, transfer of title to, T. $\$ 168$.

\section{BILL OF EXCEPTIONS:-}

See WrIT OF ERror.

BOND FOR TITLE:-

To debtor transferring to secure debt, A. §36; T. §152.

How rights of holder of are set forth in decree of title, T. $\$ \S 110-2$.

When holder of may register land, T. §26.

\section{BOUNDARIES :-}

See Adjoining Owners and Occupants; Description of the Land; SURVEY.

\section{BRIEF OF THE EVIDENCE:-}

See F,VIDENCE.

\section{BUILDING RESTRICTIONS:-}

See I,IE,NS AND ENCUMBRANCES.

How declared in decree of title, T. \$114.

To be set forth in initial petition, if any exists in favor of any adverse claimant, A. $\$ \S 7,86(22)$.

how set forth, T. $\$ 46$.

\section{BURDEN OF PROOF:-}

See FividenCE.

In attacks for fraud or forgery, T. $\$ 218$.

On exceptions to examiner's report, T. $\$ 98$.

On hearing before examiner, T. $\$ 94$.

On hearing of caveat under A. $\$ 60$, A. $\$ 59$; T. $\S 218$.

\section{CANCELLATION:-}

\section{Voluntary.}

II. Involuntary. 
References are to sections. A. $\$-$ means section of Act; T. $\&$ - means section of text

I. Voluntary.

By transferee of creditor's certificate, A. §115; T. \$159.

Certified copies of cancelled entries, how procured, A. \$101, T. $\$ 241$.

Entry of :

prima facie conclusive, A. §59; T. §§228-231.

caveat to, A. $\$ 60 ;$ T. $\$ \S 182-5$.

conclusive in twelve-months, A. §59; T. §231.

exception in case of fraud or forgery, A. \$63; T. \$231.

Form of request to cancel creditor's certificate, A. \$115.

attestation of, A. $\$ \$ 62,115$; T. $\$ 142$.

Form of request to cancel liens, encumbrances, etc., A. $\$ 115$. attestation of, A. $\S 62 ;$ T. $\$ 142$.

Limitation on proceedings to set aside entry of, A. $\$ 59$; T. $\$ 231$.

Of:

certificate of title and owner's certificate on total transfer, A. $\S 30 ;$ T. $\S 147$.

certificate of title and owner's certificate on transfer of divided portion of tract, A. $\$ 31 ;$ T. $\$ 151$.

creditor's certificate, A. $\$ \S 33,62,115 ;$ T. $\$ 159$.

liens and encumbrances, A. $\$ \S 62,116 ;$ T. $\$ \S 142,180$.

mortgages, A. $\S \S 62,116 ;$ T. $\$ \S 142,180$.

notice of lis pendens, A. $\S 82,116 ;$ T. $\S \S 142,180$.

notation of taxes and assessments, A. \$62; T. $\S \S 142,186$.

of owner's certificate not required on transfer of undivided interest, A. §31; T. §148.

\section{Involuntary.}

Certified copies of canceled registration, how procured, A. §101; T. \$241.

Of:

adverse entries on Title Register, A. $\$ 60 ; T$. $\$ \S 179,181-2$. creditor's certificate, A. $\$ 33 ;$ T. $\$ 159$.

liens and encumbrances, A. $\$ 60 ;$ T. $\$ \$ 179,181-2$.

owner's certificate, A. $\$ 52,60 ;$ T. $\$ \$ 169,171-2,185$.

advertisement of, A. $\S 52$; T. $\$ \S 172,185$.

registration, as result of reversal of judgment authorizing, 'T. $\S \S 233$.

transfer in fraud of creditors, A. \$55; T. \$207.

\section{CAVEAT TO REGISTRATION:-}

Attack by for fraud or forgery, A. $\$ 62 ;$ T. $\$ 184$.

Clerk's fees for, A. §120; T. §259. 
References are to sections. A. 8 - means section of Act; T. 8 - means section of text.

\section{CAVEAT TO REGISTRATION:-(Continued).}

Limitation on time of filing, A. §59; T. \$§229-231.

when applicable; when not, T. \$§229, 231.

Method of filing, A. $\S 60 ;$ T. $\$ 182$.

Procedure on A. $\S 60 ;$ T. $\$ \$ 182-185$.

To be noted on Title Register, A. §60; T. \$182.

\section{CERTIFICATE OF TITLE:-}

See Crepitor's Certificate; OWner's Certificate; Tithe Register.

All matters affecting the land must be entered on, A. $\$ \$ 40,73$; T. $\S \S 137,145,173-8,226,245$.

Cancellation of:

as result of judicial proceedings, A. $\S \S 49,52 ;$ T. $\S \S 171-2,208$.

not required on transfer of undivided interest, $A . \S 31$; T. $\$ 148$.

on caveat, A. $\$ 60 ;$ T. $\$ 182$.

on death of owner or co-owner, A. $\S \S 44,45 ;$ T. $\S \S 191-2$, 194-7.

on involuntary transfer, A. $\S 50,52 ;$ T. $\S \S 171-2 ; 208$.

on voluntary total transfer, A. $\$ 30 ;$ T. $\$ 147$.

on voluntary transfer of divided portion of tract, A. $\$ 31$; T. $\$ 151$.

Certified copy of:

as exclusive and conclusive evidence of title, T. $\$ 239$.

fees for issuance of, A. $\$ 120$; T. $\$ 259$.

how issued, A. \$101; T. \$241.

of plats and matters recorded outside the register, T. \$242.

where land is freed from registration, A. §65; T. \$246.

Crimes in relation to, A. \$85; T. \$258.

Conclusiveness of, see Conclusiveness.

Dating, signing and sealing, A. §29; T. §130.

Defined, T. §21

Effect of, where land is freed from registration, A. §65; T. §§234-7.

Embodiment of the conclusiveness attaching to registration, T. $\$ 226$.

Enrolment on Title, Register, A. §§28, 99; T. §§124-5.

Errors in, how corrected, A. §60; T. §§183-5.

Fees for issuance of, A. \$120; T. $\$ 259$.

Form and design of, A. \$99; T. \$\$124-132.

Enrolment on Title Register, A. $\S \S 28,99 ;$ T. $\$ \S 124-5$.

Indexing of, A. §§28, 99; T. §132.

Issuance of :

on initial registration, A. $\S \S 28 ; 99 ;$ T. $\$ \S 124-134$. 
References are to sections. A. - means section of Act; T. $\&$ - means section of text.

\section{CERTIFICATE OF TITLE:-(Continued).}

on involuntary transfer, A. $\S \S 49,50 ;$ T. $\S \S 171,208$.

on voluntary total transfer, A. $\S 30 ;$ T. $\$ 147$.

on voluntary transfer of divided portion of land, A. §31;

T. $\$ 151$.

on voluntary transfer of undivided interest, A. $\$ 31 ;$ T. $\$ 148$.

to heirs at law of deceased owner, A. $\S 45$; $T$. $\S \S 196-8$.

to personal representative of deceased owner, A. §44; T. $\$ \$ 191-2$.

Minute dating of all entries on, A. §29; T. \$273.

Numbering of, A. $\$ \S 98,99$; T. $\$ 125$.

Privilege of noting adverse claims, liens and encumbrances thereon, A. §51; T. \$145. See Registration III.

Suggestions as to preparation of on initial registration, $T$. §§125-133.

asking directions of judge in case of default, T. $\$ 131$.

description of the land, T. $\$ 126$.

reference to outside record, A. §103; T. §126.

designation of the owner, T. \$127.

designation of the owner's estate, T. \$128.

setting forth limitations, conditions, encumbrances, etc., T. $\$ 129$.

outside recordation of details, T. $\$ 129$.

Summary control of judge over. See Summary Proceedings.

Uncancelled entries to be brought forward on reissue of, A. $\S 39$, 100 ; T. $\$ 187$.

in case of involuntary transfer, T. $\S 170$.

\section{CERTIFIED COPIES:-}

See EvideNCE.

Fees for issuance of, A. $\$ 120 ;$ T. $\$ 259$.

How and when issued, A. \$101; $T$. \$241.

Of mortgage delivered to mortgagee, A. §38; T. §162.

\section{CHANGE OF NAME:-}

How registered, A. §53; T. §203.

\section{CITIES AND TOWNS:-}

See Municipalitites.

\section{CLAIMS:}

See Adverse Claims; Liens and Encumbrances.

\section{CLASS REPRESENTATION:-}

See Defindants, Service of Process. 
References are to sections. A. $\$$ means section of Act; T. $\$$ - means section of text.

\section{CLERK (OF THE SUPERIOR COURT) :-}

I. Generally.

II. Duties in Relation to the Act.

\section{Generally.}

Action against for wrong or neglect, A. \$84; T. \$\$255-7.

A ministerial officer only, A. $\$ 59 ; \mathrm{T} . \S \S 16,270,275$.

As defendant in action against assurance fund, A. $\$ 78 ;$ T. $\S 255$.

Criminal responsibility of, A. $§ 85$; T. \$258.

Costs of:

for attaching copy of plat to owner's certificate, A. $\$ 102$.

for attaching copy of outside record to certificate, A. \$103. generally, T. $\$ \$ 120,259,262$.

may demand in advance, A. § $120 ;$ T. \$263.

Dead or disqualified, who acts, A. $\S \S 3,69$; T. $\S \S 21,267$.

Definition of the word "clerk," A. §3; T. § 21 .

Deputy-clerk:

criminal responsibility of, A. $\$ 85 ;$ T. $\$ 258$.

duties of clerk performed by, A. $\S 83$; T. $\$ \S 68,268$.

included in the definition of the word "clerk," A. $\$ 3 ;$ T. $\$ 21$.

Entries of registration made by, prima facie conclusive, A. \$59;

T. $\$ \S 228-231$.

caveat to, A. $\$ \$ 59,60 ;$ T. $\$ \$ 182-5$. See Caveat.

twelve-months' limitation, when applicable, A. \$59;

T. $\S \S 229-231$.

Examiner entitled to free access to all records of, A. $\S 68$; T. $\S 82$.

Form of certificate by, as to service and notice, A. $\$ 91$.

Instructions of judge to, in ordering involuntary transfer, T. \$170.

Liability of:

for failing to publish or mail notice, A. $\S \S 13,84 ;$ T. $\$ \S 73,257$.

for falsely attesting acknowledgment of service, $A . \S \S 13,84$;

$T \S \S 68,257$.

for making false entry of notice, A. $\$ \S 13,84$; T. $\S \S 73,257$.

for registering instrument not properly attested, A. \$106;

T. 269 .

for wrong or neglect in making registrations, A. $\$ \S 59,84$; T. $\S \S 257,269$.

Limitations of the Act no protection to, against wrong or neglect, A. $\$ 84 ;$ ' $\mathrm{T}$. $\$ 257$.

Ordinary acts as, when, A. $\S 69 ;$ T. $\$ 267$.

Removal from office for offenses against the Act, A. $\$ 85 ;$ T. $\$ 258$.

Special clerk-included in definition of word "clerk," A. §3;

T. §21.

appointment of where clerk disqualified, A. $\S 69 ;$ T. $\$ 267$. 
References are to sections. A. $\$-$ means section of Act; T. $\$$ - means section of text

\section{CLERK (OF THE SUPERIOR COURT), I.:-(Continued).}

Subject to judge's directions in all matters, A. $\S 59 ;$ T. $\$ \$ 16,270$, 275.

Word "clerk" includes what, A. §\$3, 69, 83; T. §§21, 267-8.

II. Duties in Relation to the Act.

Advertising cancellation of owner's certificate not produced on involuntary transfer, A. $\$ \$ 52,60 ; T . \$ \$ 169,172,185$.

Attestation of acknowledgment of service, A. §12; T. §68. liability for false attestation, A. $\S \S 13,84$; T. $\$ \S 68,257$.

Authority to register involuntary transactions, not involving transfer, without prior order of judge, T. \$145. See Involuntary Transactions III.

Authority to register voluntary transactions, without order of judge, if owner's certificate presented, A. \$37; T. $\$ \$ 140,270$. exceptions, T. $\$ 140$.

transfer by administrator or executor, T. $\$ 193$.

transfer by husband to wife or vice versa, T. $\$ 201$.

transfer by one holding in trust or on condition, or

with unusual limitations or with powers, T. \$204.

transfer of homestead, T. \$2i0.

transfer of year's support, T. $\$ 209$.

Bringing forward uncanceled entries on transfer, A. $\S \S 39,100$;

T. $\$ 187$.

on involuntary transfer, T. $\$ 170$.

Cancellation of creditor's certificate, A. $\S 33,115 ;$ T. $\$ 159$.

Collection of assessment for assurance fund, A. \$74; T. \$249.

Dating all entries to the minute, A. \$29; T. \$273.

Determining whether transactions in proper shape for registration, A. $\S \S 59,106 ;$ T. $\$ 269$.

Docketing petition for initial registration, T. $\$ 24$.

Duplicate owner's certificate, when to issue, A. §58; T. \$135.

Enrolling decree of title, A. §§28, 98; T. \$§120-123.

Enrolling and registering certificate of title, A. \$\$28, 99; T. $\$ \$ 124-132$.

Filing away registration papers, A. §119; T. §271. method of filing, T. $\$ 272$.

Filing petition for initial registration, A. \$10; T. \$24.

Fixing return day of process, A. $\$ 10 ;$ T. $\$ 62$.

Forms prescribed by the Act as a guide to, T. $\S 270$.

Furnishing sheriff with notices to post on land, A. $\$ 14$.

In case of doubt as to any detail of registration, A. $\$ 59 ;$ T. $\$ \S 131$, $269,270,275$.

memorandum to be made in such cases, $T$. $\$ 270$.

method of applying to judge, T. $\$ 131$. 
References are to sections. A. $\$$ - means section of Act; T. $\$$ - means section of text.

\section{CLERK (OF THE SUPERIOR COURT), II.:-(Continued).}

In issuing certified copies from Title Register, A. \$101; T. \$241.

In issuing certified copies from registration files, T. \$242.

In registering:

change of name, A. $\$ 53 ;$ T. $\S 203$.

guardian's sale, $T \$ 200$.

involuntary transfers, A. $\$ \$ 49,52 ; T . \$ \$ 171-2$.

judgments, liens, etc., T. $\$ \$ 175-8$.

mortgages, A. §3S; T. \$\$161-2.

transfer as result of judicial proceedings, A. $\$ 49 ; T . \S 205$.

transfer in trust or on condition or unusual limitations or with powers, A. $\$ 38 ;$ T. $\$ 163$.

transfer to administrator or executor, A. $\$ 44$; T. $\S \S 191-2$.

transfer to heirs at law, A. §45; T. \$197.

transfer to secure debt in standard form, A. \$\$32, 38;

T. $\S \S 153,156-8$.

not in standard form, A. §38; T. \$157.

voluntary cancellation of entry, T. $\$ 180$.

voluntary total transfer in standard form, A. \$§30, 38; T. §147.

voluntary transfer by corporation, T. $\$ 164$.

voluntary transfer of divided portion of tract, A. $\S 31$; T. $\$ 151$. voluntary transfer of estate less than fee simple, T. $\$ 150$.

voluntary transfer of undivided portion of tract, A. \$31; T. $\S 148$.

voluntary transfers and mortgages not in standard form, A. $\$ 38 ;$ T. $\$ 163$.

Indexing certificates of title, A. $\S \S 28,99 ;$ T. $\$ 132$.

Indexing decrees of title, A. $\$ \$ 28,98 ;$ T. $\$ 123$.

Issuance of certified copies, A. §101; T. §§\&41-2.

Issuance of creditor's certificate, A. $\$ \$ 32,108-9$; T. $\$ \$ 153,156-8$.

Issuance of commission to take interrogatories, A. $\$ 20 ;$ T. $\$ 89$.

Issuance of owner's certificate, A. $\S \S 28,105 ;$ T. $\S 133$.

Issuing process, A. §10; T. §§62-3.

Mailing notice of registration proceedings to non-residents, A. $\$ \S 10,17 ;$ T. $\$ 64$.

Mailing notice to the occupants of the land, A. §14; T. §72.

Making owner's certificate correspond with certificate of title, and making entry on owner's certificate validating it, A. §118; T. §227.

Ministerial nature of clerk's duties, A. $\$ 59$; T. $\S \S 16,228-9,270$, 275.

Not to register,

involuntary transfer without order of judge, A. §41; T. §§144, 270.

exception, transfer to administrator of executor, A. \$44; T. $\S 191$. 
References are to sections. A. 8 - means section of Act; T. $\delta$ - means section of text.

\section{CLERK (OF THE SUPERIOR COURT), II:-(Continued),}

transaction by one holding in trust, or on condition or unusual limitation or with powers without order of the judge, A. §56; T. §204.

transaction unless properly attested, A. $\S 106 ;$ T. $\S 269$.

transfer from husband to wife or vice versa, without approval of judge, A. §48; T. \$201.

voluntary transfer unless owner's certificate is presented, A. $\S 37 ;$ T. $\S \S 140-1,215,270$.

Notifying additional defendants disclosed by examiner's report, A. $\S 17 ;$ T. $\S \S 75,84$.

Notifying interested parties disclosed in course of the proceedings, A. $\$ \S 10,17 ;$ T. $\$ 75$.

Notifying judge of filing of examiner's report, A. \$20; T. \$97.

Notifying judge of filing of petition, A. $\$ 16 ;$ T. $\$ 79$.

Numbering certificates of title, A. $\$ \$ 98-9 ;$ T. $\$ 125$.

Numbering decrees of title, A. $\$ 98 ;$ T. $\$ 120$.

Of legally and correctly registering all transactions, A. \$§28, 59, 106 ; T. $\$ 269$.

Outside recordation of plats and lengthy details, A. §§102-3; T. $\$ 121$.

Publishing notice on initial proceedings, A. $\$ \S 10,88 ; \mathrm{T} . \S 64$.

Recording decree of title on the minutes, A. $\$ \$ 26,97 ;$ T. $\$ 116$.

Recording judgment rendered in summary proceedings, A. $\$ 50$; T. $\$ 166$.

To allow examiners free access to records, A. §68; T. §82.

To file caveat where he has made error in registration, T. $\$ 183$.

To suspend registration when supersedeas obtained, T. \$118.

When certificate of title not produced on involuntary transfer, A. $\S 52 ;$ T. $\$ 172$.

When extraordinary situation arises, T. $\$ 275$.

\section{CONCLUSIVENESS:-}

Difference as to, betwcen certificate of title and owner's certificate, T. $\$ 226$.

how owner's certificate made conclusive, A. \$118; T. \$227.

Does not attach to registration of adverse claims, A. \$51; T. $\S \S 145,212$.

exceptions as to matters established on initial registration, T. $\S \S 230,243$.

Of decree of title, A. $\S \S 4,27$; T. $\$ \S 117,230,243$.

Of last certificate of title, as a source of title, when land is freed from registration, A. $\$ 65 ;$ T. $\$ 237$.

Of recital of service and notice in decree of title, A. $\S 13 ;$ T. $\S \S 74$, 101. 
References are to sections. A. $\$$ - means section of Act; T. $\$$ - means section of text.

CONCLUSIVENESS:-(Continued).

Of registration:

against adverse possession, A. §66; T. §232.

generally, A. §63; T. §§211-233.

how far affected by judge's summary jurisdiction over registration, T. §§228-9.

by limitation under, A. §59; T. §§228-231.

by reversal of judgment, $T$. $\$ 233$.

matters excepted from, generally, A. §63; T. §§220-5.

current taxes and assessments, T. §223.

highways and railways, $T$. §225.

leases for less than 3 years, T. \$224.

liens and rights under federal laws, T. §§221-2.

title of trustee in bankruptcy, T. \$222.

results of jraud or forgery, A. \$63; T. $\$ \S 184,211,217-8$. in initial registration, $T$. $\$ \S 44,219$.

innocent persons protected, T. \$§213-6.

not prevent redress for wrong or neglect, A. §84; T. \$257.

of entries of cancellation after twelve months, A. §59; T. §231.

Prima facie of all registrations, A. §59; T. §§228-231. See Caveat.

Twelve-month's limitation, A. §59; T. §§229-231.

\section{CONDEMNATION PROCEEDINGS:-}

Result of, how registered, T. §202.

\section{CONSTITUTIONAL QUESTIONS:-}

Avoided in the Georgia Act, T. \$§16-19.

Constitutionality of provisions making recital of service final, T. $\$ 101$ (n. 2).

Early acts declared unconstitutional, T. $\$ \S 16-7$.

Estoppel against raising subsequently to initial registration, T. $\$ 20$.

Later acts sustained against, T. $\$ 18$.

\section{CONSTRUCTIVE SEIZURE OF THE LAND:-}

Constitutional sufficiency of the provisions as to, T. $\$ 19$ (n. 2). Method of, A. $\S 14 ;$ T. $\S \S 64,71$.

Return of, A. $\S \$ 14,90$; T. $\$ 73$.

\section{CONTEMPT:-}

Before examiner how dealt with, T. $\$ 89$.

In refusing to produce owner's certificate, A. $\S 52 ;$ T. $\$ 169$. 
References are to sections. A. $\delta$ - means section of Act; T. $\$$ - means section of text.

\section{CORPORATIONS:-}

As petitioners for initial registration, A. $\S 5 ;$ T. $\S \S 27,28$.

Change of name of, how registered, A. \$53; T. \$203.

Having power of appointing or disposing of the fee-simple as petitioners for registration, A. \$5; T. \$27.

Transfers by, how registered, T. \$164.

Verification of petition in behalf of, A. $\S 7$; T. $\S 51$.

\section{costs:-}

Advertising action of court on caveat, A. $\$ 60 ;$ T. $\$ 181$.

Advertising cancellation of owner's certificate on involuntary transfer, A. §52; T. §172.

Assessment for assurance fund, see Assurance Fund.

Certified copy of plat or outside record attached to owner's or creditor's certificate, A. $\$ \$ 102-4$.

Clerk's fee bill, A. §120; T. §§259, 262.

Deposit for, A. \$120; T. §263.

Examiner's fees, A. \$120; T. \$\$260, 262.

Judgment for, not to be included in decree of title, T. $\$ 108$.

Power of judge over, A. §120; T. §264.

Sale under creditor's certificate, A. §35; T. §155.

Sheriff's fee bill, A. §120; T. §§261-2.

Stenographer's compensation, A. $\$ \S 71,120 ;$ T. $\$ \$ 93,260$.

Surveyor's compensation, A. \$120; T. \$262.

Taxing of:

generally, A. \$120; T. \$264.

in case of severance, $\mathrm{T}$. $\$ \$ 59,106$.

where captious objections are filed, T. $\$ \$ 52,264$.

Where petitioner has included lands not held under the same general claim of title, $T$. $\$ 106$.

\section{COTENANTS:-}

See UNDTVIDED INTERESTS.

All must join in application for initial registration, A. §5; T. $\S \S 25,105$.

All must join in freeing land from registration, A. $\S 65 ; T$. $\S 238$. Respective interests of to be designated in decree of title, T. $\S \S 110,112$.

\section{COUNTERFEITING:-}

Penalty for, A. \$85; T. \$258.

\section{COUNTIES:-}

Liability of tax-collector to, for failure to note delinquent taxes, A. \$57; T. $\$ 177$.

Service on, A. $\S 11 ;$ T. $\$ 67$. 
References are to sections. A. $\$$ - means section of Act; T. $\$-$ means section of text.

\section{COUNTY COMMISSIONERS:-}

Duty to furnish necessary books, A. §28; T. §271.

Duty to furnish filing cases, A. §119; T. §271.

\section{COURTS:-}

See Equity; Judge; Judicial Proceedings; Jurisdiction; Summary Proceidings; Venue.

Always open for registration purposes, A. \$67; T. \$265.

for summary proceedings, T. $\$ 167$.

Definition of the word "court," as used in the Act, A. $\$ 3 ;$ T. \$21. Examiner's relation to, A. \$15; T. \$77.

Proceedings before judge are court proceedings, A. $\$ 67 ;$ T. $\S \S 167$, 265.

Retain ordinary jurisdiction over registered lands, A. \$73; T. $\S \S 137-8,205-7$.

registration essential to make same effective, A. §73; T. $\S \S 138,178$.

\section{COVENANT RUNNING WITH THE LAND:-}

Created by owner's act in registering title, A. $\S 64 ;$ T. $\$ \S 20,117$. effect on constitutional questions, T. $\$ 20$.

\section{CREDITORS:-}

Transactions in fraud of, how set aside, A. \$55; T. §207.

\section{CREDITOR'S CERTIFICATE:-}

See Transfers, IV.

Cancellation of :

accomplished, how, A. $\S \S 33,62,115$; T. $\S \S 159,142,180$.

attestation of, A. $\S 115$; T. $\$ 159$.

clerk's fee for, A. $\$ 120 ;$ T. $\$ 259$.

by transferee, A. \$115; T. $\$ 159$.

involuntary; A. $\S \S 33,60,62 ; T$. $\$ \S 159,181-2$.

Certified copy of outside record attached to, A. $\$ 102-4 ;$ T. $\$ 157$.

Form:

of creditor's certificate prescribed, A. $\$ \S 108-9$.

of transfer to authorize, A. \$107.

partial transfer, A. $\$ 109$.

Issuance of, A $\S 32 ; \mathrm{T}$. $\S \S 153,156-8$.

clerk's fee for, A. $\$ 120 ;$ T. $\$ 259$.

Negotiability of, A. §33; T. §154.

Not in standard form, A. \$38; T. \$\$157-8.

Penalty for forging, stealing or counterfeiting, A. §85; T. §258.

Sale under, A. §35; T. $\$ 155$. 
References are to sections. A. $\delta$ - means section of Act; T. $\&$ - means section of text.

CREDITOR'S CERTIFICATE:-(Continued).

advertisement of, A. §35; T. \$155.

disposition of proceeds, A. §35; T. $\$ 155$.

transfer to purchaser, A. $\S 35 ;$ T. $\$ 160$.

Use of in evidence, A. §38; T. §244.

certified copy, T. $\$ 244$.

\section{CRIMES:-}

See OFFENSES.

\section{CROSS-PETITIONS:-}

See Defensive Pleadings; Petition For Initial Registration; REGISTRATION II.

Abstract of title to, T. $\$ 53$.

Assessment for assurarice fund, $T$. \$249.

Decree of title on, A. $\S 26$; T. $\$ 106$.

Effect of, on original petitioner's right to dismiss, T. $\$ 103$.

Form of, suggestions as to, T. $\$ 53$.

Right to file, A. $\$ 18 ;$ T. $\$ 53$.

Severance as a result of filing, T. $\S \S 58-9,106$.

Verification of, T. $\$ 53$.

DATE:-

Minute dating of all registrations and entries, A. §29; T. §273.

On Title Register, as date when transaction becomes operative, A. $\$ 73$ T. $\S \S 137-8$.

\section{DEATH OF OWNER:-}

See Administrators and Executors.

Transmission of title on, A. $\$ \S 42-7$; T. $\$ \$ 188-198$.

\section{DECREES:-}

See Decrees of Tithf; Equity; Judicial Proceedings; Judgments AND DECREES.

\section{DECREES OF TITLE:-}

See Judgments and Dickers; Register of Decrees of Tithe.

Binding on the world, A. $\$ \$ 4,27 ;$ T. $\$ \S 117,230,243$.

Certified copy of, as evidence, T. $\$ 243$.

Conclusiveness of, A. $\S \S 4,27$; T. $\$ \S 117,230,243$.

Covenant running with the land created by, A. $\S 64 ;$ T. \$117.

Easements, how set forth in, A. \$26; T. \$114.

Effect of, A. \$§4, 27; T. $\$ \S 117,230,243$.

Estates less than fee, how set forth in, A. $\S \S 26,97 ; T . \S \S 111,114$. 
References are to sections. A. $\$$ - means section of Act; T. $\$$ - means section of text.

\section{DECREES OF TITLE:-(Continued).}

Enrollment on Register of Decrees of Title, A. §§28, 98; T. $\$ \$ 119-123$.

Form of:

minute dating of enrolment, A. §29; T. \$273.

prescribed, A. \$97.

prescribed form to be strictly adhered to, T. $\$ 108$.

suggestions as to filling blanks in, $T$. $\$ \$ 109-114$.

declaring easements, T. $\$ 114$.

declaring lesser estates, $T$. $\$ \$ 111,114$.

declaring liens and encumbrances, T. \$113.

declaring limitations and conditions, $T$. $\$ \$ 111-2$.

declaring the ownership, T. $\$ \S 110,112$.

description of the land, T. $\$ 109$.

other matters, $T$. $\$ 114$.

statement as to right of appeal, T. $\$ 114$.

Improvements of possessor-how far noticed in, T. \$115.

Indexing of, A. $\S \S 28,98$; T. $\$ 123$.

Judgment for costs not to be included in, $T$. $\$ 108$.

Liens. encumbrances, etc., how set forth in, A. §§26, 97;

T. $\S \S 111-4$.

effect of, T. $\$ 230$.

Method of filing away papers relating to, A. $\$ 119$; T. $\$ 272$.

No issue as to mesne profits to be decided by, T. $\$ 115$.

No writ of ejectment issues on, T. $\$ 115$.

None to be rendered by default, A. $\$ 21$; T. $\$ 102$.

None where petition proves title to undivided interest only, T. $\$ 105$.

Numbering of, A. $\$ 98 ;$ T. $\$ 120$.

On cross-petition, A. §26; T. §106.

Punishment for fraud in obtaining or attempting to obtain, A. $\S 85 ;$ T. $\S 258$.

Recital of service and notice in,-conclusiveness of, A. §13; T. $\$ 101$.

Recorded on the minutes, A. $\S 26,97 ;$ T. $\$ 116$.

Rendition of, A. §26; T. \$\$106-14.

Separate to be rendered where tract divided into parcels, A. §26;

T. $\S 107,109$.

advantages, T. $\$ 107$.

Separate to be rendered, where more than one tract included in petition for registration, A. §26; T. $\$ \$ 106,109$.

Severance for purposes of, A. $\S 24 ;$ T. $\$ \$ 106,109$.

Use of, as basis for action of ejectment, T. $\$ \S 115,243$.

Where plaintiff proves title to only a portion of the land included in his petition, T. $\$ 106$. 
References are to secticns. A. $\$$ - means section of Act; T. $\$$ - means section of text.

\section{DEFAUI,T:-}

No judgment or decree by, A. \$21; T. \$102. effect of failure to present defenses in time, T. $\$ 56$.

\section{DEFENDANTS:-}

See Cross-Petitions; Defensive Pleadings; Service of Process AND NoticE.

Acknowledgment of service by, See catchword, "Waiver" below. Additional made on cross-petition, T. \$53.

Adjoining owners and occupants as, A. $\S \S 7,86(21)$; T. $\S \S \pm 5,49$.

All adverse claimants of any interest, as, A. $\S \S 9,86(19)$; T. $\S 44,49$.

“All persons whom it may concern," A. $\S \S 4,9,86(26)$; T. $\S \S 52$, 62,64 .

Class representation, when numerous, T. $\$ 66$.

Counties as, A. $\$ 11 ;$ T. $\$ \$ 44,67$.

Examiner's report as to, A. §16; T. \$§83-4. notice to additional defendants thus disclosed, A. $\$ 17 ;$ T. $\$ 75$.

Fraud in omitting, T. $\S \S 44,219$.

General provisions as to, A. $\S 9$; T. $\S 49$.

Husband as, in wife's petition, A. $\$ 86(25)$; T. $\$ \$ 48-9$.

In action against assurance fund, A. \$78; T. \$255.

Infants and persons under disability-guardians ad litem for, A. $\S 10 ;$ T. $\S 70$.

Liens and encumbrances, holders of, as, A. $\S \S 9,86(26)$; T. $\S \S 42$, $44,49$.

Municipalities, A. $\S 11$ : T. $\S \S 44,67$.

Persons dealing with the land pending registration proceedings, A. $\S 25 ;$ T. $\S 60$.

Service of process on, See Service of Process and Notice.

The State as, A. $\S 11 ;$ T. $\S \S 44,67$.

Tenants to be named as, when, $T$. $\$ 49$.

To be named in initial petition, A. $\$ \S 9,86(26)$; T. $\$ \S 45,48-9$.

Unserved persons may become, A. §18; T. §52.

Waiver of process and service by, through appearance or pleading. A. §14; T. $\$ 69$.

Waiver of process and service, in writing, by, A. $\$ 12 ;$ T. $\S 68$. attestation of, A. $\S 12 ;$ T. $\S 68$.

form of, A. $\$ 89$.

Wife as, on husband's petition, A. §86(25); T. §§48-9.

\section{DEFENSIVE PLEADINGS:-}

Amendment of, A. §24; T. §57.

Answer, A. \$18; T. \$52. 
References are to sections. A. $\$-$ means section of Act; T. $\$-$ means section of text.

DEFENSIVE PLEADINGS:-(Continued).

by persons dealing with the land pending registration proceedings, A. $\$ 25 ;$ T. $\$ 60$.

Demurrer, T. $\$ 55$.

Taxing costs for frivolous filing of, T. $\$ 52,264$.

Time of filing, T. $\$ 56$

Verifcation of, T. $\$ 54$.

before examiner, $\mathrm{T}$. $\$ 54$.

Who may file, A. §18; T. §52.

\section{DEPOSITIONS:-}

See EVIDENCE; WiTnFSSES.

Examiner's power to take, A. §20; T. §91.

\section{DEPUTIES:-}

See Clerk; Shr.riff.

Criminal responsibility of, A. $\$ 85 ;$ T. $\$ 258$.

Duties of clerk or sheriff, performed by, A. §83; §268.

Principal responsibility for acts of, A. $\$ 83$.

The word "clerk" includes deputy-clerks, A. §3; T. §21.

\section{DESCENT AND DISTRIBUTION:-}

See Administrators and Executors.

Effect of subsequent appointment of administrator when decedent's title has been transferred to heirs, A. §46; T. \$199.

Partition among established heirs, A. \$45; T. \$\$196-7.

Proceedings to establish heirship, A. \$\$45-47; T. $\$ \$ 194-5,198$.

Rights of heirs in case of no administration, A. $\$ 45$; T. $\$ \S 194-7$.

Right of heirs or devisees to compel transfer from personal representative, A. $\S 43$; T. $\$ 188$.

Ultimate rules of not affected by registration, A. $\S 42 ;$ T. $\$ 188$.

Widow as sole heir, A. $\$ 45$; T. $\$ \$ 194-5$.

\section{DESCRIPTION OF THE LAND:-}

Examiner's power to require fullness of, A. $\S \S 7,22 ;$ T. $\S 86,89$, 100.

Fullness of, required in petitions, A. §7; T. §34.

In the certificate of title, T. $\$ 126$.

In the decree of title, $T$. $\$ 109$.

Judge's power to require fullness of, A. $\S \S 7,22,24$; T. $\S \S 34,100$, 109.

Petition to contain, A. $\$ 7 ;$ T. $\S 34$.

Plat to be made when, A. §22; T. $\$ 100$. outside recordation of, A. $\$ 102 ;$ T. $\$ 121$. 
References are to sections. A. - means section of Act; T. 8 - means section of text.

DESCRIPTION OF THE LAND:-(Continued).

Published notice of initial registration to contain, A. $\S \S 10,88$; T. $\$ 64$.

Survey and setting of landmarks, when required, A. $\$ \$ 7,22$; T $\$ \S 34,89,100$.

Where several tracts included in one petition, $T$. $\$ 35$.

Where tract divided into parcels, A. $\S 8,26 ;$ T. $\$ \S 36,107$.

\section{DISABILITIES :-}

See Infants and Other Persons Under Disability; Itimitation of Actions

Suspending action against assurance fund, See Assurance Fund.

\section{DISMISSAL:-}

Of petition for registration, when ordered or allowed, A. \$23; T. $\S \S 103-5$.

Of writ of error where lis pendens not noted, T. \$233.

Right of, how far affected by filing of cross-petition, T. \$103.

Terms, power of judge to impose, A. \$23; T. \$§103-6.

When plaintiff fails to prove title, T. $\$ 103$.

When plaintiff proves title less than fee, T. $\$ 104$. amendment to avoid dismissal, T. $\$ 104$.

When plaintiff proves title to only an undivided interest, T. $\$ 105$. Writ of error to judgment of, A. §82; T. $\S 118$.

\section{DISQUALIFICATION OF OFFICERS:-}

Clerk disqualified; who acts, A. §\$3, 69; T. §§21, 267.

Judge disqualified; who acts, A. §3; T. §21.

\section{DOCKETING:-}

See Patition for Initial Registration.

Re-docketing when severance has been ordered, T. \$59.

\section{DOWER:-}

See Administrators and Executors.

Allegation as to in initial petition, A. $\S 86(15)$; T. $\$ 42$.

As an involuntary transaction, A. §3; T. \$21.

Examiner's preliminary report as to, T. $\S 83$.

Existence of not prevent sale by personal representative, T. $\$ 190$. Registered land subject to right of, A. $\S \S 42,45$; T. $\S \$ 188,190$, 195.

Registration of right of, essential to its assertion, A. $\S 42 ;$ T. $\$ 190$. 
References are to sections. A. 8 - means section of Act; T. 8 - means section of text.

\section{DUPLICATE CERTIFICATE:-}

See OWNeR's Certificate.

\section{EASEMENTS:-}

See Estates and Interests Less Than Fee-Simple; Highways; RaIL,WAYS.

\section{EMINENT DOMAIN:-}

See Condemnation Proceedings.

Exercise of the right of as an involuntary transaction, A. §3; T. \$21.

\section{ENCUMBRANCES:-}

See LiENS AND ENTCUMBRANCES.

\section{ENTRIES:-}

See Registration III.

\section{EQUITY :-}

Attack in, for fraud or forgery, T. \$217.

fraud in initial registration, $T$. $\$ 219$.

Decrees in, how effectuated against registered land, A. §49; T. $\S \S 205-8$.

Equity pleading and practice in suit for registration, A. §5; T. \$22.

equity jurisprudence not thereby adopted, T. \$22.

Jurisdiction over registrations in fraud of creditors, A. \$55.

Jurisdiction to set aside registration procured by fraud or forgery, A. §63; T. §\$217, 231.

Lis pendens must be registered to protect actions in, A. \$54; T. $\$ 178$.

Notation of equitable claims on Title Register, A. §51; T. $\S \S 173$, 178.

effect of, A. §51; T. \$145.

effect of failure to note, A. $\S \S 63,73$; T. $\S \S 137-8,145$.

rorm for noting, A. $\$ 114$.

how ranceled, A. $\$ \S 60,62 ;$ T. $\$ \S 142,179-182$.

form of request to cancel, A. $\$ 116$.

Registration does not prevent existence of equities, A. \$73; T. $\S \S 3,137-8,205$.

reconcilement between registration and equity jurisprudence, T. §212.

Transfer as result of proceedings in, A. \$49; T. $\$ \$ 166-172,205-8$. Twelve-month's limitation of A. $\$ 59$ not applicable to suits in, T. $\$ 228$. 
References are to sections. A. $\$$ - means section of Act; T. $\$-$ means section of text.

\section{ERRORS ON TITLE REGISTER:-}

How corrected, A. $\S 60 ;$ T. $\S 183$.

\section{ESTATES:-}

See EAsempints; Estatis and InTERests I Less Than Ffe Smple; REGISTERED I AND; TITIIE.

Of decedents, see Administrators and Executors; Descent and Distribution.

Of infants, insane persons, etc., see Guardians, Infants and Persons Under Disability.

On conditions or with unusual limitations, how transferred or dealt with, A. \$56; T. §204.

Phrase, "registered land," includes all kinds of, A. §3; T. §21.

\section{ESTATES AND INTERESTS LESS THAN FEE SIMPLE:-}

See Hichways; Railways.

Allegations as to in petition for initial registration, A. $\S \S 7$, $86(19,22) ;$ T. $\S \$ 44,46$.

Allegations as to value of in petition to establish, T. $\S 38$.

Amendment asking establishment of, where petitioner fails to prove title to fee simple, T. $\$ 104$.

Burden of proof as to, in initial proceedings, T. $\S 94$.

Decrec of title to set forth, A. \$26; T. $\$ \$ 111-2$.

easements, T. $\$ 114$.

Effect on when land freed from registration, A. §65; T. §\$236-7.

Examiner's innal report as to, A. \$20; T. \$95.

Examiner's preliminary report as to, A. $\$ 16 ;$ T. $\S 83$.

Existence of, not prevent initial registration, A. §5; T. \$?5.

Grant of, hrow registered, A. \$117; T. \$1E0.

How set forth in first certificate of title, T. $\$ 129$.

Included in the phrase "registered land," A. §3; T. §21.

Included in the phrases "voluntary transactions" and "involuntary transactions," A. §3; T. §21.

Leases for less than 3 years, excepted from registration, A. $\S 63$; T. $\$ \S 211,224$.

Liens and encumbances affecting to be shown in decree of title, T. $\$ 113$.

No owner's certificate in favor of holder of, T. $\$ 150$.

Owner of as defendant, A. $\S 9 ;$ T. $\$ \S 25,49$.

Owner of may establish but not initially register, A. §6; T. §30. amednment for that purpose when petitioner fails to establish fee simple, T. $\$ \$ 30,104$.

Petition for initial registration must disclose, A. $\$ \$ 7,86(15,18$, $19,22)$; T. $\$ \S 42,44,46,49$. 
References are to sections. A. $\$$ - means section of Act; T. $\$-$ means section of text.

ESTATES AND INTERESTS LESS THAN FEE SIMPLE:(Continued).

Petition to establish, A. $\S 6$; T. $\S \S 30,31$. form of suggested, T. $\$ 31$.

Transmission of title to, on death of owner, A. $\$ 442-7$; $T$. $\$ \$ 188-198$.

\section{EVIDENCE:-}

See Conclusiveness; Witnesses.

Brief of in examiner's final report, A. §20; T. §95.

Burden of proof:

in attarks on registration, A. $\S 59 ;$ T. $\S 218$.

on exceptions to examiner's report, T. $\$ 98$.

on hearing before examiner, $\mathrm{T}$. $\$ 94$.

Certificate of title and owner's certificate when land is freed form of suggested, T. $\$ 331$.

Certified copy:

from registration files, T. §247.

from Title Register, how issued, A. \$101; T. §241.

of certificate of title, T. $\$ 239$.

of creditor's certificate, A. \$38; T. \$244.

of decree of title, T. $\$ 243$.

of entry or notation, A. $\S \S 38,101$; T. $\$ \S 241,244$.

of mortgage, as primary evidence, A. §38; T. \$244.

of plat or detail recorded outside the register, T. \$242.

Commission for interrogatories, A. \$20; T. $\$ \$ 89,90$.

Depositions taken before examiner, A. \$20; T. \$91.

Duplicate of owner's certificate as, T. \$239.

Examiner's powers as to, §20; 'T. §\$89-94.

Examiner's preliminary report as, A. §16; T. §87.

Introduction of before examiner, T. $\$ 92$.

Of title, what sufficient to authorize registration, T. $\$ 94$.

On jury trial on exceptions to examiner's report, A. $\S 20 ;$ T. $\S \S 97-8$.

Owner's certificate as, T. §239.

Production of books and papers before examiner, A. $\S 20 ;$ T. $\S \S 89,90$.

Punishment for offering fraudulent, A. §85; T. §258.

Recital in decree of title as to service, A. \$13; T. \$74.

Registration as exclusive method of proving notice, A. $\$ \S 40,73$; T. §245.

Stenographer reports when, A. §71; T. §93. See Stenographer.

\section{EXAMINER:-}

Amendments allowed by, A. §24; T. $\$ \$ 57,89$.

Appointment of, A. §15; T. §77. See catchword, "Form," below. As a witness to explain his report, T. $\$ 98$. 
References are to sections. A. $\$$ - means section of Act; $T$. $\$$ means section of text.

EXAMINER:-(Continued).

Attestation of acknowledgment of service by, A. $\$ 12 ;$ T. $\$ 68$.

liability for false attestation, A. $\$ \$ 13,84 ;$ T. $\$ 68$.

Contempt before, how dealt with, T. $\$ 89$.

Crimes by in relation to the Act, A. $\$ 85 ;$ T. $\$ 258$.

Depositions taken before, A. \$20; T. \$91.

Duties of, generally, A. $\S \S 15,16,19,20 ;$ T. $\S \S 80-95,166$.

Duty to prevent slackness of pleading, T. $\$ 55$.

Exceptions to final report of:

filed when, A. $\$ 20$; T. $\$ 96$.

hearing of, A. $\$ 20 ;$ T. $\$ \$ 97-8$.

jury trial on, how obtained, A. \$20; T. §97.

evidence on, A. $\$ 20 ;$ T. $\$ \$ 97-8$.

new trial, A. §20; T. §99.

procedure on, $T$. $\$ 98$.

verdict on, effect of, A. §20; T. §97.

writ of error, A. $\S \S 20,82$; T. $\S \S 99,118$.

who may file, A. $\S 20 ;$ T. $\$ 96$.

Fees of, A. $\$ 120$; T. $\$ 260$.

Final report of:

contents, A. $\S \S 20,96$; T. $\S 95$.

duty of clerk to notify judge of its filing, A. §20; T. §97.

filed when, A. §20; T. $\$ 95$.

notice of filing, A. $\S 20 ;$ T. $\S \S 56,95$.

form of, prescribed, A. $\$ 96$.

deductions drawn from this form, T. $\$ 95$.

recommitment, A. §20; T. \$99.

to investigate objections presented after its filing, T. $\$ 56$. motion to recommit, T. $\S 96$.

Form of:

final report, A. $\$ 96$.

official oath, A. $\$ 93$.

order of appointment, A. $\$ 92$.

order of reference, A. $\$ 94$.

preliminary report, A. \$95.

Free access to all public records by, A. §68; T. $\S 82$.

General or special, A. $\$ 15 ;$ T. $\S 77$.

Hearing before, A. $\$ \S 19$, 20; T. $\$ \$ 88-94$.

allowance of amendments, A. $\S 24 ;$ T. $\$ \$ 57,89$.

burden of proof, T. $\$ 94$.

demurrer, T. $\$ 89$.

functions and duties generally, A. §20; T. $\$ 89$.

introduction of evidence, $T$. $\$ 92$.

methods of proof, T'. $\$ 94$.

notice of, A. $\S 19$; T. $\S \S 56,88$. 
References are to sections. A. $\$$ - means section of Act; T. $\$$ - means section of text.

EXAMINER:-(Continued).

parties made or stricken, T. $\S 89$.

place of, T. $\S 88$.

ruling to be noted, T. $\S 92$.

severance, A. §24; T. $\$ \S 58-9,89$.

stenographer, used when, A. §71; T. §93. See Stenographer. time of, A. §19; T. $\$ 88$.

Independent examination by, A. §20; T. \$90. report as to, 'T'. $\S \S 90,95$.

Number to be appointed, A. §15; T. \$77. consideration affecting, T. $\$ 77$.

Oath of, A. $\S \S 15,93 ;$ T. $\S 78$.

Power of:

as commissioner to take testimony, A. $\S 20 ;$ T. $\S 91$.

to cause commission for interrogatories to issue, A. §20; T. $\$ 89$.

to compel attendance of witnesses, A. $\S 20 ; T$. $\S 89$.

to compel production of books and papers, A. \$20; T. \$89.

Preliminary report of, A. $\$ 16,95$; T. $\$ \S 80-7$.

contents of, A. $\$ 16 ; T$. $\$ \$ 1-6$.

abstract of title, A. $\$ 16$; T. $\$ 82$.

finding as to service and notice, A. \$16; T. \$\$75, 83-4.

finding as to sufficiency of description, T. $\S \S 86,89$.

history of the possession, A. §16; T. §85.

names and addresses of adjoining owners and occupants,

A. $\S 16 ;$ T. $\S 84$.

names and addresses of all interested persons, A. §16;

T. $\S 83$.

result of independent examination, T. $\$ 87$.

filing of, A. $\S 16 ;$ T. $\$ 80$.

is prima facie evidence of its contents, A. $\$ 16 ; T$. $\$ 87$.

limitations on this rule, T. $\$ 87$.

Qualifications of, A. $\$ 15$; T. $\$ 78$.

Recommendation as to making description of the land more permanent, A. $\S \S 7,22 ;$ T. $\S \S 34,86,89$.

Reference to, of the initial petition for registration, A. $\S \S 16,94 ;$ T. $\$ 79$. of application for involuntary transfer, A. \$50; T. \$166.

Relation that of auditor or master in chancery, A. $\$ 15 ;$ T. $\$ \$ 77$, $89,166$.

Removable from office at pleasure of judge, A. §15; T. $\$ 78$.

Severance, ordered or allowed by, A. §24; T. §§58-9.

Stenographer for, how employed, A. §71; T. §93.

compensation of, A. $\S \S 71,120 ; T$. $\$ \S 93,260$. 
References are to sections. A. $\$$ - means section of Act; T. $\$$ - means section of text.

EXAMINER:-(Continued).

Survey, recommendation as to, A. $\S \S 7,22 ;$ T. $\$ \S 86,89,100$.

Verification of defensive pleadings before, T. $\$ 54$.

\section{EXCEPTIONS:-}

Bill of, see Writ of Error.

To examiner's report, see Examiner.

\section{EXECUTION SALE:-}

Procedure to obtain transfer to purchaser at, T. $\$ \$ 168-170$.

\section{EXECUTORS:-}

See Administrators and Executors.

\section{EXECUTORY SALE:-}

See BOND FOR TITLE.

\section{EXTRAORDINARY SITUATIONS:-}

How dealt with, T. §275.

\section{FEDERAL STATUTES:-}

Liens and rights arising under, how far excepted, A. $\S 63$; T. $\$ \S 211$, 221-2.

\section{FEES:-}

See Costs.

\section{FEE-SIMPLE:-}

See Estates and Interests Less Than Fee-Simple; Title.

Defined, T. §25.

Ownership of essential to initial registration, A. §5; T. §25. defeasible fee, T. $\$ 25$.

equitable ownership, T. $\$ 26$.

\section{FILING:-}

Cabinets for, to be furnished clerk, A. \$119; T. $\$ 271$.

Certified copies of file-papers as evidence, $T$. $\$ 247$.

Method of filing away registration papers, A. $\$ 119$; T. $\$ 272$.

Of examiner's final report, A. \$20; T. \$95.

Of examiner's preliminary report, A. $\$ 16$; T. $\$ 80$.

Of exceptions to examiner's report, A. \$20; T. $\$ 96$.

Of petition for initial registration, A. §10; T. §24.

\section{FORGERY :-}

Attacks for, A. $\S 63$; T. $\$ \$ 184,217,231$.

Burden of proof as to, T. $\$ 218$.

Cancellation procured by, T. \$231.

Punishment for, A. $\$ \S 85 ;$ T. $\$ 258$. 
References are to sections. A. $\$-$ means section of Act; T. $\$-$ means section of text.

FORGERY:-(Continued).

Registration procured by, effect of, A. $\S 63$; T. $\S \S 213-5 ; 21 \%$.

limitation on court action against, A. $\$ 63$; T. $\$ \S 217,228$.

by caveat, A. $\$ \S 59,60,63$; T. $\S \S 182-5,217,228-231$.

protection of innocent holders, A. \$63; T. §§213-214.

Safeguards of the Act against, T. §215.

Victim of, has no action against assurance fund, T. \$251.

\section{FORMS :-}

Acknowledgment of service, A. \$89.

Advantage of using prescribed forms, $\mathrm{T}$. $\$ 137$.

Advertisement cancelling owner's certificate, T. \$172.

Advertisement on initial registration, A. \$88.

Cancellation of creditor's certificate, A. \$115.

Cancellation of liens, encumbrances, etc., A. $\$ 116$.

Certificate of title, A. $\$ 99$.

Clerk's certificate as to service and notice, A. $\$ 91$.

Creditor's certificate, A. $\$ \$ 108-9$.

Cross-petition, T. \$53.

Decree of title, A. $\$ 97$.

Entry validating owner's certificate, A. §118.

Examiner:

appointment of, A. \$92.

final report of, A. $\$ 96$.

oath of, A. $\$ 93$.

preliminary report of, A. $\S 95$.

reference to, A. $\$ 94$.

Involuntary transfer, A. \$110.

Judge's order of transfer, A. $\$ 110$.

Mortgage, A. \$111.

Notice to be posted on the land, A. $\$ 88$.

Owner's certificate, A. §105; T. \$134.

Partial transfer, A. $\$ 107$.

Petition for initial registration, A. \$86.

suggestions as to filling blanks, T. \$32-51.

Power of judges in convention over, A. \$70; T. \$266.

Prescribed forms, a guide to the clerk's T. \$270.

Process, A. $\$ 87$.

Register of Decrees of Title, A. §98.

Request for,

notation of cancel!ation of liens, encumbrances, etc., A. $\$ 116$. delinquent taxes and assessments, A. \$112.

involuntary transaction not involuntary transfer, A. \$114. judgment, A. $\$ 113$. 
References are to sections. A. $\$-$ means section of Act; T. $\$-$ means section of text.

FORMS:-(Continued).

liens, encumbrances and adverse claims, A. §114. lis pendens, A. \$114.

registration of homestead or exemption, $\mathrm{T}$. $\$ 210$.

Sheriff's return, A. $\$ 90$.

Title Register, A. \$99.

Total transfer, A. \$107.

Transfer to secure debt, A. \$107.

Use of standard forms not compulsory, T. $\$ 137$.

Verification of petition for initial registration, A. $\$ 86$. cross-petition, T. $\$ 53$.

FRAUD:-

Action for, not prevented by the limitations of the Act, A. §84; T. §?57.

Attacks for, A. $\$ 63$; T. $\$ \$ 44,216-9$.

Burden of proof as to, T. $\S 218$.

Cancellation procured by, $\mathrm{T}$. §231.

In failing to list known adverse claimants in petitions for initial registration, T. $\S \S 44,219$.

Punishment for various forms of, $\S 85 ; T$. $\$ 258$.

Registration procured by, A. §63; T. §\$211, 216-8.

limitation of attacks for by court proceedings, A. §63; T. §217.

by caveat, A. $\$ \S 59,60,63$; T. $\$ \$ 182-5,217,228-231$.

protection of innocent persons, A. §63; T. §216.

Transactions in fraud of creditors, how set aside, A. §55; T. §207.

\section{FREEING LAND FROM REGISTRATION:-}

Benefits of registration still endure, T. \$237.

Effect on liens, encumbrances, etc., T. \$236.

Future transactions, how affected, A. §65; T. \$236.

General statement of the privilege and its advantages, A. §65;

T. §§234-8.

Last certificate on as a source of title, A. $\$ 65 ;$ T. $\$ 237$.

Method of, A. §65; T. §235.

Unanimous action of cotenants essential to, A. \$65; T. §238.

\section{GUARDIANS AND GUARDIANS AD LITEM:-}

See Infants and Persons Under Disability.

Guardians sales, T. $\$ 200$.

\section{HEIRS:-}

See Administrators and Executors; Descent and Distribution. 
References are to sections. A. 8 - means section of Act; T. $\&$ - means section of text.

\section{HIGHWAYS:-}

Excepted from registration, A. §63; T. §§211, 225.

\section{HOMESTEAD AND EXEMPTION:-}

Allegation as to in initial petition, A. $\S 86(15)$; T. $\$ 42$.

Examiner's preliminary report as to, T. \$83.

Registration of, A. §117; T. §210.

Sales of, A. §56; T. \$210.

Voluntary transaction, A. §3; T. §21.

\section{HUSBAND AND WIFE:-}

Allegation as to in petition for initial registration, A. \$86(24-5); T. $\$ 48$.

As defendant in every petition by married person, A. $\$ 86(26)$; T. $\$ 49$.

Transactions between made certain by registration, T. $\$ \S 10,201$. Transfers between, how registered, A. §48; T. \$201.

\section{IMPROVEMENTS:-}

Right of set-off as to, noticed in decree of title, when, $T$. $\$ 115$.

\section{INDEX:-}

See Register of Decrees of Title; Title Register.

\section{INFANTS AND OTHER PERSONS UNDER DISABILITY:-}

Age of infants, how to be set forth:

in certificate of title, T. $\$ 127$.

in decree of title, T. $\$ 110$.

in petition for initial registration, A. $\$ 86(23)$; T. $\$ 47$.

As defendants-guardian ad litem for, A. §10; T. \$70.

Bound by decree of title, A. §27; T. \$117.

Disability of should be set forth in detail, in certificate of title, T. \$127.

in decree of title, T. $\$ 110$.

in petition for initial registration, A. \$86(23); T. \$47.

Exception in favor of in limitation of actions against assurance fund, A. \$77; T. \$252.

Guardian ad litem appointed for, A. §§5, 10; T. \$§29, 70. on application for involuntary transfer, A. \$50; T. \$166.

Next friend may represent, A. §5; T. \$29.

No exception in favor of as to conclusiveness of registration, A. $\S 27,59 ;$ T. $\$ 117$.

Petitions for initial registration by, A. §5; T. $\S \S 29,47$. verification of, A. $\$ 7 ;$ T. $\$ 51$. 
References are to sections. A. $\&$ - means section of Act; T. $\$$ - means section of text.

INFANTS AND OTHER PERSONS UNDER DISABILITY:(Continued).

Recourse on assurance fund, A. §§27, 77; T. $\S \S 250,252$.

Sales of property of, by guardians, T. $\$ 200$.

Service of process perfected on, how, A. §10; T. §70.

IN REM:-

See Jurisdiction; Registration II, III.

INSANE PERSONS:-

See Infants and Other Persons Under Disability.

\section{INTERROGATORIES:-}

See EVIDENCE; WitNESSES.

\section{INVOLUNTARY TRANSACTIONS:-}

See Advitrse Claims; Condemnation Proceedings; Dower; Equity; Estates and Interests Less Than Fee-Simple; Judgments and Defcreiss; Judicial Proceedings; Liens and Encumbrances; Taxes and Assessments; Words and Phrases DeFINED.

I. Generally.

II. Involuntary Transfers.

III. Involuntary Transactions Other Than Transfers.

\section{Generally.}

All claims adverse to the registered owner are, A. §3; T. §21. See Adverse Claims.

Dealings with estates less than fee included in the definition of the phrase, A. \$3; T. §21. See Estates and Interests Less Than Fee-Simple.

Definition, A. §3; T. §21.

Delinquent taxes as, A. §3; T. §21. See Taxes and Assessments. Dower as, A. §3; T. §21.

Easements as, see Estates and Interests Less Than Fee-Simple. Eminent domain; exercise of right of as, A. §3; T. \$21. See Condemnation Proceedings.

Encumbrances as, A. §3; T. §21. See Liens and Encumbrances. Inoperative till registered $A . \S \S 40 ; 72 ; T$. $\S \S 137-8$.

Judicial proceedings as, A. §3; T. §21. See Judicial Proceedings. Liens, as, A. §31; T. §21. See Liens and Encumbrances.

To be entered on Title Register, A. §28.

Will-transmission of title by,-is, A. §3; T. §21. See Administrators and Executors. 
References are to sections. A. \&- means section of Act; T. 8 - means section of text.

INVOLUNTARY TRANSACTIONS:-(Continued).

\section{Involuntary Transfers.}

See Transfers, iII.

General discussion of, T. $\$ \$ 166-170$.

\section{Involuntary Transactions Other Than Transfers.}

Right of any one to note an adverse claim on Title Register, A. $\S 51 ;$ T. $\$ 145$.

effect of such notation, A. §51; T. §145.

form of requesting notation, A. \$114.

method of causing notation to be made, A. §61; T. \$§173-8. removal of entry of, from Title Register. See Cancellation.

\section{JUDGE:-}

See Courts; Judge's Order of Transfer; Summary Proceedings. Acts of, are acts of the court, A. $\S 67 ;$ T. $\$ \S 167,265$.

All registered rights of third persons to be protected by, in all proceedings before him, T. $\S \S 183,185,228$.

Decision of the cause by on initial registration, A. §26; T. \$101.

Definition of the word, "judge," as used in the Act, A. §3; T. \$21. Disqualification of, A. $\$ 3 ;$ T. $\$ 21$.

Duty of:

as to approval of transfers between husband and wife, A. $\S 48 ;$ T. $\S 201$.

on hearing of application for transfer to purchaser at sale under creditor's certificate, A. $\$ 35 ;$ T. $\$ 160$.

to appoint examiners, A. \$15; T. \$77.

to give directions to clerk in issuing order of transfer, T. $\$ 170$.

to instruct clerk in case of doubt, A. $\S 59 ;$ T. $\$ \S 270,275$.

to investigate and adjudge as to service, A. $\$ 13 ;$ T. $\$ \$ 74,101$.

to pass on exceptions to auditor's report, A. \$20; T. \$97.

to prevent slackness in pleading, T. \$55.

Involuntary transfer not to be registered without order of, A. $\S 41 ;$ T. $\S 144$.

Jurisdiction over involuntary transfers, A. $\$ \$ 41,49,50,52$; T. $\S \S 166-170,250-8$.

to provide for notice of hearing on, A. $\$ \S 50,72 ; T$. $\$ 166$.

Powers of:

as to modification or cancellation of entries or registration, A. $\$ 60 ;$ T. $\$ \S 183-5$.

over all extraordinary situations, T. \$275.

over correction of errors in registration, A. \$60; T. \$183.

over forged and fraudulent transfers, T. \$184. 
References are to sections. A. $\delta-$ means section of Act; ' $T$. $\delta$ - means section of text.

JUDGE:-(Continued).

to compel cancellation of liens, encumbrances and adverse entries, A. $\$ \S 60,62 ;$ T. $\$ \S 181-2$.

to compel more adequate description of the land, A. $\$ \S 7,22$;

T. $\S \S 34,100,109$.

to enlarge time of service, A. $\$ 10 ;$ T. $\$ 65$.

to prescribe methods of service or notice, A. $\$ \$ 10,72$; T. $\$ \S 65,166$.

to recommit examiner's report on his own motion, A. \$20; T. $\S \S 56,99$.

Reference of case to examiner by, A. $\$ \$ 16,94 ; T$. $\$ 79$. application for involuntary transfer, A. §50; T. \$166.

Summary jurisdiction of, see Summary Proceedings. distinction between, and court's general jurisdiction, $T$. $\$ 185$.

Supervisory powers over all registrations, A. $\S \S 59,60 ;$ T. $\S \S 139$, $270,275$.

how exercised, see Summary Proceedings.

Survey, when ordered by, A. §§7, 22; T. §§34, 100, 109.

\section{JUDGES IN CONVENTION:-}

Authority to make rules and prescribe forms, A. §70; T. $\$ 266$.

\section{JUDGE'S ORDER OF TRANSFER:-}

See Judge; Summary Procefedings; Transferrs III.

Application for, A. \$50; T. \$168.

Conclusiveness of, A. \$4; T. \$167.

Directions to clerk to be included in, T. \$170.

Essential to registration of involuntary transfer, A. §41; T. \$144. Form of, A. \$110.

Issued without production of owner's certificate, when, A. §52; T. \$169.

On proceedings to establish heirship, A. §§45, 47; T. §§195-6, 198.

On sale of homestead property, T. \$210.

On sale of year's support, T. \$209.

Required for registration of transactions by any one holding title in trust or with powers or on condition or unusual limitations, A. §56; T. \$204.

Required to register transfer from executor or administrator, T. $\$ 193$.

to heirs at law or devisees, T. $\$ 198$.

To effectuate involuntary transfers, A. $\S 50 ;$ T. $\$ \S 166-8,205$. limited when lis pendens not noted, T. $\$ 178$. 
References are to sections. A. $\delta$ - means section of Act; $T$. 8 - means section of text.

JUDGE'S ORDER OF TRANSFER:-(Continued).

To effectuate transfer to heirs at law, T. $\$ 196-7$.

To purchaser at sale under creditor's certificate, A. §35; T. $\$ 160$.

When transaction set aside as in fraud of creditors, A. §55; T. $\S 207$.

\section{JUDGMENTS AND DECREES:-}

I. Judgments and Decrees in Registration Proceedings.

II. Judgments Generally.

I. Judgments and Decrees in Registration Proceedings.

See DeCref of Tirle.

Against the assurance fund, A. §79; T. §256.

interest on, A. §81; T. §253.

Annulling transaction for fraud against creditors, A. §55; T. $\$ 207$.

Are judgments in rem: A. $\$ 4 ;$ T. $\S \S 19,22,167$.

Binding on the world, A. $\S \S 4,27 ;$ T. $\$ \S 117,230$. See Conclusiveness.

Effect of reversal of, T. §233.

For costs to be rendered separately from decree of title, $T$. $\$ 108$.

In initial proceedings:

binding on those dealing with the land pending the proceedings, A. \$25; T. $\$ 60$.

covenant attached to title by, A. $\S 64 ;$ T. $\$ \S 20,117$.

in favor of cross-petitioner, A. \$26; T. §106.

none by default, A. \$21; T. \$102.

of dismissal. See Dismissal.

recital of service and notice in conclusive, A. \$13; T. \$\$74, 117. See Conclusiveness; Decree of Title; Service of Process and Notice.

is no protection to officer in action for false return, A. $\S \S 13,84 ;$ T. $\S \S 73,255-7$.

rendition of by the judge, A. $\S \S 101-114$.

separate in case of severance, T. \$\$59, 106.

separate in case of tract divided into parcels, A. \$\$8, 26; T. $\$ 107$.

separate where more than one tract involved, $A$. $\$ \S 8,26$;

T. \$106.

to be recorded on the minutes, A. $\$ 26 ; T$. $\$ 116$.

when petitioner proves only on undivided interest, T. $\$ 105$. when title is not satisfactorily proved, A. $\$ 26$; T. $\$ \S 103-4$. 
Reforences are to sections. A. \&- means section of Act; T. \&- means section of text.

JUDGMENTS AND DECREES, I.:-(Continued).

On application for involuntary transfer, A. §50; T. $\S \S 166-8,205-8$. conclusiveness of, A. $\S 4$, T. $\$ 167$.

to be recorded on minutes, A. $\S 50 ; T$. $\$ 166$.

On caveat to registration or entry, A. $\S 60 ; T$. $\S \S 183-5$.

On proceedings to establish heirship, A. $\$ \S 45,47$; T. $\$ \$ 194-5$, 198.

Provisional nature of, in exercise of summary jurisdiction, $T$. $\$ \$ 182-5$. See Summary Proceedings.

Punishment for obtaining by fraud, A. \$85; T. \$258.

Writ of error to, A. $\$ \S 20,82$; T. $\$ 118$. See Writ of Error. lis pendens to be noted, T. $\$ \S 178,233$.

II. Judgments Generally.

See Liens and Encumbrances.

Cancellation of:

involuntary, by order of judge, A. $\S 60 ;$ T. $\$ 181-2$.

voluntary, A. $\S 62 ;$ T. $\$ \$ 142,180$. form for, A. \$116.

Clerk's fee for noting on register, A. \$120; T. \$259. for cancelling notation, A. \$120; T. §259.

Examiner's report as to, A. §83.

Lien of must be registered to affect third persons dealing with the registered land, A. $\S 54 ;$ T. $\$ 174$.

aliunde notice of, immaterial, A. $\$ 40 ;$ T. $\$ \S 174,245$.

effect of failure to register, A. $\$ \S 54,63,73 ; T$. $\$ \S 145,174$.

effect of registering, A. $\$ \S 51,54 ; T . \$ \S 145,174-5$.

form of request for registration, A. $\$ 113$.

method of registering, A. \$61; T. \$175.

No action against assurance fund for loss of lien of, T. \$251.

\section{JUDICIAL PROCEEDINGS:-}

See CourTs; EQUiTY.

Effect of registration upon rights asserted in, $T$. \$212.

Lis pendens must be registered to affect third persons, A. \$54.

T. \$178. See Lis Pendens.

form of requesting notation of, A. \$114.

Phrase "involuntary transaction" includes, A. §3; T. §21.

Transfers as the result of, A. \$49; T. \$205-7. See Transfers III.

\section{JURISDICTION:-}

See Courts; Equity; Registration; Summary Proceiding; Venue.

In rem, conferred by the provisions of the Act, A. §4; T. $\$ \$ 19$, $22,61,167$. 
References are to sections, A. \&-means section of Act; T. \&-means section of text.

JURISDICTION:-(Continued).

applies in summary proceedings, T. $\$ 167$.

effect on constitutionality of the Act, T. $\$ 19$.

seizure to confer, A. $\$ 14 ;$ T. $\$ \S 71,72$.

Of the courts over registered lands, A. \$73; T. $\$ \$ 11,12,138$, $185,205$.

Of registration proceedings, A. $\$ \S 2,5 ; T . \S \S 16,23$.

Of judge over all justiciable registration questions, A. \$\$59, $60 ;$ T. $\S \S 270,275$.

extraordinary situations, T. \$275.

how exercised, see Summary Proceedings.

\section{JURY TRIAL:-}

On exception to examiner's report, A. \$20; T. \$\$97-8. See Examiners.

On protest to survey, A. \$22; T. $\$ 100$.

\section{LAND REGISTRATION ACT:-}

A part of our general system of jurisprudence, $T$. $\$ 13$.

A remedial statute, to be liberally construed, $T$. \$13.

Constitutionality of, T. $\$ \S 16-20$. See Constitutionality of the Act.

Distinguished from Torrens Systems, T. §1.

Effective date of, A. \$121.

General objects of stated, T. §4.

General outline of, T. $\S 15$.

Official designation, A. §1; T. §21.

Practicability and simplicity of, T. $\$ 14$.

Purposes stated, A. §2; T. §4.

To be construed as creating a complete system, T. $\S \S 13,275$.

\section{LAND REGISTRATION ASSURANCE FUND:-}

See Assurance, Fund.

\section{LARCENY:-}

Of owner's certificate or other registration paper, punishment for, A. $\$ 85 ;$ T. $\$ 258$.

\section{LEASES:-}

See Estates and Interests Less Than FeE-Simple.

\section{LESSER ESTATES:-}

See Estates and INTERESTS Less Than FeE-Simple.

\section{LEVY AND SALE:-}

See Execution Sale. 
References are to sections. A. 8 - means section of Act; T. $8-$ means section of text.

\section{LIENS AND ENCUMBRANCES:-}

See Adverse Claims; Estates and Interests Less Than FeESimple; Judgments and Decrees; Taxes and Assessments.

Affecting estate less than fee-simple, T. $\$ 113$.

Arising under federal laws, A. \$63; T. \$\$211, 220, 221.

As involuntary transactions, A. $\$ 3 ; T$. $\$ 21$.

Burden of proof as to, on examiner's hearing, T. $\$ 94$.

Cancellation of:

involuntary, by order of judge, A. $\$ \S 60,62$; T. $\$ \S 181-2$.

voluntary, A. $\$ 62 ;$ T. $\$ \$ 142,180$.

form of request for, A. $\$ 116$. attestation of, A. $\S 62 ;$ T. $\$ 142$.

Clerk's fees for noting or cancelling, A. \$120; T. \$259.

Decree of title to set forth, A. $\S 26 ;$ T. $\$ 113$.

effect of inclusion in decree of title, $T$. $\$ 230$.

Examiner's final report as to, A. \$20; T. \$95.

Examiner's preliminary report as to, T. $\$ 83$.

Existence of no obstacle to initial registration, A. \$5; T. §25.

Holders of to be named as defendants, A. $\S 9$; T. $\$ 49$.

How set forth in initial petition, A. $\$ \S 7,86,(19,20)$; T. $\S 44$.

Method of setting forth in certificate of title on initial issue, $T$. $\$ 129$.

Notation of, see catchword, "Registration," below.

Petition for initial registration must fully disclose, A. §7; T. §44 fraud in failing to disclose, T. $\$ \S 44,219$.

Registration or notation of:

effect of, A. $\S \S 40,51 ;$ T. $\$ \$ 145,174$.

effect of failure to note, A. $\$ \S 54,63,73 ; T$. $\$ \$ 137,145,173-4$. entry of to be brought forward on subsequent certificate, A. $\S \S 39,100 ;$ T. $\$ 187$.

exception, $T$. $\$ 170$.

exclusive method of giving notice of, A. \$40; T. \$245.

form of request for, A. $\$ 114$.

verification of, A. $\$ 114 ;$ T. $\$ 173$.

method of, A. $\S 61 ;$ T. $\S \S 173,175-7$.

privilege of, A. $\$ 51 ; T$. $\S \S 145,173$.

When retained on Title Register after involuntary transfer and when not, $T$. $\$ 170$.

Where land is freed from registration, A. §65; T. \$§235-7.

\section{LIFE ESTATE:-}

See Estates and InTerests Less Than Fef-Simple. 
References are to sections. A. 8 - means section of Act; T. 8 - means section of text.

\section{LIMITATIONS OF ACTIONS:-}

Against the assurance fund, A. §77; T. $\S \S 250,252$. disabilities suspending, A. §77; T. §252.

For fraud or forgery, A. \$63; T. \$217. by summary proceedings, A. $\$ 59 ;$ T. $\$ \S 182,184$.

Set by the Act do not affect other suits, A. §84; T. \$254.

Set by the Act no protection to officers, A. \$84, T. \$254.

Twelve-months' limitation as to caveat to registration, A. $\$ 59$, $60 ;$ T. $\$ \S 182-5,228-231$.

not affect general jurisdiction of the courts, $T$. $\$ 228$.

\section{LIS PENDENS:-}

See Adverse Claims; Equity; Judicial, Proceedings; Writ of ERROR.

Cancellation of entry of:

by order of judge, A. $\S \S 60,62 ; T$. $\S \S 181,182$.

voluntary cancellation, A. $\S 62 ;$ T. $\$ \S 142,180$.

form for, A. $\$ 116$.

attestation of, A. $\$ 62 ;$ T. $\$ 142$.

Inoperative against third persons unless registered, A. \$\$54, 73; T. $\S \S 173,178$.

Notation of:

effect of, A. $\$ \$ 51,54 ;$ T. $\$ \$ 145,178$.

form for requesting, A. $\$ 114$.

method of, A. $\S 61$; T. $\$ 178$.

necessity for, to protect writ of error, T. \$233.

\section{LUNATICS:-}

See Infants and Other Persons Under Disability.

\section{MARRIAGE:-}

Change of name by, how registered, A. §53; T. \$203.

\section{MARRIED WOMEN:-}

See Husband and WiFE.

\section{MEASURE OF DAMAGE:-}

In actions against assurance fund, A. §77; T. §253.

\section{MESNE PROFITS:-}

No issue as to in registration proceedings, $T$. $\$ 115$.

\section{MINERAL RIGHTS:-}

See Estates and INTERESTS Less Than FEE-Simplé. 
References are to sections. A. $\delta$ - means section of Act; T. 8 - means section of text.

\section{MINORS:-}

See Infan'ts and Persons Under Disability.

\section{MORTGAGES:-}

See Creditor's Certificate; Liens and Encumbrances; TransFERS IV.

Cancellation of, involuntary, by order of judge, A. $\S \S 60,62 ;$ T. $\S \S 181-2$. voluntary, A. \$62; T. \$142.

form of request for, A. $\$ 116$. attestation of, A. $\$ 62 ;$ T. $\$ 142$.

Clerk's fees,

for cancelling, A. $\$ 120 ;$ T. \$259.

for registering, A. \$120; T. §259.

Examiner's preliminary report as to, A. \$83.

Foreclosure of, T. $\$ 162$.

How created on registered land, T. \$\$161-2.

In standard form, how registered, A. $\$ 38 ; T$. $\$ \$ 161-2$.

certified copy of entry, A. §38; T. \$244.

certified copy of mortgage, A. §38; T. \$\$162-3, 244.

standard form prescribed, A. \$111.

Not in standard form, how registered, A. §§38, 111; T. $\$ 162$.

Owner's certificate must be presented at registration of, A. $\S 37 ;$ T. $\$ \$ 141,161$.

Penalty for forgery of, A. $\$ 85 ;$ T. $\$ 258$.

Proof of in evidence, A. §38; T. \$\$162-3, 244.

Registration takes place of recording, A. $\$ \$ 38,40 ;$ T. $\$ 163$.

When clerk retains original and when not, A. §38; T. \$162.

\section{MUNICIPALITIES:-}

Liability of tax-officer to, for failure to note delinquent taxes, A. §57; T. $\$ 177$.

Service of process on, A. $\S 11 ;$ T. $\S 67$.

To be named as defendant if tax owing to, T. \$44.

\section{NAME:-}

Change of, how registered, A. §53; T. §203.

\section{NEW TRIAL:-}

See Writ of ERror.

Right of judge to grant, A. §20; T. $\$ 99$.

\section{NEXT FRIEND:-}

See Infants and Other Persons Under Disability. 
References are to sections. A. $\$$ - means section of Act; T. $\$-$ means section of text.

\section{NON-RESIDENTS:-}

As cross-petitioners, T. $\$ 53$.

As petitioners, A. $\S 7 ;$ T. $\$ 33$.

Designation of local agent or attorney by, A. §7; T. §33.

Service of process on, by publication, A. \$10; T. \$64.

constitutionality of, T. $\$ 19$ (n. 3 ).

stands as personal service, A. $\S 14,77 ;$ T. §251.

\section{NOTATION OF ADVERSE CLAIMS:-}

See Adverse Claims; Equity; Judgments and Decreis ; Judictal, Prochedings; Liens and Encumbrancrs; Registration; Taxes AND ASSESSMENTS.

\section{NOTICE:-}

See Acknowledgment of Service; AdVERTISEMmé; Service of Process and Notice.

All given under the Act stand as personal service, A. $\S 14,77$; T. $\$ \$ 74,251$.

Constitutionality of the provisions of the Act as to, T. $\$ 19$.

Examiner's preliminary report as to, A. \$16; T. \$§83-4.

Form of clerk's certificate as to, A. $\$ 91$.

Form of sheriff's return as to, A. $\$ 90$.

Form of, to be posted on the land, A. $\S 88$.

Judge's power to prescribe methods of, A. $\S \S 10,58,72 ;$ T. $\S \S 65$, $135,166,182$.

No denial of after judgment, A. §13; T. $\S \S 74,101$.

$\mathrm{Of}$,

application for duplicate on loss of owner's certificate, A. $\S 58 ;$ T. $\$ 135$.

application for involuntary transfer, A. $\$ 50 ; T . \$ 166$.

application for order of transfer to purchaser at sale under creditor's certificate, A. $\S 35$; T. $\$ \S 155,160$.

application for order of transfer where title held in trust or on condition or unusual limitations or powers, $T$. $\S 204$.

caveat to registration, A. $\S 60 ;$ T. $\S \S 181-2$.

filing of examiner's final report, A. $\$ 20 ;$ T. $\S \S 56,95$.

hearing before examiner, A. $\S 19 ;$ T. $\$ \S 56,88$.

survey, A. §22; T. $\S 100$.

"Possession is notice"-rule abolished as to registered land, T. $\S 245$.

Posting of, on the land, A. §14; T. \$71.

Publication of, see Advertisement.

in proceedings to establish heirship, A. §45; T. $\$ \$ 195-7$. 
References are to sections. A. $\delta-$ means section of Act; T. 8 - means section of text.

NOTICE:-(Continued).

in proceedings to obtain duplicate owner's certificate, A. $\$ 58 ;$ T. $\$ 135$.

of cancellation of owner's certificates on involuntary transfer, A. §52; T. $\$ \$ 169,172$.

of court's action on caveat, A. $\S 60 ;$ T. $\S \S 181,185$.

on initial registration, A. $\$ 14 ;$ T. $\$ 64$.

contents of notice, A. $\S \S 10,88$; T. $\$ 64$.

recital as to in decree, conclusive, A. $\$ 13$; T. $\$ \S 74,101$.

Registration supersedes other forms of, A. $\$ \$ 40,73 ; T$. $\$ 245$.

To judge of the filing of examiner's report, A. \$20; T. $\$ 97$.

To judge of the filing of initial petition, A. $\$ 16 ;$ T. $\$ 79$.

To occupants of the land, A. \$14; T. \$72.

To parties disclosed by examiner's report, A. $\$ 17 ;$ T. $\$ 75$.

Waived by appearance or pleading, A. $\$ 14$; T. $\$ 69$.

Waiver in writing-see Acknowledgment of Service.

What constitutes lack of, so as to give action against assurance fund, T. $\$ 251$.

Where clerk refers doubtful matter to judge, A. $\$ 59$.

OATH:-

See Verification.

Of examiner, see Examiner.

\section{OCCUPANCY :-}

See Adjoining Owners and Occupants, Leases, Possession.

Notice to occupants of the land, see Notice.

\section{ORDER OF TRANSFER:-}

See Judge's Order of Transfer.

\section{ORDINARY :-}

Act in lieu of disqualified clerk, A. $\$ 69 ;$ T. $\$ 267$.

To allow examiner free access to records, A. $\S 68 ;$ T. $\$ 82$.

\section{OFFENSES :-}

Defined and punishment prescribed, A. \$85; T. \$258.

\section{OWN:-}

Definition of the word, as used in the Act, T. $\$ 26$.

\section{OWNER'S CERTIFICATE:-}

As a source of title where land freed from registration, A. $\$ 65$; T. $\$ 237,246$. 
References are to sections. A. $8-$ means section of Act; T. 8 - means section of text.

OWNER'S CERTIFICATE:-(Continued).

As evidence, $\mathrm{T}$. $\S \S 239,246$.

how given full evidentiary value, A. §118; T. §227.

Cancellation of:

as a result of caveat, A. $\S 60 ;$ T. $\S \S 181,185$.

as a result of involuntary transfer, A. §52; T. \$\$169, 171, 172.

by advertisement, A. $\$ 52 ;$ T. $\$ \$ 172,181$.

none on registration of voluntary transfer of an undivided interest, A. $\S 31 ;$ T. $\$ 148$.

on death of owner, A. $\S \S 44,45$; T. $\S \S 191-2,196-7$.

on registration of voluntary total transfer, A. \$30; T. \$147.

on registration of voluntary transfer of divided portion of tract, A. §31; T \$151.

Copy of plat or detail recorded outside the register may be attached to, A. $\S \S 102,104 ;$ T. $\$ 133$.

Creditor's certificate to be noted on, A. $\S 32 ;$ T. $\$ 153$.

Definition of, T. §21.

Duplicate of, how and when issued, A. §58; T. $\$ 135$.

admissibility in evidence, $\mathrm{T}$. $\$ 240$.

clerk's fees for issuing, A. \$120; T. \$259.

effect of, A. §58; T. $\$ 135$.

Entry of "Valid with all entries notes," A. \$118; T. §227.

clerk's fee for making, A. \$120; T. \$259.

Form and design of, A. $\$ 105$; T. $\S \S 133-4$.

Issuance of:

on initial registration, A. \$28; T. \$133.

on owner's death to personal representative or heirs, $A$. $\S \S 44-5 ;$ T. $\$ \S 191-2,197$.

on voluntary partial transfer (divided portion), A. §31; T. §151.

on voluntary partial transfer (undivided portion), A. \$31; T. $\$ 148$.

on voluntary total transfer, A. $\S 30 ;$ T. $\S 147$.

Loss of, duplicate how procured, A. $\S 58 ;$ T. $\$ 135$.

Minute dating of all entries on, A. \$29; T. \$273.

Must accompany registration of all voluntary transactions of the owner, A. $\$ \S 37,117$; T. $\$ \S 140-1,150,210$.

transfer to secure debt, A. §32; T. $\$ 153$.

None in favor of owner of estate less than fee-simple, T. $\$ 150$.

Penalty for stealing, forging or counterfeiting, A. §85; T. §258.

Production of, how compelled, generally, A. §52; T. \$169.

when caveat is filed, A. $\S 60 ;$ T. $\$ 185$.

when co-owner desires to register voluntary transactions, T. $\$ 149$. 
References are to sections. A. \&- means section of Act; T. 8 - means section of text.

OWNER'S CERTIFICATE:-(Continued).

Transfer of, as security for debt, A. §36; T. \$152. See also Creditor's Certificate.

Uncanceled entries to be brought forward on reissue of, A. $\S \S 39,100 ;$ T. $\S 187$.

exception in case of involuntary transfer, $T$. $\S 170$.

\section{PARCEL:-}

See Tract.

PARTIAL TRANSFER:-

See Transfers.

Defined, T. 21.

\section{PARTIES :-}

See DfFindants; Petition For Initial, Registraton.

Examiner's powers as to, A. \$24; T. \$89.

Joinder, substitution or striking of, A. §24; T. §57.

Persons dealing with the land pending registration proceedings, A. $\S 25 ;$ T. $\$ 60$.

To actions against assurance fund, A. §78; T. §255.

\section{PARTITION:-}

Among heirs, A. $\$ 45 ;$ T. $\$ \$ 196-7$.

Result of partition proceedings, how registered, $T$. \$206.

\section{PERJURY :-}

In registration proceedings-punishment of, A. §85; T. §258.

\section{PERSONAL REPRESENTATIVE:-}

See Administrators and EXecutors.

\section{PETITIONS:-}

See Petition For Initial Registration.

To etsablish estate less than fee. See Estates and Interests Less Than Fee.

To establish heirship. See Descent and Distribution.

\section{PETITION FOR INITIAL REGISTRATION:-}

See Cross-Petition; Defendants; Parties; Registration II.

Abstract of title to accompany, A. $\$ 7 ;$ T. $\$ 50$. See Abstract of Title.

Acknowledgment of service on, see Acknowledgment of Service. 
References are to sections. A. $\$$ - means section of Act; T. $\$$ - means section of text.

PETITION FOR INITIAL REGISTRATION:-(Continued).

Adjoining owners and occupants to be set forth in, A. 87; T. $\$ 45$.

See catchword, "Suggestions," below.

All adverse claims to be disclosed in A. §7; T. §44. See Adverse Claims; also catchword "Suggestions," below.

All cotenants must join in, A. §5; T. §25. See Cotenants.

Amendment of, See Amendments.

Contents of stated, A. §7; T. §§31-51. See Catchword "Suggestions" below.

Defendants to be named in, A. $\S 9 ;$ T. $\S \S 48-9$. See Defendants; also catchword "Suggestions" below.

Description of the land in, A. §7; T. §§34-6. See Description of the Land; also catchword "Suggestions" below.

Dismissal of:

allowed or ordered when, A. §23; T. §§103-5.

where plaintiff fails to prove title, T. $\$ 103$.

where plaintiff proves estate less than fee, T. \$104.

amendment to avoid dismissal, T. §104.

where plaintiff proves only an undivided interest, T. \$105.

Docketing of, T. §24.

Filing of, A. \$10; T. \$24.

Form of, A. §86. See catchword "Suggestions" below.

Liens, encumbrances, etc., to be disclosed in, A. \$7; T. $\$ \$ 44,46$. See Liens and Encumbrances; also catchword "Suggestions" below.

Names and addresses of all interested persons to be given, A. \$7; T. \$44. See catchword "Suggestions" below.

Occupancy of the land to be disclosed in, A. \$7; T. \$43.

See catchword "Suggestions" below.

Ordinary rules of procedure generally applicable to, T. \$13.

Petitioners:

corporation as, A. §5; T. §§27-8.

equitable owners as, T. $\$ 26$.

executors as, T. $\$ 27$.

infants and others under disability as, A. §5; T. \$29

nonresidents as, A. §7; T. $\$ 33$.

appointment of local agent or attorney, A. \$\$7, 86(4);

T. $\$ 33$.

person or corporation having power of appointing or disposing of an estate in fee, A. $\$ 5 ;$ T. $\$ 27$.

trustee as, T. $\S 27$.

unincorporated associations, T. $\$ 28$.

who competent as, A. §5; T. $\$ \$ 25-9$. 
References are to sections. A. $8-$ means section of Act; T. 8 - means section of text.

\section{PETITION FOR INITIAL REGISTRATION:-(Continued).}

in case of bond for title or executory sale, $T$. $\$ 26$. when security deed is outstanding, T. $\$ 26$.

Process on, see Process.

Reference to examiners, see Examiners.

Several separate tracts included in, when, A. §8; T. §35.

severance as to, when ordered, $T$. $\S \S 35,58-9,106$.

Suggestions as to preparation of:

allegation as to:

age of applicant, T. $\S 47$.

assessment for taxation, T. $\$ 37$.

dower, T. $\$ 42$.

easements, T. $\S 46$.

estate or interest claimed, T. $\S 38$.

homestead or exemption, T. $\$ 42$.

liens, encumbrances, etc., T. $\$ 44$.

occupancy, T. $\$ 43$.

source of ownership, T. $\$ 39$.

title by prescription, $\mathrm{T}$. $\$ 40$.

title papers, T. $\$ 41$.

unpaid taxes, T. $\$ 44$.

value, T. $\S 37$.

appointment of local agent or attorney by non-resident petitioner, T. $\$ 33$.

attaching abstract of title, T. $\$ 50$.

description of the land, T. \$\$34-6.

dividing tract into parcels, $T$. $\S 36$.

including several parcels in same petition, $T$. $\$ 35$.

listing adjoining owners and occupants, T. $\$ 45$.

listing adverse claimants, T. $\$ 44$.

naming the defendants, $T$. $\$ 49$.

husband or wife, as defendant, T. $\$ 48$.

unknown or of unknown address, how designated, T. $\$ 44$.

Tract divided into parcles, A. $\S 8$; T. $\$ 36$.

Venue of, A. §§2, 5; T. §23.

land divided by county line, T. \$23.

Verification of, A. $\$ \$ 7,86 ;$ T. $\$ 51$.

\section{PLAT:-}

See Survey.

Certified copy of as evidence, T. \$242.

Outside recordation of, A. \$102; T. \$121.

Surveyor to make, when, A. \$22; T. \$100. 
Reforences are to sections. A. 8 - means section of Act; T. 8 - means section of text.

\section{PLEADING AND PRACTICE:-}

See Appearance; Defeinsive Pleadings; Demurrer; Petition For InITIAL REgistration; REgistration II aND III; SUMmary Procheidings.

Before examiners, see Examiners.

Equitable pleading and practice in suits for registration, A. §5; T. §22.

Ordinary rules of procedure generally applicable, T. $\$ 13$.

Power of judges in conversion to prescribe, A. \$70; T. \$266.

Slackness of not to be allowed, T. $\$ 55$.

\section{POSSESSION :-}

See Prescription.

Adverse, no rights in registered land affected by, A. \$66; T. \$232.

Adverse, not prevent sale by executor or administrator, T. $\$ 189$. History of in examiner's preliminary report, A. §16; T. \$85.

Rule that, "Possession is notice," abolished as to registered land, T. §245.

Statement as to initial petition, A. §7; T. §43.

\section{POWERS:-}

Holder of power of appointing or disposing of the fee-simple as petitioner for initial registration, A. §5; T. §27.

Transfer coupled with-see Transfers.

Transfer by holder of-see Transfers.

\section{PRACTICE:-}

See Pleadings and Practice.

\section{PRESCRIPTION:-}

See Possession.

None against registered owner, A. §66; T. \$232.

Title by, how alleged in initial petition, A. \$86(11); T. \$40.

Title by, will support petition for registration, $T$. $\$ 94$.

\section{PROCEDURE:-}

See Pleading and Practice; Petimton for Initial Registration; Registration II and III; Summary Proceedings.

Ordinary rules of, generally applicable in registration proceedings, $\mathrm{T}$. $\$ 13$.

Power of judges in convention to prescribe, A. \$70; T. \$266.

\section{PROCEEDINGS ON INITIAL REGISTRATION:-}

See Petition For Initial Registration; Registration II. 
Reforences are to sections. A. $\$$ - means section of Act; T. $\$$ - means section of text.

\section{PROCESS:-}

Copies and second originals, A. $\$ 10 ;$ T. $\$ 63$.

Defendants to be named in, A. \$10; T. \$62.

Form of, A. \$87.

Issued by the clerk, A. $§ 10 ;$ T. $\$ 62$.

Service of, see Service.

Time of return, A. $\$ 10 ;$ T. $\$ 62$.

“To whom it may concern," A. §§4, 10; T. §62.

Waiver of by appearance and pleading, A. §14; T. \$69.

Waiver of in writing, A. §12; T. §68. See Acknowledgment of Service.

\section{PRODUCTION OF BOOKS AND PAPERS:-}

See Evideince; Examiners.

\section{PROTEST TO SURVEY :-}

Filing and trial of, A. $\$ 22 ;$ T. $\$ 100$.

\section{PUBLICATION:-}

Service by, see Service of Process and Notice.

\section{RAILWAYS:-}

In actual operation, excepted from registration, A. $\S 63 ;$ T. $\S \S 211$, 225.

\section{RECEIVER:-}

How registered title may be conferred on, T. $\S \S 207-8$.

Sales by-how title transferred to purchaser, T. $\$ 168$.

\section{RECORDATION:-}

Of instruments not in standard form, A. §38; T. $\$ \S 143,162-3$.

Of lengthy details, A. \$103; T. \$129.

Of plats, A. \$102; T. \$121.

Of transfers in trust or with powers or on condition or unusual limitations, A. \$38; T. $\$ 163$.

Registration a substitute for, A. $\S \S 38,40 ; T$. $\S 245$.

\section{REGISTER OF DECREES OF TITLE:-}

See Decree of TiTLE.

Duty of county authorities to furnish, A. $\$ 28 ;$ T. $\$ 271$.

Enrollment of decrees of title thereon, A. \$\$28, 97, 98; T. $\$ \$ 119-$ 123

Form and design prescribed, A. §98; T. $\$ 119$.

Index to, how kept, A. $\S \S 28,98 ; T$. $\S \S 119,123$. 
References are to sections. A, 8 - means section of Act; T. 8 - means section of text.

\section{REGISTER OF DECREES OF TITLE:-(Continued).}

Method of enrolling decrees thereon, A. §98; T. §§120-123. dating the entry, A. §29; T. §§122, 273.

numbering, A. $\$ 98 ;$ T. $\$ 120$.

outside recordation of plats and details, A. \$102; T. \$121.

Supervisory powers of Attorney-General over, T. §274.

\section{REGISTER OF TITLES:-}

See TITLE REGISTER.

\section{REGISTERED LAND:-}

See REgistration; TitLL.

As liquid security, T. $\S 8$.

Definition of the phrase, A. §3; T. \$21.

Disposition of on death of owner, A. §§42-7; T. $\S \S 188-199$. See Administrators and Executors; Descent and Distribution.

Not affected by unregistered transaction or claim, A. $\$ \S 63,73$; T. $\S \S 137,145,173-4$.

Safety and certainty of ownership of, T. §9. See Conclusiveness.

Subject to same rights and burdens as other lands, A. §73; T. §§3, $11,12,137$.

Subject to the ordinary jurisdiction of the courts, A. $\$ 73 ;$ T. $\$ \$ 3$, 11, 12, 137-8, 205-7.

\section{REGISTRATION :-}

- See Certificate of Titre; Decree of Title; land Registration Act; REGISTFRED LANDS

\section{Generally.}

II. Proceedings on Initial Registration.

III. Matters Subsequent to Initial Registration.

\section{Generally.}

Acknowledgment or waiver of service in proceedings relating to, A. $\$ 12 ;$ T. $\$ 68$. See Acknowledgment of Service.

Advantages of, T. $\$ \$ 6-10$.

As a substitute for recordation, A. $\S \S 38,40 ;$ T. $\S 245$.

As localizing the evidence of title, T. \$7.

As Synchronizing title in evidentiary sense with title in sense of ownership, T. $\$ 6$.

As the exclusive method of perfecting rights against registered land, A. $\S \S 40,63,73$; T. $\S \S 137-8,145,211-233,239,245$.

Certified copies on matters relating to, how procured, A. $\S 101$; T. §241. See Evidence. 
References are to sections. A. $\$$ - means section of Act; T. $\&$ - means section of text.

REGISTRATION, I.:-(Continued).

Clerk's relation to, A. $\$ \$ 59,106$; T. $\$ \S 16,228-9,269,270,275$.

See Clerk.

liability of the Clerk as to, A. $\S \S 13,59,84,106 ;$ T. $\$ \S 73,257$, 269.

Clouds upon title prevented by, T. $\$ \$ 10,167$.

Compared with other methods of evidencing title, T. §5.

Complete system of, created by the Act, T. $\$ \$ 13,275$.

continuous nature thereof, T. $\$ 136$.

general outlines, T. $\$ 15$.

practicability and simplicity, T. $\$ 14$.

Conclusiveness of, see Conclusiveness.

Courts always open for purposes of, A. $\S 67 ; T . \S \S 167,265$.

Covenant attached to title by, A. $\S 64 ;$ T. $\S \S 20,117$.

Date of, as date when transaction becomes operative, A. \$73; T. \$137.

Does not change ordinary rights and burdens of ownership, A. $\S 73 ;$ T. $\S \S 3,11-2,127$.

Does not destroy jurisdiction of the courts over registered lands, A. §73; T. \$\$11-2, 137-8, 205-7. See Equity; Judicial Proceedings.

Effect of reversal of judgment authorizing, T. $\$ 233$.

Extraordinary situations in respect to, how dealt with, T. \$275. Freeing land from, see Freeing Land From Registration.

General objects of, stated, T. \$4.

Harmony between registration and ordinary court jurisdiction, T. $\$ 138$.

Judge's relation to, A. $\$ \$ 59,60 ;$ T. $\$ \S 16,228-9$, 275. See Judge.

Jurisdiction of the superior courts over, A. §2; T. \$16.

Land rendered a liquid security by, T. §8. See Registered Lands.

Land values increased by, T. $\S 8$.

Minute dating of all entries relating to, A. §29; T. \$273.

Offenses relating to, punishment of, A. \$85; T. \$258.

Of lengthy details, A. $\S 103 ;$ T. $\S \S 121,129$.

Of plats, A. $\S 102 ;$ T. $\$ 121$.

Permanent filing of all papers relating to, A. §119; T. §272.

Safety and certainty of landownership assured by, T. §9. See Conclinsiveness.

Suggestions to clerk in respect to, T. $\$ \S 270,275$. See Clerk.

Venue of proceedings relating to, A. §2; T. §23.

II. Proceedings on Initial Registration.

See Amendments; Cross-Petition; Decree of Title; Defendants; Drfensive Pleadings; Dismissal; Examiners; Evidence; 
References are to sections. A. - means section of Act; T. $\$$ - means section of text.

REGISTRATION, II.:-(Continued).

Judgments and Decrees; Parties; Petition for Inittal Registration; Process; Service of Process and Notice; Severance. Assessment for assurarice fund, A. \$74; T. §249. See Assurance Fund.

Begun by petition, A. \$5. See Petition For Initial Registration. Boundaries permanently marked how, A. \$\$7, 22; T. $\$ 100$. See Survey.

Cardinal ieatures of, summarized, T. §275.

Constructive seizure of the land, A. $\S 14 ;$ T. $\S \S 19,71-2$.

Dealings with the land pending, A. $\$ 25 ;$ T. $\$ 60$.

Decision of the cause, A. \$26; T. \$101. See Judgment and Decree. Equity pleading and practice applicable to, A. §5; T. §22.

but not equity jurisprudence, T. \$22.

Exclusive jurisdiction of superior court over, A. $\S 2$; T. $\S \S 16,23$.

Existence of liens and encumbrances no obstacle to, A. \$5; T. §25.

Filing away of documents relating to, A. §119; T. §272.

Fraud in, T. \$219.

In-rem nature of the proceedings, A. $\$ 4 ; ' \Gamma$. $\$ \$ 19,22,70-1,167$.

Jury trial in, how obtained, A. $\$ 20 ;$ T. $\$ \$ 97-8$.

No issue as to improvements or mesne profits, $T$. $\$ 115$.

No judgment by default in, A. §21; T. \$102.

Not a substitute for ejectment or other possessory action, T. $\$ 115$.

Persons dealing with the land pending, to become parties, A. \$25;

T. $\$ 60$.

Petition to establish estate less than fee, A. $\S 6$; T. 30-1. See Estates and Interests Less Than Fee-Simple.

Several tracts included, when, A. $\S 8 ;$ T. $\$ \S 35,106$.

Tract divided into parcels, A. $\S 8 ;$ T. $\S \S 36,107$.

Undivided interests not subject to initial registration, A. \$5; T. $\S \S 25,105$.

Who authorized to institute, A. §5. See Petition For Initial Registration.

Venue of registration, A. $\S 2 ; \mathrm{T} . \S 23$.

Writ of error to, A. $\S \S 20,82$; T. $\S 118$. See Writ of Error.

\section{III, Matters Subsequent to Initial Registration.}

See Involuntary Transactions; Summary Proceedings; TransFERS; VOLUNTARY TKansactions.

Cardinal provisions as to summarized, $\mathrm{T}$. $\S 275$.

Creditor's certificate-see Creditor's Certificate.

Effect of failure to register, A. $\S \S 40,63,73 ;$ T. $\S \S 138,145,245$.

Effect on, where land freed from registration, A. §65; T. §§236-7. See Freeing Land From Registration. 
Reforences are to sections. A. 8 - means section of Act; T. $8-$ means section of text.

REGISTRATION, III.:-(Continued).

Entries by clerk prima facie conclusive, A. §59; T. §§228-231. caveat to, A. $\$ \S 59,60 ;$ T. $\$ \S 181-5$. See Caveat. twelve-month's limitation, when applicable, A. \$59; T. \$\$229, 230.

Entries to be brought forward, A. $\$ \S 39,100 ;$ T. $\$ 187$. exception in case of involuntary transfers, T. \$170.

Errors in registration, how corrected, A. §60; T. \$183.

Extraordinary situations, how dealt with, T. \$275.

Filing away of instruments relating to, A. \$§38, 119; T. §272. when clerk keeps original and when not, A. §38; T. \$\$162-3.

Liability of clerk as to, A. $\$ \$ 59,84,106$; T. $\$ \$ 257,269$.

Minute dating of all entries relating to, A. \$29; T. \$273.

Notation of liens, encumbrances, etc., see Liens and Encumbrances.

judgment liens, see Judgments and Decrees.

taxes and assessments, see Taxes and Assessments.

Notation of lis pendens, see Lis Pendens.

Owner's certificate must accompany registration of all voluntary transactions by the owner. A. $\S \S 37,117 ;$ T. $\$ \$ 140-1,270$.

Proceedings as to, are proceedings in rem, A. \$4; T. \$167.

Registration of:

adverse claims, see Adverse Claims.

cancellation, see Cancellation.

change of name, A. §53; T. $\$ 203$.

guardian's sale, T. $\$ 200$.

homestead or exemption, A. §117; T. \$210.

involuntary transaction, not involving transfer, T. $\$ 145$.

involuntary transfer, see Transfers IIl.

result of condemnation proceedings, T. \$202.

transfers or dealings by those holding in trust or with powers or on condition or unusual limitations, A. $\$ 56$; T. \$204. transfer from husband to wife and vice versa, A. \$48; T. \$201. transfer to personal representative on death of owner. See Administrator and Executors.

transfer to heirs at law on death of owner. See Descent and Distribution.

transfers to secure debt, see Transfers IV. voluntary transfers, generally, see Transfers, II. year's support and transfers thereof, T. \$209.

Right of any one to note adverse claim on Title Register, A. 851; T. $\S 145$.

Supervisory powers of judge over, A. $\S \S 59,60$; T. $\S \S 139,181-4$, 270, 275. See Caveat; Summary Proceedings.

\section{RULES OF COURT:-}

Power of judges in convention to make, A. §70; T. \$266. 
Reforences are to sections. A. $\$$ - means section of Act; T. $\$$ - means section of text.

\section{SALES :-}

See Transfers.

\section{SECOND ORIGINALS:-}

See Service of Process and Notice.

\section{SECURRITY DEED:-}

Effect of existence of, on right to register land, $T$. \$26.

How rights of holder are set forth in decree of title, T. $\S \S 110-2$.

\section{SEIZURE OF THE LAND:-}

See Constructive Seizure of the Land.

\section{SERVICE OF PROCESS AND NOTICE:-}

See Notice; Process.

Acknowledgment or waiver of, A. §12; T. \$68. See Acknowledgment of Service.

by appearance or pleading, A. $\$ 14 ;$ T. $\$ 69$.

form of, A. $\S 89$.

All methods of, prescribed by the Act stand as personal service, A. $\$ \S 14,77 ;$ T. $\$ \S 74,251$.

By publication, A. $\$ 10 ;$ T. $\$ 64$. See Advertisement; Notice. form of, A. $\$ 88$.

form of clerk's certificate as to, A. $\$ 91$.

Constitutionality of the provisions of the Act as to, T. $\$ 19$.

Duty of the judge to investigate and adjudge as to, A. \$13; T. $\S \S 74,101$.

Examiner's preliminary report as to, A. §16; T. §§75, 83-4.

Form of clerk's certificate as to, A. $\$ 91$.

Form of sheriff's return as to, A. $\$ 90$.

In proceedings to establish heirship, A. §45; T. \$195.

In summary proceedings, A. $\$ \S 60,72 ; \mathrm{T}$. $\$ \S 166,182$.

Judge's power over, A. $\S \S 10,72 ;$ T. $\S \S 65,166,182$.

Liability of officer for false return, A. $\$ \S 13,84$; T. $\S \S 73,255-7$.

Method of initial registration, A. $\$ \$ 10,14 ;$ T. $\$ \S 63-7,72$.

On application for involuntary transfer, A. \$50; T. \$166.

On caveat to registration, A. $\$ 60 ; T$. $\$ 1181-2$.

Provisions of the Act as to, not unduly onerous, $T$. \$76.

Recital of in decree of title-conclusiveness of, A. $\S 13$; T. $\S \S 73-4$, 101.

Relation between prescribed methods and the object of the suit, T. $\$ 61$.

Second originals and copies for, A. $\$ 10 ;$ T. $\S 63$.

Sheriff's fees for making, A. \$120; T. §261.

Traverse of, none after judgment, A. §13; T. \$\$73-4. 
References are to sections. A. $\$-$ means section of Act; T. $\$-$ means section of text.

\section{SERVICE OF PROCESS AND NOTICE:-(Continued).}

Time of making, A. $\$ 10$.

power of judge to enlarge, A. $\S 10 ;$ T. $\S 65$.

Upon:

additional defendants disclosed in course of proceedings, A. $\S \S 10,17 ;$ T. $\S 75$.

counties, A. $\$ 11 ;$ T. $\$ 67$.

infants and persons under disability, A. $\$ 10 ;$ T. $\S 70$.

municipalities, A. $\$ 11 ;$ T. $\$ 67$.

non-residents, A. $\$ 10 ;$ T. $\$ 64$.

occupants of the land, A. $\S 14 ;$ T. $\S 72$.

representatives of a numerous class, $T$. $\$ 66$.

residents of the State, A. $\$ 10 ;$ T. $\$ 63$.

State Treasurer, A. $\$ 77$.

the State, A. $\$ 11 ;$ T. $\$ 67$.

unknown parties and parties of unknown address, A. \$10; T. $\S 64$.

\section{SEVERANCE:-}

Assessment for assurance fund in case of, $T$. $\$ 249$.

Definition of, A. \$58.

Effect of, T. §59.

Examiner's powers as to, A. §24; T. §§58, 89.

For purpose of rendering final judgment, T. \$106.

Ordered or allowed, how and when, A. §24; T. \$58.

Record on appeal in case of, $T$. $\$ 59$ (n. 1), $\$ 118$.

Terms imposed by the court, A. \$24; T. $\$ \$ 59,106$.

When petitioner has included tracts not held under same general claim of title, T. $\$ \$ 35,106$.

\section{SHERIFF :-}

See Service of Procfss and Notice.

Actions against for wrong or neglect, A. §84; T. \$257.

As defendant in action against assurance fund, A. §78; T. §255.

Constructive seizure of the land by, A. $\S 14 ; T$. $\$ 71$.

Crimes by, in relation to the Act, A. §85; T. \$258.

Deputy-sheriff:

criminal responsibility of, A. $\$ 85 ;$ T. $\$ 258$.

duties of sheriff performed by, A. $\$ 83$; T. $\$ 268$.

sheriff's responsibility for acts of, A. \$83.

Duty of,

going on the land and obtaining name of occupants, A. §14;

T. $\$ 71$.

posting notice on the land, A. $\$ 14 ;$ T. $\$ 71$.

serving resident defendants, A. $\S \S 10,14 ;$ T. $\$ \S 63,72$. 
References are to sections. A. $\$-$ means section of Act; T. $8-$ means section of text.

\section{SHERIFF :-(Continued).}

Fee bill, A. §120; T. §261.

Form of return, A. $\$ 90$.

Liability for making false return, A. $\S \S 13,84$; T. $\S \S 73,255$.

Limitations of the Act no protection to against action for wrong or neglect, A. §84; T. \$257.

Removal from office for offenses against the Act, A. §85; T. §258.

Return as to occupancy of the land, A. \$14; T. \$73.

Return of service, A. $\$ 90$.

not subject to traverse after judgment, A. §13; T. §§73-4.

\section{STATE OF GEORGIA :-}

Bound by decree of title, A. \$27; T. $\$ 117$.

Liability of tax-officer to, for failure to register delinquent taxes, A. $\$ 57 ;$ T. $\$ 177$.

Service of process on, A. $\S 11 ;$ T. $\S 67$.

\section{STATE TREASURER:-}

See Assurance Fund.

\section{STENOGRAPHER:-}

Compensation of, A. $\S \S 71,120$; T. $\$ \S 93,260$.

Employment of before examiner, A. \$71; T. \$93.

\section{SUIT FOR REGISTRATION:-}

See Petition For Initial Registration; Registration.

\section{SUMMARY PROCEEDINGS:-}

See Judge; Judge's Order of Transfer.

Application for involuntary transfer, A. $\$ \$ 49,50,52 ;$ T. $\$ \S 166-$ 172. See Transfers III.

cancellation of owner's certificate, A. §52; T. $\$ \S 169,172$. form of judge's order, A. $\$ 110$.

guardian ad litem for persons under disability, A. \$50; T. $\$ 166$.

instructions by judge to clerk, T. $\$ 170$.

Application for transfer to purchaser at sale under creditor's certificate, A. $\S 35 ;$ T. $\$ 160$. See Creditor's Certificate.

Application to confirm sale by administrator or executor, T. \$\$189-193. See Administrators and executors.

Application to establish duplicate of lost owner's certificate, A. $\S 58 ;$ T. $\$ 135$.

Attacks for fraud or forgery by, A. $\S 63$; T. $\$ \$ 184,217$.

By trustees or personal representatives to determine beneficiaries or heirs, A. $\$ 47$; T. $\$ 198$. 
Reforences are to sections. A. \&- means section of Act; T. 8 - means section of text.

SUMMARY PROCEEDINGS:-(Continued).

Caveat to registration, A. $\$ \S 59,60 ;$ T. $\$ \S 181-5$. See Caveat.

filing and notation of, A. $\S 60 ;$ T. $\$ 182$.

Clerk's fee in connection with, A. \$120; T. \$259.

Conclusiveness of registration not to be affected by, $T$. \$228.

Correction, cancellation or modification of entries and registrations, A. $\S 60 ;$ T. $\S \S 183-5$. See Caveat.

Courts always open for purposes of, A. $\S 67$; T. $\$ \S 167,265$.

Distinguished from general jurisdiction of the courts, T. $\$ 185$.

Errors on register, corrected through, A. §60; T. §183.

In rem character of the proceedings, A. $\$ 4 ; \mathrm{T} . \$ 167$.

Judge's duty as to bona fide justifiable controversies developed on, T. \$167.

Judgment on, T. $\$ 166$.

provisional nature of in contested case, $T$. \$182-5.

writ of error to, A. $\S 82 ;$ T. $\S \S 118,167$. See Writ of Error.

Judicial nature of the proceedings, T. \$167.

Notice to the parties:

generally, A. §50; T. $\$ \S 166,182$.

judge's power to provide for, A. §72; T. $\$ \$ 166,182$.

Proceedings to establish heirship, A. $\$ \$ 45,47 ;$ T. $\$ \$ 195,198$.

Registered rights of third persons to be protected, T. $\$ \S 183,185$, 228.

Twelve-months' limitation in cases of transfers and cancellations, A. $\$ 59$; T. $\$ \S 182-5,229-231$.

Where clerk refers doubtful matter to judge, A. $\$ 59$; T. $\$ \$ 131$, $269,270,275$.

method of applying, T. $\$ 131$.

notation to be made in register, $T$. $\$ 270$.

Where one holding title in trust or with powers or on condition or unusual limitations seeks to transfer or deal with the land. A. \$56; T. \$204.

as to administrators or executors, see Administrators and Executors.

sale of homestead, T. $\$ 210$.

sale of year's support, T. §209.

\section{SUPERIOR COURT:-}

See Court.

\section{SUPREME COURT:-}

See Writ of ERror.

\section{SURVEY :-}

Notice of, A. $\$ 22 ;$ T. $\$ 100$. 
References are to sections. A. 8 - means section of Act; T. 8 - means section of text.

SURVEY:-(Continued).

Ordered how and when, A. $\S \S 7,22 ;$ T. $\S \S 34,89,100$.

Protest to, how filed and tried, A. §22; T. $\$ 100$.

Surveyor's compensation, A. §120; T. §262.

\section{TAXES AND ASSESSMENTS:-}

Allegation as to in petition for initial registration, T. $\$ 44$.

Delinquent:

as an involuntary transaction, A. $\$ 3 ;$ T. \$21.

cancellation of entry of, A. $\$ 62$; T. $\$ \$ 181-2,186$.

form of noting, A. \$112.

how noted, A. §57; T. \$177.

liability of tax officer for failure to note, A. $\$ 57 ;$ T. $\$ 177$.

must be registered to bind the land, A. §57; T. \$177.

when to be noted, A. \$57; T. \$177.

Examiner's preliminary report as to, T. \$83.

For the current year excepted from registration, A. §63; T. §§211, $220,223$.

Tax-sales-how title transferred to purchaser at, T. \$168.

\section{TENANTS IN COMMON:-}

See CotENANTS.

\section{TIMBER RIGHTS:-}

See Estates and Interests Less Than Fee-Simple.

\section{TITLE:-}

See Abstract of Tithe; Bond For Title; Decree of Title; Estates; Estates and Interests Less Than Fee-Simple; Prescription.

All matters affecting must be entered in Title Register, A. \$\$28, $40,63,73 ;$ T. $\$ \$ 137-8,145,239,245$.

By prescription, how alleged in petition for initial registration,

A. $\S 86(11) ;$ T. $\S 40$.

none against registered owner, A. §66; T. §232.

By year's support, how registered, T. §209.

Clouds upon, prevented by registration, T. $\S \S 10,167$.

Covenant attached to by registration, A. $\$ 64 ;$ T. $\$ \S 20,117$.

Deeds and other title-documents, necessity of keeping dispensed with by registration, T. $\$ \S 7,9$.

Description of, in initial petition, A. §§7, 86; T. §§38-41.

Dual sense of the word, discussed, T. \$2.

Equitable, how enforced after registration, see Equities.

Equitable title may be registered, when, T. \$26.

Evidence of, localized by registration, T. \$7. 
References are to sections. A. $\$$ - means section of Act; $T$. $\$$ - means section of text.

TITLE:-(Continued).

Exact status of, permanently disclosed by registration, T. $\$ 10$. See Conclusiveness.

Freed from registration, A. §65; T. §235. See Freeing Land From Registration.

In substantive sense not affected by registration, A. §73; T. $\$ \S 2$, $3,12$.

Last certificate as a source of, where land freed from registration, A. §65; T. §237.

Limitations and conditions affecting to be set forth in certificate of title, T. $\$ 129$.

in decree of title, A. $\$ 26 ;$ T. $\$ \S 111-2$.

Methods of evidencing, discussed, T. §§5-7.

Of registered owner, not affected by adverse possession, A. \$66; T. §232.

Petitioner must prove though no objections filed, A. §21; T. §§94, 102.

Proof of, before examiner, T. \$94.

Quieted by decree of title, A. §27; T. §§9, 117.

Safety and certainty of, assured by registration, $T$. $\$ 9$.

State of, to be shown in examiner's final report, A. §20; T. §95.

To estate less than fee-simple-established but not registered, A. $\S 6 ;$ T. $\$ \$ 30,104$.

Transfer of, see Transfers.

Transmission of, on death of owner, A. §§42-7; T. $\S \S 188-198$.

Vested by registration, A. $\$ \S 4,27$; T. $\$ 117$.

What kind will support petition for registration, A. §5; T. $\S 25-6,94$.

\section{TITLE REGISTER:-}

See Certificate of Title; Registration.

All entries and registrations on, prima facie conclusive, A. \$59; T. $\S \S 228-231$.

caveat to, A. $\$ \$ 59,60$; T. $\$ \$ 182-5$. See Caveat. twelve-month's limitation, when applicable, A. §59; T. §§229231.

All matters affecting registered land must be entered on, A. $\S \S 40$, 63,73 ; T. $\$ \$ 137-8,145,211-233,239,245$.

All voluntary and involuntary transactions to be entered thereon, A. §28. See Involuntary Transactions; Transfers; Voluntary Transactions.

Certificate of title to be enrolled thereon, A. $\S \S 28,99 ; \mathrm{T} . \S 125$.

Certified copies of matters appearing on, how procured, A. $\$ 101$; T. §241.

Description of, A. $\S \S 28,99$; T. $\$ 124$.

Duty of county authorities to furnish, A. §28; T. §271. 
References are to sections. A. $\S$ - means section of Act; $T$. $\S$ - means section of text.

TITLE REGISTER:-(Continued).

Entries to be brought forward on, A. $\$ \$ 39,100 ;$ T. $\$ 187$.

Form and design of, A. $\$ 99 ;$ T. $\$ 124$.

Index to, A. \$§28, 99; T. $\S \S 124,132$.

Minute dating of all entries thereon, A. \$29; T. \$273.

Outside recordation of plats or lengthy details, A. $\$ \$ 102,103$;

T. $\$ \S 129,275$.

Overcrowding of, how dealt with, T. \$275.

Penalty for crimes in relation to, A. $\$ 85 ; T$. $\$ 258$.

Privilege of noting liens, encumbrances and adverse claims,

A. §51; T. \$145. See Adverse Claims, Liens and Encumbrances.

Supervisory powers of Attorney-General over, T. \$274.

Supervisory powers of judge over, see Summary Proceedings.

\section{TORRENS SYSTEMS:-}

See Land Registration Act; Registration.

Distinguished from the Land Registration Act, T. \$1.

Historical sketch of, T. $\S 1$. (See also preface to the Appendix, p. 335$)$.

\section{TOTAL TRANSFER:-}

See Transfirs.

Defined, T. $\S 21$.

\section{TRACT:-}

Definition of, T. $\$ 35$.

Divided into parcels, see Decree of Title; Petition for .Initial Registration; Registration II.

Including several in one petition, A. §8; T. \$35.

duty of sheriff to post separate notice on each tract, A. \$14; T. $\$ 71$.

separate decrees to be rendered for each tract, A. \$26;

T. $\S \S 106,109$.

severance as to, when ordered, T. $\S \S 58-9$; T. $\S 106$.

\section{TRANSFERS:-}

See Involuntary Transactions; Registrations; Summary Proceedings; Vot.untary Transactions.

I. Generally.

II. Voluntary Transfers.

III. Involuntary Transfers.

IV. Transfer to Secure Debt.

I. Generally.

All registrations of, prima facie conclusive, A. §59; T. §§228-231. 
Reforences are to sections. A. $\$-$ means section of Act; T. $\$$ - means section of text.

TRANSFERS, I.:-(Continued).

caveat to, A. $\S \S 59,60 ;$ T. $\$ \S 182-5$. See Caveat.

twelve-month's limitation, A. $\$ 59 ;$ T. $\$ \$ 229-231$.

Must be registered to affect the land, A. $\$ \S 40,63,73 ;$ T. $\S \S 137-8$, 245.

Of lands on death of owner, A. $\$ \$ 42-7$; T. $\$ \S 188-198$. See Administrators and Executors; Descent and Distribution.

Procured by fraud or forgery, see Fraud, Forgery.

To be entered on Title Register, A. \$28. See Certificate of Title; Title Register.

To free land from registration, see Freeing Land From Registration.

Uncanceled entries to be brought forward on new certificate, A. $\$ \S 39,100 ;$ T. $\S 187$.

\section{Voluntary Transfers.}

See Voluntary Transactions.

Attestation of, A. $\S \S 30,31$; T. $\S \S 147-8,151,153$.

clerk's duty and liability as to, A. \$106; T. \$269.

By corporations, $T$. $\$ 164$.

By trustee or quasi-trustee, A. §56; T. \$204.

by administrator or executor, see Administrators and $\mathbf{E x}$ ecutors.

by head of family under homestead, T. $\$ 210$.

by widow under year's support, T. \$209.

Certified copies of entry of registration of-use and effect of, A. §38; T. §244.

Forms of, A. $\$ 107$.

Husband to wife, A. §48; T. §201.

Instrument of, when retained by clerk, when not, A. \$38; T. $\$ 158$.

In trust or with powers or on condition or unusual limitations,

A. $\$ \S 30,38$.

how registered, A. \$38; T. $\$ 163$.

next succeeding transfer, how registered, A. \$56; $T$. \$204.

Not in standard form, how registered, A. \$\$38, 117; T. \$163.

Not to be registered unless owner's certificate accompanies, A. $\S \S 30,31,37 ;$ T. $\$ \S 140-1$.

Not to be registered unless properly attested, A. \$106; T. \$269.

Of estates less than fee-simple, A. $\$ 117$; T. $\$ 150$.

Operate as a deed, A. §30; T. \$147.

Partial transfer:

definition of, 'T. \$21.

of divided portion of tract, A. §31; T. $\$ 151$.

cancellation and reissue of certificates, A. $\$ 31 ;$ T. $\$ 151$.

cross-reference between certificates, A. $\$ 31$; 'T. $\$ 151$. 
Reforences are to sections. A. 8 - means section of Act; T. $\delta$ - means section of text.

TRANSFERS, II.:-(Continued).

description of portion transferred, A. $\$ 31 ;$ T. $\$ 151$.

registration of, A. $\$ \S 31,38 ;$ T. $\$ \S 151,163$.

of undivided interest, A. $\$ 31 ;$ T. $\$ 148$.

certificates not to be carcelled, A. §31; T. \$148.

exception in case of transfer on death of co-owner, A. $\S 44 ; T$. $\$ 192$.

registration of, A. $\$ \S 31,38$; T. $\$ \S 148,163$.

transfer not to be written on owner's certificate, T. $\$ 148$ (n. 2$)$.

where co-owner refuses possession of certificate for the registration of, T. $\$ 149$.

To free land from registration, see Freeing Land From Registration.

To hinder, delay or defraud creditors, A. \$55; T. \$207.

Total transfer, A. \$30: T. \$147.

definition of, T. \$21.

cancellation and reissue of certificates, A. $\S 30 ; T$. $\$ 147$.

not in standard form, A. §38; T. $\$ 163$.

registration of, A. $\$ 30 ;$ T. $\$ 147$.

Wife to husband, A. $\S 48 ;$ T. $\S 201$.

\section{Involuntary Transfers.}

See Judge's Order of Transfer; Summary Proceedings.

As the result of judicial proceedings:

application for, A. $\S 50 ;$ T. $\S \S 168,205$.

guardian ad litem for persons under disability, A. \$50;

T. $\$ 166$.

how effectuated, A. §50; T. §§205-7, 166-9.

how registered, A. $\S 49 ;$ T. $\$ \S 205-7$.

transactions in fraud of creditors, A. \$55; T. \$207.

Directions to clerk to be given, $T$. $\$ 170$.

Form of judge's order of, A. \$110.

Generally:

application for, A. $\$ 50 ;$ T. $\$ 168$.

guardian ad litem for persons under disability, A. $\$ 50$; T. $\$ 166$.

cancellation of owner's certificate, A. §52; T. $\S 169$.

by advertisement, A. §52; T. $\$ 172$.

how effectuated, A. $\$ \$ 50,52 ; T$. $\$ \$ 166-172$.

production of owner's certificate for cancellation how compelled, A. $\$ 52 ;$ T. $\$ 169$.

Or:

bankruptcy of the owner, T. $\S \S 168,222$.

execution sale, T. $\$ 168$. 
References are to sections. A. $\$-$ means section of Act; T. $\$$ - means section of text.

TRANSFERS, III.:-(Continued).

receiver's sale, $T$. $\$ 168$.

sale under creditor's certificate, A. $\$ 35 ;$ T. $\$ 160$.

tax sale, T. $\$ 168$.

Registered only on order of judge, A. \$41; T. \$\$144, 166.

Transfer by death of owner, A. $\S \S 42-47$; T. $\S \S 188-198$. See Administrators and Executors; Descent and Distribution.

IV. Transfer to Secure Debt.

See Ceditor's Certificate.

Ordinary, A. $\S 36 ;$ T. $\S \S 152,157$.

bond for title to debtor, A. $\S 36 ;$ T. $\$ 152$.

Original instrument of transfer, when retained by clerk, A. §38; T. $\$ 158$.

Owner's certificate must accompany registration of, A. §§32, 37; T. $\$ 141$.

With power of sale without foreclosure, A. $\$ \S 32,38 ;$ T. $\$ 153$. attestation of, A. §32; T. \$153.

creditor's certificate on, see Creditor's Certificate.

form prescribed, A. $\S \S 107,109$.

in standard form, A. \$32; T. \$153.

not in standard form, A. $\$ 38 ;$ T. $\$ \S 156-8$.

not to be written on owner's certificate, T. $\$ 153$ (n. 1 ).

registration of, A. $\$ \S 32,38$; T. $\$ \$ 156-8$.

\section{TRUSTS AND TRUSTEES:-}

See Administrators AND Executors.

No action against assurance fund for injury through breach of trust, A. $\$ 80$; 'T. $\$ 254$.

Proceedings by trustees to determine beneficiaries, A. \$47; T. $\$ 198$.

Registration does not prevent creation of, $T$. $\$ 3$.

Transfers by trustees and quasi-trustees, A. §56; T. §204. See Transfers.

Transfers in trust, see Transfers.

Trustees as petitioners for initial registration, A. §5; T. $\S \S 27,29$.

\section{UNDIVIDED INTERESTS:-}

See Cotenants; Transfers.

Not subject to initial registration, A. §5; T. §25.

Not to be freed from registration where jointly held, A. $\$ 65$; T. $\$ 238$.

Registration of voluntary transfer of, A. $\S 31$; T. $\$ \$ 148-9$. See Transfer II. 
References are to sections. A. $\S-$ means section of Act; T. $\$$ - means section of text.

UNDIVIDED INTERESTS:-(Continued).

Transfer to personal representative on owner's death, A. §44; T. §192. See Administrators and Executors.

\section{UNINCORPORATED ASSOCIATIONS:-}

As petitioners for initial registration, T. §28.

\section{UNITED STATES:-}

Liens and rights arising under laws of, how far exempted from registration, A. §63; T. §§211, 221-2.

\section{UNKNOWN CLAIMANTS AND PERSONS OF UNKNOWN AD.} DRESS:-

See Whom It May Concern.

How designated in petition for initial registration, T. §44.

Service on, T. $\$ 64$.

constitutionality of the mode of service, T. $\$ 19$ (n. 3).

\section{VENUE:-}

Of actions against assurance fund, A. §77; T. §250.

Of registration proceedings, A. \$2; T. \$23.

fixed by definition of word "court," A. §§2, 3; T. \$§21, 23.

lands divided by county line, T. $\$ 23$.

\section{VERIFICATION:-}

Of amendments, A. \$7; T. §57.

Of cross-petition, T. $\$ 53$.

Of defensive pleadings, T. $\$ 54$.

Of petitions, A. $\$ \$ 7,86 ;$ T. $\$ 51$.

Of petitions to establish heirship, A. §45; T. $\$ 195$.

Of request for notation of adverse claim on Title Register, A. $\S 114 ;$ T. $\S 173$.

\section{VOLUNTARY TRANSACTIONS:-}

Clerk registers without prior order of judge usually, A. §37;

T. $\S \S 140,270$.

exceptions stated, T. $\S 140$.

Definition of the phrase, A. §3, T. §21.

Homestead and exemption as, A. §3; T. §21.

Not operative till registered, A. $\S \S 40,73 ; T$. $\S \S 137-8$.

Not otherwise provided for, how registered, A. §117; T. \$143.

Owner's certificate must accompany registration of, A. \$37; T. $\S \S 140-1$.

Relating to lands held in trust or with powers or on condition or unusual limitations, A. $\S 56 ;$ T. $\S 204$. 
References are to sections. A. $8-$ means section of Act; T. 8 - means section of text.

VOLUNTARY TRANSACTIONS:-(Continued).

To be entered on Title Register, A. \$28. See Title Register.

Voluntary dealings with estates less than fee-simple are included in the definition of the phrase, A. \$3; T. \$21.

Voluntary transactions not involving a transfer, see Cancellation, Homestead and Exemption; Mortgages.

Voluntary transfers, see Transfers II.

\section{WAIVER:-}

Of service by appearance or pleading, A. $\$ 14 ;$ T. $\$ 69$.

Of service in writing, see Acknowledgment of Service.

\section{"WHOM IT MAY CONCERN:"-}

As defendants in initial registration, A. $\$ \$ 9,86(26)$; T. $\$ \$ 52$, 62,64 .

Bound by all registration proceedings, A. $\$ 4$.

Bound by decree of title, A. §27; T. \$117.

Notices provided by the Act, stand as personal service on, A. $\$ 14 ;$ T. $\$ 74$.

Process directed to, A. $\S 10 ;$ T. $\$ \S 62,64$.

\section{WIDOW:-}

See Dower; Descent and Distribution; Year's Support.

\section{WIFE:-}

See Husband and Wifk.

\section{WILLS:-}

See Administrators and Executors.

Transmission of title by, an involuntary transaction, A. \$3; T. §21.

\section{WITNESSES:-}

Examiner as a witness to explain his report, T. $\$ 98$.

Interrogatories for, A. §20; T. §89.

Power of examiner to compel attendance of, A. $\S 20 ;$ T. $\$ 89$.

Testimony of taken by depositions before examiner, A. \$20; T. §91.

\section{WORDS AND PHRASES DEFINED:-}

Actual notice, T. \$251.

Adjoining owners and occupants, T. $\$ 45$.

Belongs to, T. \$26.

Certificate of title, T. $\$ 21$.

Certificate of title number, T. \$125. 
References are to sections. A. $\$-$ means section of Act; T. $\$$ - means section of text.

WORDS AND PHRASES DEFINED:-(Continued).

Clerk, A. §3; T. §21.

Court, A. §3; T. §21.

Fce simple, T. §25.

Involuntary transaction, A. $\$ 3 ; T . \$ 21$.

Judge, A. §3; T. §21.

Judge of the court, A $\S 3 ;$ T. $\$ 21$.

Judge of the superior court, A. $\$ 3 ;$ T. $\$ 21$.

Judge of the superinr court of the county where the land lies, A. $\S 3 ;$ T. $\S 21$.

Land Registration Act, A. \$1; T. §21.

Lease, T. §224.

Own, T. \$26.

Owner's certificate, T. \$21.

Parcel, T. §35.

Partial transfer, T. \$21.

Register of Decrees of Title, A. $\S 98 ; T . \S 120$.

Registered land, A. §3; T. §21.

Registered title number, T. $\$ \$ 120,125$.

Same general claim of title, T. $\$ 35$.

Severance, $T$. $\$ 58$.

Title, T. \$2.

Title Register, A. $\$ 99 ;$ T. $\$ 124$.

Total transfer, T. $\$ 21$.

Tract, T. \$35.

Voluntary transaction, A. §3; T. \$21.

\section{WRIT OF ERROR:-}

Costs on. A. §120; T. \$259.

Dismissal of, when lis pendens not noted, T. \$233.

Effect of reversal of judgment authorizing registration, T. $\$ 233$.

Pendency of to be noted on Title Register, A. $\$ 54 ;$ T. $\$ \$ 118,178$. effect of failure to note, $T$. $\$ 233$.

Record on, where severance has been ordered, $T$. $\$ 59$.

Statement as to right of in decree of title, T. $\$ 114$.

To judgments and decrees, A. §82; T. \$118. supersedeas, T. $\$ 118$.

To judgment on examiner's final report, A. §:0; T. $\$ 99$.

\section{YEAR'S SUPPORT:-}

Sales of, how registered, A. §56; T. \$209.

Title by, how registered, T. §§205-8. 



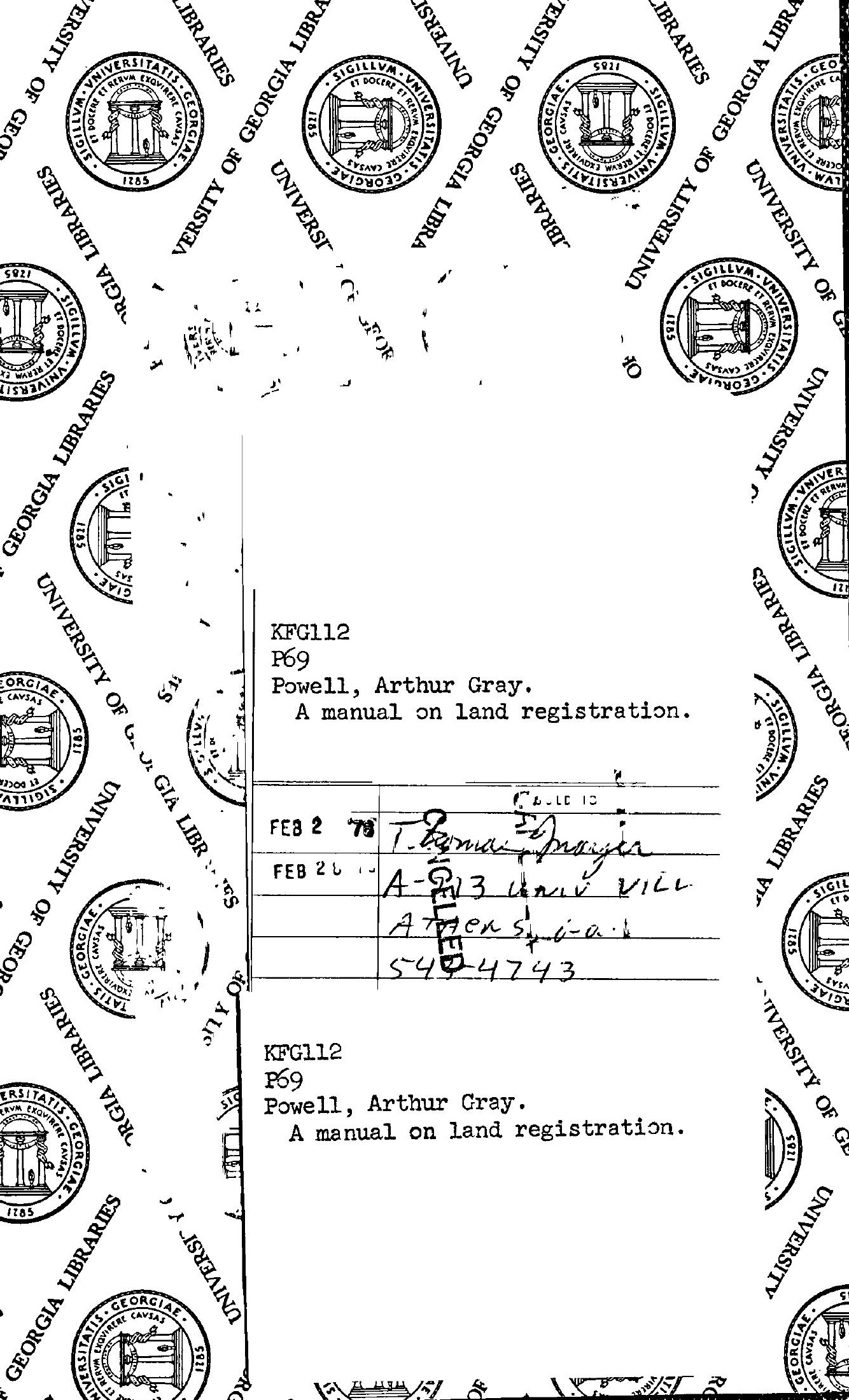


B P8 PCE

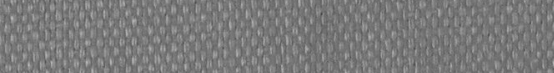

